\title{
Cenozoic Echinoids of \\ Eastern United States
}

GEOLOGIGAL SURVEY PROFESSIONAL PAPER 321

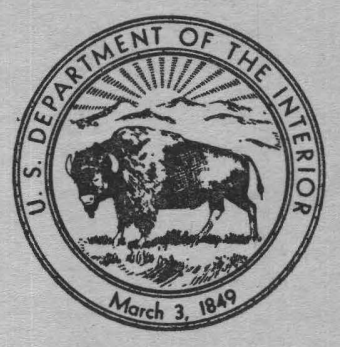




\section{Cenozoic Echinoids of}

\section{Eastern United States}

By C. WYTHE COOKE

GEOLOGICAL S URVEY PROFESSIONAL PAPER 321

Descriptions and illustrations of

fossil and Recent sea urchins

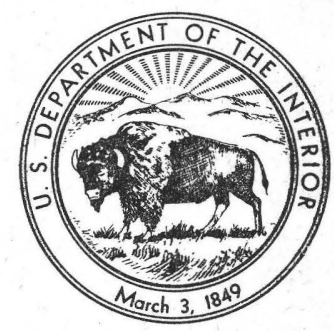




\section{UNITED STATES DEPARTMENT OF THE INTERIOR}

FRED A. SEATON, Secretary

GEOLOGICAL SURVEY

Thomas B. Nolan, Director

The U. S. Geological Survey Library has cataloged this publication as follows:

Cooke, Charles Wythe, 1887 -

Cenozoic echinoids of Eastern United States. Washington, U.S. Govt. Print. Off., 1959.

iii, 106 p. 43 plates. $30 \mathrm{~cm}$. (U. S. Geological Survey. Professional paper 321.

Bibliography: p. 93-98.

1. Sea-urchins, Fossil. 2. Paleontology-Cenozoic. 3. Paleontology-U. S. I. Title. (Series)

\begin{tabular}{lll} 
QE75.P9 no. 321 & 563.95 & G S 59-183 \\
\hline
\end{tabular}

$\dagger$

For sale by the Superintendent of Documents, U. S. Government Printing Office Washington 25, D. C. 


\section{CONTENTS}

Abstract.-

Introduction

Distribution

Paleocene fauna............

Eocene faunas.

Oligocene faunas..........

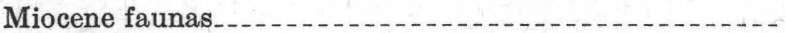

Pliocene fauna

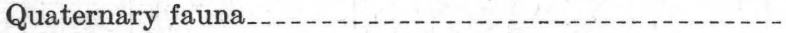

Systematic descriptions.

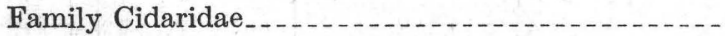

Family Saleniidae.......

Family Orthopsidae........

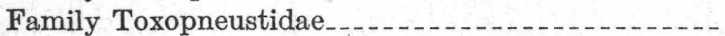

Family Echinidae....

Family Temnopleuridae..........

Family Arbaciidae .........

Family Phymosomatidae.....................

Family Stomopneustidae.

Family Strongylocentrotidae.............

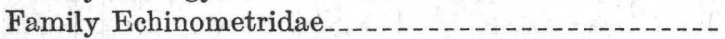

Family Echinoneidae........

Subfamily Echinoneinae..................

Subfamily Oligopyginae.

\begin{tabular}{r|} 
Page \\
1 \\
1 \\
1 \\
2 \\
2 \\
4 \\
4 \\
5 \\
5 \\
7 \\
7 \\
13 \\
14 \\
14 \\
16 \\
18 \\
19 \\
23 \\
24 \\
25 \\
25 \\
26 \\
26 \\
27
\end{tabular}

Page

Systematic descriptions-Continued

Family Fibulariidae........ 30

Family Clypeasteridae._.

Family Protoscutellidae.............. 38

Family Echinarachniidae. . . . . . .

Family Abertellidae._...... 44

Family Mellitidae

Family Laganidae_.......... 50

Family Neolaganidae........................ 51

Family Echinolampadidae.................... 55

Family Cassidulidae

Family Holasteridae.

Family Hemiasteridae_._. 67

Family Schizasteridae _...

Family Loveniidae_...

Family Unifasciidae _........................ 79

Family Spatangidae._._. 80

Family Brissidae

Glossary

Bibliography _._.

Index _.

\section{ILLUSTRATIONS}

[All plates follow p. 106]

Plate 1. Cidaris, Tylocidaris, and Phyllacanthus.

2. Salenia, Echinopsis, Lytechinus, and Tripneustes.

3. Psammechinus, Coelopleurus, Gagaria, and Arbia.

4. Arbacia and Brochopleurus.

5. Gauthieria and Dixieus.

6. Echinometra, Strongylocentrotus, and Phymotaxis.

7. Rhopostoma, Porpitella, and Amblypygus.

8. Oligopygus.

9. Echinocyamus and Fibularia.

10,11. Clypeaster.

12. Clypeaster and Periarchus.

13. Periarchus and Echinarachnius.

14. Periarchus.

15. Protoscutella.

16. Abertella.

17, 18. Encope.

19. Leodia and Mellita.

20. Weisbordella and Laganum.

21. Neolaganum and Wythella.

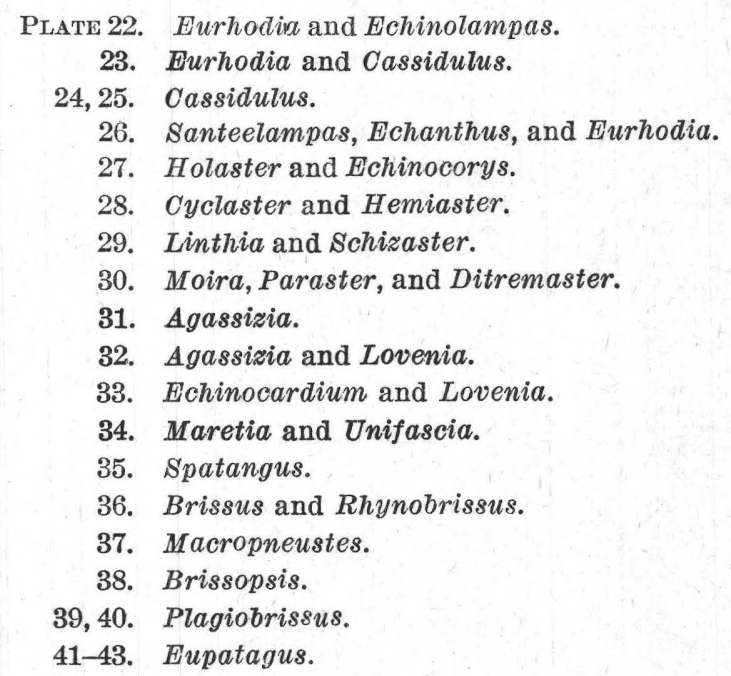





\title{
GENOZOIG EGHINOIDS OF EASTERN UNITED STATES
}

\author{
BУ C. Wrthe Cooke
}

ABSTRACT

This work describes 144 species or subspecies of echinoids from the Atlantic and Gulf Coastal Plain of the United States and from the adjacent waters. Eighteen species are restricted to the Vincentown sand of New Jersey, the Salt Mountain limestone of Alabama, or the Midway group of Alabama, all of Paleocene age. The Bashi formation of Alabama, of early Eocene age, includes one species. The middle and late Eocene formations of the Carolinas, Alabama, Mississippi, and Texas have 27 species. The late Elocene, with 43 species, has the most varied echinoid fauna; most of the species occur in the Ocala limestone or in the Inglis limestone, the Floridian equivalent of the Moodys Branch marl of Mississippi. The Oligocene faunas include only 13 species, 1 in the early Oligocene, 3 in the middle, and 11 in the late Oligocene; the middle and late have 2 species in common. Of 18 Miocene species, 3 were obtained from the early Miocene, $\mathbf{1 5}$ from the late Miocene. One specimen is doubtfully referred to the Pliocene. Of 21 species of Recent echinoids, several have been found fossil in Pleistocene beds, and 1 possibly extends back to the late Miocene. Echinoids are exceptionally good horizon markers because of their short geologic ranges.

The species fall into 60 genera and 4 subgenera, of which the following 3 genera are new: Rhopostoma, type species Ananchytes cruciferus Morton; Santeelampas, type species Catopygus oviformis Conrad; Unifascia, type species Macropneustes carolinensis Clark. The new family Unifasciidae is proposed to receive Unifascia. The type species of all the genera are designated and briefly described. New species are: Tylocidaris? salina, Tylocidaris macneili, Fibularia alabamensis, Neolaganum durhami, Hemiaster moscovensis, Lovenia alabamensis, Spatangus glenni, Brissus glenni.

Transfers of species to different genera or subgenera include: Cidaris walcotti Clark to Tylocidaris; Cidaris diatretum Morton to Echinopsis; Psammechinus floralanus Cooke to Lytechinus; Thylechinus (Gagaria) salis Cooke to Gagaria; Thylechinus (Gagaria) mossomi Cooke to Gagaria; Thylechinus (Gagaria) chickasawhay Cooke to Gagaria; Orthechinus pretiosus Clark to Brochopleurus; Cyphosoma speciosum Clark to Gauthieria; Ananchytes cruciferus Morton to Rhoposoma, new genus; Laganum dalli Twitchell to Neolaganum; Peronella cubae Weisbord to Weisbordella; Laganum johnsoni Twitchell to Weisbordella; Catopygus conradi Conrad to Cassidulus (Plagiopygus); Cassidulus (Pygorhynchus) carolinensis Twitchell to Cassidulus (Plagiopygus) ; Nucleolites lyelli Conrad to Cassidulus (Plagiopygus); Cassidulus (Pygorhynchus) georgiensis Twitchell to Cassidulus (Plagiopygus); Cassidulus (Paralampas) globosus Fischer to Cassidulus (Plagiopygus); Catopygus oviformis Conrad to Santeelampas, new genus; Cassidulus (Rhynchopygus?) holmesi Twitchell to Eurhodia (Gisopygus) ; Eupatagus? (Brissopatagus?) primus Cooke to Linthia?; Schizaster armiger Clark to Paraster; Schizaster americana Clark to Paraster; Schizaster (Linthia) ocalanus Cooke to Schizaster (Brachybrissus) ; Schizaster beckeri Cooke to Ditremaster; Macropneustes carolinensis Clark to Unifascia, new genus; Hemipatagus argutus Clark to Maretia; Hemipatagus subrostratus Clark to Maretia; Spatangus ventricosus Lamarck to Macropneustes; Eupatagus (Plagiobrissus) dixie Cooke to Plagiobrissus?; Plagionotus holmesii McCrady to Plagiobrissus?; Eupatagus (Plagiobrissus) curvus Cooke to Plagiobrissus; Euspatangus antillarum Cotteau to Eupatagus (Gymnopatagus) ; Eupatagus (Plagiobris- sus) gardnerae Cooke to Eupatagus (Gymnopatagus); Eupatagus carolinensis Clark to Eupatagus (Gymnopatagus); Eupatagus (Plagiobrissus) ocalanus Cooke to Eupatagus (Gymnopatagus).

\section{INTRODUCTION}

This report deals with the fossils echinoids of the Atlantic and Gulf Coastal Plain of the United States and some of the Recent species of the adjacent waters. It excludes the faunas of the Pacific States which were described by Grant and Hertlein (1938) in "The West American Cenozoic Echinoidea," a carefully written and still very useful work. The Cenozoic era is interpreted in its broadest sense; it includes the Paleocene era at its beginning and the Recent at its end.

This book is a revision and expansion of two papers published in the Journal of Paleontology (Cooke, 1941, 1942 ) in which the "regular" and the "irregular" Cenozoic echinoids of the eastern part of the United States were listed and described in part. The same field is covered by Clark and Twitchell's "The Mesozoic and Cenozoic Echinodermata of the United States", U. S. Geological Survey Monograph 54 (1915), but there have been many changes both in stratigraphy and taxonomy since the writing of that report, which was delayed in publication.

It is a pleasure to acknowledge the debt owed to the late Theodor Mortensen, whose monumental "Monograph of the Echinoidea" (1928-1951) has been invaluable. These volumes eased greatly the recognition of described genera, although their author did not follow consistently the international rules of zoological nomenclature and his designations of some type species are consequently not legal.

Dr. Horace G. Richards of the Academy of Natural Sciences of Philadelphia kindly arranged the loan of specimens and delivered them personally at considerable inconvenience.

The photographs were made by Nelson W. Shupe assisted by Robert H. McKinney.

The symbol USNM followed by a serial number refers to the catalogues of the United States National Museum at Washington. The symbol USGS indicates entries in the registers of Cenozoic or, in a few instances, Mesozoic localities of the United States Geological Survey, kept at the National Museum.

\section{DISTRIBUTION}

Echinoids are widely distributed throughout the marine formations of the Coastal Plain from New Jersey to Texas. They are most abundant in the limestones, 
particularly the Ocala limestone, which is rich both in number of species and in individuals. Several sandy, shallow-water formations contain a few species in great abundance. Other formations contain few or none, perhaps because living conditions were unsuitable. Table 1 includes most of the echinoid-bearing formations.

Where they occur, echinoids provide the stratigrapher with a valuable tool. Most of the species occupy a very narrow stratigraphic zone, and some of them are of great geographic range. In most instances, even the identification of the genus permits the determination of the approximate geologic age of the bed in which it was found. For instance, the genus Protoscutella seems to be restricted to beds of middle Eocene age, Periarchus to the late and possibly middle Eocene, Clypeaster to post-Eocene beds, and Arbacia to the Miocene or later. Comparison of the lists shows that few species of echinoids occupy more than one time unit.

Table 1. Distribution of Cenozoic echinoids

\begin{tabular}{|c|c|c|}
\hline \multicolumn{2}{|c|}{ Recent } & Atlantic Ocean, Gulf of Mexico. \\
\hline \multicolumn{2}{|c|}{ Pleistocene } & Horry clay (South Carolina), Anastasia formation (Florida). \\
\hline \multicolumn{2}{|c|}{ Pliocene } & Caloosahatchee formation (Florida). \\
\hline \multirow{3}{*}{ 总 } & Late & $\begin{array}{l}\text { Duplin marl (North and South Carolina), Tamiami forma- } \\
\text { tion (Florida). }\end{array}$ \\
\hline & Middle & $\begin{array}{l}\text { Choptank formation (Maryland), Chipola formation } \\
\text { (Florida). }\end{array}$ \\
\hline & Early & Tampa limestone (Florida). \\
\hline \multirow{3}{*}{ 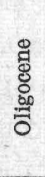 } & Late & 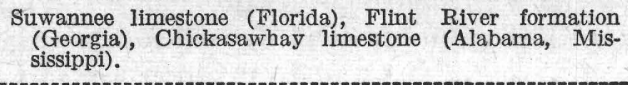 \\
\hline & Middle & Vicksburg group (Mississippi, Alabama). \\
\hline & Early & Red Bluff clay (Alabama). \\
\hline \multirow{4}{*}{ 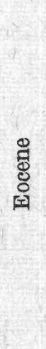 } & Late ${ }^{1}$ & $\begin{array}{l}\text { Ocala limestone (Georgia, Florida, Alabama), Yazoo clay } \\
\text { (Mississippi, Alabama). } \\
\text { Inglis limestone (Florida), Moodys Branch formation } \\
\text { (Mississippi, Alabama). }\end{array}$ \\
\hline & $\begin{array}{l}\text { Late and } \\
\text { middle }\end{array}$ & Castle Haynegimestone (North and South Carolina). \\
\hline & Middle & $\begin{array}{l}\text { Gosport sand (Alabama), Santee limestone (South and } \\
\text { North Carolina), Avon Park limestone (Florida), Win- } \\
\text { ona sand (Miss.), Weches greensand member of Mount } \\
\text { Selman formation (Texas), Warley Hill marl (South } \\
\text { Carolina), Congaree formation (South Carolina). }\end{array}$ \\
\hline & Early & Bashi formation (Alabama). \\
\hline \multicolumn{2}{|c|}{ Paleocene } & $\begin{array}{l}\text { Vincentown sand (New Jersey), Clayton formation } \\
\text { (Georgia, Alabama), Porters Creek clay (Alabama), } \\
\text { Salt Mountain limestone (Alabama). }\end{array}$ \\
\hline
\end{tabular}

${ }^{1}$ A report by Puri (1957) received after this paper had gone to the printer promotes the Ocala limestone of older authors into Ocala group. He includes in the group three limestones : The Inglis formation (herein ealled the Inglis limestone), the Williston formation, and the Crystal River formation, which is the Ocala limestone of this report.

\section{PALEOCENE FAUNA}

The Eocene series in the Southern States was formerly divided into four groups of which the oldest was the Midway group. More recently the name Paleocene series, proposed in 1874 for plant-bearing beds in Europe, has been adopted by the U. S. Geological Survey for this and other "basal" and early Eocene beds in the United States (Spieker, 1946, p. 135). The Clayton formation and the Porters Creek clay of the Midway group contain a few echinoids.

The Vincentown sand of New Jersey, a highly calcareous greensand marl, was originally classified as Cretaceous, and its fairly large fauna of echinoids was therefore described in the Cretaceous part of Monograph 54 (Clark and Twitchell, 1915, pt. 1). Later, the Vincentown was transferred to the Eocene (Cooke and Stephenson, 1928), and its echinoids were listed as early Eocene in my two Cenozoic papers (Cooke, 1941, 1942). Study of the planktonic Foraminifera led Loeblich and Tappan (1957, p. 1129) to classify the Vincentown as Paleocene.

The Salt Mountain limestone of Alabama, containing three known species of echinoids, is likewise transferred from the early Eocene to the Paleocene on the authority of Loeblich and Tappan (1957, p. 1126).

The fauna of the Paleocene includes 18 species, most of which occur in the Vincentown sand, as follows:

$\quad$ Paleocene ech
Cidaris splendens (Morton)
sp. aff. C. splendens (Morton)
Tylocidaris walcotti (Clark)
macneili Cooke, $\mathrm{n}$. sp.
salina Cooke, $\mathrm{n}$. $\mathrm{sp.}$
Salenia tumidula Clark
Echinopsis diatreta (Morton)
Gagaria salis (Cooke)
Gauthieria speciosa (Clark)
Rhopostoma cruciferum (Morton)
Echanthus georgiensis (Twitchell)
Holaster cinctus (Morton)
Echinocorys ovalis (Clark)
Hemiaster parastatus (Morton)
stella (Morton)
moscovensis Cooke, $\mathrm{n}$. sp.
Linthia alabamensis Clark
prima (Cooke)

All of these species are restricted to the Paleocene. The fauna includes several genera reminiscent of the Cretaceous, notably Hemiaster, Holaster, and Echinocorys, but Echanthrus and Linthia suggest the Eocene. The new genus Rhopostoma was formerly included in the Cretaceous genus Trematopygus.

\section{EOCENE FAUNAS}

Since the transfer of the Midway group to the Paleocene, the Eocene series has comprised only three divisions, the Wilcox group of early Eocene age, the Claiborne group of middle Eocene age, and the Jackson group of late Eocene age. Each of these has its distinctive echinoid fauna.

Early Eocene species.-Only one species, Eurhodia? elbana Cooke, is now referred to the early Eocene. It 
is known only from the Bashi formation of Alabama. Other species heretofore supposed to be early Eocene have been transferred to the Paleocene.

Middle Eocene species. - The middle Eocene appears to include at least three faunal zones. The oldest, represented by the Congaree formation of South Carolina, has yielded only Psammechinus santee. The next younger, including the Winona sand of Mississippi, the Weches greensand member of the Mount Selman formation of Texas, and the Warley Hill marl of South Carolina, carries Fibularia texana, Protoscutella mississippiensis, $P$. tuomeyi, $P$. pentagonium, and $M a-$ retia arguta. The third zone includes the Avon Park limestone of Florida with Neolaganum dalli and the Santee limestone of North and South Carolina.

The Santee fauna is quite distinctive, though there is some question as to whether some of the species attributed to it may not have come from the next younger Castle Hayne limestone. Early collectors failed to distinguish between these two limestones, which are now supposed to be separated by a stratigraphic break. The following species presumably came from the Santee: Cidaris pratti, Coelopleurus infulatus, Protoscutella conradi, $P$. plana, Santeelampas oviformis, Eurhodia rugosa.

Middle or late Eocene species.-The Castle Hayne limestone of North and South Carolina and the Gosport sand of Alabama may be partly of middle and partly of late Eocene age. The best-known locality of the Gosport is at Claiborne, but as the section there extends from well down in the underlying Lisbon formation of middle Eocene age into the late Eocene Jackson group, with Oligocene limestones exposed not far away, many fossils bearing the label Claiborne did not come from the Gosport sand, though that is the most prolific formation. Echinocyamus huxleyanus, and E. meridionalis, are reported from Claiborne and may have come from the Gosport sand. Periarchus lyelli occurs also in the basal beds of the Jackson group at Claiborne.

Echinoids attributed to the Castle Hayne limestone, some of which may have been derived from the Santee, are: Cidaris pratti, Phyllacanthus mortoni, Echinocyamus parvus, Echinolampas appendiculata, Eurhodia holmesi, Linthia hanoverensis, Unifascia carolinensis, and Eupatagus carolinensis.

One other species in the following list is of uncertain derivation. Porpitella miora was found in a well and may be older than middle Eocene.

\section{Middle or late Eocene echinoids}

Oidaris pratti Clark

Phyllacanthus mortoni (Conrad)

Coelopleurus infulatus (Morton)

Psammechinus santee Cooke

?Porpitella micra H. L. Clark
Oligopygus rotundus Cooke

Fibularia texana (Twitchell)

Echinocyamus parvus Emmons

huxleyanus Mejer

meridionalis Mejer

Periarchus lyelli (Conrad)

Protoscutella mississippiensis (Twitchell)

tuomeyi (Twitchell)

pentagonium Cooke

conradi (Cotteau)

plana (Conrad)

Neolaganum dalli (Twitchell)

Echinolampas appendiculata Emmons

Cassidulus conradi carolinensis Twitchell

Santeelampas oviformis (Conrad)

Eurhodia rugosa (Ravenel)

(Gisopygus) holmesi (Twitchell)

Linthia wilmingtonensis Clark

Linthia hanoverensis Kellum

Unifascia carolinensis (Clark)

Maretia arguta (Clark)

Eupatagus (Gymnopatagus) carolinensis Clark

Late Eocene species. -The late Eocene, with 43 species or subspecies of echinoids, was the most prolific age represented in the Coastal Plain. Two zones are recognized. The older occupies the Moodys Branch formation of Mississippi and equivalent beds in Alabama, and the Inglis limestone of Florida (Fischer, 1951). The Inglis, which is hereby given formational stature as the Inglis limestone, was first described by Vernon (1951) as the Inglis member of the Moodys Branch formation. Rocks now assigned to the Inglis limestone, though equivalent to the Moodys Branch, were formerly included in the Ocala limestone. The younger faunal zone occupies the Yazoo clay of Mississippi and western Alabama and the Ocala limestone of eastern Alabama, Georgia, and Florida. The Sandersville limestone member of the Barnwell formation in Georgia, containing Periarchus quinquefarius, is of late Ocala age or younger.

Species or varieties that seem to be confined to the Inglis limestone are Periarchus lyelli floridanus, Cassidulus ericsoni, and $C$.georgiensis globosus. Eupatagus clevei and $E$. antillarum have not been found elsewhere in the United States but occur also in the West Indies or Panama.

Most of the species in the following list occur in the Ocala limestone (the Crystal River formation of Puri, 1957).

$$
\text { Late Eocene echinoids }
$$

Cidaris pratti Clark

Phyllacanthus mortoni (Conrad)

Lytechinus floralanus (Cooke)

Brochopleurus pretiosus (Clark)

Amblypygus americanus Desor

Oligopygus wetherbyi de Loriol

haldemani (Conrad)

Protundus (Cooke) 
Fibularia vaughani (Twitchell) alabamensis Cooke, n. sp.

Periarchus lyelli (Conrad) pileus-sinensis (Ravenel) floridanus Fischer protuberans Twitchell quinquefarius (Say) quinquefarius kewi Cooke

Laganum floridanum Twitchell ocalanum Cooke

Neolaganum durhami Cooke, $\mathrm{n}, \mathrm{sp}$. Wythella eldridgei (Twitchell)

Weisbordella cubae (Weisbord) johnsoni (Twitchell)

Cassidulus conradi lyelli (Conrad) ericsoni Fischer

trojanus Cooke

(Plagiopygus) conradi (Conrad) georgiensis Twitchell globosus Fischer

Eurhodia patelliformis (Bouvé)

Paraster armiger (Clark)

Schizaster (Brachybrissus) ocalanus Cooke

Agassizia floridana de Loriol

Ditremaster beckeri (Cooke)

Macropneustes mortoni (Conrad)

Brissopsis steinhatchee Cooke biarritzensis Cotteau

Plagiobrissus curvus (Cooke) ?dixie Cooke

Eupatagus clevei (Cotteau)

(Brissopatagus) alabamensis Cooke

(Gymnopatagus) antillarum (Cotteau) gardnerae Cooke ocalanus Cooke

\section{OLIGOCENE FAUNAS}

The list of echinoids referred to the Oligocene includes only 13 species, as follows:

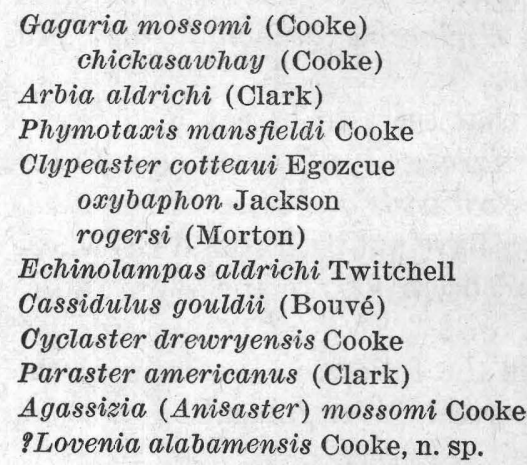

These 13 species are divisible into 3 faunas, of which the oldest includes only 1 , the middle one includes 3 , and the youngest one 11. The middle and youngest zones have 2 species in common.

Early Oligocene species.-The only echinoid known from the Red Bluff clay of Alabama is Cyclaster drewryensis. This species has not been found elsewhere.

Middle Oligocene species.-The Vicksburg group of
Mississippi and Alabama contains Clypeaster rogersi, Cassidulus gouldii?, and Paraster americanus. The first two occur also in the late Oligocene.

Late Oligocene species.-The Suwannee limestone of Florida carries Gagaria mossomi, Phymotaxis mansfieldi. Clypeaster oxybaphon, $C$. cotteaui, $C$. rogersi, Cassidulus gouldii, and Agassizia mossomi. Two of the Clypeasters were first described from late Oligocene formations of the West Indies, the other from the Vicksburg group. The remaining species are unknown elsewhere except Cassidulus gouldii, whose type came from the Flint River formation of Georgia, a littoral extension of the Suwannee. The Flint River contains also Clypeaster rogersi.

The Chickasawhay formation of Mississippi and Alabama has yielded Gagaria chickasawhay, Arbia aldrichi, Echinolampas aldrichi, and probably Lovenia alabamensis, whose age is open to question.

\section{MIOCENE FAUNAS}

All but 3 of the 18 species in the following list were derived from beds referred to the late Miocene. The exceptions are Lovenia clarki, from the Tampa limestone of Florida; Echinocyamus chipolanus, from the next younger formation, the Chipola formation of Florida; and Echinocardium orthonotum, from the Chipola and the presumably nearly contemporaneous Choptank formation of Maryland.

Many of the remaining 15 species were dredged from the Intracoastal Waterway canal in Horry County, South Carolina. They were imbedded in hard sandy limestone presumably contemporaneous with the Duplin marl, though possibly including younger beds. Several of the Waterway species occur typically at The Grove in Berkeley County, South Carolina, in beds doubtfully referred by Cooke $(1936$, p. 129-130) to the Waccamaw formation of Pliocene age but probably contemporaneous with the Tamiami formation of Florida, now classified as late Miocene. Fourteen of these species seem to be restricted to this zone, but Encope emarginata, a Recent species (if it has been correctly identified) may have come from the Pleistocene.

\section{Miocene echinoids}

Arbacia waccamaw Cooke

rivuli Cooke

improcera (Conrad)

sloani (Clark)

Echinocyamus chipolanus Cooke

Clypeaster concavus Cotteau

Encope emarginata (Leske)

macrophora (Ravenel)

tamiamiensis Mansfield

Leodia caroliniana (Ravenel)

Cassidulus sabistonensis Kellum 
Agassizia porifera (Ravenel)

Lovenia clarki (Lambert)

Echinocardium orthonotum (Conrad) gothicum (Ravenel)

Spatangus glenni Cooke, n. sp.

Brissus glenni Cooke, n. sp.

Plagiobrissus? holmesii (McCrady)

\section{PLIOCENE FAUNA}

One specimen of Encope macrophora, elsewhere occurring in the late Miocene of South Carolina, is labeled Alligator Creek, Florida, where it presumably was taken from the Caloosahatchee formation though the Tamiami formation of late Miocene age crops out not far away.

The type of Diplothecanthus dalli Twitchell (=Clypeaster rosaceus (Linnaeus)) was supposed to have been taken from the Caloosahatchee, but it almost certainly is Pleistocene, for Pleistocene fossils occur at the type locality, and the species has not since been found there in the Caloosahatchee.

\section{QUATERNARY FAUNA}

Twenty-one species of Recent echinoids are described herein-most of them live near the shore and are frequently cast up on the beaches. Some of them have been found fossil in Pleistocene deposits, and one, Encope emarginata, is associated with late Miocene species on the Intracoastal Waterway canal in South Carolina. Possibly these specimens have been misidentified, or they may have been taken from Pleistocene beds, which occur in the same area. No attempt has been made to include all the Recent species-but most of the common species are described, and some of the rarer ones.

\section{Quaternary echinoids}

Cidaris abyssicola (A. Agassiz)

affinis Philippi

tribuloides (Lamarck)

Tripneustes ventricosus (Lamarck)

Arbacia punctulata (Lamarck)

Strongylocentrotus dröbachiensis (Müller)

Echinometra Iucunter (Linnaeus)

Clypeaster rosaceus (Linnaeus) subdepressus (Gray)

Echinarachnius parma (Lamarck)

Encope emarginata (Leske)

michelini Agassiz

Mellita quinquiesperforata tenuis $\mathrm{H}$. L. Clark

Leodia sexiesperforata (Leske)

Moira atropos (Lamarck)

Echinocardium cordatum (Pennant)

Brissus unicolor (Leske)

Macropneustes ventricosus (Lamarck)

Brissopsis atlantica Mortensen

Plagiobrissus grandis (Gmelin)

Rhynobrissus cuneus Cooke

468544-59-2
KEY TO THE GENERA OF AMERICAN CENOZOIC ECHINOIDS

1 Periproct within the apical system; ambulacra not petaloid; test usually circular.

2 Ambulacra of nearly uniform width, narrow, without primary tubercles.

3 Apical plates caducous; ambulacral plates simple; periproct central Cidaridae

4 Primary tubercles perforated; spines tapering.

5 Apical system larger than peristome; zygopores narrow, oblique; pores not conjugate; spines slender._._-____-_-___-_ Cidaris

5 Apical system smaller than peristome; zygopores wide, transverse pores conjugate; spines thick_-_-_-_-_-_-_ Phyllacanthus

4 Primary tubercles imperforate; spines club

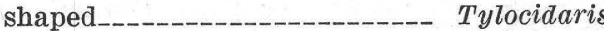

3 Apical plates persistent; ambulacral plates bigeminate; periproct eccentric; tubercles imperforate____. Saleniidae Salenia

2 Ambulacra increasing in width to the ambitus; having primary tubercles.

3 Tubercles perforated_--_-_Orthopsidae Echinopsis

3 Tubercles imperforate.

4 Ambulacra trigeminate throughout.

5 Zygopores in inclined groups of three throughout; tubercles smooth.

6 Notches deep; tubercles few

Toxopneustidae Lytechinus

6 Notches shallow; tubercles many

Echinidae Psammechinus

5 Zygopores not in inclined groups of three throughout.

6 Poriferous zones straight throughout; surface not beaded___._-_._-_ Gagaria

6 Poriferous zones straight above, in inclined groups of three below; surface beaded_-_-_-_-_-_-_-_ Brochopleurus

4 Ambulacra not trigeminate throughout.

5 Ambulacral plates simple near apex; trigeminate below; without sphaeridial pits; upper median part of interambulacra bare

Arbia

5 Ambulacral plates polyporous.

6 Sphaeridial pits present; upper part of poriferous zones straight.

7 One sphaeridial pit; upper median part of interambulacra bare or not

Arbacia

7 Several sphaeridial pits; upper median part of interambulacra bare; ambulacra bordered by a raised thread__._-__-_-_- Coelopleurus

6 Without sphaeridial pits; poriferous zones not straight.

7 Tubercles crenulate; poriferous zones uniserial, nearly straight Gauthieria

7 Tubercles smooth; zygopores in ares or multiple rows.

8 Zygopores in vertical rows.

9 Two vertical rows of zygopores in each ambulacral plate above the ambitus, one below ; two rows of primary tubercles in each area. Dixieus 
Key to the genera of American Cenozoic echinoids-Continued

9 Three vertical rows of zygopores throughout; many rows of small tubercules

Tripneustes

8 Zygopores in ares, one arc in each ambulacral plate.

9 Zygopores in connected ares of six or seven; more than two rows of primary tubercles in each area_...Phymotawis

9 Zygopores in disconnected arcs.

10 Horizontal outline circular; tubercles small Strongylocentrotus

10 Outline usually not circular; two rows of large primary tubercles in each area. Echinometra

1 Periproct outside the apical system.

2 Anterior ambulacrum like the others; apical system monobasal (madreporite central).

3 Ambulacra narrow, straight, not plainly petaloid.

4 Ambulacra not petaloid, poriferous zones continuous ; outline oval.

5 Periproct supramarginal, large; peristome oblique _._._._._._. Rhopostoma, n. gen.

5 Periproct inframarginal, large, elongated

Echinoners

4 Ambulacra subpetaloid.

5 Periproct large, elongated; outline circular or subcircular; peristome oblique

Amblypygus

5 Periproct small, circular; peristome not oblique. 6 Test moderately large ; peristome transverse, deeply sunken Oligopygus

6 Test very small; peristome circular Fibulariidae

7 Periproct supramarginal. Porpitella

7 Periproct inframarginal.

8 Test inflated; without internal partitions Fibularia

8 Test flat; with internal partitions Echinocyamus

3 Ambulacra plainly petaloid.

4 Test shield shaped, base flat or concave, no floscelle.

5 Ambulacral food grooves conspicuous; petals open distally, closed apically.

6 Without buccal tubes; grooves usually straight; five genital pores

Clypeasteridae Clypeastre

6 With buccal tubes; grooves usually forked.

7 Without lunules or ambulacral notches; with or without a posterior notch.

8 Five genital pores_.- Protoscutellidae 9 Outline circular or faintly fluted; periproct not near the margin; grooves branching

Periarchus

9 Outline not circular; periproct near the margin; grooves simple. Protoscutella
Key to the genera of American Cenozoic echinoids-Continued

8 Four genital pores.

9 Outline circular; periproct marginal or supramarginal

Echinarachnius

9 Having posterior lobes; periproct inframarginal___-_Abertella

7 With lunules or ambulacral notches

Mellitidae

8 Five genital pores; outline sagittate or not__.__________ncope

8 Four genital pores; outline circular, not sagittate.

9 Without lunule in anterior ambulacrum__._. Mellito

9 With lunule in anterior ambulacrum _-_________Leodia

5 Ambulacral food grooves not conspicuous; petals closed distally, open apically.

6 Five genital pores (petals of the type species of Laganum are open) _.._. "Laganum"

6 Four genital pores__._._._._._-_Neolaganidae

7 Hydropores in a groove; base flat.

8 Outline broadly oval_..._-_Neolaganum

8 Outline elongated decagonal_Wythella

7 Hydropores not in a groove; base concave Weisbordella

4 Test not shield shaped; upper surface swollen; peristome surrounded by a floscelle.

5 Periproct inframarginal Echinolampas

5 Periproct supramarginal.

6 Periproct wider than high.

7 Periproct flush, not sunken; peristome wider than long.

8 Periproct not terminal

8 Periproct terminal Cassidulus (Cassidulus)

Cassidulus (Plagiopygus)

7 Periproct sunken, not terminal; peristome longer then wide___Eurhodia

6 Periproct higher than wide, terminal.

7 Outline oval; upper surface inflated

Santeelampas n. gen.

7 Outline subpentagonal; upper surface low Echanthus

2 Apical system not monobasal.

3 Apical system elongated; without fascioles.

4 Anterior ambulacrum like the others; no anterior sulcus

Echinocorys

4 Anterior ambulacrum unlike the others; with anterior sulcus

Holaster

3 Apical system not elongated; with fascioles.

4 Posterior ocular plates in contact (apical system ethmorphractic) Hemiasteridae

5 Four genital pores; peripetalous fasciole only Hemiaster

5 Three genital pores; subanal and incomplete peripetalous fascioles__._._._-_Cyclaster

4 Posterior ocular plates separated by the madreporite (apical system ethmolytic).

5 Anterior ambulacrum subpetaloid; peripetalous and lateral fascioles Schizasteridae 
Key to the genera of American Cenozoic echinoids-Continued

6 Anterior ambulacrum deeply depressed. 7 Four genital pores.

8 Anterior paired petals widely spreading; apical system nearly central; posterior petals long

Linthia

8 Anterior petals less widely spreading; apical system posterior; posterior petals short _____Paraster

7 Two genital pores.

8 Ambulacral depressions open

Schizaster

8 Ambulacral depressions partly roofed over-____ Moira

6 Anterior ambulacrum not deeply depressed.

7 Four genital pores; anterior poriferous zone of anterior paired petals greatly reduced in width or obsolescent. Agassizia

7 Two genital pores; poriferous zones equal; lateral fascioles obscure

Ditremaster

5 Anterior ambulacrum not petaloid.

6 With apical ("internal") fasciole_Loveniidae

7 Test high; without large tubercles Echinocardium

7 Test low; with large tubercles_.__Lovenia 6 Without apical fasciole.

7 Marginal fasciole only; petals long, widely spreading; genital pores far apart

Unifasciidae Unifascia, n. gen.

7 Without marginal fasciole; genital pores close together.

8 Subanal fasciole only_--_Spatangidae 9 Primary tubercles on all interambulacra; labrum short; lower part of posterior ambulacra narrow__Spatangus

9 Posterior interambulacra without primary tubercles; labrum long; lower part of posterior ambulacra wide_.._-_Maretia

8 Subanal and peripetalous fascioles

Brissidae

9 No anal fasciole or branches ; peripetalous fasciole indented.

10 Posterior petals widely diverging; with primary tubercles

Macropneustes

10 Posterior petals not widely diverging; without primary tubercles

11 Anterior ambulacrum flush; anterior petals parallel ; posterior petals straight, not adjacent

Brissus
Key to the genera of American Cenozoic echinoids-Continued

11 Anterior ambulacrum depressed; anterior petals widely diverging $\mathrm{but}$ not parallel; posterior petals curved outward distally, adjacent apically

Brissopsis

9 Peripetalous fasciole not indented 10 Sides of plastron parallel; lower part of posterior ambulacra narrow.

11 Large tubercles within the peripetalous fasciole____Plagiobrissus

11 Without large tubercles

Rhynobrissus

10 Sides of plastron not parallel; lower part of posterior ambulacra wider; anal branches of fasciole usually absent__Eupatagus

\section{SYSTEMATIC DESCRIPTIONS}

\section{Family CIDARIDAE}

Mortensen (1928, p. 61) divides the Cidaridae into three subfamilies, Streptocidarinae, Stereocidarinae, and Diplocidarinae. The first and third have long been extinct, but the second ranges from the Jurassic to the Recent and includes the genus Cidaris. He arranges the Stereocidarinae into seven groups based mainly on the structure of their pedicellariae. His key to these groups (Mortensen, 1928, p. 68) is unworkable for denuded tests because its main divisions are characteristics of the pedicellariae, which are easily detached. The following key, in which the pedicellariae are subordinated, can be carried farther because it is based primarily on features of the corona.

\section{Key to Mortensen's classification}

1 Coronal plates imbricating and bevelled_..- Streptocidarinae

1 Coronal plates with rigid sutures.

2 Zygopores (pore pairs) arranged in double

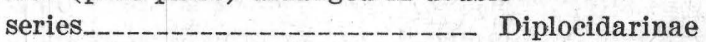

2 Zygopores arranged in single series_..-- Stereocidarinae 3 Internal ridges on and near the peristome

3 No internal ridge. Group Histocidarina

4 Horizontal sutures pitted_-_- Group Goniocidarina

4 Horizontal sutures not pitted.

5 Upper primary spines and tubercules rudimentary_-_.-_ Group Stereocidarina

6 Pores strongly conjugate, far apart, zygopores transverse_..._._._. Group

Rhabdocidarina

6 Pores close together, zygopores usually oblique. 
Key to Mortensen's classification-Continued

7 Valves of large globiferous pedicellariae with a distinct end tooth_-_ Group Cidarina

7 Valves of large globiferous pedicellariae without a distinct end tooth.

8 Small globiferous pedicellariae with a distinct end tooth_--- Group Stylocidarina

8 Small globiferous pedicellariae without a distinct end tooth Ctenocidarina

The Cidarina, Stylocidarina, and Ctenocidarina are divided by Mortensen into 18 so-called genera based mainly on the character of the spines. Most of these "genera" would be lumped by paleontologists into the single genus Cidaris, the divisions having no higher rank than sections or at most subgenera.

Among the Cenozoic cidarids here studied, only three genera are recognized: Cidaris, with narrow, oblique zygopores, perforated tubercles, and slender spines; Phyllacanthus, with wide, transverse zygopores, conjugate pores, perforated tubercles, and thick spines; and Tylocidaris, with imperforate tubercles and clubshaped spines.

\section{Genus CIDARIS Leske}

Cidaris Leske, 1117, Klein's Naturalis dispositio enchinodermatum, p. 125.

Dorocidaris A. Agassiz, 1869, Harvard College Mus. Comp. Zoology Bull., v. 1, p. 253 . Type species, D. abyssicola A. Agassiz.

Stylocidaris Mortensen, 1909, Enchinoiden deutschen Südpolar Expedition, p. 52, 54. Type species, Cidaris affinis Philippi.

Cidaris Leske. Mortensen, 1928, Monograph of the Echinoidea, v. 1, p. 286 . Includes additional synonymy.

Eucidaris Pomel. Mortensen, 1928, Idem, v. 1, p. 384.

Stylocidaris Mortensen. Mortensen, 1928, Idem, v. 1, p. 334.

Cidaris Leske. Grant and Hertlein, 1938, California Univ. (Los Angeles) Pub. Math. Phys. Sci., v. 2, p. 4.

Cidaris Leske. Cooke, 1941, Jour. Paleontology, v. 15, no. 1, p. 5 .

Cidaris Leske. Cooke, 1946, Idem, v. 20, no. 3, p. 199.

Cidaris Leske. Cooke, 1953, U. S. Geol. Survey Prof. Paper 254, p. 4.

Type species, Cidaris papillata Leske, $1778=$ Echinus cidaris Linnaeus, 1758 , by absolute tautonomy. Linnaeus' original concept of Echinus cidaris, before the publication of the tenth edition of his Systema Naturae, seems to have been based on a large, denuded Phyllacanthus, which was figured by Loven (1887, pl. 5) under the name Echinus cidaris L. In the tenth edition, Linnaeus altered the description of Echinus cidaris so that it does not fit that specimen but does apply to the species living in the "Oceano Norvegico," which has since been identified as Cidaris papillata Leske (Loven, 1887, p. 149).
H. L. Clark (1909, p. 88) cites Cidarites metularia Lamarck as the type species of Eucidaris Pomel (1883, p. 109). This designation is not valid, for that species is not 1 of the 6 (all Jurassic) named by Pomel. These Jurassic species are $C$. morieri, $C$. honorinae, $C$. propinqua, $C$. monilifera, and $C$. multipunctata. I here designate Cidarites monilifera Goldfuss (1826; Cotteau, $1875-1880$, p. 163 , pls. 185,186 ) as the type of Eucidaris. Whether the genuine Eucidaris should be considered a valid subgenus of Cidaris, as Pomel proposed it, or a genus, as Mortensen (1928, p. 384) treats it, I am not prepared to recommend.

According to Mortensen, Cidaris cidaris ranges in shape from nearly spherical to flattened; in size from less than $18 \mathrm{~mm}$ in horizontal diameter to more than $59 \mathrm{~mm}$. Small specimens have 5 or 6 tiers of interambulacral plates, large ones have 8 or 9 . The ambulacra are distinctly sinuous; they are one-fifth as wide as the interambulacra, and the interporiferous zones are about twice as wide as the poriferous zones. Mortensen's (1928, pl. 31, figs. 1-7) figures show that the apical system is subpentagonal, somewhat more than half as wide as the horizontal diameter; it is slightly larger than the peristome, which is plainly pentagonal. Each interambulacral plate has one large perforated primary tubercle in a rather depressed areole, which is bordered by a ring of imperforate miliary tubercles somewhat larger than those that cover the rest of the plate. The primary spines are long, slender to robust, gently tapering to fusiform. The shaft is provided with fine spicules arranged in 12 to 16 longitudinal ridges.

\section{Cidaris abyssicola (A. Agassiz)}

Dorocidaris abyssicola A. Agassiz, 1869, Harvard College Mus. Comp. Zoology Bull. v. 1, p. 253.

Cidaris (Dorocidaris) papillata (Leske) (part). A. Agassiz, 1872, Harvard College Mus. Comp. Zoology Mem., v. 3, p. 254 , pl. 1, figs. $1-4$.

Dorocidaris abyssicola A. Agassiz. H. L. Clark, 1907, Harvard College Mus. Comp. Zoology Bull., v. 51, no. 7, p. 208.

Cidaris abyssicola (A. Agassiz). Mortensen, 1928, Monograph of the Echinoidea, v. 1, p. 301, pl. 31, figs. 11-14; pl. 33, fig. 4. Includes additional synonymy.

Dorocidaris abyssicola A. Agassiz. Cooke, 1941, Jour. Paleontology, v. 15, no. 1, p. 6.

Occurrence.-Off the eastern coast of North America south of Marthas Vineyard at depths usually greater than 200 meters. It has not been reported fossil.

Geologic unit.-Recent.

Type.-Probably in the Museum of Comparative Zoology, Cambridge, Mass.

Remarls.-A. Agassiz (1872) united this species with the very variable Cidaris papillata (=C. cidaris), from which it is distinguishable by its smooth primary spines (H. L. Clark, 1907, p. 208). 


\section{Cidaris Affinis Philippi}

Cidaris affinis Philippi, 1845, Archiv für Naturgeschichte, Jahrg. 11, v. 1, p. 351.

Tretocidaris affinis (Philippi). H. L. Clark, 1907, Harvard College Mus. Comp. Zoology Bull., v. 51, p. 203.

Stylocidaris affinis (Philippi). Mortensen, 1928, Monograph of the Echinoidea, v. 1, p. 336, pl. 36, figs. 1-7; pl. 72, fig. 15. Includes additional synonymy.

According to Mortensen (1928) the apical system is about half the horizontal diameter, and the peristome is somewhat smaller. The horizontal diameter of 15 specimens ranges from $4 \mathrm{~mm}$ to $43 \mathrm{~mm}$, and the number of tiers of interambulacral plates ranges from 4 to 7. The ambulacra are scarcely distinguishable from those of $C$. cidaris. The long, slender spines are provided with about 18 longitudinal serrate ridges.

Occurrence.-Mediterranean Sea, Caribbean Sea, and off Florida, in water 30 meters to 1000 meters deep.

Geologic unit.-Recent.

Type.-Unknown.

Remarks.-This species was identified as Dorocidaris papillata (=Cidaris cidaris) by A. Agassiz (1872) but later was made the type of a new genus, Stylocidaris Mortensen (1909).

\section{Cidaris tribuloides (Iamarck)}

Plate 1, figures 1, 2

Cidarites tribuloides Lamarck, 1816, Histoire naturelle des animaux sans vertèbres, v. 3 , p. $56 ; 2$ ed. $(1840)$, v. 3, p. 380 .

Cidaris tribuloides (Lamarck). A. Agassiz, 1872, Harvard College Mus. Comp. Zoology Mem., v. 3, pt. 2, p. 99, 253, pl. $1 d$; pl. 2 , figs. $1-3$; pl. 2c, fig. 13.

Cidaris tribuloides (Lamarck). H. L. Clark, 1907, Harvard College Mus. Comp. Zoology Bull., v. 51, no. 7, p. 185.

Eucidaris tribuloides (Lamarck). Mortensen, 1928, Monograph of the Echinoidea, v. 1, p. 400 , pl. 41, figs. $9-16$; pl. 48 , fig. $1 ;$ pl. 73 , fig. 1 ; pl. 86 , fig. 16 . Includes additional synonymy.

Eucidaris tribuloides (Lamarck). H. L. Clark, 1933, New York Acad. Sci., Scientific Survey of Porto Rico and the Virgin Islands, v. 16, pt. 1, p. 76.

Cidaris tribuloides (Lamarck). Cooke, 1941, Jour. Paleontology, v. 15, no. 1, p. 5.

Apical system subcircular or subpentagonal, easily detached, less than half the horizontal diameter. Periproct pentagonal, covered with polygonal plates. Peristome circular, nearly half the horizontal diameter, covered with imbricating plates. Ambulacra nearly straight; poriferous zones narrower than the interpuriferous zones; zygopores slightly oblique, pores separated by a projecting wall; interporiferous zones bordered on each side by a row of imperforate miliary tubercles interspersed with small granules. Interambulacra composed of 5 to 12 tiers of plates in individuals ranging from $10 \mathrm{~mm}$ to $53 \mathrm{~mm}$ in horizontal diameter (Mortensen, 1928, p. 402). Each plate sup- ports on its outer edge one large raised perforated tubercle surrounded by a ring of imperforate miliary tubercles; median part covered by transverse rows of smaller imperforate miliary tubercles. Primary tubercles supporting long, rather thick, cylindrical spines decorated with longitudinal rows of circular nodes; miliary circles bearing short, flat, ribbed spines; other miliary tubercles bearing shorter, narrower, flat spines.

Horizontal diameter of an individual having 8 tiers of coronal plates, $34.5 \mathrm{~mm}$; height $24 \mathrm{~mm}$; diameter of apical system, $14.3 \mathrm{~mm}$; diameter of peristome, $15.6 \mathrm{~mm}$.

This description is based mainly on specimens from Jamaica (USNM 27843).

Occurrence.-Atlantic Ocean from South Carolina to Bermuda and Brazil. It is mainly a littoral form but has been dredged from water as deep as 450 meters.

Geologic unit.-Recent.

Type.-Jardin des Plantes, Paris (fide A. Agassiz). Figured specimen USNM 562261, from the north shore of Cuba, R. E. Dickerson.

Remarks.-This common West Indian species has not been found fossil in the United States. Jackson (1922) figures it from questionable Miocene deposits near Santiago, Cuba. It is easily distinguishable from Cidaris abyssicola by the greater number of its coronal plates and by its conspicuously raised, not sunken, primary tubercles.

Cidaris tribuloides has been referred to Eucidaris Pomel (1883, p. 109) on the supposition that Cidarites metularia Lamarck is the type of Eucidaris.

\section{Cidaris splendens (Morton)}

Plate 1, figure 10

Cidarites splendeus Morton, 1841, Acad. Nat. Sci. Philadelphir Proc., v. 1, p. 132. Typographical error for splendens.

Cidarites armiger Morton, 1842, Acad. Nat. Sci. Philadelphia Jour., ser. 1, จ. 8, p. 215, pl. 2, fig. 1.

Cidaris splendens (Morton). Clark, 1893, U. S. Geol. Survey Bull. 97 , p. 33, pl. 6, figs. 3a-g.

Cidaris splendens (Morton). Clark in Weller, 1907, New Jersey Geol. Survey Paleontology ser., v. 4, p. 279, pl. 7, figs. 1-9.

Cidaris splendens (Morton). Clark, 1915, U. S. Geol. Survey Mon. 54, p. 46, pl. 9, figs. 4a-b, 5a-f, 6.

Cidaris splendens (Morton). Cooke, 1941, Jour. Paleontology, v. 15, no. 1. Not pl. 1, fig. 12 (=Cidaris sp. aff. C. splendens). Not pl. 1, figs. 13-15 (=Tylocidaris? sp.).

Apical system occupying more than half the horizontal diameter, circular, larger than the peristome. Ambulacra sinuous; poriferous zones narrow, zygopores oblique, pores separated by a high wall; interporiferous zones more than twice as wide as the poriferous zones, bordered on each side by a row of beadlike imperforate tubercles, median part covered by several rows of smaller beads. Interambulacra composed of about six tiers of coronal plates, each with a large perforate tubercle, which occupies only about half of the 
plate; remainder of plate covered with coarse beads. Peristome about half the horizontal diameter, pentagonal. Spines long, cylindrical.

Horizontal diameter of specimen figured by Clark (USNM 559497) $39.7 \mathrm{~mm}$.

Occurrence.-New Jersey: Timber Creek (Acad. Nat. Sci. Philadelphia 1454, S. G. Morton, type). Vincentown (USNM 559497, F. B. Meek).

Geologic unit.-Paleocene, Vincentown sand.

Type.-Academy of Natural Sciences of Philadelphia 1454.

Remarks.-Cidaris splendens has proportionately fewer and larger coronal plates than $C$. pratti and $C$. tribuloides or Phyllacanthus mortoni, and consequently its plates are narrower and more nearly equilateral.

\section{Cidaris sp. aff. C. splendens (Morton)}

Plate 1, figure 11

Cidaris splendens (Morton) part. Cooke, 1941, Jour. Paleontology, v. 15, no. 1, p. 5, pl. 1, fig. 12.

Fragments of a $C$ idaris having coarsely beaded plates resembling those of Cidaris splendens are rare in the Salt Mountain limestone. Inasmuch as the fragments represent a test much smaller than those of Cidaris splendens, the species is probably different. Spindleshaped spines in the Salt Mountain are tentatively referred to Tylocidaris.

Occurrence-Alabama: Salt Mountain, 6 miles south of Jackson, Clarke County (USGS 13395, C. W. Cooke; USGS 3646, T. W. Vaughan). Richmond Branch, 0.5 mile north of Salt Mountain (L. D. Toulmin).

Geologic unit.-Paleocene, Salt Mountain limestone.

Figured specimen.-USNM 498879a.

\section{Cidaris pratti Clark}

Plate 1, figures 6, 18, 19

Cidaris pratti Clark, 1915, U. S. Geol. Survey Mon. 54, p. 114, pl. 55, fig. 3.

Cidaris smithi Clark, 1915, idem, p. 157, pl. 73, figs. 2a-c, 3 . Not Cidaris smithii Wright, 1855.

Cidaris (Dorocidaris) smithi Clark. Lambert and Thiéry, 1925, Nomenclature raisonnée des échinides, fasc. 8 , p. 560 .

Cidaris pratti Clark. Lambert and Thiery, 1925, idem. p. 559.

Cidaris pratti Clark. Kellum, 1926, U. S. Geol. Survey Prof. Paper 143, p. 14.

Cidaris smithi Clark. Cooke, 1941, Jour. Paleontology, v. 15, no. 1, p. 5 .

Test small to medium sized. Apical system circular, small. Peristome unknown. Ambulacra straight, fairly wide for the genus; zygopores slightly oblique, separated by a strong thread, which gives the pores a conjugate appearance though they are separated by a raised wall; interporiferous zones about as wide as the poriferous zones, bordered by a row of large nodules, one to each zygopore, rows separated by a variable number of smaller granules. Interambulacra composed of many coronal plates, at least nine tiers in the type of $C$. smithi; tubercles well elevated, perforated, those on the upper half smooth, others crenulated; remainder of plate covered with large granules. Detached spines cylindrical, set with longitudinal serrate ridges separated by finely lined spaces.

Horizontal diameter of type of $C$. smithi (slightly crushed), about $35 \mathrm{~mm}$. Diameter of apical system $11.6 \mathrm{~mm}$. Fragments from North and South Carolina are smaller.

Occurrence.-North Carolina: Wilmington (USGS 782, type; 783, T. W. Stanton; USGS 5611, USNM 166500 b, 166504, L. W. Stephenson; USGS 7302, B. L. Miller). Castle Hayne (USGS 4286, L. W. Stephenson).

South Carolina: Santee-Cooper Diversion Canal near Eadytown; Berkeley County (USGS 18353, C. W. Cooke and F. S. MacNeil).

Alabama: The Rocks, sec. 35, T 9 N, R $1 \mathrm{E}$, Clark County (USNM 498880, type of $C$. smithi Clark, T. H. Aldrich).

Geologic unit.-Middle and late Eocene; Castle Hayne or Santee limestone in North Carolina, Santee limestone in South Carolina, probably Ocala limestone in Alabama.

Types.-USNM 164663, a fragment. Type of $O$. smithi Clark, USNM 498880, the figured specimen.

Comparisons.-Cidaris pratti differs from Phyllacanthus mortoni in its relatively more numerous coronal plates, the narrowness and greater inclination of its zygopores, and the more perfect roundness of its horizontal outline. It probably did not grow so large. It has more coronal plates than $\sigma$. splendens, and its ambulacra are straighter. The threads separating its zygopores are much higher and more conspicuous than those of $C$. tribuloides. Its perforated tubercles and cylindrical spines distinguish it from Tylocidaris walcotti.

\section{Genus Phyllacanthus Brandt}

Cidarites (Phyllacanthus) Brandt, 1835, Prodomus descriptionis animalium, p. 67.

?Rabdocidaris Desor, 1855, Synopsis des échinides fossiles, fasc. 1, p. 2,39 .

Leiocidaris Desor, 1856, idem, fasc. 3, p. 48.

?Rhabdocidaris Desor. Cotteau, 1861, Paléontologie française, Terrain crétacé, ser. 1, v. 7, p. 335.

Oidaris (Phyllacanthus) Brandt. A. Agassiz, 1872, Harvard College Mus. Comp. Zoology Mem., v. 3, pt. 1, p. 149; 1873, pt. 3, p. 387.

?Rabdocidaris Desor. De Loriol, 1873, Échinologie helvétique, pt. 2, p. 57.

Leiocidaris Desor. De Loriol, 1873, idem, p. 63.

?Rhabdocidaris Desor. Cotteau, 1875, Paléontologie française, Terrain jurassique, ser. 1, v. 10, p. 247.

?Rhabdocidaris (Phyllacanthus) Brandt. Pomel, 1883, Classification méthodique et genera des échinides, p. 111.

?Rhabdocidaris Desor. Döderlein, 1887, Die japanischen Seeigel, pt. 1, p. 42.

Leiocidaris Desor. Döderlein, 1887, idem, p. 43.

Cidaris (Rhabdocidaris) Desor. Duncan, 1889, Linnean Soc. London Jour., Zoology, v. 23, p. 31.

?Rhabdocidaris Desor. Cotteau, 1892, Paléontologie française, Terrain tertiaire, ser. 1, v. 2, p. 451.

Phyllacanthus Brandt. Döderlein, 1906, Wissenschaftliche Ergebnisse der deutschen Tiefsee-Expedition auf dem Dampfer "Valdivia" 1898-1899, v. 5, pt. 2, p. 103. 
Phyllacanthus Brandt. H. L. Clark, 1907, Harvard College Mus. Comp. Zoology Bull., v. 51, no. 7, p. 186.

?Rhabdocidaris Desor. Lambert and Thiéry, 1910, Nomenclature raisonnée des échinides, fasc. 2, p. 136.

Leiocidaris Desor. Lambert and Thiéry, 1910, idem, p. 153.

?Rhabdocidaris Desor. Mortensen, 1928, Monograph of the Echinoidea, v. 1, p. 490.

Phyllacanthus Brandt. Mortensen, 1928, idem, p. 500.

Phyllacanthus Brandt. Cooke, 1941, Jour. Paleontology, v. 15, no. 1 , p. 3 .

Type species, Cidarites (Phyllacanthus) dubius Brandt, designation validated by Opinion 208 of the International Commission on Zoological Nomenclature. This Recent species, known only from the Bonin Islands (Mortensen, 1928, p. 512), has sometimes been confused with Phyllacanthus imperialis (Lamarck), the type species of Leiocidaris Desor, designated by de Loriol (1873, p. 63).

The type species of Rabdocidaris Desor is Cidaris orbignyana Agassiz (Cotteau, 1878, p. 299, pl. 223-226) a Jurassic species, designated by Savin (1903, p. 23). It is large, has wide poriferous zones, conjugate pores, transverse zygopores, and strongly crenulated tubercles. Besides the greater size of this species, which is not a distinctive generic feature, the most conspicuous difference between it and Phyllacanthus dubius appears to be the crenulation of its tubercles-a feature of little taxonomic importance.

Phyllacanthus dubius differs from $C$ idaris cidaris in the proportionately larger size of its apical system, the more conspicuous conjugation of its pores, its transverse, not inclined zygopores, and its proportionately fewer coronal plates.

\section{Phyllacanthus mortoni (Conrad)}

Plate 1, figures 15-17

?Cidaris alabamensis Morton, 1846, Acad. Nat. Sci. Philadelphia Proc., v. 3, p. 51.

Cidarites mortoni Conrad, 1850, Acad. Nat. Sci. Philadelphia Jour., ser. 2, v. 2, p. 40, pl.1, fig. 13.

Cidaris mitchellii Emmons, 1858, North Carolina Geological Survey, Agriculture of the eastern counties, p. 305, fig. 237, Cidaris carolinensis Emmons, 1858, idem, p. 305, fig. 238.

?Cidaris blandus de Gregorio, 1890, Monographie de lap faune éocenique de l'Alabama, p. 253, pl. 44, fig. 5. Typographical error for blandis.

?Cidaris moerens de Gregorio, 1890, idem, p. 252, pl. 43, figs. $22,23$.

?Cidaris modestus de Gregorio, 1890, idem, p. 253, pl. 43, fig. 26. ?Cidaris ordinatus de Gregorio, 1890, idem, p. 252, pl. 44, fig. 1. ?Cidaris perdubius de Gregorio, 1890, idem, p. 253, pl. 44, fig. 2. ?Cidaris moereus de Gregorio. Clark and Twitchell, 1915, U. S. Geol. Survey Mon. 54, p. 115. Typographical error for moerens.

?Cidaris modestus de Gregorio. Clark and Twitchell, 1915, idem, p. 115.

?Cidaris ordinatus de Gregorio, Clark and Twitchell, 1915, idem, p. 115.
?Cidaris perdubius de Gregorio. Clark and Twitchell, 1915, idem, p. 116.

?Cidaris blandis de Gregorio. Clark and Twitchell, 1915, idem, p. 116.

Cidaris mortoni (Conrad). Clark and Twitchell, idem, p. 157, pl. 73, fig. 1.

?Cidaris alabamensis Morton. Clark and Twitchell, idem, p. 116.

Cidaris georgiana Clark in Clark and Twitchell, idem, p. 158, pl. 73, fig. 4.

Cidaris (Dorocidaris) georgiana Clark. Lambert and Thiéry, 1925, Nomenclature raisonnée des échinides, fasc. 8 , p. 560. Leiocidaris carolinensis (Emmons). Lambert and Thiéry, 1925 , idem, p. 560.

Leiocidaris mitchelli (Emmons). Lambert and Thiéry, 1925, idem, p. 560 .

Phyllacanthus mortoni (Conrad). Cooke, 1941, Jour. Paleontology, v. 15, no. 1, p. 3, pl. 1, figs. 16-18.

Cidaris (Phyllacanthus) mortoni (Conrad). Fischer, 1951, Florida Geol. Survey Bull. 34, pt. 2, p. 55.

Test large, maximum known horizontal diameter about $75 \mathrm{~mm}$. Apical system subcircular, larger than peristome. Ambulacra nearly uniform in width, ribbonlike; poriferous zones about twice as wide as the interporiferous zones; pores round or oval, conjugate; zygopores transverse, separated by a ridge; interporiferous zones granular. Interambulacra composed of about 8-10 tiers of plates, the median area somewhat sunken; plates wider than high; tubercles smooth, perforated, high; granules arranged in transverse rows separated by a groove. Peristome pentagonal, the angles truncated at the ambulacra.

Disconnected spines from near Albany, Georgia (USGS 7121), where Phyllacanthus mortoni is the only cidarid known, are decorated with longitudinal rows of spinelets. On some the spinelets are uniform in size; others have longer thornlike spinelets at regular intervals.

Occurrence.-Alabama: Washington County (type of Cidaris alabamensis, fide Morton). Clarke County 5 miles southeast of Whatley (USGS 7159, C. W. Cooke). Claiborne, Monroe County (types of Cidaris blandis, $O$. modestus, $C$. moerens, $C$. ordinatus, C. perdubius). South of the center of sec. 22, T $1 \mathrm{~N}, \mathbf{R} 18 \mathrm{E}, 0.75$ mile west of Adams Crossroads, Covington County (USGS 16923, F. S. MacNeil).

Georgia : Near Palmyra, Lee County (type of $C$. mortoni). Flint River at bridge of Seaboard Railway west of Coney, Crisp County (USGS 4034, S. W. McCallie). North of Albany (USGS 3617, type of Cidaris georgiana, T. W. Vaughan) USGS 7121, C. W. Cooke; USGS 12021, C. W. Cooke and W. H. Monroe). Flint River at Dry Bread Shoals (USGS 7126, C. W. Cooke). Flint River at Normans Ferry (USGS 7127, C. W. Cooke and J. E. Brantly). Newton road $73 / 4$ miles from Bainbridge (USGS 3770, S. W. McCallie). Bainbridge (USGS 6171 , L. W. Stephenson; USGS 7097, C. W. Cooke; USGS 13611, A. F. Foerste)

Florida: Kendrick, Marion County (USGS 14125, W. C. Mansfield and C. W. Mumm). Pit on Steinhatchee River in Dixie County north of US 19 (USGS 14541, C. W. Cooke; R. B. 
Becker). Perry road 5.2 miles west of Mayo, Lafayette County (USGS 14537, C. W. Cooke).

North Carolina: Craven County (types of Cidaris carolinensis and $C$. mitchellii).

Geologic unit.-Middle and late Eocene: Gosport sand (Claiborne, Ala.); Ocala limestone (Alabama, Georgia, and Florida); Castle Hayne limestone or Santee limestone (North Carolina).

Types.-The types of Cidaris alabamensis and Cidarites mortoni appear to be lost; they are not in the Academy of Natural Sciences of Philadelphia. The types of Cidaris carolinensis and $C$. mitchellii are in the United States National Museum, USNM 498882 and 498883 , respectively, deposited by Williams College. The types of Cidaris blandis, C. modestus, C. moerens, $C$. ordinatus, and $C$. perdubius presumably are in the De Gregorio collection at Palermo, Italy. They are unidentifiable fragments of spines resembling spines from USGS 7159. The type of Cidaris georgiana is USNM 166485.

Comparisons.-Phyllacanthus mortoni is larger, when mature, than any other cidarid from the Eastern States. Its ambulacra are straighter, its zygopores are wider and more nearly transverse, and its pores are more conspicuously conjugate. Its ambulacra are more constricted along the median suture-a feature that becomes more conspicuous with increasing size.

There is considerable variation in the coarseness of its granulation. The granules on the type of $O$. carolinensis are coarser than those of $C$. mitchellii, which are more like the average specimen from Georgia.

\section{Genus Tylocidaris Pomel}

Tylocidaris Pomel, 1883, Classification méthodique et genera des échinides, p. 109.

'I'ylocidaris Pomel. Döderlain, 1887, Die japanischen Seeigel, Theil 1, p. 41.

'I'ylocidaris Pomel. H. L. Clark, 1909, Harvard College Mus. Comp. Zoology Bull., v. 51, p. 183.

Tylocidaris Pomel. Lambert and Thiéry, 1910, Nomenclature raisonnée des échinides, fasc. 2, p. 156.

Tylocidaris Pomel. Mortensen, 1928, Monograph of the Echinoidea, v. 1, p. 485.

Tylocidaris Pomel. Mortensen, 1934, Geol. Mag., v. 71, no. 843, p. 398.

Tylocidaris Pomel. Cooke, 1941, Jour. Paleontology, v. 15, no. 1, p. 6.

Type species, Cidaris gibberula Agassiz, from the Cenomanian of France, designated by Savin (1905, p. 282). This species was described from an isolated spine. As figured by Cotteau (1862, p. 234, pl. 1051, figs. 15-18; pl. 1054, figs. 1-7), Tylocidaris gibberula differs from $C$ idaris cidaris chiefly in its imperforate tubercles and spindle-shaped spines. Tylocidaris clavigera (König), from the White Chalk of England, has bludgeon-shaped spines, and some of its tubercles show a rudimentary perforation. Mortensen (1928, p. 486) considers it as the type species.

\section{Tylocidaris walcotti (Clark)}

Plate 1, figures 7-9

Cidaris walrotti Clark, 1891, Johns Hopkins Unit. Circ., v. 10, no. 87 , p. 75 .
Cidaris walcotti Clark. Clark, 1893, idem, v. 12, no. 103, p. 51. Cidaris walcotti Clark. Clark, 1893, U. S. Geol. Survey Bull. 97 , p. 37 , pl. 6 , figs. $4 a-d$.

Cidaris walcotti Clark. Clark in Weller, 1907, New Jersey Geol. Survey, Paleontology ser., v. 4, p. 281, pl. 7, figs. 10-13.

Cidaris walcotti Clark. Clark, 1915, U. S. Geol. Survey Mon. 54 , p. 45 , pl. 9 , figs. $3 a-d$.

Cidaris walcotti Clark. Lambert and Thiéry, 1925, Nomenclature raisonée des échinides, fasc. 8, p. 559.

Tylocidaris walcotti (Clark). Cooke, 1941, Jour. Paleontology, v. 15 , no. 1, p. 6.

Test small. Ambulacra narrow; zygopores short, pores round, close together, separated by a wall; interporiferous zones having two rows of small imperforate tubercles. Primary tubercles imperforate, sunken, widely separated; miliary spaces coarsely granulated.

Height of type, a fragment, $12.8 \mathrm{~mm}$.

Occurrence.-New Jersey: Timber Creek (type). Vincentown. Blackwoodstown (USNM 18828, F. B. Meek).

Geologic unit.-Paleocene, Vincentown sand.

Type-Acad. Nat. Sci. Philadelphia 1451. Figured specimen (pl. 1, figs. 7, 8). USNM 18828 .

Tylocidaris? salina Cooke, n. sp.

Plate 1, figures 12-14

Cidaris splendens (Morton) part. Cooke, 1915, Jour. Paleontology, v. 15, no. 1, p. 5, pl. 1, figs. 13-15.

Spines stout, fusiform, with nodose longitudinal ribs.

Length of longest cotype $22 \mathrm{~mm}$; maximum diameter $4.1 \mathrm{~mm}$.

Occurrence.-Alabama: Salt Mountain, Clarke County, about 5 miles south of Jackson (USGS 3646, USNM 166498, T. W. Vaughan; USGS 13395, USNM 498879b, type, C. W. Cooke). Richmond Branch, 1/2 mile north of Salt Mountain (L. D. Toul$\min )$.

Geologic unit.-Paleocene, Salt Mountain limestone.

Types.-USNM 498879b, from USGS 13395.

Remarks.-This species, known only from detached spines, differs from Cidaris splendens (Morton) in the shape of its spines, which are shorter and fusiform as contrasted with long and straight sided. They are much longer and more slender than those of Tylocidaris macneili Cooke. They are fairly common in the Salt Mountain limestone.

$$
\begin{gathered}
\text { Tylocidaris macneili Cooke, n. sp. } \\
\text { Plate 1, figures 3-5 }
\end{gathered}
$$

Test small, globular. Ambulacra straight, narrow; pores small, close together; zygopores slightly oblique. Interambulacra wide, coarsely granulated; tubercles proportionately large, smooth, protruding, imperforate. Disconnected spines longitudinally ribbed, nodose, terminating in a rosette; short and strongly clubshaped or weakly fusiform; very large in proportion to the size of the test.

\section{Height of test $7 \mathrm{~mm}$.}

Occurrence.-Alabama: Road cut in the SW $1 / 4$ sec. 36, T. 9 N, R $28 \mathrm{E}$, in Henry County (USGS 18053, 15178, F. S. MacNeil). 
Geologic unit.-Paleocene, Clayton formation.

Types.-Holotype, a fragment of the test, USNM 562262a; paratypes, disconnected spines, USNM 562262b, c.

Remarks.-This species, though much smaller, is similar to Tylocidaris clavigera (König) from the Senonian of Europe. There is no assurance that the spines figured represent the same species, though similar spines are attached to a test of Tylocidaris baltica figured by Mortensen (1928, p. 485, fig. 152). Other longer, more slender spines from the same locality may represent a species of Cidaris.

\section{Family SALENIIDAE}

Genus Salenia Gray

Salenia Gray, 1835, Zool. Soc. London Proc., v. 3, p. 58. Salenia Gray. Mortensen, 1935, Monograph of the Echinoidea, v. 2, p. 367. Includes additional synonymy.

Salenia Gray. Cooke, 1941, Jour. Paleontology, v. 15, no. 1, p. 7. Salenia Gray. Cooke, 1946, Jour. Paleontology, v. 20, no. 3, p. 202.

Salenia Gray. Cooke, 1953, U. S. Geol. Survey Prof. Paper 254, p. 5.

Type species Cidarites scutiger Münster (in Goldfuss, 1826 , pt. 1, p. 121, pl. 49, figs. 4a-b), by monotypy, from the Cenomanian of Germany. This species has been figured also by Cotteau (1861, p. 154, pls. 1036, 1037) and by Mortensen (1935, p. 369, fig. 195a-c), who copies some of Cotteau's figures. The specific name, meaning "shield bearer" or "shield bearing," was suggested by the thick, rigid shieldlike apical system, which includes 5 exsert ocular plates, 5 perforated genital plates, and a central suranal plate. The periproct occupies an eccentric location behind and to the right of the suranal plate. The peristome is circular and plainly notched. The ambulacra are narrow and ribbonlike, as in Cidaris, and are decorated with 2 rows of small, even, imperforate tubercles, 1 to every other zygopore, and small granules. The number of interambulacral plates varies with the age (four and seven tiers are shown by Cotteau), and each plate carries granules and small tubercles, which do not form a continuous ring around the primary tubercle.

Salenia first appeared in the Early Cretaceous; three species are recognized in the Comanche series of Texas, and one in the Anacacho limestone of Late Cretaceous age (Cooke, 1953, p. 6). Only one species is known in the Vincentown sand of Paleocene age of New Jersey, and one in the Salt Mountain limestone of Paleocene age of Alabama. Mortensen describes five species living in the oceans at depths ranging from 90 to 540 meters.

Specific distinctions in Salenia are based primarily on the shape and ornamentation of the apical plates, both of which features are subject to considerable individual variation. Young individuals commonly appear to be more depressed than mature ones because their apical system is proportionately larger. As the coronal plates increase in size and number, the shape of the test becomes more nearly globular.

\section{Salenia tumidula Clark}

Plate 2, figures 1-7

Salenia tumidula Clark, 1891, Johns Hopkins Univ. Circ., v. 10, no. 87, p. 75 .

Salenia bellula Clark, 1891, idem, v. 10, no. 87, p. 75.

Salenia tumidula Clark. Clark, 1893, idem, v. 12, no. 103, p. 51. Salenia bellula Clark. Clark, 1893, idem, v. 12, no. 103, p. 51.

Salenia tumidula Clark. Clark, 1893, U. S. Geol. Survey Bull. 97, p. 41, pl. 11, figs. 1a-j.

Salenia belluta Clark. Clark, 1893, idem, p. 43, pl. 11, figș. 2a-g. Salenia tumidula Clark. Clark in Weller, 1907, New Jersey Geol. Survey, Paleontology ser., v. 4, p. 282, pl. 8, figs. 1-10. Salenia bellula Clark. Clark in Weller, 1907, idem, p. 283, pl. 8, figs. 11-17.

Salenia tumidula Clark. Clark, 1915, U. S. Geol. Survey Mon. 54, p. 50, pl. 13, figs. 1a-j.

Salenia bellula Clark. Clark, 1915, idem, p. 51, pl. 13, figs. 2a-g. Salenia tumidula Clark. Cooke, 1941, Jour. Paleontology, v. 15, no. 1, p. 7 .

Salenia bellula Clark. Cooke, 1941, idem, p. 7.

Test small, subglobular. Apical system pentagonal, all the plates shaped like cogwheels and decorated with nodular threads radiating from the center; ocular plates a segment of about $150^{\circ}$ with the apex outward, all exsert. Periproct subtriangular, at the junction of the suranal plate and two genital plates, encroaching on all three, bordered by a thickened rim. Ambulacra narrow, of nearly uniform width throughout, slightly sinuous, containing two rows of imperforate tubercles, one on each plate, separated by granules; poriferous zones uniserial, zygopores oblique, two to each plate. Interambulacra containing about five tiers of plates, each having one primary, crenulated, raised, imperforate tubercle, those near the ambitus much the largest; small tubercles and granules numerous. Peristome circular, about 0.4 times the horizontal diameter, weakly notched.

Diameter of type $13.3 \mathrm{~mm}$; height $9.9 \mathrm{~mm}$. Diameter of type of S. bellula $12.6 \mathrm{~mm}$; height $9.0 \mathrm{~mm}$.

Diameter of USNM $29471 \mathrm{a} 12.3 \mathrm{~mm}$; height $8.1 \mathrm{~mm}$. The largest specimen at hand measures $15.2 \mathrm{~mm}$ in diameter.

Occurrence.-New Jersey: Timber Creek near Vincentown (types). Rancocas Creek near Vincentown (USNM 29471, Charles Schuchert). E. Roberts' farm $2 \frac{1}{2}$ miles west of Vincentown on road to Cross Roads, Burlington County (USGS 16924, F. S. MacNeil).

Geologic unit.-Paleocene, Vincentown sand.

Types.-Acad. Nat. Sci. Philadelphia 1448 (type of S. tumidula and 1446 (type of $S$. bellula). Figured specimen USNM $29471 a$. 


\section{Family ORTHOPSIDAE}

\section{Genus ECHINOPSIS Agassiz}

Echinopsis Agassiz, 1840, Catalogus systematicus ectyporum echinodermatum, p. 9, 18.

Echinopsis Agassiz. Agassiz and Desor, 1847, Catalogue raisonné des échinodermes (reprint), p. 50.

Echinopsis Agassiz. Desor, 1858, Synopsis des échinides fossiles, p. 98.

Hebertia Michelin, 1859, Soc. géol. France Bull., ser. 2, v. 17, p. 147.

Echinopsis Agassiz. Pomel, 1883, Classification méthodique et genera des échinides, p. 99.

Hebertia Michelin. Pomel, 1883, idem, p. 103.

Echinopsis Agassiz. Cotteau, 1893, Paléontologie française, Terrain tertiaire, ser. 1, v. 2 , p. 577.

Hebertia Michelin. Cotteau, 1893, idem, p. 588.

Echinopsis Agassiz. Lambert and Thiéry, 1910, Nomenclature raisonnée des échindes, fasc. 3, p. 185.

Echinopsis Agassiz. Mortensen, 1943, Monograph of the Echinoidea, v. 3, pt. 2 , p. 35.

Type species, Echinopsis elegans Agassiz, from the Eocene of France, designated by Lambert and Thiéry (1910, p. 185). This species, though generally credited to Des Moulins (1836) was first described in Agassiz and Desor (1846). Agassiz's original description of the genus listed no described species, only four nomina nuda, among them $E$. elegans as first named.

Cotteau's (1893, pls. 338, 339) figures of $E$. elegans show a more or less inflated test having a pentagonal apical system with small ocular plates, two of which reach the large, central periproct, and very wide genital plates. The ambulacra have narrow, trigeminate, uniserial poriferous zones bordered by a row of smooth, perforated primary tubercles; the median area contains several small tubercles. Though the zygopores maintain a fairly straight line from apex to peristome, the line curves a little around each tubercle; they appear not to be doubled or distorted near the peristome. The interambulacra are about twice as wide as the ambulacra; their plates are transversely elongated, and each plate bears one smooth, central, perforated primary tubercle and many small tubercles or granules. The peristome is about one-third of the total diameter; it is conspicuously notched.

Mortensen (1943, p. 38) excludes Echinopsis from the Orthopsidae because its primary tubercles are supposedly crenulate, yet Cotteau's figures of the type species show smooth tubercles. Crenulation appears to be of little significance, for some species of echinoids contain smooth and crenulated tubercles on the same individual.

\section{Echinopsis diatreta (Morton)}

Plate 2, figures 8-11

Cidaris diatretum Morton, 1833, Am. Jour. Sci., ser. 1, v. 23, p. 294.

Cidarites diatretum (Morton). Morton, 1834, Synopsis of the organic remains of the Cretaceous, p. 75, pl. 10, fig. 10.
Pseudodiadema diatretum (Morton). Desor, 1858, Synopsis des échinides fossiles, p. 73.

Pseudodiadema diatretum (Morton). Cotteau, 1864, Paléontologie française, Terrain cretacé, ser. 1, จ. 7, p. 519.

Pseudodiadema diatretum (Morton). Clark, 1893, U. S. Geol. Survey Bull. 97, p. 46, pl. 13, figs. 1a-f.

Pseudodiadema diatretum (Morton). Clark in Weller, 1907, New Jersey Geol. Survey, Paleontology Series, v. 4, p. 285, pl. 9, figs. 1-6.

Polydiadema diatretum (Morton). Lambert and Thiéry, 1910, Nomenclature raisonnée des échinides, fasc. 3, p. 190.

Pseudodiadema diatretum (Morton). Clark, 1915, U. S. Geol. Survey Mon. 54, p. 56, pl. 19, figs. 1a-f.

Pseudodiadema diatretum (Morton). Cooke, 1941, Jour. Paleontology, v. 15, no. 1, p. 8.

As figured by Clark, the type of this species is a tumid disc $35 \mathrm{~mm}$ in diameter and $13 \mathrm{~mm}$ high. The ambulacra are two-thirds as wide as the interambulacra. The poriferous zones are narrow, nearly straight, with three or four zygopores to each compound plate. Each area has two rows of large, perforated, crenulated primary tubercles. The peristome is circular, weakly notched, and occupies one-third of the total diameter.

Occurrence.-New Jersey: Gloucester (type), Timber Creek, and Vincentown (fide Clark).

Geologic unit.-Paleocene, Vincentown sand.

Type-Acad. Nat. Sci. Philadelphia 1471, apparently lost or mislaid.

Remarks.-This species seems to fit Echinopsis better than $P$ seudodiadema because its zygopores are not multiplied around the peristome, which is much smaller and less lobate than that of $P$. pseudodiadema, and its byssal notches are shallower.

\section{Family TOXOPNEUSTIDAE}

\section{Genus IYTECHINUS A. Agassiz}

Lytechinus A. Agassiz, 1863, Harvard College Mus. Comp. Zoology Bull., v. 1, p. 24.

Lytechinus A. Agassiz. Verrill, 1867, Connecticut Acad. Arts and Sci. Trans., $\nabla .1$, p. 302.

Schizechinus Pomel, 1869, Revue des échinodermes, p. 42.

Oligophyma Pomel, 1869, Revue des échinodermes, p. 43.

Anapesus Holmes. Pomel, 1883, Classification méthodique et genera des échinides, p. 80.

Oligophyma Pomel, 1883, idem, p. 81.

Lytechinus A. Agassiz. H. L. Clark, 1912, Harvard College Mus. Comp. Zoology Mem., v. 24, pt. 2, p. 244.

Lytechinus A. Agassiz. Cooke, 1941, Jour. Paleontology, v. 15, no. 1 , p. 16.

Lytechinus A. Agassiz. Mortensen, 1943, Monograph of the Echinoidea, v. 3, pt. 2, p. 434. Includes additional synonymy.

Oligophyma Pomel. Mortensen, 1943, idem, v. 3, pt. 2, p. 462. Schizechinus Pomel. Mortensen, 1943, idem, v. 3, pt. 2, p. 463.

Type species, Echinus variegatus Lamarck 1816= Cidaris variegata (part) Leske 1778 , designated by Verrill (1867). This species should not be confused with Tripneustes gratilla (Linnaeus), which Leske included in $C$. variegata and which Alexander Agassiz figured 
under the name Hipponoë variegata. (See H. L. Clark, 1912, footnote.)

\section{Iytechinus variegatus (Leske)}

Plate 2, figures 12,13

Cidaris variegata (part) Leske, 1778, Klein's Naturalis dispositio Echinodermatum, p. 149, pl. 10, figs. B, C.

Echinus variegatus Lamarck. Holmes, 1860, Post-Pleiocene fossils of South Carolina, p. 4, pl. 2, fig. 1.

Toxopneustes variegatus (Lamarck). Clark and Twitchell, 1915, U. S. Geol. Survey Mon. 54, p. 222.

Lytechinus variegatus (Leske). Cooke, 1941, Jour. Paleontology, v. 15, no. 1, p. 17.

Lytechinus variegatus (Lamarck). Mortensen, 1943, Monograph of the Echinoidea, v. 3, pt. 2, p. 437. Includes additional synonymy.

Test hemispherical, large. Apical system with serrate outline; the two posterior ocular plates insert. Periproct large, oval, eccentric. Ambulacra wide, trigeminate, the upper two zygopores of each plate near the outer edge, the lower one near the tubercle; zygopores forming a continuous row along the peristome in each ambulacrum. Plates much wider than high near the ambitus. Tubercles smooth, imperforate; two continuous rows in each area, passing through the center of each plate; additional rows in the interambulacra not reaching the apex, leaving bare median areas. Peristome subpentagonal; about one-third the total diameter; gill slits deep. Spines rather short, tapering, longitudinally ribbed.

Horizontal diameter of figured specimen, from a beach in Florida, $51 \mathrm{~mm}$; height $26 \mathrm{~mm}$; diameter of peristome $18 \mathrm{~mm}$.

Occurrence.-Recent: North Carolina to Santos, Brazil. South Carolina: Intracoastal Waterway canal near Little River (USGS 18759, L. C. Glenn)

Geologic unit.-Pleistocene and Recent.

Figured specimen.-USNM 562263.

\section{Iytechinus floralanus (Cooke)}

Plate 2, figures 17-21

Psammechinus floralanus Cooke, 1941, Jour. Paleontology, v. 15, no. 1, p. 15, pl. 3 figs. 10, 11.

Psammechinus? ocalanus Cooke, 1941, Jour. Paleontology, v. 15, no. 1, p. 16, pl. 2, figs. 9-11.

Test small, circular, depressed. Apical system unknown. Ambulacra nearly three-quarters as wide as the interambulacra; zygopores in arcs of three to each compound plate, alined in oblique groups of three; compound plates about twice as wide as high. Tubercles imperforate, smooth; primary tubercles in the center of each plate, two vertical rows in each area; secondary tubercles nearly as large, in vertical rows. Granules encircling the primary tubercles and filling the intermediate spaces, leaving no bare areas. Peristome large; notches as deep as wide.
Horizontal diameter $22.5 \mathrm{~mm}$; height $11 \mathrm{~mm}$; diameter of peristome about $11 \mathrm{~mm}$.

Occurrence.-Alabama: Quarry of Florida Lime Products Company $1 / 4$ mile northwest of Adams Crossroads on lower Hacoda-Florala road, Covington County (type, USGS 14604, F. S. MacNeil).

Georgia: Bainbridge (USGS 13611, August Foerste, type of $P$. ocalanus).

Geologic unit.-Late Eocene, Ocala limestone.

Type.-USNM 498891, from USGS 14604. Type of Psammechinus? ocalanus, USNM 498889

Remarks.-This species is represented by only the two imperfect types. Their gill slits, which are not well preserved, are much deeper and sharper than those of Psammechinus but seem to be shallower and proportionately wider than those of Lytechinus variegatus. Their coronal plates are less elongated than those of $L$. variegatus-probably because of their smaller size-and the entire surface is covered with tubercles or granules. The arrangement of the pores is similar to that of Oligophyma cellense Pomel (Mortensen, 1943, p. 463, fig. 290), but the secondary tubercles seem to be larger and more numerous than in that species.

The type of $P$. ocalanus is smaller and not as well preserved as that of $L$. floralanus, but there seem to be no recognizable specific differences. They probably occupied the same stratigraphic zone, though the type of $L$. floralanus was originally reported as late Oligocene. Mr. MacNeil has since recognized its horizon as Ocala limestone.

\section{Genus TRIPNEUSTES Agassiz}

Tripneustes Agassiz, 1841, Monographies d'échinodermes, Introduction, p. 7.

Tripneustes Agassiz. Cooke, 1941, Jour. Paleontology, v. 15, no. 1, p. 17.

Tripneustes Agassiz. Mortensen, 1943, Monograph of the Echinoidea, v. 3, pt. 2, p. 427. Includes additional synonymy.

Type species, Echinus ventricosus Lamarck (1816), by original designation, a common West Indian species usually called Tripneustes esculenta (Leske).

\section{Tripneustes ventricosus (Lamarck)}

Plate 2, figures 14-16

Echinus ventricosus Lamarck, 1816, Histoire naturelle des animaux sans vertèbres, v. 3, p. 44.

Tripneustes ventricosus (Lamarck). Agassiz and Desor, 1847, Catalogue raisonné des échinodermes (reprint), p. 59.

Hipponoë esculenta (Leske). A. Agassiz, 1872, Harvard College Mus. Comp. Zoology Mem., v. 3, no. 4, p. 301, pl. 6a, figs. 1-3; pl. 8 fig. 29.

Tripneustes esculenta (Leske). Cooke, 1941, Jour. Paleontology, จ. 15, no. 1, p. 18.

Tripneustes ventricosus (Lamarck). Mortensen, 1943, Monograph of the Echinoidea, v. 3, pt. 2, p. 490, pl. 33, fig. 4; pl. 36 , figs. $1-4$; pl. 37 , figs. $3,11,12$; pl. 38 , figs. $5-8$; pl. 56 , figs. $3,6,7,9,15-17$. Includes additional synonymy.

Test large; horizontal outline circular to subpentagonal; upper surface strongly inflated; lower surface flatter; ambitus broadly rounded. Apical system 
rather large, outline serrate; two or more ocular plates broadly insert; covered with tubercles. Ambulacra evenly expanding to the ambitus; poriferous zones triserial, the outer rows of zygopores evenly aligned, the inner row irregular; zygopores crowded around the peristome. Peristome circular, deeply notched, of variable size, usually small. Periproct central, subcircular, covered with movable plates. Tubercles small, imperforate, in many vertical rows.

Diameter of figured specimen, a comparatively small individual with unusually large peristome, $67 \mathrm{~mm}$; height $38 \mathrm{~mm}$; diameter of peristome $21 \mathrm{~mm}$.

occurrence.-Florida to Ferando Noronha, Brazil ; west coast of Africa.

Geologic unit.-Recent, littoral to about 15 fathoms.

Figured specimen.-USNM E3042a, Barbados.

Remarks.-Mortensen (1943, p. 497) has discussed the nomenclature of this species. Cidaris esculenta Leske $(1778$, p. 74), with which it has been confused, is a synonym of Echinus esculentus Linnaeus.

\section{Family ECHINIDAE}

\section{Genus PSAMMECHINUS Agassiz}

Echinus (Psammechinus) Agassiz in Agassiz and Desor, 1846, Annales Sci. Nat. (Zool.), ser. 3, v. 6, p. 368 (1847, reprint, p. 64).

Psammechinus Agassiz. Savin, 1903, Soc. histoire nat. de Savoie Bull., ser. 2, v. 8, p. 156.

Psammechinus Agassiz. Cooke, 1915, Jour. Paleontology, v. 15 , no. 1, p. 15.

Psammechinus Agassiz. Mortensen, 1943, Monograph of the Echinoidea, v. 3, pt. 3, p. 123 . Includes a d d ition a l synonymy.

Type species Echinus miliaris Müller, 1771, designated by Savin (1903, p. 156). This is the common species living along the eastern coasts of the Atlantic from Iceland to the Cape Verde Islands. It has been described and figured by Mortensen (1943, p. 127, pl. 10, figs. $3-5$; pl. 18, figs. $1-7,20-21$; pl. 58, figs. 19 , 23-25). Only one other Recent species is recognized by Mortensen. Psammechinus mitiaris is rather small, hemispherical, with a dicyclic apical system decorated with small tubercles. The ambulacra are rather narrow, regularly expanding to the ambitus, with trisociate plates; pores arranged in groups of three zygopores, which become more oblique as the peristome is approached. The peristome ranges in size from about half the horizontal diameter in very small tests to about one-third in tests measuring $47 \mathrm{~mm}$ in horizontal diameter. The tubercles are small, imperforate, arranged in vertical rows, about six on the ambulacra and about 10 on the interambulacra. The spines are short, rapidly tapering, longitudinally ribbed; transverse sections resemble a wheel with spokes.

\section{Psammechinus philanthropus (Conrad)}

Plate 3, figures 1, 2

Echinus philanthropus Conrad, 1843, Acad. Nat. Sci. Philadelphia Proc., v. 1, p. 310.

Echinus ruffini Forbes, 1845, Geol. Soc. London Quart. Jour., v. 1, p. 426, figs. 1a-d.

Echinus ruffini Forbes. Forbes, 1845, Geol. Soc. London Proc., v. 4, p. 560, text figs.

Echinus philanthropus Conrad. Conrad, 1846, Am. Jour. Sci., ser. 2 , v. 1, no. 2 , p. 220.

Psammechinus exoletus McCrady in Tuomey and Holmes, 1857, Pleiocene fossils of South Carolina, p. 4, pl. 2, fig. 6 .

Psammechinus ruffini (Forbes). Desor, 1858, Synopsis des échinides fossiles, p. 121.

Echinus ruffini Forbes. Emmons, 1858, North Carolina Geol. Survey Report, Agriculture of the eastern counties, p. 306 , figs. 239a-d.

Psammechinus philanthropus (Conrad). Meek, 1864, Check list of the invertebrate fossils of North America; Miocene, p. 2.

Psammechinus philanthropus (Conrad). Stefanini, 1912, Soc. geol. italiana Bol., v. 30, p. 705.

Psammechinus philanthropus (Conrad). Clark and Twitchell, 1915, U. S. Geol. Survey Mon. 54, p. 181, pl. 84, figs. 6a-c.

Psammechinus exoletus McCrady. Clark and Twitchell, 1915, idem, p. 182.

Psammechinus philanthropus (Conrad). Cooke, 1941, Jour. Paleontology, v. 15, no. 1, p. 16.

Psammechinus exoletus McCrady. Cooke, 1941, idem, p. 16.

Test small, hemispherical, lower surface gently rounded. Apical system dicyclic, with serrate outline; ocular and genital pores near the outer edges of the plates; a row of three tubercles bordering the periproct on each genital plate and one central tubercle on each ocular plate. Ambulacral zygopores arranged in oblique groups of three throughout. Ambulacra wider than the interambulacra at the peristome. Periproct large, obliquely oval. Peristome decagonal, very weakly notched. Tubercles large, smooth, imperforate; arranged in vertical rows, about four rows in each ambulacrum, eight in each interambulacrum at the ambitus. Tubercles encircled by coarse granules.

Horizontal diameter of figured specimen $22.8 \mathrm{~mm}$; height $14.4 \mathrm{~mm}$; diameter of peristome $10.5 \mathrm{~mm}$.

Occurrence.-Virginia: James River near Smithfield (type). James River at J. A. Mogart's 5 miles north of Smithfield (USNM 166501, W. M. Twitchell). Rock Wharf road on Day's farm 11/2 miles northeast of Smithfield (W. M. Twitchell). Day Point, James River (USGS 14065, W. C. Mansfield and C. W. Mumm). Yorktown (USNM 373038, Julia Gardner). $21 / 2$ miles northwest of Suffolk (USGS 10198, W. C. Mansfield). Burwell's Mill near Williamsburg (Charles Lyell, type of Echinus ruffini, fide Lyell.

North Carolina: Locality unknown (fide Emmons).

South Carolina: Smith's, Goose Creek (type of Psammechinus exoletus (fide Tuomey and Holmes).

Geologic unit.-Late Miocene: Yorktown formation in Virginia, Duplin marl in the Carolinas.

Figured specimen.-USNM 562264. 
Comparison.-Psammechinus philanthropus is so closely related to the living $P$. miliaris (Müller) that they can scarcely be distinguished. The granulation in the Miocene species seems to be somewhat coarser, and the notches on the peristome weaker.

\section{Psammechinus santee Cooke}

Plate 3, figures 3, 4

Psammechinus santee Cooke, 1941, Jour, Paleontology, v. 15, no. 1, p. 15, pl. 2, figs. 7, 8 .

Test small, subhemispherical; upper surface slightly depressed, lower surface rounded. Genital pores large, each with a small tubercle between the pore and the periproct; madreporite inflated. Ocular plates apparently not reaching the periproct. Periproct elliptical. Ambulacra about half as wide as the interambulacra; zygopores in oblique groups of three. Peristome large; gill slits wide and shallow. Tubercles imperforate, uniform in size; two rows on each ambulacrum, four on each interambulacrum. Spines long, slender, with fine serrate ribs.

Diameter of most complete cotype $15.6 \mathrm{~mm}$; height $11 \mathrm{~mm}$.

Occurrence.-South Carolina: Orangeburg County not far from the Santee River (USGS 4255, Earl Sloan; probably 0.8 mile east of the Keitt place, which is about $4 \frac{1}{2}$ miles northwest of Creston, now in Calhoun County).

Geologic unit.-Early part of the middle Eocene, Congaree formation.

Cotypes.-USNM 498890.

Remarks.-This species is represented by impressions of several individuals, some with attached spines, in two lumps of porous sandstone. The exact locality is unknown, but Sloan (1908, p. 329) records "numerous casts of an echinoderm 0.8 mile east of the Keitt place" in Orangeburg (Calhoun) County.

\section{Genus GAGARIA Duncan}

Micropsis (Gagaria) Duncan, 1889, Linnean Soc. London Jour., Zoology, v. 23, p. 91.

Gagaria Duncan. Cotteau, 1892, Paléontologie française, Terrain tertiaire, v. 1, p. 523 .

Thylechinus Pomel (part). Lambert, 1897, Soc. géol. France Bull., ser. 3, v. 25, p. 496.

Thylechinus Pomel (part). Lambert and Thiéry, 1910, Nomenclature raisonnée des échinides, fasc. 3, p. 214.

Gagaria Duncan. Mortensen, 1935, Monograph of the Echinoidea, v. 2, p. 472.

Thylechinus (Gagaria) Duncan. Cooke, 1941, Jour. Paleontology, v. 15, no. 1, p. 13.

Gagaria Duncan. Mortensen, 1943, Monograph of the Echinoidea, v. 3, pt. 2 , p. 371

Type species, Micropsis venustula Duncan and Sladen (1884, p. 119, pl. 22, figs. 1-7), from the Eocene (Khirtar) of Sind, by monotypy. This species, as figured by Duncan, has one (the right posterolateral) ocular plate broadly insert, the others all plainly exsert. Its poriferous zones are straight, and there are three zygopores to each compound plate. Its ambulacra are of the "echinoid" type (Mortensen, 1943, p. 2). Each area has two rows of crenulated, imperforate, primary tubercles.

Gagaria differs from Thylechinus in the arrangement of its apical plates (Cooke, 1941, p. 13) which are not completely dicyclic as in Thylechinus said, and in the "echinoid" character of its ambulacra as contrasted with the "diadematoid" ambulacra of Thylechinus (Mortensen, 1943, p. 371).

\section{Gagaria salis (Cooke)}

Plate 3, figures 7-9

Thylechinus (Gagaria) salis Cooke, 1941, Jour. Paleontology, v. 15 , no. 1 , p. 13, pl. 2 , figs. 12-14.

Test small, subhemispherical, slightly concave below. Madreporite tumid; ocular I (right posterior, wanting in type) apparently was broadly insert, but oculars II (right anterior) and III (anterior) are exsert; ocular IV and $V$ are wanting in the type. Ambulacra less than half as wide as interambulacra; poriferous zones straight, uniserial, pores small, round, zygopores slightly inclined, three to each compound plate. Tubercles small, apparently imperforate and not crenulate, two rows of primaries in each area and several rows of very small tubercles. Peristome round, strongly notched, less than half the horizontal diameter.

Diameter $20 \mathrm{~mm}$; height $12.3 \mathrm{~mm}$; diameter of peristome $8 \mathrm{~mm}$.

Occurrence.-Alabama: Salt Mountain, 5 miles south of Jackson, Clarke County (USGS 3643, near base of section at southern end, T. W. Vaughan).

Geologic unit.-Presumably Paleocene, Salt Mountain limestone, though formations of middle and late Oligocene age are exposed in that vicinity.

Type.-USNM 166497.

Comparison.-This species is represented by one badly corroded individual. Its peristome appears to be proportionately somewhat larger than that of Gagaria mossomi. The tubercles are much smaller, but they may have been reduced in size by corrosion.

\section{Gagaria mossomi (Cooke)}

Plate 3, figures 10-14

Thylechinus (Gagaria) mossomi Cooke, 1941, Jour. Paleontology, v. 15, no. 1, p. 13, pl. 2, fig. 16 ; pl. 3, figs. $6-9$; pl. 4, figs. $3-5$.

Test subhemispherical; horizontal outline circular or subpentagonal. Apical system pentagonal; madreporite swollen; ocular I barely reaching the periproct, other oculars exsert. Periproct large, nearly circular, central. Ambulacra about half as wide as interambulacra; poriferous zones uniserial, straight, trigeminate; plates composed of a narrow upper member with one zygopore and a wide compound member with two 
zygopores. Two vertical rows of large crenate imperforate primary tubercles in each area. Smaller tubercles and granules abundant on and below the ambitus. Peristome medium sized; moderately notched.

Height of larger cotype, a fragment, $20 \mathrm{~mm}$; horizontal diameter of smaller cotype $15 \mathrm{~mm}$; height 14.5 $\mathrm{mm}$; diameter of peristome $6 \mathrm{~mm}$.

Occurrence.-Florida: Spoil bank at Blackwater Creek at crossing of Seaboard Airline Railway and highway, Hillsborough County (USGS 11116, types, C. W. Cooke and Stuart Mossom; H. I. Tucker Rowland, paratypes). Quarry of Florida Rock Products Company $3 / 4$ mile southwest of Brooksville (USGS 11113, C. W. Cooke and Stuart Mossom; USGS 12322, W. C. Mansfield and F. S. MacNeil ; Florida Geol. Survey I-1605, G. M. Ponton). Old quarry 5 miles west of Brooksville (USGS 12318, W. C. Mansfield and G. M. Ponton).

Geologic unit.-Late Oligocene, Suwannee limestone.

Types.-USNM 372885.

Remarks.-This species seems to be common at the type locality but is not usually well preserved. Only one individual retains the apical system. The madreporite is inflated and ocular I penetrates to the periproct. Some individuals have a subpentagonal outline, in this respect resembling Gagaria venustula (Duncan and Sladen), the type species.

\section{Gagaria chickasawhay (Cooke)}

\section{Plate 3, figure 18}

Thylechinus (Gagaria) chickasawhay Cooke, 1941, Jour. Paleontology, v. 15, no. 1, p. 14, pl. 2, figs. 17a-d.

Test of medium size. Oculogenital ring and peristome unknown. Ambulacra with two rows of large crenulate, imperforate tubercles, each tubercle surrounded by a squared ring of small tubercles; pore pairs uniserial, nearly straight, three pairs in each compound plate; pores of each pair separated by a granule. Interambulacra wider, with two contiguous median rows of crenulate, imperforate large tubercles and one row of smaller tubercles' on each margin, each large tubercle enclosed in a ring of little tubercles. Detached spines long, slender, cylindrical, slightly swollen near the tip, smooth when perfect but longitudinally corrugated when slightly corroded. Larger spines flattened, spoonshaped.

Occurrence.-Mississippi: Chickasawhay River above the highway bridge $2 \frac{1}{2}$ miles south of Waynesboro (USGS 13388 , C. W. Cooke).

Geologic unit.-Late Oligocene, Chickasawhay limestone.

Cotypes.-USNM 498885.

Remarks.-This species is known only from fragments of the test and from detached spines. The name is an Indian word pronounced Chick-a-saw-hay.

\section{Family TEMNOPLEURIDAE}

Genus BROCHOPLEURUS Fourtau

Brochopleurus Fourtau, 1920, Egypt Geol. Survey, Palaeont. Ser. no. 4, p. 25.
Brochopleurus Fourtau. Mortensen, 1943, Monograph of the Echinoidea, v. 3, pt. 2, p. 354 .

Type species, Temnechinus stellulatus Duncan and Sladen (1882, p. 304, pl. 47, figs. 8, 9), from the Gaj series of Miocene age of India, by original designation. Mortensen (1943, p. 354, fig. 216 a, b) copies Duncan and Sladen's figures. These figures show it to be small, subhemispherical, with nearly straight, uniserial poriferous zones, three zygopores to each ambulacral plate. The primary tubercles are small, imperforate, arranged in vertical rows, two rows to each area. The surface is decorated with raised threads or confluent granules, many of which radiate from the tubercles.

\section{Brochopleurus pretiosus (Clark) \\ Plate 4, figures 4-6}

Orthechinus pretiosus Clark, 1915, U. S. Geol. Survey Mon. 54, p. 118 , pl. 56, figs. 2a-b.

Gagaria americana Clark, 1915, U. S. Geol. Survey Mon. 54, p. 159 , pl. 73 , figs. 8a-b.

Thylechinus americanus (Clark). Lambert and Thiéry, 1925, Nomenclature raisonnée des échindes, fasc. 8, p. 567.

Progonechinus pretiosus (Clark). Cooke, 1941, Jour. Paleontology, v. 15, no. 1, p. 15, pl. 2, figs. 4-6.

Pseudodiadema? americanum (Clark), Cooke, 1941, Jour. Paleontology, v. 15, no. 1, p. 8.

Horizontal outline circular; upper surface inflated, ambitus rounded, lower surface slightly concave around the peristome. Apical system dicyclic, with serrate outline, large; genital plates large, perforated near the outer ends of the prongs, bearing several small imperforate tubercles from which radiate vermiculate threads. Periproct nearly circular. Ambulacra regularly expanding to the ambitus; poriferous zones trigeminate, nearly straight above, in slightly inclined groups of three below, not at all expanded at the peristome. Interambulacra about twice as wide as ambulacra; plates not much wider than high. Tubercles small, imperforate, arranged in vertical rows, one on each plate, with additional secondaries chiefly on the lower surface; two rows on ambulacra adjacent to the poriferous zones and two on interambulacra passing through the center of the plates. Surface covered with elongated, confluent granules and threads, many of which radiate from the tubercles. Peristome rather small, circular, weakly notched.

Diameter of holotype $20 \mathrm{~mm}$; height (crushed) 18.2 $\mathrm{mm}$.

Occurrence.-Alabama: Near Dead Level, Choctaw County (USGS 2893, type, Charles Schuchert). The Rocks, Clarke County (USNM 559478, type of Gagaria americana, T. H. Aldrich). Sec. 14, T 9 N, R 2 E (USNM 559885, C. E. Branson). $\mathrm{NE}_{1 / 4} \mathrm{NW}^{1 / 4}$ Sec. 21 , T $9 \mathrm{~N}, \mathrm{R} 2 \mathrm{E}$ (USNM 559886, C. E. Branison).

Geologic unit.-Late Eocene, Ocala limestone and Yazoo clay. 
Type-USNM 146455. Type of Gagaria americana USNM 559478 (JHU T 102), deposited by Johns Hopkins University.

Remarks.-Mortensen's (1943, p. 35, pl. 21, figs. 1-3) photographs of Progonechinus eocenicus (Duncan and Sladen) show a quite different type of decoration from that of this species, which seems very similar to Brochopleurus stellulatus (Duncan and Sladen).

\section{Family ARBACIIDAE}

\section{Genus ARBACIA Gray}

Arbacia Gray, 1835, Zool. Soc. London Proc., pt. 3, p. 58.

Arbacia Gray. Mortensen, 1935, Monograph of the Echinoidea, v. 2, p. 562. Includes additional synonymy.

Arbacia Gray. Grant and Hertlein, 1938, California Univ. (Los Angeles), Math and Phys. Sci. Pub., v. 2, p. 18.

Arbacia Gray. Cooke, 1941, Jour. Paleontology, v. 15, no. 1, p. 9. Arbacia Gray. Bernasconi, 1953, Montevideo Mus. Historia Nat. Anales, ser. 2, v. 6, no. 2, p. 12.

Type species, Echinus pustulosus Lamarck 1816 $=C i$ daris pustulosa Leske $1778=$ Echinus lixula Linnaeus 1758, designated by Agassiz and Clark (1908, p. 67). Linnaeus gives as habitat the Indian Ocean, but A. Agassiz (1872, p. 233) cites it from the west coast of France. According to Mortensen (1935, p. 572) it is an exclusively littoral form, very common in the Mediterranean and along the Atlantic coasts of Africa and Brazil.

As figured by Loven (1887, p. 112, pl. 3; pl. 7, figs. $1,2)$ the types of Arbacia lioula have a dicyclic apical system, the ocular plates are all exsert, and the ocular pores are apparently double. The ambulacra are narrow though evenly expanding from the apex to the ambitus; the zygopores form a nearly straight line on the upper surface but turn obliquely in groups of three near the peristome, into which the poriferous zones protrude like lips. There are two continuous rows of small imperforate tubercles in the ambulacra and about 14 rows of similar tubercles in the interambulacra at the ambitus. The outer rows are continuous to the apex, but the inner rows drop out gradually until there are only a few scattered tubercles near the apex. The peristome is subpentagonal and very large. The periproct is obliquely elongated. There appears to be one sphaeridial pit in the middle of each ambulacrum near the peristome.

The spines of Arbacia tixula are rather short, slender, gently tapering, circular or flattened in cross section, and longitudinally striated. The flattened spines, which are confined to the bottom, have a polished fluted tip.

The dicyclic apical system, the poriferous zones expanding near the peristome, and the single sphaeridial pit appear to be generic features. Other species referred to Arbacia have less elongated interambulacral plates and a different arrangement of the tubercles; many have a conspicuously bare space in the middle of the upper part of each interambulacrum.

Arbacia punctulata (Lamarck)

Plate 4, figures 7-9

Echinus punctulatus Lamarck, 1816, Histoire naturelle des animaux sans vertèbres, v. 3, p. 47 ; 2 d ed., 1840, v. 3, p. 363. Arbacia punctulata (Lamarck). Gray, 1835, Zool. Soc. London Proc., p. 58.

Anapesus carolinus Troschel. Holmes, 1860, Post-Pleiocene fossils of South Carolina, p. 5, pl. 2, fig. 2.

Arbacia punctulata (Lamarck). Mortensen, 1935, Monograph of the Echinoidea, v. 2, p. 573, pl. 87, figs. 7-10. Includes additional synonymy.

Arbacia punctulata (Lamarck). Cooke, 1941, Jour. Paleontology, v. 15, no. 1, p. 10.

Apical system pentagonal, dicyclic; ocular plates plainly exsert, decorated with a group of granules; pores double, at outer edge of plate. Ambulacra narrow, regularly expanding to the ambitus, thence maintaining their maximum width to the peristome; poriferous zones straight on upper surface, breaking into oblique groups of three zygopores, which become nearly transverse at the peristome. Peristome large, pentagonal. Periproct obliquely oval. Tubercles rather large; two rows on ambulacra, becoming obsolete toward the apex; four or six rows on interambulacra, the outer rows continuous, the inner rows absent above the ambitus, leaving medial spaces bare. Spines tapering, faintly grooved, nearly as long as the diameter of the test. One sphaeridial pit in middle of ambulacrum at peristome.

\section{Horizontal diameter $36 \mathrm{~mm}$; height $19 \mathrm{~mm}$.}

Occurrence.-Living along the eastern coast from Cape Cod to Florida, northern coast of Cuba, Yucatan, Curaçao, Trinidad, and Tobago (Mortensen, 1935, p. 575).

South Carolina: Charleston, Simmons Bluff, and Wando (Holmes, 1860).

Geologic unit.-Pleistocene and Recent.

Type.-Probably at the Jardin des Plantes at Paris. Figured specimen 3 miles north of Crescent Beach, St. Johns County, Florida.

Comparisons.-Arbacia punctulata differs from A. lixula in the presence of conspicuous bare spaces in the interambulacra; it has fewer rows of tubercles, and the tubercles are larger. Its upper surface is smoother than that of Arbacia waccamaw, it is higher, and it lacks tubercles on its ocular plates. Its bare places and its much smoother surface distinguish it from Arbacia rivuli, which also has tubercles on its ocular plates.

\section{Arbacia waccamaw Cooke}

Plate 4, figures 15-17

Echino-cidaris sp. indet. Tuomey and Holmes, 1855, Pleiocene fossils of South Carolina, fasc. 1, pl. 2, figs. 5, 5a.

Arbacia waccamaw Cooke, 1941, Jour. Paleontology, v. 15, no. 1, p. 10, pl. 1, figs. $1-3$. 
Test medium-sized, circular; upper surface depressed, subconical; lower surface evenly rounded. Periproct large, central, obliquely elongated. Oculogenital ring dicyclic; genital plates large, corrugated to granular, pores large; ocular plates smaller, each with a large central tubercle. Ambulacra with two rows of imperforate tubercles, which are large on the lower surface but are reduced to granules at the apical ends; pore pairs three in each plate, uniserial and straight on the upper surface, curved around the tubercles at the ambitus, and very oblique at the peristome; one sphaeridial pit in each area near the peristome. Interambulacra twice as wide as the ambulacra on the upper surface, about equally wide on the lower surface because of the expansion of the poriferous zones; four rows of large imperforate tubercles on the base and ambitus, only the outer rows extending to the apex; bare spaces covered by a shagreenlike corrugation; plates wider than high. Peristome large, subpentagonal; gill slits broad and very shallow.

Diameter $34 \mathrm{~mm}$; height $17.4 \mathrm{~mm}$; diameter of peristome $17 \mathrm{~mm}$.

Occurrence.-South Carolina: Intracoastal Waterway canal about 4.5 to 5 miles southwest of Little River (USGS 13377, type, C. W. Cooke; USNM Accession 179251, L. C. Glenn.

Florida: U. S. Engineers well HE 23 in southeastern Hendry County, altitude -7 feet (USGS 18125).

Geologic unit.-Late Miocene(?)

Type.-USNM 498888.

Comparisons.-Arbacia waccamaw differs from A. punctulata in the occurrence of tubercles on the ocular plates and in the shagreened surface of the bare interambulacra. Arbacia rivuti has no large bare areas, and its surface is coarsely granular. The upper interambulacral plates of $A$. improcera and $A$. sloani are much wider and lower.

\section{Arbacia rivuli Cooke}

Plate 4, figures 10, 11

Arbacia rivuli Cooke, 1941, Jour. Paleontology, v. 15, no. 1, p. 10, pl. 1, figs. 4-6.

Test medium sized; outline circular, tumid above, evenly rounded below the ambitus. Periproct suboval, oblique. Oculogenital ring dicyclic or with one or more ocular plates insert; each ocular plate has a large central tubercle. Ambulacra about half as wide as interambulacra at ambitus; evenly expanding to ambitus; of nearly equal width below; poriferous zones straight to ambitus, in oblique or curved groups of three zygopores below, groups nearly horizontal at peristome; interporiferous zones decorated with two continuous rows of imperforate tubercles, one tubercle on each plate; miliary areas granular. Interambulacra decorated with four rows of imperforate tubercles, of which the marginal rows extend to the apex, the inner rows not quite so far; interspaces coarsely granular.
Tubercles largest on under surface. Peristome wide, subpentagonal, weakly notched. One sphaeridial pit in middle of each ambulacrum near the peristome.

Horizontal diameter of type $36 \mathrm{~mm}$; height $19 \mathrm{~mm}$; width of peristome about $17 \mathrm{~mm}$.

occurrence.-South Carolina: Intracoastal Waterway canal about 5 miles southwest of Little River, Horry County (USGS 13377, type, C. W. Cooke; USNM Access. 179251, L. C. Glenn; S. F. Blake).

Geologic unit.-Late Miocene(?)

Type-USNM 498887. Figured specimen, USNM 562292.

Comparison.-Arbacia rivuli differs from A. waccamaw in its coarsely granular, not rugose surface, in the lack of conspicuous bare spaces on the interambulacra, and in that some of its ocular plates may reach the periproct. It has fewer and larger tubercles than $A$. lixula, its poriferous zones are less expanding at the peristome, and it has large tubercles on its ocular plates.

\section{Arbacia improcera (Conrad)}

Plate 4, figures 1-3

Echinus improcerus Conrad, 1843, Acad. Nat. Sci. Philadelphia Proc., ser. 1, v. 1, p. 310.

Psammechinus improcerus (Conrad). Stefanini, 1911, Soc. geol. italiana Bol., v. 30, p. 705.

Coelopleurus improcerus (Conrad). Clark and Twitchell, 1915, U. S. Geol. Survey Mon. 54, p. 180, pl. 84, figs. 4a-c.

Arbacia improcera (Conrad). Cooke, 1941, Jour Paleontology, v. 15, no. 1, p. 11, pl. 1, figs. 7-9.

Horizontal outline circular; upper surface much depressed; lower surface evenly rounded. Apical system dicyclic; plates covered with elongated granules; ocular plates having one high imperforate tubercle; genital plates of juvenile specimen having a similar central tubercle. Ambulacra narrow, regularly expanding to the ambitus, maintaining nearly the maximum width to the peristome; poriferous zones straight on upper surface, expanding near the peristome because of the increasing inclination of the groups of three zygopores; one sphaeridial pit in the middle of each area near the peristome. Interambulacral plates nearly three times as wide as high, tubercle-free areas covered by coarse elongate granules. Periproct rather large, oblique. Tubercles high, imperforate; largest on margin and lower surface; two rows in each ambulacrum, becoming obsolete toward the apex; four rows on and below the ambitus in each interambulacrum, only the outer rows, much reduced in size, continuing to the apex. Peristome large, subpentagonal.

Horizontal diameter $36.5 \mathrm{~mm}$; height $15 \mathrm{~mm}$; diameter of peristone $17 \mathrm{~mm}$.

Occurrence.-Virginia: James River near Smithfield (type). J. T. Williams' marl pit, Smith County, 0.5 mile below the dam at Suffolk waterworks (USNM 166487, L. W. Stephenson). Bank facing tidal flats of Nansemond River at Suffolk (USGS 10201, W. C. Mansfield). 
Geologic unit.-Late Miocene, upper part of the Yorktown formation, of Duplin age.

Type.-Unknown. Figured specimen, USNM 166487.

Comparison.-Arbacia improcera is closest related to $A$. sloani (Clark), which was contemporaneous with it and may prove to be a synonym. It is much flatter than the type of that species, whose granules seem not to be elongated. Its bare interambulacral spaces suggest Arbacia punctulata (Lamarck) but its interambulacral plates are much wider and its surface decoration of elongated granules is quite different.

\section{Arbacia sloani (Clark)}

Plate 4, figures 12-14

Coelopleurus sloani Clark, 1915, U. S. Geol. Survey Mon. 54, p. 181, pl. 84, figs. 5a-b.

Arbacia sloani (Clark). Cooke, 1941, Jour. Paleontology, v. 15, no. 1, p. 11.

Test rather small, high-arched above, evenly rounded below. Apical system large; left posterior ocular insert, others exsert. Ambulacra narrow, evenly expanding to the ambitus, of equal width below; poriferous zones straight, zygopores below ambitus in oblique groups of three, nearly horizontal near peristome; having one sphaeridial pit near the peristome. Plates of interambulacrum low and very wide. Tubercles larger on bottom than on top; imperforate; two rows on ambulacra, four on interambulacra at ambitus, outer rows continuous to apex though diminishing in size; intermediate areas above ambitus bare. Surface granular. Peristome large, subpentagonal. Periproct large, obliquely oval.

Horizontal diameter $26.5 \mathrm{~mm}$; height $14.4 \mathrm{~mm}$.; diameter of peristome $13 \mathrm{~mm}$.

Occurrence.-South Carolina: Bostick's Landing, Great Pee Dee River, Florence County (L. W. Stephenson).

Geologic unit.-Late Miocene, Duplin marl.

Type.-USNM 166488.

Comparisons.-The great width of its interambulacral plates distinguishes Arbacia sloani from all other American species except $A$. improcera, which is flatter and has more rugose sculpture. The upper surface of $A$. sloani is badly corroded, but its sculpture appears to have been granular. Its ocular plate probably had tubercles, but they are obliterated.

\section{Genus ARBIA Cooke}

Arbia Cooke, 1948, Jour. Paleontology, v. 22, no. 5, p. 606.

Arbia Cooke. Mortensen, 1951, Monograph of the Echinoidea, v. 5, pt. 2, p. 558 .

Type species, Coelopleurus aldrichi Clark, by original designation.

Apical system probably dicyclic, pentagonal, encircling the periproct. Ambulacra narrower than the interambulacra throughout; poriferous zones uniserial, the zygopores forming a straight line above the ambitus, arranged in slightly oblique groups of three at and below it, not at all expanded at the peristome; zygopores one to each plate near the apex, three to each compound plate below; without sphaeridial pits. Tubercles imperforate, more abundant below the ambitus. Peristome small, circular, moderately notched.

Arbia bears a superficial resemblance to Coelopleurus and Arbacia, from both of which it differs in the presence of simple plates in the upper part of the ambulacra, in the total lack of sphaeridial pits (Arbacia has one, Coelopleurus several), and in the smaller peristome. From Arbacia it differs further in the narrowness of its poriferous zones at the peristome. The bare medial interambulacral areas of Arbia aldrichi, which are flush with the lateral parts, contrast with the sunken areas of Coelopleurus. The pattern of decoration is more suggestive of Arbacia.

\section{Arbia aldrichi (Clark)}

Plate 3, figures 15-17

Coelopleurus aldrichi Clark, 1915, U. S. Geol. Survey Mon. 54, p. 158 , pl. 73, figs. $6 \mathrm{a}-\mathrm{b}, 7 \mathrm{a}-\mathrm{c}$.

Arbacia aldrichi (Clark). Cooke, 1941, Jour. Paleontology, v. 15, no. 1, p. 11.

Arbia aldrichi (Clark). Cooke, 1948, Jour. Paleontology, v. 22, no. 5, p. 606.

Arbia aldrichi (Clark). Mortensen, 1951, Monograph of the Echinoidea, v. 5, pt. 2, p. 558, fig. 280a-c (after Clark).

Horizontal outline subpentagonal, upper surface moderately inflated, lower surface gently rounded. Apical system pentagonal, rather large, with at least three ocular plates exsert (other oculars not preserved); ocular plates carrying two or three small tubercles; genital plates bearing a line of small tubercles beside the periproct. Ambulacra narrow, regularly expanding to the ambitus; apical part composed of simple plates, each carrying one zygopore, remainder composed of compound plates, each with three zygopores; poriferous zones uniserial, nearly straight, the groups of three zygopores only slightly oblique on and below the ambitus, not at all expanded at the peristome. Interambulacra about twice as wide as ambulacra; plates about twice as wide as high. Primary tubercles rather small, evenly graded in size, two continuous rows on ambulacra, four rows on base of interambulacra, only the outer rows extending to the apex. Secondary tubercles numerous except on bare parts of interambulacra. Peristome small, about one-third the horizontal diameter, circular, conspicuously notched.

Horizontal diameter $36.6 \mathrm{~mm}$; height $19 \mathrm{~mm}$; diameter of peristome $12.1 \mathrm{~mm}$.

Occurrence.-Alabama: Perdue Hill, Monroe County (USNM 559494, type, T. H. Aldrich).

Mississippi: Waterfall on Patton Creek $1 / 4$ mile above highway $45,1.5$ miles east of Waynesboro, Wayne County (USGS 14287, W. C. Mansfield and F. S. MacNeil). 
Geologic unit.-Late Oligocene, Chickasawhay limestone in Alabama. Paynes Hammock sand of early Miocene age, in Mississippi. MacNeil referred the bed at Patton Creek to the upper Chickasawhay, which he now calls the Paynes Hammock sand.

Types.-Two cotypes, USNM 559494, deposited by Johns Hopkins University ( $T$ 104).

Comparisons.-Arbia aldrichi differs from the American species of Arbacia in the presence of simple ambulacral plates in the apical region, in the lack of spaeridial pits, and in the narrowness of the poriferous zones near the peristome. Its peristome is much smaller than that of Coelopleurus infulatus, its bare interambulacral areas are not at all sunken, and Coelopleurus has several sphaeridial pits.

\section{Genus COELOPLEURUS Agassiz}

Coelopleurus Agassiz, 1840, Catalogus systematicus ectyporum Echinodermatum fossilium Musei Neocomensis, pp. 12, 19. Coelopleurus Agassiz. Mortensen, 1935, Monograph of the Echinoidea, v. 2, p. 605 . Includes additional synonymy. Coelopleurus Agassiz. Grant and Hertlein, 1938, California Univ. (Los Angeles) Math. and Phys. Sci. Pub., v. 2, p. 21. Coelopleurus Agassiz. Cooke, 1941, Jour. Paleontology, v. 15, no. 1, p. 8.

Type species, Echinus equis Valenciennes=Cidaris coronatis Leske, by monotypy; the only other species listed is a nomen nudum. Coelopleurus coronalis has been described and figured by Cotteau (1893, p. 560, pl. 335) and (under the name Coelopleurus equis) by Desor (1858, p. 97, pl. 16, figs. 4-6) and by Duncan and Sladen (1884, p. 251, pl. 39, figs. 3-8). Cotteau records it from the upper Eocene of Biarritz, France, and from several places in Spain. This species has swollen ambulacra with two complete rows of large imperforate tubercles and trigeminate poriferous zones. Its interambulacra have four rows of similar tubercles on the base and ambitus; the outer rows, reduced in size, extend to the apical system, but the median areas on the upper surface are bare and sunken. Specimens in the National Museum that probably represent this species have a vertical row of about eight pits in the median line of the ambulacra near the peristome. The peristome is nearly half as wide as the horizontal diameter.

Coelopleurus resembles Arbacia in many features but differs from it in the narrowness of its poriferous zones near the peristome (the zones of Arbacia are notably widened there) and in the presence of seven or eight sphaeridial pits along the median suture of each ambulacrum instead of only one, as in Arbacia. The type species of the two genera differ also in the shape of the interambulacral plates, those of Coelopleurus coronatis being much less elongated than those of Arbacia lixula, though they differ little from those of other species referred to Arbacia. Moreover, Coelopleurus coronalis has only two primary tubercles on each interambulacral plate below the ambitus, and only one, the outer, much reduced in size, above it, whereas Arbacia lixula, when full grown, has a row of five or more equal primary tubercles below the ambitus and no bare area above it. However, other species referred to Arbacia closely resemble Coelopleurus in tuberculation. The bare areas in Coelopleurus are more or less abruptly sunken, whereas those in Arbacia are flush.

\section{Coelopleurus infulatus (Morton)}

Plate 3, figures 5, 6

Echinus infulatus Morton, 1833, Am. Jour. Sci., ser. 1, v. 24, p. 131, pl. 10 , fig. 7.

Echimus infulatus Morton. Morton, 1834, Synopsis of the organic remains of the Cretaceous group, p. 75, pl. 10, fig. 7 .

Coelopleurus infulatus (Morton). Desor, 1858, Synopsis des échinides fossiles, p. 98.

Coelopleurus infulatus (Morton). Clark and Twitchell, 1915, U. S. Geol. Survey Mon. 54, p. 117, pl. 56, figs. 1a-i.

Coelopleurus infulatus (Morton). Cooke, 1941, Jour. Paleontology, v. 15, no. 1, p. 9.

Coelopleurus carolinensis Cooke, 1941, Jour. Paleontology, v. 15, no. 1, p. 9, pl. 2, figs. 1-3.

Horizontal outline circular or subhexagonal; upper surface moderately inflated; ambitus broadly rounded; lower surface somewhat flattened. Apical system dicyclic; genital pores moderately large, distal from the center of the plates. Periproct large, central, subpentagonal, bordered by a row of granules. Ambulacra rather wide, regularly expanding to the ambitus, very slightly narrowing to the peristome; poriferous zones uniserial, trisociate, nearly straight near the apex, slightly curved around the tubercles; two rows of primary imperforate tubercles extending the entire length in mature individuals, rudimentary near the apex in juveniles; five sphaeridial pits form a median line near the peristome in each ambulacrum. Interambulacra bearing four rows of primary tubercles on the lower side; the two middle rows extend above the ambitus; the remainder of the upper surface is smooth except for a raised thread or row of granules, which extends to the apex in the line of the outer row of basal tubercles. Peristome, large, covering about half the diameter, moderately notched, calluses extending well into the test.

Diameter of type of Coelopleurus carolinensis, a juvenile, $14.2 \mathrm{~mm}$; height $7.2 \mathrm{~mm}$; diameter of peristome $6.4 \mathrm{~mm}$. Diameter of presumed type $19.5 \mathrm{~mm}$; height $10 \mathrm{~mm}$ (Clark and Twitchell).

Occurrence.-South Carolina: Locality of type not specified (Morton). Pooshee Plantation, Berkeley County (Tuomey). Santee-Cooper Diversion Canal near Eadytown, Berkeley County (USGS 18353, C. W. Cooke and F, S. MacNeil).

North Carolina: Wilmington (type of C. carolinensis, USNM 166500, L. W. Stephenson).

Geologic unit.-Late middle Eocene, Santee limestone. 
Type.-Probably Acad. Nat. Sci. Philadelphia 1076, figured by Clark and Twitchell. Type of Coelopleurus carolinensis, USNM 166500.

Remarks.-The preceding description is based on Clark and Twitchell's figure of a specimen in the Academy of Natural Sciences of Philadelphia, presumably Morton's type; a fragment from the Santee-Cooper Diversion Canal; and the type of Coelopleurus carolinensis Cooke. This last is smaller than the others, and the interambulacral tubercles near the apex are rudimentary. Presumably it is juvenile.

\section{Family PHYMOSOMATIDAE}

\section{Genus GAUTHIERIA Lambert}

Phymosoma (Cosmocyphus) (part) Pomel, 1883, Classification méthodique et genera des échinides, p. 91.

Gauthieria Lambert, 1888, Soc. hist. et nat. de l'Yonne Bull., v. 42 , pt. 2, p. 7 .

Gauthieria Lambert. Duncan, 1891, Linn. Soc. London Jour. Zoology, v. 23, p. 88.

Gauthieria Lambert. Cotteau, 1892, Soc. zool. France Mém., v. 5, p. 732

Gauthieria Lambert. Lambert, 1897, Soc. géol. France Bull., ser. 3, v. 25, p. 498

Gauthieria Lambert. Lambert and Thiéry, 1910, Nomenclature raisonnée des échinides, fasc. 3, p. 222.

Gauthieria Lambert. Mortensen, 1935, Monograph of the Echinoidea, v. 2, p. 478 .

Type species, Cyphosoma radiatum Sorignet, from the Late Cretaceous (Senonian and Turonian) of Europe, by monotypy. This species has been figured by Wright (1864, p. 142, pl. 29, figs. 2, 3), by Cotteau (1865, p. 609, pl. 1147, figs. 1-14; pl. 1148), and by Mortensen (1935, p. 478, fig. 278), who copies some of Cotteau's figures. Its apical system, usually caducous, is large, pentagonal, and the posterior prong is longer than the others. As figured by Lambert $(1888$, p. 5$)$ it includes five perforated genital plates, five oculars, all insert, and at least six additional hexagonal periproctal plates in front of the periproctal opening. The zygopores curve in simple arcs about the primary tubercles and are not multiplied near the peristome. According to Mortensen $(1935$, p. 478$)$ the ambulacra consist of polyporous plates throughout. Each area has two rows of primary crenulated tubercles, each capped by a rather small, imperforate mamelon. The tubercles on the upper surface are somewhat smaller than those on the base.

Cyphosoma radiatum was the first-named of three species included by Pomel (1883) in his section or subgenus Cosmocyphus under Phymosoma. This earlier assignment seems to have been overlooked by Lambert (1888) when he proposed Gauthieria for C. radiatum. Nine years later, however, Lambert (1897) proposed to restrict Cosmocyphus to Pomel's third species, Phymosoma (Cosmocyphus) saemanni (Coquand) because of the bigeminate character of its poriferous zones, so that species becomes the type of Cosmocyphus.
Gauthieria speciosa (Clark)

Plate 5, figures 1-7

Cyphosoma speciosum Clark, 1891, Johns Hopkins Univ. Circ., v. 10, no. 87, p. 76.

Coptosoma speciosum (Clark). Clark, 1893, Johns Hopkins Univ. Circ., v. 12 , p. 51.

Coptosoma speciosum (Clark). Clark, 1893, U. S. Geol. Survey Bull. 97, p. 52, pl. 18, figs. 1a-h.

Pseudodiadema speciosum (Clark). Clark in Weller, 1907, New Jersey Geol. Survey Paleontology Ser., v. 4, p. 286, pl. 9, figs. 7-14.

Coptosoma speciosum (Clark). Clark, 1915, U. S. Geol. Survey Mon. 54, p. 61, pl. 19, figs. 3a-h.

Gauthieria? speciosa (Clark). Mortensen, 1935, Monograph of the Echinoidea, p. 474

Microsoma speciosum (Clark). Cooke, 1941, Jour. Paleontology, v. 15 , no. 1 , p. 12 , pl. 3 , figs. $1-4$.

Horizontal outline circular; upper surface evenly rounded; lower surface flattened; ambitus broadly rounded. Apical scar large, irregularly pentagonal, one prong longer than the others. Ambulacra half as wide as the interambulacra; zygopores in groups of 3 near the apex, 4 distally, usually straight but showing a tendency to form arcs. Tubercles imperforate, crenulated; primary tubercles arranged in two vertical rows on the ambulacra, 4 on the interambulacra. Peristome small, circular, occupying about one-third of the diameter, weakly notched.

Diameter of type $18 \mathrm{~mm}$; height $9.7 \mathrm{~mm}$; diameter of peristome $6.4 \mathrm{~mm}$.

Occurrence.-New Jersey: Timber Creek (type). Rancocas Creek, Vincentown (USNM 29468, F. B. Meek).

Geologic unit.-Paleocene, Vincentown sand.

Type.-Acad. Nat. Sci. Philadelphia 1468. Figured specimen USNM 29468.

Remarks.-Though this species is similar in general appearance to typical Gauthiera, it does not quite fit the diagnosis of that genus because its ambulacra are not polyporous throughout.

\section{Genus DIXIEUS Cooke}

Dixieus Cooke, 1948, Jour. Paleontology, v. 22, no. 5, p. 607. Dixieus Cooke. Mortensen, 1951, Monograph of the Echinoidea, v. 5 , pt. 2 , p. 558 .

Type species, Phymosoma dixie Cooke (1941, p. 17, pl. 2 , fig. 15 ; pl. 4, figs. 1, 2, 9), from the Ocala limestone of late Eocene age of Florida, by original designation. The only other species included was Phymosoma peloria Arnold and Clark (1927, p. 18, pl. 2, figs. 1-3), from the late Eocene(?) of Jamaica.

Dixieus dixie differs from Phymosoma koenigi (Mantell), the type species of Phymosoma, in the greater number of zygopores (there are twice as many) in the biserial part of its poriferous zones, in the smaller size and more nearly equilateral shape of its apical system, in its more tumid, less discoid shape, in its larger, more deeply notched peristome, and in its smaller, more evenly graded tubercles. 


\section{Dixieus dixie (Cooke)}

Plate 5, figures 8-10

Phymosoma dixie Cooke, 1941, Jour. Paleontology, v. 15, no. 1, p. 17 , pl. 2, fig. 15 ; pl. 4 , figs. $1,2,9$.

Dixieus dixie (Cooke). 1948, Jour. Paleontology, v. 22, no. 5, p. 607.

Dixieus dixie (Cooke). Mortensen, 1951, Monograph of the Echinoidea v. 5, pt. 2, p. 558, fig. 281 (after Cooke).

Test moderately large, circular; upper surface gently arched; lower surface evenly rounded, depressed at the peristome; ambitus evenly rounded. Apical system almost monocyclic, the anterior and right anterolateral ocular plates barely or not quite reaching the periproct, the other ocular plates widely insert; right anterior genital plate larger than the others, the madreporite tumid and encroaching on the large periproct. Ambulacra nearly half as wide as the interambulacra; poriferous zones biserial above the ambitus, each compound plate bearing two rows of five or six zygopores each, becoming disarranged on the ambitus, changing to a single line of connected open arcs of five or six zygopores below the ambitus, and breaking into disconnected diagonal lines of three zygopores near the peristome. Coronal plates having one rather small, imperforate, crenulated primary tubercle near the center and several small secondary tubercles chiefly near the corners, the primaries forming two straight radial rows in each area. Tubercles evenly graduated in size, those on the ambitus not much larger than the others. Peristome large, circular, deeply notched, bilobate in the ambulacra.

Diameter of type $43 \mathrm{~mm}$; height $18.5 \mathrm{~mm}$; diameter of peristome $18 \mathrm{~mm}$; width of ambulacra at ambitus about $12.2 \mathrm{~mm}$; width of interambulacra about $14.2 \mathrm{~mm}$.

Comparisons.-Dixieus dixie closely resembles in decoration Dixieus pelorius (Arnold and Clark) from Jamaica, but the peristome of $D$. pelorius appears to be proportionately smaller. The two individuals of $D$. dixie are only half as large as the figured type of $P$. pelorius and the single paratype in the U. S. National Museum, though they fall within the range in size of $P$. pelorius as recorded by Arnold and Clark. Both of them retain the apical plates, which appear to be rarely if ever preserved in $D$. pelorius.

Occurrence.-Florida: Quarry east of Steinhatchee River north of U. S. Highway 19 near Clara, in Dixie County (USGS 12747,15150 , W. C. Mansfield and G. M. Ponton).

Geologic unit.-Late Eocene, Ocala limestone.

Type.-USNM 372867.

\section{Family STOMOPNEUSTIDAF}

\section{Genus PHYMOTAXIS Lambert and Thiéry}

Circopeltis (Micropeltis) Pomel, 1883, Classification méthodique et genera des échinides, p. 89. Not Micropeltis Redtenbacher 1867.
Micropeltis Pomel. Cotteau, 1892, Paléontologie française, ser. 1, v. 2, Terrain tertiaire, p. 517.

Phymotaxis Lambert and Thiéry, 1914, Nomenclature raisonnée des échinides, fasc. 4, p. 253.

Phymotaxis Lambert and Thiéry. Mortensen, 1935, Monograph of the Echinoidea, v. 2, p. 514.

Phymotaxis Lambert and Thiéry. Cooke, 1941, Jour. Paleontology, v. 15, no. 1, p. 18.

Type species, Leiosoma tournoueri Cotteau (1866, p. 768, pl. 1187), from the Upper Cretaceous (Senonian) of France, by original designation. Cotteau's figures show a subhemispherical form with rounded base; rather wide ambulacra with uniserial, somewhat undulating poriferous zones above, biserial zones below, widening near the peristome. Each area has two continuous rows of large, imperforate tubercles, and there are two additional rows in the interambulacra below the ambitus.

\section{Phymotaxis mansfieldi Cooke}

Plate 6, figures 4-8

Phymotaxis mansfieldi Cooke, 1941, Jour. Paleontology, v. 15, no. 1 , p. 18, pl. 4 , figs. $6-8$.

Test large, subhemispherical, with evenly rounded margin, slightly concave near the peristome. Apical system unknown. Ambulacra about half as wide as the interambulacra; poriferous zones forming single ares of about eight zygopores above the ambitus, zygopores irregularly distributed in a broader zone below the ambitus. Tubercles large, imperforate, two rows on each ambulacrum, four rows on each interambulacrum at the ambitus, the lateral rows not extending to the apex; each primary tubercle surrounded by a row of little tubercles that generally follow the edges of the plate, one little tubercle at each angle of the plate being somewhat larger than the others. Peristome rather small, subdecagonal; gill slits moderately deep, callous.

Horizontal diameter of largest cotype $56 \mathrm{~mm}$; height $27 \mathrm{~mm}$.; diameter of peristome $20 \mathrm{~mm}$.

Occurrence.-Florida: Old quarry of Florida Rock Products Company $3 / 4$ mile southwest of Brooksville (USGS 12755, W. C. Mansfield and G. M. Ponton). Consolidated Rock Products Company 3 miles northeast of Brooksville (USGS 12321, W. C. Mansfield and F. S. MacNeil).

Geologic unit.-Late Oligocene, Suwannee limestone.

Types.-USNM 372868, two nearly complete individuals and one smaller fragment.

Comparison.-No other American species of Phymotaxis are known. Phymotaxis mansfieldi differs from $P$. tournouri of Cretaceous age as figured by Cotteau in the less plainly biserial arrangement of the zygopores on the under surface and in the more conspicuous arcuate arrangement on the upper surface. In these respects it is more nearly similar to $P$. biarritzensis of Eocene age (Cotteau, 1892, pl. 322, figs. 5-7) and $P$. vidali (Cotteau, 1892, pl. 322 , fig. 8 ; pl. 323 ), but its gill slits are deeper and sharper. 


\section{Family STRONGYLOCENTROTIDAE}

Genus STRONGYLOCENTROTUS Brandt

Echinus (Strongylocentrotus) Brandt, 1835, Acad. imp. Sci. St. Pétersbourg, Recueil des Actes p. 263. Reprint (Prodromus) p. 63.

Strongylocentrotus Brandt. A. Agassiz, 1872, Harvard College, Mus. Comp. Zoology Mem., v. 3, pp. 161, 276.

Strongylocentrotus Brandt. H. L. Clark, 1912, Harvard College Mus. Comp. Zoology Mem., v. 34, p. 352.

Strongylocentrotus Brandt. Cooke, 1941, Jour Paleontology, v. 15 , no. 1 , p. 19.

Strongylocentrotus Brandt. Mortensen, 1943, Monograph of the Echinoidea, v. 3, pt. 3, p. 193 . Includes additional synonymy.

Type species, Echinus chlorocentrotus Brandt $1835=$ Echinus dröbachiensis Müller 1776, validated by Opinion 208 of the International Commission on Zoological Nomenclature. Brandt described Strongylocentrotus as a subgenus under Echinus and doubtfully included under it one other species, Echinus tuberculatus Lamarck, which is now referred to Heliocidaris.

Strongylocentrotus dröbachiensis (Müller)

Plate 6, figure 3

Echinus dröbachiensis Müller, 1776, Zoologiae danicae prodromus, p. 235.

Echinus (Strongylocentrotus) chlorocentrotus Brandt, 1835, Acad. imp. Sci. St. Pétersbourg, Recueil des Actes, p. 264. Reprint (Prodromus), p. 64.

Strongylocentrotus aröbachiensis (Müller). A. Agassiz, 1872, Harvard College Mus. Comp. Zoology Mem., v. 3, pp. 277, 441 , pl. 4a, figs. $2,3,6$; pls. $9,10$.

Strongylocentrotus dröbachiensis (Müller). Cooke, 1941, Jour. Paleontology, v. 15, p. 19.

Strongylocentrotus drøbachiensis (O. Fr. Müller). Mortensen, 1943, Monograph of the Echinoidea, v. 3, pt. 3, p. 198, pl. 23, figs. 1-11; pl. 59, figs. 1-5, 10. Includes additional synonymy.

Horizontal outline subcircular; upper surface strongly inflated; lower surface depressed around the peristome; ambitus broadly rounded. Apical system large; two ocular plates broadly insert; madreporite very large. Periproct circular, eccentric; covered with movable plates. Ambulacra evenly expanding to the ambitus, equalling in width the interambulacra at the peristome; zygopores arranged in oblique groups of five. Peristome subdecagonal, notches shallow. Tubercles small, smooth, imperforate; two rows of primaries on ambulacra, four or more on interambulacra; many secondary tubercles and granules.

Diameter of figured specimen $62 \mathrm{~mm}$; height 36.5 $\mathrm{mm}$; diameter of peristome $21 \mathrm{~mm}$.

Occurrence.-Circumpolar; north Atlantic coast as far south as Chesapeake Bay (Mortensen, 1943, p. 213).

Geologic unit.-Recent.
Figured specimen.-USNM E 3032, from Dumpling Island, North Haven, Maine.

Remarks.-The preceding description is based upon the figured specimen. The species is said to be very variable. Clark and Twitchell (1915, p. 216, pl. 99, figs. 1a-c) refer two individuals from the Caloosahatchee formation of Pliocene age of Florida to this common northern species. This identification should be accepted with reservation, for the specimens are very poorly preserved.

\section{Family ECHINOMETRIDAE} Genus ECHINOMETRA Gray

Echinometra Gray, 1825, Annals of Philosophy, ser. 2, v. 10, p. 426.

Echinometra (Breynius) Gray. Mortensen, 1943, Monograph of the Echinoidea, v. 3, pt. 3, p. 352. Includes additional synonymy.

Type species, Echinus lucunter Linnæus, living in the Atlantic Ocean, by original implicit designation. Gray included in the genus also Echinometra atratus and $E$. mammillatus, both attributed to Klein. $\mathrm{He}$ stated, however, that these last two species will most probably form a new genus.

\section{Echinometra lucunter (Linnaeus) \\ Plate 6, figures 1,2}

Echinus Iucunter Linnaeus, 1758, Systema naturae, 10th editiou, p. 665 .

Echinometra lucunter (Linnaeus). Cooke, 1941, Jour. Paleontology, v. 15, no. 1, p. 18.

Echinometra lucunter (Linnaeus). Mortensen, 1943, Monograph of the Echinoidea, v. 3, pt. 3, p. 357. Includes additional synonymy.

Horizontal outline obliquely elliptical or subpentagonal; variably inflated; ambitus broadly rounded. Apical system rather large; one or more ocular plates insert or not; madreporite swollen. Periproct oval, slightly eccentric. Ambulacra regularly expanding to the ambitus, about equal in width to the interambulacra at the peristome; zygopores arranged in disconnected arcs of six, more or less, except near the peristome, where they lie in straight, oblique lines. Peristome nearly circular, weakly notched. Primary tubercles large, smooth, imperforate; in two rows on each area, largest on the interambulacra.

Horizontal diameter of figured specimen 55 by 43 $\mathrm{mm}$; height $30 \mathrm{~mm}$; diameter of peristome $23 \mathrm{~mm}$. The largest specimen recorded by Mortensen (1943, p. 360 ) is 94 by $78 \mathrm{~mm}$ in horizontal diameter.

Occurrence.-Florida to Brazil and the Bermudas and western coast of Africa.

Geologic unit.-Recent.

Figured specimen.-USNM 562292, from Cayo la Vela, Cuba, R. E. Dickerson. 


\section{Family ECHINONEIDAE}

Subfamily ECHINONEINAE

Genus RHOPOSTOMA Cooke, new genus

Horizontal outline oval, upper surface inflated, margin rounded, concave around the peristome. Apical system having only four genital plates, all perforated; posterior ocular plates not in contact; madreporite central, extending between the posterior genital plates. Ambulacra narrow, not petaloid, nearly uniform in width; plates simple; pores circular; pore pairs transverse apically, becoming narrower and oblique distally. Peristome large, oblique, longer dimension extending from left anterior to right posterior. Periproct large, pyriform, supramarginal, opening into a wide, shallow sulcus.

Type species, Ananchytes cruciferus Morton. This species was identified by d'Orbigny (1853-1860, p. 387) with his new genus Trematopygus, which has petaloid or subpetaloid ambulacra and is said to have a fifth, unperforated genital plate. Rhopostoma differs from Trematopygus also in the shape of its peristome, which is subtrigonal rather than pentagonal, and in the greater size and lower location of its periproct. Trematpygus seems to have a much more conspicuous posterior sulcus.

Rhopostoma bears some resemblance to Gateraster Cotteau (Mortensen, 1948, p. 83) but differs from it in the shape and greater inclination of its peristome and in the shape and direction of elongation of its periproct.

The simple ambulacra, twisted peristome, and pyriform periproct ally Rhopostoma with the Echinoneidæ.

The name Rhopostoma is derived from the Greek words rhope (inclination) and stoma (mouth.) It is of neuter gender.

\section{Rhopostoma cruciferum (Morton)}

Plate 7, figures 1-4

Ananchytes cruciferus Morton, 1830, Am. Jour. Sci., ser. 1, v. 18 , p. 245 , pl. 3 , fig. 8 .

Ananchytes cruciferus Morton. Morton, Acad. Nat. Sci. Philadelphia Jour., ser. 1, v. 6, p. 201, 202.

Nucleolites crucifer (Morton). Morton, 1833, Am. Jour. Sci., ser. 1, v. 23, p. 294.

Nucleolites crucifer (Morton). Morton, 1834, Synopsis of the organic remains of the Cretaceous group, p. 75, pl. 3, fig. 15.

Nucleolites orucifer (Morton). Agassiz, 1840, Catalogus systematicus ectyporum Echinodermatum, p. 4.

Nuculites cruciferus (Morton). Agassiz and Desor, 1847, Catalogue raisonné des échinodermes, p. 97.

Nucleolites cruciferus (Morton). d'Orbigny, 1850, Prodrome de paléontologie stratigraphique, p. 271.

Pygorhynchus crucifer (Morton). Ravenel, 1850, Am. Assoc. Adv. Sci. Proc., p. 160.

Echinobrissus crucifer (Morton). d'Orbigny, 1854, Rev. et mag. zoologie, ser. 2, v. 6, p. 25.
Trematopygus crucifer (Morton). d'Orbigny, 1858, Paléontologie française, Terrain cretacé, ser. 1, t. 6, p. 387, pl. 953, figs. 10, 11 (after Morton) ; pl. 963, figs. 1-5.

Nucleolites (Tremiatopygus) crucifer (Morton). Desor, 1858, Synopsis des échinides fossiles, p. 262.

Trematopygus crucifer (Morton). Clark, 1891, Johns Hopkins Univ. Circ., v. 10, no. 87, p. 76.

Trematopygus crucifer (Morton). Clark, 1893, U. S. Geol. Survey Bull. 97 , p. 63 , pl. 27 , figs. 1a-i.

Trematopygus crucifer (Morton). Clark in Weller, 1907, New Jersey Geol. Survey, Paleontology ser., v. 4, pt. 2, p. 289, pl. 11, figs. 1-9.

Trematopygus cruciferus (Morton). Clark, 1915, U. S. Geol. Survey Mon. 54, p. 71, pl. 28, figs. 3a-c; pl. 29, figs. 1a-f. Trematopygus crucifer (Morton). Cooke, 1942, Jour. Paleontology, v. 16, no. 1, p. 10.

Horizontal outline oval; upper surface unevenly inflated, sloping more steeply forward than backward; lower surface rounded, concave around the peristome; margin broadly rounded. Apical system anterior; four genital plates, all perforated; madreporite central, not extending behind the posterior ocular plates; ocular plates fairly large, posterior pair separated by small interambulacral plates. Ambulacra narrow, not expanding toward the margin, not petaliferous; plates apparently simple throughout though becoming higher toward the peristome; pore pairs transverse and fairly wide near the apex, becoming oblique and narrower distally. Interambulacral plates about three times as high as ambulacral. Peristome subtriangular, oblique, longest dimension extending from left anterior to right posterior as viewed from below. Periproct large, pyriform, supramarginal, opening into a broad, shallow sulcus, which indents the margin. Tubercles fairly large, sunken.

Length of type $26.5 \mathrm{~mm}$; width $23 \mathrm{~mm}$; height $15 \mathrm{~mm}$.

Occurrence.-New Jersey : Timber Creek, Gloucester County (type, S. G. Morton). Rancocas Creek, Vincentown (USNM 29470 , F. B. Meek). E. Roberts' farm 2.5 miles west of Vincentown on road to Cross Roads, Burlington County (USGS 16924, F. S. MacNeil).

Georgia: Internal mold, possibly this species, 9 miles southeast of Lumpkin (USGS 5498, Otto Veatch).

Alabama: 4.5 miles south of Highland Home, SE1/4 SE1/4, sec. 25, T. 11 N., R. 17 E., on Ala. 9, Crenshaw County (USGS 17530, W. H. Monroe and Winnie McGlamery).

Arkansas: Internal mold, possibly this species, upstream from crossing of Route 35 (Edison Avenue) and small branch near lumber yard, Benton, Saline County (USGS 16917, Julie Gardner and Ruth Smidt).

Geologic unit.-Paleocene; Vincentown sand in New Jersey. Type-Acad. Nat. Science Philadelphia 1464.

\section{Genus AMBLYPYGUS Agassiz}

Amblypygus Agassiz, 1840, Catalogus systematicus ectyporum Echinodermatum, p. 5, 17.

Amblypygus Agassiz. Agassiz and Desor, 1847, Catalogue raisonné des échinides, p. 108. 
Amblypygus Agassiz. d'Orbigny, 1955, Paléontologie française, Terrain cretacé, ser. 1, v. 6, p. 373.

Amblypygus Agassiz. Desor, 1858, Synopsis des échinides fossiles, p. 255.

Not Amblypygus Agassiz. Wright, 1864, Geol. Soc. London Quart. Jour., v. 20, p. 482. Probably Echinoneus.

Amblypygus Agassiz. Cotteau, 1863, Échinides fossiles des Pyrenées (Congrès sci. France Mem, session 28 Bordeaux,) v. 30, p. 109.

Amblypygus Agassiz. De Loriol, 1875, Schweizer. paleont. Gesell. Verh., Band 2, p. 43.

Amblypygus Agassiz. Pomel, 1883, Classification méthodique et genera des échinides, p. 59.

Amblypygus Agassiz. Duncan and Sladen, 1883, Palæontologia Indica, ser. 14, vol. 1, pt. 4, p. 12.

Amblypygus Agassiz. Cotteau, 1887, Paléontologie française, Terrian tertiaire, ser. 1, v. 1, p. 487.

Amblypygus Agassiz. Duncan, 1889, Linnean Soc. London Jour. Zoology, v. 23, p. 170.

Amblypygus Agassiz. Hawkins, 1912, Zool. Soc. London Proc., p. $453,491$.

Amblypygus Agassiz. Lambert and Thiéry, 1921, Nomenclature raisonnée des échinides, fasc. 5, p. 341.

Amblypygus Agassiz. Grant and Hertlein, 1938, Univ. California Los Angeles, Pub. Math. Phys. Sciences, v. 2, p. 106.

Amblypygus Agassiz. Cooke, 1942, Jour. Paleontology, v. 16, no. 1, p. 9 .

Amblypygus Agassiz. Mortensen, 1948, Monograph of the Echinoidea, v. 4, pt. 1, p. 148

Type species, Amblypygus dilatatus Agassiz and Desor (1847, p. 109; Cotteau, 1887, p. 488, pls. 130, 131) from the Eocene of Europe, designated by Duncan and Sladen (1883, p. 15). This species, named by Agassiz $(1840$, p. 5) without description, was attributed to the Cretaceous of the Crimea, but Cotteau cites only localities in France, Switzerland, Italy, and Spain. Characters of $A$. dilatatus as figured by Cotteau are long, straight, open petals extending to the margin, with circular inner pores and elongated outer pores; oblique distorted central peristome; large, flush, bilunate periproct between the margin and the peristome.

The circular shape and large, flush periproct of Amblypygus resemble Holectypus, but the circular, notched peristome of Holectypus is quite different. Amblypygus appears to be more closely related to Echinoneus, which has similar peristome and periproct but differs in that its ambulacra are less distinctly petaloid and that the outer pores on its upper surface are not elongated.

\section{Amblypygus americanus Desor}

Plate 7, figures 8,9

Amblypygus americanus Michelin MS Desor, 1858, Synopsis des échinides fossiles, p. 256.

Amblypygus americanus Michelin. Duncan and Sladen, 1883, Palæontologia Indica, ser. 14, v. 1, pt. 4, p. 13.

Amblypygus merrilli Twitchell, 1915, U. S. Geol. Survey Mon. 54, p. 165, pl. 76, figs. 1a-d ; pl. 57, figs. 1a-b ; pl. 78, figs. 1a-b.
Amblypygus americanus Michelin. Lambert and Thiẻry, 1921, Nomenclature raisonnée des échinides, fasc. 5, p. 341.

Amblypygus merrilli Twitchell. Lambert and Thiéry, 1921 Nomenclature raisonnée des échinides, fasc. 5, p. 341.

Amblypygus americanus Desor. Jackson, 1922, Carnegie Inst. Washington Pub. 306, p. 55.

Amblypygus americanus Desor. Arnold and Clark, 1927, Harvard College, Mus. Comp. Zoology Mem., v. 50, no. 1, p. 25, pl. 3, figs. 1-3.

Amblypygus americanus Desor. Cooke, 1942, Jour. Paleontology, v. 16, no. 1 , p. 10.

Test large; horizontal outline circular; upper surface more or less inflated; lower surface gently rounded, concave around the peristome and less so around the periproct; margin broadly rounded. Apical system central, with four genital pores; a large central madreporite fills in the spaces beside the much smaller genital plates; ocular plates small. Ambulacra narrow, continuous, expanded on upper side into petals with round inner pores and elongated outer pores; petals extending to the margin, inner pores forming a straight line, outer sides of petals slightly arched. Peristome subtriangular, oblique, wider than long, without floscelle. Periproct on the lower surface, large, longer than wide, nearer the peristome than the margin. Tubercles small, sunken; intermediate spaces and madreporite granulated.

Length of type of $A$. merrilli $113 \mathrm{~mm}$; width 110 $\mathrm{mm}$; height $58 \mathrm{~mm}$.

Occurrence--Jamaica (type).

Florida : Kendrick, Marion County (USGS 4246, G. P. Merrill, type of Amblypygus merrilli). NE1/4 SW $1 / 4$ sec. $1, \mathrm{~T} 17 \mathrm{~S}$, R 22 E, Marion County (USGS 19843, G. H. Espenshade). Clarke, Alachua County (USGS 2825, L. M. Everet). Pit 1.5 miles south of Newberry, Alachua County (USGS 6812, C. W. Cooke)

Georgia: East bank Chattahoochee River above US 84 near Saffold, Early County (USGS 12100, C. W. Cooke and W. H. Monroe).

Geologic unit.-Late Eocene, Ocala limestone.

Type-Y 5, a plaster cast of which is in the Louis Agassiz collection, Mus. Comp. Zoology 724 (fide Jackson). Type of A. merrilli, USNM 164934, from USGS 4246.

Remarks.-The preceding description is based on Twitchell's type of Amblypygus merrilli. There seems little doubt that this species is the same as that occurring in Jamaica, although direct comparison has not been made. Amblypygus douvillei Lambert (Sanchez Roig, 1949 , p. 126, pl. 36, fig. 4) may be a synonym.

The specimen from Georgia is smaller (length $85 \mathrm{~mm}$ ) but has a wider periproct. Considerable variation in the proportions of the periproct and in the degree of inflation of the upper surface is to be expected.

\section{Subfamily OLIGOPYGINAE Duncan \\ Genus OLIGOPYGUS de Loriol}

Oligopygus de Loriol, 1887, Recueil zool. suisse, v. 4, no. 3, p. 394. Oligopygus de Loriol. Duncan, 1889, Linnean Soc. London Jour., Zoology, v. 23, p. 174. 
Oligopygus de Loriol. Cotteau, 1891, Soc. zool. France Mem., v. 4, p. 632. Discussion of 0 . costulatus (Desor).

Otigopygus de Loriol. Clark and Twitchell, 1915, U. S. Geol. Survey Mon. 54, p. 166.

Oligopygus de Loriol. Lambert and Thiéry, 1924, Nomenclature raisonnée des échinides, fasc. 6, p. 387.

Not Oligopygus de Loriol. Brighton, 1926, Geol. Mag., v. 63, p. 360 (=Haimea).

Not Oligopygus de Loriol. Hawkins, 1926, Geol. Mag., v. 63, p. 371 (=Haimea).

Not Oligopygus de Loriol. Sanchez Roig, 1926, Equinodermos fósiles de Cuba, p. 80 (= Haimea).

Oligopygus de Loriol. Jeannet, 1928, Soc. paléont. suisse, v. 48, p. 5.

Oligopygus de Loriol. Lambert, 1931, Soc. géol. France Bull., ser. 5, v. 1, p. 290.

Oligopygus de Loriol. Davies, 1935, Tertiary faunas, p. 82.

Oligopygus de Loriol. Cooke, 1942, Jour. Paleontology, v. 16, pt. 1, p. 7.

Otigopygus de Loriol. Mortensen, 1948, Monograph of the Echinoidea, v. 4, pt. 1, p. 256.

Type species, Oligopygus wetherbyi de Loriol, from the late Eocene of Florida, by monotypy. Characteristic features of this species are its monobasal apical system, open petals, oval peristome deeply sunken in a transverse depression, and small round basal periproct. Features not apparent from the outside are a thickening of the interambulacra, which produces a conspicuous fluting on the inside of the oral surface; double-pronged auricles; and strong jaws.

The three references to Brighton, Hawkins, and Sanchez Roig purporting to deal with Oligopygus are based on Echinolampas ovum-serpentis Guppy, which is a Haimea. Haimea differs from Oligopygus in its pentagonal peristome with inflated bourrelets. It lacks the deep transverse peristomial depression.

Mortonia Gray (1851), which Mortensen (1948, v. 4, pt. 2, p. 174) treats as a subgenus under Echinocyamus, bears considerable resemblance to Oligopygus.

\section{Oligopygus wetherbyi de Loriol}

Plate 8 , figures 9-12

Oligopygus wetherbyi de Loriol, 1887, Recueil zool. suisse, ser. 1, v. 4, no. 3, p. 396, pl. 17, figs. $7-7$ d.

oligopygus wetherbyi de Loriol. Clark and Twitchell, 1915, U. S. Geol. Survey Mon. 54, p. 166, pl. 78, figs. 2a-d, 3a-b. Oligopygus floridanus Twitchell, U. S. Geol. Survey Mon. 54, p. 169, pl. 79, figs. 1a-f.

Oligopygus wetherbyi de Loriol. Cooke and Mossom, 1929, Florida Geol. Survey Ann. Rept. 20, pl. 3, figs. 2a-b (after Clark and Twitchell).

Oligopygus wetherbyi de Loriol. Lambert, 1931, Soc. géol. France Bull., ser. 5, v. 1, p. 290.

Oligopygus wetherbyi de Loriol. Cooke, 1942, Jour. Paleontology, v. 16, no. 1, p. 8.

Oligopygus floridanus Twitchell. Cooke, 1942, Jour. Paleontology, v. 16, no. 1, p. 8.
Oligopygus wetherbyi de Loriol. Cooke, 1945, Florida Geol. Survey Bull. 29, fig. 5, no. 2 (after Clark and Twitchell). Oligopygus wetherbyi de Loriol. Mortensen, 1948, Monograph of the Echinoidea, v. 4, pt. 1, p. 247, fig. 247 (after de Loriol).

Horizontal outline ovate to subpentagonal; upper surface moderately inflated, sloping evenly in all directions from the central apex; margin broadly rounded; lower surface somewhat flat, with a short, wide, deep depression around the peristome. Apical system central, buttonlike, monobasal, with four genital pores. Petals straight, extending two-thirds the way to the margin, wide open distally; pores circular, conjugate; composed of narrow plates; slightly constricted at the distal end. Extrapetalous part of ambulacra widening to the margin; plates twice as wide as those in the petals. Interambulacral plates four to seven times as wide as the adjoining ambulacral plates. Peristome transversely oval, at the bottom of a deep depression; having jaws and double-pronged auricles. Periproct small, round, midway between the peristome and the margin. Tubercles deeply sunken, covering entire surface except the poriferous zones; intermediate spaces granulated.

Length of largest figured specimen $54 \mathrm{~mm}$; width $45.5 \mathrm{~mm}$; height $25.5 \mathrm{~mm}$.

Occurrence.-Florida: Alachua County 6 miles southwest of Gainesville (USNM 164622, A. G. Wetherby). Nigger Sink, 2 miles south of Gainesville (USNM 164660). 5.5 miles southwest of Gainesville (USGS 14135, W. C. Mansfield and C. W. Mumm). Pit one-eighth mile southeast of Martin Station, 9 miles north of Ocala (USGS 6808, C. W. Cooke). Plant no. 3, Florida Lime Company, Zuber, Marion County, 6.5 miles north of Ocala (USGS 6807, C. W. Cooke). Ocala (USNM 165685, G. P. Merrill). Cummer Lumber Company quarry at Kendrick, 4.8 miles north of Ocala (USGS 14125, W. C. Mansfield and C. W. Mumm; USGS 12754a, C. W. Cooke). Taylor County rock pit in Lafayette County 4.8 miles northwest of Mayo (USGS 14537a, C. W. Cooke and F. S. MacNeil; USGS 16913, G. M. Ponton). Road from Perry to Mayo in Lafayette County 8.6 miles east of Taylor County line (USGS 14537, C. W. Cooke and W. D. Havens). Suwannee River $2 \frac{1}{4}$ miles above Branford in Lafayette County (USGS 7345, C. W. Cooke). Suwannee River at Dowling Park (USGS 14003, F. S. MacNeil; USGS 14538, C. W. Cooke). Suwannee River at Luraville (USGS 15051, C. W. Cooke and F. S. MacNeil). Johnsons limesink in Levy County (USNM 137881, L. C. Johnson). Santa Fe River, Alachua County (USNM 164689, L. C. Johnson). Quarry east of Steinhatchee River opposite Clara in Dixie County (USGS 14541, C. W. Cooke and W. D. Havens). Crystal River Rock Company quarry 6 miles southeast of Crystal River, Citrus County (USGS 14141, W. C. Mansfield and C. W. Mumm).

Geologic unit.-Late Eocene, Ocala limestone.

Type.-Unknown; probably at the University of Geneva, Switzerland (Stefanini, 1911, p. 678). Figured specimens USNM 562271 and 562272. 
Oligopygus haldemani (Conrad)

Plate 8, figures 6-8

Discoidea haldemani Conrad, 1850, Acad. Nat. Sci. Philadelphia Jour., ser. 2, v. 2, p. 40, pl. 1, fig. 12.

Oligopygus haldermani (Conrad). Clark and Twitchell, 1915, U. S. Geol. Survey Mon. 54, p. 167, pl. 78, figs. 4a-d, 5a-d.

oligopygus haldermani (Conrad). Cooke and Mossom, 1929, Florida Geol. Survey Ann. Rept. 20, pl. 3, figs. 3a-b (after Clark and Twitchell).

Oligopygus colsoni Lambert, 1931, Soc. géol. France Bull., ser. 5, v. 1, p. 290, pl. 17, figs. 1-4.

Oligopygus haldemani (Conrad). Cooke, 1942, Jour. Paleontology, v. 16, no. 1, p. 8.

otigopygus haldemani (Conrad). Cooke, 1945, Florida Geol. Survey Bull. 29, fig. 5, no. 3 (after Clarke and Twitchell). Oligopygus haldemani (Conrad). Fischer, 1951, Florida Geol. Survey Bull. 34, pt. 2, p. 56.

Horizontal outline broadly ovate, nearly circular when young; upper surface moderately tumid; lower surface nearly flat in front, slightly turned down behind and sloping toward the peristome; margin broadly rounded. Apical system central, tumid, monobasal, with four genital pores. Petals short, extending little more than halfway to the margin, the anterior the longest, expanding distally and open at the tips; poriferous zones narrower than the interporiferous; pores circular, conjugate; plates narrow. Extrapetaliferous parts of ambulacra expanding to the margin; plates wider. Interambulacra thickened around the peristome internally. Peristome central, oval, deeply sunken in a transversely elongated pit whose anterior side stands nearly vertical and whose posterior side slopes less steeply and extends about halfway to the margin. Auricles erect; prongs erect, separate, far apart. Jaws present. Periproct small, circular, submarginal. Tubercles small, sunken.

Length of figured specimen $35.8 \mathrm{~mm}$; width $32 \mathrm{~mm}$; height $16.4 \mathrm{~mm}$.

Occurrence.-Georgia: Bainbridge (type from 70-foot well, J. H. Cooper, fide Conrad). Flint River, from Red Bluff, 6 miles above Bainbridge, to Blue Spring, 4 miles below Bainbridge (USGS 3380, 3387, 3390, T. W. Vaughan; A. H. Brooks; USGS 6171, L. W. Stephenson; USGS 3370, S. W. McCallie; USGS 7097, C. W. Cooke). Chattahoochee River near A. C. L. Ry. bridge at Saffold, Early County (USGS 8249, H. K. Shearer; USGS 12100, C. W. Cooke and W. H. Monroe). Dry Bread Shoals, Flint River, $8 \frac{1}{2}$ miles below Newton (USGS 7126, 7127, C. W. Cooke and J. E. Brantly).

Florida: Chipola River at Marianna (C. W. Cooke and T. M. Kirby). North of Marianna (type of $O$. colsoni, fide Lambert). Quarry 1.5 miles west of Springfield Church, about 12 miles north of Marianna (USGS 14152, 14182, W. C. Mansfield and C. W. Mumm). Florida Basic Rock Co. quarry 12 miles north of Marianna and $3 / 4$ mile east of Florida Road No. 6 (USGS 12058, G. M. Ponton and W. C. Mansfield). Franklyn Phosphate Company 1.5 miles northwest of Newberry (USGS 6814, C. W. Cooke). 1 mile east of Newberry (USGS $468544-59-3$
14180, W. C. Mansfield and C. W. Mumm). About 3 miles north of Newberry (USGS 13843, W. C. Mansfield and F. S. MacNeil). 3 miles northeast of Newberry (USGS 14177, W. C. Mansfield and C. W. Mumm). 3.5 miles northeast of Newberry (USGS 14178, W. C. Mansfield and C. W. Mumm). Johnson's lime sink, Levy County (USNM 137881a, L. C. Johnson). Old French Phosphate mines east of Anthony (USGS 7366, C. W. Cooke). Ocala (USNM 112506, 164661, Clark and Twitchell's figured specimens, Joseph Willcox; USGS 6804, C. W. Cooke). 2 miles southeast of Ocala (USGS 6805 , C. W. Cooke). 2.5 miles southeast of Ocala (USGS 14137, W. C. Mansfield and C. W. Mumm). 5 miles south of Ocala (USGS 14181, W. C. Mansfield and C. W. Mumm). Kendrick, 4 miles north of Ocala (USGS 12754a, C. W. Cooke and T. E. Kirby) USGS 14125, W. C. Mansfield and C. W. Mumm). Zuber, 6.5 miles north of Ocala (USGS 6807 , C. W. Cooke). 2 miles northeast of Sumterville, Sumter County (USGS 12751, W. C. Mansfield and C. W. Mumm). East of US 41, 1.5 miles north of Williston (USGS 15046, C. W. Cooke and T. E. Kirby). Fort White, Columbia County (USGS 6817, C. W. Cooke). Clark, 5 miles south of High Springs (USGS 6815 , C. W. Cooke). 1 mile north of Istachatta, Hernando County (USGS 11112, C. W. Cooke and D. S. Mossom). Willow Sink, Levy County (USGS 7367, C. W. Cooke). Bushnell Road 3.5 miles southeast of Floral City, Citrus County (USGS 14133, W. C. Mansfield and C. W. Mumm).

Geologic unit.-Late Eocene, Ocala limestone.

Types.-Unknown. Clark and Twitchell's figured specimens USNM 112506, 164661. Specimen figured here USNM 562270, from USGS 7097, Flint River at old factory at Bainbridge, Ga.

Comparisons.-Oligopygus haldemani is commonly smaller than 0 . wetherbyi, it is less elongated, and its periproct is much nearer the margin. $O$. colsoni Lambert is evidently a juvenile specimen of $O$. haldemani. Oligopygus rotundus has longer petals and the posterior slope of its oral depression is much steeper.

\section{Oligopygus rotundus Cooke}

\section{Plate 8, figures 1-5}

Oligopygus rotundus Cooke, 1942, Jour. Paleontology, v. 16, no. 1, p. 9, pl. 2, figs. 1-3.

Horizontal outline nearly circular; upper surface inflated; lower surface flatter; margin broadly rounded. Apical system central, tumid, with four genital pores, monobasal. Petals tumid; paired petals extending more than halfway to the margin, odd petal somewhat longer; poriferous zones narrow, regularly expanding, open distally; pores circular, conjugate. Peristome central, oval, at the bottom of a deep, straight-walled transverse depression occupying less than one-third the total diameter of the test. Periproct small, round, flush, near the posterior third of the lower side. Tubercles rather large, sunken; intermediate spaces granulated.

Length of type $22 \mathrm{~mm}$; width $20.7 \mathrm{~mm}$; height 13.2 $\mathrm{mm}$.

Occurrence.-Alabama : Koons Mill on Cripple Creek, Geneva County (Ala. Geol. Survey, T. H. Aldrich). Bluff on east bank of Pea River 150 yards above the site of the abandoned County Line Bridge, Coffee County (USGS 16925, F. S. MacNeil). 
Double Bridges Creek, Geneva County (Geol. Survey Alabama, Fred Devin).

Geologic unit.-Late Elocene, Moodys Branch formation; or middle Eocene, Claiborne group.

Type-USNM 498991, deposited by Geological Survey of Alabama. Figured specimen USNM 562269 from USGS 16925.

Comparison.-Oligopygus rotundus is very similar to 0 . collignoni Lambert (1931, p. 291, pl. 17, figs. 5-7) from Cuba and may prove to be identical with it. The peristomial depression is similar in shape but is smaller. A larger suite of both species is needed to determine whether this difference is an individual variation. The location of the periproct-farther from the margin than in 0 . haldemani and closer to it than in 0 . wetherbyiand the steeper slopes of the walls of the peristomial depression distinguish Oligopygus rotundus from other North American species.

\section{Family FIBULARIIDAE Gray}

\section{Genus FIBULARIA Lamarck}

Fibularia (part) Lamarck, 1816, Histoire naturelle des animaux sans vertèbres, v. 3, p. 16.

Fibularia Lamarck. Desor, 1858, Synopsis des échinides fossiles, p. 220.

Fibularia Lamarck. A. Agassiz, 1873, Harvard College Mus, Comp. Zoology Mem., v. 3, p. 506.

Echinocyamus Van Phelsom. Lambert and Thiéry, 1914, Nomenclature raisonnée des échinides, fasc. 4, p. 287.

Fibularia Lamarck. Cooke, 1942, Jour. Paleontology, v. 16, no. 1, p. 7.

Fibularia Lamarck. Mortensen, 1948, Monograph of the Echinoidea, v. 4, pt. 2, p. 203 . Includes additional synonymy.

Fibularia Lamarck. Durham, 1955, California Univ. Pub. Geol. Sci., v. 31, no. 4, p. 132.

Type species, Fibularia ovulum Lamarck (validated in Bull. Zool. Nomenclature, v. 4, p. 519), figured by Mortensen (1948, p. 208, pl. 46, figs. 15-17, 21-24). H. L. Clark identified this species with Echinocyamus craniolaris Leske, but Mortensen disagrees. Mortensen's figures show Fibularia ovulum to be small, ovoid; with central apical system, open petals; circular, central, depressed peristome; small circular periproct. It lacks internal radiating supports. This lack of internal supports is regarded by Mortensen as the main feature separating Fibularia from Echinocyamus.

Another distinguishing characteristic is the usually smooth surface of Fibularia as contrasted with the usually pitted surface of Echinocyamus.

\section{Fibularia texana (Twitchell) \\ Plate 9, figures 15-19}

Echinocyamus texanus Twitchell, 1915, U. S. Geol. Survey Mon. 54, p. 120, pl. 57, figs. 2a-d.

Echinocyamus texamus (Twitchell). Lambert and Thiéry, 1925, Nomenclature raisonnée des échinides fasc. 8, p. 576.

Fibularia texana (Twitchell). Cooke, 1942, Jour. Paleontology, v. 16, no. 1, p. 7.

Horizontal outline oval; upper and lower surfaces inflated; margin broadly rounded. Apical system central, with four genital pores, close together. Petals long; poriferous zones straight, far apart, expanding, wide open distally. Peristome central, circular, rather small. Periproct small, circular, nearer the peristome than the margin. Tubercles sunken, close together.

Length of type $5.1 \mathrm{~mm}$; width $4.6 \mathrm{~mm}$; height 4.1 $\mathrm{mm}$.

Occurrence.-Texas: Lee County (type, T. H. Aldrich). San Augustine-Nacogdoches road 6.7 miles east of Attoyac Bayou, San Augustine County (USGS 15093, Julia Gardner and Alex Osanik).

Geologic unit.-Middle Eocene, Weches greensand member of the Mount Selman formation.

Type-USNM 559480, deposited by Johns Hopkins University (T 2002). Figured specimen from USGS 15093, USNM 562296.

Comparison.-Fibularia texana is less elongated than $F$. vaughani, its genital plates are closer together, and its petals are longer. The latter two differences hold also for $F$. alabamensis, whose shape is similar. Most of the specimens from USGS 15093 are more highly inflated than the type, the only one in its lot.

\section{Fibularia vaughani (Twitchell)}

Plate 9, figures 23-27

Echinocyamus vaughani Twitchell, U. S. Geol. Survey Mon. 54, p. 160, pl. 74, figs. 1a-f.

Echinocyamus vaughani Twitchell. Lambert and Thiéry, 1925, Nomenclature raissonnée des échinides, fasc. 9, p. 576.

Echinocyamus vaughani Twitchell. Cooke and Mossom, 1929, Florida Geol. Survey Ann. Rept. 20, pl. 3, figs. 4a-b (after Twitchell).

Fibularia vaughani (Twitchell). Cooke, 1942, Jour. Paleontology, v. 16, no. 1, p. 7 .

Fibularia vaughani (Twitchell). Cooke, 1945, Fla. Geol. Survey Bull. 29, fig. 5, no. 4 (after Twitchell).

Fibularia vaughani (Twitchell). Fischer, 1951, Florida Geol. Survey Geol. Bull. 34, pt. 2, p. 55, text fig. 1.

Test elongated, smaller in front than behind, inflated above and below, depressed around the peristome. Apical system central, with four genital pores wide apart. Petals extending about halfway to the margin; poriferous zones straight, slightly diverging, open at the outer ends; interporiferous zones slightly wider than the poriferous. Peristome circular, large, slightly sunken, central. Periproct small, circular, nearer the peristome than the margin. Tubercles close-set, sunken.

Length of type $7.3 \mathrm{~mm}$; width $5.2 \mathrm{~mm}$; height 4.2 $\mathrm{mm}$.

Occurrence.-Georgia : Little Horseshoe Bend on Flint River 4 miles below Bainbridge (type, USGS 3380, T. W. Vaughan).

Florida: Well near Cedar Keys, depths 115-288 feet (USGS 13143). Well at Leesburg (USGS 2076, L. C. Johnson). 1 mile northwest of Newberry (USGS 6810, C. W. Cooke). Suwannee River at Dowling Springs (USGS 7338, C. W. Cooke). Oakhurst Lime Company 2.5 miles southeast of Ocala (USGS 11749, C. W. Cooke and Stuart Mossom). 2 miles northeast of Sumterville (USGS 12751, W. C. Mansfield and C. W. mumm). Withlacoochee River, W1/2 sec. 3 , T. $17 \mathrm{~S}$, R. $16 \mathrm{E}$, 
Citrus and Levy Counties (UsGS 18749, A. G. Fischer and J. E. Banks).

Comparisons.-Fibularia vaughani is longer than $F$. texana, its genital pores are farther apart, and its peristome is larger. Its peristome is larger and it is commonly longer than $F$. alabamensis, though that species shows considerable variation in dimensions.

Geologic unit.-Late Eocene, Ocala limestone; Inglis limestone.

Type.-USNM 166486. Figured specimen from USGS 18749, USNM 562295 .

Fibularia alabamensis Cooke, n. sp.

Plate 9, figures 20-22

Test ovoid. Apical system central, with four genital pores rather far apart, apparently having large ocular plates, the posterior pair in contact. Petals extending more than halfway to the margin; plates simple, crooked, increasing in width distally ; pore pairs oblique, pores conjugate. Peristome central, small, circular, slightly depressed. Periproct smaller, circular, nearer the peristome than the margin. Tubercles sunken, close together.

Length of type $7.4 \mathrm{~mm}$; width $5.9 \mathrm{~mm}$; height 5.4 $\mathrm{mm}$.

Occurrence.-Alabama: Stream on line between sec. 20 and 29, T 4 N, R 15 E, 6 miles west of Andalusia, Covington County, bed above "Scutella" ledge (USGS 10014, C. W. Cooke and Julia Gardner). "Scutella" ledge on West bank Choctawhatchee River at L. \& N. Railway bridge at Geneva, Geneva County (USGS 6757, C. W. Cooke). Bluff on Conecuh River, SE1/4 sec. 29, T 4 N, R 15 E, Covington County, basal conglomerate overlying beds containing Ostrea sellaeformis (USGS 15561f, F. S. MacNeil). Bluff on Pea River at site of old County-Line Bridge, NW1/4 sec. 35, T 3 N, R $19 \mathrm{E}$, Coffee County; hard marlstone ledge forming break in bluff (USGS 15488, F. S. MacNeil).

Geologic unit.-Late Eocene, probably Moodys Branch formation.

Type.-USNM 372887, from USGS 10014.

Comparisons.-The peristome of Fibularia alabamensis is smaller than that of $F$. vaughani and the test is shorter. The petals are shorter and the genital pores are farther apart than in $F$. texana.

\section{Genus ECHINOCYaMUS van Phelsum}

Echinocyamus van Phelsum, 1774, Brief aan Cornelius Nozeman, over de Gewelvslekken of Zee-egelen, p. 131.

Echinocyamus (part) Leske, 1778, Klein's Naturalis dispositio Echinodermatum, p. 215.

Fibularia (part) Lamarck, 1816, Histoire naturelle des animaux sans vertèbres, v. 3, p. 16 .

Fibularia Lamarck. Lambert and Thiéry, 1914, Nomenclature raisonnée des échinides, fasc. 4, p. 289.

Echinocyamus Leske. Cooke, 1942, Jour. Paleontology, v. 16, no. 1, p. 27.

Echinocyamus (v. Phelsum) Leske. Mortensen, 1948, Monograph of the Echinoidea, v. 4, pt. 2, p. 170. Includes complete synonymy.

Echinocyamus van Phelsum. Durham, 1955, California Univ. Pub. Geol. Sci., v. 31, no. 4, p. 133.
Type species, Spatangus pusillus Müller, 1776. The genus was validated as of van Phelsum and the type species was designated in Opinion 207 of the International Commission on Zoological Nomenclature. Echinocyamus pusillus, a species living in the eastern Atlantic, has been described by A. Agassiz (1873, p. 505, pl. 11e, fig. 3 ; pl. 13, figs. 1-8) and by Mortensen (1948, p. 178, text figs. $96,100,101,103-105)$, who cites many other references. It is small, oval, flattish, shaped much like a watermelon seed. Its apical system is central, with four widely spaced genital pores. Its petals extend about half-way to the rounded margin; the poriferous zones are nearly straight, diverging, and wide open at both ends; the pores are circular and the pairs are oblique. The peristome is small, circular. The periproct is smaller, circular, and about midway between the peristome and the margin. Thin internal buttresses strengthen the test. The auricles are fused into single blunt projections. The tubercles are rather large, slightly sunken, but not conspicuous.

\section{Echinocyamus parvus Emmons}

Plate 9, figures 9-11

Echinocyamus parvus Emmons, 1858, Agriculture of the eastern counties, p. 307, fig. 244.

Echinocyamus parvus Emmons, Clark and Twitchell, 1915, U. S. Geol. Survey Mon. 54, p. 119.

Echinocyamus parvus Emmons. Kellum, 1926, U. S. Geol. Survey Prof. Paper 143, p. 14.

Echinocyamus parvus Emmons. Cooke, 1942, Jour. Paleontology, v. 16, no. 1, p. 28, pl.1, figs. $6-8$.

Horizontal outline ovate, the anterior end the smaller; upper and lower surfaces flat; margin rounded. Apical system central, with four genital pores very far apart. Petals short, extending less than halfway to the margin; poriferous zones nearly parallel, open at both ends, composed of four or five oblique pairs of pores about as far apart as the distance between the pores. Peristome large, central, circular. Periproct small, circular, less than half as wide as the peristome, about midway between the peristome and the margin. Tubercles sunken.

Length of figured specimen $5.8 \mathrm{~mm}$; width $4 \mathrm{~mm}$; height $1.8 \mathrm{~mm}$.

Occurrence.-North Carolina: Craven County (type). Farm of J. M. Thomas 10 miles north of Jacksonville, Onslow County (USGS 10636, L. B. Kellum).

Alabama: Railroad bridge over Choctawhatchee River at Geneva (USGS 10036, C. W. Cooke and Julia Gardner).

Geologic unit.-Late middle Eocene, Castle Hayne limestone in North Carolina.

Type,-Lost. Not found at Williams College, where other of Emmons' types were deposited. Figured specimen USNM 499002, from USGS 10636.

Remarks.-A specimen from USGS 10636 shows the internal buttresses. 


\section{Echinocyamus huxleyanus Meyer}

Plate 9, figures 12-14

Echinocyamus huxleyanus Meyer, 1886, Alabama Geol. Survey Bull. 1, p. 85, pl. 3, fig. 23.

Echinocyamus huxleyanus Meyer. De Gregorio, 1890, Faune éocenique de l'Alabama, p. 251, pl. 43, fig. 15 (after Meyer).

Echinocyamus husleyanus Meyer. Clark and Twitchell, U. S. Geol. Survey Mon. 54, p. 119, pl. 57, figs. 1a-d.

Fibularia huxleyi (Meyer). Lambert and Thiéry, 1925, Nomenclature raisonnée des échinides, fasc. 9, p. 577. Error for F. huxleyanus.

Echinocyamus huxleyanus Meyer. Cooke, 1942, Jour. Paleontology, v. 16, no. 1, p. 29, pl. 1, figs. 1-5.

Horizontal outline ovate, the anterior end the smaller; upper and lower surfaces slightly rounded; margin rounded. Apical system slightly anterior, with four large (female?) or small (male?) genital pores, rather far apart. Petals straight, open at both ends, extending more than halfway to the margin; poriferous zones including six or eight oblique pairs of small pores. Peristome rather large, circular, sunken. Periproct smaller, circular, nearer the margin than the peristome. Tubercles sunken.

Length of figured specimen (male?) $5.3 \mathrm{~mm}$; width $4 \mathrm{~mm}$; height $2 \mathrm{~mm}$.

Occurrence.-Alabama : Claiborne.

Geologic unit.-Late middle Eocene, Gosport sand.

Type.-USNM 559484, deposited by Johns Hopkins University (T 2005). Figured specimen USNM 559481, one of a lot of four specimens, of which the smallest (a female?) was figured by Clark and Twitchell.

Remarks.-The type is broken in halves, revealing the internal buttresses that are characteristic of Echinocyamus. The species is longer and higher than Echinocyamus meridionalis. Its petals are longer and its genital pores closer together than those of Echinocyamus parvus.

\section{Echinocyamus meridionalis Meyer}

Plate 9, figures 4, 5

Echinocyamus meridionalis Meyer, 1887, Senkenburg. naturf. Gesell. Ber. 1887, Vorträge, p. 12, pl. 2, figs. 21, 21 a.

Echinocyamus meridionalis Meyer. De Gregorio, 1890, Faune éocenique de l'Alabama, p. 251, pl. 43, figs. 13, 14 (after Meyer).

Fibularia meridionalis (Meyer). Clark and Twitchell, 1915, U. S. Geol. Survey Mon. 54, p. 121, pl. 57, figs. 3a-d.

Fibularia meridionalis (Meyer). Lambert and Thiéry, 1925, Nomenclature raisonnée des échinides, fasc. 9 , p. 577.

Echinocyamus meridionalis Meyer. Cooke, 1942, Jour. Paleontology, v. 16, no. 1, p. 29.

Horizontal outline oval; flat on top and underneath; margin rounded. Apical system and petals obscure. Peristome large, central, circular. Periproct small, circular, submarginal.

Length of figured specimen $2.5 \mathrm{~mm}$; width $2.1 \mathrm{~mm}$; height $0.4 \mathrm{~mm}$.
Occurrence.-Alabama: Claiborne (type)

Mississippi: Jackson (fide Meyer). This specimen is said to be more elliptical.

Geologic unit.-Probably late middle Eocene, Gosport sand; possibly late Eocene, Moodys Branch formation.

Type.-USNM 559486, deposited by Johns Hopkins University. Figured specimen USNM 559485, the smallest of 4 assigned that number, 1 of which was figured by Clark and Twitchell.

Comparisons.-Echinocyamus meridionalis is rounder and flatter than any other Echinocyamus here described, and the periproct is nearer the margin. The specimen figured is smaller than the type.

\section{Echinocyamus chipolanus Cooke \\ Plate 9, Figures 1-3}

Echinocyamus chipolanus Cooke, 1942, Jour. Paleontology, v. 16, no. 1, p. 29, pl. 1, figs. 9-11.

Horizontal outline oval; upper surface somewhat inflated; lower surface flat; margin rounded. Apical system central, with four genital pores, far apart. Petals obscure, poriferous zones apparently widely diverging. Peristome large, about one-third the total width, circular. Periproct small, circular, nearer the margin than the peristome. Having two thin internal marginal buttresses in each interambulacral area. Auricles fused, hoe shaped.

Length $4 \mathrm{~mm}$; width $3.3 \mathrm{~mm}$; height $1.3 \mathrm{~mm}$.

Occurrence.-Florida: Lower bed at Alum Bluff, Apalachicola River, Liberty County (USGS 2211, Frank Burns).

Geologic unit.-Early Miocene, Chipola formation.

Type.-USNM 499003.

Comparisons.-This species is more inflated than any other Echinocyamus described here, and its peristome is much larger. The genital pores are farther apart than those of $E$. huxleyanus, and its poriferous zones appear to be more widely diverging. The type is a unique specimen. It has been broken since figuring, revealing the auricles and the buttresses.

\section{Echinocyamus macneili Cooke, n. sp. Plate 9, figures $6-8$}

Horizontal outline ovate, the anterior end the narrower; upper surface rather high, rounded; lower surface gently rounded, concave around the peristome; margin broadly rounded. Apical system slightly anterior, with four very large genital pores (female?) far apart. Petals long, straight; poriferous zones parallel; anterior pair widely diverging, nearly forming a straight line. Peristome large, central, circular, sunken. Periproct small, circular, more than halfway from the peristome to the margin. Tubercles large, sunken, crowded.

Length $5.6 \mathrm{~mm}$; width $4.0 \mathrm{~mm}$; height $2.4 \mathrm{~mm}$.

occurrence-Alabama: Creek flowing into Conecuh River in the NE1/4 sec. 32 , T. 4 N., R. 15 E., Covington County, upper Pecten bed (USGS 15562, F. S. MacNeil). 
Geologic unit.-Late Eocene, probably an equivalent of the Moodys Branch formation.

Type.-USNM 562297.

Comparison.-The horizontal outline of Echinocyamus macneili is similar to that of $E$. parvus, but the upper surface is higher and more rounded. The genital pores are not so far apart but are much larger in the type, probably a female, the only specimen known.

\section{Genus PORPITELIA Pomel}

Scutellina (Porpitella) Pomel, 1883, Classification méthodique et genera des échinides, p. 72.

Porpitella Pomel. Lambert, 1905, Lyon Univ. Annales, n. s., fasc. 17, p. 138.

Porpitella Pomel. Lambert and Thiéry, 1914, Nomenclature raisonnée des échinides, fasc. 4, p. 294.

Porpitella Pomel. H. L. Clark, 1937, Jour. Paleontology, v. 11, no. 3, p. 248.

Porpitella Pomel. Cooke, 1942, Jour. Paleontology, v. 16, no. 1, p. 30.

Porpitella Pomel. Mortensen, 1948, Monograph of the Echinoidea, v. 4, pt. 2, p. 231.

Porpitella Pomel. Durham, 1955, California Univ. Pub. Geol. Sci, v. 31, no. 4, p. 136.

Type species, Scutellina hayesiana Agassiz (Agassiz and Desor, 1847, p. 82) designated by Lambert (1905, p. 138). This name is a synonym of Scutellina supera Agassiz (1841, p. 103, pl. 21, figs. 24-28), which was discarded by Agassiz and Desor, who identified it as Cassidulus hayesianus Desmoulins, a nude name. Scutellina supera was revived by Cotteau (1899-1894, p. 339, pl. 285, pl. 286, figs. 1-7). Mortensen (p. 231, figs. 140, 141), copies some of Cotteau's figures.

The figures indicate that Porpitella supera is nearly circular, slightly arched on top, concave underneath. It has four genital pores. Its petals are slightly open at the apical end, wider open distally. About half-petal distance from the apex the ambulacral plates widen and the interambulacral plates contract; the ambulacra are much wider than the interambulacra at the margin. The peristome is small, central, circular. The periproct is small, circular, supramarginal, nearer the margin than the apex.

Although Pomel did not actually use the combination Scutellina (Porpitella) indicated in the synonymy, the capital and lower-case type in which Porpitella is set indicates that he regarded Porpitella as a subgenus or section of Scutellina, which is printed in capital and small capital letters.

\section{Porpitella micra H. L. Clark}

Plate 7, figures 5-7

Porpitella micra H. L. Clark, 1937, Jour. Paleontology, จ. 11, no. 3, p. 248.

Porpitella micra H. L. Clark. Cooke, 1942, Jour. Paleontology, จ. 16, no. 1, p. 30 .
Horizontal outline ovate, smaller end in front; upper surface gently rounded; lower surface concave; margin acutely rounded. Apical system slightly anterior, with four genital pores rather far apart. Petals extending little more than halfway to the margin, nearly as wide as long, wide open at both ends; inner rows of pores straight, parallel; outer rows convex outwardly; pore pairs rather far apart, slightly oblique. Peristome central, circular, depressed. Periproct on the upper surface, not far from the margin, small, circular. Tubercles depressed, covering entire surface.

Length of figured paratype $8.7 \mathrm{~mm}$; width $7.5 \mathrm{~mm}$; height $3.1 \mathrm{~mm}$.

Occurrence.-Alabama: Cuttings from a well (Oakley Estate well 2) sec. 9, T. 3 N., R. 29 E., Houston County, depth 38004000 feet, associated with Ostrea sellaeformis Conrad.

Geologic unit.-Probably middle Eocene, Lisbon formation.

Type-Alabama Mus. Nat. History no. 85, Tuscaloosa, Ala. Paratypes in Alabama Mus. Nat. History, Mus. Comp. Zoology, and USNM 562294 (figured).

Remarks.-According to Clark this species has ten internal marginal buttresses bounding the ambulacra as in Echinocyamus. The open apical ends of the petals also suggest Echinocyamus, from which Porpitella is readily distinguished by the supramarginal location of its periproct.

\section{Family CLYPEASTERIDAE L. Agassiz Genus CLYPEASTER Lamarck}

Clypeaster Lamarck, 1801, Système des animaux sans vertèbres, p. 349.

Clypeaster Lamarck, 1816, Histoire naturelle des animaux sans vertèbres, v. 3, p. 12 .

Echinanthus Gray, 1825, Annals of Philosophy, ser. 2, v. 10, p. 427.

Stolonoclypus A. Agassiz, 1863, Harvard College Mus. Comp. Zoology Bull., v. 1, p. 25. Type species, Clypeaster prostratus Ravenel=Echinanthus subdepressa Gray, designated by H. L. Clark (1911, p. 595).

Clypeaster (Echinorodum) Pomel, 1883, Classification méthodique et genera des échinides, p. 68. Type species, Echinus rosaceus Linnaeus, designated by Cooke (1942, p. 11).

Diplothecanthus Duncan, 1891, Linnean Soc. London Jour., Zoology, v. 23, p. 153. Type species, Echinus reticulatus Linnaeus $=$ Echinus rosaceus Linnaeus, by monotypy.

Clypeaster Lamarck. H. L. Clark, 1911, Annals and Mag. Nat. History, ser. 8, v. 7, p. 604.

Clypeaster Lamarck. Cooke, 1942, Jour. Paleontology, v. 16, no. 1, p. 11.

Clypeaster Lamarck. Mortensen, 1948, Monograph of the Echinoidea, v. 4, pt. 2, p. 39. Includes additional synonymy.

Clypeaster Lamarck. Durham, 1955, California Univ., Pub. Geol. Sci., v. 31, no. 4, p. 118. Includes additional synonymy.

Type species, Echinus rosaccus Linnaeus, fixed by elimination by Lamarck (1816, p. 13). See H. L. Clark (1911, p. 594).

Key to the species of Clypeaster

Inner rows of pores of petals straight.

Peristome not deeply sunken Clypeaster rogersi Peristome deeply sunken Clypeaster cotteaui 
Inner rows of pores of petals curved.

Lower side nearly flat; submargin depressed.

Tips of lateral petals strongly incurved_..._._._._._. Clypeaster subdepressus

Tips of lateral petals not strongly incurved_................ Clypeaster oxybaphon

Lower side deeply depressed; submargin not depressed.

Tips of lateral petals very strongly incurved

Tips of lateral petals less strongly incurved

Clypeaster rosaceus Clypeaster concavus

Clypeaster rosaceus (Linnaeus)

Plate 10, figures 1-3

Echinus rosaceus Linnaeus, 1758, Systema naturae, ed. 10, p. 665.

Clypeaster rosaceus (Linnaeus). Lamarck, 1801, Système des animaux sans vertèbres, $p .349$.

Diplothecanthus rosaceus (Lamarck). Clark and Twitchell, 1915 U. S. Geol. Survey Mon. 54, p. 219, pl. 102, figs. 1a-b; pl. 103, figs. 1a-b.

Diplothecanthus dalli Twitchell, 1915, U. S. Geol. Survey Mon. 54, p. 218, pl. 99, figs. 2a-b; pl. 100, figs. 1a-b.

Clypeaster rosaceus (Linnaeus). Jackson, 1922, Carnegie Inst. Washington Pub. 306, p. 33.

Clypeaster rosaceus (Linnaeus). Cooke, 1942, Jour. Paleontology, v. 16, no. 1, p. 11.

Clypeaster rosaceus (Linnaeus). Mortensen, 1948, Monograph of the Echinoidea, $\nabla .4$, pt. 2 , p. 40 , pl. 1 , figs. $2-4$; pl. 64 , figs. 1-5. Includes additional synonymy.

Clypeaster rosaceus (Linnaeus). Sanchez Roig, 1949, Equinodermos fósiles de Cuba, p. 78.

Clypeaster rosaceus (Linnaeus). Durham, 1955, California Univ. Pub. Geol. Sci., v. 31, no. 4, text figs. 15a, 25 a.

Clypeaster rosaceus (Linné). DuBar, 1958, Florida Geol. Survey Bull. 40, p. 209, pl. 12, fig. 17.

Test large; horizontal outline subpentagonal; upper surface strongly inflated, with swollen petals; lower surface flattish near the margin, with five conspicuous ambulacral grooves, deeply concave around the peristome; margin broadly rounded. Apical system central, with a large central madreporite; genital pores five, usually outside the apical system. Petals long, broad, swollen, completely closed at the apex, moderately open distally; poriferous zones proportionately narrow, strongly curved inward near the tips; pores circular, conjugate. Peristome central, deeply sunken, pentagonal. Periproct small, circular, submarginal. Tubercles sunken in small scrobicules, perforated.

Length of figured specimen, a small denuded specimen of Recent age, $93.0 \mathrm{~mm}$; width $73.0 \mathrm{~mm}$; height $30.0 \mathrm{~mm}$.

Occurrence.-Littoral from South Carolina to Barbados (fide Mortensen, 1948, p. 43).

Florida: Ragged Keys (Recent, USNM 19632, J. E. Benedict). Caloosahatchee River 2.5 miles below LaBelle (fossil, USGS 4955, F. G. Clapp). Four-mile Hammock, between Fort
Thompson and Denaud (USGS 2094, W. H. Dall, type of Diplothecanthus dalli). About 1 mile below LaBelle (Florida Geol. Survey I-209).

Dominican Republic: Gato (USNM 328234, Rodolfo Cambiarso).

Geologic unit.-Pleistocene and Recent. The specimens from Florida originally credited to the Caloosahatchee formation of Pliocene age probably came from the Fort Thompson formation of Pleistocene age.

Types.-The type of Diplothecanthus dalli is USNM 164670, from the Pleistocene of Florida. Figured specimen, USNM 19632, a small Recent specimen from Ragged Keys, Florida.

Remarks.-This species, the type of Clypeaster Lamarck, is variable in height, degree of inflation of the petals, and in other features. Two of the three fossil specimens from the Caloosahatchee River named Diplothecanthus dalli by Twitchell have somewhat more inflated petals than the other, which Twitchell identified as $D$. rosaceus. There seems to be no doubt that all are Clypeaster rosaceus and that they are Pleistocene rather than Pliocene, as had been supposed.

\section{Clypeaster concavus Cotteau}

Plate 10, figures 4-6; plate 11, figure 5

Clypeaster ellipticus Michelin. Guppy, 1866, Geol. Soc. London Quart. Jour., v. 22, p. 299.

Clypeaster concavus Cotteau, 1875, K. svenska vetensk.-akad. Handl., v. 13, no. 6, p. 16, pl. 2, figs. 4-8.

?Clypeaster antillarum Cotteau, $1875, \mathrm{~K}$. svenska vetensk.-akad. Handl., v. 13, no. 6, p. 15, pl. 2, figs. 1-3.

Clypeaster convavus Cotteau. Guppy, 1882, Sci. Assoc. Trinidad Proc., pt. 12, p. 195.

Clypeaster lanceolatus [Azpeitia MS] Egozcue, 1897, Com. Mapa Geol. España Bol. v. 22, p. 39, pl. 9, figs. 1-3.

?Clypeaster antillarum Cotteau. Egozcue, 1897, Com. Mapa Geol. España Bol., v. 22, p. 35, pl. 7, figs. 1-3 (after Cotteau).

Clypeaster concavus Cotteau. Egozcue, 1897, Com. Mapa Geol. España Bol., v. 22, p. 36, pl. 7, figs. 4-8 (after Cotteau).

Not Diplothecanthus concavus (Cotteau). Brown, 1933, Acad. Nat. Sci. Philadelphia Proc., v. 65, p. 600.

Not Diplothecanthus antillarum (Cotteau). Brown, Acad. Nat. Sci. Philadelphia Proc., v. 65, p. 601.

Clypeaster lanceolatus Cotteau [Egozcue]. Jackson, 1917, U. S. Natl. Mus. Proc., v. 55, no. 2218, p. 490, pl. 62, figs. 1, 2.

Clypeaster gatuni Jackson, 1917, U. S. Natl. Mus. Proc., v. 55, no. 2218 , p. 491 , pl. 63 , fig. 1 ; pl. 64 , fig. 1 .

Clypeaster gatuni Jackson. Jackson, 1918, U. S. Natl. Mus. Bull. 103 , p. 105 , pl. 47 , fig. 1 ; pl. 48 , fig. 1 (after Jackson, 1917).

Clypeaster lanceolatus Cotteau [Egozcue]. Jackson, 1918, U. S. Natl. Mus. Bull. 103, p. 104, pl. 46, figs. 1, 2.

Clypeaster concavus Cotteau. Jackson, 1922, Carnegie Inst. Washington Pub. 306, p. 34, pl. 2, figs. 10-12.

Clypeaster lanceolatus Cotteau [Egozcue]. Jackson, 1922, Carnegie Inst. Washington Pub. 306, p. 38, pl. 4, fig. 2.

?Clypeaster antillarum Cotteau. Jackson, 1922, Carnegie Inst. Washington Pub. 306, p. 39, pl. 5, figs. 1, 2.

Clypeaster concavus Cotteau. Sanchez Roig, 1924, Soc. cubana historia nat. Felipe Poey Mem., v. 5, no. 1, p. 24.

Clypeaster lanceolatus Cotteau [Egozcue]. Sanchez Roig, 1924, Soc. cubana historia nat. Felipe Poey Mem., v. 5, no. 1, p. 25. 
?Clypeaster antillarum Cotteau. Sanchez Roig, 1924, Soc. cubana historia nat. Felipe Poey Mem., v. 5, no. 1, p. 26.

Clypeaster gatuni Jackson. Cooke, 1942, Jour. Paleontology, v. 16, no. 1, p. 13, pl.1, fig. 15.

Clypeaster concavus Cotteau. Sanchez Roig, 1949, Equinodermos fósiles de Cuba, p. 68.

Clypeaster lanceolatus Azpeitia [Egozcue]. Sanchez Roig, 1949, Equinodermos fósiles de Cuba, p. 70.

Clypeaster concavus Cotteau. Caso, 1957, Inst de Biologīa Mexicana Anales, v. 27, p. 497, 524.

Horizontal outline oval to subpentagonal; upper surface moderately inflated, petals slightly swollen; lower surface gently rounded near the margin, more or less deeply concave around the peristome, ambulacral grooves conspicuous; margin rounded. Apical system pentagonal, central; five genital pores at the corners of the central madreporite. Petals broad, lanceolate, extending about two-thirds the way to the margin, strongly convex near the tips; poriferous zones rather broad, completely closed at the apex, nearly closed distally; inner pores small, circular; outer pores larger, oval; pores conjugate; interporiferous zones more than twice as wide as the poriferous at the widest part. Peristome central, small. Periproct circular or transversely oval; near the margin. Tubercles crowded, sunken, smaller on the upper surface than on the lower; one row between each two pairs of zygopores.

Length of figured specimen $93.0 \mathrm{~mm}$; width 78.5 $\mathrm{mm}$; height $24.6 \mathrm{~mm}$.

Occurrence.-Anguilla, British West Indies; two cotypes and four other specimens (USNM 115373, 115375, 115376, 115377, 115384 , R. J. L. Guppy). Crocus Bay (USGS 6893, 6967, T. W. Vaughan; USNM 561746, R. A. Christman).

Tintamarre (Flat Island), French West Indies: North Cove (USNM 561747, R. A. Christman).

Puerto Rico: Moca quadrangle $\mathrm{K} 4.2$ route $112,2.2 \mathrm{k}$ from south edge of quadrangle (USGS 19764, C. W. Cooke and A. D. Watt). Eastern edge of San Sebastian quadrangle, $1.5 \mathrm{k}$ south of north edge (USGS 19812, C. W. Cooke and A. D. Watt). San Sebastian quadrangle, K 9.9 on road running south-southeast from Central Soller and about $0.4 \mathrm{k}$ south of it (USGS 19798, C. W. Cooke and A. D. Watt).

Dominican Republic: Arroyo Blanco near Cevicos (USGS 8598, USNM 328233, C. W. Cooke and C. P. Ross, four-rayed specimen figured by Jackson).

Cuba: Jique de la Argolla, Rio Seco de San Antonio, Guantánamo (USNM 561748, C. T. Ramsden).

Canal Zone: From upper limestone bed near Tower N (USGS 5865, D. F. MacDonald). Gaillard Cut, east side, 100 yards up Río Masambí (USGS 16955, W. P. Woodring and T. G. Moran). Gatun Lake area, stream $1 / 4$ mile east of Río Caraba, 11/2 miles south-southeast of mouth of Rio Caraba (USGS 17685, W. P. W'oodring). Near Gatun Dam site (USGS 5662, D. F. MacDonald, type of Clypeaster gatuni Jackson).

Panama: Río Chagres, limestone at Marcelita, just below Bajilla rain gauge station, about 1 mile below mouth of Río Pequeni (USGS 8386, A. A. Olsson). Transisthmian Highway, 0.8 mile north of Madden Highway, in underpass at Roque (USGS 16945, W. P. Woodring and J. R. Schultz.
Florida: One mile below Baileys Ferry, Chipola River, Calhoun County (USGS 2213, USNM 164671, Frank Burns, figured by Cooke, 1942).

Geologic unit.-Early Miocene, Chipola formation in Florida, Anguilla formation in Anguilla, Gatun formation and Empereador limestone in Canal Zone, Cevicos limestone in Dominican Republic, Cibao limestone in Puerto Rico.

Types.-Cotypes of $C$. concavus, USNM 115375, 115376, from Anguilla. Type of $O$. gatuni, USNM 234453, from USGS 5662, Canal Zone. Possible type of $C$. antillarum, USNM 115390, reported to be from Antigua but labelled Porto Rico. Type of C. lanceolatus, from Matanzas, Cuba, Comision del Mapa Geológico de España, Madrid. Specimen from Florida figured by Cooke (1942) under the name C. gatuni, USNM 164671. Fourrayed specimen from the Dominican Republic figured by Jackson (1922, pl. 2, fig. 12) USNM 328233. Specimen from Crocus Bay, Anguilla, figured here, USNM 561746.

Remarks.-Like most Clypeasters, Clypeaster concavus shows considerable variation in size, shape, the degree of flatness of the under side, and the deepness of the concavity. The specimen in the Cleve collection labelled Clypeaster antillarum (USNM 115390) has a thicker margin than customary for $C$. concavus but otherwise resembles it.

Several Clypeasters from Cuba described as new species by Lambert or by Sanchez Roig may be Clypeaster concavus. Their names have been omitted from the synonymy because the figures are too obscure to permit their identification.

Clypeaster oxybaphon Jackson

Plate 11, figure 1

Clypeaster oxybaphon Jackson, 1922, Carnegie Inst. Washington Pub. 306, p. 44, pl. 7, figs. 3, 4; pl. 8, figs. 1-3.

Clypeaster platygaster Jackson, 1922, Carnegie Inst. Washington Pub. 306, p. 45, pl. 9, figs. 1, 2.

Clypeaster platygaster Jackson. Sanchez Roig, 1924, Soc. cubana historia nat. Felipe Poey Mem., v. 5, no. 1, pl. 28.

Clypeaster oxybaphon Jackson. Cooke, 1942, Jour. Paleontology, v. 16, no. 1, p. 13, pl. 8, fig. 7.

Clypeaster oxybaphon Jackson. Sanchez Roig, 1949, Equinodermos fósiles de Cuba, p. 81.

?Clypeaster polygonalis Sanchez Roig, 1949, Equinodermos fósiles de Cuba, p. 84, pl. 7, figs. 1, 2.

?Clypeaster pinarensis Lambert and Sanchez Roig in Sanchez Roig, 1949, Equinodermos fósiles de Cuba, p. 86, pl. 12, figs. $1,2$.

9Clypeaster profundus Sanchez Roig, 1949, Equinodermos fósiles de Cuba, p. 91, pl. 6, figs. 1-3.

Clypeaster platygaster Jackson. Sanchez Roig, 1949, Equinodermos fósiles de Cuba, p. 92.

Clypeaster oxybaphon Jackson. Caso, 1957, Inst. de Biología Mexicana Anales, v. 27, p. 505, figs. 6-8.

Horizontal outline subpentagonal; upper surface depressed below the margin, more or less swollen in the apical region; lower surface nearly flat, with a shallow depression around the peristome and narrow ambulacral furrows; margin thick, rounded. Apical system central, defective in all the specimens at hand. Petals flush or slightly swollen, extending about two-thirds the way to the margin, lanceolate, rather wide, incurved near the tip; poriferous zones rather wide, 
pores conjugate; interporiferous zones about twice as wide as the poriferous. Peristome nearly central. Periproct near the margin. Tubercles small, sunken.

Length of holotype $115.0 \mathrm{~mm}$; width $112.0 \mathrm{~mm}$; height $18.3 \mathrm{~mm}$.

Occurrence.-Antigua, British West Indies: Willoughby Bay (USGS 6881, type, T. W. Vaughan; USNM 328289, W. R. Forrest).

Puerto Rico: Corozal quadrangle, $7.5 \mathrm{k}$ southwest of Vega Alta (USGS 19240, O. W. Cooke and A. D. Watt). Camuy quadrangle, $\mathrm{K} 10.8$ on route 129 at hairpin bend $2 \mathrm{k}$ from the south edge of the quadrangle (USGS 19700 , C. W. Cooke and A. D. Watt). Peñuelas quadrangle, road south of Peñuelas at K 1.75 (USGS 19672, C. W. Cooke and A. D. Watt). Guánica quadrangle, K 2.3 on road to Faro de Guánica (USGS 19683, C. W. Cooke and A. D. Watt). Guánica harbor (Am. Mus. Nat. History, C. A. Reeds, fide Jackson).

Cuba: Havana, not far from the university (Am. Mus. Nat. History 18569, Barnum Brown (fide Jackson, type of Clypeaster platygaster).

Canal Zone: From creamy limestone a mile or less north of New Frijoles on the relocated line of the Panama Railroad (USGS 5908, D. F. MacDonald).

Florida: NW1/4 sec. 36 T.4N, R.13W., Washington County (USGS 15068a, F. S. MacNeil).

Geologic unit.-Late Oligocene, Antigua formation in Antigua, Suwannee limestone in Florida. Juána Díaz formation and equivalents in Puerto Rico.

Types.-Holotype of CTypeaster oxybaphon, USNM 328241; of $C$.platygaster, Am. Mus. Nat. History 18569; of C.polygonalis, Sanchez Roig collection 132, Havana; of $O$. pinarensis, Sanchez Roig collection 135; of 0 . profundus, Sanchez Roig collection 139. Specimen from Florida figured by Cooke, USNM 499006.

Remarks.-The shape of the petals, the thickened margin, the broad posterior truncation, and the nearly flat lower surface appear to be constant features in this species. The submargins in all the specimens available are lower than the margins, but the degree of inflation of the apical region is variable.

The three species of Sanchez Roig, all from Cuba, tentatively placed in the synonymy are too poorly figured for certain recognition.

\section{Clypeaster subdepressus (Gray)}

Plate 11, figures 2-4

Echinanthus subdepressa Gray, 1825, Annals of Philosophy, ser. 2, v. 10, p. 427.

Clypeaster prostratus Ravenel, 1848, Echinidae, Recent and fossil, of South Carolina, p. 3.

Clypeaster subdepressus (Gray). A. Agassiz, 1874, Harvard College Mus. Comp. Zoology Mem., v. 3, p. 306, pl. 11b ; pl. 11e, figs. 1,2 ; pl. 12d, fig. 4 ; pl. 13, figs. 10-18.

Clypeaster subdepressus (Gray). H. L. Clark, 1914, Harvard College Mus. Comp. Zoology Mem., v. 46, p. 38, pl. 123, figs. 11, 12.

Clypeaster subdepressus (Gray). Cooke, 1942, Jour. Paleontology, จ. 16, no. 1, p. 11, pl. 4, fig. 5.

Clypeaster (Stolonoclypus) subdepressus (Gray). Mortensen, 1948, Monograph of the Echinoidea, v. 4, pt. 2, p. 112, pl. 23 , figs. $1-3$; pl. 24, fig. 3 ; pl. 25 , fig. 6 ; pl. 26 , figs. 1,6 ; pl. 27 , fig. 4 ; pl. 45 , figs. $4,11,14,15$. Includes additional synonymy.
Clypeaster (Stolonoclypus) prostratus Ravenel. Mortensen, 1948, Monograph of the Echinoidea, v. 4, pt. 2, p. 118, pl. 16, fig. 1 ; pl. 24 , fig. 1 ; pl. 25 , figs. 1 , 2 ; pl. 26 , fig. 5 .

Test large; horizontal outline subovate to subpentagonal, usually truncate or reentrant in the interambulacra; upper surface tumid in the petaloidal region, flatter marginally; lower surface nearly flat, slightly concave at the peristome, having narrow ambulacral furrows, the paired furrows bent towards each other near the peristome; margin rather thin. Apical system pentagonal, with five genital pores at the corners of the madreporite. Petals rather short, extending more than halfway to the margin, the anterior the longest; poriferous zones curved inward at the outer tips but more or less open, pores near the apex inconspicuous, hence seemingly wide open; interporiferous zones wide; pores conjugate. Peristome central, circular. Periproct near the posterior margin. Tubercles small.

Length of Recent specimen from Longboat Key, Florida, $130.0 \mathrm{~mm}$; width $110.0 \mathrm{~mm}$; height $25.0 \mathrm{~mm}$.

Occurrence.-(Recent) Florida to Brazil (fide Mortensen). Gulf of Mexico off Longboat Key (USNM, J. Brookes Knight).

South Carolina: Intracoastal Waterway canal about $\mathbf{3}$ miles southwest of Little River, about 1.5 miles southwest of the highway bridge near Nixons Crossroads, and about 15 miles northeast of Myrtle Beach, Horry County (Charleston Museum, Robert Lunz; USGS 13377, C. W. Cooke; USGS 18759 , L. C. Glenn).

Geologic unit.-Pleistocene to Recent.

Figured specimen.-USNM 562274b, from USGS 18759.

Remarks.-The fossil species from South Carolina appeara to have no constant differences from the Recent species, which is rather variable. The anterior petal tends to be somewhat, wider open than those of the specimens figured by Mortensen under the name of $\sigma$. subdepressus, in this respect agreeing with the Recent specimens from South Carolina figured by him as $C$. prostratus. The collections from the Intracoastal Waterway are from dredgings that appear to represent a mixture of deposits of late Miocene and Pleistocene age. This species presumably came from the Pleistocene.

\section{Clypeaster rogersi (Morton)}

Plate 12, figures 4-6

Scutella rogersi Morton, 1834, Synopsis of the organic remains of the Cretaceous group, p. 77, pl. 13, fig. 3.

Lagana rogersi (Morton). Agassiz, 1840, Catalogus systematicus ectyporum Echinodermatum, p. 6.

Not Scutella rogersi Morton. Agassiz, 1841, Mon. échinodermes vivans et fossiles, Mon. 2, p. 85, pl. 19a, figs. 1-4 (=Periarchus quinquefarius (Say)).

Scutella jonesi Forbes in Lyell, 1845, Geol. Soc. London Proc., v. 4, p. 574, text fig.; Geol. Soc. London Quart. Jour., v. 1, p. 440 , text fig.

Not Mortonia rogersi (Morton). Desor, 1858, Synopsis des échinides fossiles, p. 231. (=Periarchus quinquefarius (Say)).

Clypeaster rogersi (Morton). Conrad, 1866, Smithsonian Misc. Coll., v. 7 (200), p. 22. 
Mortonia turgida Conrad, 1865, Acad. Nat. Sci. Philadelphia Proc., v. 17, p. 184.

Scutella (Mortonia) rogersi (Morton). De Gregorio, 1890, Mon. faune éocenique de l'Alabama, p. 250, pl. 43, fig. 16 (after Morton). Not description nor figs. 17-20 (=Periarchus quinquefarius (Say) after Agassiz).

Clypeaster rogersi (Morton). De Loriol, 1891, Soc. physique et d'histoire nat. de Genève Mem. v. sup. 1890, no. 8, p. 99.

Clypeaster douvillei Stefanini, 1911 Soc. geol. italiana Boll. 30, p. 682 , p. 22 , figs. 1a-c.

Clypeaster rogersi (Morton). Clark and Twitchell, 1915, U. S. Geol. Survey Mon. 54, p. 136, pl. 64, figs. 2a-d, 3a-d.

Clypeaster rogersi (Morton). Cooke, 1926, Alabama Geol. Survey Special Rept. 14, pl. 97, fig. 7.

Clypeaster rogersi (Morton). Cooke and Mossom 1929, Florida Geol. Survey Ann. Rept. 20, pl. 7, fig. 7 (after Cooke).

Clypeaster marinanus Jackson, 1937, U. S. Natl. Mus. Proc., v. 84 , no. 3015 , p. 231 , pl. 12, fig. 2 ; pl. 13, fig. 1.

Clypeaster rogersi (Morton). Cooke, 1942, Jour. Paleontology, จ. 16, no. 1, p. 12.

Clypeaster brodermani Sanchez Roig, 1949, Equinodermos fósiles de Cuba, p. 74, pl. 9, figs. 1-3.

Clypeaster marinanus Jackson. Caso, 1957, Inst. de Biología Mexicana Anales, p. 508.

Length ranging from less than $40 \mathrm{~mm}$ to $90 \mathrm{~mm}$ or more. Outline oval to subpentagonal; upper surface low to tumid apically; lower surface flattish, slightly concave near the peristome; margin usually thin. Apical system central, with five genital pores, tumid. Petals extending more than halfway to the margin, completely closed apically, wide open distally; poriferous zones somewhat narrower than the interporiferous, inner pores circular, outer pores slightly elongated, pores weakly conjugate; inner side of poriferous zones almost straight, outer side slightly convex. Peristome central, pentagonal, sides slightly swollen, like bourrelets. Ambulacral grooves straight, narrow, extending to the margin. Periproct circular, located about one-fifth the distance from the margin to the peristome. Tubercles on upper surface small, sunken; tubercles on lower surface larger, in much larger scrobicules; intermediate spaces pitted.

Occurrence.-Alabama: Monroe County (type). Whitsett's quarry in Washington County 3 miles south of Collumburg (USGS 7208, C. W. Cooke and W. C. Mansfield). Hillside 1/4 mile east of the A. T. \& N. Railway 2.5 miles north of Millry, Washington County (USGS 6702, C. W. Cooke). Many other localities listed by Cooke (1942, p. 12).

Mississippi: Chickasawhay River 11/4 miles northwest of the mouth of Limestone Creek, 4 miles northwest of Waynesboro, and 11/4 miles southwest of Boyce, Wayne County (USGS 6647a, W. H. Monroe and F. S. MacNeil). Other localities listed by Cooke (1942, p. 12).

Georgia: Old Jacksonboro, fork of Brier and Beaverdam Creeks, Screven County (type of Scutella jonesi Forbes). Other localities listed by Cooke (1942, p. 12).

Florida: Marianna (USGS 6767, C. W. Cooke; 14330, W. C. Mansfield, F. S. MacNeil). Suwannee River near Ellaville, lowest bed (USGS 14070, W. C. Mansfield and C. M. Mumm; USGS 12744, W. C. Mansfield). Suwannee River about 6 miles $468544-59-4$ below Ellaville lowest bed (USGS 12740, W. C. Mansfield, Herman Gunter, G. M. Ponton). Miley rock pit in sec. 36, T. 20, S. R. 18 E. in Citrus County (USGS 14554, C. W. Cooke and W. D. Havens). Taylor County, 6.5 miles south of Nutall's Rise on Aucilla River, and 16 miles south of Lamont (USGS 14924, C. W. Cooke). Falling Water 4 miles south of Chipley, Washington County (USGS 7188, C. W. Cooke and W. C. Mansfield). Cuba: Colonia Cristales, finca Juan Criollo, Jatibonico, Camagüey ( $C$. brodermani).

Mexico: Cerro Chamal Soto la Marina; south of Topila (type of Clypeaster marinanus Jackson).

Geologic unit.-Middle and late Oligocene; Vicksburg group in Mississippi and Alabama, Flint River formation in Georgia, Suwannee limestone in Florida, Meson formation in Mexico.

Type.-Acad. Nat. Sci. Philadelphia 1070. Four cotypes. The one figured here is larger and better preserved than Morton's figured specimen. The oldest label reads "Scutella rogersi S. G. M., Alab." Another label specifies Claiborne, but the types evidently came from the Marianna limestone, which crops out a few miles east of Claiborne on the road to Monroeville.

Remarks.-The shape and size of Clypeaster rogersi is quite variable, but the shape of the petals is relatively constant. The species appears to be included in the section Orthanthus Mortensen (1948, p. 45).

The specimens from the Suwannee limestone (USGS 14924), from the Flint River formation, and from the Meson formation tend to have slightly wider interporiferous zones than the typical form from the Marianna limestone, and their margin is thinner.

\section{Clypeaster cotteaui Egozcue}

Plate 12, figures 1-3

Clypeaster cotteaui Egozcue, 1897, Com. Mapa Geol. España Bol., v. 22, p. 40, pl. 10, figs. 1-4.

Clypeaster cotteaui Egozcue. Lambert, 1915, Soc. Acad. Agric., Sci., Arts, et Belles Lettres de l'Aube (Troyes) Mem. v. 79, p. 24.

Clypeaster cotteaui Egozcue. Jackson, Carnegie Inst. Washington Pub. 306, p. 41, pl. 6, figs. 6-8.

Clypeaster cotteaui Egozcue. Cooke, 1942, Jour. Paleontology, v. 16, no. 1, p. 13.

Clypeaster cotteaui Egozcue. Sanchez Roig, 1949, Equinodermos fósiles de Cuba, p. 68.

Horizontal outline ovate, narrower in front; upper surface slightly arched; margin thick, broadly rounded; lower surface deeply concave. Apical system central. Petals extending three-fourths the way to the margin, slightly tumid; closed apically, wide open distally; inner rows of pores straight except near the apex, outer rows curved, rows nearly meeting at the tip, where there is a group of four pores. Peristome small, deeply sunken. Periproct near the margin. Tubercles large, deeply sunken in large scrobicules.

Length of figured specimen $64.4 \mathrm{~mm}$; width $52.7 \mathrm{~mm}$; height $20.0 \mathrm{~mm}$.

Occurrence-Cuba: Matanzas (type). Farm of Marco Sanchez at base of Monte Toro, northwest of Guantannamo (USNM 559297, C. T. Ramsden) 
Georgia: Worth County on road from Isabella to Albany 6.4 miles west of Isabella and about 12 miles east of Albany (USGS 7995, C. W. Cooke).

Geological unit.-Late Oligocene, Suwannee limestone in Georgia.

Type.-Comision del Mapa Geológico de España. Figured specimen USNM 559297, from Cuba.

Remarks.-The preceding description is based on the figured Cuban specimen which was identified and figured by Jackson. The only specimen from Georgia is rather defective, but the identification seems certain. The petals of Clypeaster cotteaui are similar to those of $C$. rogersi, but the margin is thicker, the lower concavity is much deeper, the tubercles are a little larger, and the periproct is nearer the margin.

\section{Family PROTOSCUTELIIDAE Durham}

\section{Genus PROTOSCUTELIA Stefanini}

Protoscutella Stefanini, 1924, Geol. Soc. America Bull., v. 35, p. 843.

Protoscutella Stefanini. Cooke, 1942, Jour. Paleontology, v. 16, no. $1, \mathrm{p} .17$.

Protoscutella Stefanini. Mortensen, 1948, Monograph of the Echinoidea, v. 4, pt. 2, p. 250, 390.

Protoscutella Stefanini. Durham, 1955, California Univ. Pub. Geol. Sci., v. 31, no. 4, p. 153.

Type species, Scutella mississippiensis Twitchell, by monotypy.

Horizontal outline subovate or faintly lobed; oral surface flat; upper surface slightly swollen medially; margin and submargin thin. Apical system central, with central madreporite and five genital pores. Amulacra petaloid, poriferous zones closed apically, slightly open distally, inner pores circular, outer pores elongated, plates of petals simple. Interambulacra discontinuous at the basicoronal plate, as in Abertella. Peristome central, circular, surrounded by five buccal tubes. Ambulacral grooves straight, unbranched, generally extending to the margin. Periproct small, circular, marginal or inframarginal.

Protoscutella resembles Abertella in the arrangement of its plates; it differs in having five, not four, genital pores and straight, not branching, ambulacral grooves. It differs from Scutella in having five genital pores and discontinuous interambulacra. Monostychia has only four genital pores, its ambulacral grooves extend over the upper surface, and there are fewer interambulacral plates on the oral surface. The known species of Protoscutella are confined to the middle Eocene of North America.

Specific distinctions in Protoscutella are based mainly on the location of the periproct and on the relative proportions of the test. In $P$. mississippiensis the periproct is always near the margin; typically it is below the margin, but in some specimens it is marginal, and in a few from Alabama it is above the margin. This species is wider than long. In $P$. conradi the periproct is nearly marginal, always on the oral side, but the species is longer than wide. $P$. tuomeyi also is longer than wide, but the periproct is somewhat farther from the margin. The periproct is still farther from the margin in $P$. plana, which is somewhat elongated. In $P$. pentagonium the location of the periproct is nearly as in $P$. tuomeyi, but the horizontal dimensions are nearly equal and the shape is subpentagonal.

\section{Key to the species of Protoscutella}

Periproct marginal or nearly marginal

Test wider than long--_--_ Protoscutella mississippiensis

Test longer than wide; periproct inframarginal Protoscutella conradi

Periproct not marginal

Periproct not more than two-thirds the radius from the

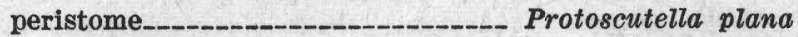

Periproct more than two-thirds the radius from the peristome

Outline ovate, widest behind the midline

Protoscutella tuomeyi

Outline pentagonal, widest in front of the midline

Protoscutella pentagonium

Protoscutella mississippiensis (Twichell)

Plate 15, figures 12, 13

Scutella mississippiensis Twitchell, 1915, U. S. Geol. Survey Mon. 54, p. 124, pl. 59, figs. 1a-f.

Protoscutella mississippiensis ('Twitchell). Stefanini, 1924, Geol. Soc. America Bull., v. 35, p. 843.

Monostychia mississippiensis (Twitchell). Lambert and Thiéry, 1925, Nomenclature raisonnée des échinides, fasc. 8, p. 583. Protoscutella mississippiensis (Twitchell). Cooke, 1942, Jour. Paleontology, v. 16, no. 1, p. 17.

Protoscutella mississippiensis (Twitchell). Mortensen, 1948, Monograph of the Echinoidea, v. 4, pt. 2, p. 390, text fig. 227 (after Twitchell).

Protoscutella mississippiensis (Twitchell). Durham, 1955, California Univ., Pub. Geol. Sci., v. 31, no. 4, text fig. $32 f$.

Horizontal outline subtrigonal, slightly wider than long, weakly notched behind; upper surface gently tumid; lower surface nearly flat, slightly depressed around the peristome; margin thin. Apical system central, with five genital pores and a large central madreporite. Ambulacra petaloid; plates simple; petals extending halfway to the margin, lanceolate, closed at the apical end, nearly closed distally; poriferous zones about as wide as the interporiferous, constricted near the distal end; inner pores circular, outer pores elongated. Peristome central, small, circular, having one pair of pores at each ambulacrum. Periproct very small, marginal or submarginal, circular. Tubercles small, depressed.

Length of type $50.5 \mathrm{~mm}$; width $53.0 \mathrm{~mm}$; height 7.0 $\mathrm{mm}$.

Occurrence.-Mississippi : Cemetery Creek west of Enterprise, Clarke County (USGS 115, 116, 129 type, L. C. Johnson'). 
Chickasawhay River at Enterprise (USGS 246, 2629, Frank Burns). McCanns Creek bluff on Chickasawhay River 4 miles southwest of Enterprise (USGS 345, Frank Burns). About three-quarters of a mile south of Basic Clarke County (USGS 15950, Julia Gardner). Highway 11, 11/4 miles south of Lauderdale, Clarke County (USGS 15109, Julia Gardner).

Alabama: Road cut 4 miles south of Gilbertown, Choctaw County (Julia Gardner, C. W. Cooke, Edgar Bowles). Cut on highway 28 just south of Souwilpa Creek, NE1/4 sec. 19, T. 10 N., R. 3 W., Choctaw County (USGS 17048, C. W. Cooke, F. S. MacNeil).

Texas: Mt. Enterprise, southeast part of Rusk County (USGS 2056, L. C. Johnson). San Augustine (USGS 5121, T. W. Vaughan; 13144, 14239, Julia Gardner). Nacadoches road 9.5 miles west of San Augustine (Julia Gardner).

Geologic unit.-Middle Eocene, Winona sand in Mississippi, Mount Selman formation in Texas; basal Lisbon formation and top of Tallahatta formation in Alabama.

Type.-USNM 137655, from USGS 129. Figured specimens 137674, from USGS 116.

Remarks.-The nearly or quite terminal location of the periproct is the most distinctive feature of Protoscutella mississippiensis. Ordinarily the periproct is on the under side, but on the specimens from Souwilpa Creek (USGS 17048) it is supramarginal. Possibly these represent a different species. They may occupy a slightly lower horizon.

Protoscutella mississippiensis seems to be closely related to $P$. conradi (Cotteau), but its periproct is more nearly terminal, it attained a larger size, and it is usually proportionally wider.

\section{Protoscutella tuomeyi (Twitchell)}

Plate 15, figures 9-11

Scutella tuomeyi Twitchell, 1915, U. S. Geol. Survey Mon. 54, p. 125 , pl. 60, figs. 1a-d.

Periarchus tuomeyi (Twitchell). Stefanini, 1924, Geol. Soc. America Bull., v. 35, p. 843

Protoscutella tuomeyi (Twitchell). Cooke, 1942, Jour. Paleontology, v. 16, no. 1, p. 18.

Protoscutella tuomeyi (Twitchell). Mortensen, 1948, Monograph of the Echinoidea, v. 4, pt. 2, p. 390.

Horizontal outline subovate, widest behind the midline, weakly lobate posteriorly, with a faint posterior notch; upper surface rising slightly in the central part; oral surface nearly flat, apparently somewhat concave near the peristome; margin thin. Apical system central ; five genital pores. Petals of equal length, extending halfway to the margin, sides nearly straight, open at the outer ends, nearly closed at the apex; poriferous zones somewhat narrower than the interporiferous; inner pores circular, outer pores elongated. Peristome central, circular, rather small. Periproct small, elongated, three-fourths the way from the peristome to the margin. Tubercles small, sunken.

Length of type $40.0 \mathrm{~mm}$; width $39.5 \mathrm{~mm}$; height $5 \mathrm{~mm}$.

Occurrence.-South Carolina: Cave Hall, Calhoun County, 14 miles south of Fort Motte station (type, USGS 2017, Frank Burns).
North Carolina: J. C. Teachey's farm, 3 miles northeast of Teachey depot, Duplin County (USGS 10620, L. B. Kellum). Duplin County 2.5 miles southwest of Charity (USGS 11816, W. C. Mansfield). These two lots are doubtfully identified; though they have somewhat similar proportions, they are much smaller than the type, and their periproct is nearer the margin. They may be $P$. pentagonium or an undescribed species.

Geologic unit.-Middle Eocene, Warley Hill marl.

Type.-USNM 137970.

Comparison.-Protoscutella tuomeyi occupies nearly the same stratigraphic position as $P$. mississippiensis, but its proportions are different and its periproct is farther from the margin.

\section{Protoscutella pentagonium Cooke}

Plate 15, figures 6-8

Protoscutella pentagonium Cooke, 1942, Jour. Paleontology, v. 16, no. 1, p. 18, pl. 2, figs. 4-6.

Protoscutella pentagonum Cooke. Mortensen, 1948, Monograph of the Echinoidea, v. 4, pt. 2, p. 390.

Horizontal outline subpentagonal, nearly equilateral; upper surface strongly tumid medially, much flatter in the submargin; margin thin, turned down; oral surface nearly flat. Apical system central; five genital pores; large central madreporite. Petals equal in length, extending halfway to the margin; anterior petal swollen near the apex, presumably from the pressure of a jaw; conspicuously open at each end; poriferous zones equal in width to the interporiferous; inner pores circular, outer pores strongly elongated. Peristome small, central, circular; ambulacral grooves straight, extending nearly to the margin, occupied by long buccal tubes. Periproct small, circular, four-fifths the way from the peristome to the margin, connected with the margin by a shallow furrow.

Length of type $30.0 \mathrm{~mm}$; width $31.4 \mathrm{~mm}$; height $6.1 \mathrm{~mm}$.

Occurrence.-Florida: Well of the Chipley Oil Company at Falling Water, 4 miles south of Chipley, Washington County; depth unknown, probably about 600 feet; embedded in white sand (USGS 13145, type, C. W. Cooke).

Texas: Nacogdoches County (USGS 7951, _ Bruyere). Nacogdoches road 12 to 13 miles west of San Augustine (USGS 13269, Julia Gardner). Nacogdoches road 5 miles west of San Augustine (USNM 499111, Julia Gardner).

Geologic unit.-Middle Eocene; probably of Lisbon age, Mount Selman formation in Texas.

\section{Type.-USNM 498992.}

Remarks.-The specimens from Texas, which are rounder and smaller than the type, tend to have swollen interambulacral areas on the oral face. Their identity with Protoscutella pentagonium is open to question. They resemble in size and general appearance some from USGS 10620 and 11816 in North Carolina which are tentatively identified as $P$. tuomey $i$.

\section{Protoscutella conradi (Cotteau)}

\section{Plate 15, figures 4, 5}

Sismondia marginalis Conrad, 1865, Acad. Nat. Sci. Philadelphia Proc., p. 75. Not Des Mouline 1837. 
Mortonia (Periarchus) marginalis (Conrad). Conrad, 1866. Smithsonian Misc. Coll. v. 7 (200), p. 21.

Sismondia conradi Cotteau, 1891, Paléontologie française, Terrain tertiaire, ser. 1, v. 2, p. 300.

Monostychia marginalis (Conrad). Gregory, 1891, Geol. Soc. America Bull., v. 3, p. 105.

Periarchus (?) marginalis (Conrad). Stefanini, 1911, Soc. Geol. italiana Boll., v. 30, p. 699.

Scutella (?) conradi (Cotteau). Clark and Twitchell, 1915, U. S. Geol. Survey Mon. 54, p. 126, pl. 64, figs. 1a-d.

Protoscutella conradi (Cotteau). Cooke, 1942, Jour. Paleontology, v. 16, no. 1, p. 17.

Protoscutella conradi (Cotteau). Mortensen, 1948, Monograph of the Echinoidea, v. 4, pt. 2, p. 390.

Horizontal outline suboval, slightly truncated and weakly notched behind; upper surface tumid centrally, submargin flat; margin tending to turn down; oral surface flat medially, concave near the margin. Apical system central, with a large central madreporite and five genital pores. Petals lanceolate, extending halfway to the margin, nearly equally long, slightly open at the apical ends, somewhat wider open at the distal ends; poriferous zones slightly narrower than the interporiferous, inner pores circular, outer pores elongated or oval. Peristome central, small, circular, surrounded by five radiating buccal tubes. Periproct small, circular, located about four-fifths the way from the peristome to the margin. Tubercles small, sunken.

Length of type $21.0 \mathrm{~mm}$; width $19.8 \mathrm{~mm}$; height 4.0 $\mathrm{mm}$. A specimen from USGS 18353 measures $29 \mathrm{~mm}$ in length.

Occurrence.-South Carolina: Near Charleston (probably Santee Canal) (type). Santee-Cooper diversion canal near Eadytown, Berkeley County (USGS 18353, C. W. Cooke and F. S. MacNeil).

North Carolina: J. A. Stokes' farm 2 miles north from creek near Maple Cypress, Craven County (USGS 8165, J. A. Cushman). Farm of Douglas Green about 1 mile west of Maple Cypress (USGS 12007, W. C. Mansfield). Craven County 3 miles east of Quinerly and 2 miles north of Neuse River (USGS 10627, L. B. Kellum). Farm of A. R. Bland 1.5 miles northeast of Rose Hill, Duplin County (USGS 10621, L. B. Kellum).

Geologic unit.-Middle Eocene, probably Santee limestone, possibly Castle Hayne limestone.

Type-Acad. Nat. Sci. Philadelphia 1081.

Comparisons. - The periproct of this species is usually farther from the margin than that of Protoscutella mississippiensis, which attained a larger size. The proportions are different, $P$. conradi being longer than wide, whereas $P$. mississipiensis is shorter than wide. In $P$. plana the periproct is still farther from the margin; the oral side is flatter, the margin not being turned down; and the posterior notch is absent or very inconspicuous. In Protoscutella pentagonium the periproct is farther from the margin, which is turned down; the shape is equilateral, pentagonal; and the interambulacra are swollen on the oral face.
Protoscutella plana (Conrad)

Plate 15, figures 1-3

Scutella crustuloides Morton. Morton, 1833, Am. Jour. Sci., v. 24, pl. 10, fig. 8. (Not description, p. 131.)

Scutella lyelli Conrad. Morton, 1834, Synopsis of the organic remains of the Cretaceous group p. 77, pl. 10, fig. 8 (figure same as the preceding).

Sismondia plana Conrad, 1865, Acad. Nat. Sci. Philadelphia Proc. p. 75.

Mortonia (Periarchus) planus (Conrad). Conrad, 1866, Smithsonian Misc. Coll., v. 7 (200), p. 21.

Sismondia plana Conrad. Cotteau, 1891, Paléontologie francaise, Terrain tertiaire, ser. 1, v. 2, p. 299.

Monostychia plana (Conrad). Gregory, 1891, Geol. Soc. America Bull., v. 3, p. 105.

Periarchus planus (Conrad). Stefanini, 1891, Soc. geol. italiana Boll., v. 30, p. 699.

Sismondia? plana Conrad. Clark and Twitchell, 1915, U. S. Geol. Survey Mon. 54, p. 121, pl. 57, figs. 4a-d.

Protoscutella plana (Conrad). Cooke, 1942, Jour. Paleontology, จ. 16, no. 1, p. 18.

Protoscutella plana (Conrad). Mortensen, 1948, Monograph of the Echinoidea, v. 4, pt. 2, p. 390.

Horizontal outline ovate, slightly wider behind than in front at the midline; upper surface slightly swollen medially, flatter near the margin; margin thin; lower surface nearly flat. Apical system obscure, probably having five genital pores and a large central madreporite. Petals lanceolate, moderately broad, closed at the apical end, open distally, extending halfway to the margin; poriferous zones about equal in width to the interporiferous zones; inner pores circular, outer pores slightly elongated. Peristome small, central. Periproct small, less than two-thirds the way from the peristome to the margin. Tubercles small, sunken.

Length of type (fide Clark and Twitchell) $17 \mathrm{~mm}$; width $15 \mathrm{~mm}$; height $2 \mathrm{~mm}$.

Occurrence.-South Carolina: Eutaw Springs, 2 miles east of Eutawville, Orangeburg County (USGS 7968, 13391, C. W. Cooke).

Geologic unit.-Middle Eocene, Santee limestone.

Type.-Acad. Nat. Sci. Philadelphia 1080 (fide Clark and Twitchell). Figured specimen USNM 562275.

Remarks.-The preceding description is based chiefly on the photographs of the type published by Clark and Twitchell (1915, pl. 57, figs. $4 a-d)$, from which the identification of the specimens in the National Museum was made.

This species, as known only from small, presumably immature individuals, differs from typical Protoscutella in the total lack of a posterior emargination, in the much greater distance of the periproct from the margin, and in the greater elongation of the test. However, it seems to agree with Protoscutella in the discontinuity of the interambulacra and in the occurrence of radial and concentric internal partitions. The occurrence of five genital pores is inferred from the similarity of this species to young individuals of Protoscutella tuomeyi. 


\section{Genus PERIARCHUS Conrad}

Mortonia Desor, 1858, Synopsis des échinides fossiles, p. 231. Not Mortonia Gray, 1851.

Mortonia (Periarchus) Conrad, 1866, Smithsonian Misc. Coll. v. 7 (200), p. 21.

Mortonella Pomel, 1883, Classification méthodique et genera des échinides, p. 70. For Mortonia Desor.

Periarchus Conrad. Grabau and Shimer, 1910, North American index fossils, v. 2, p. 591.

Mortonella Pomel. Stefanini, 1911, Soc. geo. italiana Boll., v. 30, p. 684 .

Periarchus Conrad. Stefanini, 1911, Soc. geol. italiana Boll., v. 30, p. 687.

Mortonella Pomel. Lambert and Thiéry, 1914, Nomenclature raisonnée des éhinides, fasc. 4, p. 316.

Periarchus Conrad. Lambert and Thiéry, 1914, Nomenclature raisonée des échinides, fasc. $4, \mathrm{p} .316$.

Mortonella Pomel. Clark and Twitchell, 1915, U. S. Geol. Survey Mon. 54, p. 128.

Periarchus Conrad. Clark and Twitchell, 1915, U. S. Geol. Survey Mon. 54, p. 130.

Periarchus Conrad. Davies, 1935, Tertiary faunas, v. 1, p. 87.

Mortonella Pomel. Davies, 1935, Tertiary faunas, v. 1, p. 87.

Periarchus Conrad. Cooke, 1942, Jour. Paleontology, v. 16, no. 1, p. 13.

Mortonella Pomel. Mortensen, 1948, Monograph of the Echinoidea, v. 4, pt. 2, p. 391.

Mortonella (Periarchus) Conrad. Mortensen, 1948, Monograph of the Echinoidea, v. 4, pt. 2, p. 392.

Periarchus Conrad. Durham, 1955, California Univ. Pub. Geol. Sci., v. 31, no. 4, p. 153.

Mortonella Pomel. Durham, 1955, California Univ. Pub. Geol. Sci., v. 31, no. 4, p. 155.

Type species Sismondia alta Conrad 1865, first species, designated by Stefanini (1911, p. 687). The type of Sismondia alta is the specimen from Wadsworth's Eocene marl, Craven County, N. C. named Scutella sp. by Emmons (1858, p. 308, text figs. 247, 248), later well figured by Clark and Twitchell (1915, p. 130, pl. 58) as Periarchus altus Conrad, and now USNM 498960. It appears to be a variant of Periarchus lyelli (Conrad), differing from the normal form of that species in that its highest point stands in front of the apical system. Its horizontal outline is nearly circular, upper surface tumid, margin thin, and lower surface flat. The apical system is slightly posterior, with a large central madreporite and five conspicuous genital pores. The lanceolate petals are nearly equal in length and extend about halfway to the margin. The poriferous zones are slightly open at the ends. The inner pores are circular, the outer pores strongly elongated. The small, circular peristome lies directly under the apical system; the still smaller periproct is on the oral side less than halfway to the margin. The five ambulacral food grooves branch about halfway to the margin. They terminate at buccal tubes.

The type species of Mortonella Pomel as validated by Opinion 358 of the International Commission on
Zoological Nomenclature is Scutella quinquefaria Say, which was misidentified by Desor (following L. Agassiz) as Scutella rogersi Morton, a Clypeaster. The reason for putting Mortonella in the synonymy of Periarchus is discussed under Periarchus quinquefarius.

\section{Key to the species of Periarchus}

Petals longer than half the radius_-. Periarchus quinquefarius Margin not bevelled, usually thick Periarchus quinquefarius quinquefarius Margin bevelled, very thin_ Periarchus quinquefarius kewi Petals not longer than half the radius.

Anterior interporiferous zone protruding; petals short; margin fluted; periproct near the peristome-_--- Periarchus protuberans

Anterior interporiferous zone not protruding; petals longer ; periproct farther from the peristome_-_ Periarchus lyelli Median area conical____ Periarchus lyelli pileus-sinensis Median area not conical

Test medium sized; petals half the radius

Periarchus lyelli lyelli

Test larger; petals less than half the radius; very low; margin very thin Periarchus lyelli floridanus

\section{Periarchus lyelli (Conrad)}

Plate 13, figure 1; plate 14, figures 1-3

Scutella lyelli Conrad, 1834, Acad. Nat. Sci. Philadelphia Jour., ser. 1, v. 7, p. 152.

Soutella sp. Emmons, 1858, Agriculture of the eastern counties, p. 308 , figs. $247,248$.

Sismondia lyelli (Conrad). Conrad, 1865, Acad. Nat. Sci. Philadelphia Proc., ser. 2, v. 9, p. 74.

Sismondia alta Conrad, 1865, Acad. Nat. Sci. Philadelphia Proc., ser. 2, v. 9, p. 74.

Sismondia lyelli (Conrad). Conrad, 1865, Acad. Nat. Sci. Philadelphia Proc., ser. 2, v. 9, p. 74.

Mortonia (Periarchus) altus (Conrad). Conrad, 1866, Smithsonian Misc. Coll., v. 7 (200), p. 21.

Scutella lyelli Conrad. De Gregorio, 1890, Monographie de la faune éocenique de l'Alabama, p. 250 . Not pl. 43, fig. 21.

Periarchus altus (Conrad). Stefanini, 1911, Soc. geol. italiana Boll., v. 30, p. 687.

Periarchus altus (Conrad). Clark and Twitchell, 1915, U. S. Geol. Mon. 54, p. 130, pl. 58, figs. 1a-e.

Periarchus lyelli (Conrad). Clark and Twitchell, 1915, U. S. Geol. Survey Mon. 54, p. 131, pl. 61, figs. 2a-f; pl. 62, figs. $1 \mathrm{a}-\mathrm{c}, 2 \mathrm{a}-\mathrm{d}$.

Periarchus lyelli (Conrad). Cooke 1942, Jour. Paleontology, v. 16, no. 1, p. 14 .

Periarchus lyelli (Conrad). Mortensen, 1948, Monograph of the Echinoidea, v. 5, pt. 2, p. 392, text figs. 299a-b (after Clark and Twitchell).

Periarchus lyelli (Conrad). Durham, 1955, California Univ. Pub. Geol. Sci., v. 31, no. 4, text fig. 3e.

Periarchus rutriformis Paulson, 1958, Jour. Paleontology, v. 32, p. 362, text figs. 5, 6, 8 .

Horizontal outline subcircular; upper surface slightly tumid to conical centrally, nearly flat marginally; margin usually thin; oral side flat. Apical system central; madreporite large, central; five genital pores. Petals lanceoplate, extending halfway to the margin, 
open at the outer ends; poriferous zones nearly equal in width to the interporiferous; inner pores circular, outer pores elongated; pores conjugate; plates simple. Interambulacra continuous. Peristome central, circular, small; ambulacral grooves shallow, straight to the midradius, divaricating beyond; buccal tubes slightly projecting into the opening; granular within. Periproct less than halfway to the margin, small. Tubercles small, sunken.

Length of figured specimens $68.2,78.7 \mathrm{~mm}$; width $67.2,76.0 \mathrm{~mm}$; height $6.5 \mathrm{~mm}$.

Occurrence,-Alabama River a few miles south of Claiborne (type locality). Alabama River below Marshallville (USGS 295, L. O. Johnson, figured specimen). Gopher Hill, Tombigbee River, Washington County (USGS 6087, George Little, figured specimen). Other places listed by Cooke (1942, p. 15).

North Carolina: Wadsworth's marl bed, Craven County (type of Sismondia alta). Other places listed by Cooke (1942, p. 14).

South Carolina: About 6 miles south of Black Oak Lock of Santee Canal (type of Scutella pileus-sinensis). Santee Canal (USNM 5133, Col. Totten). Lime pit 3.5 miles south-southwest of Holly Hill and 0.5 mile west of Four Holes station, Orangeburg County (USGS 16922, C. W. Cooke).

Georgia: Many localities, listed by Cooke (1942, p. 14).

Florida: Mouth of Withlacoochee River, Citrus and Levy counties (type of Periarchus lyelli floridanus).

Mississippi : Localities listed by Cooke (1942, p. 15).

Louisiana: Below the ferry landing at Montgomery, Grant Parish (USGS 2638, T. W. Vaughan, fragments presumably this species).

Texas: Southeast corner of John Lang headright 5.5 miles northeast of Hemphill (USGS 11108, C. E. Cooke, identification doubtful).

Geologic unit.-Middle Eocene, Gosport sand and equivalents ; late Erocene, Jackson group. May occur also in the Cook County Mountain formation of middle Eocene age and equivalents.

Type.-Type of Scutella lyelli unknown; type of Sismondia alta USNM 498960, deposited by Williams College, figured by Clark and Twitchell (1915, pl. 58).

Remarks.-Periarchus lyelli is very abundant and variable. The typical variety occurring near Claiborne, Alabama, is lowdomed but grades into the higher, conical variety pileus-sinensis. The large flat subspecies floridanus is more stable.

\section{Periarchus 1yelli pileus-sinensis (Ravenel)}

Plate 13, figures 2, 3

Scutella pileus-sinensis Ravenel, 1844, Acad. Nat. Sci. Philadelphia Proc., v. 2, p. 97.

Scutella pileus-sinensis Ravenel. Ravenel, 1850, Am. Assoc. Adv. Sci. Proc., v. 3, p. 160.

Sismondia pileus-sinensis (Ravenel), Conrad, Acad. Nat. Sci. Philadelphia Proc., ser. 2, v. 9, p. 74.

Mortonia (Periarchus) pileus-sinensis (Ravenel). Conrad, 1866, Smithsonian Misc. Coll., v. 7 (200), p. 21.

Periarchus pileus-sinensis (Ravenel). Stefanini, 1911, Soc. geol. italiana Boll., v, 30, p. 688, pl. 22, figs. 4a-c, 5a-b.

Periarchus pileus-sinensis (Ravenel). Clark and Twitchell, 1915 , U. S. Geol. Survey Mon. 54, p. 135, pl. 63, figs. 1a-e, $2 a-d$.
Periarchus lyelli pileus-sinensis (Ravenel). Cooke, 1942, Jour. Paleontology, v. 16, no. 1, p. 15.

Periarchus lyelli pileus-sinensis (Ravenel). Durham, 1955, California Univ. Pub. Geol. Sci., v. 31, no. 4, text figs. 14d, $18 d$.

This variety differs from what may be regarded as the typical form of Periarchus lyelli in the conical shape of its petaliferous area. All gradations may be found between a high form with concave slopes resembling a volcano and the low dome-shaped typical variety common at Claiborne, Alabama.

Occurrence.-South Carolina : Estate of Dr. Philip G. Prioleau in St. Johns Parish about 6 miles south of Black Oak Lock Santee Canal (type, fide Ravenel).

Georgia: Abundant in Ocala limestone.

Alabama: Abundant in Ocala limestone.

Mississippi: Shubuta Creek 2.5 miles north of Shubuta, Clarke County (USGS 331, Frank Burns).

Geologic unit.-Late Eocene, Ocala limestone (east of Tombigbee River in Alabama) and Yazoo clay (west of Tombigbee River); probably also in Moodys Branch formation and equivalents.

Type.-Unknown.

\section{Periarchus lyelli floridanus Fischer}

Plate 13, figure 4

Periarchus lyelli floridanus Fischer, 1951, Florida Geol. Survey Geol. Bull. 34 , pt. 2, p. 60 , pl. 1, figs. $1-4$; text figs. $4,5$.

Large, nearly flat, having a very thin margin; petals proportionally shorter and wider than customary in Periarchus lyelli. The large size and thinness may be the result of living in quiet offshore water with an oozy bottom. The typical variety of $P$. Tyelli evidently inhabited shallow, near-shore water with a bottom of coarse sand.

Occurrence.-Florida: Mouth of Withlacoochee River (USNM 560418, 560419, 560422, A. G. Fissher and J. E. Banks). Pit between Inglis and Yankeetown, Levy County (USGS 14544, C. W. Cooke and W. D. Havens). Drainage ditch in Citrus County 5.2 miles northwest of Crystal River on Florida 15 (USGS 14545, C. W. Cooke and W. D. Havens). Dunnellon road in Levy County 2.8 miles south-southeast of Otter Creek (C. W. Cooke). Southern Phosphate Development Co. pit no. 1, $1 / 4$ miles southwest of Inverness, Citrus County (USGS 7378, c. W. Cooke).

Geologic unit.-Late Eocene, Inglis limestone.

Type.-USNM 560418; paratypes USNM 560419, 560422.

\section{Periarchus protuberans Twitchell}

Plate 12, figures 7-9

Periarchus protuberans Twitchell, 1915, U. S. Geol. Survey Mon. 54, p. 133, pl. 62, figs. 3a-f.

Periarchus protuberans Twitchell. Cooke, 1942, Jour. Paleontology, v. 16, no. 1, p. 15.

Periarchus protuberans Twitchell. Mortensen, 1948, Monograph of the Echinoidea, v. 4, pt. 2, p. 392. 
Horizontal outline nearly circular, fluted; upper surface conical in apical region, highest point in front of the anterior genital pore; submargin nearly flat; margin thin; oral side nearly flat, depressed around the peristome. Apical system having a large central madreporite and five genital pores directly between the ocular pores. Petals short, extending less than halfway to the margin, the anterior petal somewhat longer than the others; anterior petal strongly swollen and constricted near the apical end, forming an arch terminating at the anterior genital pore; poriferous zones slightly open distally with two pairs of pores forming a projecting tip; inner pores circular, outer pores elongated; pores faintly conjugate. Peristome small, subcircular with small phyllodelike swellings in the interambulacra; buccal tubes projecting into the opening; ambulacral grooves straight to the midradius, where they bifurcate and extend to the margin. Periproct nearly as large as the peristome, triangular, less than one-third of the radius from the peristome. Tubercles small, sunken.

Length of type $52.6 \mathrm{~mm}$; width 52.4 ; height $9.8 \mathrm{~mm}$.

Occurrence.-Mississippi: Shubuta Creek 2.5 miles north of Shubuta, Clarke County (USGS 331, Frank Burns).

Alabama : Cut on US 84, 3.8 miles west of Gosport, Clarke County (USGS 18785, C. W. Cooke and F. S. MacNeil).

Geologic unit.-Late Eocene; Yazoo clay in Mississippi, Ocala limestone transitional to Yazoo clay in Alabama.

Type.-USNM 164685, from USGS 331.

Comparison.-Periarchus protuberans differs from $P$. lyelli, with which it is associated, in its shorter petals, the protruding anterior ambulacrum, and in the location of the periproct, which is nearer the peristome. In other respects it greatly resembles $P$. lyelli pileus-sinensis.

Remarlss.-The protruding ambulacrum might be a pathologic feature, but it occurs with the other distinctive features in beds of the same age about 50 miles apart.

\section{Periarchus quinquefarius (Say)}

Plate 14, figures 6-8

Scutella 5-faria Say, 1825, Acad. Nat. Sci. Philadelphia Jour., ser. 1, v. 5, p. 228.

Scutella rogersi (Morton). Agassiz, 1841, Monographies d'échinodermes, Mon. 2, p. 85, pl. 19a, figs. 1-4.

Mortonia rogersi (Morton). Desor, 1858, Synopsis des échinides fossiles, p. 231.

Mortonia quinquefaria (Say). Conrad, 1866, Smithsonian Misc. Coll., จ. 7 (200), p. 32.

Mortonia rogersi (Morton). Zittel, 1876, Handbuch der Palaeontologie, v. 1, p. 522 .

Mortonella rogersi (Morton). Pomel, 1883; Classification méthodique et genera des échinides, p. 70.

Scutella (Mortonia) rogersi (Morton). De Gregorio, 1890, Monographie de la faune éocenique de l'Alabama, p. 250, pl. 43, figs. 17-20 (not fig. 16).

Mortonella rogersi (Agassiz not Morton). Stefanini, 1911, Soc. geol italiana Boll., จ. 30, p. 685, pl. 22, figs. 2 , 3 .
Mortonella quinquefaria (Say). Clark and Twitchell, 1915, U. S. Geol. Survey Mon. 54, p. 128, pl. 60, figs. 2a-f; pl. 61, figs. 1a-b.

Periarchus quinquefarius (Say). Cooke, 1942, Jour. Paleontology, v. 16, no. 1, p. 15 .

Mortonella quinquefaria (Say). Mortensen, 1948, Monograph of the Echinoidea, v. 4, pt. 2, p. 391, text figs. 228a-c (after Agassiz, 1841).

Mortonella quinquefaria (Say). Durham, 1955, California Univ. Pub. Geol. Sci., v. 31, no. 4, p. 155, text figs. 1L, 18c.

Horizontal outline circular; upper surface slightly tumid centrally, submargin flat; margin generally rather thick or bevelled, oral side flat. Apical system central, having a large central madreporite and five genital pores. Petals wide, of nearly equal lengths, extending three-quarters of the way to the margin, outer edges convex; poriferous zones wider than the interporiferous zones, closed at the apical ends, open distally; inner pores circular, in nearly straight lines; outer pores elongated; pores conjugate. Peristome small, circular, central; food grooves extending halfway to the margin, where the grooves bifurcate; each branch of the grooves has an outward branch extending nearly at right angles to it before curving to the margin; grooves punctate. Periproct smaller than the peristome, circular, nearly midway between the peristome and the margin. Sunken tubercles cover the entire surface, including the apical system.

Length of figured specimens $52.0,60.0 \mathrm{~mm}$; width $54.0,62.0 \mathrm{~mm}$; height 9.4, $11.5 \mathrm{~mm}$.

Occurrence.-Georgia : Near Milledgeville (fide Say). Spring and limesink 1 mile southwest of the courthouse at Sandersville, Washington County (USGS 3955, S. W. McCallie; USGS 10489, C. W. Cooke and T. M. Prettyman; USGS 5250, T. W. Vaughan; 7705, C. W. Cooke). Quarry of Atlantic Lime Rock Company 1.5 miles south of Sandersville (USGS 12099, C. W. Cooke and W. H. Monroe). Limestone quarry about 1 mile southwest of Sandersville, under power line (USGS 15495, F. S. MacNeil and P. E. LaMoreaux). Cut on Central of Georgia Railway between mileposts 138 and 139, Washington County (USGS 3959, S. W. McCallie). Dublin road 4.6 miles southwest of Tennille, Washington County, at crossing of Central of Georgia Railway (USGS 10500, C. W. Cooke and T. M. Prettyman). 1.5 miles northwest of Tennille (USGS 3761, S. W. McCallie). T. W. Smith's farm 2.2 miles south of Warthen, Washington County (USGS 3953, S. W. McCallie). 1 mile south of Waynesboro, Burke County (USGS 10504, C. W. Cooke and T. M. Prettyman). Roadside at Hatcher's mill, 31/2 miles north of Alexander, Burke County (USGS 14570, C. W. Cooke and A. C. Munyan).

Geologic unit.-Late Eocene, Sandersville limestone member of the Barnwell formation.

Type-Unknown. Figured specimens USNM 262279, 562276.

Comparison.-Periarchus quinquefarius can readily be distinguished from Periarchus lyelli and varieties by its proportionally longer petals, by its usually thicker margin, and by its deeper and more conspicuous ambulacral grooves.

Remarks.-This species occupies a somewhat higher horizon than Periarchus lyelli. It is known only from Georgia. Old 
labels referring it to Alabama are in error because of Louis Agassiz's confusion of this species with Clypeaster rogersi (Morton), whose type came from near Claiborne, Alabama. Say's statement that his species is abundant "near Milledgeville' is true only in a very broad sense, for Milledgeville is built on unfossiliferous rocks of the Piedmont.

This species became the type of Mortonella Pomel (1883, p. 70) but the differences between Mortonella and Periarchus seem too insignificant to justify the retention of Mortonella as a genus. The most conspicuous difference is in the thickness of the margin, but the thickness of the margin is variable in both type species, and some individuals of $P$. quinquefarius are as thin as some of $P$. lyelli. If Mortonella is to be retained, it should not rank higher than subgenus.

\section{Periarchus quinquefarius kewi Cooke}

Plate 14, figures 4, 5

Periarchus kewi Cooke, 1942, Jour. Paleontology, v. 16, no. 1, p. 16, pl. 1, figs. 12-14.

Horizontal outline circular; upper surface tumid medially, swollen beyond the petals, sloping steeply to the margin; margin thin; oral side flat. Other features as in the typical variety.

Occurrence.-Georgia: Highway US 341, 4.2 miles southeast of Clinchfield, Houston County (USGS 15097, W. S. W. Kew and C. W. Cooke). S. W. Smith's farm $2 \frac{1}{4}$ miles south of Warthen, Washington County (USGS 3953, S. W. McCallie). Geologic unit.-Late Eocene, Sandersville limestone member of the Barnwell formation.

Type.-USNM499000, from USGS 15097.

Remarks.-Periarchus kewi is here considered a variety of $P$. quinquefarius because it is associated with the typical form, whose margin not rarely shows a tendency to become bevelled. The distinguishing features of the variety are the strongly tumid central region, the swollen submargin, and the plainly bevelled edge.

\section{Family ECHINARACHNIIDAE}

\section{Genus ECHINARACHNIUS Gray}

Echinarachnius (part) Gray, 1825, Annals of Philosophy, ser. 2, จ. 10, p. 428.

Echinarachnius Gray. Cooke, 1942, Jour. Paleontology, v. 16, no. 1, p. 16.

Echinarachnius Gray. Mortensen, 1948, Monograph of the Echinoidea, v. 4, pt. 2, p. 363. Includes synonymy.

Echinarachnius Gray. Durham, 1955, California Univ. (Los Angeles) Pub. Geol. Sci., v. 31, no. 4, p. 163.

Type species, Scutella parma Lamarck, fixed by elimination by L. Agassiz, 1841.

\section{Echinarachnius parma (Lamarck)}

Plate 13, figures 5, 6

Scutella parma Lamarck, 1816, Histoire naturelle des animaux sans vertèbres, $\nabla .3$, p. 11.

Echinarachnius parma (Lamarck). Gray, 1825, Annals of Philosophy, ser. 2, v. 10, p. 428.

Echinarachnius parma (Lamarck). Agassiz, 1841 Monographies d'échinodermes, Mon. 2, p. 89, pl. 20, figs. 9-18.
Echinarachnius parma (Lamarck). Cooke, 1942, Jour. Paleontology, v. 16, no. 1, p. 16.

Echinorachnius parma (Lamarck). Mortensen, 1948, Monograph of the Echinoidea, v. 4, pt. 2, p. 367, pl. 71, figs. 16, 23-26. Includes additional synonymy.

Echinarachnius parma (Lamarck). Durham, 1955, California Univ. (Los Angeles) Pub. Geol. Sci., v. 31, no. 4, p. 164, figs. 1i, 3b, 6e, 8a, 9a, 10a, 23, 24, 26L, 34a-c ; pl. 4, fig. 4 .

Echinarachnius parma (Lamarck). Durham, 1957, Jour. Paleontology, v. 31, no. 3, p. 629, pl. 72, fig. 5 .

Horizontal outline circular; upper surface gently convex; lower surface flat; margin thin. Apical system central; madreporite large, central; four genital pores. Five petals alike, extending half the radius; poriferous zones closed apically, wide open distally, inner pores circular, outer pores somewhat elongated. Peristome central, circular, small. Periproct small, marginal; in a shallow posterior notch.

Length of figured specimen $46 \mathrm{~mm}$; width $46 \mathrm{~mm}$; height $8.2 \mathrm{~mm}$.

Occurrence.-Atlantic coast from Labrador to Maryland; Pacific coast from Puget Sound to the Aleutian Islands and Japan. Geologic unit.-Recent.

Figured specimen.-USNM E 3303a, from Five-fathom Lightship, 14 miles off Wildwood, N. J., Horace G. Richards.

Remarks.-This very variable species is the common sand dollar of the northern coasts. It has not been reported fossil.

\section{Family ABERTELIIDAE Durham}

\section{Genus ABERTELIA Durham}

Abertella Durham, 1953, Jour. Paleontology, v. 27, no. 3, p. 350. Abertella Durham. Durham, 1955, California Univ. Pubs. in Geol. Sci., v. 31, no. 4, p. 177

Type species, Scutella aberti Conrad, by original designation.

According to Durham "Abertella is easily separable from the European Scutella and Parascutella by its widely interrupted interambulacral areas on the oral surface. None of the Pacific Coast species referred to Scutella by Kew and others are at all closely related."

\section{Abertella aberti (Conrad)}

Plate 16, figures 1-3

Scutella aberti Conrad. 1842, Natl. Inst. Promotion Sci. Proc., จ. 2, p. 194.

Scutella alberti Conrad. Broun, 1848, Index palæontologicus, v. 1, p. 1125, v. 2, p. 196. Error for aberti.

Scutella aberti Conrad. Clark, 1904, Maryland Geol. Survey, Miocene, p. 432, pl. 119, figs. 2, 2a; pl. 120, figs, 1a-b, 2a-b. Scutella aberti Conrad. Clark, 1906, Maryland Geol. Survey Rept., v. 6, p. 258, pl. 22, fig. 17.

Scutella aberti Conrad. Stefanini, 1911, Soc. geol. italiana Boll., v. 30, p. 705.

Scutella aberti Conrad. Clark and Twitchell, 1915, U. S. Geol. Survey Mon. 54, p. 187, pl. 86, figs. 1a-b; pl. 87, figs. 1a-d. Scutella aberti Conrad. Cooke, 1942, Jour. Paleontology, v. 16, no. 1, p. 19. 
Scutella floridana Cooke, 1942, Jour. Paleontology, v. 16, no. 1, p. 19 , pl. 4, figs. 9,10 .

Abertella aberti (Conrad). Durham, 1953, Jour. Paleontology, v. 27, no. 3, p. 350, text fig. 1C.

Abertella aberti (Conrad). Durham, 1955, California Univ., Pubs. in Geol. Sci., v. 31, no. 4, text fig. 32e.

Test shield shaped; horizontal outline semicircular in front, fluted behind, with a deep posterior notch of variable width and shallower rounded indentations in the posterior ambulacra; upper surface slightly inflated in the apical region, nearly flat marginally; oral surface flat; margin thin. Apical system fused, star shaped, with the points protruding between the petals and four genital pores at the ends, usually somewhat raised. Petals lanceolate, extending about two-thirds of the radius; pores small, circular, deeply conjugate, inner row nearly straight, outer row broadly arched; poriferous zones wider than the interporiferous zones, moderately open at each end. Ambulacra widely expanding beyond the petals. Interambulacra narrowing from the outer ends of the petals to the margin, slightly expanding within the margin on the oral face but interrupted by two long postbasicoronal ambulacral plates. Each submarginal plate of the oral side contains a maze of internal passageways. Peristome central, small, circular; surrounded by five radiating food grooves, which bifurcate at the ends of the basicoronal plates and curve broadly almost to the margin, where they branch repeatedly. Periproct on the oral side about three-quarters of the radius from the margin, the distance from the margin varying with the depth of the posterior notch.

Length of figured specimen $112 \mathrm{~mm}$; width $119 \mathrm{~mm}$; height $11 \mathrm{~mm}$.

Occurrence.-Maryland: Patuxent River, presumably Drum Cliff near Jones Wharf, St. Marys County (type, Philadelphia Acad., T. A. Conrad). Jones Wharf (USGS 2451, USNM 146005, Frank Burns; USNM 559476, figured by Clark, 1904, and Clark and Twitchell, 1915). Governors Run, 5 miles southeast of Prince Frederick, Calvert County (USGS 17112, H. K. Brooks). Scientists Cliffs, Calvert County (USGS 15617, 16919, W. E. Salter ; W. F. Foshag). Dover Bridge, Dorchester County (fide Clark).

North Carolina : 4 miles south of Clinton, Sampson County (USGS 11821, fragments, W. C. Mansfield).

Florida: Wakulla County, Sopchoppy River 3 miles west of Sopchoppy (USGS 4977, F. G. Clapp; 7468, G. C. Matson; USGS 10972, W. C. Mansfield).

Geologic unit.-Miocene, Choptank formation in Maryland, Chipola formation in Florida.

Type--Acad. Natural Sciences of Philadelphia, not numbered. Type of Scutella floridana USNM 498980.

Figured specimen.-USNM 562280, from USGS 17112.

Comparison.-The poriferous zones of Abertella aberti are narrower than those of $A$. cazonesensis (Kew) as figured by Kew $(1917$, p. 132, pl. 19, fig. 1). Whether that difference is of specific importance must await the comparison of a larger suite of the Mexican species.

The specimens from Florida, originally named scutella floridana Cooke, have a narrower posterior notch than many of those from Maryland, but the shape of the notch in both States is variable. The apical star of the specimens from Florida is more distinctly raised than in those from Maryland. This difference is attributed to the greater corrosion of the Maryland specimens.

\section{Family MELLITIDAE}

\section{Genus MELLITA Agassiz}

Mellita Klein. Agassiz, 1841, Monographies d'échinodermes, Mon. 2, p. 34.

Mellita Klein. Agassiz and Desor, 1847, Catalogue raisonné des échinodermes, p. 80.

Prostethes Gistl, 1848, Naturgeschichte des Thierreichs für höhere Schulen, p. x. New name for Mellita Agassiz, 1841. Fide Neave.

Mellita Agassiz. Gray, 1852, Zool. Soc. London. Proc. (for 1851), v. 19, p. 36.

Mellita Klein. Desor, 1858, Synopsis des échinides fossiles, p. 236.

Mellita. Michelin, 1858, Revue et Mag. de Zool., no. 8, p. 2. Fide Mortensen.

Mellita Klein. A. Agassiz, 1872, Harvard College Mus. Comp. Zoology Mem., v. 3, p. 319.

Mellita Klein. Pomel, 1883, Classification méthodique et genera des échinides, p. 71.

Melita Klein. Duncan, 1889, Linnean Soc. London Jour., Zoology, v. 23, p. 161.

Mellita Agassiz. H. L. Clark, 1911, Annals and Mag. Nat. History, ser. 8, v. 7, p. 599, 605 .

Mellita Agassiz. H. L. Clark, 1914, Harvard College Mus. Comp. Zoology Mem., v. 46, p. 76.

Mellita Klein. Lambert and Thiéry, 1921, Nomenclature raisonnée des échinides, fasc. 5, p. 324 .

Mellita Agassiz. Tortonese, 1933, Instituto e Mus. di zoologia e di anatomia comp. di R. Univ. Torino Boll., ser. 3, v. 43, no. 34, p. 154.

Mellita. Davies, 1935, Tertiary faunas, v. 1, p. 87.

Mellita Agassiz. Grant and Hertlein, 1938, California Univ. (Los Angeles) Pub. Math. and Phys. Sci., p. 101.

Mellita Agassiz. H. L. Clark, 1940, U. S. Natl. Mus. Proc., v. 89 (no. 3099), p. 437.

Mellita Agassiz. Cooke, 1942, Jour. Paleontology, v. 16, no. 1, p. 21.

Mellita Klein. Mortensen, 1948, Monograph of the Echinoidea, v. 4, pt. 2, p. 420 .

Mellita Agassiz. Durham, 1955, California Univ., Pub. in GeolSci., v. 31, no. 4, p. 172.

Type species, Echinodiscus quinquiesperforatus Leske, designated under the name Mellita testudinata Klein by Pomel (1883, p. 71), and also designated by H. L. Clark (1911, p. 599). Pomel credited the genus to Klein, a pre-Linnean writer, and Clark to Agassiz.

Opinion 393 of the International Commission on Zoological Nomenclature validates Mellita Agassiz 1841 and suppresses Mellita Fabricius 1823.

Distinctive features of Mellita quinquiesperforata are five long, narrow lunules-four in the paired am- 
bulacra beyond the petals and another in the posterior interambulacrum lying for the most part between the petals. Conspicuous perforated food grooves bifurcate near the peristome and nearly encircle the paired lunules. The ends of short buccal tubes project into the peristome.

\section{Mellita quinquiesperforata (Leske) \\ Plate 19 , figures 6,7}

Echinodiscus quinquies perforatus Leske, 1778, Klein's Naturalis dispositio echinodermatum, p. 197 , pl. 21 , figs. c, d.

Clypeaster pentaporus Lamarck, 1801, Système des animaux sans vertèbres, p. 349.

Scutella quinquefora Lamarck, 1816, Histoire naturelle des animaux sans vertèbres, p. 3,9 .

Mellita quinquefora (Lamarck). Agassiz, 1841, Monographies d'échinodermes, Mon. 2, p. 36, 145, pl. 3.

Encope pentapora Agassiz. 1841, Monographies d'échinodermes, Mon. 2, pl. 3 (title of plate).

Mellita quinquefora ampla Holmes, 1860, Post-Pleiocene fossils of South Carolina, p. 3, pl. 1, figs. 6a-b.

Mellita testudinata Klein. A. Agassiz, 1872, 1873, Harvard College Mus. Comp. Zoology Mem., v. 3, p. 141, 538, pl. 11, figs., $13-22$; pl. $12 \mathrm{a}$; pl. 12c, figs., 1, 2 ; pl. 37, figs. $1,2$.

Mellita pentapora (Gmelin). Clark and Twitchell, U. S. Geol. Survey Mon. 54, p. 225, pl. 106, fig. 1; pl. 107, figs. 1a-c.

Mellita quinquiesperforata (Leske). W. Berry, 1941, U. S. Natl. Mus. Proc., v. 90, no. 3113, p. 443, pl. 65, fig. 5.

Mellita quinquiesperforata (Leske). Cooke, 1942, Jour. Paleontology, v. 16, no. 1, p. 22, pl. 3, figs. 12, 13.

Mellita quinquiesperforata (Leske). Caso, 1946, Mexico Instituto de Biologia, v. 17, p. 247, text figs. $1,2$.

Mellita quinquiesperforata (Leske). Mortensen, 1948, Monograph of the Echinoidea, v. 4, pt. 2, p. 422 , pl. 62 , fig. 3 ; pl. 72, fig. 16. Includes complete synonymy.

Horizontal outline subcircular, usually flattened behind and weakly notched in front; upper surface nearly flat, sloping evenly in all directions from the apical system to the very thin margin; lower surface flat. Test perforated by narrow radial slots near the outer ends of the paired ambulacra and by a longer slot in the median part of the posterior interambulacrum. Apical system having five small ocular pores; four genital pores at the paired interambulacral tips of the large starshaped madreporite. Petals extending about halfway to the margin, anterior paired petals slightly shorter and rounder than the others; poriferous zones about as wide as the interporiferous zones, open at the rounded tips. Peristome small, central. Periproct elongated, midway between the peristome and the posterior slot. Food grooves narrow, shallow, divaricating near the peristome, the branches nearly surrounding the ambulacra, starting from five nodes, each covering twin buccal tubes. Surface covered with short acicular spines, which are longest around the perforations and on the lower surface.
Usual size 50 to 100 millimeters in diameter. Pleistocene specimens are half again as large.

Occurrence.-Littoral zone of the Atlantic Oceans from Nantucket to Santos, Brazil.

South Carolina: Wando River (USGS 7320, Edmund Ravenel); Simmons Bluff, Yonges Island, on Wadmalaw Sound (USGS 2023, Frank Burns) ; "Nordmalan" (probably misprint for Wadmalaw) type of M. ampla Michelin.

Georgia: Brunswick Canal (USNM 146633, J. W. Couper). Figured specimen.-USNM 562281. Denuded specimen from Amelia Island, Fla., C. W. Cooke, 1940.

Geologic unit.-Pleistocene to Recent.

\section{Mellita quinquiesperforata tenuis H. L. Clark}

Mellita quinquiesperforata tenuis $\mathrm{H}$. L. Clark, 1940, U. S. Natl. Mus. Proc. v. 89, no. 3099, p. 442, pl. 60, fig. 2 ; pl. 61, fig. 2. Mellita quinquiesperforata tenuis H. L. Clark. Cooke, 1942, Jour. Paleontology, v. 16, no. 1, p. 22.

Mellita quinquiesperforata tenuis H. L. Clark. Mortensen, 1948, Monograph of the Echinoidea, v. 4, pt. 2, p. 426.

H. L. Clark (1940, p. 436$)$ characterizes this variety as having a "test more or less pentagonal, rather stout, the apex tending toward the anterior; periproct little or moderately elongated." The variety grades into the typical form by connecting links. It has been recognized only on the west coast of Florida.

Occurrence.-Florida: Two miles off Sanibel Island (W. J. Clench) ; Tarpon Springs (E. J. Shadle); Charlotte Harbor (W. H. Dall).

Geologic unit.-Recent.

Type.-USNM E 5656, Sanibel Island.

\section{Genus IEODIA Gray}

Leodia Gray, 1852, Zool. Soc. London Proc. for 1851, pt. 15, p. 36. Leodia Gray. Lambert and Thiéry, 1921, Nomenclature raisonnée des échinides, fasc. 5, p. 324.

Leodia Gray. H. L. Clark, 1940, U. S. Natl. Mus. Proc., v. 89, no. 3099 p. 435.

Leodia Gray. Cooke, 1942, Jour. Paleontology, v. 16, no. 1, p. 22. Mellita (Leodia) Gray. Mortensen, 1948, Monograph of the Echinoidea, v. 4, pt. 2, p. 421.

Leodia Gray. Durham, 1955, California Univ. Pub. Geol. Sci., v. 31, no. 4, p. 172.

Type species, Leodia richardsonii Gray $=$ Echinodiscus sexies perforatus Leske, 1778 , by monotypy. This species differs from Mellita quinquiesperforata (Leske) chiefly in having a sixth lunule in the anterior ambulacrum. According to A. Agassiz (1872, p. 321, pl. 11, figs. 1-12) the lunules of Mellita sexforis (=Leodia sexiesperforata) originate by resorption of the test rather than by the closing of marginal notches as in Mellita quinquiesperforata.

\section{Ieodia sexiesperforata (Leske) \\ Plate 19, figures 4,5}

Echinodiscus sexies perforatus Leske, 1778, Klein's Naturalis dispositio echinodermatum, p. 199, pl. 50, figs. 3, 4 .

Echinus hexaporus Gmelin, 1788, Linnaei systema naturae, ed. 13 , p. 3189 . 
Scutella sexforis Lamarck, 1816, Histoire naturelle des animaux sans vertèbres, $\nabla .3$, p. 9 .

Mellita hexapora (Gmelin). L. Agassiz, 1841, Monographies d'échinodermes, Mon. 2, p. 41, pl. 4, figs. 4-7; pl. 4e, figs. 11, 12.

Mellita similis L. Agassiz, 1841, Monographies d'échinodermes, Mon. 2, p. 43, pl. 4, figs. 1-3.

Leodia richardsonii Gray, 1852, Zool. Soc. London Proc. for 1851, pt. 19, p. 36.

Mellita sexforis (Lamarck). A Agassiz, 1872, 1873, Harvard College Mus. Comp. Zoology Mem., v. 3, pp. 141, 536, pl. 11, figs. $1-12 ;$ pl. 11d, fig. 3.

Leodia sextiesperforata (sic) (Leske). Lambert and Thiéry, 1921, Nomenclature raisonnée des échinides, fasc. 5, p. 324.

Leodia sexiesperforata (Leske). Cooke, 1942, Jour. Paleontology, v. 16, no. 1, p. 22.

Mellita (Leodia) sexiesperforata (Leske). Mortensen, 1948, Monograph of the Echinoidea, v. 4, pt. 2, p. 429, pl. 58, fig. 4 ; pl. 61 , fig. 7 ; pl. 72, fig. 19 . Includes complete synonymy.

Horizontal outline subcircular, flattened behind; upper surface nearly flat, highest at the anterior petal; lower surface flat. Apical system central; madreporite starshaped, with 5 sharp points; 4 genital pores outside the madreporite and detached from it. Petals short, less than half the radius, nearly equal in length, lanceolate; poriferous zones as wide as the interporiferous, inner pores oval, outer pores elongated, pores conjugate. All five ambulacra penetrated by a long, narrow, straight lunule between the petals and the margin; posterior lunule slightly wider, occupying the middle third of the radius. Peristome small, circular, central, with paired buccal tubes. Periproct small, pear-shaped, lying midway between the peristome and the lunule. Food grooves deep, narrow, perforated; divaricating at the peristome, each branch running parallel to that of the neighboring ambulacrum and branching several times near the margin. Spines short, straight.

Length of figured specimen $66 \mathrm{~mm}$; width $65 \mathrm{~mm}$; height $7.3 \mathrm{~mm}$.

Occurrence.- South Carolina to Uruguay.

Geologic unit.-Recent. Probably also Pleistocene, but no specimens good enough for accurate identification are in the collection of the National Museum.

Figured specimen.-USNM E 1183, from Morning Star Bay, St. Thomas, Danish West Indies, depth 1 fathom (C. R. Shoemaker).

\section{Leodia caroliniana (Ravenel)}

\section{Plate 19, figures 1-3}

Scutella caroliniana Ravenel, 1841, Acad. Nat. Sci. Philadelphia Jour., ser. 1, v. 8, p. 333, text fig.

Mellita caroliniana (Ravenel). Ravenel, 1848, Echinidae, Recent and fossil, of South Carolina, p. 4.

Mellita caroliniana (Ravenel). Tuomey and Holmes, 1857, Pleiocene fossils of South Carolina, p. 3, pl. 1, figs. 4, 4a-b.

Mellita caroliniana (Ravenel). Clark and Twitchell, 1915, U. S. Geol. Survey Mon. 54, p. 204, pl. 91, figs. 1a-b; pl. 92, figs. 1a-b.
Leodia caroliniana (Ravenel). Cooke, 1942, Jour. Paleontology, v. 16, no. 1, p. 23.

The following description is based on Tuomey and Holmes' figures, which appear to be accurate: Horizontal outline subcircular or subtrigonal, slightly wider behind; upper surface nearly flat; lower surface flat. Apical system central with a large star-shaped madroporite and four (?) genital pores. Petals nearly equal in length, lanceolate, extending more than halfway to the margin. One small lunule in each ambulacrum between the petals and the margin, a sixth much larger lunule in the posterior interambulacrum. Peristome central, circular, small, Periproct small, pear shaped, midway between the peristome and the posterior lunule. Food grooves forking near the peristome and having several lateral branches.

Length about $53 \mathrm{~mm}$; width about $55 \mathrm{~mm}$; height about $5 \mathrm{~mm}$. Tuomey and Holmes report fragments twice as large.

Occurrence.-South Carolina: The Grove Plantation, Cooper River 5 miles northwest of Wando; Goose Creek; Wadmalaw River (fide Tuomey and Holmes).

Geologic unit.-Late Miocene.

Type.-Unknown, possibly Charleston (S. C.) Museum.

Remarks.-This species has proportionately longer petals than Leodia sexiesperforata, and its food grooves form a different pattern, diverging nearer the peristome.

A Leodia measuring $113 \mathrm{~mm}$ in diameter probably representing Leodia caroliniana was obtained by Dr. J. McGonigle from the Miami oolite of Pleistocene age at a golf course near Miami, Fla. (USGS 4867, T. W. Vaughan). Another larger specimen, $127 \mathrm{~mm}$ in diameter, from the Yorktown formation of Miocene age at Days Point, James River, west of the mouth of Pagan Creek about 4 miles north of Smithfield, Va. (USGS 16920, G. C. Barclay) is too heavily coated with hard matrix to be identified with certainty.

\section{Genus ENCOPE I. Agassiz}

Encope Agassiz, 1840, Catalogus systematicus ectyporum echinodermatum, p. 6,17.

Encope Agassiz. Agassiz, 1841, Monographies d'échinodermes, Mon. 2, p. 45.

Encope Agassiz. Agassiz and Desor, 1847, Catalogue raisoné des échinodermes, p. 79.

Encope Agassiz. Desor, 1858, Synopsis des échinides fossiles, p. 237.

Encope Agassiz. A. Agassiz, 1872, Harvard College Mus. Comp. Zoology Mem., v. 3, p. 324.

Encope Agassiz. Cooke, 1942, Jour. Paleontology, v. 16, no. 1, p. 19.

Encope Agassiz. Mortensen, 1948, Monograph of the Echinoidea, v. 4, pt. 2, p. 433.

Encope Agassiz. Durham, 1950, Geol. Soc. America Mem. '43, pt. 2, p. 42.

Encope Agassiz, Durham, 1955, California Univ. Pub. Geol. Sci., v. 31, no. 4, p. 174.

Type species, Encope grandis L. Agassiz (1840, p. 6 ; 1842 , p. 57, pl. 6), by monotypy. This species is roughly elliptical, truncated behind, the periphery cut by five 
deep, wide ambulacral notches and the posterior truncation slightly reentrant. The test is rather flat, thickest in the posterior interambulacrum, which is pierced by a very large ovate lunule. The apical system consists of a large five-pointed star with five genital pores at the points. The three anterior petals are broadly lanceolate, extending two-thirds of the radius; the posterior pair are longer and curve around the lunule. The inner pores are circular, the outer are smaller and tend to elongate; the pores are conjugate. The peristome is circular and has five pairs of buccal tubes. The periproct is rather far from the peristome, near the lunule. The deeply sunken food grooves divaricate several times. Encope grandis inhabits the littoral region of the Gulf of California.

Key to the species of Encope

Lunule oval or nearly circular

Lunule very large, test longer than wide

Encope macrophora Ravenel

Lunule much smaller, test as wide as long

Encope tamiamiensis Mansfield

Lunule strongly elongated

Test usually without anterior ambulacral notches; if notches are present they show no tendency to close Encope michelini Agassiz

Test having fire ambulacral notches, all of which may close at the outer ends, forming oval or circular lunules_._._._._._Encope emarginata (Leske)

\section{Encope macrophora (Ravenel)}

\section{Plate 17, figures 1, 2}

Scutella macrophora Ravenel, 1842, Acad. Nat. Sci. Philadelphia Jour., ser. 1, v. 8, pt. 2, p. 334, text fig.

Encope macrophora (Ravenel). Ravenel, 1848, Echinidae, Recent and fossil, of South Carolina, p. 3.

Encope macrophora (Ravenel). Tuomey and Holmes, 1857, Pleiocene fossils of South Carolina, p. 2, pl. 1, fig. 3 .

Ravenellia macrophora (Ravenel). Lütken, 1864, Dansk naturh. Foren. Vidensk. Meddelelser, 1863, p. 168.

Macrophora macrophora (Ravenel). Conrad, 1865, Acad. Nat. Sci. Philadelphia Proc., p. 74.

?Macrophora raveneli Conrad. 1865, Acad. Nat. Sci. Philadelphia Proc., p. 74.

Encope macrophora (Ravenel). Stefanini, 1911, Soc. geol. italiana Boll., v. 30, p. 708.

Encope macrophora (Ravenel). Clark and Twitchell, 1915, U. S. Geol. Survey Mon. 54, p. 206, pl. 93, figs. 2a-e; pl. 94, figs. 1a-f, 2.

Encope macrophora (Ravenel). Cooke, 1942, Jour. Paleontology, จ. 16, no. 1, p. 20.

Horizontal outline elliptical, truncated behind; deep posterior ambulacral notches, shallower anterolateral ambulacral notches, and a very shallow anterior emargination; upper surface flattish in front, highest in the posterior interambulacrum, where the test is perforated by a very wide oval lunule; lower surface slightly concave or flat; margin thick. Apical system plainly an- terior, with a large star-shaped madreporite and five genital pores. The three anterior petals lie nearly at right angles to each other and extend about threefourths of the radius; the odd petal lanceolate, the anterior paired petals nearly straight; the posterior petals are much longer and curve around the lunule. Poriferous zones wider than the interporiferous zones, open distally; inner pores circular, outer pores elongate; pores conjugate. Peristome below the apical system, small, pentagonal. Periproct small, adjacent to the lunule. Food grooves bifurcating near the peristome and slightly diverging; several lateral branches.

Length of type $71.5 \mathrm{~mm}$; width $67 \mathrm{~mm}$; height $11 \mathrm{~mm}$. Length of largest specimen at hand $90 \mathrm{~mm}$; width 76 $\mathrm{mm}$; height $19 \mathrm{~mm}$.

Occurrence.-South Carolina: The Grove Plantation, Cooper River, 5 miles northwest of Wando (USNM 145411, 145410, E. Ravenel; USNM 2512, W. Stimpson; USNM 9970).

Florida: Alligator Creek (USNM 164658, J. Willcox).

Geologic unit.-Late Miocene(?) (South Carolina); Pliocene, Caloosahatchee formation (Florida).

Comparisons.-Encope macrophora is narrower than $E$. grandis, Agassiz, and its notches are shallower and show no tendency to close. Its anterior notch is reduced to merely a slight indentation. From $\mathbb{E}$. tamiamiensis Mansfield it differs in these same features, and its lunule is much smaller and its margin thinner.

Type.-USNM 145410, Edmund Ravenel, collector, here designated.

Encope tamiamiensis Mansfield

Plate 17, figures 3,4

Encope macrophora tamiamiensis Mansfield, 1932, U. S. Geol. Survey Prof. Paper 170-D, p. 48, pl. 17, fig. 8.

Encope michelini Agassiz. Berry, 1941, U. S. Natl. Mus. Proc. v. 90 , no. 3113 , pl. 65 , fig. 4.

Encope tamiamiensis Mansfield. Cooke, 1942, Jour. Paleontology, v. 16, no. 1, p. 20.

Horizontal outline subcircular, concavely truncated behind, with four large lateral ambulacral notches and a weaker anterior notch, and a rather small posterior lunule; upper surface nearly flat, highest at the front end of the lunule; lower surface flat; margin rather thin. Apical system slightly anterior, with a large central star-shaped madreporite and five genital pores. The three anterior petals lanceolate, extending about two-thirds of the radius, equal; the posterior petals longer, curved around the lunule; poriferous zones open, inner pores circular, outer pores elongated, pores conjugate. Peristome slightly anterior, subcircular. Periproct near the lunule, smaller than the peristome. Lunule oval. Food grooves bifurcating near the peristome, branches slightly diverging, nearly straight, obscure lateral branches near the outer ends.

Lengths of type and two figured specimens 89, 69, $54 \mathrm{~mm}$; widths $87.5,75,55 \mathrm{~mm}$; heights $13,7,7.8 \mathrm{~mm}$. 
Occurrence.-Florida: Tamiami Trail 5 miles east of Carnestown and about 7 miles northeast of Everglades, Collier County (type, USGS 11177, C. W. Cooke, W. C. Mansfield, Stuart Mossom). Collier County 16 to 22 miles south of Immokalee (figured specimens, USGS 13409 G. M. Ponton). Tamiami Trail 56 miles west of Miami (USGS 13410, G. M. Ponton). Tamiami Trail at Carnestown, 4 miles north of Everglades (USGS 11180, C. W. Cooke, W. C. Mansfield, Stuart Mossom). Pit east of road to Immokalee, 6 miles north of Tamiami Trail (USGS 15050, C. W. Cooke and T. P. Kirby). East side of State road 164, 9.5 miles north of intersection with US 94 (Tamiami Trail) (USGS 15223, C. W. Cooke and G. G. Parker). Five miles west of intersection of Tamiami Trail and west end of road to Pinecrest (USGS 14187, W. C. Mansfield and F. S. MacNeil).

Geologic unit.-Late Miocene, Tamiami formation.

Type.-USNM 371328 from USGS 11177. Figured specimens USNM 562284, from USGS 13409.

Comparisons.-Encope tamiamiensis has variable proportions but it is usually shorter and wider than either E. grandis or E. macrophora. It differs from both also in the much smaller lunule. Its anterior paired petals are more broadly lanceolate than those $E$. macrophora and do not extend in a straight line but form an angle of approximately $154^{\circ}$.

\section{Encope michelini I. Agassiz \\ Plates 18, figures 2, 3}

Encope michelini Agassiz, 1841, Monographies d'echinodermes, Mon. 2, p. 58, pl. 6a, figs. 9, 10.

Encope michelini Agassiz. A. Agassiz, 1872, Harvard College Mus Comp. Zoology Mem., v. 3, p. 329, pl. 12b, fig. 4; pl. 12c, figs. 3,$4 ;$ pl. 12 d, fig. 1 .

Encope michelini Agassiz. Berry, 1941, U. S. Natl. Mus. Proc., v. 90 , no. 3113 , pl. 63 , figs. $2,5,8$. Not the description nor the other figures.

Not Encope michelini Agassiz. Cooke, 1942, Jour. Paleontology, v. 16, no. 1, p. 21, pl. 4; fig. 6 (=Encope tamiamiensis Mansfield).

Encope michelini Agassiz. Mortensen, 1948, Monograph of the Echinoidea, v. 4, pt. 2, p. 441 , pl. 70, fig. 23 . Includes additional synonymy.

Encope michelini Agassiz. Leutze, 1956, Florida Acad. Sci. Quart. Jour., v. 19, no. 1, p. 65.

Test spade shaped, longer than wide, highest behind the apical center, lower surface flat. L. Agassiz's figures show five rather deep, wide ambulacral notches and a slot-shaped posterior lunule, but the more common variety has only two posterior ambulacral notches and a lunule, the three anterior ambulacra being only slightly indented. Apical system central, star shaped, with five genital pores. Petals broadly lanceolate, open; poriferous zones wide, pores conjugate; inner pores circular, larger than the outer pores, which tend to enlarge along the conjugations. Peristome small, central, circular, with five pairs of buccal tubes. Periproct oval, within the first postbasicoronal plates; covered with moveable plates.

Occurrence.-Gulf of Mexico.

Florida: St. Lucie Canal 1 mile from Lake Okeechobee, Palm Beach County (USGS 10593, C. W. Cooke, Herman Gunter,
Stuart Mossom), identification doubtful. High bank, Volusia County, NE $1 / 4$ SW $1 / 4$ sec. 28 T. 16 S. R. 33 E. (Florida Geol. Survey I-8227, fide Leutze)

Geologio unit-Pleistocene and Recent.

Figured specimen.-USNM 562283, Gulf of Mexico, 2 miles off Longboat Key, Fla. (Brookes Knight).

\section{Encope emarginata (Leske)}

Plate 17, figure 5; plate 18, figure 1

Echinodiscus emarginatus Leske, 1778, Klein's Naturalis dispositio echinodermatum, p. 200, pl. 50, figs. 5, 6.

Ecope emarginata (Leske). L. Agassiz, 1841, Monographies d'échinodermes, Mon. 2, p. 47, pl. 10.

Encope emarginata (Leske). A. Agassiz, 1872, Harvard College Mus. Comp. Zoology Mem., v. 3, p. 325, pl. 12, figs. 14-24; pl. 12b, figs. 1-3; pl. 12d, figs. 2 , 3.

Encope emarginata (Leske). Cooke, 1942, Jour. Paleontology, v. 16, no. 1, p. 20, pl. 3, figs. 14, 15.

Encope emarginata (Leske). Mortensen, 1948, Monograph of the Echinoidea, v. 4, pt. 2, p. 438, pl. 62, fig. 2. Includes additional synonymy.

Horizontal outline elliptical, truncated behind; upper surface gently tumid, usually higher in front than behind; lower surface flat; margin thin. Posterior lunule long and rather wide. Five deep ambulacral notches, which tend to become oval and to close at the outer end. Apical system anterior; madreporite star shaped: 5 genital pores. Petals broadly lanceolate, extending more than halfway to the margin; poriferous zones wide, curved together at the outer ends but not closed. Peristome below the apical system, circular, with five pairs of buccal tubes. Food grooves diverging near the peristome and curving together around the notches; several branches near the margin. Periproct near the lunule.

Occurrence.-Living along the east coast of the Americas from Uruguay to Yucatan, perhaps to South Carolina

South Carolina: Intracoastal Waterway canal near Little River in Horry County 1 to 1.5 miles southwest of the highway bridge on US 17 near Nixon's Crossroads, about 15 miles northeast of Myrtle Beach (USGS 18759, L. C. Glenn; USGS 13377, O. W. Cooke; USGS 13427, W. C. Mansfield and F. S. MacNeil; S. F. Blake). Intracoastal Waterway canal 1 to 2 miles northeast of the Atlantic Coast Line bridge near Myrtle Beach (USGS 18760, L. C. Glenn).

North Carolina: Farm of James Dawson 3 miles north of Grifton, Pitt County (USNM 166525, Harvey Bassler). North shore of Lake Waccamaw, Columbia County, base of upper bed (USGS 13379, F. S. MacNeil).

Florida: Tamiami Trail in Collier County 10.3 miles west of the Dade County line (USGS 15224, O. W. Cooke and G. G. Parker). Dredged from Biscayne Bay at foot of N. E. 39th Street, Miami (USGS 13400, G. M. Ponton). Big Pine Key, Monroe County, on railroad to Key West (USGS 4954, Samuel Sanford).

Geologic unit.-Late Miocene (?) to Recent.

Figured specimen.-USNM 562282, from USGS 18760, Pleistocene. 
Remark8.-Most of the Recent specimens from off South America are flat on top or slightly higher in front, but many from the Miocene and Pleistocene of the United States, including the figured specimen, are higher behind. The open or closed notches distinguish this species from the common Encope michelini of the Gulf of Mexico, which usually has no notches.

The notches of the specimens attributed to the late Miocene are closed, whereas those from the Pleistocene are usually open.

\section{Family LAGANIDAE Desor}

Key to the Laganidae and Neolaganidae

Five genital pores ; margin swollen, submargin depressed

Submarginal plates conspicuously swollen

Laganum ocalanum

Submarginal plates not conspicuously swollen

Laganum floridanum

Four genital pores

Oral side flat; food grooves conspicuous.

Outline nearly circular._._._- Neolaganum archerensis Test longer than wide; margin thin, truncated

Wythella eldridgei

Oral side concave; food grooves not conspicuous ; poriferous zones open apically Weisbordella

Petals short, wide open apically_-_Weisbordella cubae Petals longer, less open apically.

Poriferous zones wide________-Weisbordella dall Poriferous zones narrow_-_-_Weisbordella johnsoni

\section{Genus IAGANUM Iink}

Laganum Link, 1806, Beschreibung der Naturalien-Sammlung der Universität zu Rostock, Abt. 1, p. 161.

Lagana Gray, 1825, Annals of Philosophy, ser. 2, v. 10, p. 427.

Laganum Klein, Agassiz (part), 1841, Monographies d'échinodermes, Mon. 2, p. 105.

Laganum Klein. Agassiz and Desor (part), 1847, Catalogue raisonné des échinides (reprint), p. 73.

Laganum Klein. Desor (part), 1858, Synopsis des échinides fossiles, p. 227.

Laganum Klein. A. Agassiz, 1872, 1874, Harvard College Mus. Comp. Zoology Mem., v. 3, p. 137, 516.

Laganum Klein. Pomel, 1883, Classification méthodique et genera des échinides, p. 69.

Laganum. Bell, 1883, Annals and Mag. Nat. History, ser. 5, v. 11, p. 130.

Laganum Klein. Duncan (part), 1889, Linnean Soc. London Jour. Zoology, v. 23, p. 156.

Laganum Klein. Cotteau, 1891, Paléontologie française, Terrain tertiaire, ser, 1, v. 2, p. 250, 251.

Laganum Gray. H. L. Clark, 1914, Harvard College Mus. Comp. Zoology Mem., v. 46, no. 1, p. 44.

Jacksonaster Lambert in Lambert and Thiéry, 1914, Nomenclature raisonnée des échinides, fasc. 4, p. 313.

Laganum Klein. Lambert and Thiéry, 1914, Nomenclature raisonnée des échinides, fasc. 4, p. 313.

Laganum Gray. Jackson, 1922, Carnegie Inst. Washington Pub. 306, p. 46.

Jacksonaster Lambert. Sanchez Roig, 1926, (Cuba) Bol. de Mines no. 10, p. 58 .

Laganum Link. Cooke, 1942, Jour. Paleontology, v. 16, no. 1, p. 23.

Laganum Klein. Mortensen, 1948, Monograph of the Echinoidea, v. 4 , pt. 2, p. 301.
Laganum Link. Durham, 1955, California Univ. Pub. Geol. Sci., v. 31, no. 4, p. 139.

Type species, Laganum petalodes Link 1806, =Echinus laganum Gmelin 1792=Echinodiscus laganum Leske (1778, p. 204, pl. 22, figs. a-c), by tautonomy. This is the species called Laganum bonani by Agassiz (1841, p. 108, pl. 23, figs. 8-12; pl. 22, figs. 25-29) and A. Agassiz (1874, p. 517, pl. 13e, figs. 6, 7). It has been described under the name Langanum laganum (Leske) by Mortensen (1948, p. 308, pl. 52, figs. 1-11, 13, 15-17; pl. 70, figs. 1-7) and figured by Durham (1955, text figs. $1 \mathrm{c}, 2 \mathrm{c}, 7 \mathrm{~b}, 7 \mathrm{e}, 12 \mathrm{~b}, 15 \mathrm{e}, 31 \mathrm{f})$.

Laganum laganum has five genital pores; its hydropores are in grooves. Its petals are open at the apical end but nearly closed at the distal end. The petaliferous part is slightly tumid, the margin is thicker than the submargin, and the lower side is somewhat concave. According to Louis Agassiz the ambulacral furrows are conspicuous, straight, and extend halfway to the margin. They are finely punctate, especially near the peristome. The periproct is about midway between the peristome and the margin.

The most conspicuous difference between Laganum and Peronella or Rumphia is the number of genital pores, Laganum having 5, Peronella and Rumphia 4 each. This difference was noted by L. Agassiz, Desor, and several later writers, but was not considered a valid generic distinction. Alexander Agassiz, H. L. Clark, Mortenson, and others disagreed.

The American species here referred to Laganum differ from the type in that the periproct is nearer the margin and the ambulacral grooves are very inconspicuous or wanting.

Laganum floridanum Twitchell

Plate 20, figures 8-10

Laganum floridanum Twitchell, 1915, U. S. Geol. Survey Mon. 54, p. 163, pl. 75, figs. 3a-d.

Echinodiscus floridanus (Twitchell). Lambert and Thiéry, 1925, Nomenclature raisonée des échinides, fasc. 9, p. 581. Laganum floridanum Twitchell. Cooke, and Mossom, 1929, Fla. Geol. Survey Ann. Rept. 20, pl. 3, figs. 5a-b (after Twitchell). Laganum floridanum (Twitchell) Cooke, 1942, Jour. Paleontology, v. 16, no. 1, p. 23.

Laganum floridanum Twitchell. Cooke, 1945, Fla. Geol. Survey Bull. 29, fig. 5, no. 5 (after Twtichell).

Horizontal outline oval; upper surface tumid in the apical region, depressed in the submargin; margin thick, rounded; lower surface very slightly concave. Apical system having five genital pores far apart. Petals lanceolate, broad; poriferous zones curved inward at each end, wide open at the apical end, nearly closed distally. Peristome small, central. No ambulacral furrows. Periproct small, circular, about one-fourth 
the way from the margin to the peristome. Tubercles sunken.

\section{Length $19.6 \mathrm{~mm}$; width $17.7 \mathrm{~mm}$; height $4.2 \mathrm{~mm}$.}

Occurrence.-Florida: Johnson's sink, Levy County (USGS 365, type, L. C. Johnson).

Geologic unit.-Late Eocene, Ocala limestone.

Type.-USNM 137884.

Comparisons.-The petals of Laganum floridanum resemble those of L. laganum but are proportionately shorter. The poriferous zones are closer together at the apical ends than those of $L$. ocalanum Cooke. The periproct is farther back than in $L$. laganum, and ambulacral furrows are wanting. The species is represented by the type and two other specimens from the same locality.

\section{Iaganum ocalanum Cooke}

Plate 20, figures 11-15

Laganum ocalanum Cooke, 1942, Jour. Paleontology, v. 16 no. 1, p. 23 , pl. 2 , figs. $7-10$.

Laganum ocalanum Cooke. Fischer, 1951, Florida Geol. Survey Geol. Bull. 32 pt. 2, p. 57.

Horizontal outline suboval; upper surface tumid in the apical region, depressed in the submargin; margin thick, rounded; lower surface flat. Apical system having five genital pores rather far apart between the inner ends of the poriferous zones; hydropores apparently in very fine, short, inconspicuous grooves. Petals short, extending halfway to the margin, spade-shaped; poriferous zones nearly closed at the distal end, wide open at the apical end. Plates of submargin conspicuously tumid. Peristome pentagonal, central. Periproct small, circular, one-third or less the way from the margin to the peristome. Ambulacra on lower surface punctate, without grooves. Tubercles small, depressed; thickly scattered on upper surface, farther apart on lower.

Length of holotype $22.3 \mathrm{~mm}$; width $19.5 \mathrm{~mm}$; height $3.0 \mathrm{~mm}$. Length of paratype USNM $49899337.0 \mathrm{~mm}$; width $30.5 \mathrm{~mm}$; height $5.8 \mathrm{~mm}$.

Occurrence.-Florida: Pit 2 miles northeast of Sumterville (USGS 12751, type, W. C. Mansfield and G. M. Ponton; USNM 372881, Florida Geol. Survey 2317). Drainage ditch at Great Wall sink near Sumterville (Fla. Geol. Survey 2318, paratype). Old MacDonald quarry 1 mile north of Istachatta (USGS 11112, C. W. Cooke and Stuart Mossom). Ocala (USGS 6804, C. W. Cooke). 1.5 miles northwest of Newberry (USGS 6814, C. W. Cooke), 1.5 miles south of Newberry (Stuart Mossom). Old French phosphate mine east of Anthong (USGS 7366, C. W. Cooke). Near Citra (USGS 7266, L. C. Johnson). Johnson's sink, Levy County (USGS 365, L. C. Johnson). 1.5 miles west of Croom, Hernando County (USGS 7364, C. W. Cooke). Suwannee River at Branford (USGS 7341, C. W. Cooke). Well at Leesburg (USGS 2076, L. C. Johnson). 1 mile south of Williston (Fla. Geol. Survey 2319). 6 miles southeast of Crystal River (USGS 14141, W. C. Mansfield and C. W. Mumm). Pit between Inglis and Yankeetown, Levy County (USGS 14544, C. W. Cooke and W. D. Havens) Newberry (Stuart Mossom). Northwest edge of Citra, Marion County (C. W. Cooke and Stuart
Mossom). Quarry east of US Highway 41, 1.5 miles north of Williston (USGS 15046, C. W. Cooke and Tom Kirby). 3 miles north of east of Newberry, Alachua County (USGS 14177, W. C. Mansfield and C. W. Mumm). Road to Bushnell 3.5 miles southeast of Floral City, Citrus County (USGS 14133, W. C. Mansfield and C. W. Mumm). Withlacoochee River, W 1/2 sec. 3, T. 17 S., R. 16 E. Citrus and Levy Counties (USGS 18749, A. G. Fischer and J. E. Banks). Withlacoochee River in sec. 5, T. 17 S., R. 16 E. (USGS 18756, A. G. Hisher and J. E. Banks). Borrow pit north of highway in SW $1 / 4$ sec. 33, T. 13 S., R. $15 \mathrm{E}$., Levy County (USGS 18751, A. G. Fischer and J. E. Banks).

Geologic unit.-Late Eocene, Ocala limestone and Inglis limestone.

Types.-Holotype, USNM 372873, from USGS 12751. Figured paratype, USNM 498993, from USGS 6804 . Figured specimen USNM 562288, from USGS 18756.

Comparison.-This species differs from Laganum floridanum Twitchell in the tumid plates of the submarginal area and in the greater distance between the poriferous zones at the apical end of the petals.

\section{Family NEOLAGANIDAE Durham Genus NEOLAGaNUM Durham}

Neolaganum Durham, 1954, Jour. Paleontology, v. 28, no. 5, p. 680.

Neolaganum Durham. Durham, 1955, California Univ. Pub. Geol. Sci., v. 31, no. 4, p. 146.

Type species, Laganum archerensis Twitchell, by monotypy and original designation. This species is a synonym of Laganum dalli Twitchell. Durham's study of the genus was based on a misidentified species, which is herein described as Neolaganum durhami. Fortunately, there seem to be no generic differences between Laganum dalli and Neolaganum durhami, so Durham's description of the genus still applies.

The flat lower surface and conspicuous food grooves distinguish Neolaganum from Weisbordella, which is concave and lacks food grooves. The type species of Wythella has both these features, but it is much larger, more elongated, and has a thinner margin. Whether these are valid generic differences seems questionable.

\section{Neolaganum dalli (Twitchell)}

Plate 21, figures 1-4

Laganum archerensis Twitchell, 1915, U. S. Geol. Survey Mon. 54, p. 161, pl. 75, figs. 1a-d.

Laganum dalli Twitchell, 1915, U. S. Geol. Survey Mon. 54, p. 164, pl. 75, figs. 4a-d.

Echinodiscus archerensis (Twitchell). Lambert and Thiéry, 1925, Nomenclature raisonnée des échinides, fasc. 9, p. 581. Echinodiscus dalli (Twitchell). Lambert and Thiéry, 1925, Nomenclature raisonnée des échinides, fasc. 9, p. 581.

Laganum dalli Twitchell. Cole and Ponton, 1932, Am. Jour. Sci., ser. 5, v. 24 , p. 23 , figs. 1a-12b.

Laganum archerensis Twitchell. Cooke and Mossom, 1929, Florida Geol. Survey Ann. Rept. 20, pl. 3, figs. 6a-b (after Twitchell).

Peronella dalli (Twitchell). Cooke, 1942, Jour. Paleontology, v. 16, no. 1, p. 26. 
Rumphia archerensis ('Twitchell). Cooke, 1945, Florida Geol. Survey Bull. 29, fig. 5, no. 6 (after Twitchell).

Peronella dalli (Twitchell). Cooke, 1948, Jour. Paleontology, v. 22 , no. 1 , p. 91 , pl. 22 , figs. 5,6 .

Peronella dalli (Twitchell). Fischer, 1951, Florida Geol. Survey Bull. 34, pt. 2, p. 57.

Horizontal outline subpentagonal; upper surface nearly flat, slightly depressed in the submargin; margin thick, rounded; lower surface concave. Apical system central; four genital pores, far apart; hydropores, when visible, in a crooked groove. Petals extending twothirds the radius, broad, rounded at the tip; poriferous zones very wide, closed distally, open at the apex; inner pores circular, outer pores elongate, pores conjugate. Peristome central, pentagonal; surrounded by five short ambulacral grooves ending in a pair of buccal pores. Periproct circular, less than half the radius from the margin, location variable. Tubercles rather large, sunken, scattered.

Length of holotype 15.9 ; width 15.0 ; height $4.6 \mathrm{~mm}$.

Occurrence.-Florida: Archer (type, USNM 164667b, W. H. Dall). International Mineral \& Chemical Company well 1, Noralyn plant, depth 600 feet, sec. 25 , T. 30 S. R. 24 E, Polk County. Well at Davenport. Well at Leesburg (USGS 2076, L. C. Johnson). Well at Bradenton, depth 985-1000 feet (Stuart Mossom). Well 50 miles west of Miami, depth 1250 feet (E. F. P. Brigham). Well at Kissimmee, depth 68-100 feet (USGS 5016, G. C. Matson). Well S-540 near Miami (USGS Water Resources Branch).

Panama: Madden Field (USGS 16889, W. P. Woodring and J. R. Schultz).

Geologic unit.-Middle Eocene, Avon Park limestone.

Type.-USNM 164667b. Figured specimen, USNM 562285. Type of Laganum archerensis, USNM 164667a.

Remarks.-The specific name dalli is preferred to archerensis, which has page precedence, because dalli has been correctly identified and is a well known species, whereas archerensis has been repeatedly confused with the species herein described as Neolaganum durhami. The latter species is twice as large and has much closer tubercles.

The types of Laganum dalli and $L$. archerensis originally received the same catalogue number. The locality is stated as Archer, Florida, but they probably came from a well, for no specimens have since been found at the surface.

The closest relative of Neolaganum dalli seems to be N. antillarum (Cotteau) [Sismondia] from the St. Bartholomew limestone of Eocene age of the West Indies. That species, known only from the type, a small specimen, has narrower poriferous zones and closer tubercles; its closed petals remove it from Sismondia. As was pointed out by Cole and Ponton (1932), the location of the periproct of $N$. dalli is variable.

The species is very abundant in wells in the Florida Peninsula in beds referred to the upper 50 feet of the Avon Park limestone. Vernon (1951, p. 101) suggests "that the Peronella bed may represent a continuation of Avon Park deposition into Inglis time," because in some wells the species is associated with Inglis Foraminifera; but it seems more probable that this association was caused by reworking of the echinoid into the Inglis, which unconformably overlies the Avon Park.
Neolaganum durhami Cooke, n. sp.

Plate 21, figures 5-7

Rumphia archerensis (Twitchell). Cooke, 1942, Jour. Paleontology, v. 16, no. 1, p. 27, pl. 2, figs. 11-13.

Peronella archerensis (Twitchell). Fischer, 1951, Florida Geol. Survey Bull. 34, pt. 2, p. 58, pl. 2, fig. 3; text figs. $2,3$.

Neolaganum archerensis (Twitchell). Durham, 1954, Jour. Paleontology, v. 28, no. 5, text fig. 28.

Neolaganum archerensis (Twitchell). Durham, 1955, California Univ. Pub. Geol. Sci., v. 31, no. 4, text figs. 15f, $30 \mathrm{~b}$.

Horizontal outline broadly oval to subdecagonal; upper side slightly tumid at the apex, depressed submarginally; margin usually thick, rounded; lower side flat. Apical system nearly central; four genital pores rather far apart; hydropores in crooked grooves. Petals long, extending nearly three-fourths the radius, equal, spatulate; poriferous zones nearly as wide as the interporiferous zones, nearly closed distally, open at the apex; inner pores circular or oval, outer pores elongated; plates compound. Peristome small central, pentagonal; teeth usually preserved; five pairs of large buccal pores. Ambulacral grooves straight, extending nearly halfway to the margin. Periproct small, circular, about three-fourths the radius from the peristome. Tubercles small, sunken, numerous. Internal concentric passageways near the margin.

Length of type $29 \mathrm{~mm}$; width $26.5 \mathrm{~mm}$; height 4.9 $\mathrm{mm}$.

Occurrence.-Florida: Quarry of the Williston Shell Rock Company 3 miles north of east of Newberry, Alachua County (USGS 14177, W. C. Mansfield and C. W. Mumm). 3.5 miles northeast of Newberry (USGS 14178, W. C. Mansfield and C. W. Mumm). Pit 3 miles north of Newberry (USGS 13843, W. C. Mansfield and F. S. MacNeil). Nixons, Levy County (USGS 355, L. C. Johnson). Pit between Inglis and Yankeetown, Levy County (USGS 14544, C. W. Cooke and W. D. Havens). Withlacoochee River in W1/2 sec. 3 T. 17 S., R. 16 E (USGS 18749, type, A. G. Fischer). Withlacoochee River in W1/2 sec. 4, T. 17 S., R. 16 E. (USGS 18755, A. G. Fischer and J. E. Banks). Borrow pit on north side of highway in SW1/4 sec. 33, T. 13 S., R. 15 E. (A. G. Fischer and J. E. Banks). Polk County oil well, depth unknown (USNM 498994, Florida Geol. Survey).

Geologic unit.-Late Eocene, Inglis limestone and Ocala limestone.

Type.-USNM 562290a; paratype, USNM 562290b.

Figured specimen.-USNM 562289.

Remarks.-Neolaganum durhami is about twice as large as $N$. dalli, proportionately thinner, and its tubercles are much closer together.

\section{Genus WYTHELLA Durham}

Wythella Durham, 1954, Jour. Paleontology, v. 28, no. 5, p. 682. Wythella Durham. Durham, 1955, California Univ. Pub. Geol. Sci., v. 31, no. 4, p. 148.

Type species, Laganum eldridgei Twitchell, by monotypy and original designation. 
In general appearance Wythella closely resembles Rumphia Desor, with which the unique type species has been confused. It differs from Rumphia rostrata (L. Agassiz, 1841, p. 118, pl. 25) in the arrangement of the plates on the oral side, that species having more, narrower plates, so that the periproct of $W$. eldridge $i$ lies at the ends of the first postbasicronal plates, whereas that of $R$. rostrata, which occupies nearly the same location, lies about the ends of the fifth postbasicoronal plates. The food grooves of Rumphia are simple, but those of Wythella are faintly bifurcating. The petals of Rumphia are open; those of Wythella eldridgei are closed.

Wythella eldridgei is much larger, more elongated, and more angular in outline than Neolaganum dalli. It is much thinner and lacks the swollen rim of Neolaganum.

\section{Wythella eldridgei (Twitchell)}

Plate 21, figures 8-10

Laganum eldridgei Twitchell, 1915, U. S. Geol. Survey Mon. 54, p. 160 , pl. 74, figs. $2 a-d$.

Rumphia eldridgei (Twitchell). Stefanini, 1924, Geol. Soc. America Bull., v. 35, p. 831, 843.

Rumphia eldridgei (Twitchell). Cooke and Mossom, 1929, Florida Geol. Survey Ann. Rept. 20, pl. 3, fig. 7 (after Twitchell).

Rumphia eldridgei (Twitchell). Cooke, 1942, Jour. Paleontology, v. 16, no. 1, p. 27, pl. 2, fig. 14.

Rumphia eldridgei (Twitchell). Cooke, 1945, Florida Geol. Survey Bull. 29, fig. 5, no. 1 (after Twitchell).

Wythella eldridgei (Twitchell). Durham, 1954, Jour. Paleontology, v. 28, no. 5, p. 682, text fig. 3D.

Wythella eldridgei (Twitchell). Durham, 1955, California Univ. Pub. Geol. Sci., v. 31, no. 4, text fig. 27 d.

Horizontal outline suboval, usually truncated in front, behind, and in posterior ambulacra; upper surface low, slightly tumid centrally, some specimens having tumidities near the proximal ends of the ambulacra apparently caused by pressure of the jaws; lower surface flat, food grooves bifurcating; margin thin. Apical system somewhat anterior; four (sometimes three) genital pores; madreporic pores in crooked grooves. Petals lanceolate, the anterior the longest, the anterior pair the shortest and widest; plates compound; poriferous zones wide, inner pores oval, outer pores elongated, zones closed distally, slightly open apically, where the ocular plates protrude between the zones. Interambulacra terminating in a single large plate at the apex. Peristome suboval, wider than long. Periproct large, circular, one-third the way from the margin to the peristome. Tubercles sunken, smaller on upper side than on lower.

Length of type $94.0 \mathrm{~mm}$; width $74.1 \mathrm{~mm}$; height 11.1 $\mathrm{mm}$. Length of figured specimen $70.0 \mathrm{~mm}$; width 56.4 $\mathrm{mm}$; height $9.1 \mathrm{~mm}$.
Occurrence.-Florida: Suwannee River below a sulphur spring 17 miles south of Ellaville (type, USGS 2612, G. H. Eldridge). Suwannee River at Dowling Springs, Suwannee County (USGS 7338, C. W. Cooke; USGS 12311, 12312, W. C. Mansfield and G. M. Ponton; USGS 14538, C. W. Cooke). Suwannee River 4 to 4.5 miles below Ellaville (USGS 12743, W. C. Mansfield, Herman Gunter, and G. M. Ponton). 5 miles northwest of Mayo on road to Dowling Park (USGS 11114, C. W. Cooke and Stuart Mossom). Road to Perry 5.2 miles west of Mayo (USGS 14537, C. W. Cooke and W. D. Havens). One mile north of Mayo (I-2413 Fla. G. S., G. M. Ponton). Suwannee River below Troy Springs, Lafayette County (USGS 7347, C. W. Cooke). U. S. 19 east of Steinhatchee River opposite Clara, in Dixie County (USGS 12747, W. C. Mansfield and G. M. Ponton; USGS 14148, W. C. Mansfield and C. W. Mumm; USGS 14541, C. W. Cooke and W. D. Havens; USGS 15150, G. M. Ponton). Miley rock pit in sec. 36, T. 20 S., R. 18 E., Citrus County (USGS 14536, C. W. Cooke). 6 miles southeast of Crystal River (USGS 14141, W. C. Mansfield and C. W. Mumm). Georgia : Left bank of Flint River at Mitchell-Dougherty County line (USGS 15142, W. C. Mansfield and F. S. MacNeil). Geologic unit.-Late Eocene, Ocala limestone.

Type.-USNM 164683, from USGS 2612; figured specimen USNM 562287, from USGS 14541.

\section{Genus WEISBORDELLA Durham}

Weisbordella Durham, 1954, Jour. Paleontology, จ. 28, no. 5, p. 682.

Weisbordella Durham. Durham, 1955, California Univ. Pub. Geol. Sci. v. 31, no. 4, p. 148.

Type species, Peronella caribbeana Weisbord= Peronella cubae Weisbord, by original designation.

This genus differs from Peronella Gray 1855 in having long basicoronal and first postbasicoronal interambulacral plates, and compound plates in the petals. Its genital plates lie within the apical system, but those of Peronella peronii lie outside of it, between the petals. According to Durham Weisbordella caribbeana resembles Peronella in not having its hydropores in grooves, but the species from Florida here identified without direct comparison as Weisbordella cubae and supposed to be synonymous with $P$. caribbeana has hydroporic grooves, though they are usualiy very obscure. Like Peronella, Weisbordella has four genital pores.

Weisbordella differs from Neolaganum in its concave oral side (Neolaganum is flat) and in its lack of food grooves. It is usually much more tumid.

Weisbordella cubae (Weisbord)

Plate 20, figures 1-4

Peronella cubae Weisbord, 1934. Bull. Am. Paleontology, v. 20, no. 70C, p. 217 (53), pl. 24 (5), figs. 4-6.

Peronella quinquenodulata Weisbord, 1934, Bull. Am. Paleontology, v. 20, no. 70C, p. 214 (50), pl. 24 (5), figs. 1-3.

Peronella caribbeana Weisbord, 1934, Bull. Am. Paleontology, v. 20, no. 70C, p. 216 (52), pl. 24 (5), figs. 7-9.

Peronella cubae Weisbord. Cooke, 1942, Jour. Paleontology, จ. 16, no. 1, p. 25, pl. 2, figs. 15-21. 
Peronella cubae Weisbord, Cooke, 1945 Florida Geol. Survey Bull. 29, fig. 6, no. 6 (after Cooke, 1942).

Peronella cubae Weisbord, Cooke, 1948, Jour. Paleontology, v. 22 , no. 1, p. 91.

Peronella caribbeana Weisbord. Sanchez Roig, 1949, Equinodermos fósiles de Cuba, p. 96.

Peronella cubae Weisbord. Sanchez Roig, 1949, Equinodermos fósiles de Cuba, p. 97.

Peronella quinquenodulata Weisbord. Sanchez Roig, 1949, Equinodermos fósiles de Cuba, p. 99.

Weisbordella caribbeana (Weisbord). Durham, 1954, Jour. Paleontology, v. 28, no. 5, p. 682, text figs. 2A, 3A.

Weisbordella caribbeana (Weisbord). Durham, 1955, California Univ. Pub. Geol. Sci., v. 31, no. 4, text figs. 27c, 30a.

Test oval; upper surface more or less convex; lower surface slightly concave; margin rounded. Apical system central or anterior; four small genital pores, usually obscure, moderately far apart; hydropores confined to small crooked grooves. Petals wide, short, pointed, extending little more than half the radius, nearly closed at the tips; plates compound, structure complex; poriferous zones narrow, slightly incurved at the apical end but wide apart there and almost touching the adjacent petals; inner pores punctate, outer pores elongate. Peristome small, central, pentagonal, usually retaining the teeth. Periproct transversely oval, about onefourth the radius from the margin. Tubercles sunken, those on the upper surface rather widely spaced; small except a central cluster of larger ones between the genital pores; a few large adventitious tubercles present or not on the interambulacra; tubercles on the oral surface larger than the ordinary ones on the upper surface.

Length of holotype $13 \mathrm{~mm}$; width $12 \mathrm{~mm}$; height 2.5 $\mathrm{mm}$ (fide Weisbord). Length of figured specimen USNM 499114, $19.6 \mathrm{~mm}$; width $17.6 \mathrm{~mm}$; height 5.3 $\mathrm{mm}$. Length of figured specimen USNM 56228644.6 $\mathrm{mm}$; width $40 \mathrm{~mm}$; height $10.9 \mathrm{~mm}$.

Occurrence-Cuba: Loma Calisto, Camagüey (type, N. E. Weisbord).

Florida: Pit of the Crystal River Rock Company about 6 miles southeast of Crystal River, Citrus County (USGS 14141, W. C. Mansfield and C. W. Mumm), Suwannee River at Dowling Springs (USGS 7338, C. W. Cooke; USGS 14003, W. C. Mansfield and F. S. MacNeil). East of Steinhatchee River opposite Clara (USGS 12747, W. C. Mansfield and G. M. Ponton; USGS 14541, C. W. Cooke and W. D. Havens, USGS 15150, G. M. Ponton). Zuber, 6.5 miles north of Ocala (USGS 6807, C. W. Cooke). Alachua Sink, 3.5 miles east of Gainesville (USGS 6799 , T. W. Vaughan and C. W. Cooke). 2 miles southeast of the cemetery at Alachua (USGS 13656, Stuart Mossom). 2 miles north of High Springs (USGS 6787, T. W. Vaughan and C. W. Cooke). Luraville, Suwannee River (USGS 2613, G. H. Eldridge; USGS 15051, C. W. Cooke and F. S. MacNeil). Old MacDonald quarry 1 mile north of Istachatta, Hernando County (USGS 11112, C. W. Cooke and Stuart Mossom). Johnson's sink, Levy County (USGS 365, L. C. Johnson). Old phosphate mine east of Anthony, Marion County (USGS 7366, C. W.
Cooke). 5.5 miles southwest of Gainesville (USGS 14135, W. C. Mansfield and C. W. Mumm). Kendrick, Marion County (USGS 14125, W. C. Mansfield and C. W. Mumm). Pit west of Fla. 19; 5 miles south of Salem, Taylor County (USGS 14539, C. W. Cooke and W. D. Havens). One mile north of Mayo (USNM 372871 , G. M. Ponton). Perry road 5.2 miles west of Mayo (USGS 14537, C. W. Cooke and W. D. Havens). Left bank Suwannee River at Branford (USGS 7341, C. W. Cooke). Three miles north of Newberry, Alachua County (USGS 13843, W. C. Mansfield and F. S. MacNeil). Withlacoochee River in sec. 5, T. 17 S., R. 16 E., Levy County (USGS 18750, A. G. Fischer and J. E. Banks). Withlacoochee River in sec. 3, T. 17 S., R. 16 E., Levy County (USGS 18749, A. G. Fischer and J. E. Banks).

Georgia : East bank Flint River at mouth of creek in northeast corner of Dougherty County (USGS 7235, C. W. Cooke).

Geologic unit.-Late Eocene, Ocaia limestone; Inglis limestone.

Type--Paleontological Research Institution, Ithaca, N. Y.

Figured specimens.-USNM 499114, from USGS 7341; USNM 562286, from USGS 14537.

Remarks. - The number of large adventitious tubercles on Weisbordella cubae is variable; some individuals have more than the figured specimens, many have none.

\section{Weisbordella johnsoni (Twitchell)}

Plate 20, figures 5-7

Laganum? crustuloides (Morton). Clark and Twitchell, 1915, U. S. Geol. Mon. 54, p. 122, figs. 5a-d, 6a-d.

Laganum johnsoni Twitchell, 1915, U: S. Geol. Survey Mon. 54, p. 162 , pl. 75 , figs. $2 \mathrm{a}-\mathrm{d}$.

Echinodiscus crustuloides (Morton). Lambert and Thiéry, 1925, Nomenclature raisonnée des échinides, fasc. 9, p. 581.

Echinodiscus johnsoni ('Twitchell). Lambert and Thiéry, 1925, Nomenclature raisonnée des échinides, fasc. 9, p. 581.

Laganum johnsoni Twitchell. Cooke, 1926, Ala. Geol. Survey Special Report 14, pl. 96, fig. 2.

Peronella crustuloides (Morton). Cooke, 1942, Jour. Paleontology, v. 16, no. 1, p. 24.

Peronella crustuloides (Morton). Fischer, 1951, Florida Geol. Survey Geol. Bull. 34, pt. 2, p. 57.

Horizontal outline suboval; upper surface tumid; lower surface concave; margin swollen, round. Apical system slightly anterior; four genital pores rather close together; hydropores confined to crooked grooves. Petals lanceolate, long, narrow, extending more than two-thirds the radius; plates compound; poriferous zones moderately open at the apical end, nearly closed distally; inner pores punctate, outer pores elongate. Peristome slightly anterior, small, pentagonal, teeth usually preserved. Periproct small, circular, about onethird the radius from the margin. Tubercles small, sunken, closer on upper surface than on lower.

Length of holotype $33.2 \mathrm{~mm}$; width $30.0 \mathrm{~mm}$; height $9.5 \mathrm{~mm}$. A specimen from Florida (USGS 14182) measures 54.4 by 49.0 by 11.0 millimeters.

Occurrence.-Alabama : Turk's Cave in sec. 19, T. 4 N., R. 13 E., Conecuh County (USGS 305, L. C. Johnson, type). NW1/4 sec. 30 , T. 4 N., R. $13 \mathrm{E}$, south side of Red Branch near Turk's or Sanders' cave (USGS 10030 , C. W. Cooke and Julia Gard- 
ner). Conecuh River at sharp bend 1 mile east of Harts Bridge, Covington County SW1/4 sec. 28, T. 3 N., R. 14 E. (USGS 10025, C. W. Cooke and Julia Gardner; USGS 13398, C. W. Cooke). Louisville and Nashville Railway $3 / 4$ mile north of Drewry, Monroe County (USGS 6720, C. W. Cooke). Old quarry $3 / 4$ mile northwest of Monroeville (USGS 6722, C. W. Cooke). Rock House Bluff on Conecuh River near line between secs. 28 and 29, T. 3 N., R. 14 E, Conecuh County (USGS 6750, C. W. Cooke). Lone Star Cement quarry, St. Stephens (USNM 559883, C. C. Branson).

Georgia: Bainbridge (USGS 3387, 3390, T. W. Vaughan; 3770, S. W. McCallie; 13611, August Foerste). Flint River at Red Bluff, 6 miles above Bainbridge (USGS 7098, C. W. Cooke; USGS 6159, L. W. Stephenson). Flint River at spring 2 miles below Normans Ferry, Mitchell County (USGS 7128, C. W. Cooke). Flint River at Dry Bread Shoals 9 miles below Newton (USGS 7126, C. W. Cooke). Power plant 2 miles north of courthouse at Albany (USGS 5054, T. W. Vaughan: USGS 12040, C. W. Cooke and W. H. Monroe). Well at Cordele, depth 225 feet (USGS 3814, S. W. McCallie).

Florida: Florida Basic Rock Company 12 miles north of Marianna (USGS 12058, W. C. Mansfield and G. M. Ponton; USGS 14152, 14182, W. C. Mansfield and C. W. Mumm).

Geologic unit.-Late Eocene, Ocala limestone.

Types.-Holotype, USNM 137202, from USGS 305. Figured specimen USNM 372896, from USGS 10025.

Remarks.-This species is the same as that identified as Scutella crustuloides Morton (1833) by Clark and Twitchell (1915) but the type of that species is lost. Weisbordella johnsoni is evidently not the species first figured by Morton (1833, pl. 10, fig. 8), which may be a Protoscutella. The petals of $W$. johnsoni are wider open at the apex than those of the later figure by Morton (1834, pl. 15, fig. 10). According to Morton $(1834$, p. 77) Scutella crustuloides "is found in considerable numbers in the calcareous strata of South Carolina." Weisbordella johnsoni has not been found in South Carolina.

\section{Family ECHINOLAMPADIDAE}

\section{Genus ECHINOLAMPAS Gray}

Echinolampas Gray, 1825, Annals of Philosophy, ser. 2, v. 10, p. 429.

Echinolampas Gray (part). D'Archiac and Haime, 1853, Animaux fossiles du groupe nummulitique de l'Inde, p. 209.

Echinolampas Gray. Desor, 1858, Synopsis des échinides fossiles, p. 300.

Echinolampas Gray. A. Agassiz,, 1872, Harvard College Mus. Comp. Zoology Mem., v. 3, p. 335.

Echinolampas Gray. Pomel, 1881, Classification méthodique et genera des échinides, p. 62.

Echinolampas (Miolampas) Pomel, 1883, Classification méthodique et genera des échinides, p. 62.

Echinolampas Gray. Cotteau, 1889, Paléontologie française, Terrain tertiaire, ser. 1, v. 2, p. 5, 178 .

Echinolampas Gray. H. L. Clark, 1917, Harvard College Mus. Comp. Zoology, Mem., v. 46, no. 2, p. 111.

Echinolampas Gray. Lambert and Thiéry, 1921, Nomenclature raisonnée des échinides, fasc. 5, p. 377.

Echinolampas Gray. Cooke, 1942, Jour. Paleontology, v. 16, no. 1, p. 37.

Echinolampas Gray. Mortensen, 1948, Monograph of the Echinoidea, v. 4, pt. 1, p. 270. Includes complete synonymy.

Type species, Echinus oviformis Gmelin, 1788=Echi- nanthus ovatus Leske (1778, p. 191, pl. 20, figs. $c, d)$, living in the tropical zone of the Indian Ocean, designated by Pomel (1883, p. 62). As illustrated by Mortensen (1948, p. 275, pl. 4, figs. 1-8) Echinolampas ovata is moderately large, with an ovate outline, inflated upper surface, rounded margin and slightly concave oral surface. Its apical system is monobasal, its poriferous zones are gently curved and of unequal lengths. Its peristome is nearly central, subtriangular, with rounded corners, weak bourrelets and inconspiculus phyllodes. Its periproct is submarginal, transverse, almost horizontal.

Echinolampas aldrichi Twitchell

Plate 22, figures 11-13

Echinolampas aldrichi Twitchell, 1915, U. S. Geol. Survey Mon. 54, p. 173, pl. 81, figs. 1a-d, 2.

Echinolampas (Miolampas) aldrichi Twitchell. Lambert and Thiéry, 1921, Nomenclature raisonnée des échinides, fasc. 5, p. 383.

Echinolampas aldrichi Twitchell. Cooke, 1942, Jour. Paleontology, v. 16, no. 1, p. 38 .

Test rather large. Horizontal outline oval, nearly as wide as long; upper surface tending to be subconical, the apex slightly forward, coinciding with the apical system; margin broadly rounded; lower surface gently concave to the peristome. Apical system nearly central, monobasal, four genital pores. Petals long, extending nearly three-fourths the way to the margin, sides gently curved; poriferous zones much narrower than the interporiferous, wide open distally; inner zones of paired petals longer than the outer; pores conjugate, inner row oval, outer row slightly elongate. Peristome nearly central, large, subtriangular, with rounded corners, wider than long; bourrelets gently swollen; phyllodes long, narrow, straight sided. Periproct submarginal, transverse, large, sloping upward and backward at a low angle, not indenting the margin. Tubercles small, depressed, little larger on the lower surface. No bare median band.

Length of type $56 \mathrm{~mm}$; width $53 \mathrm{~mm}$; height $25.4 \mathrm{~mm}$.

Occurrence.-Alabama: Bluff east of Jackson-Rockville road 200 yards north of Salt Creek, Clarke County, NW1/4 sec. 34, t $6 \mathrm{~N}, \mathrm{R} 2 \mathrm{E}$ (USGS 7165, C. W. Cooke). 1 mile north of Glendon, Clarke County NW1/4 sec. 31 , T 7 N, R 3 E (USGS 7163, C. W. Cooke). One-half mile northwest of Glendon (USGS 14514, F. S. MacNeil). Perdue Hill, Monroe County (USGS 2398, Frank Burns). Road to Lambards Landing, 1.7 miles southeast of Gainestown, Clarke County (USGS 10050, C. W. Cooke and Julia Gardner). Gainestown Ferry, Clarke County (USGS 10052, C. W. Cooke and Julia Gardner), Gainestown (type, T. H. Aldrich). Choctaw Bluff, Alabama River (Univ. Alabama). 1.3 miles north of Millry, Washington County (USGS 14291, W. C. Mansfield). East bank Murder Creek 1.5 miles above Kirkland, Escambia County (USGS 6736, C. W. Cooke). 
Mississippi : 4 miles north of Waynesboro on road to Shubuta, near middle of sec. 24, T $9 \mathrm{~N}, \mathrm{R} 7 \mathrm{~W}$ (USGS 10053, C. W. Cooke and Julia Gardner). Taylor Mill Creek 1.5 miles north of Waynesboro (USGS 14281a, W. C. Mansfield and F. S. MacNeil; USGS 14347, Julia Gardner). Sandy Creek, Wayne County (USGS 14345, Julia Gardner). West bank Chickasawhay River downstream from the Waynesboro-Laurel road (USGS 14348, 14362, 14350, Julia Gardner; USGS 14517, W. C. Mansfield and F. S. MacNeil).

Puerto Rico: Arecibo quadrangle at $\mathrm{K} 71.8$ on route 10 , about 9 kilometers south-southeast of Arecibo (USGS 19821, C. W. Cooke and A. D. Watt). Manatí quadrangle, at K 1.5 on route 642,4 kilometers south of Manatí (USGS 19840, C. W. Cooke and A. D. Watt).

Geologic unit.-Late Oligocene, Chickasawhay limestone in Alabama and Mississippi.

Type.-USNM 559490 (T 1099a), deposited by Johns Hopkins University.

Comparisons.-No other species from the United States at all closely resembles Echinolampas aldrichi. The species is similar to $\mathbb{E}$. ovata (Leske) but is more nearly circular.

\section{Echinolampas appendiculata Emmons}

Plate 22, figures 5, 6

Echinolampas appendiculatus Emmons, 1858, Agriculture of the eastern counties, p. 307, figs. 240, 241.

Echinolampas appendiculatus Emmons. Clark and Twitchell, 1915, U. S. Geol. Survey Mon. 54, p. 149, pl. 68, figs. 2a-h.

Echinolampas (Isolampas) appendiculatus Emmons. Lambert and Thiéry, Nomenclature raisonnée des échinides, fasc. 5, p. 380.

Echinolampas (Miolampas) appendiculatus Emmons. Lambert and Thiéry, 1921, Nomenclature raisonnée des échinides, fasc. 5 , p. 382 .

Echinolampas appendiculata Emmons. Cooke, 1942, Jour. Paleontology, v. 16, no. 1, p. 38.

Test rather small. Horizontal outline ovate, somewhat protracted behind; upper surface moderately inflated, rostrate above the periproct; margin broadly rounded; lower surface concave around the peristome. Apical system slightly anterior, monobasal, four genital pores. Petals extending about two-thirds the way to the margin, nearly straight, open distally; poriferous zones somewhat narrower than the interporiferous, inner zones of paired petals somewhat longer than the outer; pores conjugate, inner pores circular, outer pores slightly elongated. Peristome slightly anterior, large, subtriangular, with rounded corners, wider than long. Periproct, large, transverse, flush, inframarginal, inclined upward and backward at an angle approximating $45^{\circ}$, not visible from above. Tubercles small, sunken, not much larger on the oral surface; intermediate spaces pitted.

Length of figured specimen $32.8 \mathrm{~mm}$; width 28.1 $\mathrm{mm}$; height $17.8 \mathrm{~mm}$. This specimen is the same as the one figured by Clark and Twitchell.

Occurrence.-North Carolina: City Rock Quarry, Wilmington (USNM 166521, L. W. Stephenson; USGS 7302, B. L. Miller;
USGS 10340, C. W. Cooke; USGS 3602, Frank Burns). Rocky Point (USGS 779, T. W. Stanton). Lanes Ferry, 3 miles east of Rocky Point (USNM 166519, L. W. Stephenson). Castle Hayne (USNM 166522, L. W. Stephenson). Marl pit 2.5 miles southwest of Charity, Duplin County (USGS 11816, W. C. Mansfield). Farm of R. G. Ross 1 mile northwest of Lanes Ferry, North East Cape Fear River, Pender County (USNM 166520, L. W. Stephenson). Cedar Fork swamp 5 miles southeast of Beulahville, Duplin County (USGS 19020, C. W. Cooke). Geologic unit.-Late middle Eocene, Castle Hayne limestone. Type.-USNM 499113, deposited by Williams College, received without label. Figured specimen USNM 138017, from USGS 779, Rocky Point, N. C.

Comparison.-This species is easily distinguished from $E$. aldrichi by its compressed, proboscislike posterior end and smaller size. It should be compared with several middle and late Eocene species described by Cotteau in series 1, volume 2 of the Paléontologie française, specimens of which are not available for direct comparison.

\section{Family CASSIDULIDAE \\ Key to the Cassidulidae}

1 Periproct vertically elongated.

2 Periproct marginal; margin acutely rounded Echanthus georgiensis

2 Periproct supramarginal; margin broadly rounded Santeelampas oviformis

1 Periproct transverse.

2 Peristome longer than wide_______________Eurhodia

3 Periproct not terminal________Eurhodia (Eurhodia)

4 Broadly truncated behind________Eurhodia rugosa

4 Not broadly truncated behind.

5 Test long and narrow_-_Eurhodia patelliformis

5 Test short and wide________Eurhodia? elbana

3 Periproct terminal__-_Eurhodia (Gisopygus) holmesi

2 Peristome not longer than wide; periproct supramarginal.

3 Periproct not terminal_____Cassidulus (Cassidulus)

4 Margin rounded_..._-_Cassidulus sabistonensis

4 Margin acute.

5 Petals wide; test large.

6 Periproct not far from the margin

6 Periproct far from the margin Cassidulus gouldi

Cassidulus ericsoni

5 Petals narrow; test small__Cassidulus trojanus

3 Periproct terminal_________Cassidulus (Plagiopygus)

4 Test much longer than wide

Cassidulus (Plagiopygus) conradi

5. Pointed behind_____Cassidulus conradi conradi

5. Not pointed behind.

6. Petals long_Cassidulus conradi carolinensis

6. Petals not as long_Cassidulus conradi lyelli

4. Test not much longer than wide.

5. Upper surface moderately inflated

5. Upper surface strongly inflated Cassidulus georgiensis Cassidulus georgiensis globosus

\section{Genus CASSIDULUS Lamarck}

Cassidulus Lamarck, 1801, Système des animaux sans vertèbres, p. 348.

Rhyncholampas A. Agassiz, 1869, Harvard College Mus. Comp. Zoology, Bull., v. 1, p. 270. 
Cassidulus Lamarck. Cooke, 1942, Jour. Paleontology, v. 16, no. 1, p. 30.

Cassidulus Lamarck. Mortensen, 1948, Monograph of the Echinoidea, v. 4, pt. 1, p. 198 . Includes complete synonymy. Type species, Cassidulus cariboearum Lamarck (1801, p. 349), living in the Caribbean Sea, by monotypy, the other species mentioned being nomina nuda. This specific name was first spelled with the diphthong oe, not $a e$ as used by Lütken and Mortensen. Mortensen's figures (1948, p. 205, pl. 2, figs. 5, 14-18) of Cassidulus cariboearum are rather small; the horizontal outline is ovate, broadest behind; fairly low, with acutely rounded margin, and somewhat concave under surface. The species apparently has a monobasal apical system with four genital pores. The petals are open distally and are described as having small round pores of nearly equal size, not conjugate, the poriferous zones usually of unequal length, the outer series the longer. The naked median part of the posterior interambulacrum is described as covered by deep irregular pits. The peristome is subpentagonal, with low bourrelets and rather inconspicuous, narrow phyllodes. The periproct is supramarginal, flush, transverse, and opens into a shallow, sloping sulcus, which scarcely indents the margin.

\section{Cassidulus sabistonensis Kellum}

Plate 23, figures 6-14

Cassiduhus (Pygorhynchus) berryi Kellum, 1926, U. S. Geol. Survey Prof. Paper 143, p. 15, pl. 1, figs. 4-7. Not Cassidulus berryi Twitchell, 1915.

Cassidulus (Pygorhynchus) sabistonensis Kellum, 1931, Washington Acad. Sci. Jour., v. 21, no. 4, p. 51. New name for C. berryi Kellum.

Cassidulus (Rhynchopygus?) evergladensis Mansfield, 1932, U. S. Geol. Survey Prof. Paper 170, p. 48, pl. 18, figs. 1-10. Cassidulus (Cassidulus) evergladensis Mansfield. Cooke, 1942, Jour. Paleontology, v. 16, no. 1, p. 30, pl. 8, figs. 5, 6.

Cassidulus (Cassidulus) sabistonensis Kellum. Cooke, 1942, Jour. Paleontology, v. 16, no. 1, p. 31.

Test large; horizontal outline ovate to oval; upper surface inflated, rostrate above the preiproct; lower surface slightly concave; margin broadly rounded. Apical system slightly anterior, with four genital pores and central madreporite. Petals long, lanceolate; poriferous zones narrow, open distally, inner pores circular, outer pores elongated, inner zones of paired petals longer than the outer ; interporiferous zones wide. Peristome below the apical system, pentagonal, wider than long; bourrelets strongly inflated; phyllodes longer than wide. Periproct nearly terminal, well above the margin, flush, opening onto a very shallow sulcus. Tubercles small and crowded on the upper surface, larger and deeply sunken on the oral surface. Median area on the oral surface pitted.

Original length of type about $62 \mathrm{~mm}$; width $58.3 \mathrm{~mm}$; height $28 \mathrm{~mm}$. Lengths of figured specimens from South Carolina 60 and $69.5 \mathrm{~mm}$; widths 53 and $58 \mathrm{~mm}$; heights 38.3 and $35 \mathrm{~mm}$.

Occurrence.-North Carolina : Farm of E. W. Sabiston, 2 miles north of Jacksonville, Onslow County (USGS 10637, L. B. Kellum).
South Carolina : Intracoastal Waterway canal about 5 miles southwest of Little River and about 15 miles northeast of Myrtle Beach (USGS 13377, C. W. Cooke; USGS 18759, L. C. Glenn).

Florida: Tamiami Trail 5 miles east of Carnestown and about 7 miles northeast of Everglades, Collier County (USGS 11177, C. W. Cooke, W. C. Mansfield, and Stuart Mossom). Tamiami Trail 9 miles west of Pinecrest in sec. 13, T. $54 \mathbf{S}, \mathbf{R}$. 32 E.(USGS 11179, C. W. Cooke, W. C. Mansfield, and Stuart Mossom). Collier County 18 miles south of Immokalee (Florida Geol. Survey I-3148, Clarence Simpson; this place was reported as "near Moorehaven" by Mansfield, who was misinformed as to its location).

Geologic unit.-Late Miocene. Tamiami formation in Florida. Types.-USNM 35233, from USGS 10637. Cotypes of $C$. evergladensis USNM 37329, from USGS 11177; paratype USNM 371330, from USGS 11179. Figured specimens from South Carolina USNM 562301, from USGS 18759.

Remarks.-The preceding description is based on the two figured specimens from South Carolina, which ilustrate the considerable variation in size and shape that is common to many species of Cassidulus.

Kellum attributed this species to the Castle Hayne limestone, but the only other species reported from the type locality is Eurhodia rugosa (Ravenel), characteristic of the Santee limestone, which had not then been recognized in North Carolina. The matrix of the type is hard calcareous sandstone. It seems probable, as suggested by Cooke $(1942$, p. 31), that the Cassidulus is indigenous to the Trent and that the Eurhodia was reworked from the Santee or that it was collected from a different formation.

\section{Cassidulus gouldii (Bouvé)}

Plate 24, figures 5-12

Pygorhynchus gouldii Bouvé, 1846, Boston Soc. Nat. History Proc., v. 2, p. 192.

Pygorhynchus gouldii Bouvé. Bouvé, 1847, Am. Jour. Sci., ser. 2, จ. 3, p. 437.

Pygorhynchus gouldii Bouvé. Bouvé, 1847, Annals and Mag. Nat. History, ser. 1, v. 20, p. 142.

Nucleolites mortoni Conrad, 1850, Acad. Nat. Sci. Philadelphia Jour., ser. 2, v. 2, p. 40, pl.1, fig. 11.

Pygorhynchus gouldii Bouvé. Bouvé, 1851, Boston Soc. Nat. History Proc., v. 4, p. 2, 2 text figs.

Pygorhynchus gouldii Bouvé. Desor, 1858, Synopsis des échinides fossiles, p. 299.

Ravenelia gouldii (Bouvé). McCrady, 1859, Elliott Soc. Nat. History Charleston, S. C., Proc., v. 1, p. 282.

Pygorhynchus gouldii Bouvé. Cotteau, 1888, Paléontologie française, Terrain tertiaire, ser. 1, v. 1, p. 550 .

Nucleolites mortoni Conrad. Boyle, 1893, U. S. Geol. Survey Bull. 102, p. 200.

Pygorhynchus gouldii Bouvé. Stefanini, 1911, Soc. geol. italiana Boll., v. 30, p. 696.

Cassidulus (Pygorhynchus) gouldii (Bouvé). Clark and Twitchell, 1915, U. S. Geol. Survey Mon. 54, p. 171, pl. 79, figs. 3a-d; pl. 80, figs. 1a-f, 2a-d.

Cassidulus (Pygorhynchus) alabamensis Twitchell, 1915, U. S. Geol. Survey Mon. 54, p. 172, pl. 80, figs. 3a-d.

Procassidulus (Hardouinia) alabamensis (Twitchell). Lambert and Thiéry, 1921, Nomenclature raisonnée des échinides, fasc. 5, p. 362.

Procassidulus (Hardouinia) gouldii (Bouvé). Lambert and Thiẻry, 1921, Nomenclature raisonnée des échinides, fasc. 5, p. 363 . 
Cassidulus (Cassidulus) alabamensis Twitchell. Cooke 1942, Jour. Paleontology, v. 16, no. 1, p. 31.

Cassidulus (Cassidulus) gouldii (Bouvé). Cooke, 1942, Jour. Paleontology, v. 16, no. 1, p. 31.

Horizontal outline subovate, weakly truncated in front and behind, wider behind. Upper surface inflated, highest point near the front, tending to be subconical, rostrate above the periproct. Lower surface nearly flat. Margin subacute. Apical system somewhat anterior; madreporite central, large; four genital pores. Petals rather long, extending more than halfway to the margin, lanceolate, open distally, somewhat swollen; inner poriferous zones of paired petals longer than the outer; pores oval, conjugate or not. Peristome farther forward than the apical system, pentagonal, wider than long; phyllodes longer than wide, bourrelets swollen. Periproct supramarginal, at the posterior fifth, transverse, opening into a well defined sulcus, which indents the margin. Tubercles depressed, small on upper surface, much larger and deeply depressed on lower surface. Median area on lower surface bare.

Length of figured specimen $45 \mathrm{~mm}$; width $40.6 \mathrm{~mm}$; height $22 \mathrm{~mm}$.

Occurrence.-Georgia: Baker County (type). 2.5 miles north of Cuthbert (USGS 4058, S. W. McCallie). A. E. Belcher's well in lot 180, 16th District, Decatur County (USGS 3755, S. W. McCallie). Leesburg (USGS 7421, W. D. Pierce). Flint River 0.5 mile below Newton (USGS 6106, L. W. Stephenson). Georgia Southern and Florida Railway 32 miles south of Macon (USGS 3783, S. W. McCallie). 2 miles south of Perry (USGS 3966, S. W. McCallie). Hawkinsville (USGS 2311, Frank Burns). Abbeville road 3.5 miles south of Hawkinsville (USGS 6194, L. W. Stephenson). 9 miles southwest of Abbeville and 0.5 mile northeast of Center School, Wilcox County (USGS 10324, C. W. Cooke and T. M. Prettyman). Albany Road 9 miles north of Camilla (USGS 14921, C. W. Cooke).

Florida: Many places in Alachua, Columbia, Gadsden, Hamilton, Hernando, Hillsborough, Jefferson, Pasco, and Suwannee Counties. Aucilla River, Taylor County, 6.5 miles south of Nuttalls Rise and 16 miles south of Lamont (USGS 14924, C. W. Cooke). Natural Bridge Walton County, SE1/4 sec. 26, T $6 \mathrm{~N}$, R. $20 \mathrm{~W}$. (USNM 559443, Type of $C$. alabamensis).

Mississippi: Heidelberg (USNM 156464, L. C. Johnson). Bed of creek in sec. 22(?), T $4 \mathrm{~N}$, R $1 \mathrm{E}$, about 3.5 miles east of Byram (USGS 14071a, 14605, W. C. Mansfield and F. S. MacNeil).

Geologic unit,-Oligocene: Mint Spring(?) marl member of the Marianna limestone of middle Oligocene age, in Mississippi ; Byram limestone of middle Oligocene age and Suwannee limestone of late Oligocene age, in Florida; Flint River formation of late Oligocene age in Georgia.

Type--Boston Soc. Nat. History 1756A (lectotype, a cast of the interior), deposited in Museum of Comparative Zoology at Cambridge, Mass. Figured specimen, USNM 562302, from USGS 14924, Aucilla River, Florida. Type of Cassidulus alabamensis Twitchell, USNM 559443, deposited by Johns Hopkins University.

Remarks.-Cassidulus gouldii is very abundant and variable. The type, a silicious mold of the interior from the Flint River formation in Baker County, Georgia, is somewhat larger (61.5 by 48 by $24.5 \mathrm{~mm}$ ) than the average. It was well figured by Clark and Twitchell (1915, pl. 79, figs. 3a-d). Its longitudinal profile is tumid in front but slopes evenly from the apex to the periproct. Other specimens from Georgia are more tumid posteriorly. The two other specimens shown by Clark and Twitchell $(1915$, pl. 80, figs. 1a-f, 2a-d) are from a deep well at Padlock, 7 miles south of Live Oak, Suwannee County, Fla. Both are subconical, higher than the specimen from Taylor County figured here. The type of Cassidulus alabamensis is unusually large ( 68.5 by 63 by $28.5 \mathrm{~mm}$ ), low, and somewhat crushed, it came from the Byram limestone at Natural Bridge, Walton County, Fla.

Most specimens of Cassidulus gouldii are smaller than $C$. sabistonensis Kellum and have more acute margins.

Cassidulus ericsoni Fischer

Plate 24, figures 13-16

Cassidulus ericsoni Fischer, 1951, Florida Geol. Survey Geol. Bull. 34, pt. 2, p. 65 , text figs. $6-10$; pl. 2 , figs. 1,2 ; pl. 3 , figs. 1-3.

Horizontal outline subovate, wider behind. Upper surface strongly inflated, highest in front of the apical system, rostrate above the periproct. Lower surface flat. Margin acute. Apical system monobasal, with four genital pores. Petals lanceolate, extending about halfway to the margin, open distally; inner poriferous zones of paired petals longer than the outer. Peristome directly below the apical system, small, pentagonal, wider than long; phyllodes nearly as wide as long; bourrelets globular. Periproct small, transverse, supramarginal, near the posterior fourth, opening into a long, wide, shallow sulcus, which indents the margin. Tubercles sunken, small on upper surface, much larger on lower surface. Median band in front of and behind the peristome without tubercles.

Length of paratype USNM 560420, $45.5 \mathrm{~mm}$; width $41.2 \mathrm{~mm}$; height $29.7 \mathrm{~mm}$.

Occurrence.-Florida: Dredged from Withlacoochee River in Citrus County near Faris Landing at Crackertown (type, R. 0 . Vernon). Withlacoochee River 4 miles below Stokes Ferry (paratypes, USNM 560420, 560421, A. G. Fischer and J. E. Banks).

Geologic unit.-Late Eocene, Inglis limestone.

Type.-Florida Geol. Survey I-5358-1; paratypes FGS I-5358-2, 3, USNM 560420, 560421.

Comparisons.-Cassidulus ericsoni is larger, proportionally shorter, wider, and higher than C. trojamus Cooke and has proportionately smaller peristome and periproct. It is similar to C. gouldii (Bouvé) in general appearance, but its periproct is much farther forward.

\section{Cassidulus trojanus Cooke}

Plate 24, figures 1-4

Cassidulus (Cassidulus) trojanus Cooke, 1942, Jour. Paleontology, v. 16 no. 1, p. 32, pl. 2, figs. 22-25.

Outline subquadrate, wider behind than in front. Upper surface moderately inflated except behind the 
periproct, where there is a broad, shallow sulcus; rostrate above the periproct. Lower surface flat. Margin acute. Apical system slightly eccentric anteriorly; four genital pores; madreporite central. Petals lanceolate, of nearly equal length, extending somewhat more than halfway to the margin, open at the distal ends; pores round or oval; interporiferous zones wider than poriferous zones; outer poriferous zones of paired petals longer than the inner. Peristome farther forward than the apical system, pentagonal, slightly wider than long. Oral lobes swollen. Phyllodes about as long as the diameter of the peristomial opening. Periproct supramarginal, transversely elliptical, flush, about one-third the way from the margin to the apex. Upper surface finely granulated between small tubercles; tubercles on lower surface much larger than on the upper, deeply sunken except on the margin, where they are much smaller. Longitidunal median band on base moderately wide, deeply pitted,

Length $25.4 \mathrm{~mm}$; width $22 \mathrm{~mm}$; height $11.4 \mathrm{~mm}$.

Occurrence.-Florida: Suwannee River below Troy Springs, Lafayette County (USGS 7347, type, C. W. Cooke). Suwannee River at Dowling Springs, Suwannee County (USGS 7338, C. W. Cooke). Road to Dowling Park 5 miles northwest of Mayo (USGS 11114, C. W. Cooke and Stuart Mossom). Perry road 5.2 miles west of Mayo (USGS 14537, C. W. Cooke). East side of Steinhatchee River in Dixie County opposite Clara (USGS 12747, W. C. Mansfield and G. M. Ponton); USGS 14158, W. C. Mansfield and C. W. Mumm). 12 miles north of Marianna (USGS 14182, W. C. Mansfield and C. W. Mumm). Taylor County rock pit near Mayo, Suwannee County (USGS 16913, G. M. Ponton). Suwannee River opposite Dowling Park (USGS 14003, W. C. Mansfield and F. S. MacNeil).

Georgia: Miller County about 1 mile southeast of Joe Shingler and about 5 miles west of Colquitt (USGS 8287, C. W. Cooke). Spring Creek at Colquitt (USGS 10168, C. W. Cooke and T. M. Prettyman.)

Geologic unit.-Late Eocene, Ocala limestone.

Type.-USNM 498996, from USGS 7347.

Comparisons.-Cassidulus trojanus is proportionately longer and narrower than $C$. gouldii, the peristome is smaller, and the petals are narrower. The petals are narrower than those of $C$. sabistonensis, the size is much smaller, and the periproct is farther forward.

\section{Subgenus PLAGIOPYGUS Lambert}

Pygorhynchus Agassis. Desor, 1858, Synopsis des échinides fossiles, p. 297.

Plagiopygus Lambert, 1898, Soc. belge géologie Bull. (Mem., 1897 ), p. 162 (footnote). Not Plagiopyga Boheman, 1848.

Pleuropygus Lambert and Thiéry in Lambert, 1913, Schweizer. palaeont. Gesell, Abh., จ. 39, p. 126. For Plagiopygus Lambert.

Rhyncholampas A. Agassiz (part). Lambert and Thiéry, 1921, Nomenclature raisonnée des échinides fasc. 5, p. 369.

Anisopetalus Arnold and Clark, 1927, Harvard College Mus. Comp. Zoology, Mem., v. 50, no. 1, p. 44.

Cassidulus (Paralampas) Duncan and Sladen. Cooke, 1942, Jour. Paleontology, v. 16, no. 1, p. 32.
Cassidulus Lamarck (part). Mortensen, 1948, Monograph of the Echinoidea, v. 4, p. 1, p. 198.

Anisopetalus Arnold and Clark. Mortensen, 1948, Monograph of the Echinoidea, v. 4, pt. 1, p. 314.

Type species, Nucleolites grignonensis Defrance, from the middle Eocene of France. This species has been figured by Desor (1858, p. 298, pl. 31, figs. 1-3), by Cotteau (1888, p. 526, pls. 143-145) and by Mortensen (1948, p. 202, fig. 175a-c after Desor). It differs from Cassidulus cariboearum in that its periproct is terminal, though well above the margin, which is more broadly rounded. These seem to be the most important differences between Cassidulus s. s. and Plagiopygus.

Cooke (1942, p. 32) doubtfully identified this subgenus with Paralampas Duncan and Sladen (1882), suspecting that the apparent absence of the median actinal band characteristic of Cassidulus is due to the state of preservation of the Indian specimens. However, as Duncan and Sladen state several times that the band is absent, and as the type species, Paralampas pileus, differs notably in shape from Cassidulus (Plagiopygus) grignonensis, the assumption seems justified that Plagiopygus is not a a synonym of Paralampas.

An inequality in the length of the poriferous zones was the main reason assigned by Arnold and Clark for separating Anisopetalus from Cassidulus. But the species here referred to Cassidulus s. s. also have unequal poriferous zones. Cotteau (1888) does not mention any inequality in the poriferous zones of "Pygorhynchus" grignonensis, yet his figures seem to indicate that there may be some difference in length. The relative lengths of the poriferous zones seems to be a variable feature within the Cassidulidae.

\section{Cassidulus (Plagiopygus) conradi (Conrad)}

Plate 25, figures 3-6

Catopygus conradi Couper MS Conrad, 1850, Acad. Nat. Sci. Philadelphia Jour., ser. 2, v. 2, p. 39, pl. 1, fig. 9.

Catopygus conradi Conrad. A. Agassiz, 1883, Harvard College Mus. Comp. Zoology Mem., v. 10, no. 1, p. 90.

Cassidulus conradi Couper in Conrad. Stefanini, 1911, Soc. geol. italiana Boll., v. 30, p. 700.

Cassidulus (Pygorhynchus) conradi (Conrad). Clark and Twitchell, 1915, U. S. Geol. Survey Mon. 54, p. 145, pl. 67, figs. 1a-f.

Rhyncholampas conradi (Conrad). Lambert and Thiéry, 1921, Nomenclature raisonnée des échinides, fasc. 5, p. 370.

Cassidulus (Paralampas) conradi (Conrad). Cooke, 1942, Jour. Paleontology, v. 16, no. 1, p. 33.

Horizontal outline oval, usually somewhat compressed posterolaterally; upper surface evenly tumid, rostrate above the periproct; lower surface usually slightly concave around the peristome; margin broadly rounded. Apical system anteriorly eccentric, monobasal, with four genital pores. Petals long and rather 
straight, open distally; inner poriferous zones of paired petals longer than the outer; inner pores circular, outer pores oval. Peristome large, pentagonal, wider than long, nearer the center than the apical system; phyllodes nearly as wide as long; bourrelets elongated, swollen, granulated. Periproct terminal, at the top of a narrow vertical truncation, wider than high. Tubercles depressed, small on upper surface, larger on lower; covering entire test except a narrow pitted band behind the peristome.

Length of type $40.8 \mathrm{~mm}$; width $34 \mathrm{~mm}$; height 22.7 $\mathrm{mm}$. Length of figured specimen 41.4 ; width 35.2 ; height $20 \mathrm{~mm}$.

Occurrence.-Georgia: Palmyra, Lee County (type, J. H. Couper, the original label specifies only Georgia). Kinchafoonee Creek 2 or 3 miles north of Albany (USGS 5054, T. W. Vaughan; USGS 7121, C. W. Cooke and J. E. Brantly; USGS 10507, C. W. Cooke and T. M. Prettyman). About 5 miles west of Colquitt (USGS 8247 , C. W. Cooke, internal mold). Ichawaynochaway Creek about 4 miles west of Newton, Baker County (USGS 10919, Stuart Mossom, internal mold).

Florida: Steinhatchee River opposite Clara, north of US Highway 19 (USG 15150, G. M. Ponton).

Geologic unit.-Late Eocene, Ocala limestone.

Type.-Acad. Nat. Sci. Philadelphia 1078. Figured specimen USNM 562304, from USGS 15150.

\section{Cassidulus conradi carolinensis Twitchell}

Plate 25, figures $7-10$

Cassidulus (Pygorhynchus) carolinensis Twitchell, 1915, U. S. Geol. Survey Mon. 54, p. 146, pl. 67, figs. 2a-g.

Rhyncholampas conradi Couper. Lambert and Thiéry, 1921, Nomenclature raisonnée des échinides, fasc. 5 , p. 370.

Cassidulus (Paralampas) carolinensis Twitchell. Cooke, 1942, Jour. Paleontology, v. 16, p. 34.

Cassidulus carolinensis is usually somewhat smaller and proportionately shorter than typical $C$. conradi; it is less compressed behind, and has wider poriferous zones, narrower interporiferous zones. Lambert and Thiéry thought it is probably a synonym of $C$. conradi, but Cooke regarded it as distinct.

Occurrence.-North Carolina: Smith Creek, near Wilmington (type). Rocky Point, Pender County (USGS 779, T. W. Stanton). City rock quarry, near Wilmington (USGS 3602, Frank Burns; USGS 4285, L. W. Stephenson). Castle Hayne (USNM 166490, L. W. Stephenson). 1 mile northwest of Lanes Ferry, Northeast Cape Fear River (USNM 166523, L. W. Stephenson) Cedar Fork swamp 5 miles southeast of Beulaville, Duplin County (USGS 19020, C. W. Cooke).

Geologic unit.-Late middle Eocene, Castle Hayne limestone. Type.-USNM 559488, deposited by Johns Hopkins Univ., T 2004.

\section{Cassidulus conradi lyelli (Conrad)}

Plate 25, figures 1, 2

Nucleolites lyelli Conrad, 1850, Acad. Nat. Sci. Philadelphia Jour., ser. 2, v. 2, p. 40, pl. 1, fig. 14.
Cassidulus lyelli (Conrad). Conrad, 1865, Acad. Nat. Sci. Philadelphia Proc., p. 75.

Pygorhynchus Tyelli (Conrad). Cotteau 1888, Paléontologie française, Terrain tertiaire, ser. 1, v. 1, p. 550.

Cassidulus (Rhynchopygus) lyelli (Conrad). Clark and Twitchell, 1915, U. S. Geol. Survey Mon. 54, p. 141, pl. 65, figs. $4 a-d$.

Rhyncholampas tyelli (Conrad). Lambert and Thiéry, 1921, Nomenclature raisonnée des échinides, fasc. 5, p. 370.

Cassidulus (Paralampas) lyelli (Conrad). Cooke, 1942, Jour. Paleontology, v. 16, no. 1, p. 33.

This variety is more nearly oval than typical Cassidulus conradi, lacking the posterolateral constriction that gives $C$. conradi a pointed appearance. It is proportionately somewhat longer and narrower than $C$. carolinensis.

Occurrence.-Georgia: Baker County (type, J. A. Couper) Flint River near Bainbridge (USGS 13611, A. F. Foerste).

Alabama : Conecuh River 1 mile east of Harts Bridge, Covington County, SW $1 / 4$ sec. 28, T 3 N, R 14 E (USGS 10025, C. W. Cooke and Julia Gardner).

Florida: Basic Rock Company's quarry 12 miles north of Marianna (USGS 12058, G. M. Ponton and W. C. Mansfield; USGS 14152, 14182, W. C. Mansfield and C. W. Mumm). Suwannee River at Dowling Park (USGS 14003, W. C. Mansfield and F. S. MacNeil). Taylor County rock pit near Mayo, Suwannee County (USGS 16913, G. M. Ponton). Steinhatchee River near US Highway 19 opposite Clara (USGS 14541, C. W. Cooke ; USGS 15150, G. M. Ponton).

Geologic unit.-Late Eocene, Ocala limestone.

Type.-Probably the specimen figured by Clark and Twitchell, now presumably deposited in the Museum of Comparative Zoology. Figured specimen USNM 562305, from USGS 13611, Bainbridge, Ga.

\section{Cassidulus (Plagiopygus) georgiensis Twitchell}

\section{Plate 25, figures 14-17}

Cassidulus (Pygorhynchus) georgiensis Twitchell, 1915, U. S. Geol. Survey Mon. 54, p. 170, pl. 79, figs. 2a-d.

Rhyncholampas georgiensis (Twitchell). Lambert and Thiéry, 1921, Nomenclature raisonée des échinides, fasc. 5, p. 370.

Cassidulus (Paralampas) tyelli (Conrad) (part). Cooke, 1942, Jour. Paleontology, v. 16, p. 33.

Cassidulus (Paralampasq lyelli (Conrad). Fischer, 1951, Florida Geol. Survey Geol. Bull. 34, pt. 2, p. 69, text figs. 8-10.

Horizontal outline subquadrate, widest near the posterior end, not much longer than wide; upper surface variably inflated, highest point ranging from behind the apical system (type) to in front of it, slightly rostrate above the periproct; oral surface nearly flat; margin subacutely to broadly rounded; widest part usually above the margin. Apical system anteriorly eccentric, monobasal, with four genital pores; petals lanceolate extending about halfway to the margin, not very wide; pores circular or oval; poriferous zones unequally long, the inner zones of the paired petals longer than the outer. Peristome directly beneath the apical system, rather large, pentagonal, wider than long; phyllodes almost 
straight sided, nearly as wide as long; bourrelets elongated, wall-like. Periproct wider than long, terminal, well above the margin. Tubercles depressed, much smaller on top than underneath; covering entire test except a wide pitted longitudinal band on lower surface.

Occurrence-Georgia: Bainbridge (type, USGS 3293, А. H. Brooks; USGS 6171, L. W. Stephenson; USGS 7197, C. W. Cooke and W. C. Mansfield; USGS 13611, A. F. Foerste. Red Bluff, Flint River, 6 miles above Bainbridge (USGS 6159, L. W. Stephenson). Chattahoochee River at A. C. L. Ry. bridge near Saffold, Early County (USGS 8249, H. K. Shearer; USGS 12100, C. W. Cooke and W. H. Monroe).

Florida: Chattahoochee River about 5 miles below Neals Landing and about 4 miles above Bartons Landing, Jackson County (USGS 6763, C. W. Cooke). Chattahoochee River about 1/4 mile below Bartons Landing (USGS 6765, C. W. Cooke). Quarry 1.5 miles west of Springfield Church about 12 miles north of Marianna, Jackson County (USGS 14152, W. O. Mansfield and C. W. Mumm). Suwannee River opposite Dowling Park in Lafayette County (USGS 12313, G. M. Ponton). Holder phosphate mines 5 miles southwest of Inverness, Citrus Country (USGS 7382, C. W. Cooke). Pit between Inglis and Yankeetown, Levy County, north of State Highway 15-A (USGS 14544, C. W. Cooke). Pit 3 miles north of Newberry, Alachua County (USGS 13843 , W. C. Mansfield and F. S. MacNeil). Borrow pit north of highway in SW $1 / 4$ sec. 33, T $13 \mathrm{~S}, \mathrm{R} 15 \mathrm{E}$, Levy County (USGS 18751, A. G. Fischer and J. E. Banks).

Geologic unit.-Late Eocene, Ocala limestone.

Type.-USNM 164747, from USGS 3293.

Comparisons.-Cassidulus georgiensis is closely related to $C$. lyelli. As now identified, $C$. lyelli is proportionately longer and narrower, oval rather than subquadrate, and its petals are proportionately narrower.

\section{Cassidulus georgiensis globosus Fischer}

Plate 25, figures 11-13

Cassidulus (Paralampas) globosus Fischer, 1951, Florida Geol. Survey Geol. Bull. 34, pt. 2, p. 71, pl. 4, figs. 1-5; text figs. 8-10.

Much more highly inflated than the type of $C$. georgiensis but little more so than many specimens from Bainbridge, Ga., the type locality of the species. Usually higher in front than behind.

Occurrence.-Borrow pit on west side of US Highway 19, 2 miles southwest of Gulf Hammock, SE1/4 SW1/4 sec. $34, \mathrm{~T} 14$ S, R 16 E, Levy County (type, Florida Geol. Survey I-5346; USNM 562308, F. S. MacNeil, figured specimen). Borrow pit west of US Highway 19 between Gulf Hammock and Lebanon Station Levy County (Florida Geol. Survey I-5345). Dolomite on north bank of Waccasassa River just west of US Highway 19, Levy County). Massive dolomite bed 4 feet above laminated dolomite of the Avon Park limestone below Florida Power Company dam on Withlacoochee River, Levy County (Florida Geol. Survey I-5347). Dredged from Withlacoochee River near Faris Landing at Crackertown (Florida Geol. Survey I-5350). New Lebanon quarry, Levy County (Florida Geol. Survey I-5382). Withlacoochee River 1.5 miles below Isaac Walton Lodge at Yankeetown, Levy County (Florida Geol. Survey I-5355). Borrow pit in sec. 14, T 15 S, R 16 E, about 1.5 miles north of Lebanon Station (USGS 18753, A. G. Fischer).
Waccasassa River below highway 15, 1.6 miles northwest of Gulf Hammock, Levy County (USGS 18754, A. G. Fischer). Wekiva Springs, E1/2 SE1/4 sec. 12, T 14 S, R 16 E, Levy County (USGS 18752, A. G. Fischer and J. E. Banks). Withlacoochee River, W1/2 sec. 23, T 17 S, R 16 E, Citrus and Levy Counties (USGS 18749, A. G. Fischer and J. E. Banks).

Geologic unit.-Late Eocene, Inglis limestone.

Type.-Florida Geological Survey I-5346-1. Paratypes Florida Geol. Surv. I-5344, 5346-9, 5346-5. Figured specimens USNM 562307, from USGS 18753, USNM 562308.

\section{Genus SANTEELAMPAS Cooke, new genus}

Type species Catopygus oviformis Conrad.

Upper surface inflated, margin rounded, concave around the peristome. Apical system monobasal, with four genital pores. Petals straight, open distally; pores circular, conjugate. Peristome pentagonal, wider than long, depressed; phyllodes short, wide; bourrelets inconspicuous. Periproct terminal, flush, longer than wide, at the top of a shallow depression. Tubercles small, depressed, somewhat larger on the upper surface, covering all but a very narrow pitted median area on the lower surface.

Santeelampas can be distinguished from most other cassiduloids by its vertically elongated periproct. In general appearance it resembles Oligopodia Duncan, whose peristome, however, is wider than long and whose periproct is described as deeply sunken (Mortensen, 1948, p. 226). The shape of the peristome and the weak bourrelets distinguish Santeelampas from Catopygus.

\section{Santeelampas oviformis (Conrad)}

Plate 26, figures 1-8

Catopygus oviformis Conrad, 1850, Acad. Nat. Sci. Philadelphia Jour. ser. 2, v. 2, p. 39, pl. 1, fig. 15.

Nuoleolites oviformis (Conrad). Conrad in Cook, 1868, Geology of New Jersey, p. 722.

Catopygus oviformis Conrad. Clark, 1891, Johns Hopkins Univ. Circ., v. 10, no. 87, p. 76.

Catopygus oviformis (Conrad). Clark, 1893, Johns Hopkins Univ. Circ., v. 12, no. 103, p. 52.

Catopygus oviformis Conrad. Clark, 1893, U. S. Geol. Survey Bull. 97, p. 64, pl. 27, figs. 2a-f.

Catopygus oviformis Conrad. Clark, 1915, U. S. Geol. Survey Mon. 54, p. 72, pl. 29, figs. 2a-f.

Breynella gregoryi Twitchell, 1915, U. S. Geol. Survey Mon. 54, p. 148, pl. 68, figs. 1a-f.

Phyllobrissus oviformis (Conrad). Lambert, 1916, Révue critique de paléozoologie Année 20, no. 4, p. 169.

Phyllobrissus oviformis (Conrad). Lambert and Thiéry, 1921, Nomenclature raisonnée des échinides, fasc. 5, p. 351.

Echinanthus gregoryi (Twitchell). Lambert and Thiéry, 1921, Nomenclature raisonnée des échinides, fasc. 5, p. 367.

Cassidulus (Paralampas?) gregoryi (Twitchell). Cooke, 1942, Jour. Paleontology, v. 16, no. 1, p. 34.

Cassidulus? oviformis (Conrad). Cooke, 1942, Jour. Paleontology, v. 16, no.1, p. 34. 
Horizontal outline oval, widest behind the midline, narrowly truncated behind; upper surface evenly inflated; lower surface slightly concave; margin broadly rounded. Apical system monobasal, with four genital pores; eccentric anteriorly, somewhat farther forward than the peristome. Petals fairly long, the anterior pair shorter than the others, open distally; poriferous zones of equal length, slightly narrower than the interporiferous; pores circular, obliquely conjugate. Peristome somewhat anterior, broader than long; phyllodes short and stubby, nearly as wide as long; bourrelets very slightly swollen, granulated. Periproct terminal, about midheight, flush, vertical, at the top of a shallow vertical sulcus, higher than wide. Tubercles small, depressed, crowded, not much larger on the lower surface, covering the entire test except a short, narrow median band behind the peristome.

Length $30 \mathrm{~mm}$; width $25 \mathrm{~mm}$; height $17.8 \mathrm{~mm}$. Length of type $19.8 \mathrm{~mm}$; width $16.7 \mathrm{~mm}$; height $12 \mathrm{~mm}$.

Occurrence.-South Carolina: Santee Canal (type of Breynella gregoryi). Santee River at Santee-Cooper dam (USNM 562298 , L. C. Glenn). Santee River about one-quarter mile below the dam, Berkeley County (USGS 19018 F. S. MacNeil and Hal Molde). Santee-Cooper Diversion Canal (USGS 18353, F. S. MacNeil). The original label accompanying the type of Catopygus oviformis gives the locality as New Jersey, and Conrad's description specifies Timber Creek, New Jersey. This is probably a mistake, for the matrix and the state of preservation (coated with calcite) resemble those of specimens from the Santee limestone of South Carolina.

Geologic unit.-Middle Elocene, Warley Hill marl and probably Santee limestone. Conrad ascribes the type to "Cretaceous limestone," i. e., the Vincentown sand, now classified as Paleocene.

Types.-Acad. Nat. Sci. Philadelphia 1477. Type of Breynella gregoryi, Am. Mus. Nat. History. Figured specimens, USNM 562298.

\section{Genus ECHANTHUS Cooke}

Echinanthus Breynius. Desor, 1858, Synopsis des échinides fossiles, p. 291.

Echinanthus Breynius. Duncan and Sladen, 1882, Palaeontologia Indica, ser. 14, v. 1, pt. 3, p. 12.

Echinanthus Breynius. Pomel, 1883, Classification méthodique et genera des échinides, p. 61.

Echinanthus Breynius. Cotteau, 1888, Paléontologie française, Terrain tertiaire, ser. 1, v. 1, p. 553.

Echinanthus Breynius. Duncan, 1889, Linnean Soc. London Jour., Zoology, v. 23, p. 149, 183.

Echinanthus Breynius. Lambert and Thiéry, 1921, Nomenclature raisonnée des échinides, fasc. 5, p. 366.

Echanthus Cooke, 1942, Jour. Paleontology, v. 16, no. 1, p. 37.

Echinanthus Breynius. Mortensen, 1948, Monograph of the Echinoidea, v. 4, pt. 1, p. 240.

Not Echinanthus Leske, 1778, Klein's Naturalis dispositio echinodermatum, p. 185=Clypeaster.

Not Echinanthus Gray, 1825, Annals of Philosophy, v. 26, p. 34=Clypeaster.

Not Echinanthus Gray, 1851, Zool. Soc. London Proc., p. 34= Clypeaster.
Not Echinanthus Leske. D'Archaic and Haime, 1853, Animaux fossiles due groupe nummulitique de l'Inde, p. 207= Clypeaster.

Not Echinanthus Breynius. D'Orbigny, 1856, Paléontologie française, Terrain cretacé, ser. 1, v. 6, p. 291=Echinolampas.

Not Echinanthus Breynius. A. Agassiz, 1872, Harvard College Mus. Comp. Zoology Mem., v. 3, p. 106, 110=Clypeaster.

Type species, Echinanthus georgiensis Twitchell, by monotypy and original designation.

Echanthus seems to be the genus called Echinanthus by Desor and several others, who attribute the name to Breynius, a preLinnean writer. It is quite different from Echinanthus, Leske, the first post-Linnean writer to use the name, and from d'Orbigny's interpretation of Echinanthus Breynius, which seems to be Echinolampas. Gregory $(1892$, p. 600) proposed Breynella for species usually called Echinanthus, but his type species, Pygorhynchus vassali Wright, has an inclined periproct like that of Echinolampas.

Echanthus georgiensis differs from Echinolampas ovata (Leske), the type of Echinolampas Gray, in its petals, which have equal poriferous zones in contrast to the markedly unequal zones of $E$. ovata; and in the location, direction of elongation, and position of its periproct, which is terminal, longitudinal, and erect as opposed to submarginal, transverse, and inclined. The subangular, pentagonal horizontal outline, contrasting with the smoother, ovate shape of Echinolampas, may be a generic feature. The posterior vertical sulcus is lacking in Echinolampas.

\section{Echanthus georgiensis (Twitchell)}

Plate 26, figures 13-16

Echinanthus georgiensis Twitchell, 1915, U. S. Geol. Survey Mon. 54, p. 139, pl. 65 , figs. $1 \mathrm{a}-$ d.

Echanthus georgiensis (Twitchell). Cooke, 1942, Jour. Paleontology, v. 16, no. 1, p. 37, pl. 8, figs. 1-3.

?Cassidulus (Galerolampas) fontis Cooke, 1942, Jour. Paleontology, v. 16, no. 1, p. 35, pl. 2, figs. 26-29.

Horizontal outline subpentagonal, slightly emarginate in front, sulcate behind, widest behind the midline; upper surface moderately inflated, highest point behind the apical system but in front of the center, slightly rostrate above the periproct; lower surface concave around the peristome; margin rounded. Apical system monobasal, four genital pores. Petals spatulate, open distally, extending more than halfway to the margin; poriferous zones of equal length, pores circular, obliquely conjugate; interporiferous zones wider than the poriferous. Peristome anterior, beneath the apex, pentagonal, wider than long; phyllodes longer than wide; bourrelets inflated, granulated. Periproct terminal, vertical, higher than wide, in a vertical sulcus, above the margin. Upper surface and margin covered with small, crowded sunken tubercles; tubercles on lower surface larger; narrow sternal area without tubercles.

Occurrence-Georgia: Dr. A. J. Parker's farm, EllavilleAmericus road 5 miles south of Ellaville (USGS 4033, s. W. McCallie, type). 
Alabama: Luverne road 4.6 miles south of Highland Home, Crenshaw County (USGS 10497, L. W. Stephenson). 5 miles south of Highland Home on Alabama 9 in SE1/4 sec. 25, T 11 N, R 17 E (USGS 14920, C. W. Cooke and A. C. Munyan). Sec. 21, T $10 \mathrm{~N}, \mathrm{R} 28 \mathrm{E}$, Barbour County, 21/4 miles east of Cotton Hill (USGS 10910, C. W. Cooke). South slope to Beaver Branch in SW corner sec. 4, T $8 \mathrm{~N}, \mathrm{R} 18 \mathrm{E}, 2$ miles south of Luverne, Crenshaw County (USGS 16916, F. S. MacNeil).

Geologic unit.-Paleocene, Clayton formation.

Type.-USNM 165683b, from USGS 4033.

Remarks.-The type is a silicious pseudomorph damaged on the left side but otherwise well preserved. All the other specimens are molds of the interior. The unique type of Cassidulus (Galerolampas) fontis has a transverse periproct, which has been distorted by crushing and which probably was vertical originally. It was found at a depth less than 1600 feet in a well drilled near Falling Water, 4 miles south of Chipley, Fla. The petals resemble those of Echanthus georgiensis.

\section{Genus EURHODIA d'Archiac and Haime}

Eurhodia d'Archiac and Haime, 1853, Animaux fossiles du groupe nummulitique de l'Inde, p. 213.

Eurhodia d'Archiac and Haime. Desor, 1858, Synopsis des échinides fossiles, p. 300 .

Ravenelia McCrady, 1959, Elliott Soc. Nat. History Charleston, S. C., Proc., v. 1, p. 283.

Eurhodia d'Archiac and Haime. Duncan and Sladen, 1882, Palaeontologia Indica, ser. 14, v. 1, pt. 3, p. 69.

Eurhodia d'Archiac and Haime. Pomel, 1883, Classification méthodique et genera des échinides, p. 64 .

Eurhodia d'Archiac and Haime. Duncan, 1889, Linnean Soc. London Jour., Zoology, v. 23, p. 184.

Eurhodia d'Archiac and Haime. Lambert and Thiéry, 1921, Nomenclature raisonnée des échinides, fasc. 5, p. 364.

Eurhodia d'Archiac and Haime. Davies, 1935, Tertiary faunas, p. 95.

Eurhodia d'Archiac and Haime. Cooke, 1942, Jour. Paleontology, v. 16, no. 1, p. 35 .

Eurhodia d'Archiac and Haime. Mortensen, 1948, Monograph of the Echinoidea, v. 4, pt. 1, p. 252.

Type species, Pygorhynchus morrisi d'Archiac, from the late Eocene (Ranikot) of Sind, by monotypy. This species has been figured by Duncan and Sladen (1882, p. 70, pl. 18, figs. 1-7). Their description and figures show it to be large, elongated, oval, with moderately arched upper surface and nearly flat bottom. Its apical system has a central madreporite and four genital pores. Its petals are open at the distal ends, the anterior petal widely open, and the posterior poriferous zones of the posterior petals are narrower than the others. The inner pores are circular, the outer slightly elongated. The peristome is pentagonal, longer than wide. The floscelle has round, swollen, granulated bourrelets; the phyllodes are nearly as wide as long and have central rows of sphaeridial pits. The periproct is supramarginal, opens into a shallow sulcus, which apparently continues forward into the test as a shelf under the periproct. The tubercles on the upper surface are small; those on the lower surface are larger and sunken. There seems to be a pitted surface behind the peristome.

The American species here referred to Eurhodia differ from the type in that all the poriferous zones of the petals are of approximately the same size. If direct comparison with the Indian type should show unsuspected generic differences, the genus Ravenelia McCrady, of which Rhynchopygus rugosus Ravenel is the type species, may be revived.

Eurhodia differs from Cassidutus in the elongation of the peristome; in the presence of an inner shelf beneath the periproct; and in the greater elongation.

Eurhodia rugosa (Ravenel)

Plate 22, figures 1-4

Pygorhynchus rugosus Ravenel, 1848, Echinidae, Recent and fossil, of South Carolina, p. 4, figs. 7, 8 .

Pygorhynchus crucifer (Morton). Ravenel, 1848, Echinidae, Recent and fossil, of South Carolina, p. 4, figs. 9, 10.

Ravenetia crucifer (Morton). McCrady, 1859, Elliot Soc. Nat. History Charleston, South Carolina, Proc., v. 1, p. 283.

Ravenelia rugosa (Ravenel). McCrady, 1859, Elliot Soc. Nat. History Charleston, South Carolina, Proc., p. 283.

Cassidulus (Rhynchopygus) raveneli Twitchell, 1915, U. S. Geol. Survey Mon. 54, p. 142, pl. 65, figs. 5a-d; pl. 66, figs. 1a-c, $2 \mathrm{a}-\mathrm{b}$.

Pygorhynchus rugosus Ravenel. Clark and Twitchell, 1915, U. S. Geol. Survey Mon. 54, p. 147.

Eurhodia rugosa (Ravenel). Lambert and Thiéry, 1921, Nomenclature raisonnée des échinides, fasc. 5, p. 365 .

Eurhodia raveneli Twitchell. Cooke, 1942, Jour. Paleontology, v. 16, no. 1, p. 35 .

Test large; horizontal outline elliptical, nearly 1.5 times as long as wide; upper surface evenly arched, somewhat rostrate above the periproct; oval surface slightly concave, margin acutely rounded. Apical system in front of the center, directly above the peristome; monobasal, with four genital perforations. Ambulacra petaloid; petals lanceolate, closed at the apex, open distally; pores oval, the outer ones somewhat longer than the inner; all poriferous and interporiferous zones about equal in width. Peristome pentagonal, longer than wide; floscelle star shaped; phyllodes having a pair of conspicuous pits or pores at the inner end and several irregularly distributed pores or pits distally; bourrelets tumid, granulated. Periproct supramarginal, well back from the margin, transversely elongated, opening into a shallow depression, which extends backward to the margin and forward about $2 \mathrm{~mm}$ into the periproct, forming a shelf beneath it. Entire upper surface and margin closely covered with small depressed tubercles; oral side decorated with-large, deeply depressed tubercles in the lateral interambulacra, and deep pits in the posterior interambulacrum and anterior ambulacrum, the intermediate spaces in these areas covered with very small tubercles. 
Length of figured specimen $35 \mathrm{~mm}$; width $25 \mathrm{~mm}$; height $13.6 \mathrm{~mm}$. A larger specimen measures 51 by 36 by $18 \mathrm{~mm}$.

Occurrence.-South Carolina: Santee River (Ravenel). Santee Cooper Diversion Canal near Eadytown, Berkeley County (USGS 18353, C. W. Cooke, and F. S. MacNeil). Eutaw Springs (F. S. MacNeil).

North Carolina: County rock quarry near Wilmington (USNM 166494, 164656 Frank Burns; USGS 10340, C. W. Cooke; USGS 10613, E. W. Berry). E. W. Sabiston's farm in Onslow County 2 miles north of Jacksonville (USGS 10637, L. B. Kellum). Lanes Ferry, Northeast Cape Fear River (USNM 166493, L. W. Stephenson).

Geologic unit.-Middle Eocene, Santee limestone.

Type.-The location of the type is unknown, possibly it is in the Charleston Museum. The figured specimen is from USGS 18353.

Remarks.-Ravenel's figure of Pygorhynchus rugosus is only about half as large as the one he misidentified as "Nucleolites crucifer", and the anterior paired ambulacra diverge at a smaller angle. This latter difference is doubtless an inaccuracy of the drawing. A similar large specimen in the American Museum of Natural History became the type of Cassidulus (Rhynchopygus) raveneli Twitchell. A suite of 21 specimens dredged from the Santee-Cooper Diversion Canal shows many intermediate sizes.

\section{Eurhodia patelliformis (Bouvé)}

Plate 22, figures 7-10

Catopygus patelliformis Bouvé, 1851, Boston Soc. Nat. History Proc., v. 4, p. 2, 2 text figs.

Cassidulus patelliformis (Bouvé). Desor, 1858, Synopsis des échinides fossiles, p. 290.

"Cassidulus" patelliformis (Bouvé). Cotteau, 1888, Paléontologie française, Terrain tertiaire, ser. 1, v. 1, p. 521.

Cassidulus patelliformis (Bouvé). Stefanini, 1911, Soc. geol. italiana Boll., $\nabla .30$, p. 700.

Cassidulus (Rhynchopygus?) patelliformis (Bouvé). Clark and Twitehell, 1915, U. S. Geol. Survey Mon. 54, p. 143, pl. 66, figs. $3 a-d$.

Cassidulus (Rhynchopygus) depressus Twitchell, 1915, U. S. Geol. Survey Mon. 54, p. 144, pl. 66, figs. 4a-e, 5a-b.

Procassidulus patelliformis (Bouvé). Lambert and Thiéry, 1921, Nomenclature raisonnée des échinides, fasc. 5, p. 362.

Procassidulus depressus (Twitchell). Lambert and Thiéry, 1921, Nomenclature raisonnée des énchinides, fasc. 5, p. 362.

Eurhodia patelliformis (Bouvé). Cooke, 1942, Jour. Paleontology, vol.16, no. 1, p. 35, pl. 5, figs. 1-4.

Cassidulus (Rhynchopygus) depressus Twitchell. Sanchez Roig, 1949, Equinodermos fosiles de Cuba, p. 141.

Test elongated; horizontal outline semicircular in front, narrowly truncated behind, broadly truncated on posterolateral margins; upper surface evenly arched; lower surface flat; margin subacute. Apical system slightly anterior, directly above the periproct, monobasal, four genital pores. Petals lanceolate, closed at the apex, open distally, the anterior pair somewhat shorter than the others; poriferous zones of nearly equal length, somewhat narrower than the interporiferous; inner pores circular, outer pores oval or elongate. Per- istome pentagonal, slightly longer than wide; bourrelets strong, bulbous; details of phyllodes obscure. Periproct supramarginal, nearly circular, opening into a shallow sulcus, which indents the margin and continues forward into the periproct, forming an internal shelf or tube. Upper surface and margin covered with small sunken tubercles; tubercles on lower surface much larger, sunken in deep pits; posterior interambulacrum on lower surface without tubercles but deeply pitted; similar pits surround the anterior phyllode.

Length of USNM 498988, $25.3 \mathrm{~mm}$; width $17.8 \mathrm{~mm}$; height $10 \mathrm{~mm}$.

Occurrence.-Georgia: Baker County (type? and type of Cassidulus depressus). Power plant 2 miles north of Albany (USGS 5054, USNM 498988, T. W. Vaughan) ; USGS 7121, C. W. Cooke and J. E. Brantly). Power plant at mouth of Kinchafoonee Creek, 3.3 miles north of Albany (USGS 10507, C. W. Cooke and T. M. Prettyman). Huguenen Ferry, Flint River, mouth of Gum Creek, Crisp County (USGS 7109, C. W. Cooke).

Alabama: Conecuh River 1 mile east of Harts Bridge (USGS 10025, C. W. Cooke and Julia Gardner).

Geologic unit.-Late Eocene, Ocala limestone.

Type.-Boston Soc. Nat. History, 1558. Type of Cassidulus depressus, Boston Soc. Nat. History 1557. Both deposited in Mus. Comp. Zoology at Harvard University. Figured specimens, USNM 498988.

Comparison.-Eurhodia patelliformis is smaller than E. rug$o s a$, and its periproct is more nearly circular. The posterior truncation is narrower, and the posterolateral sides are straighter.

\section{Eurhodia? elbana Cooke}

Plate 26, figures 9-12

Eurhodia? elbana Cooke, 1942, Jour. Paleontology, v. 16, no. 1, p. 36 , pl. 5, figs. 5-8.

Test small, subquadrate; upper surface moderately tumid; lower surface slightly concave; margin rounded. Tubercles larger on lower than on upper surface. Apical system excentric anteriorly. Paired petals open at the distal ends; anterior pair widely divergent; pore pairs oblique; pores conjugate. Peristome pentagonal, nearly equilateral, anteriorly excentric; oral lobes rounded. Periproct small, transversely oval, nearly round, supramarginal, within a short tube that merges into a posterior sulcus.

Length $20 \mathrm{~mm}$; width $16.7 \mathrm{~mm}$; height $9.7 \mathrm{~mm}$.

Occurrence.-Alabama: Pea River at power plant 4 miles below Elba (USGS 10013, C. W. Cooke and Julia Gardner).

Geologic unit.-Early Eocene, Wilcox group, Bashi formation. Type.-USNM 498981.

Remarks.-This species is represented by only a single individual, from which the apex and part of the petals are missing. It does not closely resemble any other American species. Its periproct suggests that of Eurhodia patelliformis (Bouvé), but its test is broader, its peristome is not much elongated, and its margin is not so sharp. Its equilateral peristome distinguishes it from other species of Eurhodia. In general appearance it resembles Cassidulus conradi carolinensis Twitchell, but its 
periproct is farther forward and more deeply sunken, and its margin is less broadly rounded.

\section{Subgenus GISOPYGUS Gauthier}

Gisopygus Gauthier, 1899, in Fourtau, Inst. Égyptien Mem., v. 3, fasc. 8, p. 648 .

Gisopygus Gauthier. Fourtau, 1908, Inst. Égyptien Bull., ser 5, v. 2, p. 133.

Gisopygus Gauthier. Fourtau, 1913, Catalogue des invertèbres fossiles de l'Égypte, Terrain tertiaire, pt. 1, Échinides éocenes, p. 23.

Eurhodia Haime (part). Mortensen, 1948, Monograph of the Echinoidea, v. 4, pt. 1, p. 254.

Eurhodia Haime (part). Lambert and Thiéry, 1921, Nomenclature raisonnée des échinides, fasc. 5, p. 365.

Type species, Rhynchopygus navillei de Loriol, from the Eocene of Egypt, designated by Lambert and Thiéry (1921, p. 365). De Loriol's figures of this species are copied by Mortensen (1948, fig. 242a-c). The species appears to differ from typical Eurhodia chiefly in shape, being much shorter, more nearly equilateral, than Eurhodia morrisi. Its periproct, not clearly shown, appears to be rounder.

Lambert and Thiéry placed Gisopygus without hesitation in the synonymy of Eurhodia, but Mortensen was doubtful, suspecting that there may be more differences than are apparent. Gisopygus is here treated as a subgenus because the difference in shape appears to be constant, with no gradations between the elongated form characteristic of typical Eurhodia and the more robust, equilateral shape of Gisopygus.

Eurhodia (Gisopygus) holmesi (Twitchell)

Plate 23, figures 1-5

Cassidulus (Rhynchopygus?) holmesi Twitchell, 1915, U. S. Geol. Survey Mon. 54, p. 140, pl. 65, figs. 3a-d.

Rhyncholampas holmesi (Twitchell). Lambert and Thiéry, 1921, Nomenclature raisonnée des échinides, fasc. 5, p. 370.

Cassidulus (Pygorhynchus) carolinensis var. cravenensis Kellum, 1926, U. S. Geol. Survey Prof. Paper 143, p. 15, pl. 1, figs. 1-3.

Eurhodia holmesi (Twitchell). Cooke 1942, Jour. Paleontology, v. 16, no. 1, p. 36.

Horizontal outline suboval, narrowly truncated behind, slightly compressed posterolaterally; upper surface evenly arched; lower surface somewhat concave; margin broadly rounded. Apical system nearly central, above the peristome; monobasal, four genital pores and a central madreporite. Petals lanceolate, closed at the apex, nearly closed distally, of nearly equal length; poriferous zones equal, narrower than the interporiferous; inner pores circular, outer pores oval. Peristome pentagonal, longer than wide; phyllodes rather short and wide, with central pits; bourrelets broadly swollen, granulated. Periproct oval, wider than high; nearly terminal, supramarginal, opening into a shallow sulcus, which indents the margin and extends into the test as a shelflike floor to the periproct. Tubercles small on upper surface, larger and more deeply sunken underneath. Areas between the posterior end and the periproct and adjacent to the anterior phyllode with cribriform pitting but without tubercles.

Length $24.6 \mathrm{~mm}$. ; width $21.7 \mathrm{~mm}$; height $13.6 \mathrm{~mm}$. A larger specimen measures 29 by 25.4 by $15 \mathrm{~mm}$.

Occurrence.-South Carolina: Santee River? (type). Cave Hall, 4.5 miles north-northeast of Elloree (USGS 4586, Earle Sloan and T. W. Vaughan).

North Carolina: Farm of T. J. Falkner 3 miles east of Quinerly and 2 miles north of Neuse River in Pitt County (USGS 10627, L. B. Kellum). Farm of J. A. Stokes 2 miles north of creek near Maple Cypress, Craven County (USGS 8165, J. A. Cushman). Farm of Douglas Green about 1 mile west of Maple Cypress (USGS 12007, W. C. Mansfield).

Geologic unit.-Middle Eocene, Santee limestone.

Type.-American Mus. Nat. History (fide Twitchell). The type of Cassidulus cravenensis is USNM 353256, from USGS 10627.

Remarks.-The preceding description is based on Kellum's type of $C$. cravenensis. The specimens from Cave Hall, S. C., are slightly more elongated and their margin is somewhat more acute than those from other places.

\section{Family HOLASTERIDAE}

\section{Genus HOLASTER Agassiz}

Holaster Agassiz, 1836, Soc. sci. nat. Neuchâtel Mem., v. 1, p. 183. Holaster Agassiz. Cooke, 1942, Jour, Paleontology, v. 16, no. 1, p. 52.

Holaster Agassiz. Cooke, 1946, Jour. Paleontology, v. 20, no. 3, p. 233.

Holaster Agassiz. Mortensen, 1950, Monograph of the Echinoidea, v. 5, pt. 1, p. 47. Includes full synonymy.

Holaster Agassiz. Cooke, 1953, U. S. Geol. Survey Prof. Paper 254-A, p. 26.

Holaster Agassiz. Cooke, 1955, U. S. Geol. Survey Prof. Paper 264-E, p. 107.

Type species, Spatangus nodulosus Goldfuss (1829, 1862 , pt. 1 , p. 139 , pl. 45 , figs. $6 \mathrm{a}-\mathrm{c}$ ), from the Cenomanian of Europe, designated by Savin (1905, p. 173). A generalized description of Holaster nodulosus was given by Cooke (1955, p. 107).

\section{Holaster cinctus (Morton)}

Plate 27, figures 1-5

Ananchytes cinctus Morton, 1830, Acad. Nat. Sci. Philadelphia Jour., ser. 1, v. 6, p. 200.

Ananchytes fimbriatus Morton, 1830, Acad. Nat. Sci. Philadelphia Jour., ser. 1, v. 6, p. 200.

Ananchytes cinctus Morton. Morton, 1830, Am. Jour. Sci., ser. 1, v. 18, p. 246 , pl. 3 , fig. 7 .

Ananchytes fimbriatus Morton. Morton, 1830, Am. Jour. Sci., ser. 1, v. 18, p. 245, pl. 3, fig. 9 .

Ananchytes cinctus Morton. Morton, 1834, Synopsis of the organic remains of the Cretaceous group, p. 78, pl. 3, fig. 19.

Ananchytes fimbriatus Morton. Morton, 1834, Synopsis of the organic remains of the Cretaceous group, p. 77, pl. 3, fig. 20. 
Holaster cinctus (Morton). Agassiz, 1840, Catalogus ectyporum Echinodermatum fossilium Musei Neocomensis, p. 1.

Holaster fimbriatus (Morton). Agassiz and Desor, 1847, Catalogue raisonné des échinodermes, p. 141.

Cardiaster cinctus (Morton). Bronn, 1853-1856, Lethaea geognostica, v. 2, pt. 5, p. 205.

Curdiaster cinctus (Morton). d'Orbigny, 1855, Paléontologie française, Terrain cretacé, ser. 1, v. 6, p. 147, pl. 905, fig. 4 (after Morton).

Cardiaster fimbriatus (Morton). d'Oribgny, 1885, Paléontologie française, Terrain cretacé, ser. 1, v. 6, p. 146, pl. 905, fig. 3 (after Morgan).

Cardiaster cinctus (Morton). Desor, 1858, Synopsis des échinides fossiles, p. 346.

Holaster cinctus (Morton). Clark, 1891, Johns Hopkins Univ. Circ., v. 10, no. 87, p. 77.

Cardiaster cinctus (Morton). Clark, 1893, U. S. Geol. Survey Bull. 97, p. 75, pl. 37, figs. 1a-h.

Cardiaster cinctus (Morton). Weller, 1907, New Jersey Geol. Survey Paleontology Series, vol. 4, pt. 2, p. 296, pl. 16, figs. 1-8 (after Clark).

Cardiaster cinctus (Morton). Clark, 1915, U. S. Geol. Survey Mon. 54, p. 83, pl. 36, figs $2 \mathrm{a}-\mathrm{h}$. Includes several additional references.

Holaster cinctus (Morton). Cooke, 1942, Jour. Paleontology, v. 16 , no. 1, p. 52.

Test cordate, nearly as broad as long; upper surface strongly arched, nearly hemispherical, with a deep, rounded anterior sulcus and a slight posterior keel; posterior end truncated, slightly overhanging; lower surface nearly flat. Apical system nearly central; elongated, all paired plates adjacent to their opposites and all four genital plates perforated. Anterior ambulacrum deeply depressed from apical system to peristome; pores small, pore pairs oblique, divided by a small bead. Paired ambulacra flush, all alike, subpetaliferous; pores oval to elongated; anterior poriferous zones of each ambulacrum slightly narrower than the posterior; anterior pair widely diverging, slightly curved forward; posterior pair nearly straight, diverging at an angle approximating $85^{\circ}$. Peristome transversely oval, weakly lipped behind. Periproct elliptical, higher than wide, at the top of a small posterior truncation, under a weak keel. Surface closely granulated, with rather large perforated, crenulated sunken tubercles surrounding the apical system, extending on the anterior interambulacra along both sides of the sulcus, on the under side of the margin, and along the sternal area; smaller tubercles are evenly scattered over the intervening areas.

Length of type $47.4 \mathrm{~mm}$; width $45.9 \mathrm{~mm}$; height 30.5 $\mathrm{mm}$.

Occurrence.-New Jersey: Timber Creek (type); Rancocas Creek, Vincentown (USNM 29467, F. B. Meek). E. Roberts' farm 2.5 miles west of Vincentown on road to Cross Roads (USGS 16924, F. S. MacNeil).

Geologic unit.-Paleocene, Vincentown sand.
Type--Acad. Nat. Sci. Philadelphia 1485 (types of Ananchytes cinctus and $A$. fimbriatus).

Remarles.-The preceding description is based on the type except as to the decoration, which is better preserved on three specimens numbered USNM 29467. This species is proportionately shorter than Holaster nodulatus (Goldfuss) and has a deeper anterior sulcus. Desor (1858) thought that it was a Cardiaster because of the length of the sulcus, but lack of a fasciole removes it from that genus.

\section{Genus ECHINOCORYS Leske}

Echinocorys Leske, 1778, Klein's Naturalis dispositio echinodermatum, p. 175.

Ananchytes Lamarck, 1801, Système des animaux sans vertèbres, p. 347.

Echinocorys Leske. Cooke, 1942, Jour. Paleontology, v. 16, no. 1, p. 38 .

Echinocorys Breynius. Mortensen, 1950, Monograph of the Echinoidea, v. 5, pt. 1, p. 64.

Echinocorys Leske. Cooke, 1953, U. S. Geol. Survey Mon. 254, p. 24. Includes additional synonymy.

Type species, Echinocorys scutatus Leske, by monotypy.

\section{Echinocorys ovalis (Clark)}

Plate 27, figures 6-9

Ananchytes ovatis Clark, 1893, Johns Hopkins Univ. Circ., v. 12 , no. 103 , p. 52.

Ananchytes ovalis Clark. Clark, 1893, U. S. Geol. Survey Bull. 97 , p. 74 , pl. 36 , figs. la-h.

Ananchytes ovalis Clark. Weller, 1907, New Jersey Geol. Survey Paleontology Ser., v. 4 , pt. 2 , p. 295 , pl. 13 , figs. $1-8$ (after Clark).

Ananchytes ovatis Clark. Clark, 1915, U. S. Geol. Survey Mon. 54, p. 81, pl. 35, figs. la-h (after Clark, 1893).

Echinocorys ovalis (Clark). Lambert and Thiéry, 1924, Nomenclature raisonnée des échinides, fasc. 6, p. 418.

Echinocorys ovalis (Clark). Cooke, 1942, Jour. Paleontology, v. 16, no. 1, p. 39.

Horizontal outline ovate, produced behind; upper surface strongly inflated; lower surface flattish, swollen near the periproct; margin acutely rounded. Apical system nearly central; elongated, each paired plate adjacent to its mate. Ambulacra subpetaliferous, narrow, gradually expanding to the margin; pore pairs transverse near the apex, becoming oblique distally, visible pores extending to the margin. Peristome near the anterior third, oval, transverse. Periproct submarginal, inclined, not visible from above, at the end of a short proboscislike extension. Tubercles perforated, sparsely scattered, not at all sunken.

Length $43.2 \mathrm{~mm}$; width $38.8 \mathrm{~mm}$; height $28 \mathrm{~mm}$.

Occurrence.-New Jersey : Vincentown.

Geologic unit.-Paleocene, Vincentown sand.

Type.-USNM 559479, deposited by Johns Hopkins Univ. (T. 3011).

Comparison.-Echinocorys ovalis resembles a specimen (USNM 73500) from the Blege limestone (Danian) at Monsted, 
Denmark, labelled $E$. sulcatus (Goldfuss) but proportionally shorter and with less inflated plates than Goldfuss' figure (d'Orbigny, 1853-1860, p. 70 , pl. 809), which represents the type, from the Senonian at Maestricht. E. ovalis differs from the Danian specimen chiefly in that its peristome is somewhat farther back. The swollen, proboscislike protuberance of both of these species is more conspicuous than that of any European Echinocorys figured in the Paléontologie française. Echinocorys texanus (Cragin) (Cooke, 1953, p. 25, pl. 10, figs. 1, 2; pl. 11, fig. 17), of middle Senonian age, also lacks the proboscis.

\section{Family HEMIASTERIDAE \\ Genus HEMTASTER Desor}

Hemiaster Desor in Agassiz and Desor, 1847, Annales sci. nat. (zoologie), v. 8, p. 16; Catalogue raisonné des échinodermes (reprint), p. 122.

Hemiaster Desor. Cooke, 1946, Jour. Paleontology, v. 20, no. 3, p. 222.

Hemiaster Desor. Mortensen, 1950, Monograph of the Echinoidea, v. 5, pt. 1, p. 378. Includes full synonymy.

Hemiaster Desor. Cooke, 1953, U. S. Geol. Survey Prof. Paper 254, p. 30.

Hemiaster Desor, Cooke, 1955, U. S. Geol. Survey Prof. Paper 264, p. 109.

Type species, Spatangus bufo Brongniart, from the Cenomanian of France, designated by Savin in 1903. Its most significant characteristics are described by Cooke (1953). The geologic range of Hemiaster is reported by Mortensen (1950, p. 380) as Cretaceous (Aptian) to Recent. It was most prolific in the Upper Cretaceous.

\section{Hemiaster parastatus (Morton)}

Plate 28, figures 15-20

Spatangus parastatus Morton, 1833, Am. Jour. Sci., ser. 1, v. 23, p. 294.

Spatangus parastatus Morton, 1834, Synopsis of the organic remains of the Cretaceous group, p. 77, pl. 3, fig. 21.

Hemiaster parastatus (Morton). Agassiz and Desor, 1847, Catalogue raisonné des échinodermes, p. 141.

Hemiaster parastatus (Morton). d'Orbigny, 1853-1856, Paléontologie française, Terrain cretacé, ser. 1, v. 6, p. 265, pl. 894, figs. $3,4$.

Hemiaster parastatus (Morton). Desor, 1858, Synopsis des échinides fossiles, p. 373.

Holaster parastatus (Morton). Gabb, 1859, Catalogue of the invertebrate fossils of the Cretaceous formation, p. 19.

Hemiaster parastatus (Morton). Clark, 1893, U. S. Geol. Survey Bull. 97, p. 83, pl. 45, figs. la-m.

Hemiaster parastatus (Morton). Weller 1907, New Jersey Geol. Survey Paleontology ser., v. 4, pt. 2, p. 298, pl. 15 (after Clark).

Hemiaster parastatus (Morton). Clark, 1915, U. S. Geol. Survey Mon. 54, p. 92 , pl. 48, figs. la-n. Includes additional references.

Hemiaster (Leymeriaster) parastatus (Morton). Lambert and Thiéry, 1924, Nomenclature raisonnée des échinides, fasc. 7, p. 501.

Hemiaster parastatus (Morton). Cooke, 1942, Jour. Paleontology, v. 16, no. 1, p. 43.
Horizontal outline ovate, widest in front of the midline, rounded and slightly emarginate in front, tapering behind; highest near the posterior end, sloping gently forward nearly to the anterior end, vertically truncated behind. Apical system near the posterior third; four genital pores wider apart across than longitudinally. Paired petals forming a rectangular cross; moderately sunken; anterior pair twice as long as posterior pair; poriferous zones about as wide as interporiferous zones; pores elongated. Anterior ambulacrum sunken, indenting the margin; poriferous zones straight, far apart; pores round, each pair divided by a conspicuous bead. Peripetalous fasciole continuous, very slightly indented. Peristome transversely oval, strongly lipped posteriorly; at the anterior quarter. Periproct oval, higher than wide, high on the posterior truncation.

Length $42.6 \mathrm{~mm}$; width $41.3 \mathrm{~mm}$; height $31 \mathrm{~mm}$.

Occurrence.-New Jersey: Timber Creek (type, S. G. Morton). Rancocas Creek, Vincentown (USNM 29472, F. B. Meek). Geologic unit.-Paleocene, Vincentown sand.

Type--Acad. Nat. Sci. Philadelphia 1487. Figured specimen USNM 29472.

Remarks.-The type of this species is worn nearly smooth but otherwise is well preserved. It shows no trace of fascioles. The description is based on USNM 29472 , on which a peripetalous fasciole is quite plain. There is no trace of lateral fascioles, and the part that would carry the subanal fasciole if it had one is broken.

Comparisons.-In general appearance Hemiaster parastatus closely resembles $\boldsymbol{H}$. minimus (Agassiz) as figured by Cotteau (d'Orbigny, 1854-1860, pl. 872), but its peristome is farther forward and its anterior paired petals are not quite as widely diverging.

\section{Hemiaster stella (Morton)}

Plate 28, figures 10-14

Spatangus stella Morton, 1830, Am. Jour. Sci., ser. 1, v. 18, p. 245, pl. 3, fig. 11.

Spatangus stella Morton. Morton, 1830, Acad. Nat. Sci. Philadelphia Jour., ser. 1, v. 6, p. 200.

Spatangus stella Morton. Morton, 1834, Synopsis of the organic remains of the Cretaceous group, p. 78, pl. 3, fig. 18.

Hemiaster stella (Morton). Agassiz and Desor, 1847, Catalogue raisonné des échinodermes, p. 141.

Hemiaster stella (Morton). d'Orbigny, 1855, Paléontologie française, Terrain cretacé, ser. 1, v. 6, p. 245. Not pl. 882.

Hemiaster stella (Morton). Desor, 1858, Synopsis des échinides fossiles, p. 373.

Hemiaster incrassatus Clark, 1891, Johns Hopkins Univ. Circ., v. 10, no. 87, p. 77.

Hemiaster stella (Morton). Clark, 1893, Johns Hopkins Univ. Circ., v. 12, no. 103, p. 52.

Hemiaster stella (Morton). Clark, 1893, U. S. Geol. Survey Bull. 84, pl. 44, figs. 1a-d.

Hemiaster stella (Morton). Weller, 1907, New Jersey Geol. Survey Paleontology ser., v. 4, pt. 2, p. 300 , pl. 16, figs. 1-4 (after Clark).

Hemiaster stella (Morton). Clark, 1915, U. S. Geol. Survey Mon. 54, p. 93, pl. 48, figs. 2a-d. 
Hemiaster (Integraster) stella (Morton). Lambert and Thiéry, 1924, Nomenclature raisonnée des échinides, fasc. 7, p. 504. Hemiaster stella (Morton). Cooke, 1942, Jour. Paleontology, v. 16, no. 1, p. 44.

Horizontal outline ovate, semicircular in front, slightly protracted behind; highest point near the posterior end, thence sloping gradually forward; anterior margin evenly rounded, without trace of sulcus; posterior end vertically truncated. Apical system somewhat posterior; the four genital pores nearly equally distant, forming a square; the posterior genital plates in contact. Petals slightly depressed, short; anterior pair forming an obtuse angle, posterior pair forming an acute angle, the opposite anterior and posterior petals nearly in a straight line; posterior pair much shorter than the anterior pair; pores of paired petals slightly elongated; pores of anterior petal circular, pore of each pair separated by a bead, pairs rather far apart. Peristome at the anterior third, transversely elongated, with a strong posterior lip. Periproct rather small, high up on the posterior truncation. Tubercles in sunken areoles. Peripetalous fasciole without conspicuous indentations.

Length of figured specimen $28 \mathrm{~mm}$; width $24 \mathrm{~mm}$; height $19 \mathrm{~mm}$.

Occurrence.-New Jersey : Timber Creek (type, S. G. Morton). Timber Creek near Blackwoods, Camden County (F. B. Meek). Geologic unit.-Paleocene, Vincentown sand.

Type.-Acad. Nat. Sci. Philadelphia 1491 (original number 256). Figured specimen USNM 2208.

Remarks.-In 1834 Morton regarded this species as the young of Hemiaster parastatus, which has a continuous anterior sulcus and longer petals. He stated that it occurs abundantly at Prairie Bluff, Ala., presumably mistaking it for the Cretaceous species Hemiaster wetherbyi de Loriol, which Clark (1915) put in the synonymy, but which has a shallow anterior sulcus and longer and wider petals.

\section{Hemiaster moscovensis Cooke, n. sp.}

Plate 28, figures 5-9

Horizontal outline subovate, slightly emarginate in front, truncated behind; upper surface highest behind, gently sloping forward to the apical system, more steeply in front; lower surface gently convex; margin broadly rounded. Apical system ethmophractic, madreporite central; four genital pores rather far apart. Anterior ambulacrum slightly depressed, deepest in the petaliferous part; zygopores oblique, pores separated by a bead. Paired petals nearly equal in length, straight, depressed, anterior pair diverging at an angle of $117^{\circ}$, posterior about $50^{\circ}$; pores elongated. Peristome near the anterior third, subpentagonal, moderately lipped. Periproct rather small, longitudinally elogated, well up on the posterior truncation, barely visible from above. Peripetalous fasciole complete, rather wide, deeply indented between the lateral petals.
Length $29 \mathrm{~mm}$; width $26 \mathrm{~mm}$; height $17 \mathrm{~mm}$.

Occurrence.-Alabama: Moscow Bluff, Tombigbee River, Sumter County, horizon No. 3 (USGS 5658, T. W. Vaughan). Geologic unit.-Paleocene, Porters Creek clay.

Type.-USNM 562457.

Remarks.-The type, collected in 1908, is the only specimen known. Its shallow anterior depression suggests Hemiaster cranium Cooke from the Weno limestone of the Comanche series (Cretaceous) of Texas, but its posterior petals are much longer and its sides are straighter.

\section{Genus CYCLASTER Cotteau}

Cyclaster Cotteau, 1856, Soc. géol. France Bull., ser. 2, v. 13, p. 345.

Cyclaster Cotteau. Pomel, 1883, Classification méthodique et genera des échinides, p. 34.

Cyclaster Cotteau. Cotteau, 1886, 1887, Paléontologie francaise, Terrain tertiaire, ser. 1, v. 1, p. 133, 442.

Cyclaster Cotteau. Lambert and Thiéry, 1924, Nomenclature raisonnée des échinides, fasc. 7, p. 485.

Cyclaster Cotteau. Sanchez Roig, 1926, Cuba, Bol. de Minas, no. 10, p. 113.

Cyclaster Cotteau and Leymerie, Cooke, 1942, Jour. Paleontology, v. 16, no. 1, p. 50 .

Cyclaster Cotteau. Mortensen, 1951, Monograph of the Echinoidea, v. 5 , pt. 2, p. 441 . Includes additional sysnonymy.

Type species, Cyclaster declivis [declivus by error] Cotteau, from the late Eocene or Oligocene of France, by monotypy. As figured by Cotteau (1887, p. 444, pl. 121, fig. 4 ; pl. 122), this species is higher behind than in front; its apical system is plainly ethmophractic, with three genital pores. Its petals are short, widely spreading and depressed. It has an incomplete peripetalous fasciole and an annular subanal fasciole.

Cyclaster is usually classified with the Brissidae, from which its ethmophractic apical system seems to remove it. It is here tentatively placed with the Hemiasteridae for convenience although its subanal fasciole and its three genital pores show that it does not properly belong there.

\section{Cyclaster drewryensis Cooke}

Plate 28, figures 1-4

Cyclaster drewryensis Cooke, 1942, Jour. Paleontology, v. 16, no. 1, p. 50, pl. 3, figs. 9-11.

Horizontal outline obovate, weakly emarginate in front, truncated behind. Upper surface subconical, steeply sloping in front, gently sloping and rostrate behind. Margin rounded. Apical system slightly anterior; ethmophractic, the madreporite confined to the anterior right quadrant; three genital pores, the right anterior plate not perforated. Anterior ambulacrum slightly depressed, especially at each end; pore pairs oblique, pores separated by a bead. Paired petals deeply depressed, straight, extending about halfway to the margin ; anterior pair diverging at an angle of approxi- 
mately $130^{\circ}$, posterior near $55^{\circ}$; inner pores oval, outer pores elongated, conjugate; poriferous zones open distally, equalling the interporiferous zones. Peristome at the anterior fifth, semilunate, ends rounded, strongly lipped. Periproct terminal, vertical, higher than wide, high up on the posterior truncation. Peripetalous fasciole broad, reentrant between the lateral petals, diffuse and incomplete in front. Subanal fasciole broad, wider than long, suboval, somewhat indented in front. Tubercles perforated, scrobiculated, smaller on upper surface than on lower; interspaces granulated.

Length of figured specimen from St. Stephens (USNM 559882) $35 \mathrm{~mm}$; width $33 \mathrm{~mm}$; height $23 \mathrm{~mm}$.

Occurrence.-Alabama: Lowest bed at Drewry, Monroe County, in sec. 15, T 6 N, R 8 E (holotype, USGS 10026, C. W. Cooke). Clarke County 2 or 3 miles southeast of Whatley (paratype, USGS 2957, Frank Burns). St. Stephens Bluff, Washington County (USGS 6712, C. W. Cooke; USNM 559882, C. C. Branson).

Geologic unit.-Early Oligocene, limestone facies of the Red Bluff clay.

Types.-Holotype, USNM 372880 from USGS 10026; paratype, USNM 154148, from USGS 2957; figured specimen, USNM 559882, from St. Stephens Bluff.

Comparison.-This species is higher in front than behind, contrasting with Cyclaster declivis Cotteau, which is higher behind.

\section{Family SCHIZASTERIDAE}

\section{Genus IINTHIA Desor}

Linthia Desor, 1853, Soc. helvétique sci. nat. Actes (Porrentruy) (Schweizer, naturf. Gesell. Verh.), p. 278.

Linthia Merian. Desor, 1858, Synopsis des échinides fossiles, p. 395.

Linthia Merian. A. Agassiz, 1872, Harvard College Mus. Comp. Zoology Mem., v. 3, p. 604.

Linthia Merian. Duncan and Sladen, 1882, Palaeontologia Indica, ser. 14, v. 1, pt. 3, p. 17.

Linthia Merian. Pomel, 1883, Classification méthodique et genera des échinides, p. 36.

Linthia Merian. Cotteau, 1886, Paléontologie française, Terrain tertiaire, ser. 1 , v. 1, p. 206.

Linthia Desor. Lambert and Thiéry, 1925, Nomenclature raisonnée des échinides, fas. 8 , p. 518.

Linthia Desor. Gardner, 1935, Texas Univ. Bull. 3301, p. 109.

Linthia Desor. Grant and Hertlein, 1938, California Univ. (Los Angeles) Pub. Math. and Phys. Sci., v. 2, p. 124.

Schizaster (Linthia) Desor. Cooke, 1942, Jour. Paleontology, v. 16, no. 1, p. 41.

Linthia Desor. Mortensen, 1951, Monograph of the Echinoidea, v. 5, pt. 2, p. 233. Includes additional synonymy.

Linthia Desor. Cooke, 1955, U. S. Geol. Survey Prof. Paper 254-A, p. 35.

Type species, Escheria insignis Merian, designated by Desor $(1855,1858$, p. 395), from the Eocene at Blangg, near Yberg, Switzerland.

As figured by Desor (1858, pl. 43, fig. 9 ; Mortensen, 1951 , p. 235 , fig. 116) and Cotteau (1886, p. 232, pl. 70)

Linthia insignis is large, with central apical system, widely spreading, straight, paired petals, a moderately deep, steep-walled frontal furrow, and a peripetalous and lateral fascioles. Closely related species have four genital pores in an ethmolytic apical system.

Linthia differs from Schizaster in having four instead of two genital pores and more widely spreading anterior paired petals; its apical system is farther forward, and there are other minor differences.

\section{Linthia wilmingtonensis Clark}

Plate 29, figures 1-4

Linthia wilmingtonensis Clark, 1915, U. S. Geol. Survey Mon. 54, p. 152, pl. 70, figs. 3a-c.

Linthia wilmingtonensis Clark. Lambert and Thierry, 1925, Nomenclature raisonnée des échinides, fasc. 8, p. 519.

Schizaster (Linthia) wilmingtonensis (Clark). Cooke, 1942, Jour. Paleontology, v. 16, no. 1, p. 41.

Horizontal outline cordate; upper surface inflated, higher behind than in front; lower surface slightly tumid; margin broadly rounded. Apical system central; four genital pores, the lateral pores close together; madreporite extending behind the posterior ocular plates. Frontal depression deep, $\mathbf{U}$-shaped, extending from the apical system to the peristome; pore pairs slightly oblique, pores separated by a bead; pairs rather close together. Paired petals deeply sunken; anterior pair the longer, extending about three-fourths of the radius, diverging at an angle of about $135^{\circ}$, straight; posterior pair extending about half the radius, diverging at an angle of about $50^{\circ}$, curved slightly backward; pores slightly elongated; poriferous zones wider than the interporiferous. Peristome near the anterior quarter, reniform, with a strong posterior lip, rather large. Peripetalous fasciole strongly indented in all interambulacra; lateral fascioles present. Tubercles large, perforated; interspaces granular.

Length of type about $55 \mathrm{~mm}$; width $55.5 \mathrm{~mm}$; height about $33 \mathrm{~mm}$. Length of figured specimen from Rocky Point $32.3 \mathrm{~mm}$; width $31.0 \mathrm{~mm}$; height $21.6 \mathrm{~mm}$.

Occurrence.-North Carolina: Wilmington (USNM 166482, type). Rocky Point, Pender County (USGS 779, T. W. Stanton).

Geologic unit.-Middle Eocene, Santee limestone (or Castle Hayne limestone).

Type-USNM 166482. Figured specimen USNM 164673, from USGS 779 .

\section{Linthia alabamensis Clark \\ Plate 29, figures 5-7}

Linthia alabamensis Clark, 1915, U. S. Geol. Survey Mon. 54, p. 153, pl. 71, figs. 1a-d, 2a-d.

Linthia maverickensis Gardner, 1935, Texas Univ. Bull. 3301, p. 110 , pl. 4, figs. 13,14 .

Schizaster (Linthia) alabamensis (Clark). Cooke, 1942, Jour. Paleontology, v. 16, no. 1, p. 42. 
Horizontal outline subcircular, emarginate in front, truncated behind; upper surface moderately swollen, highest behind the apical system, sloping steeply backward, more gently forward; margin rounded. Apical system central, four genital pores, the lateral pairs the closer, ethmolytic, the madreporite extending backward. Frontal depression rounded, extending to the peristome; pore pairs oblique, pores separated by a bead. Petals straight; the anterior pair the longer, extending three-fourths of the radius, diverging at an angle of approximately $128^{\circ}$; posterior pair extending less than half the radius, diverging at an angle of approximately $57^{\circ}$; pores elongated; interporiferous areas equal to the poriferous. Peristome reniform, lipped, at the anterior quarter. Periproct on the sloping posterior truncation, visible from above, longer than wide. Peripetalous fasciole strongly reentrant between the lateral petals; lateral fascioles normal. Tubercles perforated.

Length of holotype $33.5 \mathrm{~mm}$; width $35.0 \mathrm{~mm}$; height $19.0 \mathrm{~mm}$.

Occurrence.-Alabama: Prairie Creek, Wilcox County (type, USGS 264, L. C. Johnson). Brundidge, Pike County (Johns Hopkins Univ., T. H. Aldrich).

Arkansas: Railroad cut $1 / 2$ mile southeast of Grand Glaise, Jackson County (USNM 166483, L. W. Stephenson).

Texas: Indio Ranch, 6 miles below the McFarland sheep pens on the Windmill (Jacal) ranch road (USGS 11754, Julia Gardner, type of Linthia maverickensis).

Geologic unit.-Paleocene; Clayton formation in Alabama, Midway formation in Arkansas, Wills Point(?) formation in Texas.

Remarks.-This species is represented in the collections of the U. S. National Museum only by the type and paratype and by the type of Linthia maverickensis, a small internal mold that cannot certainly be identified.

\section{Linthia hanoverensis Kellum}

Plate 29, figures 8-12

Linthia hanoverensis Kellum, 1926, U. S. Geol. Survey Prof. Paper 143, p. 15, pl. 1, figs. 8, 9.

Schizaster (Linthia) hanoverensis (Kellum). Cooke, 1942, Jour. Paleontology, v. 16, no. 1, p. 42.

Horizontal outline ovate; upper surface strongly inflated, highest behind the apical system, sloping steeply forward and less steeply to the nearly vertical posterior truncation; lower surface swollen; margin rounded. Apical system slightly anterior; four genital pores close together, ethmolytic, the madreporite extending between but not behind the posterior ocular plates. Anterior depression weak, barely indenting the margin, not reaching the peristome; pore pairs obscured. Paired petals slightly sunken, long, posterior pair nearly as long as the anterior; pores slightly elongated; anterior pair diverging at an angle of $125^{\circ}$, posterior $45^{\circ}$. Peristome apparently reniform, lip not preserved; at the anterior quarter. Periproct longer than wide, rather large, well up on the posterior truncation. Peripetalous fasciole reentrant between the lateral petals, evenly curved in front; lateral fascioles normal. Tubercules perforated.

Length of holotype $28.0 \mathrm{~mm}$; width $27.1 \mathrm{~mm}$; height about $20 \mathrm{~mm}$.

Occurrence.-North Carolina: Wilmington (type, USGS 782, T. W. Stanton). City rock quarry, east side of Wilmington (USGS 10613, L. B. Kellum).

Geologic unit.-Middle Eocene; Castle Hayne limestone (or Santee limestone).

Type.-USNM 164664, from USGS 782. Figured specimen USNM 562458 from USGS 10613.

Remarks.-Linthia hanoverensis superfically resembles Unifascia carolinensis (Clark), which occurs also at Wilmington, but that species lacks peripetalous and lateral fascioles and its genital pores are smaller and farther apart.

\section{Linthia? prima (Cooke) \\ Plate 43, figures 1-4}

Eupatagus? (Brissopatagus?) primus Cooke, 1942, Jour. Paleontology, v. 16 , no. 1, p. 59 , pl. 4 , figs. $1-4$.

Test cordate; upper surface high, highest point in front of the apical system; anterior margin deeply cut by a rounded sulcus, which slopes steeply from a point in front of the apical system to the peristome. Apical system nearly central, with four genital pores. Petals in broad depressions; anterior pair longer than the posterior, extending nearly to the margin, straight, widely diverging, nearly closed; pores round, conjugate; zones equally wide distally, but interporiferous zones and front poriferous zones narrowing more rapidly than the back poriferous zone near the apical system. Posterior petals straight, extending about two-thirds the way to the margin; outer poriferous zones longer than the inner. Pore pairs of the anterior ambulacral area oblique, narrow, crossing the tumid part of the test and becoming much wider apart and replaced by single pores alternating in position in the sulcus. Posterior interambulacral area arched, apparently covered with tubercles and granules. Peristome far forward.

Length (broken) $34.5 \mathrm{~mm}$; width $35 \mathrm{~mm}$; height about $24 \mathrm{~mm}$.

Occurrence.-Georgia: Dr. A. J. Parke's farm on the Americus road 5 miles south of Ellaville, Schley County (USGS 4033 , s. W. McCallie).

Geologic unit.-Paleocene, Clayton formation.

Type.-USNM 498978.

Remarks.-This species is represented by only one mold of the interior, to which a few fragments of the silicified test are clinging. It was associated with Echanthus georgiensis (Twitchell). The proper generic affiliation cannot be determined until better specimens are obtained. The long, straight petals suggest Linthia. 


\section{Genus PARASTER Pomel}

Paraster Pomel, 1869, Revue des échinodermes, p. 14.

Paraster Pomel. Pomel, 1883, Classification méthodique et genera des échinides, p. 36.

Schizaster Agassiz (part). Dunean, 1889, Linnean Soc. London J'our., Zoology, v. 23, p. 234.

Schizaster (Schizaster) Agassiz (part). Lambert and Thiéry, 1925, Nomenclature raisonnée des échinides, fasc. 8, p. 524.

Paraster Pomel. Jackson, 1922, Carnegie Inst. Washington Pub. 307, p. 74.

Schizaster Agassiz (part). Cooke, 1942, Jour. Paleontology, v. 16 , no. 1, p. 39.

Paraster Pomel. Mortensen, 1951, Monograph of the Echinoidea, v. 5, pt. 2, p. 215. Includes additional references.

Type species, Schizaster gibberuhus, a Red Sea species of Recent age, by original designation. As figured by Mortensen (1951, p. 218, pl. 22, fig. 7) this species has an ethmolytic apical system with four close-set genital pores, moderately sunken, straight petals, the anterior pair diverging at an angle of approximately $95^{\circ}$, the posterior about $80^{\circ}$, a peripetalous fasciole indented between the paired petals, and lateral fascioles.

In 1942 I regarded Paraster as a synonym of Schizaster, being misled by a statement of Cotteau (1886, p. 347 ) that the apical system of Schizaster studeri (the type species of Schizaster) apparently has four genital pores. There now seems to be general agreement that it has only two. Besides the difference in the number of genital pores, Paraster has straighter, less flexuous petals, it is less pointed behind, and its anterior furrow is shallower and less constricted.

\section{Paraster armiger (Clark)}

Plate 30, figures 13-15

A sea urchin Harris, 1894, Arkansas Geol. Survey Ann. Rept. for 1892 , v. 2, p. 172, pl. 6, fig. 11.

Schizaster armiger Clark, 1915, U. S. Geol. Survey Mon. 54, p. 152, pl. 70, figs. 1a-d.

Schizaster floridanus Clark, 1915, U. S. Geol. Survey Mon. 54, p. 175 , pl. 82, figs. 1a-c.

Schizaster armiger Clark. Lambert and Thiéry, 1925, Nomenclature raisonnée des échinides, fasc. 8, p. 524 .

Sohizaster armiger Clark. Cooke, 1942, Jour. Paleontology, v. 16, no. 1, p. 39.

Schizaster armiger Clark. Cooke, 1948, Jour. Paleontology, v. 22 , no. 1, p. 92, pl. 22, figs. 1-4.

Horizontal outline subrhombic, longer than wide, indented in front; highest behind, curving gradually downward to the margin, truncated behind. Apical system slightly posterior; four genital pores, the posterior pair far apart, the anterior pair somewhat smaller and closer together, very near the posterior pair; madreporite extending between and beyond the posterior ocular plates. Petals deeply depressed; paired petals extending about three-fourths of the radius; anterior pair the longer, straight or slightly flexuous, diverging at an angle of nearly $90^{\circ}$; posterior pair curved together to an angle of $35^{\circ}$; pores large, oval, strongly conjugate; interporiferous zones about as wide as poriferous. Pores of anterior petal small, circular, pairs slightly inclined; interporiferous zones wide. Peristome at the anterior quarter, lunate, covered by a projecting rimmed lip. Periproct terminal, high on the posterior truncation, longer than wide. Peripetalous fasciole deeply indented; lateral fascioles gently curved to their junction well below the periproct. Anterior ambulacral furrow extending to the peristome. Posterior ridge terminating at the periproct.

Length of figured specimen $58 \mathrm{~mm}$; width $52.5 \mathrm{~mm}$; height $36.5 \mathrm{~mm}$.

Occurrence.-Alabama: Old Cocoa Post Office, SW1/4 sec. 13 T. 11 N., R. 5 W., Choctaw County (USGS 2637, type 2892, Charles Schuchert; USGS 7219, C. W. Cooke and W. C. Mansfield). Near Fail, Choctaw County (USGS 2869, Charles Schuchert). Near Melvin, Choctaw County, NW corner NW1/4 SE1/4 sec. 24, T. 11 N., R. 5 W. (USGS 12560, R. Kellog and N. H. Boss). Zitterow's field south of sec. 24, T. 11 N., R. 5 W., Choctaw County (USGS 12561, R. Kellogg and N. H. Boss). Near middle of sec. 24, T. 11 N., R. 5 W., Sanford Mitchell's field 11/2 miles southeast of Melvin (USGS 12562, R. Kellog and N. H. Boss). 2.4 miles south of Melvin by road (USGS 12720, R. Kellogg and N. H. Boss). 2 to 3 miles southeast of Whatley, Clarke County (USGS 2957, Frank Burns ). E. $1 / 2$ sec. 34 , T. 8 N., R. 3 E., 5 miles southeast of Whatley (USGS 7159 , C. W. Cooke). Sec. 35 , T. 8 N., R. 3 E., 500 feet east of Jones' Field Branch, 5 miles southeast of Whatley (USGS 7161 , C. W. Cooke). Cut on US 84 west of Gosport (USGS 18785, C. W. Cooke and F. S. MacNeil). SE1/4 NW1/4 SE1/4 sec. 34, T. 10 N., R. 3 E., Clarke County (USNM 559889, C. C. Branson). Road leading down to Claiborne Ferry, Monroe County (USGS 10023, C. W. Cooke; USGS 5567, T. W. Vaughan; USGS 12166 , O. W. Cooke and R. B. Stewart). Claiborne road west of Double Branches, $2 \frac{1}{2}$ miles southwest of Monroeville (USGS 6730, C. W. Cooke). 11/2 miles southwest of Perdue Hill (USGS 10043, C. W. Cooke and Julia Gardner; USGS 15064, F. S. MacNeil). Tombigbee River $3 / 4$ mile above St. Stephens Bluff (USGS 7392, C. W. Cooke).

Mississippi : Pachuta Prairie, Clarke County (USGS 3095, Frank Burns). Chickasawhay River near Shubuta (USGS 332, Frank Burns). Railroad cut southwest of pumping station, Jackson (USGS 12172, C. W. Cooke, R. B. Stewart, W. H. Monroe).

Arkansas: East bank Sabine River at Cornish Ferry (Caveness Landing) about 5 miles east-northwest of Warren, Bradley County (USGS 2412, G. D. Harris.

Georgia: Bank of Muckafoonee Creek near its confluence with Flint River, about $1 \frac{1}{2}$ miles above Albany (USGS 7906 , R. M. Harper). Power plant on Kinchafoonee Creek 2 miles north of Albany (USGS 7121, C. W. Cooke and J. E. Brantly). Flint River at the northeast corner of Dougherty County (USGS 7235, C. W. Cooke).

Florida: Johnson's sink, Levy County (USGS 365, type of Schizaster floridanus, L. C. Johnson). Suwannee River 17 miles south of Ellaville (USGS 2612, G. H. Eldridge). Suwannee River 100 yards below Troy Springs, 6 miles northwest of Branford (USGS 7347, C. W. Cooke). Troy Springs (USGS 14607, C. W. Cooke). Lowest bed at mouth at Withlacoochee River at Ellaville (USGS 11111, C. W. Cooke and Stuart Mossom). Road to Dowling Park 5 miles northwest of Mayo (USGS 11114, O. W. 
Cooke and Stuart Mossom). Steinhatchee River in Dixie County opposite Clara (USGS 12747, W. C. Mansfield and G. M. Ponton; USGS 14541, C. W. Cooke and W. D. Havens, Jr.; USGS 14158, W. C. Mansfield; USGS 15150 , G. M. Ponton). Quarry on highway 5-A in Suwannee County 9.3 miles from the Lafayette County line and 5.2 miles from the courthouse at Mayo (USGS 14981, W. C. Mansfield and F. S. MacNeil). Taylor County rock pit near Mayo (USGS 16913, G. M. Ponton; USGS 14537a, C. W. Cooke and F. S. MacNeil).

Panama : Madden Air Field (USGS 16889, W. P. Woodring and J. R. Schultz).

Geologic unit.-Late Eocene, of Jackson age: Yazoo clay in Choctaw County, Ala., Ocala limestone east of Tombigbee River in Alabama and in Florida.

Type.-USNM 141104, from USGS 2637. Figured specimen USNM 562460, from USGS 7906, Georgia. Type of Schizaster floridanus USNM 164655, an internal cast from USGS 365, Florida.

Remarks.-The type and other specimens from western Alabama have wider petals than those from Florida. There is some variation in the relative length of the posterior petals.

\section{Paraster americanus (Clark)}

\section{Plate 30 , figures $5-8$}

Schizaster americana Clark, 1915, U. S. Geol. Survey Mon. 54, p. 176, pl. 82 , figs. $2 a-d$.

Schizaster americanus Clark. Lambert and Thiéry, 1925, Nomenclature raisonnée des échinides, fasc. 8, p. 526.

Schizaster americanus Clark. Cooke, 1942, Jour. Paleontology, v. 16, no. 1, p. 40.

Horizontal outline subcircular, indented in front, highest behind, sloping to the rounded margin; truncated behind. Apical system slightly posterior; four genital pores, the two posterior pores far apart, the anterior pair near the posterior; madreporite extending between and beyond the genital pores. Petals deeply sunken; the anterior pair nearly twice as long as the posterior pair, straight, diverging at an angle of nearly $90^{\circ}$; the posterior twisted to an angle approximating $37^{\circ}$; pores of paired petals far apart, interporiferous zones about the same width. Anterior sulcus extending to the peristome. Peristome at the anterior third, reniform, covered by a protruding rimmed lip. Periproct high on the posterior truncation. Peripetalous fasciole deeply indented; lateral fascioles straight, meeting below the periproct.

Length of type $39 \mathrm{~mm}$; width $38.5 \mathrm{~mm}$; height $25.5 \mathrm{~mm}$.

Occurrence.-Mississippi: Yost's lime kiln near Brandon (USGS 3951, A. F. Crider). Vicksburg (USNM 1832, А. H. Worthen; USGS 6450 , from ledges forming waterfall at Mint Spring Bayou, C. W. Cooke and E. N. Lowe). Sylvarena road about $4 \frac{1}{2}$ miles west of Bay Springs (USGS 7374, C. W. Cooke and E. N. Lowe). Panther Creek, 7 miles north of Youngton, Warren County, in sec. 22 (USGS 7447, O. B. Hopkins). A creek probably in sec. 22 , T. 4 N., R. $1 \mathrm{E}$, about $3 \frac{1}{2}$ miles east of Byram, Rankin County, 12 to 15 feet above the Mint Spring marl member of the Mariana limestone (USGS 14606, F. S. MacNeil and W. C. Mansfield).
Alabama: Old Weaver Chute 2 or 3 miles below McGowans Bridge, Escambia County (USGS 6753, C. W. Cooke). Georgia: Ocmulgee River at mill $3 / 4$ mile below Hawkinsville (USGS 10482, H. S. Cave).

Geologic unit.-Oligocene, Vicksburg group in Mississippi and Alabama.

Type.-USNM 165695, from USGS 3951, near Brandon, Miss.

Comparison.-Paraster americanus is proportionately shorter than Paraster armiger, and its posterior petals are somewhat shorter.

\section{Genus SCHIZASTER Agassiz}

Schizaster L. Agassiz (part), 1836, Soc. sci. nat. Neuchâtel, Mém., v. 1, p. 185.

Schizaster Agassiz. Agassiz, 1840, Catalogus systematicus ectyporum echinodermatum, p. 2,15.

Schyzaster Agassiz. Sismonda, 1843, Memoria geo-zoologica sulgi echinidi fossili del contado di Nizza, p. $\mathbf{3 0 .}$

Schizaster Agassiz. Agassiz and Desor, 1847, Catalogue raisonné des échinodermes (reprint), p. 126.

Sohizaster Agassiz. Desor, 1858, Synopsis des échinides fossiles, p. 389.

Schizaster Agassiz. Cotteau, 1875, K. svenska vetensk.-akad. Handl., v. 13, no. 6, p. 28.

Schizaster Agassiz. Cotteau, 1886, Paléontologie française, Terrain tertiaire, v. 1, p. 270.

Schizaster Agassiz. Duncan, 1889, Linnean Soc. London Jour., v. 23, p. 234.

Schizaster Agassiz. Lambert, 1906, Soc. géol. France Mem., Paléontologie, no. 24, p. 110.

Schizaster Agassiz. Fourteau, 1908, Inst. égyptien Bull., ser. 5, v. 1, p. 193.

Schizaster Agassiz. Lambert and Thiéry, 1925, Nomenclature raisonnée des échinides, fasc. 8, p. 522.

Schizaster Agassiz. Cooke, 1942, Jour. Paleontology, v. 16, no. 1, p. 39.

Schizaster Agassiz. Mortensen, 1951, Monograph of the Echinoidea, v. 5, pt. 2, p. 295 . Includes additional synonymy.

Type species, Schizaster studeri Agassiz, credited by Agassiz to the Tertiary of Italy, designation validated by Opinion 209 of the International Commission on Zoological Nomenclature. The plaster cast of the type as figured by Cotteau (1886, p. 344, pl. 104, figs. 4, 5) has its apical system at the posterior third, apparently with only two, widely separated genital pores. The petals are deeply depressed, the anterior pair flexuous, diverging at an angle of approximately $87^{\circ}$, twice as long as the posterior pair, which diverge at an angle of about $73^{\circ}$. The anterior sulcus strongly indents the margin.

According to Mortensen (1951, p. 206) "the number of genital pores is of very great classificatory importance and a very practical means of distinguishing the genera" of the Schizasteridae, Schizaster having only 2, Paraster 4.

All species referred to Schizaster have a deeply indented peripetalous fasciole and lateral fascioles that join beneath the periproct. The lateral fascioles may be very obscure. 
Subgenus BRACHYBRISSUS Pomel

Schizaster (Brachybrissus) Pomel, 1883, Classification méthodique et genera des échinides, p. 37.

Schizaster (Brachybrissus) Pomel. Lambert, 1906, Soc. géol. France Mem., Paleontologie no. 24, p. 113.

Schizaster (Brachybrissus) Pomel. Lambert and Thiéry, 1925, Nomenclature raisonnée des échinides, fasc. 8, p. 527.

Type species, Spatangus ambulacrum Deshayes, from the early Oligocene (Tongrian) of France, designated by Lambert (1906, p. 113). This species, as figured by Cotteau (1885-1889, p. 320, pls. 95, 96), is subglobular, with two genital pores, deeply depressed, widely spreading petals, large circular periproct, and peripetalous and lateral fascioles. Its more widely spreading petals, less pointed posterior end, and more globular shape distinguish it from Schizaster studeri, and it seems to be less strongly truncated behind, and its periproct is probably larger and less elongated.

Ditremaster Munier-Chalmas (1885), type species Hemiaster nux Desor, may be a synonym of Brachybrissus. The chief difference as reported is the lack of lateral fascioles in Ditremaster, but lateral fascioles may be very inconspicuous or obliterated in fossils.

Schizaster (Brachybrissus) ocalanus Cooke

Plate 29, figures 13-17

Schizaster (Linthia) ocalanus Cooke, 1942, Jour. Paleontology, v. 16, no. 1, p. 42, pl. 5, figs. 18-22.

Test subglobular, cordate, the anterior depression extending from the apical system to the peristome, the upper surface more inflated than the lower. Apical system nearly central, with two large genital pores, one between the ends of each lateral pair of petals, and the madreporite extending behind them. Anterior ambulacral area moderately sunken; pores of each pair separated by a high granule. Petals nearly straight, sunken; anterior pair diverging at an angle of approximately $135^{\circ}$, the posterior at an angle of approximately $65^{\circ}$; anterior pair about twice as long as the posterior; open at the distal ends; poriferous zones about as wide as interporiferous zones; pores conjugate, elongated. Peripetalous fasciole concave between the lateral petals, convex elsewhere; lateral fascioles very narrow, usually obscure. Peristome far forward, subtrigonal to subpentagonal, strongly lipped posteriorly, weakly lobate anterolaterally. Periproct as large or larger than the peristome, nearly circular, slightly elongated, high up on the posterior end, visible from above. Surface covered with small tubercles.

Length of holotype $20.3 \mathrm{~mm}$; width $20.7 \mathrm{~mm}$; height $16.0 \mathrm{~mm}$. Length of largest paratype from USGS $14539,33.2 \mathrm{~mm}$; width $32.2 \mathrm{~mm}$; height $27.7 \mathrm{~mm}$.
Occurrence.-Florida: Pit of Ocala Limerock Company near Kendrick (type, USGS 13429, T. H. Hubbell). Pit of Cummer Lumber Company near Kendrick, four miles north of Ocala (USGS 12754a, C. W. Cooke and T. P. Kirby). Old MacDonald quarry 1 mile north of Istachatta (USGS 11112, C. W. Cooke and Stuart Mossom). Oakhurst Lime Company, 21/2 miles southeast of Ocala (USGS 11749, C. W. Cooke and Stuart Mossom). Spoil bank of drainage canal on US 19, 5 miles south of Salem, Taylor County (USGS 14539, C. W. Cooke and W. D. Havens, Jr.). Quarry 6 miles southeast of Crystal River (USGS 14141, W. C. Mansfield and C. W. Mumm; Florida Geological Survey, Frank Westendick).

Geologic unit.-Late Eocene, Ocala limestone.

Type.-USNM 498990, from Kendrick, Florida. Figured specimen, USNM 562459, from USGS 14141.

Remarks.-This species is more globular than other American species referred to schizaster. Its petals are more widely spreading than those of Paraster armiger or Paraster americanus, which have four genital pores and differently shaped peristomes.

\section{Genus MoIRA A. Agassiz}

Moera Michelin, 1855, Revue et magazin de zoologie, ser. 2 v. 246, not Huebner, 1819.

Moira A. Agassiz, 1872, 1874, Harvard College Mus. Comp. Zoology Mem., v. 3, pt. 1, p. 146; pt. 2, p. 365. For Moera Michelin.

Moira A. Agassiz. Cooke, 1942, Jour. Paleontology, v. 16, no. 1, p. 43.

Moira A. Agassiz. Mortensen, 1951, Monograph of the Echinoidea, v. 5, pt. 2 , p. 325 . Includes additional synonymy.

Type species, Spatangus atropos Lamarck, validated by Opinion 209 of the International Commission on Zoological Nomenclature.

\section{Moira atropos (Lamarck) \\ Plate 30 , figures $1-4$}

Spatangus atropos Lamarck, 1816, Histoire naturelle des animaux sans vertèbres, v. $3, \mathrm{p} .32$.

Echinocardium atropos (Lamarck). Gray, 1825, Annals of Philosophy, ser. 2, v. 10, p. 430.

Schizaster atropos (Lamarck). Agassiz, 1836, Prodrome d'une monographie des radiaires ou échinodermes, p. 18.

Schizaster atropos (Lamarck). Ravenel, 1848, Echinidae, Recent and fossil, p. 4.

Schizaster atropos (Lamarck). Holmes, 1860, Post-Pleiocene fossils of South Carolina, p. 5, pl. 2, fig. 3.

Moira atropos (Lamarck). A. Agassiz, 1874, Harvard College Mus. Comp. Zoology Mem., v. 3, pt. 2, p. 365, pl. 23.

Moira atropos (Lamarck). Cooke, 1942, Jour. Paleontology, จ. 16, no. 1, p. 43.

Moira atropos (Lamarck). Mortensen, 1951, Monograph of the Echinoidea, v. 5, pt. 2, p. 329 , pl. 19, figs. 15, 20 ; pl. 55, figs. 11, 16, 19-23. Includes additional synonymy.

Horizontal outline suboval with an anterior notch, truncated behind; upper surface swollen behind, sloping steeply forward from the apical system; margin rounded; lower surface rounded. Apical system slightly posterior; two genital pores far apart, behind the anterior paired ocular pores but in line with the 
anterior ocular pore. Petals deeply sunken, depressions constricted at the top; posterior paired petals much shorter than the anterior pair. Peristome at the anterior quarter, reniform, strongly lipped. Periproct high on the posterior truncation, longer than wide. Peripetalous fasciole deeply indented in all five interambulacra, lying near the edges of the petals; lateral fascioles normal. Sutures bare. Long, curved, brown spines give a furry, mouselike appearance to the test.

Occurrence.-Littoral, North Carolina to Brazil.

South Carolina: Abbapoola Creek, Johns Island (fide Holmes). Intracoastal Waterway canal in Horry County 1 to $1 / 2$ miles southwest of the bridge on US 17 near Nixons Crossroads about 15 miles northeast of Myrtle Beach (USGS 18759, L. O. Glenn).

Geologic unit.-Pleistocene and Recent. Fla.

Figured specimen.-USNM 562461, from Panama City Beach,

Remarks.-This fragile little species is widely distributed in the Atlantic and Gulf of Mexico. According to Mortensen it has not been recorded from water deeper than 145 meters.

\section{Genus AGASSIZIA Valenciennes}

Agassizia Valenciennes, 1846, Voyage sur La Venus, Zoophytes, pl. 1, figs. 2-2f.

Agassizia Valenciennes. Agassiz and Desor, 1847, Catalogue raisonné des échinodermes, (reprint) p. 126.

Agassizia Valenciennes. Desor, 1858, Synopsis des échinides fossiles, p. 294.

Agassizia Valenciennes. A. Agassiz, 1872, Harvard College Mus. Comp. Zoology Mem., v. 3, p. 88, 353.

Agassizia Valenciennes. Cotteau, 1875, K. svenska vetensk.akad. Handl., Bandet 13, no. 6, p. 82.

Agassizia Valenciennes. Pomel, 1883, Classification méthodique et genera des échinides, p. 35.

Agassizia Valenciennes. H. L. Clark, 1917, Harvard College Mus. Comp. Zoology Mem., v. 46, no. 2, p. 163.

Agassizia Valenciennes. Jackson, 1922, Carnegie Inst. Washington Pub. 306, p. 70.

Agassizia Valenciennes. Lambert and Thiéry, Nomenclature raisonnée des échinides, fase. 8, p. 516.

Agassizia Valenciennes. Grant and Hertlein, 1938, California Univ. (Los Angeles) Pub. Math. and Phys. Sci., v. 2, p. 113.

Agassizia Valenciennes. Cooke, 1942, Jour. Paleontology, v. 16, no. 1, p. 44.

Agassizia Valenciennes. Mortensen, 1951, Monograph of the Echinoidea, v. 5, pt. 2, p. 339.

Type species, Agassizia scrobiculata Valenciennes (1846) by monotypy, living off the west coast of tropical and subtropical America. This species has been figured by A. Agassiz (1872, pl. 19a, figs. 1-3), Grant and Hertlein (1938, pl. 29, figs. 2, 3; pl. 30, fig. 12; text fig. 10 after Valenciennes), and Mortensen (1951, p. 342, pl. 19 , figs. $4,10,11$; pl. 55 , figs. $1-4,7,10,13,15)$. A distinctive feature is the great reduction in the width of the anterior poriferous zones of the anterior paired petals. The pores are consequently very inconspicuous. The species has a peripetalous fasciole, which is marginal in front, and lateral fascioles. This combination might better be described as a marginal fasciole and a hemipetalous fasciole.

\section{Agassizia porifera (Ravenel) \\ Plate 31, figures 1-8}

Brissopsis poriferus Ravenel, 1848, Echinidae, Recent and fossil, of South Carolina, p. 4, figs. 5, 6.

?Brissopsis rimulatus Ravenel, 1848, Echinidae, Recent and fossil, of South Carolina, p. 4, figs. 3,4 .

Agassizia porifera (Ravenel). McCrady in Tuomey and Holmes, 1857, Pleiocene fossils of South Carolina, p. 5, pl. 1, figs. $5-5 \mathrm{~b} ;$ pl. 2, figs. 4, $4 \mathrm{a}$.

?Agassizia rimulata (Ravenel). McCrady in Tuomey and Holmes, 1857, Pleiocene fossils of South Carolina, p. 5.

Agassizia porifera (Ravenel). Clark and Twitchell, 1915, U. S. Geol. Survey Mon. 54, p. 212, pl. 97, figs. 1a-d.

?Brissopsis rimulatus Ravenel. Clark and Twitchell, 1915, U. S. Geol. Survey Mon. 54, p. 154.

Agassizia porifera (Ravenel). Cooke, 1942, Jour. Paleontology, จ. 16, no. 1, p. 45.

?Agassizia rimulata (Ravenel). Cooke, 1942, Jour. Paleontology, v. 16, no. 1, p. 45.

Horizontal outline ovate, widest in front, truncated behind; upper surface strongly inflated to subconical, highest at the apical system, sloping steeply forward, less steeply to the posterior truncation; margin broadly rounded; lower surface gently inflated. Apical system nearly central; four genital pores, rather close together; ethmolytic, the madreporite extending beyond the posterior ocular pores. Anterior ambulacrum very slightly depressed, not at all depressed at the margin; pores obscure. Paired petals moderately depressed; long, the anterior pair extending nearly to the margin, the posterior pair somewhat shorter; anterior paired petals in line near the apex, curving gently forward to an angle of approximately $97^{\circ}$; posterior pair curving slightly outward to an angle of approximately $70^{\circ}$; pores of posterior petals and posterior zone of anterior pair oval, large; pores of anterior zone of anterior pair very small and inconspicuous, pore pairs oblique; interporiferous zones narrow. Peristome at the anterior quarter, reniform; labium large. Periproct large, transversely elliptical; at the top of truncation, which is depressed. Plastron expanding for more than half its length, then sides curving inward. Marginal fasciole complete, curving downward below the periproct; hemipetalous fasciole indented in the posterior and posterolateral interambulacra, meeting the marginal fasciole behind the anterior paired petals.

Length of larger specimen $68 \mathrm{~mm}$; width $63 \mathrm{~mm}$; height $49 \mathrm{~mm}$.

Occurrence.-South Carolina: The Grove, Cooper River (type, Ravenel, fide McCrady). Intracoastal Waterway canal in Horry County 1 to $1 \frac{1}{2}$ miles southwest of the bridge on US 17 near Nixons Crossroads, about 5 miles southwest of Little River (USGS 18759, L. C. Glenn). Near Oakley Inlet, Waccamaw 
(American Mus. Nat. History, figured by Clark and Twitchell). Geologic unit.-Late Miocene.

Figured specimens.-USNM 562462, from USGS 18759.

Remarks.-Agassizia rimulata, known only from Ravenel's figures, appears to be the same as A. porifera in spite of the fact that Ravenel attributes it to the Eocene. McCrady describes it as conical, less spherical than $A$. porifera, but one of the specimens here figured is subconical.

\section{Agassizia floridana de Loriol}

Plate 32, figures 1-4

Agassizia floridana de Loriol, 1887, Recueil zool. suisse, ser. 1 , v. 4, no. 3, p. 398, pl. 17, figs. 9-9f.

Agassizia conradi (Bouvé). Clark and Twitchell, 1915, U. S. Geol. Survey Mon. 54, p. 174, pl. 81, figs. 3a-d.

Agassizia inflata Jackson, 1922, Carnegie Inst. Washington Pub. 306 , p. 70, pl. 12, figs. $2-4$.

Agassizia egozcuei Lambert, 1922, Annals and Mag. Nat. History, ser. 9, v. 9, p. 596.

Agassizia inflata Jackson. Arnold and Clark, 1927, Harvard College Mus. Comp. Zoology Mem., v. 50, p. 56.

Agassizia conradi (Bouvé). Pijpers, 1933, Geog. geol. Medeleel. (Utrecht Rijksuniv. geog.' en mineral.-geol. Inst.) Phys.geol. Reeks no. 8, p. 92.

Agassizia caribbeana Weisbord, 1934, Bull. Am. Paleontology, v. 20 , no. 700 , p. 238 , pl. 27 , figs. 1-6.

Agassizia floridana de Loriol. Cooke, 1942, Jour. Paleontology, v. 16, no. 1, p. 44, pl. 3, figs. 1-4.

Agassizia floridana de Loriol. Fischer, 1951, Florida Geol. Survey Geol. Bull. 34, p. 73, pl. 6, figs. 3, 4 .

Horizontal outline obovate, truncated behind; upper surface strongly inflated, highest in front of the genital system; margin broadly rounded; lower surface gently convex. Apical system behind the center; four genital pores, close together; ethmolytic, madreporite extending between the ocular plates. Anterior ambulacrum very slightly depressed. Paired petals straight, slightly depressed; anterior pair twice as long as the posterior; both pairs diverging at an angle of approximately $90^{\circ}$; pores of posterior petals and posterior zone of anterior paired petals oval; plates of anterior zone of anterior paired petals small, pores very minute; interporiferous zones narrow. Peristome at the anterior third, large, reniform, weakly lipped. Periproct transversely oval, about midway up the posterior end, at the top of a truncation. Marginal fasciole curving downward below the periproct; hemipetalous fasciole meeting the marginal fasciole behind the anterior paired petals.

Length of figured specimen $36.2 \mathrm{~mm}$; width $35 \mathrm{~mm}$; height $28.4 \mathrm{~mm}$.

Occurrence.-Florida: Near Gainesville (type, Prof. Wetherby, fide de Loriol). About 12 miles north of Marianna (USGS 12058, W. C. Mansfield and G. M. Ponton, Florida Basic Rock Company, W. C. Mansfield and G. M. Ponton; USGS 14152, 11/2 miles west of Springfield Church, W. C. Mansfield and C. W. Mumm). Ocala (USGS 7383, C. W. Cooke). Zuber (USGS 6807, C. W. Cooke). Newberry (USGS 6812, C. W. Cooke).
Two miles northeast of Sumterville (USGS 12751, W. C. Mansfield and C. W. Mumm). One and one-quarter miles southwest of Inverness (USGS 7378, C. W. Cooke). Steinhatchee River opposite Clara (USGS 14541, figured specimen, C. W. Cooke; USGS 12747, W. C. Mansfield and G. M. Ponton). Crystal River Rock Company, 6 miles southeast of Crystal River (USGS 14141, W. C. Mansfield and C. W. Mumm). Johnson's lime sink (USNM 137881, L. C. Johnson). Between Inglis and Yankeetown, Levy County (USGS 14544, C. W. Cooke).

Georgia: Near Bainbridge (USGS 3770, figured by Clark and Twitchell, S. W. McCallie; USGS 6159, 6171, L. W. Stephenson; USGS 7097, C. W. Cooke and W. C. Mansfield).

West Indies: St. Bartholomew (types of $A$. inflata and $A$. egozcuei). Bonaire ( $A$. conradi, fide Pijpers). Jamaica ( $A$. inflata, fide Arnold and Clark). Cuba (type of $A$. caribbeana).

Geologic unit.-Late Eocene: Ocala limestone in Georgia and Florida and Inglis limestone in Florida; equivalent limestones in the West Indies.

Figured specimen.-USNM 562463, from USGS 14541, Steinhatchee River, Fla.

Remarks.-This species was identified as Hemiaster conradi Bouvé (1851, p. 3, 2 text figs.) by Clark and Twitchell, but according to H. L. Clark (Cooke, 1942, p. 45) the type of that species is "absolutely unidentifiable even to the family, let alone genus or species." Agassizia inflata Jackson, placed by Pijpers in the synonymy of $A$. conradi as identified by Clark and Twitchell, appears to be a synonym of A. floridana though its base is a little flatter, its peristome somewhat smaller, and its periproct somewhat lower; these features, particularly the location of the periproct, are obscure in the type of $A$. inflata. Both $A$. inflata and $A$. egozcuei are based on part of $A$. (Anisaster) clevei Cotteau (1875, p. 33, pl. 6, figs. 9, 10, not figs. 2-8) from which they differ in their more widely diverging anterior petals and in other features.

\section{Subgenus ANISASTER Pomel}

Anisaster Pomel, 1886, Soc. géol. France Bull., ser. 3, v. 14, pp. $610,612$.

Anisaster Pomel. Cotteau, 1887, Paléontologie française, Terrain tertiaire, ser. 1, v. 1, p. 374 .

Prenaster (Anisaster) Pomel. Lambert and Thiéry, 1925, Nomenclature raisonée des échinides, fasc. 8 , p. 515.

Eoagassizia Grant and Hertlein, 1938, California Univ. (Los Angeles) Pubs. in Math. and Phys. Sci. v. 2, p. 115.

Agassizia (Anisaster) Pomel. Cooke, 1942, Jour. Paleontology, v. 16, no. 1, p. 46.

Anisaster Pomel. Mortensen, 1951, Monograph of the Echinoidea, v. 5, pt. 2, p. 347 .

Type species, Agassizia gibberula Cotteau (1876) from the Eocene of Egypt, designated by Cotteau (1887, p. 381). This species has been figured by Cotteau and by de Loriol (1880, pl. 8, figs. 1-7; Mortensen, 1951, p. 347, text fig. 158). It appears to differ from Agassizia chiefly in that the plates of the anterior zone of the anterior paired petals are less reduced and their pores are consequently more conspicuous. It differs from Prenaster alpinus Desor in that its apical system is farther back, its anterior petals much less spreading, and its peristome longer than wide. 


\section{Agassizia (Anisaster) wilmingtonica Cooke} Plate 32, figures 10-13

Agassizia (Anisaster) wilmingtonica Cooke, 1942, Jour. Paleontology, v. 16, no. 1, p. 46, pl. 5, figs. 9-13.

Horizontal outline oval, truncated behind; upper surface moderately inflated, highest in the apical region, sloping forward rather steeply to the rounded margin, less steeply behind to the top of the truncation; lower surface gently inflated. Apical system near the posterior third; four genital pores rather far apart; ethmolytic, the madreporite extending between the posterior ocular plates. Anterior ambulacrum very slightly depressed near the apical system and the peristome; pores inconspicuous. Paired petals straight, slightly depressed, the anterior twice as long as the posterior; anterior pair diverging at an angle of approximately $110^{\circ}$, posterior about $85^{\circ}$; inner pores circular, outer pores elongated; plates of anterior poriferous zone of anterior pair smaller than others, distal pores oblique and larger than proximal pores, which are very inconspicuous. Peristome reniform, at the anterior third. Periproct transversely oval, at the top of the truncation. Sides of plastron curved. Marginal fasciole passing down below the periproct; hemipetalous fasciole meeting the marginal behind the anterior petals.

Length $21.2 \mathrm{~mm}$; width $18.5 \mathrm{~mm}$; height $14.2 \mathrm{~mm}$.

Occurrence.-North Carolina : City rock quarry near Wilmington (USNM 499004, L. W. Stephenson).

Geologic unit.-Late middle Eocene, Castle Hayne limestone. Type.-USNM 499004.

Remarks.-This species, known only from the type, is less inflated than A. floridana, its anterior petals are more divergent, the posterior petals are less divergent, and the anterior plates of the anterior paired petals are larger so that the distal pores are plainly visible.

\section{Agassizia (Anisaster) mossomi Cooke}

Plate 32, figures 5-9

Agassizia (Anisaster) mossomi Cooke, 1942, Jour. Paleontology, v. 16, no. 1, p. 46, pl. 5, figs. 14-17.

Horizontal outline oval, truncated behind; upper surface greatly inflated, steeply sloping forward from the apical system, very gently behind; margin broadly rounded; lower surface moderately convex. Apical system central; four genital pores close together; madreporite extending far behind. Anterior ambulacrum weakly depressed; pores far apart. Paired petals moderately depressed; anterior pair nearly twice as long as the posterior, diverging at an angle of approximately $90^{\circ}$; posterior pair diverging somewhat less; pores elongated-oval; anterior poriferous zone of anterior pair much narrower near the apex; interporif- erous zones narrow. Peristone at the anterior third, transversely oval, moderately lipped. Periproct large, transversely oval, at the top of the posterior truncation. Marginal fasciole descending below the periproct; hemipetalous fasciole meeting the marginal behind the anterior paired petals.

Length of holotype $27 \mathrm{~mm}$; width $24.5 \mathrm{~mm}$; height $23.4 \mathrm{~mm}$. Length of figured paratype $25.2 \mathrm{~mm}$; width $24 \mathrm{~mm}$; height 22.

Occurrence.-Florida: Florida Rock Products quarry $3 / 4$ mile southwest of Brooksville (types, USGS 11113, C. W. Cooke and Stuart Mossom). Consolidated Rock Products quarry 3 miles northeast of Brooksville (USGS 12321, W. C. Mansfield and Herman Gunter).

Georgia: Silicious molds of the interior, probably this species: Dawson-Albany road 31/2 miles south of Sasser (USGS 4059 , S. W. McCallie). Road from Americus to Plains 1/1/2 miles west of Muckalee Creek (USGS 12090, C. W. Cooke and W. H. Monroe).

Mississippi : Rocky Branch, SW $1 / 4$ sec. 8 , T. 8 N, R 5 W, 1 mile north-northeast of Denham, Wayne County (USGS 14288a, W. C. Mansfield and F. S. MacNeil).

Geologic unit.-Late Oligocene: Suwannee limestone in Florida, Flint River formation in Georgia, Chickasawhay limestone in Mississippi.

Type.-Holotype and paratype, USNM 498989, from USGS 11112.

Remarks.-Agassizia mossomi is higher and more nearly spherical, its apex is farther forward, its petals are more deeply sunken, and the anterior pores of the front pair are more fully developed than in A. floridana or A. wilmingtonica.

\section{Genus DITREMASTER Munier-Chalmas}

Ditremaster Munier-Chalmas, 1885, Acad. sci. Paris Comptes rendus, p. 1046.

Ditremaster Munier-Chalmas. Cotteau, 1887, Paléontologie française, Terrain tertiaire, ser. 1, t. 1, p. 411.

Ditremaster Munier-Chalmas. Mortensen, Monograph of the Echinoidea, v. 5, pt. 1, p. 397. Includes other references.

Type species, Hemiaster nux Desor, from the Nummulitic at Sauerbrunnen near Yberg, Switzerland, designated by Cotteau (1887, p. 422). As figured by Cotteau (1887, p. 419, pl. 117, figs. 7-12; pl. 118, figs. 1-4) this species is subglobular, with a very weak frontal depression; two genital pores, between which the madreporite protrudes; widely spreading petals, the anterior pair much the longer; and a peripetalous fasciole only. Perhaps the apparent lack of lateral fascioles may be the result of fossilization. The American species Schizaster beckeri, here referred to Ditremaster, seems to have lateral fascioles, though they are very obscure.

Ditremaster differs from Schizaster in its lack of a deep, continuous anterior sulcus and in its apparent lack of lateral fascioles. Its anterior paired petals are more widely spreading and less flexuous. 


\section{Ditremaster beckeri (Cooke)}

Plate 30, figures $9-12$

Schizaster beckeri Cooke, 1942, Jour. Paleontology, v. 16, no. 1, p. 40 , pl. 3, figs. 5-8.

Horizontal outline oval, wider in front than behind; upper surface strongly inflated, highest in the posterior half, sloping steeply forward to the rounded margin; lower surface gently convex. Apical system at the posterior third; 2 posterior genital pores; madreporite apparently extending between and beyond the posterior oculars. Anterior depression moderately deep in the petaliferous portion, very slight at the margin but still perceptible at the peristome; pore pairs strongly oblique, far apart. Paired petals depressed; anterior pair much longer than the posterior, nearly straight, nearly at right angles, rounded at the tips; posterior pair very short, nearly at right angles; pores elongated; interporiferous zones about equal to the poriferous zones. Peristome reniform, far forward, strongly lipped. Periproct elliptical, higher than wide, high up on the vertical posterior truncation. Fascioles very obscure because of an incrustation with calcite; apparently a peripetalous fasciole with deep reentrants between the lateral petals and straight or convex in front; apparently having lateral fascioles. Tubercles small, crowded.

Length of holotype $28.7 \mathrm{~mm}$; width $25.0 \mathrm{~mm}$; height $22.3 \mathrm{~mm}$. Length of paratype $31.5 \mathrm{~mm}$; width $28.2 \mathrm{~mm}$; height $24.3 \mathrm{~mm}$.

Occurrence.-Florida: Gainesville rock pit southeast of Arredondo, Alachua County (type, R. B. Becker). Suwannee River at bridge near Dowling Park, in Lafayette County (paratype, USGS 14553, C. W. Cooke).

Geologic unit.-Late Eocene, Ocala limestone.

Type.-USNM 499008 ; paratype USNM 499009.

Remarks.-This species seems to resemble Ditremaster nux (Desor), but its anterior petals are longer and its apical system is farther back. Schizaster subcylindricus Cotteau, from the St. Bartholomew limestone of Eocene age in the West Indies, is very closely related but has somewhat shorter anterior petals.

\section{Family LOVENIIDAE}

\section{Genus LOVENIA Desor}

Lovenia Desor in Agassiz and Desor, 1847, Annales sci. nat. (zoologie), ser. 3, v. 8, p. 11 (reprint, p. 116).

Lovenia Desor. A. Agassiz, 1872, 1873, Harvard College Mus. Comp. Zoology Mem., v. 3, p. 139, p. 574.

Sarsella Pomel, 1883, Classification méthodique et genera des échinides, p. 28. Type species Breynia sulcata Haime. Not Sarsella Haeckel, 1879.

Vasconaster Lambert, 1915, Schweizer. palaeont. Gesell. Abh., v. 41, p. 191 (note). For Sarsella Pomel.

Lovenia Desor. Cooke, 1942, Jour. Paleontology, v. 16, no. 1, p. 60 .

Vasconaster Lambert. Cooke, idem, p. 61.
Lovenia Desor. Mortensen, 1951, Monograph of the Echinoidea, v. 5, pt. 2, p. 89. Includes additional synonymy.

Type species Lovenia hystrix Desor $1847=$ Spatangus elongatus Gray 1845, living in the Indo-West Pacific region, by monotypy. Lovenia elongata has been figured by Agassiz and Desor (1847, p. 1, 16, fig. 16), by A. Agassiz (1874, p. 575, pl. 19c, figs. 1-4, etc.), and by Mortensen (1951, p. 97, pl. 7, figs. 1-10; pl. 8, fig. 1; pl. 12, fig. 5 ; pl. 47 , figs. $10-23)$. This species has an apical ("internal") fasciole, a bilobate subanal fasciole, crossshaped petals, and large, deeply sunken tubercles on the upper surface in the anterior interambulacra and the anterior part of the posterolateral interambulacra. The sunken tubercles protrude on the inside of the test. This seems to be a specific, not a generic feature; it is the principal difference between Lovenia and $V$ asconaster.

Lovenia alabamensis Cooke, n. sp.

Plate 32, figures 14-17

Horizontal outline heart shaped, emarginate in front, truncated behind, widest in front of the center; upper surface depressed; lower surface slightly concave; margin acutely rounded; posterior truncation concave. Apical system slightly anterior; four genital pores, close together; madreporite extending far behind. Anterior ambulacrum depressed. Petals V-shaped, terminating apically at the apical ("internal") fasciole; pores oval, conjugate. Peristome at the anterior third, semilunate; posterior lip slightly protruding. Periproct oval, wider than high, vertical, on the posterior truncation. Apical fasciole inconspicuous; subanal fasciole bilobate. Plastron very wide. Groups of large, imperforate, deeply sunken tubercles in the anterior interambulacra and in the anterior half of the posterolateral interambulacra; a few smaller tubercles along the median part of the posteriar interambulacrum.

Length $46 \mathrm{~mm}$; width $41.7 \mathrm{~mm}$; height $15 \mathrm{~mm}$.

Occurrence.-Alabama : Road cut just south of old mill in the NE1/4 sec. 8, T. 6 N., R. 3 E. Clarke County (USNM 562469, C. C. Branson and F. S. MacNeil).

Geologic unit.-Probably late Oligocene, Chickasawhay limestone.

Type.-USNM 562469.

Comparisons.-This species, known only from the type, is more slender than Lovenia clarki. Its poriferous zones are straighter and its posterior end wider than Lovenia elongata. The test is narrower and the large tubercles less extensive than those of Lovenia dumblei Kew.

\section{Lovenia clarki (Lambert)}

Plate 33, figure 6

Echinocardium depressum Clark, 1915, U. S. Geol. Survey Mon. 54, p. 214 , pl. 98 , figs. 3a-c. Not Amphidetus depressus Agassiz, 1847. 
Amphidetus clarki Lambert in Lambert and Thiéry, 1924, Nomenclature raisonnée des échinides, fasc. 6, p. 470. For Echinocardium depressum Clark.

Lovenia clarki (Lambert). Cooke, 1942, Jour. Paleontology, v. 16, no. 1, p. 60 .

Test cordate, depressed, truncated behind. Known only as molds of the interior, which show cross-shaped petals, evidently terminated apically by an apical fasciole.

Occurrence.-Florida: Chattahoochee, Gadsden County, 78 feet above sea level (USGS 2565 type, W. H. Dall and Joseph Stanley-Brown; USGS 4836, F. G. Clapp; USGS 3405; T. W. Vaughan; USGS 7168, G. C. Matson; USGS 6185, L. W. Stephenson; USGS 12282, W. C. Mansfield and G. M. Ponton).

Geologic unit.-Early Miocene, base of Tampa limestone.

Type.-USNM 164654.

Remarks. -The generic location of this species is somewhat uncertain because many of its features are unknown. It is referred to Lovenia because it is much flatter than Echinocardium and apparently had large tubercles.

\section{Genus ECHINOCARDIUM Gray}

Echinocardium Gray, 1825, Annals of Philosophy, ser. 2, v. 10, p. 430.

Amphidetus Agassiz, 1836, Soc. sci. nat. Neuchâtel Mem., v. 1, p. 184.

Amphidetus Agassiz. Agassiz and Desor, 1847, Annales sci. nat. (zoologie), ser. 3, v. 7, (reprint) p. 117.

Echinocardium Agassiz. A. Agassiz, 1872, Harvard College Mus. Comp. Zoology Mem., v. 3, p. 109, 349.

Echinospatagus Breynius. Pomel, 1883, Classification méthodique et genera des échinides, p. 28

Echinospatagus (Echinocardium) Gray. Pomel, 1883, idem, p. 28.

Echinospatagus (Amphidetus) Agassiz. Pomel, 1883, idem, p. 28.

Echinocardium Gray. H. L. Clark, 1917, Harvard College Mus. Comp. Zoology Mem., v. 46, no. 2, p. 261.

Echinocardium Gray. Lambert and Thiéry, 1924, Nomenclature raisonnée des échinides, fasc. 6, p. 468.

Amphidetus Agassiz. Lambert and Thiéry, 1924, idem, p. 469.

Echinocardium Gray. Cooke, 1942, Jour. Paleontology, v. 16, no. 1 , p. 59.

Echinocardium Gray. Mortensen, 1951, Monograph of the Echinoidea, v. 5, p. 2, p. 149. Includes additional synonymy.

Type species, Spatangus pusillus Leske 1778= Echinus cordatus Pennant 1777, validated by Opinion 209 of the International Commission on Zoological Nomenclature.

Echinocardium is characterized by four V-shaped petals, a conspicuous apical ("internal") fasciole, a subanal fasciole with anal branches, but no peripetalous fasciole. It differs conspicuously from Lovenia in the lack of large sunken tubercles.

\section{Echinocardium cordatum (Pennant)}

Echinus cordatus Pennant, 1777, British Zoology, v. 4, p. 58, pl. 34, fig. 2.
Echinocardium cordatum (Pennant). A. Agassiz, 1872, 1873, Harvard College Mus. Comp. Zoology Mem., v. 3, p. 109, 349 , 580 , pl. 19 , figs. $10-17$; pl. 20 , figs. $5-7$; pl. 25 , figs. 27 , 28 ; pl. 33, fig. 6.

Echinocardium cordatum (Pennant). H. L. Clark, 1917, idem, v. 46, no. 2, p. 262.

Echinocardium cordatum (Pennant). Cooke, 1942, Jour. Paleontology, v. 16, no. 1, p. 60.

Echinocardium cordatum (Pennant). Mortensen, 1951, Monograph of the Echinoidea, v. 5, pt. 2, p. 152, pl. 18, figs. 6 , 7. Includes additional synonymy.

The test of this highly variable species is higher behind than in front. The anterior ambulacrum is deeply sunken. The apical system is near the posterior third; it has four genital pores, the lateral pairs far apart, the front and back pores close together; it is ethmolytic, the madreporite extending behind the ocular plates. The four petals are $V$-shaped; the posterior poriferous zones of the anterior pair diverge at right angles and terminate apically at the apical ("internal") fasciole, the anterior zones terminate before reaching it; the posterior petals are less divergent and shorter. The reniform peristome lies near the anterior third; it is much wider than long and has a prominent lip. The periproct is high up on the somewhat pointed posterior end. The apical fasciole is about twice as long as wide and has somewhat rounded contours. The subanal fasciole is shield shaped, higher than wide. It adjoins a narrow anal fasciole, which extends upward close to the periproct and beyond it. A group of fairly large tubercles adjoins the anterior ambulacrum.

Occurrence.-Nearly world-wide, in water less than 230 meters deep (Mortensen, 1951, p. 157).

Geologic unit.-Recent.

\section{Echinocardium orthonotum (Conrad)}

Plate 33, figures 1-5

Spatangus orthonotus Conrad, 1843, Acad. Nat. Sci. Philadelphia Proc., v. 1, p. 327.

Amphidetus virginianus Forbes, 1845, Geol. Soc. London Quart. Jour., v. 1, p. 425, 3 figs.

Amphidetus orthonotus (Conrad). Tuomey and Holmes, 1855, Pleiocene fossils of South Carolina, pl. 2, figs. 1-1c.

Echinocardium virginianum (Forbes). Desor, 1858, Synopsis des échinides fossiles, p. 408.

Amphidetus virginianus Forbes. Emmons, 1858, North Carolina Geol. Survey, Agriculture of the eastern counties, p. 310, figs. 245a-c.

Echinocardium orthonotum (Conrad). Clark, 1904, Maryland Geol. Survey, Miocene, p. 430, pl. 119, figs, la-c.

Echinocardium orthonotum (Conrad). U. S. Geol. Survey Mon. 54, p. 213, pl. 97, figs. 2a-c; pl. 98, figs. la-c, 2a-c.

Echinocardium orthonotum (Conrad). Schoonover, 1941, Jour. Paleontology, v. 15, p. 92.

Echinocardium orthonotum (Conrad). Cooke, 1942, Jour. Paleontology, v. 16, no. 1, p. 60. 
Horizontal outline subquadrate, emarginate in front, widest in front of the center; upper surface high, highest and rostrate behind, sides steep; margin acutely rounded. Apical system slightly anterior; four genital pores, close together; ethmolytic. Anterior ambulacrum sunken, not petaloid. Petals V-shaped, open apically, nearly closed distally; pores circular, far apart; posterior poriferous zone of anterior petals crossing the apical fasciole, other poriferous zones entirely outside the fasciole. Peristome wider than long, reniform, strongly lipped; at the anterior third. Periproct nearly circular, vertical, on a sunken area. Plastron long, V-shaped, rostrate behind. Escutcheon shield shaped, vertical, surrounded by a subanal fasciole. Anal fasciole not apparent. Apical ("internal") fasciole pentagonal, longer than wide, straight sided, anterolateral sides parallel, posterolateral sides Vshaped. Lateral interambulacra excluded from the peristome. A group of fairly large tubercles adjoins the anterior ambulacrum.

Lengths of figured specimens $50,44 \mathrm{~mm}$; widths 48 , $43 \mathrm{~mm}$; heighths $25,26.3 \mathrm{~mm}$.

Occurrence.-Virginia: Near Coggins Point, James River (type, fide Conrad). Chuckatuk, just below mill dam north of village (USNM 116517, M. W. Twitchell). Prince George (USNM 1688, J. L. Bridges).

Maryland: Jones Wharf, Patuxent River (Maryland Geological Survey). About one-quarter mile north of Scientists Cliffs, Chesapeake Bay, Calvert County (USNM 498690, W. F. Foshag and James Benn).

Florida: Jackson Bluff, Ochlockonee River, lower part of Cancellaria zone (USGS 13949a, W. C. Mansfield and F. S. MacNeil).

Geologic unit.-Miocene; Choptank formation in Maryland, Yorktown(?) formation in Virginia, Duplin marl in Florida.

Figured specimens.-USNM 498960, from Scientists Cliffs.

Remarks.-The specimens from Maryland appear to be proportionately shorter, more quadrate than those from Virginia, which are not well represented in the collections of the National Museum. Perhaps they should be given a new name. The Maryland form is locally very abundant. Its apical system is farther forward than that of $E$. cordatum and the sides of its apical fasciole are straighter.

\section{Echinocardium gothicum (Ravenel)}

Plate 33, figures $\mathbf{7 - 1 0}$

Amphidetus gothicus Ravenel, 1848, Echinidae, Recent and fossil, of Carolina, p. 4, figs. 1, 2.

Amphidetus ampliflorus McCrady in Toumey and Holmes, 1855, Pleiocene fossils of South Carolina, p. 6, pl. 3, figs. 2, 2a.

Amphidetus gothicus Ravenel. McCrady in Toumey and Holmes, 1855, Pleiocene fossils of South Carolina, p. 7, pl. 3, figs. 3, $3 \mathrm{a}-\mathrm{f}$.

Echinocardium gothicus (Ravenel). Clark and Twitchell, 1915, U. S. Geol. Survey Mon. 54, p. 214.

Amphidetus gothicus Ravenel. Lambert and Thiéry, 1924, Nomenclature raisonnée des échinides, fasc. 6, p. 470.
Echinocardium gothicum (R a venel). Cooke, 1942, Jour. Paleontology, v. 16, no. 1, p. 60.

Horizontal outline suboval, emarginate in front; upper surface strongly inflated, steeply sloping on all sides; oral side rather flat; margin acutely rounded. Apical system nearly central; four genital pores close together; ethmolytic, the madreporite extending far behind. Anterior ambulacrum slightly depressed. Paired petals narrow at the outer ends, very wide apically, poriferous zones much reduced within the apical ("internal") fasciole except the posterior zone of the anterior paired petals. Apical fasciole V-shaped behind, sides parallel in front, crossing the anterior ambulacrum near the front end. Peristome large, lunate; strong posterior lip. Periproct not preserved.

Length (posterior end broken) about $80 \mathrm{~mm}$; width $70 \mathrm{~mm}$; height $49 \mathrm{~mm}$.

Occurrence.-South Carolina: The Grove, Cooper River (fide McCrady). Intracoastal Waterway canal in Horry County 1 to $1 \frac{1}{2}$ miles southwest of bridge on US 17 near Nixons Crossroads, about 15 miles northeast of Myrtle Beach (USGS 18759, L. C. Glenn).

Geologic unit.-Probably late Miocene

Type-Unknown. Figured specimen USNM 562468 from USGS 18759.

\section{Family UNIFASCIIDAE, new family}

Apical system ethomolytic, four genital pores. Anterior ambulacrum not petaliferous. Petals long; an terior pair very widely diverging; pores slightly elon. gated. A marginal fasciole; no other fascioles.

This new family is proposed to receive the new genus Unifascia, which seems to fit into none of the established families.

\section{Genus UNIFASCIA Cooke, new genus}

Type species, Macropneustes carolinensis Clark. This species, described more fully herein, resembles Macropneustes in many features but lacks a subanal fasciole and a peripetalous fasciole. Instead it has a rather wide marginal fasciole, which lies well beyond the ends of the petals and is not at all indented. The four genital pores are farther apart than those of Macropnenstes mortoni, and the madreporite seems not to extend so far back. The primary tubercles are not confined within the fasciole but cover nearly the whole test.

The posterior petals of Unifascia carolinensis are much less widely spreading than those of Mauritanaster gentili Lambert as figured by Lambert (Mortensen, 1951 , p. 551, fig. 276), and that species is said to lack fascioles. It also is much lower.

Unifascia does not fit into any of the families recognized in Mortensen's Monograph of the Echinoidea.

The long, widely spreading petals suggest Linthia, but the fasciole is quite different, the genital pores are 
farther apart, and the anterior ambulacrum is less depressed.

\section{Unifascia carolinensis (Clark)}

Plate 34, figures 7-13

Macropneustes carolinensis Clark, 1915, U. S. Geol. Survey Mon. 54, p. 154, pl. 71, figs. 5a-d.

Mauritamaster carolinensis (Clark). Lambert and Thiéry, 1924, Nomenclature raisonnée des échinides, fasc. 7, p. 493. Macropneustes carolinensis Clark. Cooke, 1942, Jour. Paleontology, v. 16, no. 1, p. 51 .

Test hemispherical. Horizontal outline oval, truncated in front and behind. Upper surface strongly swollen, highest behind the apical system, flattened in front. Margin broadly rounded. Lower surface gently convex. Apical system at the anterior third; four genital pores, rather far apart; ethmolytic, the madreporite extending between the ocular plates. Anterior ambulacrum flattened or slightly depressed; not petaloid; pore pairs oblique, far apart. Petals long, straight, moderately sunken; anterior pair the longer, diverging at an angle of $138^{\circ}$; posterior pair diverging at an angle of $40^{\circ}$; pores oval or slightly elongated, conjugate; interporiferous zones as wide as the poriferous, not expanding medially. Peristome semilunate, labrum prominent. Periproct oval, higher than wide, vertical, near midheight at the top of a flattened area. Tubercles perforated, crenulated, widely distributed. Marginal fasciole rather wide, circular, passing just above the periproct and below the ends of the petals. No other fascioles.

Length of type $28 \mathrm{~mm}$; width $27.4 \mathrm{~mm}$; height $22 \mathrm{~mm}$. Length of largest figured specimen $38 \mathrm{~mm}$; width 37.7 $\mathrm{mm}$; height $27.5 \mathrm{~mm}$.

Occurrence.-North Carolina: Wilmington (type, USGS 3602, Frank Burns). J. A. Stokes' farm 2 miles north of creek near Maple Cypress, Craven County (USGS 8165, J. A. Cushinan). Southern Drainage Canal about 9 miles northwest of Vanceboro, Pitt County (USGS 11810, W. C. Mansfield).

Geologic unit.-Middle Eocene, Castle Hayne limestone.

Type-USNM 164651. Figured specimens, USNM 562447, from USGS 8165; USNM 562448, from USGS 11810.

\section{Family SPATANGIDAE}

Genus SPATANGUS Gray

Spatangus Klein. Gray, 1825, Annals of Philosophy., v. 10, p. 430.

Spatangus Klein. A Agassiz, 1873, Harvard College Mus. Comp. Zoology Mem., v. 3, p. 564.

Prospatangus Lambert. Lambert and Thiéry, 1924, Nomenclature raisonnée des échinides, fasc. 6, p. 459.

Spatangus Müller. Grant and Hertlein, 1938, California Univ. (Los Angeles) Pub. Math. and Phys. Sci., v. 2, p. 131.

Spatangus Gray. Mortensen, 1951, Monograph of the Echinoidea, v. 5, pt. 2, p. 6. Includes additional synonymy.

Type species, Spatangus purpureus Müller, by monotypy. Genus validated as of Gray 1852 by Opinion 209 of the International Commission on Zoological Nomenclature. Spatangus purpureus, as figured by $\mathbf{A}$. Agassiz (pl. 34, figs. 3, 4) is heart shaped, with long closed paired petals. The anterior poriferous zone of the anterior pair is rudimentary near the apex but normal distally. The species has a complete subanal fasciole but lacks other fascioles. It inhabits the eastern part of the Atlantic Ocean.

\section{Spatangus glenni Cooke, n. sp.}

Plate $\mathbf{3 5}$, figures $\mathbf{1 - 5}$

Horizontal outline obovate, with a shallow frontal notch; upper surface strongly inflated, geniculate in front, sloping evenly behind; lower surface flattish; margin subacute. Apical system slightly anterior, not preserved. Anterior ambulacrum not at all petaloid. Paired petals irregularly lanceolate, nearly closed distally; pores circular; proximal half of anterior poriferous zone of anterior petals rudimentary; interporiferous zones much wider than poriferous zones. Peristome at the anterior third, lunate, with a high, prominent labrum. Periproct transversely oval, terminal, not visible from above, visible from below, at the top of a concave depression. Subanol fasciole canoe shaped, wider than high; no other fascioles apparent. Floscelle having a single row of pores on each side. Large scrobiculate tubercles on apical part of interambulacra; tubercles elsewhere small.

Length $108 \mathrm{~mm}$; width about $101 \mathrm{~mm}$; height $58 \mathrm{~mm}$.

Occurrence.-South Carolina: Intracoastal Waterway canal in Horry County 1 to $1 \frac{1}{2}$ miles southwest of the bridge on US 17 near Nixons Crossroads, about 15 miles northeast of Myrtle Beach (USGS 18759, L. C. Glenn).

Geologic unit.-Probably late Miocene.

Type and two paratypes.-USNM 562499.

Remarks.-This species is known only from the type and two paratypes, all imperfect. Its interporiferous zones are much wider than those of Spatangus purpureus as figured by A. Agassiz $(1873$, pl. 34, fig. 3 ). The specific name commemorates the late Prof. L. C. Glenn of Vanderbilt University.

\section{Genus MARETIA Gray}

Spatangus (Maretia) Gray, 1855, Catalogue of the Recent Echidna, p. 48.

Hemipatagus Desor, 1858, Synopsis des échinides fossiles, p. 416. Type species spatangus hoffmanni Goldfuss.

Maretia Gray. A. Agassiz, 1874, Harvard College Mus. Comp. Zoology Mem., v. 3, p. 568.

Hemipatagus Desor. Pomel, 1883, Classification méthodique et genera des échinides, p. 29.

Maretia Gray. Cotteau, 1885, Paléontologie française, Terrain tertiaire, ser. 1, t. 1, p. 24.

Hemipatagus Desor. Lambert and Thiéry, 1924, Nomenclature raisonnée des échinides, fasc. 6, p. 456. 
Hemipatagus Desor. Cooke, 1942, Jour. Paleontology, v. 16, no. 1, p. 52 .

Maretia Gray. Mortensen, 1951, Monograph of the Echinoidea, v. 5, no. 2, p. 21 . Includes additional synonymy.

Type species, Spatangus planulatus Lamarck, by monotypy. This species, living in the Indo-Pacific region, has been figured by Mortensen (1951, p. 27, pl. 4 , figs. 1-5, 10, 11; pl. 5, figs. 3-17). It has large, perforated tubercles on the upper surface in the paired interambulacra but none in the posterior interambulacrum. It has a subanal fasciole but no others.

A difference possibly validating Hemipatagus as a subgenus is that large tubercles are confined to the anterior half of the paired interambulacra. This seems to be usual in the Eocene species.

\section{Maretia arguta (Clark)}

Plate 34, figures 1-4

Hemipatagus argutus Clark, 1915, U. S. Geol. Survey Mon. 54, p. 150 , pl. 69 , figs. 1a-d.

Hemipatagus argutus Clark. Cooke, 1942, Jour. Paleontology, v. 16, no. 1, p. 52.

Horizontal outline angularly cordate, emarginate in front, truncated behind and on the anteriolateral and posterolateral margins; widest in front of the center; upper surface rather low, highest behind, rostrate behind; margin subacute; lower surface nearly flat. Apical system at the anterior third; four genital pores; apparently ethmolytic. Anterior ambulacrum not petaloid, slightly depressed, forming a wide V-shaped emargination in front. Paired petals straight, rather short, extending little more than halfway to the margin; anterior pair diverging at an angle of approximately $150^{\circ}$; posterior pair diverging at an angle of approximately $40^{\circ}$; pores oval; interporiferous zones nearly equal to the poriferous zones, tapering slightly at each end. Peristome farther forward than the apical system, transverse, ends rounded, labrum prominent. Periproct terminal, transversely oval, vertical. Subanal fasciole nearly obliterated. Large scrobiculate tubercles confined to the anterior interambulacra and the anterior half of the posterior paired interambulacra on the upper surface; smaller tubercles on the lower surface.

Length of type $28 \mathrm{~mm}$; width $27.5 \mathrm{~mm}$; height 13.3 $\mathrm{mm}$.

Occurrence.-Mississippi: Chickasawhay River at Enterprise (type, USGS 2629, Frank Burns). Rose Hill road 8 miles west of Enterprise (USGS 2621, Frank Burns). North of mile post 20, New Orleans \& Northeastern Railway, 1 mile north of Wautubbee, Clarke County (USGS 6479, E. N. Lowe and C. W. Cooke)

Geologic unit.-Eariy middle Eocene, Winona sand.

Type.-USNM 141107, from USGS 2629

\section{Maretia subrostrata (Clark)}

Plate 34, figures 5, 6

Hemipratagus subrostratus Clark, 1915, U. S. Geol. Survey Mon. 54, p. 151, pl. 69, figs. 2a-b.

Hemipratagus subrostratus Clark. Cooke, 1942, Jour. Paleontology, v. 16, no. 1, p. 53 .

The type of this species is very similar to that of $M$. arguta, and the differences may be merely individual variations. It is slightly larger, its horizontal outline is more rounded, less angular, and its posterolateral margins are less compressed. Though it probably will prove to be a synonym of $M$. arguta, $M$. subrostrata is tentatively kept separate because there are recognizable differences between the types and because they occupy slightly different horizons, $M$. subrostrata being the younger, though both are middle Eocene.

Length of type $32.2 \mathrm{~mm}$; width $28.7 \mathrm{~mm}$; height 14.9 $\mathrm{mm}$.

Occurrence.-North Carolina: Wilmington (type, USGS 3602, Frank Burns; county rock quarry, USNM 166516, L. W. Stephenson.)

Geologic unit.-Late middle Eocene, Castle Hayne limestone or Santee limestone.

Type.-USNM 164652. Figured specimen, USNM 166516.

Comparison.-Maretia subrostrata appears to be very similar to Maretia desmoulinsi (Cotteau) as figured by Cotteau $(1885$, p. 26, pl. 2, figs. 1-6).

\section{Family BRISSIDAE}

Genus Brissus Gray

Brissus Gray, 1825, Annals of Philosophy, ser. 2, v. 10, p. 431. Brissus Aristotle, Klein. Desor, 1858, Synopsis des échinides fossilies, p. 403.

Brissus Klein. A. Agassiz, 1872, Harvard College Mus. Comp. Zoology Mem., v. 3, p. 356.

Brissus Gray. Cooke, 1942, Jour. Paleontology, v. 16, no. 1, p. 47.

Brissus Gray, Mortensen, 1951, Monograph of the Echinoidea, v. 5 , pt. 2 , p. 505 . Includes additional synonymy.

Type species, Spatangus brissus var. unicolor Leske (1778), designation validated by Opinion 209 of the International Commission on Zoological Nomenclature. Characteristic features are an ethomlytic, anterior apical system with four genital pores; wide-spreading anterior paired petals; a sinuous peripetalous fasciole and a reniform subanal fasciole.

Brissus unicolor (Leske)

Plate 36, figures $1-4$

Spatangus brissus var. unicolor Leske, 1778, Klein's Naturalis dispositio echinodermatum, p. 248, pl. 26, figs. B, C.

Brissus unicolor (Leske). Gray, 1825, Annals of Philosophy, ser. 2, v. 10, p. 431.

Brissus unicolor (Leske). A. Agassiz, 1872, Harvard College Mus. Comp. Zoology Mem., v. 3, pp. 97, 357, pl. 22, figs. 1, 2; pl. 37 , fig. 19. 
Brissus unicolor (Leske). Cooke, 1942, Jour. Paleontology, v. 16, no. 1, p. 47.

Brissus unicolor (Leske). Mortensen, 1951, Monograph of the Echinoidea, v. 5, pt. 2, p. 509, pl. 38, fig. 10. Includes additional synonymy.

Horizontal outline obovate; upper surface moderately inflated; margin rounded; lower surface gently convex. Apical system at the anterior third; four genital pores; ethmolytic, the madreporite extending between the posterior ocular plates. Anterior ambulacrum flush; pores far apart. Anterior paired petals nearly in a straight line, slightly curved forward, extending three-fourths of the width. Posterior petals straight, somewhat longer, diverging at an angle of $40^{\circ}$; pores oval; interporiferous zones narrow. Peristome semilunate, at the anterior third, weakly lipped. Periproct longer than wide; well up on the posterior end. Peripetalous fasciole sinuous; subanal fasciole reniform. Tubercles perforated.

Length of figured specimen $25 \mathrm{~mm}$; width $19.7 \mathrm{~mm}$; height $13 \mathrm{~mm}$. Another specimen from the same place measures $32.7 \mathrm{~mm}$ by $25 \mathrm{~mm}$ by $17 \mathrm{~mm}$.

Occurrence.-Southern Florida, tropical Atlantic, and Mediterranean (Clark).

South Carolina: Intracoastal Waterway canal in Horry County 1 to $1 \frac{1 / 2}{2}$ miles southwest of the bridge on US 17 near Nixons Crossroads, about 15 miles northeast of Myrtle Beach (USGS 18759, L. C. Glenn).

Geologic unit.-Pleistocene to Recent.

Figured specimen.-USNM 562450, Cayo la Vela, Cuba, (R. E. Dickerson).

\section{Brissus glenni Cooke, n. sp. \\ Plate 36, figures 5, 6}

Test large, deformed by pressure, lower surface wanting. Apical system anterior; four genital pores close together; ethmolytic, the madreporite extending far behind the posterior ocular plates. Anterior ambulacrum flush or slightly depressed, pore pairs longitudinal. Paired petals depressed, the depression increased by distortion; anterior pair nearly in line, slightly curved forward; posterior pair longer, slightly diverging, bent outward beyond the midlength; pores circular, conjugate; interporiferous zones narrow. Peripetalous fasciole deeply reentrant.

Length (shortened by compression) $108 \mathrm{~mm}$; width (incomplete) $57 \mathrm{~mm}$; height (incomplete) $54 \mathrm{~mm}$.

Occurrence.-South Carolina: Intracoastal Waterway canal in Horry County 1 to $1 \frac{1}{2}$ miles southwest of the bridge on US 17 near Nixons Crossroads, about 15 miles northeast of Myrtle Beach (USGS 18759, L. C. Glenn).

Geologio unit.-Probably late Miocene.

Type.-USNM 562451.

Remarks.-This species, known only from the deformed, broken type is much larger than Brissus unicolor from the American region, and the peripetalous fasciole is more deeply reentrant. It is named in memory of Prof. L. C. Glenn, the collector.

\section{Genus MACROPNEUSTES Agassiz}

Macropneustes Agassiz in Agassiz and Desor, 1847, Annales sci. nat. (zoologie), ser. 3, v. 8, p. 9 (reprint, Catalogue raisonné, p. 114).

Meoma Gray, 1851, Annals and Mag. Nat. History, ser. 2, v. 7, p. 131.

Macropneustes Agassiz. Desor, 1858, Synopsis des échinides fossiles, p. 409.

Meoma Gray. Desor, 1858 Synopsis des échinides fossiles, p. 423. Rhyssorbrissus A. Agassiz, 1863, Harvard College Mus. Comp. Zoology Bull. v. 1, p. 27.

Hemibrisuss Pomel, 1869, Revue des échinodermes, p. 13. Typr: species, Spatangus ventricosus Lamarck.

Brissus (Meoma) Gray. A. Agassiz, 1872, Harvard College Mus Comp. Zoology Mem., v. 3, p. 142, 358.

Macropneustes Agassiz. Pomel, 1883, Classification méthodiqun! et genera des échinides, p. 32.

Meoma Gray. Pomel, 1883, Classification méthodique et genera des échinides, p. 35.

Not Macropneustes Agassiz. Duncan and Sladen, 1884, Palaeontologia Indica, ser. 14, v. 1, pt. 3, p. 229.

Macropneustes Agassiz. Cotteau, 1886, Paléontologie française, Terrain tertiaire, ser. 1, v. 1, p. 140.

Eupatagus (Macropneustes) Agassiz (part). Duncan, 1889 Linnean Soc. London Jour., Zoology, v. 23, p. 255.

Macropneustes Agassiz. Egozcue y Cia, 1897, Comision del Mapa Geológico de España Bol., v. 22, p. 89.

Meoma Gray. H. L. Clark, 1917, Harvard College Mus. Comp. Zoology Mem., v. 47, no. 2, p. 220.

Macropneustes Agassiz. Jackson, 1922, Carnegie Inst. Washington Pub. 306, p. 84.

Macropneustes Agassiz. Lambert and Thiéry, 1924, Nomenclature raisonnée des échinides, fasc. 7, p. 493.

Meoma Gray. Lambert and Thiéry, 1924, idem, p. 495.

Macropneustes Agassiz. Grant and Hertlein, 1938, California Univ. (Los Angeles) Pub. Math. and Phys. Sci., v. 2, p. 127.

Meoma Gray. Grant and Hertlein, 1938, idem, p. 130.

Meoma Gray. Cooke, 1942, Jour. Paleontology, v. 16, no. 1, p. 47.

Mracropneustes Agassiz. Cooke, Jour. Paleontology, v. 16, no. 1, p. 50.

Macropneustes Agassiz. Mortensen, 1951, Monograph of the Echinoidea, v. 5, pt. 2, p. 450. Includes additional synonymy.

Meoma Gray. Mortensen, 1951, idem, p. 524.

Type species, Macropneustes deshayesii Agassiz (first named without description under Micraster), from the Eocene of the Paris Basin, designated by Jackson (1922, p. 84). This species has been figured by Desor (1858, pl. 44, figs. 2, 3) by Cotteau (1886, p. 141, pls. 31-33), and by Mortensen (1951, fig. 221 after Cotteau). Cotteau's figures show a broad, heart-shaped test with a nearly central apical system; weak frontal depression extending to the peristome; long, widely spreading slightly depressed paired petals; an elliptical periproct higher than wide; a nearly circular peripetalous fasciole; and a bilobed or reniform subanal fasciole. 
As here interpreted, the genus shows a good deal of variation in the depth of the ambulacral depressions. Middle Eocene species usually have a conspicuous anterior depression and moderately depressed petals, whereas in late Eocene species they tend to be almost flush.

Peripneustes Cotteau (1875, p. 38), type species $P$. clevei Cotteau, here designated, is usually considered a synonym of Macropneustes but may be different. Its apical system is farther forward, its anterior ambulacrum and paired petals are deeply depressed, its peripetalous fasciole is strongly reentrant; and its large tubercles are confined within the fasciole. Cotteau's figured specimen of Peripneustes antillarum Cotteau, from Cuba, probably represents the same species as $P$. clevei, from the Miocene of Anguilla. Cotteau's specimen of $P$. antillarum from the Eocene of the St. Bartholomew limestone of the West Indies, figured by Jackson (1922, pl. 15, fig. 1) under Macropneustes, has been renamed Schizobrissus jacksoni Lambert (Sanchez Roig, 1926, p. 121). Lambert (1922, p. 590) transfers Peripneustes clevei to Schizobrissus.

There seem to be no generic distinctions between the Eocene Macropneustes deshayesii and the two Recent species heretofore referred to Meoma, namely Meoma grandis Gray (the type species) from the Pacific Ocean and Spatangus ventricosus Lamarck from the Atlantic.

\section{Macropneustes mortoni (Conrad)}

Plate 37, figures 5-9

Holaster mortoni Conrad, Acad. Nat. Sci. Philadelphia Jour., ser. 2, v. 2, p. 40, pl. 1, fig. 10.

Macropneustes cubensis Cotteau, 1875, K. vetensk-akad. Handl., v. 13 , no. 6 , p. 6 .

Macropneustes cubensis Cotteau. Cotteau, 1876, Soc. géol. France Bull, ser. 3, v. 5, p. 130.

Macropneustes cubensis Cotteau. Cotteau, 1881, Soc. géol. Belgique Annales, v. 9, p. 48, pl. 4, fig. 7.

Macropneustes cubensis Cotteau. Egozcue y Cia, 1897, Com. mapa geol. España Bol., v. 22, p. 91 , pl. 23, figs. 1-4; pl. 25, fig. 7 .

Asterostoma castroi Egozcue, 1897, idem, p. 92. MS name cited and identified as $M$. cubensis.

Macropneustes mortoni (Conrad). Clark and Twitchell, 1915, U. S. Geol Survey Mon. 54, p. 155, pl. 72, figs. 1a-d.

Eupatagus cubensis (Cotteau). Jackson, 1922, Carnegie Inst. Washington Pub. 306, p. 94.

Mauritanaster cubensis (Cotteau). Lambert in Sanchez Roig, 1923, Soc. cubana historia nat. "Felipe Poey" Mem., v. 5, no. 1, p. 44 (1924, reprint, p. 42 ).

Antillaster castroi (Egozcue). Lambert in Sanchez Roig, 1923, Soc. cubana historia nat. "Felipe Poey" Mem., v. 5, no. 1, p. 44 (1924, reprint, p. 42).

Trachypatagus castroi (Egozcue). Lambert in Sanchez Roig, 1923, Soc. cubana historia nat. "Felipe Poey" Mem., v. 5, no. 1, p. 48 (reprint, p. 46 ).
Antillaster castroi (Egozcue). Sanchez Roig, 1923, Soc. cubana historia nat. "Felipe Poey" Mem., v. 5, no. 1, p. 35 (reprint, p. 33).

Mauritanaster cubensis (Cotteau). Sanchez Roig, 1923, Soc. cubana historia nat. "Felipe Poey" Mem., v. 5, no. 1, p. 38 (1924, reprint, p. 36).

Macropneustes mortoni (Conrad). Cooke, 1926, Alabama Geol. Survey Special Rept. 14, pl. 96, figs. 1a-b.

Macropneustes mortoni (Conrad). Cooke, 1942, Jour. Paleontology, v. 16, no. 1, p. 51.

Test thin. Horizontal outline broadly oval, flattened or very slightly emarginate in front. Upper surface swollen, evenly rounded. Margin broadly rounded. Lower surface flattish, depressed around the peristome. Apical system at the anterior third; 4 genital pores, close together; ethmolytic, the madreporite extending far behind the ocular plates. Anterior ambulacrum not petaloid, slightly depressed, plainly depressed near the peristome. Petals flush or slightly depressed, straight, long, extending nearly to the margin, open distally; inner pores circular, outer pores oval, pores conjugate; interporiferous zones equal in width to the poriferous zones, not expanding medially. Peristome lunate, with a prominent posterior lip; at the anterior third. Periproct large, broadly oval, erect, higher than wide, about midheight, at the top of a slight depression. Peripetalous fasciole narrow, circular in front, straight or offset behind, zig-zag on the sides. Subanal fasciole broadly $\mathrm{U}$-shaped. Large tubercles crenulate, perforated, not confined within the fascioles.

Length of figured specimen from USGS $712178 \mathrm{~mm}$; width (broken) more than $68 \mathrm{~mm}$; height about $48 \mathrm{~mm}$.

occurrence.-Georgia: Palmyra, Lee County (type, fide Conrad). Powerplant on Kinchafoonee Creek north of Albany (USGS 7121, C. W. Cooke and J. E. Brantly; USGS 10507, C. W. Cooke and T. M. Prettyman). Just above bridge of Albany Northern Railway over Muckafoonee Creek near Albany (USGS 3617, T. W. Vaughan). East side Flint River at powerplant above Albany (USGS 12021, C. W. Cooke and W. H. Monroe). East bank of Flint River at mouth of creek in the northeastern corner of Dougherty County (USGS 7235, C. W. Cooke).

Alabama: Claiborne road west of Double Branches, 21/2 miles west of Monroeville (USGS 6730, C. W. Cooke). Creek at road in $\mathrm{SW} 1 / 4$ sec. 7 , T. 6 N., R. 6 E., 11/2 miles southwest of Perdue Hill, Monroe County (USGS 10043, C. W. Cooke and Julia Gardner; USGS 15064, F. S. MacNeil). Near middle of $\mathrm{E} 1 / 2$ sec. 34 , T. 8 N., R., 3 E., 5 miles southwest of Whatley, Clarke County (USGS 7159, C. W. Cooke). Fail Post Office, Choctaw County (USGS 2864, Charles Schuchert). Little Stave Creek, secs. 20, 21, T. 7 N., R. 2 E., Clarke County (Alabama Geol. Survey, Winnie McGlamery). St. Stephens Bluff, Tombigbee River (Alabama Geol. Survey). Frankville, Washington County (Alabama Geol. Survey).

Florida: State park near Marianna (Florida Geol. Survey I-3957, Herman Gunter and Clarence Simpson).

Cuba: San Martin, Matanzas (type of M. cubensis, fide Cotteau). Finca Cervantes, San Jose de las Lajas (USNM 352862, 352867, Mario Sanchez Roig). 
Geologic unit.-Late Eocene, Ocala limestone in Georgia, Florida, and Alabama.

Figured specimens.-USNM 562452, from USGS 7121; USNM 372898, from USGS 7159.

Remarks.-One of the specimens from Cuba was labelled Mauritanaster cubensis (Cotteau), the other, from the same locality, Antillaster castroi (Egozcue). Asterostoma castroi was a manuscript name applied by Egozcue to a specimen, later identified by Cotteau as Macropneustes cubensis, mentioned by Egozcue $(1897$, p. 92$)$ in his Spanish translation of Cotteau's (1881) "Echinides fossiles de l'ile de Cuba." The specimen was figured by Egozcue (1897, pl. 23) under the name Macropneustes cubensis Cotteau.

\section{Macropneustes ventricosus (Lamarck)}

\section{Plate 37, figures $1-4$}

Spatangus ventricosus Lamarck, 1816, Histoire naturelle des animaux sans vertèbres, v. 3, p. 29.

Meoma ventricosa (Lamarck). Lütken, 1864, Naturh. Forening Kjöbenhavn, vidensk. Meddelelser, 1863, ser. 2, v. 6, p. 120.

Brissus (Meoma) ventricosus (Lamarck). A. Agassiz, 187, 1874, Harvard College Mus. Comp. Zoology Mem., v. 3, p. 143, 358,603 , pl. 20 , fig. 8 ; pl. 22 , figs. 3,4 ; pl. 26 , figs. $31-34$; pl. 38, figs. 24, 25.

Meoma ventricosia (Lamarck). Cooke, 1942, Jour. Paleontology, จ. 16, no. 1, p. 48.

Meoma ventricosa (Lamarck). Mortensen, 1951, Monograph of the Echinoidea, v. 5, pt. 2, p. 529, pl. 36, fig. 1; pl. 52, figs. $1,6,15$. Includes additional synonymy.

Test large, attaining a length of $188 \mathrm{~mm}$, width 158 $\mathrm{mm}$, height $100 \mathrm{~mm}$; horizontal outline oval; upper surface moderately inflated; margin broadly rounded; lower surface gently convex; posterior truncation slightly overhanging. Apical system slightly anterior; four genital pores close together; ethmolytic, the madreporite extending beyond the posterior ocular plates. Anterior ambulacrum not petaloid, slightly depressed, the depression extending to the peristome; pore pairs very small and far apart. Petals slightly depressed, long, nearly equal in length; anterior pair slightly bent forward at the outer end, diverging at an angle of $135^{\circ}$; posterior pair straight, diverging at an angle of $55^{\circ}$. Peristome at the anterior fourth, reniform, large, covered by movable plates. Periproct higher than wide, large, at the top of the posterior truncation, not visible from above. Peripetalous fasciole very sinuous; subanal fasciole reniform, upper part obscure. Tubercles perforated, crenulated, of various sizes; intermediate spaces granulated.

Length of figured specimen, $56 \mathrm{~mm}$; width $46 \mathrm{~mm}$; height $32 \mathrm{~mm}$.

Occurrence.-Southern Florida, the Bahamas, and the West Indies.

Geologio unit.-Recent.

Figured specimen USNM E 1034, from Port-au-Prince, Haiti.

\section{Genus BRISSOPSIS Agassiz}

Brissopsis Agassiz, 1840, Catalogus systematicus ectyporum Echinodermatum, p. 3, 16.

Brissopsis Agassiz. Agassiz and Desor, 1847, Catalogue raisonné des échinides (reprint), p. 120.

Kleinia Gray, 1851, Annals and Mag. Natural History, ser. 2, v. 7, p. 133. Type species, Kleinia Iuzonica Gray, by monotypy.

Brissopsis Agassiz. Wright, 1855, Annals and Mag. Nat. History, ser. 2, v. 15, p. 187.

Brissopsis Agassiz. Desor, 1858, Synopsis des échinides fossiles, p. 378.

Toxobrissus Desor, 1858, Synopsis des échinides fossiles, p. 399. Type species, Brissopsis crescenticus Wright, designated by Pomel (1883, p. 34).

Brissopsis Agassiz. A. Agassiz, 1872-74, Harvard College Mus. Comp. Zoology Mem., v. 3, p. 95, 354, 593.

Brissopsis Agassiz. Cotteau, 1875, K. svenska vetensk-akad Handl., v. 13, no. 6, p. 36.

Brissopsis Agassiz. Pomel, 1883, Classification méthodique et genera des échinides, p. 34.

Toxobrissus Desor. Pomel, 1883, Classification méthodique et genera des échinides, p. 34.

Brissopsis Agassiz. Duncan and Sladen, Palaeontologia Indica, ser. 14, v. 1, pt. 3, p. 202.

Brissopsis Agassiz. Cotteau, 1886, Paléontologie française, Terrain tertiaire, ser. 1, v. 1, p. 130, 182.

Brissopsis (Brissoma) Pomel, 1887, Algeria, Service de la carte géol., Zoophytes, fasc. 2, liv. 2, p. 41. Type species, Brissopsis duciei Wright, designated by Lambert and Thiéry (1924, p. 488).

Brissopsis Agassiz and Desor. H. L. Clark, 1917, Harvard College Mus. Comp. Zoology Mem., v. 46, no. 2, p. 199.

Brissopsis Agassiz. Lambert and Thiéry, 1924, Nomenclature raisonnée des échinides, fasc. 7, p. 489.

Brissoma Pomel. Lambert and Thiéry, 1924, Nomenclature raisonnée des échinides, fasc. 7, p. 287.

Brissopsis (Kleinia) Gray. Lambert and Thiéry, 1924, Nomenclature raisonnée des échinides, fasc. 7, p. 490.

Brissopsis Agassiz. Grant and Hertlein, 1938, Am. Midland Naturalist, v. 19, no. 2, p. 482.

Brissopsis Agassiz. Grant and Hertlein, 1938, California Univ. (Los Angeles) Pub. Math. Phys. Sci., v. 2, p. 126.

Brissopsis Agassiz. Cooke, 1942, Jour. Paleontology, v. 16, no. 1, p. 48.

Brissopsis Agassiz. Mortensen, 1951, Monograph of the Echinoidea, v. 5, pt. 2 , p. 371 . Includes additional synonymy.

Type species, Brissopsis elegans Agassiz (1840, p. 3), from the late Eocene of France, by monotypy. The description of the genus (Agassiz, 1840, p. 16) validates this species as of 1840 (International Commission on Zoological Nomenclature, Opinion 46). As described and figured by Cotteau (1886, p. 184, pls. 52, 53), this species has a central ethmolytic system with four genital pores; flexuous sunken petals with slightly elongated pores, the anterior pair widely spreading, the posterior pair near together; an indented peripetalous fasciole and a heart-shaped subanal fasciole. The pores of the anterior petal are separated by a bead. 


\section{Brissopsis atlantica Mortensen}

Plate 38, figures 19-22

Brissopsis atlantica Mortensen, 1907, Danish Ingolf-Expedition, pt. 2, Echinoidea, p. 160, pl. 3, figs. 6, 10, 17 ; pl. 18, figs. 5, 9, $10,13,19,20,24$; pl. 19 , figs. $1,4,5,11,25,28,32,33$.

Brissopsis atlantica Mortensen. Cooke 1943, Jour. Paleontology, v. 16, no. 1, p. 49.

Brissopsis atlantica Mortensen. Mortensen, 1951, Monograph of the Echinoidea, v. 5, pt. 2, p. 415, pl. 31, flg. 11 ; pl. 59, fig. 7. Includes additional synonymy.

The name Brissopsis atlantica was applied to a species inhabiting the western part of the Atlantic that had previously been included in Brissopsis lyrifera (Forbes), a European species. Inasmuch as both supposed species seem to be very variable and as the ranges overlap in the Mediterranean, it seems probable that the differences between $B$. lyrifera and $B$. atlantica are merely varietal.

The specimen figured here, from the Atlantic off North Carolina, was originally labelled Brissopsis lyrifera. Later the identification was changed to Brissopsis atlantica, presumably by A. H. Clark.

Occurrence.-According to Mortensen (1951, p. 419) «*** the typical atlantica is known with certainty only from the West Indian seas, while the var. mediterranea is known, besides from the Mediterranean, from the Atlantic off the N. W. African, the Gulf of Guinea, and the N. American coasts."

Geologic unit.-Recent.

Figured specimen.-USNM 562453 (station 2600, U. S. Fish Commission, Steamer Albatross, 1885).

\section{Brissopsis steinhatchee Cooke}

Plate 38, figures 9-13

Brissopsis steinhatchee Cooke, 1942, Jour. Paleontology, v. 16, no. 1 , p. 49 , pl. 5, figs. $29-32$.

Brissopsis steinhatchee Cooke, 1945, Florida Geol. Survey Bull. 29 , p. 61 , fig. 6 , no. 4 (after Cooke, 1942).

Horizontal outline suboval, emarginate in front, truncate behind; upper surface flattish, sloping gently forward, with depressed petals and anterior ambulacrum; margin broadly rounded; lower surface gently convex, somewhat rostrate behind. Apical system near the anterior third; ethmolytic; four genital pores. Anterior ambulacrum not petaloid, depressed throughout but nearly flush near the peristome. Petals sunken, extending about halfway to the margin; anterior pair straight, diverging at an angle of approximately $130^{\circ}$; posterior pair the longer, curving outward to an angle of approximately $40^{\circ}$; both sunken in a single depression; pores elongate-oval; interporiferous zones nearly as wide as the poriferous; inner poriferous zones narrowing and becoming obsolete near the apex. Peristome curved, with rounded ends and a posterior lip. Periproct large, vertical, higher than wide. Peripeta- lous and subanal fascioles very obscure because of an incrustation of calcite.

Length of holotype $51 \mathrm{~mm}$; width $42 \mathrm{~mm}$; height about $23 \mathrm{~mm}$. Length of figured paratype $38 \mathrm{~mm}$; width $32 \mathrm{~mm}$; height $19.3 \mathrm{~mm}$.

Occurrence.-Florida: Pit near Steinhatchee River on U. S. 19 opposite Clara, in Dixie County (USGS 14541, C. W. Cooke and W. D. Havens; USGS 12747, W. C. Mansfield and G. M. Ponton; USGS 14158, W. C. Mansfield and C. W. Mumm).

Geologic unit.-Late Eocene, Ocala limestone.

Types.-USNM 498987; type and paratype, from USGS 14541.

\section{Brissopsis biarritzensis Cotteau}

Plate 38, figures 14-18

Brissopsis biarritzensis Cotteau, 1884, Annales des sci. géol. v. 16 , art. 2, p. 30.

Brissopsis biarritzensis Cotteau. Cotteau, 1886, Paléontologie française, Terrain tertiaire, ser. 1, v. 1, p. 193, pls. $56 ; 57 ; 58$, figs. 1-3.

Horizontal outline subovate, emarginate in front; upper surface flattish, higher behind, sloping gently forward; lower surface moderately convex, subrostrate behind; margin broadly rounded. Apical system nearly central, ethmolytic; four genital pores, the anterior pair much the closer. Anterior ambulacrum depressed, less so near the peristome. Petals rather short, extending about halfway to the margin, nearly equal in length, slightly flexuous; anterior pair nearly at right angles, posterior pair diverging at an angle of approximately $38^{\circ}$; pores elongated; interporiferous zones narrower than poriferous; inner poriferous zones diminishing in width near the apex. Peristome near the anterior fourth, transverse, rounded ends, provided with a prominent lip. Periproct terminal, vertical, higher than wide. Peripetalous fasciole reentrant in lateral interambulacra; subanal fasciole heart shaped. Upper surface granulated; tubercles on lower surface moderately large; ambulacra bare.

Length $24.6 \mathrm{~mm}$; width $21 \mathrm{~mm}$; height $13.8 \mathrm{~mm}$.

Occurrence.-France: Lou Cout, Villa Eugénie near Biarritz (fide Cotteau).

Alabama: NE $1 / 4$ SE $1 / 4$ sec. 25 , T. 7 N., R. 7 E., Monroe County (USNM 562454, J. B. Ivey).

Geologic unit.-Late Eocene, Ocala limestone in Alabama.

Figured specimens.-USNM 562454, from Monroe County, Ala.

Remarks.-There seem to be no distinguishing features between this European species as figured by Cotteau and the specimens from Alabama. The most conspicuous difference between them and Brissopsis steinhatchee Cooke is the less spreading anterior paired petals of the Alabama specimens.

Brissopsis blanpiedi Grant and Hertlein

Plate 38, figures 1-8

Brissopsis blanpiedi Grant and Hertlein, 1938, Am. Midland Naturalist, v. 19, no. 2, p. 482, text figs. 5, 6, 8-10. 
Brissopsis blanpiedi Grant and Hertlein. Cooke, 1942, Jour. Paleontology, v. 16, no. 1, pl. 5, figs. 23-28.

Test cordate, higher behind than in front; upper surface inflated; lower surface slightly convex, arched posteriorly. Apical system slightly in front of the center; four close-set genital pores; madreporite between and behind the posterior pair of pores. Petals sunken, slightly curved outward; anterior pair diverging at an angle of $85^{\circ}$, extending about two-thirds the distance to the ambitus, a little longer than the posterior pair, which extend about halfway to the ambitus and diverge at an angle of $37^{\circ}$. Pores of paired petals large, oval, conjugate, those nearest the longitudinal axis obsolescent near the apical center; poriferous zones wider than the interporiferous zones. Anterior ambulacrum in a deep furrow, which deeply indents the margin but becomes obsolete near the peristome; pores small. Peristome large, oval, with a posterior lip; at the anterior fourth. Periproct large, round, at the top of a truncation, which slopes steeply backward, partly covered with plates.

Length of figured specimen $33 \mathrm{~mm}$; width $25.3 \mathrm{~mm}$; height $16 \mathrm{~mm}$.

Occurrence.-Mississippi : Gully about 200 yards east of highway 35 on Glaze farm 1/4 mile west of Lemon and about 9 miles north of Raleigh, Smith County (USGS 13435, L. W. Stephenson and C. W. Cooke).

Geologic unit.-Middle Oligocene, near bottom of the Glendon limestone member of the Byram formation.

Types.-California Acad. Sci. 7171-7173. Figured topotypes, USNM 498998.

\section{Genus PLAGIOBRISSUS Pomel}

Brissus (Plagionotus) Agassiz in Agassiz and Desor, 1847, Catalogue raisonnée des échinodermes [reprint] p. 119. Not Plagionotus Mulsant, 1842.

Plagionotus Agassiz. Cotteau, 1875, K. svenska vetensk.-akad Handl., v. 13, no. 6, p. 41.

Plagiobrissus Pomel, 1883, Classification méthodique et genera des échinides, p. 29.

Plagiobrissus Pomel. H. L. Clark, 1917, Harvard College Mus. Comp. Zoology Mem., v. 46, no. 2, p. 207.

Plagiobrissus Pomel. Jackson, 1922, Carnegie Inst. Washington Pub. 306, p. 83.

Plagiobrissus Pomel. Lambert and Thiéry, 1924, Nomenclature raisonnée des échinides, fasc. 7, p. 495.

Eupatagus (Plagiobrissus) Pomel. Cooke, 1942, Jour. Paleontology, v. 16, no. 1, p. 54 .

Plagiobrissus Pomel. Mortensen, 1951, Monograph of the Echinoidea, v. 5, pt. 2, p. 494.

Type species, Spatangus pectoralis Lamarck $=$ Echinus grandis Gmelin, by original designation. This species differs from Eupatagus valenciennesii in the shape of its petals, which are long, narrow, and somewhat flexuous, whereas those of Eupatagus s. s. are broadly lanceolate. Like Eupatagus, it has a peripetalous and a subanal fasciole, but it has also a broad $U$-shaped anal fasciole adjoining the subanal fasciole. Another structural feature is the long plastron connected with the short labrum, contrasting with the $\mathbf{V}$-shaped plastron and long, narrow labrum of Eupatagus.

\section{Plagiobrissus grandis (Gmelin)}

Plate 39 , figures 1,2 ; plate 40 , figure 6

Echinus grandis Gmelin, 1791, Linné, Systema naturae, v. 1, pt. 6, p. 3200 .

Spatangus pectoralis Lamarck, 1816, Histoire naturelle des annimaux sans vertèbres, v. 3, p. 29.

Brissus (Plagionotus) pectoralis (Lamarck). Agassiz and Desor, 1847, Catalogue raisonné des échinodermes (reprint), p. 119, pl. 16, fig. 15 .

Eupatagus pectoralis (Lamarck). D'Archiac and Haime, 1853, Description des animaux fossiles du groupe nummulitique de l'Inde, p. 217.

Metalia pectoralis (Lamarck). A. Agassiz, 1872, 1874, Harvard College Mus. Comp. Zoology Mem., v. 3, p. 144, 600, pl. 21, figs. 4,5 .

Plagiobrissus pectoralis (Lamarck). Pomel, 1883, Classification méthodique et genera des échinides, p. 30.

Plagiobrissus grandis (Gmelin). H. L. Clark, 1917, Harvard College Mus. Comp. Zoology Mem., v. 46, no. 2, p. 207, pl. 146, figs. 21, 22.

Eupatagus (Plagiobrissus) grandis (Gmelin). Cooke, 1942, Jour. Paleontology, v. 16, no. 1, p. 54.

Plagiobrissus grandis (Gmelin). Mortensen, 1951, Monograph of the Echinoidea, v. 5 , pt. 2 , pls. $40 ; 41 ; 43$, figs. $13,16$. Includes additional synonymy.

Test very large; horizontal outline suboval, truncated and somewhat emarginate in front; upper surface flat on top, steeply sloping at each end; lower surface gently convex; margin acutely rounded. Apical system slightly anterior; proportionately small; four genital pores; strongly ethmolytic, the madreporite extending far beyond the ocular plates. Anterior ambulacrum narrow, depressed; plates nearly equilateral; pore pairs small, longitudinal. Petals narrow, somewhat flexuous, depressed, extending more than two-thirds the way to the margin; anterior pair diverging at an angle of $100^{\circ}$, posterior pair, $37^{\circ}$; pores circular, strongly conjugate; interporiferous zones the narrower. Ambulacra on lower surface very narrow; posterior pair nearly parallel. Peristome at the anterior quarter, semilunate; floscelle conspicuous. Paired interambulacra excluded from the peristome. Periproct submarginal, sloping upward and backward, not visible from above; longer than wide. Escutcheon semilunate, concave behind; surrounded by a wide subanal fasciole. Anal fasciole broadly U-shaped, wider than high, branches extending about even with the upper end of the periproct. Peripetalous fasciole narrow, nearly oval. Tubercles of paired interambulacra large, perforated; confined within the peripetalous fasciole. Tubercles of posterior interambulacrum somewhat smaller, confined to median region 
but extending beyond the fasciole almost to the posterior end.

Length of figured specimen $235 \mathrm{~mm}$; width $180 \mathrm{~mm}$; height $67 \mathrm{~mm}$.

Occurrence.-West Indian region, from Florida and the Bahamas to Bahia on the Brazilian coast (Mortensen, 1951, p. 498). Geologic unit.-Recent.

Figured specimen.-USNM 19295, from the Bahamas.

\section{Plagiobrissus? dixie (Cooke)}

Plate 40, figures 1-5

?Eupatagus floridanus (part) Clark, 1915, U. S. Geol. Survey Mon. 54 , p. 176 , pl. 82 , figs. $2 a-d$. Not pl. 83 , figs. 1a-c, $2 \mathrm{a}-\mathrm{d}$.

?Brissoides (Koilospatangus) floridanus (Clark). Lambert Thiéry, 1924, Nomenclature raisonnée des échinides, fasc. $6, \mathrm{p} .454$.

Eupatagus (Plagiobrissus) dixie Cooke, 1942, Jour. Paleontology, v. 16, no. 1, p. 55, pl. 6, figs. 1-3.

Test oval, depressed, truncate behind, margin rounded, upper surface little more inflated than the lower, rostrate above the periproct. Apical system slightly anterior; four genital pores; ethmolytic, the madreporite extending behind the ocular plates. Anterior ambulacrum not petaloid nor depressed, narrow, plates nearly equilateral. Petals plainly depressed; anterior pair widely spreading, curving forward; posterior pair straight, diverging at an angle of $50^{\circ}$, somewhat longer than the anterior pair; pores oval, conjugate; anterior poriferous zone of anterior petals narrowing toward the apex. Ambulacra on under side narrow; outer edges of posterior pair parallel. Paired interambulacra excluded from the peristome. Plastron wide, connected with the labrum. Peristome large, suboval, lip nearly flat. Periproct large, pear shaped, visible from above. Peripetalous fasciole narrow, weakly reentrant behind. Subanal fasciole heart shaped, wider than long; no anal projections detected. Large tubercles confined within the peripetalous fasciole.

Length of holotype $47.3 \mathrm{~mm}$; width $38.5 \mathrm{~mm}$; height $21.6 \mathrm{~mm}$. Length of figured specimen $79 \mathrm{~mm}$; width $68.5 \mathrm{~mm}$; height $27 \mathrm{~mm}$.

Occurrence.-Florida: Taylor County rock pit 1 mile north of Mayo, Lafayette County (type, G. M. Ponton). 5.2 miles west of Mayo (USGS 14537, C. W. Cooke). Dixie County north of U. S. 19 east of Steinhatchee River opposite Clan (USGS 14541, figured paratype, C. W. Cooke and W. D. Havens, Jr.; USGS 15150, G. M. Ponton). Silicified casts of the interior, probably this species: Alachua (USGS 6791, T. W. Vaughan and C. W. Cooke) ; Arredondo (USGS 380, L. C. Johnson) ; Johnson's lime sink, Levy County (type of Eupatagus floridanus, L. C. Johnson).

Georgia: Small island in Flint River about $2 \frac{1}{2}$ miles below Cedar Creek, Crisp County (USGS 7114, C. W. Cooke). Dam on Flint River at Kinchafoonee Creek north of Albany (USGS 10507, C. W. Cooke and T. M. Prettyman).
Geologic unit.-Late Eocene, Ocala limestone.

Types.-H'olotype, USNM 498985; paratype, USNM 498986, from USGS 14541; figured specimen, USNM 562456, from USGS 15150 .

Remarks.-The reference of this species to Plagiobrissus is questioned because no evidence of the presence of an anal fasciole has been found. Moreover, the anterior petals curve forward whereas those of Plagiobrissus grandis curve slightly backward. The species is removed from Eupatagus because of the narrowness of the ambulacra and the length of the plastron.

The type of Eupatagus floridanus is an internal mold. It has the general appearance of this species except that its petals do not curve forward. The description of $E$. floridanus was based on two other specimens, which are here referred to Eupatagus antillarum Cotteau.

\section{Plagiobrissus? holmesii (McCrady)}

Plagionotus holmesii McCrady in Tuomey and Holmes, 1857, Pleiocene fossils of South Carolina, p. 9, pl. 3, figs. 2, 2a.

Plagionotus ravenelianus McCrady in Tuomey and Holmes, 1857, Pleiocene fossils of South Carolina, p. 10, pl. 3, figs. 3, 3a.

Metalia pectoralis (Lamarck). A.' Agassiz, 1872, Harvard College Mus. Comp. Zoology Mem., v. 3, pt. 1, p. 144.

Plagiobrissus holmesi (McCrady). Stefanini, 1911, Soc. geol. italiana Boll., v. 30, p. 707.

Plagiobrissus ravenelianus (McCrady). Stefanini, 1911, Soc. geol. italiana Boll., v. 30, p. 707.

Metalia raveneliana (McCrady). Clark and Twitchell, 1915, U. S. Geol. Survey Mon. 54, p. 215.

Metalia holmesi (McCrady). Clark and Twitchell, 1915, U. S. Geol. Survey Mon. 54, p. 215.

Eupatagus (Plagiobrissus) holmesii (McCrady). Cooke, 1942, Jour. Paleontology, v. 16, no. 1, p. 54,

Occurrence.-South Carolina: Smith's, Goose Creek (Yeamans Hall) ; the Grove, Cooper River.

Geologic unit.-Late Miocene.

Remarks.-These two nominal species, based on fragments, are unrecognizable from their figures and descriptions without topotypic material. Alexander Agassiz (1872, p. 144) put them in the synonymy of Plagiobrissus grandis but later (1875, p. 751) he listed them separately.

\section{Plagiobrissus curvus (Cooke)}

Plate 39, figures 3-6

Eupatagus (Plagiobrissus) curvus Cooke, 1942, Jour. Paleontology, v. 16, no. 1, p. 56, pl. 7, figs. 5-7.

Test thin, ovate, margin rounded. Apical system slightly anterior. Anterior ambulacrum narrow, slightly depressed; plates nearly equilateral. Petals flush; anterior pair widely diverging, nearly straight, narrowing near the tips; posterior pair curving backward to an angle of about $30^{\circ}$, the inner edge nearly straight; pores oval, strongly conjugate; poriferous zones nearly closed distally, fairly wide; interporiferous equalling the poriferous at the middle, diminishing in width at each end. Peristome at the anterior third. Periproct terminal, large, pear shaped, higher than wide, vertical. Peripetalous fasciole without lateral 
sinuations, slightly bent backward at the anterior end and more strongly bent backward at the posterior end. Subanal fasciole wider, apparently heart shaped; indications of an anal branch. Large perforated, crenulated tubercles confined within the peripetalous fasciole in the paired interambulacra. Plastron extending to the labrum. Outer edges of posterior ambulacra parallel on lower surface.

Length of type about $58 \mathrm{~mm}$; width $49 \mathrm{~mm}$; height $22 \mathrm{~mm}$.

Occurrence.-Florida: Chipola River $1 / 4$ mile above old bridge at Marianna (type, USNM 498984, C. W. Cooke).

Georgia : Flint River at mouth of Kinchafoonee Creek above Albany (figured specimen, USGS 7121, C. W. Cooke; USGS 5054, L. W. Stephenson and Otto Veatch). Flint River at Bainbridge (USGS 7097, C. W. Cooke).

Geologic unit.-Late Elocene, Ocala limestone.

Type.-USNM 498984. Figured specimen, USNM 562455, from USGS 7121.

\section{Genus RHYNOBRISSUS A. Agassiz}

Rhynobrissus A. Agassiz, 1872, Harvard College Mus. Comp. Zoology Bull., v. 3, p. 590.

Rhinobrissus A. Agassiz. Mortensen, 1951, Monograph of the Echinoidea, v. 5, pt. 2, p. 486 . Includes additional synonymy.

Rhynobrissus A. Agassiz. Cooke, 1957, U. S. Nat. Mus. Proc., v. 107, no. 3379 , p. 9. Includes additional synonymy.

Type species, Rhynobrissus pyramidalis A. Agassiz, 1872, from China, by monotypy. The genus has been reviewed by Mortensen.

\section{Rhynobrissus cuneus Cooke}

Plate 36, figures 7-11

Rhynobrissus cuneus Cooke, 1957, U. S. Natl. Mus. Proc., v. 107, no. 3379 , p. 10 , pl. 1.

Horizontal outline ovate, rounded in front, widest at the midline, bluntly pointed behind; longitudinal outline wedged shaped (whence the specific name cuneus, a wedge), base line nearly flat; profile of the upper surface slightly arched, the highest point near the posterior end, thence sloping steeply forward to the acutely rounded ambitus; profile of the posterior end gently convex, slightly overhanging; transverse outline nearly semicircular, convex above. Apical system nearly central, ethmolytic, the madreporite extending between and beyond the posterior ocular plates; four large genital pores (three when immature), the anterior pair circular and close together, the posterior pair the larger, oval, diverging. Anterior ambulacrum flush, not petaloid; pores small, far apart, inconspicuous. Paired petals rather long, nearly equal, straight, sunken; anterior pair widely separated, diverging at an angle of approximately $137^{\circ}$; posterior pair much closer together, diverging at an angle of approximately $39^{\circ}$; poriferous zones wider than the interporiferous, pores oval, conjugate.

The posterior paired interambulacra do not reach the peristome. The odd interambulacrum includes a straight-sided amphisternous plastron extending from the labrum to the posterior truncation, where it adjoins a circular subanal plastron surrounded by the subanal fasciole. The anal fasciole touches the subanal fasciole, and it extends upward and nearly encloses the periproct in a vertically elongated ellipse, which is not quite closed at the top. The area within the anal fasciole differs little in decoration from that outside the fasciole. A weakly scalloped elliptical peripetalous fasciole touches the ends of the petals.

Peristome strongly reniform, covered by many movable plates; mouth arched over by the projecting, bluntly pointed labrum. Phyllodes conspicuous. Periproct bilunate or pyriform, set high on the narrow posterior end, covered with movable plates. Tubercles small, close, covering all the upper surface except the peripetalous fasciole and extending down the sides; tubercles on the plastron are somewhat larger. Spines long, hairlike, silky, many have flat, spatulate ends.

Length of holotype $37 \mathrm{~mm}$; width $37 \mathrm{~mm}$; height 23.5 mm. A smaller test measures 25 by 25.3 by $15.5 \mathrm{~mm}$.

Occurrence.-North Carolina : Fort Macon Beach.

Geologic unit.-Recent.

Type.-USNM E-8032; paratype E-8033.

Comparisons. - The horizontal outline of this species is similar to that of Rhynobrissus pyramidalis, but the petals are proportionately longer. The two species are markedly different in vertical profile; the posterior end of the Chinese species slopes backward, whereas that of the American species is nearly vertical, even slightly overhanging. This difference in slope is caused by the much shorter, nearly equilateral lower surface of $R$. cuneus. According to A. Agassiz (1873, p. 592) the anal fasciole of $R$. pyramidalis begins immediately above the subanal plastrons but is not connected with it; in $R$. cuneus the two fascioles are in contact and separate the anal area from the subanal plastron.

The sloping upper surface and wedgelike shape distinguish Rhynobrissus cuneus from $\boldsymbol{R}$. hemiasteroides as figured by Mortensen $(1951$, p. 490 , pl. 28 , figs. $3,4,7-9,13,14)$. The upper surface in $\boldsymbol{R}$. hemiasteroides is almost flat in vertical profile. Mortensen's figure 13 also shows a wide separation between the anal fasciole and the subanal fasciole, which are in contact in R. cuneus.

\section{- Genus EUPATAGUS Agassiz}

Eupatagus Agassiz in Agassiz and Desor, 1847, Ann Sci. nat., ser. 3, v. 8, p. 9 (reprint p. 115).

Eupatagus Agassiz. Archiac and Haime, 1853, Description des animaux fossiles du groupe nummulitique de l'Inde, p. 217.

Eupatagus Agassiz. Desor, 1858, Synopsis des échinides fossiles, p. 413.

Spatangus (Eupatagus) Agassiz. A. Agassiz, 1872, 1873, Harvard College Mus. Comp. Zoology Mem., v. 3, p. 128, 572.

Eupatagus Agassiz. Pomel, 1883, Classification méthodique et genera des échinides, p. 28. 
Euspatangus Agassiz. Cotteau, 1885, Paléontologie française, Terrain tertiaire, ser. 1, v. 1, p. 44.

Eupatagus Agassiz. Duncan, 1889, Linnean Soc. London, Zoology v. 23, p. 253.

Eupatagus Agassiz. H. L. Clark, 1917, Harvard College Mus. Comp. Zoology Mem., v. 46, no. 2, p. 226.

Eupatagus Agassiz. Jackson, 1922, Carnegie Inst. Washington Pub. 306, p. 88.

Brissoides (Brissoides) Klein. Lambert and Thiéry, 1924, Nomenclature raisonneé des échinides, fasc. 6, p. 450.

Brissoides Klein. Sanchez Roig, 1926, Cuba, Bol. de Minas, No. 10, p. 101.

Eupatagus Agassiz. Grant and Hertlein, 1938, Univ. California (Los Angeles) Pub. in Math. and Phys. Sci., v. 2, p. 134.

Eupatagus Agassiz. Cooke, 1942, Jour. Paleontology, v. 16, no. 1, p. 53.

Eupatagus Agassiz. Mortensen, 1951, Monograph of the Echinoidea, v. 5, pt. 2, p. 456.

Type species, Eupatagus valenciennesii Agassiz, living around Bass Strait, Australia, designated by Pomel (1883). This species is figured by A. Agassiz (1873, p. 572, pl. 15a, figs. 3, 4) and by Mortensen (1951, p. 466 , pl. 27 , figs. $1-3,6,7$; pl. 60 , figs. $20-22,24,27$ ). It has broad, rounded, nearly closed, flush petals, with narrow poriferous zones. Its anterior ambulacrum is not petaloid nor depressed. Its peripetalous fasciole is without indentations. Its subanal fasciole is described as closed, heart shaped, broad, and with an indistinct anal branch. A few large tubercles lie within the peripetalous fasciole in the four paired interambulacra.

\section{Eupatagus clevei (Cotteau)}

\section{Plate 41, figures 6-8}

Euspatangus clevei Cotteau, 1875, K. svenska vetensk.-akad. Handl., v. 13, no. 6, p. 44, pl. 8, figs. 1-4.

Euspatangus grandiflorus Cotteau, 1875, K. svenska vetensk.akad. Handl., v. 13, no. 6, p. 45, pl. 8, figs. 5, 6.

Eupatagus clevei (Cotteau). Guppy, 1882, Sci. Assoc. Trinidad Proc., pt. 12, p. 199.

Eupatagus grandiflorus (Cotteau). Jackson, 1922, Carnegie Inst. Washington Pub. 306, p. 89, pl. 15, figs. 5, 6.

Eupatagus clevei (Cotteau). Jackson, 1922, Carnegie Inst. Washington Pub. 306, p. 90, pl. 16, figs. 1, 2.

Eupatagus grandiflorus (Cotteau). Molengraaff, 1929, Geologie en Geohydrologie het Eiland Curaçao, p. 72, pl. 24, figs. 1,$2 ;$ pl. 25 , fig. 1 .

Eupatagus grandiflorus (Cotteau). Arnold and Clark, 1934, Harvard College Mus. Comp. Zoology Mem., v. 54, no. 2, p. 156.

Eupatagus clevei (Cotteau). Cooke, 1948, Jour. Paleontology, v. 22 , no. 1 , p. 92 , pl. 22, fig. 9 .

Eupatagus clevei (Cotteau). Fischer, 1951, Florida Geol. Survey Bull. 34, pt. 2, p. 83, pl. 7, figs. 1-3; text fig. 18.

Test large, hemispherical; horizontal outline oval; upper surface strongly inflated, slightly flattened in front; lower surface nearly flat; margin very broadly rounded. Apical system slightly anterior, small; four genital pores; ethmolytic, the madreporite protruding far behind the ocular plates. Anterior ambulacrum narrow ( $8 \mathrm{~mm}$ wide at ambitus), plates nearly equilateral, pore pairs very small. Petals long, extending to the margin, very wide, flush, lanceolate, more or less open distally; pores oval, conjugate; poriferous zones narrow, much narrower than the interporiferous zones; paired ambulacra much expanded at the ends of the petals. Peristome at the anterior third, reniform, twice as wide as long, strongly lipped; floscelle conspicuous. Plates of the trivium almost excluding the interambulacral plates at the peristome. Periproct terminal, vertical, higher than wide. Peripetalous fasciole narrow, not indented. Subanal fasciole apparently heart shaped. Tubercles rather small, scrobiculate.

Length of figured specimen $89 \mathrm{~mm}$; width $78 \mathrm{~mm}$; height $50 \mathrm{~mm}$.

Occurrence:-Lesser Antilles : St. Bartholomew (types, USNM 115371, 115379, R. J. L. Guppy). Curaçao (fide Molengraaff). Panama: Madden Field (USNM 560197, W. P. Woodring and J. R. Schultz).

Jamaica: (Mus. Comp. Zoology, B. W. Arnold, fide H. L. Clark).

Florida: Withlacoochee River, Citrus County, on west line of Sec. 3, T. 17 S., R. 16 E'. (USNM 104175, A. G. Fischer). Geologic unit.-Late Eocene, Inglis limestone, of early Jackson age.

Types.-USNM 115379; USNM 115371 (type of $\boldsymbol{E}$. grandiflorus). Figured specimen USNM 104175, from Florida.

Comparison.-Eupatagus clevei is much more inflated than Eupatagus valenciennesii Agassiz and its apical system is more nearly central. It differs also in that a narrow plate reaches or nearly reaches the peristome in each lateral interambulacrum, whereas the lateral interambulacra are completely excluded in the Recent species.

\section{Subgenus Gymnopatagus Döderlein}

Gymnopatagus Döderlein, 1901, Zool. Anzeiger, v. 24, p. 22.

Gymnopatagus Döderlein. Döderlein, 1906, Wissenschaffliche Ergebnisse der deutschen Tiefsee-Expedition "Valdivia" v. 5, Lief. 2, p. 266.

Gymnopatagus Döderlein. H. L. Clark, 1917, Harvard College, Mus. Comp. Zool. Mem., v. 46, no. 2, p. 226.

Brissoides (Gymnopatagus) Döderlein. Lambert and Thiéry, 1924, Nomenclature raisonnée des échinides, fasc. 6, p. 453.

Eupatagus (Gymnopatagus) Döderlein. Cooke, 1942, Jour. Paleontology, v. 16, no. 1, p. 53.

Gymnopatagus Döderlein. Mortensen, 1951, Monograph of the Echinoidea, v. 5, pt. 2, p. 446.

Type species Gymnopatagus valdiviae Döderlein, living off the east coast of Africa, by monotypy. As figured by Döderlein (1906, p. 226, pl. 29, fig. 7; pl. 32, figs. 2, 2a) this species is heart shaped. The anterior ambulacrum is narrow, strongly depressed. The apical system is at the anterior third, ethmolytic, with four genital pores close together. The petals are short, flush, narrowly lanceolate, nearly closed, the anterior pair 
widely spreading, the posterior pair much less so. The peristome is oval, well forward; the labium long and narrow. The plastron is short, $\mathrm{V}$-shaped; the adjoining ambulacra are wide. The peripetalous fasciole is without indentations but appears to be incomplete in front. The subanal fasciole is described as very wide. A variable number of large tubercles are confined within the peripetalous fasciole in the paired interambulacra.

The petals of this species are narrower than those of Eupatagus valenciennesii and their poriferous zones are wider. The deep anterior furrow is probably not a generic feature.

\section{Eupatagus (Gymnopatagus) antillarum (Cotteau)}

Plate 41, figures 1-5

Euspantangus antillarum Cotteau, 1875, K. svenska Vetenskakad. Handl., v. 13, no. 6, p. 43, pl. 7, figs. 8-12.

Eupatagus antillarum (Cotteau). Guppy, 1882, Sci. Assoc, Trinidad Proc., pt. 12, p. 199.

Eupatagus mooreanus Pilsbry, 1914, Acad, Nat. Sci. Philadelphia Proc., v. 66, p. 206, pl. 8.

Eupatagus floridanus (part) Clark, 1915, U. S. Geol. Survey Mon. 54, p. 176, pl. 83, figs. 1a-2b (not pl. 82, figs. 2a-d).

Eupatagus antillarum (Cotteau). Jackson, 1922, Carnegie Inst. Washington Pub. 306, p. 91, pl. 16, figs. 3-6.

Eupatagus cf. antillarum (Cotteau). Hawkins, 1924, Geol. Mag., v. 61, p. 322.

Maretia twitchelli Lambert in Sanchez Roig, 1926, Bol. Minas (Cuba), v. 10, p. 112.

Maretia clarki Lambert in Sanchez Roig, 1926, Bol. Minas (Cuba), v. 10, p. 112.

Eupatagus antillarum (Cotteau). Arnold and Clark, 1927, Harvard College Mus. Comp. Zoology Mem., v. 50, no. 1, p. 64.

Eupatagus (Gymnopatagus) mooreanus Pilsbry. Cooke, 1942, Jour. Paleontology, v. 16, no. 1, p. 54, pl. 1, fig, 16.

Eupatagus (Gymnopatagus) mooreanus Pilsbry. Cooke, 1945, Florida Geol. Survey Bull. 29, p. 60, fig. 6, no.1.

Eupatagus (Gymnopatagus) mooreanus Pilsbry. Fischer, 1951, Florida Geol. Survey Bull. 34, p. 74, pls. 2, 5, 6; text figs. 12-17.

Horizontal outline obovate, truncated behind; upper surface moderately elevated, highest midway between the apical system and the periproct, sloping gently forward; lower surface flat; margin rounded. Apical system slightly eccentric forward, ethmolytic, the madreporite protruding far behind the ocular plates; four genital pores close together. Anterior ambulacrum narrow, not petaloid, slightly flattened, plates nearly equilateral. Petals long, extending nearly to the margin, slightly flexuous; anterior pair diverging at an angle of approximately $145^{\circ}$, posterior pair $40^{\circ}$; pores circular, strongly conjugate; poriferous zones nearly closed, narrow. Peristome at the anterior third, rounded, somewhat wider than long; labrum not conspicuously projecting. Floscelle conspicuous. All interambulacra reaching the peristome. Periproct term- inal, vertical, higher than wide, about midheight, at the top of a small truncation. Peripetalous fasciole not indented; subanal fasciole heart shaped. Large tubercles arranged in parallel zigzag rows in the four lateral interambulacra, confined within the peripetalous fasciole. Smaller tubercles closely cover the interambulacra on the lower side. Tubercles arranged in radiating rows on the escutcheon, forming a pattern suggestive of a pair of spread wings. Lower parts of ambulacra smooth and appearing calloused.

Length of figured specimens 58.5 and $42.3 \mathrm{~mm}$; width 50.3 and 35.5 ; height 29 and $18.5 \mathrm{~mm}$.

Occurrence.-Leeward Islands : St. Bartholomew (type, R. J. L. Guppy).

West Indies: Jamaica ( $f$ ide H. L. Clark).

Florida: Withlacoochee River (Acad. Nat. Sci. Philadelphia 1147, type of Eupatagus mooreanus, C. M. Moore). Dredged from Withlacoochee River in W1/2 sec. 3, T. $17 \mathrm{~S}$, R. 16 E., Levy and Citrus Counties (USGS 18749, A. G. Fischer and J. E. Banks). Mouth of Withlacoochee River in center of sec. 14 , T. 17 S., R. 15 E. (USGS 18757 , A. G. Fischer and J. E. Banks). Levy County between Inglis and Yankeetown (USGS 14544, C. W. Cooke and W. D. Havens, Jr.). Inglis (USGS 11118, Herman Gunter and Stuart Mossom). Phosphate pit $1 \frac{1}{4}$ miles southwest of Inverness (USGS 7378, C. W. Cooke). Phosphate pit north of Dunnellon (USGS 7381, C. W. Cooke). Silver Springs, Marion County (USGS 14572, Mr. Ray).

Alabama: Bluff on east side of Conecuh River in the SE1/4. sec. 29, T. 4 N., R. 15 E., Covington County (USGS 15561f, F. S. MacNeil).

Geologic unit.-Early part of late Eocene, Inglis limestone in Florida.

Types and figured specimens.-USNM 115395, type of $E$. antillarum; Acad. Nat. Sci. Philadelphia, type of E. mooreanils; USNM 372879, from USGS 7378, figured by Cooke, 1942 ; USNM 562465, from USGS 18749, pl. 41, figs. 1-4; USNM 562464, from USGS 18757, pl. 41, fig. 5; type of Maretia clarki, Wagner Free Inst. Sci., Philadelphia, figured by Clark, 1915, pl. 83, fig. 1; type of Maretia twitchelli, Mus. Comp. Zoology at Cambridge, Mass., figured by Clark, 1915, pl. 83, fig. 2.

Remarks.-Cotteau based this species on two specimens from St. Bartholomew, of which the smaller is here designated as the type. The larger is considerably deformed and possibly represents a different species. Both have been figured by Jackson (1922, pl. 16, figs. 3 and 4 (larger) and 4 and 6 (the type).

Clark's description of Eupatagus floridanus was taken from two specimens from Florida, but his type, a silicious mold of the interior, evidently represents a different species. Lambert gave a new name to each of the two. Pilsbry's description of Eupatagus mooreanus was published while Clark's monograph was in press.

Attention should be called to Fischer's careful description and excellent figures of this species.

\section{Eupatagus (Gymnopatagus) gardnerae Cooke Plate 42 , figures 1-3}

Eupatagus (Plagiobrissus) gardnerae Cooke, 1942, Jour. Paleontology, v. 16, no. 1, p. 56, pl. 7, figs. 1-4.

Horizontal outline suboval; upper surface inflated, highest at the apical system, steeply sloping in front; 
margin broadly rounded. Apical system slightly in front of the center; four genital pores close togther; ethmolytic. Anterior ambulacrum not petaloid; pore pairs strongly inclined; narrow, flattened but not depressed. Petals rather long; anterior pair diverging at an angle of approximately $150^{\circ}$, posterior about $50^{\circ}$; pores circular, conjugate; anterior poriferous zone of anterior petals diminishing in size near the apex; petals nearly closed distally. Peristome large, semilunate; at the anterior third or more. Periproct and fascioles not. preserved. Large tubercles in paired interambulacra apparently confined within the peripetalous fasciole. Plastron V-shaped.

Length $40 \mathrm{~mm}$; width $37.4 \mathrm{~mm}$; height $24.3 \mathrm{~mm}$.

Occurrence.-Alabama: Stream 6 miles west of Andalusia, on line between secs. 20 and 29, T. 4 N., R. 15 E. (USGS 10014, C. W. Cooke and Julia Gardner).

Geologic unit.-Late Eocene, Ocala limestone, just above the Periarchus lyelli bed at base of formation.

Remarks.-This species, based on one imperfect individual appears to be proportionately shorter than Eupatagus ocalanus, it is more steeply sloping in front, and its tubercles are larger.

Eupatagus (Gymnopatagus) carolinensis Clark

Plate 42 , figures $4-7$

Eupatagus carolinensis Clark, 1915, U. S. Geol. Survey Mon. 54, p. 153, pl. 71, figs. 3a-d, 4 .

Eupatagus (Plagiobrissus) carolinensis Clark. Cooke, 1942, Jour. Paleontology, v. 16, no. 1, p. 56.

Horizontal outline oval, narrowly truncated behind; upper surface moderately inflated, steeply sloping in front; lower surface gently convex; margin broadly rounded. Apical system behind the anterior third, small; four genital pores; ethmolytic, the madreporite moderately extended. Petals slightly sunken, straight, narrowly lanceolate, nearly closed; anterior pair diverging at an angle of $132^{\circ}$, posterior $38^{\circ}$; pores oval, strongly conjugate; anterior poriferous zone of anterior pair narrowing near the apex; interporiferous zones about as wide as the poriferous. Anterior ambulacrum flattened, not petaloid. Peristome large, suboval; at the anterior third. Periproct oval, higher than wide, barely visible from above. Under side of posterior ambulacra wide, outer edges diverging backward; almost touching at the posterior end of the labrum.

Peripetalous fasciole oval, narrow ; subanal fasciole narrow below, broader above, probably heart shaped. The right-hand branch of an anal fasciole is visible on USNM 166495. Large tubercles confined to the paired interambulacra within the peripetalous fasciole.

Occurrence.-North Carolina: Wilmington (type, USNM 166484, L. W. Stephenson; paratype, USGS 3602, USNM 164674, Frank Burns). City rock quarry near Wilmington (USGS 10340, C. W. Cooke). Northeast Cape Fear River 31/4 miles above Castle Hayne (USNM 164495, L. W. Stephenson).
Alabama: Rock House Bluff, Conecuh River, sec. 28 or 29, T. 3. N., R. 14 E., Conecuh County (USGS 6750, C. W. Cooke; identification doubtful).

Geologic unit.-Late middle Eocene, Castle Hayne limestone in North Carolina.

Types.-Holotype, USNM 166484 ; paratype, figured by Clark, USNM 164674.

Remarks.-The structure of the lower surface of this species is so similar to that of $E$. antillarum and $E$. ocalanus that it seems necessary to refer it to the same subgenus in spite of the presence of an anal fasciole and the lack of large tubercles in the anterior interambulacra. It differs from Plagiobrissus in having a long narrow labrum, which is almost separated from the interambulacrum by the widened ambulacra.

\section{Eupatagus (Gymnopatagus) ocalanus Cooke}

Plate 42, figures 8-12

Eupatagus (Plagiobrissus) ocalanus Cooke, 1942, Jour. Paleontology, v. 16, no. 1 , p. 57, pl. 6 , figs. 4-8.

Horizontal outline subovate, truncated behind; upper surface moderately inflated, median line horizontal behind the apex, rostrate behind, rather steeply sloping in front; lower surface nearly flat; margin broadly rounded. Apical system slightly anterior; small; four genital pores close together; ethmolytic, the madreporite extending behind the ocular plates. Anterior ambulacrum flattened, narrow, the plates nearly equilateral; pore pairs small, longitudinal. Petals slightly sunken, flexuous, extending about two-thirds the way to the margin, the posterior pair the longer; anterior pair diverging at an angle of $145^{\circ}$, the posterior about $40^{\circ}$; pores oval, strongly conjugate; anterior poriferous zone of anterior petals diminishing in width near the apical system. Peristome large, oval, at the anterior third; labrum not conspicuous. Periproct large, oval, vertical, higher than wide; at the top of a vertical truncation; barely visible from above. Peripetalous fasciole oval, narrow, subanal fasciole heart shaped, enclosing an escutcheon. Large tubercles confined within the peripetalous fasciole, arranged linearly in paired interambulacra; somewhat smaller and scattered on posterior interambulacrum.

Length of type $68.5 \mathrm{~mm}$; width $58 \mathrm{~mm}$; height $27 \mathrm{~mm}$.

Occurrence.-Florida: Taylor County rock pit 1 mile north of Mayo, Lafayette County (type, Florida Geol. Survey I-2406, G. M. Ponton).

Alabama: Railway cut $3 / 4$ mile north of Drewry, Monroe County, upper bed (USGS 6719, C. W. Cooke). NE1/4NE $1 / 4 \mathrm{NW}^{1} 1 / 4$ sec. 8 , T. 6 N., R. 8 E., Monroe County (J. B. Ivey and R. M. Brown).

Georgia: Bainbridge (USGS 13611, A. F. Foerste). Geologic unit.-Late Eocene, Ocala limestone.

Type-USNM 372884. Figured specimen USNM 562466; locality unknown.

Comparisons.-Eupatagus ocalanus is more delicate than E. antillarum and the plates in the upper parts of its paired interambulacra are less swollen. Its apical system is farther 
forward, and the slope to the anterior edge is more abrupt. Its upper surface resembles that of Plagiobrissus grandis, but its anterior petals are more widely spreading, its posterior ambulacra are much wider underneath, and their outer edges are not parallel but diverge backward. Moreover, it appears to lack an anal fasciole although there is some indication of an incipient one.

\section{Subgenus Brissopatagus Cotteau}

Brissopatagus Cotteau, 1863, Congrès sci. France, sess. de Bordeaux, p. 143.

Brissopatagus Cotteau. Pomel, 1883, Classification méthodique et genera des échinides, p. 32.

Brissopatagus Cotteau. Duncan and Sladen, 1884, Paleontologia Indica, ser. 14, v. 3, pt. 3, p. 226.

Brissospatangus Cotteau, 1886, Paléontologie française, Terrain tertiaire, ser. 1, v. 1, p. 128, 135.

Brissopatagus Cotteau. Duncan, 1889, Linnean Soc. London, Zoology, v. 23, p. 250.

Brissopatagus Cotteau. Lambert and Thiéry, 1924, Nomenclature raisonnée des échinides, fasc. 7, p. 491.

Eupatagus (Brissopatagus) Cotteau. Cooke, 1942, Jour. Paleontology, v. 16, no. 1, p. 57.

Brissopatagus Cotteau. Mortensen, 1951, Monograph of the Echinoidea, v. 5, pt. 2, p. 453.

Type species Brissopatagus caumonti Cotteau (1863) from the late Eocene of Biarritz, France, designated by Cotteau (1886, p. 135, footnote). As figured by Cotteau (1886, p. 136, pl. 30 ) this species has short widely spreading anterior petals, which curve slightly forward. They lie in broad, shallow depressions, which extend into the interambulacra. In other features it seems to be similar to Eupatagus.

\section{Eupatagus (Brissopatagus) alabamensis Cooke}

Plate 43, figures 5-11

Eupatagus (Brissopatagus) alabamensis Cooke, 1942, Jour. Paleontology, v. 16, no. 1, p. 58, pl. 4, figs. 7, 8.

Eupatagus (Brissopatagus) georgianus Cooke, 1942, Jour. Paleontology, vol. 16, no. 1, p. 58, pl. 7, figs. 8-11.

Test oval, slightly emarginate in front; upper surface rather low, highest in front of the apical system, geniculate in front. Apical system about the anterior third; four genital pores, close together; ethmolytic, the madreporite protruding far behind. Anterior ambulacrum narrow, moderately sunken. Petals in broad, shallow depressions; anterior pair very widely spreading, curved slightly forward; posterior pair longer, straight, diverging at an angle of $45^{\circ}$; pores oval, weakly conjugate; zones about equal in width. Peristome at the anterior quarter, reniform, three times as wide as long, with a strongly protruding lip. Labium long and narrow, adjoining a rather short, V-shaped plastron. Ambulacra on lower side wide. Interambulacra reaching the peristome. Peripetalous fasciole narrow, slightly reentrant in interambulacra. Subanal fasciole wider, enclosing a heart-shaped escutcheon. A few very large tubercles confined within the peripetalous fasciole in paired interambulacra.

Length of crushed holotype with margin broken $38 \mathrm{~mm}$; width $38 \mathrm{~mm}$; height $11 \mathrm{~mm}$.

Occurrence.-Alabama : Base of St. Stephens Bluff on Tombigbee River, Washington County (type, USGS 12168, C. W. Cooke, W. H. Monroe, and Ralph Stewart). Monroe County $11 \frac{2}{2}$ miles southwest of Perdue Hill (USGS 10043, C. W. Cooke and Julia Gardner; USGS 15064, F. S. MacNeil). Washington County 31/2 miles southeast of Cullomburg (USGS 7203, C. W. Cooke and W. C. Mansfield). Clark County 2 or 3 miles southeast of Whatley (USGS 2957, Frank Burns).

Georgia : Power plant on Kinchafoonee Creek north of Albany (type of $E$. georgianus, USGS 10507, C. W. Cooke and T. M. Prettyman). Flint River below the mouth of Cedar Creek, Crisp County (USGS 7113, C. W. Cooke).

Geologic unit.-Late Eocene, Ocala limestone and Jackson group.

Types.-USNM 498979, from USGS 12168. Type of $E$. georgianus, USNM 498982, from USGS 10507. Figured specimen, USNM 562467, from USGS 15064.

\section{GLOSSARY}

Abactinal. Dorsal or upper side.

Actinal. Oral or lower side.

Ambitus. The horizontal periphery.

Ambulacral furrows. Food grooves.

Ambulacrum, pl. ambulacra. One of the five double columns of perforated plates.

Anterior. Front; see orientation.

Apex. Apical system.

Apical fasciole. A fasciole surrounding the apical system and crossing the petals. Usually called internal fasciole. Defined by Cooke $(1942$, p. 59$)$.

Apical system. A group of plates, usually nine or ten, at the upper junction of the ambulacra, including 5 ocular plates, 4 or 5 genital plates, and in some families one or more supplementary plates.

Apophysis, pl. apophyses. A projection from the inside of the basicoronal plates.

Areola, areole. A smooth area surrounding a tubercle.

Basicoronal plates. The ring of plates surrounding the peristome.

Bigeminate. Having the zygopores arranged in two longitudinal rows.

Biserial. Bigeminate.

Bivium. The two posterior ambulacra.

Bourrelets. Swollen interambulacral plates around the peristome.

Caducous. Falling off.

Compound plate. An ambulacral plate composed of a group of platelets and containing more than one zygopore.

Conjugate. Having the two pores of a zygopore connected by a groove.

Coronal plates. The ambulacral and interambulacral plates of a regular echinoid.

Dicyclic. In two rings; ocular plates not insert.

Disjunct. Having the posterior ocular plates separated from the remainder of the apical system.

Elongated apical system. Having each paired plate in contact with its mate. 
Ethmolytic. Having the madreporite extended between the posterior ocular plates.

Ethmophractic. Having the posterior ocular plates in contact and the madreporite confined to the right anterior genital plate.

Exsert ocular plate. Excluded from the periproct.

Fasciole. A narrow granular band.

Floscelle. A more or less star-shaped area composed of bourrelets and phyllodes surrounding the peristome of certain irregular echinoids.

Food grooves. Straight or branching furrows radiating from the peristome of certain irregular echinoids.

Genital plates. Five or four plates in the apical system at the ends of the interambulacra, the posterior plate wanting in some families. The right anterior plate includes the madreporite.

Genital pore. A pore in a genital plate.

Hydropores. Pores in the madreporite. Restricted to grooves in some genera.

Insert ocular plates. Reaching the periproct.

Interambulacrum, pl. interambulacra. One of the five double columns of plates between the ambulacra.

Internal fasciole. An apical fasciole. It is external.

Interporiferous zone. The area between the rows of zygopores in an ambulacrum.

Irregular echinoid. One whose periproct is excluded from the apical system.

Labrum. The posterior part of the periproct of a spatangoid.

Lower surface. The side containing the peristome. Actinal side.

Lunule. A more or less elongated opening through the test.

Madreporite. A porous part of the apical system usually restricted to the right anterior genital plate.

Miliary. Small and numerous.

Monobasal apical system. The madreporite is central and the genital plates are fused.

Monocyclic. In one ring; all ocular plates insert.

Ocular plate. One of five perforated plates in the apical system at the ends of the ambulacra.

Ocular pore. The single small pore in an ocular plate.

Oculogenital ring. The ocular and genital plates of a regular echinoid.

Orientation. The odd or unpaired ambulacrum marks the anterior end, and the unpaired interambulacrum marks the posterior end of all echinoids. In regular echinoids, most of which are symmetrical, the anterior ocular plate adjoins the left (as seen from above) side of the genital plate containing the madreporite. In Loven's system of numbering, the ambulacra are numbered from $I$ to $V$ beginning with the right posterior ocular plate and counting counterclockwise, ambulacrum III being the anterior one. The interambulacra are numbered from 1 to 5 , counting in the same direction, starting with 1 in the right posterior and ending with 5 in the posterior position, as viewed from above.

Pedicellaria, pl. pedicellariae. Small external grasping organs, seldom preserved in fossils.

Peripetalous fasciole. A fasciole that passes around the ends of the petals.

Periproct. The opening containing the anus. In regular echinoids it lies within the apical system. In irregular echinoids it is always posterior but may lie below, on, or above the margin.

Peristome. The opening containing the mouth. It is always ventral.

$468544-59-7$
Petal. The expanded part of an ambulacrum.

Phyllodes. Conspicuous poriferous areas near the peristome.

Plastron. Part of the posterior interambulacrum extending behind the labrum.

Posterior. See orientation.

Regular echinoid. One whose periproct lies within the apical system.

Scrobicule. The smooth sunken space surrounding a tubercle.

Simple plate. An ambulacral plate having only one zygopore.

Sphaeridial pit. A small depression near the peristome, especially in the Arbaciidae.

Subanal fasciole. Usually reniform, it encloses the subanal plastron.

Trigeminate. Having three longitudinal rows of zygopores.

Trisociate. Having three zygopores on a compound plate.

Trivium. The three anterior ambulacra.

Uniserial. Having only one longitudinal row of zygopores.

Upper surface. The side containing the apical system. Abactinal side.

Zygopore. A pair of pores on an ambulacral plate. Usually called pore pair. Defined by Pomel $(1883$, p. 8$)$.

\section{BIBLIOGRAPHY}

[Besides references to the Coastal Plain Echinodermata, this bibliography includes titles of some general works and papers relating to the Pacific Coast States, Mexico, Central America, Panama, South America, and the West Indies]

Agassiz, Alexander, 1872-1874, Revision of the echini : Harvard College Mus. Comp. Zoology Mem., v. 3, 762 p., 94 pls.

Agassiz, Louis, 1836, Prodrome d'un monographie des radiaires ou échinodermes: Soc. sci. nat. Neuchâtel Mém., v. 1, p. 168-199.

1840, Catalogus systematicus ectyporum echinodermatum fossilium Musei Neocomensis. $20 \mathrm{p}$.

1841, Des scutelles: Monographies d'échinodermes vivans et fossiles, Mon. 2, vi, 151 p., 27 pls.

Agassiz, Louis, and Desor, E., 1847, Catalogue raisonné des familles, des genres et des espèces de la classe des échinodermes. Reprint, 167 p., 2 pls.

Anisgard, H. W., 1954 (1955), An echinoid [Eupatagus (Plagiobrissus)] from the Eocene of western Venezuela: Jour. Paleontology, v. 28, no. 6, p. 830-834, 5 figs.

Arnold, B. W. and Clark, H. L., 1927, Jamaica fossil echini ; with descriptions of new species of Cainozoic Echinoidea by Herbert L. Hawkins: Harvard College Mus. Comp. Zoology Mem., v. 50, no. 1, 84 p., 3 figs., 22 pls.

1934, Some additional fossil echini from Jamaica : Harvard College Mus. Comp. Zoology Mem., v. 54, no. 2, p. 139-156, pls. 1-5.

Berry, E. Willard, 1941, Pamlico fossil echinoids: U. S. Natl. Mus. Proc., v. 90, no. 3113, p. 443-445, 3 pls.

Böse, Emilio, 1906, Sobre algunos faunas terciarias de México: México, Instituto Geologico Bol. 22, 96 p., 12 pls. Encope tatetlaensis is only echinoid.

Bouvé, T. T., 1846, Pygorhynchus gouldii, a new Echinus from the Millstone grit of Georgia: Am. Jour. Sci., ser. 2, v. 3, p. 437, 1847; Boston Soc. Nat. History Proc., v. 2, p. 192, 1846 ; Annals and Mag. Nat. History, v. 20, p. 142, 1847.

1851, [New species of echinoderms from the lower Tertiary rocks of Georgia]: Boston Soc. Nat. History Proc., จ. 4, p. 2-4, il. 
Brandt, J. F., 1835, Prodromus descriptionis animalium ab H. Mertensio in orbis terrarum circumnavigatione observatorum. 75 p. Repr. from Acad. imp. Sci. St. Pétersbourg, Recueil des Actes, 1834, p. 201-276.

Brighton, A. G., 1926, Eocene echinoids from N. W. Peru : Geol. Mag., จ. 63, p. 359-371, pl. 26.

Brodermann \& Vignier, Jorge, 1949, Significacion estratigráfica de los equinodermos fósiles de Cuba : Paleontólogie Cubana, I, p. 305-330.

Caso, M. E., 1946, Contribucion al conocimiento de los equinoideos de México; I. Distribution y morfológia de Mellita quinquiesperforata (Leske), M. lata Clark y $M$. longifissa Michelin: Inst. de Biología Mexicana Anales, v. 17, nos. 1-2, Mexico, p. 247-259, 10 figs.

1948, Contribucion al conocimiento de los equinideos de México; II, Algunas especies de equinoideos litorales: Inst. de Biología Mexicana Anales, v. 19, no. 1, p. 183-231.

- 1949, Contribucion al conocimiento de los equinodermos litorales de México: Mexico, Inst. de Biología Mexicana Anales, v. 20, nos. 1, 2, p. 341-353, figs.

- 1951, Los equinoides fosiles del Cenozoico de México: Asoc. Mexicana de Geólogos Petroleros, v. 3, nos. 1-2, p. $57-96$.

- 1957, El genero Clypeaster Lamarck 1801, en el Terciario de México: Inst. de Biología Mexicana Anales, v. 27, no. 2, p. 487-528, 23 figs.

Clark, Austin Hobart, 1942, Echinodermata, Part 6 of Geology and biology of North Atlantic deep-sea cores between Newfoundland and Ireland: U. S. Geol. Survey Prof. Paper 196-D, p. 111-117, 2 pls.

Clark, H. L., 1907, The Cidaridae: Harvard College Mus. Comp. Zoology Bull., v. 51, no. 7, p. 163-230, 11 pls.

-1911, The genera of Recent clypeastroids: Annals and Mag. Nat. History, ser. 8, v. 7, p. 593-605.

- 1914, Hawaiian and other Pacific echini: The Clypeastridae, Arachnoididae, Laganidae, Fibulariidae, and Scutellidae: Harvard College Mus. Comp. Zoology Mem. v. 46, no. 1,78 p., pls. $122-143$.

- 1917, The Echinoneidae, Nucleolitidae, Urechinidae, Echinocorythidae, Calymnidae, Pourtalesiidae, Paleostomatidae, Aeropsidae, Palaeopneustidae, Hemiasteridae, and Spatangidae: idem, pt. 2, p. 85-283, pls. 144-161.

1929, A new Miocene echinoid [Megapetalus lovenioides] from California: San Diego Soc. Nat. History Trans., $\nabla .5$, no. 17, p. $257-262,1$ pl.

- 1933, A handbook of the littoral echinoderms of Porto Rico and the other West Indian islands: New York Acad. Sci., Sci. Survey of Porto Rico and the Virgin Islands, v. 16, pt. 1, 147 p., 7 pls. Echinoidea, p. 74-92.

- 1934, A new sea-urchin [Astropyga magnifica] from Florida : Washington Acad. Sci. Jour., v. 24, no. 1, p. 52-53. 1937, A new Eocene sea-urchin [Porpitella micra] from Alabama: Jour. Paleontology, v. 11, no. 3, p. 248-249, 3 figs. 1937, A new sea-urchin [Brisaster maximus] from the "Oligocene" of Oregon: San Diego Soc. Nat. History Trans., v. 8, no. 28 , p. $367-374,1$ pl.

- 1940, A revision of the keyhole urchins (Mellita) : U. S. Natl. Mus. Proc., v. 89 , no. 3099 , p. $435-444$, pls. $60-62$.

1946, The echinoderm fauna of Australia, its composition and its origin: Carnegie Inst. Washington Pub. 566. Echinoidea, p. 277-382.

- 1947, A new and remarkable keyhole urchin Mellita notabilis, n. sp.: Southern California Acad. Sci. Bull., v. 46 , pt. 2, p. 77-78 (May-August). No figure.
Clark, W. B., 1893, The Mezozoic Echinodermata of the United States: U. S. Geol. Survey Bull. 97, 207 p., 50 pls.

1904, Echinodermata: Maryland Geol. Survey Miocene p. $430-433$, illus.

1915, The Mesozoic Echinodermata: U. S. Geol. Survey Mon. 54, pt. 1, p. 9-100, pls. 1-54.

Clark, W. B., and Twitchell, M. W., 1909, The geological distribution of the Mesozoic and Cenozoic Echinodermata of the United States (abst.) Science, n. S., v. 29, p. 635; 1910, Geol. Soc. America Bull., v. 20, p. 686-688.

- 1915, The Mesozoic and Cenozoic Echinodermata of the United States: U. S. Geol. Survey Mon. 54, 341 p., 108 pls. Cole, W. S., and Ponton, G. M., 1932, Variations of Laganum dalti Twitchell : Am. Jour. Sci., ser. 5, v. 24, p. 23-27, 1 fig.

Conrad, T. A., 1850, Descriptions of one new Cretaceous and seven new Eocene fossils : Acad. Nat. Sci. Phila., ser. 2, v. 2, p. $39-41$, illus.

1865, Descriptions of new species of Echinidae: Acad. Nat. Sci. Phila. Proc., 1865, p. 75.

Cooke, C. Wythe, 1936, Geology of the Coastal Plain of South Carolina: U. S. Geol. Survey Bull. 867, 196 p., 18 pls.

1937, The Pleistocene Horry clay and Pamlico formation near Myrtle Beach, S. C. : Washington Acad. Sci. Jour., v. 27, no. 1, p.1-5.

1941, Cenozoic regular echinoids of eastern United States: Jour. Paleontology, v. 15, no. 1, p. 1-20, pls. 1-4.

1941, Oligopygus nancei, a new echinoid from Venezuela: Jour. Paleontology, v. 15, no. 3, p. 305-306, 3 figs.

1942, Cenozoic irregular echinoids of eastern United States: Jour. Paleontology, v. 16, no. 1, p. 1-62, pls. 1-8.

- 1943, (Feb. 12, 1944), Geology of the Coastal Plain of Georgia: U. S. Geol. Survey Bull. 941, 121 p., 1 pl.

1945, Geology of Florida: Florida Geol. Survey Bull. 29, 339 p., 1 pl., 47 figs.

- 1946, Comanche echinoids: Jour. Paleontology, v. 20, no. 3, p. 193-237, 4 pls.

1947, A new Jurassic Stomechinus from the Big Horn Basin, Wyo.; Jour. Paleontology, v. 21, no. 5, p. 473-475, 6 figs.

1948, Arbia and Dixieus, two new genera of echinoids: Jour. Paleontology, v. 22, no. 5, p. 606-607.

1948, Eocene echinoids from Panama : Jour. Paleontology, v. 22 , no. 1 , p. $91-93,1$ pl.

- 1949, Two Cretaceous echinoids [Orthopsis titicacana, n. sp., Hemiaster (Macraster) cascajalensis, n. sp.] from Peru: Jour. Paleontology, v. 23, no. 1, p. 84-86, pl. 22.

- 1949, Pygurostoma pasionensis, a Cretaceous echinoid from Guatemala : Am. Mus. Nat. History Novitates, no. 1422, 3 p., 1 fig.

1953, American Upper Cretaceous Echinoidea : U. S. Geol. Survey Prof. Paper 254-A, p. 1-44, pls. 1-16.

1954, Pliocene echinoids from Okinawa: U. S. Geol. Survey Prof. Paper 264-C, p. 45-52, pl. 9-12.

- 1955, Some Cretaceous echinoids from the Americas:

U. S. Geol. Survey Prof. Paper 264-E, p. 87-112, pls. 18-29. 1957, Echinoids [Geology of Saipan, Mariana Islands]:

U. S. Geol. Survey Prof. Paper 280-J, p. 361-364, pl. 119.

1957, [Annotated bibliography of Recent] Echinoids: Geol. Soc. America Mem. 67, v. 1, p. 1191-1192.

1957, [Annotated bibliography of] Echinoids of the postPaleozoic: Geol. Soc. America Mem. 67, v. 2, p. 981-982.

1957, Rhynobrissus cuneus, a new echinoid from North Carolina : U. S. Natl. Mus. Proc., v. 107, no 3379, p. 9-12 pl. 1. 
Cortázar, Daniel de, 1880, Descripcion de un nuevo equinodermo de la isla de Cuba, Encope ciae n. sp.: Com. Mapa Geol. España Bol. 7, p. 227-232, illus.

Cotteau, G. H., 1861-1867, Échinides: Paléontologie française, Terrain crétacé, ser. 1, v. 7, 892 p., pls. 1007-1204.

- 1875, Description des échinides tertiaires des îles St. Barthélemy et Anguilla: K. svenska vetensk.-akad. Handl. n. F., v. 13, no. 6,47 p., illus.

1875-1880, Échinides réguliers: Paléontologie française, Terrain jurassique, ser. 1, v. 10, pt. 1, 958 p., pls. 143-520. - 1881, Description des échinides fossiles de l'île de Cuba : Soc. géol. Belgique Annales, v. 9, p. 3-49, illus.

- 1885-1889, Échinides éocènes: Paléontologie française, Terrain tertiaire, ser. 1, v. 1, p. 672, pls. 1-200.

1889-1904, Échiniỡes éocènes: Paléontologie française, Terrain tertiaire, ser. 1, v. 2, 765 p., pls. 201-384.

Cotteau, G. H. and Egozcue y Cía, J., 1897, Descripcion de los equinoides fósiles de la Isla de Cuba: Com. mapa geol. España Bol. 22, p. 1-99, 29 pls.

Davies, A. M., 1935, Tertiary faunas. A text-book for oilfield palaeontologists and students of geology. V. 1, The composition of Tertiary faunas; Chapter II, Tertiary Echinoidea ; London, p. 64-115.

Desor, Edouard, 1855-1858, Synopsis des échinides fossiles, 490 p., $44 \mathrm{pls}$.

Dexter, R. W., 1944, The bottom community of Ipswich Bay, Massachusetts: Biology, Brooklyn, v. 25, p. 352-359.

Döderlein, Ludwig, 1887, Die japanischen Seeigel, Theil 1, Familie Cidaridae und Saleniidae, 59 p., 11 pls., Stuttgart. - 1906, Die Echinoiden der deutschen Tiefsee-Expedition: Wissenschafliche Ergebnisse der Deutschen Tiefsee-Expedition auf dem Dampfer "Valdivia" 1898-1899, v. 5, Lief. 2,290 , p., 42 pls., 46 text figs.

Duncan, P. M., 1889, A revision of the genera and great groups of the Echinoidea: Linnean Soc. London Jour., Zoology, v. 23, p. 1-311.

Durham, J. W., 1944, Megafaunal zones of the Oligocene of northwestern Washington: California Univ. Pub. Geol., v. 27, p. 101-197, pls. 13-18. Echinoderma at p. 192.

- 1949, Dendraster elsmerensis Durham, n. sp. : Am. Jour. Sci., v. 247 , no. 1, p. 49-62, illus.

1950, The 1940 E. W. Scripps cruise to the Gulf of California, Part 2, Megascopic paleontology and marine stratigraphy : Geol. Soc. America Mem. 43, vii, 216 p., illus.; echinoids, p. 40-52, pls. 37-47.

- 1953a, Scutellaster and Anorthoscutum: Jour. Paleontology, v. 27, no. 1, p. 147-149, 1 text fig.

1953b, Type species of Scutella: Jour. Paleontology, $\nabla$. 27 , no. 3, p. 347-352, pl. 47, 1 text fig.

1954, A new family [Neolaganidae] of clypeastroid echinoids: Jour. Paleontology, v. 28, no. 5, p. 677-684, 3 text figs.

- 1955, Classification of clypeastroid echinoids: California Univ. Pub. in Geol. Sciences, v. 31, no. 4, p. 73-198, frontis., pls. $3-4$, 38 text figs.

- 1957, Notes on echinoids: Jour. Paleontology, v. 31, no. 3, p. 625-631.

Eaton, J. E., Grant, U. S. IV, and Allen, H. B., 1941, Miocene of Caliente Range and environs, Calif. : Am. Assoc. Petroleum Geologists Bull., v. 25, no. 2, p. 193-262, 9 pls. Several descriptions of new species of Astrodapsis by Grant and Eaton.
Egozcue ₹ Cía, Justo, 1897, Description de los equinoides fósiles de la isla de Cuba : Com. Mapa Geol. España Bol., v. 22, p. 1-99.

Emmons, Ebenezer, 1858, Agriculture of the eastern counties, together with descriptions of the fossils of the marl beds: North Carolina Geol. Survey Rept., xvi, 314 p., illus.

Fischer, A. G., 1951, The echinoid fauna of the Inglis member, Moodys Branch formation: Florida Geol. Survey Geol. Bull. 34, pt. 2, p. 47-101, 7 pls.

Gabb, W. M., 1881, Descriptions of Caribbean Miocene fossils: Acad. Nat. Sci. Phila. Jour., ser. 2, v. 8, p. 337-348, pls. 44-47. Describes Schizaster scherzeri, p. 348, pl. 45, fig. $28 \mathrm{~b}$.

Gardner, J. A., 1933 [1935], The Midway group of Texas, including a chapter on the coral fauna by Thomas Wayland Vaughan and Willis Parkison Popenoe: Texas Univ. Bull. 3301, 403 p., 4 figs. 28 pls. Dated Jan. 1, 1933 ; pub. May 1935. Describes genus Linthia Desor, Linthia alabamensis Clark? and Linthia maverickensis, n. sp.

Grant, U. S. IV, and Hertlein, L. G., 1938, The West American Cenozoic Echinoidea : California Univ. (Los Angeles), Pubs. in Math. Phys. Sci., v. 2, 225 p., 30 pls.

1938, Brissopsis blanpiedi, a new species of echinoid from the medial Tertiary of Mississippi: Am. Midland Naturalist, v. 19 , no. 2 , p. $482-486,10$ figs.

Gray, J. E., 1825, An attempt to divide the Echinida or sea eggs, into natural families: Annals of Philosophy, ser. 2, v. 10, p. $423-431$.

- 1851, Description of two new genera and some new species of Scutellidae and Echinolampadidae in the collection of the British Museum : Zool. Soc. London Proc., pt. 19, p. 34-38.

Greacen, K. F., 1941, The stratigraphy, fauna and correlation of the Vincentown formation: New Jersey Dept. Cons., Geol. ser. Bull. 52, 83 p., 1 pl. Lists Eocene [Paleocene] echinoids from the the Vincentown formation.

Gregorio, Antoine de, 1890, Monographie de la faune éocenique de l'Alabama: Ann. géologie et paléontologie, v. 7-8, 346 p., illus., Palermo.

Gregory, J. W., 1892, The relations of American and European echinoid faunas: Geol. Soc. America Bull., v. 3, p. 101-108. ica Bull., v. 3, p. 101-108.

Guppy, R. J. L., 1866, On Tertiary echinoderms from the West Indies: Geol. Soc. London Quart. Jour., v. 22, p. 297-301, illus.

- 1879, On the fossil echinodermata of the West Indies: Sci. Assoc. Trinidad, Proc., v. 2, p. 193-199. Repr. 1921, Bull. Am. Paleontology, no. 35, p. 103-109.

Hanna, G. D., 1941, Characteristic fossils of California: California Dept. Nat. Resources, Div. Mines Bull. 118, pt. 2, p. 165-182, 202 figs.

Hawkins, H. L., 1923, Some Cretaceous Echinoidea from Jamaica : Geol. Mag., v. 60, p. 199-216, pl. 9.

1924, Notes on a new collection of fossil Echinoidea from Jamaica : Geol. Mag., v. 61, p. 312-324, pl. 18.

1926, The echinoid genus Oligopygus De Loriol: Geol. Mag., v. 63, p. 371-376, 4 text figs.

Holmes, F. S., 1858-1860, Post-Pleicene fossils of South-Carolina, xii, 122 p., 28 pls. Echinoids described in fasc. 1, p. 3-6, 1858. 
Israelski, M. C., 1924, Notes on some echinoids from the San Rafael and Tuxpam beds of the Tampico region: California Acad. Sci. Proc., ser. 4, v. 13, p. 137-145, pls. 2-4.

1933, A new species of echinoid [Oligopygus putnami] from Tamaulipas, Mexico: San Diego Soc. Nat. History Trans., v. 7, no. 22, p. 272-283, 1 pl.

Jackson, R. T., 1917, Fossil Echini of the Panama Canal Zone and Costa Rica: U. S. Natl. Mus. Proc., v. 53, p. 489-501, illus.

1918, Fossil echini of the Panama Canal Zone and Costa Rica: U. S. Natl. Mus. Bull. 103, p. 103-116, pls. 46-52. Essentially a reprint of Jackson, 1917.

1922, Fossil Echini of the West Indies: Carnegie Inst. Washington Pub. 306, 103 p., 18 pls.

1937, Mexican fossil echini: U. S. Natl. Mus. Proc., v. 84, no. 3015 , p. $227-237,4$ pls.

Jeannet, Alphonse, 1928, Contribution a l'étude des échinides tertiaires de la Trinité et du Venezuela: Schweizer, palaeont. Gesell. Abh., Band 48, p. 1-49, pls. 1-6.

Jordan, E. K., 1936, The Pleistocene fauna of Magdalena Bay, Lower California, with an introduction by Leo George Hertlein: Stanford Univ. Dept. Geol. Contr., v. 1, no. 4, p. 107144,3 pls.

Kellum, L. B., 1926, Paleontology and stratigraphy of the Castle Hayne and Trent marls in North Carolina: U. S. Geol. Survey Prof. Paper 143, 56 p., 1 fig., 11 pls.

Kew, W. S. W., 1914, Tertiary echinoids of the Carrizo Creek region in the Colorado Desert: California Univ., Dept. Geology Bull., v. 8, no. 5, p. 39-60, pls. 1-5.

1914, Echinoderms of the San Pablo [abs.] Geol. Soc. America Bull., v. 25, p. 152.

- 1915, Tertiary echinoids from the San Pablo group of middle California: California Univ., Dept. Geol. Sci., Bull., จ. 8, p. 365-376, illus.

1917, Recent additions to our knowledge of California Cenozoic echinoids (abst.): Geol. Soc. America Bull., v. 28, p. 226.

- 1918, Geologic range and evolution of the more important Pacific coast echinoids (abs.): Geol. Soc. America Bull., v. 29, p. 164.

1920, Cretaceous and Cenozoic Echinoidea of the Pacific coast of North America : California Univ. Pubs. in Geology, จ. 12 , no. 2 , p. $23-236$, pls. $3-42,5$ text figs.

Kew, W. S. W., and Dickerson, R. E., 1917, The fauna of a medial Tertiary formation and the associated horizons of northeastern Mexico: California Acad. Sci., Proc., ser. 4, จ. 7, p. 125-156, illus.

1917, Tertiary mollusks and echinoderms from the vicinity of Tuxpam, Mexico [abs.]: Geol. Soc. America Bull., จ. 28, p. 224-225.

Lambert, Jules, 1916, [Review of] The Mesozoic and Cainozoic Echinodermata of the United States, by William Bullock Clark and Mayville W. Twitchell : Rev. crit. zoologie, v. 20, no. 4, p. 168-171. Proposes the new genera Porobrissus (type species Echinobrissus angustatus Clark), Clarkiella (type species Cassidulus hemisphaericus Slocum or O.conoideus Clark), and Twitchellia (type species Astrodapsis merriami Anderson).

1922, Nouvelles observations sur quelques échinides néogenes de l'île d'Anguilla: Annals and Mag. Nat. History, ser. 9, v. 9, p. 587-596, pl. 9.
Lambert, Jules, 1928, Note sur quelques échinides recueillis par Mr. Walter Staub dans l'est du Méxique: Eclogae geol. Helvetiae, v. 21, no. 1, p. 272-283, 6 figs., 1 pl.

- 1928, Sur deux échinides fossiles de Cuba: Bull. Soc. geol. de France, 4th ser., v. 28, p. 19-21, 1928.

1931, Note sur le groupe des Oligopygus, la nouvelle famaille des Haimeidae, et sur quelques échinides fossiles de Cuba : Soc. géol. France Bull., ser. 5, v. 1, fasc. 3-4, p. 289304, 3 figs., 1 pl.

- 1935, Notes sur quelques échinides fossiles; pt. 3 , Échinides du Méxique: Soc. géol. France, ser. 5, v. 5, fasc. 4-7, p. $365-376,4$ figs.

Lambert, Jules, and Sanchez Roig, Mario, 1930, Neuvas especies de équinodermos fósiles cubanos: Havana Inst. nac. inv. cien., Mus. historia nat. Mem. 1929, v. 1, no. 1, p. 143-150, 5 figs.

- 1934, Nueva especie fosil del genero "Clypeaster": Rev. agricultura, comercio $\mathrm{y}$ trabajo, ano 14 , v. 14, no. 51, p. 22-24, 2 figs.

Lambert, Jules, and Thiéry, P., 1909-1925, Essai de nomenclature raisonnée des échinides : $605 \mathrm{p}$., 15 pls.

Leske, N. G., 1778, Iacobi Theodori Klein Naturalis dispositio Echinodermatum : 278 p., 54 pls.

Leutze, W. P., 1956, Encope michelini from the Pamlico formation of Volusia County, Florida: Florida Acad. Sci. Quart. Jour., v. 19, no. 1, p. 65-67.

Loeblich, A. R., Jr., and Tappan, Helen, 1957, Correlation of the Gulf and Atlantic Coastal Plain Paleocene and lower Eocene formations by means of planktonic Foraminifera: Jour. Paleontology, v. 31 , no. 6, p. 1109-1137.

Loriol, Percival de, 1873, Echinologie helvétique. Description des oursins fossiles de la Suisse, Deuxieme partie. Échinides de la periode crétacé. 398 p., 33 pls.

- 1887, Notes pour servir a l'étude des échinodermes: Recueil zool. Suisse, v. 4, p. 365-407, pls. 15-18.

Loven, Sven, 1887, On the species of Echinoidea described by Linnaeus in his work Museum Ludovicae Ulricae: K. svenska vetensk.-akad. Handl. Bihang, v. 13, pt. 4, no. 5, $183 \mathrm{p} ., 9 \mathrm{pls}$.

Merriam, J. C., 1898, The distribution of the Neocene sea urchins of middle California and its bearing on the classification of the Neocene formations: California Univ. Dept. Geology Bull., v. 2, p. 109-118.

1899, The Tertiary sea-urchins of Middle California and The fauna of the Sooke beds of Vancouver Island : California Acad. Sci. Proc., ser. 3, v. 1, nos. 5, 6, p. 161-170, pls. 21-22 ; p. 175-180, pl. 23.

Michelin, Hardouin, 1850, Notice sur deux espèces d'échinides fossiles: Revue et Mag. de zoologie, ser. 2, v. 2, 240-241. Describes Clypeaster meridanensis Michelin from environs de Merida (Yucatan) and Pygorhynchus mortonis Michelin from environs de Pohtotock (Pontotoc) Mississippi.

1855, Sur les oursins vivants et fossiles des Antilles et du Golfe du Méxique: Soc. Géol. France, ser. 2, v. 12, p. 756-759. 1856, [Sur deux oursins tertiaires de la Jamaĩque] : Soc. Géol. France Bull., ser. 2, v. 13, p. 222.

- 1858, Revue des espèces connues et nouvelles du genre Mellita: Rev. et Mag. de Zool. 1858, no. 8, p. 2.

Molengraaff, G. J. H., Geologie en geohydrologie van het Eiland Curaçao: xii, 150 pp., 52 pls., Delft.

Moore, H. B., 1936, The biology of Echinocardium cordatum: Marine Biol. Assoc. Plymouth, Jour., v. 20, p. 655-672, 5 figs. 2 pls. 
Mortensen, Th., 1903, 1907, Echinoidea: The Danish IngolfExpedition, v. 4, pt. 1, 1903, 193 p., 21 pls; ; pt. 2, 1907, 200 p., 19 pls.

1928-1951, A monograph of the Echinoidea, $5 \mathrm{v}$. and index. v. 1, 1928, Cidaroidea, 551 p., 88 pls. ; v. 2, 1935, Bothriocidaroida, Melonechinoida, Lepidocentroida, and Stirodonta, 647 p., 89 pls. ; v. 3, pt. 1, 1940, Aulodonta, 370 p., 77 pls. ; pt. 2, 1943, Camarodonta I, 553 p., 56 pls.; pt. 3, 1943, Camarodonta II, 446 p., 66 pls. ; v. 4, pt. 1, 1948, Holectypoida, Cassiduloida, 363 p., 14 pls.; pt. 2, 1948, Clypeastroida, 471 p., 72 pls.; v. 5, pt. 1, 1950, Spatangoida I, 432 p, 25 pls.; pt. 2, 1951, 593 p., 64 pls.; Index, 1951, 63 p.

Morton, S. G., 1834, Synopsis of the organic remains of the Cretaceous group, 88 p., 19 pls., Philadelphia. Repr. from Am. Jour. Sci., 1830, v. 17, 18.

1841, Description of several new species of fossil shells from the Cretaceous deposits of the United States: Acad. Nat. Sci. Philadelphia Proc., v. 1, p. 106-110.

-1842, Description of some new species of organic remains of the Cretaceous group of the United States: Acad. Nat. Sci. Phila. Jour., v. 8, p. 207-227, illus.

- 1846, Description of two new species of Echinodermata from the Eocene of the United States: Acad. Nat. Sci. Phila. Proc., v. 3, p. 51 ; Am. Jour. Sci., ser. 2, v. 2, p. 273 ; Annals and Mag. Nat. History, v. 18, p. 357

Orbigny, Alcide d', 1853-1860, Échinoides irréguliers: Paléontologie française, Terrain crétacé, ser. 1, v. 6, 596 p., pls. 801-1006.

Pack, R. W., 1909, Notes on echinoids from the Tertiary of California: California Univ. Dept. Geol. Sci. Bull., v. 5, p. 275-283, illus.

1913, Notes on Scutella norrisi and Scutaster andersoni: California Univ. Dept. Geol. Sci. Bull., v. 7, p. 299-304, illus.

Paulson, O. L., Jr., 1958, A new species of the Eocene echinoid Periarchus: Jour. Paleontology, v. 32, no. 2, p. 362-365, 8 text figs.

Pilsbry, H. A., 1914, Description of new echinoderm [Eupatagus mooreanus] : Acad. Nat. Sci. Phila. Proc., Feb. 1914, p. 206-207, pl. 8.

Pomel, N. A., 1869, Revue des Échinodermes et de leur classification pour servir d'introduction à l'étude des fossiles. Paris.

— 1883, Classification méthodique et genera des échinides, vivants and fossiles: 131 p., 1 pl., Alger.

Puri, H. S., 1957, Stratigraphy and zonation of the Ocala group: Florida Geol. Survey Bull. 38, 248 p., 15 pls.

Raup, D. M., 1956, Dendraster, a problem in echinoid taxonomy : Jour. Paleontology, v. 30, no. 3, p. 685-694, 4 text figs.

Ravenel, Edmund, 1842, Description of two new species of Scutella from South Carolina: Acad. Nat. Sci. Phila. Jour., v. 8, p. 333-336.

- 1844, Description of some new species of fossil organic remains, from the Eocene of South Carolina: Acad. Nat. Sci. Phila. Proc., v. 2, p. 96-98. Describes Scutella pileussinensis.

1845, Description of a new Recent species of Scutella: Acad. Nat. Sci. Phila. Proc., v. 2, p. 253. Scutella gibbosa Ravenel dredged at sea in about 14 fathoms off Charleston, S. C.

Jan. 1848, Echinidae, recent and fossil, of South Carolina: 4 p., 10 figs., Burges and James, Charleston, S. C. $1850, * * *$ a catalogue of the recent and fossil echinoderms of Carolina: Am. Assoc. Proc., v. 3, p. 159-161.
Rémond, August, 1863, Description of four new species of Echinodermata from the Tertiaries of Contra Costa Co.: California Acad. Nat. Sci. Proc., v. 3, p. 52-54.

1863, Description of two species of Scutella: California Acad. Nat. Sci. Proc., v. 3, p. 13-14.

Richards, G. L., Jr., 1935, Revision of some California species of Astrodapsis: San Diego Soc. Nat. History Trans., v. 8, no. 9, p. 59-66, 1 pl.

1936, Astrodapsis faunal zones of California upper Miocene and lower Pliocene formations [abs.]: Pan. Am. Geologist, v. 63, no. 5, p. 374-375; Geol. Soc. America Proc. 1935, p. 412-413.

- 1937, Foraminiferal, echinoid, molluscan correlations of the Santa Margarita and San Pablo formations [Calif.] abstract: Geol. Soc. America Proc. 1936, p. 386.

1944, Notes on the geology and paleontology of the Cape May Canal, New Jersey: Acad. Nat. Sci. Phila., Notulae Naturae, no. 134, 12 p., 4 figs. Records the presence of Mellita quinquesperforata in the Cape May formation.

Sánchez Roig, Mario, 1923, Revision de los equínidos fósiles cubanos: Soc. Cubana Historia Nat. "Felipe Poey" Mem., v. 5, no. 1, p. 6-92. (Reprint, p. 3-68, 1924), pls. 1-13.

1923-24, Nuevas especies de equínidos fósiles cubanos: Soc. cubana historia nat. "Felipe Poey" Mem., v. 6, no. 1, 2, p. $75-92,7$ pls.

1926, Los equinodermos fósiles de Cuba : Cuba, Direccion de Montes y Minas Bol. Minas, no. 10, p. 1-143, 43 pls.

- 1949, Los echinodermos fósiles de Cuba: Paleontologia Cubana, v. 1, 302 p., 50 pls.

1951, Faunula de equinodermos fósiles del Terciario de Moron, Provincia de Camagüey: Soc. cubana de historia natural "Felipe Poey" Mem., v. 20, no. 2, p. 37-64, pls. 23-40.

1952, Nuevos géneros $y$ especies de equinoideos fósiles cubanos: Torreia, no. 17, 18 p., 9 pls. October 20, 1952.

1952, Revision de los clypeasteridos cubanos: Revista de Agricultura, p. 118-155, pls. 1-16. July 1952.

- 1953, Dos nuevos géneros de equinoideos cubanos: Soc. cubana de historia natural Mem., v. 21, no. 3, p. 257-262, pls. 27-29. Lambertona, n. gen., type Victoriaster lamberti Sanchez Roig.; Neopatagus, n. gen., type Breynia cubensis Cotteau.

Schenck, Hubert G., 1928, A new echinoid [Spatangus stapinus] from the California Eocene: San Diego Soc. Nat. History Trans., v. 5, no. 12, p. 195-202, pl. 24.

Schoonover, L. M., 1941, A Miocene echinoid colony from Maryland: Jour. Paleontology, v. 15, no. 1, p. 92-93. Describes a colony of Echinocardium orthonotum (Conrad) in fine sand and dense lumpy clay at Scientists Cliffs, Calvert County, Md.

Stefanini, G., 1912, Sugli echini terziari dell' America del Nord: Soc. geol. italiana Bol., v. 30, p. 677-714, illus.

- 1924, Relations between American and European Tertiary echinoid faunas: Geol. Soc. America Bull., v. 35, no. 4 , p. 827-846, 4 figs.

Stevenson, R. E., 1956, Observations on the morphology of Astrodapsis: Jour. Paleontology, v. 30, no. 2, p. 338-344, pl. 45, 1 text fig. The position of the auricles and the character of the internal walls and pillars of some Miocene species confirm the reference of Astrodapsis to the Scutellidae.

Stewart, Ralph, 1946, Geology of Reef Ridge, Coalinga district, California: U. S. Geol. Survey Prof. Paper 205-C, p. 81-115, pls. 11-17. Figures Scutella! cf. S.? andersoni Twitchell, pl. 12, fig. 1, and Astrodapsis? merriami Anderson, pl. 12, fig. 2. 
Tortonese, E., 1933, Echinodermi americani raccolti dal Dr. E. Festa $(1895-98)$ : Musei di Zoologia e di Anatomia comparata della R. Univ. di Torino Boll., $\nabla .43$, ser. 3 , no. 28 , p. 5-18, pls. 1-3. Echinoids described and figured: Eucidaris thouarsii (Agassiz and Desor) ; Lytechinus semituberculatus (Agassiz and Desor); Tripneustes esculentus (Leske); Caenocentrotus gibbosus (Agassiz and Desor); Echinometra lucunter (L.); Echinometra vanbrunti A. Agassiz.

Toula, Franz, 1911, Die jungtertiäre Fauna von Gatun am Panama-Kanal, pt. 2: K. k. geol. Reichsantalt Jahrb., v. 61, pts. 3 and 4, p. 487-530, pls. 30-31. Encope gatunensis, n. sp. is only echinoid described.

Tuomey, M, and Holmes, F. S., Pleiocene fossils of South Carolina: 152 p., 30 pls., Charleston, 1857. Pages 1-30 published 1855; 31-152, 1856 (Sillimans Journal, 1855-1857).

Vernon, R. O., 1951, Geology of Citrus and Levy counties, Florida : Florida Geol. Survey Bull. 33, 256 p., 2 pls.

Weaver, C. E., 1905, Contribution to the paleontology of the Martinez group: Univ. California Pub. Geology, v. 4, p. 101123.

1908, New echinoids from the Tertiary of California: California Univ. Dept. of Geol. Sci. Bull., v. 5, p. 271-274, illus.

1942 (Dec. 31, 1943), Paleontology of the marine Tertiary formations of Oregon and Washington; Part I, Coelenterata, Vermes, Echinodermata, Molluscoidea, Mollusca: Washington Univ. Pub. in Geology, v. 5, 268 p., 103 pls. (Part III). Echinoids described p. 5-11.
Weisbord, N. E., 1934, Some Cretaceous and Tertiary echinoids from Cuba: Bull. Am. Paleontology, v. 20, no. 70C, p. 167266, pls. 20-28.

Weller, Stuart, 1907, A report on the Cretaceous paleontology of New Jersey, based upon the stratigraphic studies of George N. Knapp: New Jersey Geol. Survey, Paleontology ser., v. 4, 1106 p., illus.

Woodring, W. P., and Bramlette, 1950 [Jan. 24, 1951], Geology and paleontology of the Santa Maria district, California: U. S. Geol. Survey Prof. Paper 222, 142 p., 23 pls. Dendraster cf. D. coalinaensis Twitchell ; Dendraster ashleyi (Arnold) ; Merriamaster cf. M. perrini (Weaver).

Woodring, W. P., Stewart, R. B., and Richards, W. W., 1940, Geology of the Kettleman Hills oil field, California, stratigraphy, paleontology, and structure: U. S. Geol. Survey Prof. Paper 195, 170 p., 61 pls. Includes full discussion of the Dendrasters, p. 79,83 , pls. 39-46; describes Dendraster coalingaensis macer Stewart, n. var., Dendraster gibbsii mirus Stewart, n. var.

Wright, Thomas, 1855, On fossil Echinodermata from the island of Malta; with notes on the stratigraphical distribution of the fossil organisms in the Maltese beds: Annals and Mag. of Natural History, ser. 2, v. 15, p. 101-127, 175-196, 262-277, pls. 4-7. 


\section{INDEX}

[Italic numbers indicate descriptions]

A

Page

Abertella

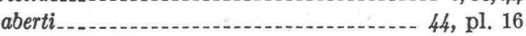
cazonesensis.

Abertellidae.

aberti, Abertella Scutelta

44, pl. 16

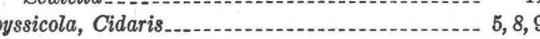

Dorocidaris

affinis, Cidaris ............................ 5, 8,

Stylocidaris

Tretocidaris.

Agassizia...........

caribbeana................................... 75

conradi_......... 75

egozcuei............ 75

floridana

gibberula

inflata

porifera........ 5, 74, pl. 31

rimulata...... 74, 75

scrobiculata................................ 74

(Anisaster) clevei.

mossomi_.......... 4, 76, pl, 32

wilmingtonica

alabamensis, Cassidulus.

Cassidulus (Cassidulus)

76, pl, 32

(Pygorhynchus)

$\begin{array}{ll}-58, \text { pl. } & 24 \\ -\ldots & 58\end{array}$

57

Eupatagus (Brissopatagus) Fibularia Linthia............................ 2, 69, pl. 29 Lovenia _......................... 4, 77

Procassidulus (Hardouinia) .............. 57 Schizaster (Linthia) _........................... 69

aldrichi, Arbia .

Coelopleurus................................ 21

Echinolampas_....... 4, 55, pl. 22

(Miolampas)

alpinus, Prenaster

alta, Sismondia

altus, Mortonia (Periarchus) Periarchus....... 41

Amblypygus __.- 6,26 americanus_._._._._. $3,27, \mathrm{pl} .7$

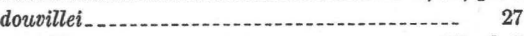
merrilli_.__._-_._._. 27, pl. 7

ambulacrum, Spatangus.-.-.-.-. 73

americana, Gagaria_.......................... 18, 19 Schizaster.

mericanum, Pseudodiadema................... 18

americanus, Amblypygus ___. 3, 27, pl. 7 Paraster _............................. 72, 73, pl. 30

Schizaster

Thylechinus.

Amphidetus.

ampliflorus

clarki.

depressus.

gothicus.

orthonotus

virginianus.

(Amphidetus), Echinospatagus.

ampla, Mellita.

Mellita quinquefora.
Page

mpliforus, Amphidetus

Ananchytes . .

cinctus_._._. 65,66

cruciferus

fimbriatus. - 65,66

Anapesus

carolinus.

Anisaster.

(Anisaster), Prenaste

clevei, Agassizia.

mossomi, Agassizia

wilmingtonica, Agassizia

Anisopetalus................................... 59

antillarum Clypeaster

Diplothecanthus........................ 34

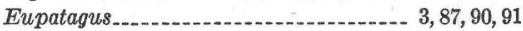
(Gymnopatagus)

Euspantangus.................................. 90

Neolaganum

Peripneustes

Antillaster castroi 83
83,84

appendiculata, Echinolampas................. 3, 56, pl. 22

appendiculatus, Echinolampas

Echinolampas (Isolampas) .................. 56

Arbacia improcera

lixula 19, 20,22

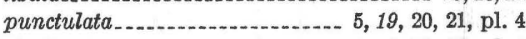

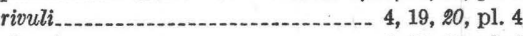

sloani ........................ 4, 20, 21, pl. 4

waccamaw

Arbaciidae. .

Arbia

aldrichi ............................ 4, 21, pl. 3

archerensis, Echinodiscus.

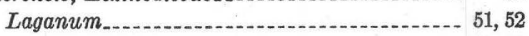

Neolaganum

Peronella................................. 52

Rumphia _.................. 52

arguta, Maretia

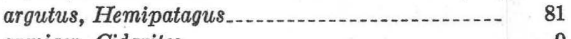

armiger, Cidarites

Paraster

Schizaster.

$4,71,72,73, \mathrm{pl} .30$

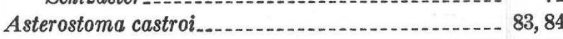

atlantica, Brissopsis_....... 5, $85, \mathrm{pl} .38$

atratus, Echinometra ............................ 25

atropos, Echinocardium............. 73 Moira

Schizaster.

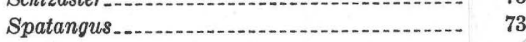

B

baltica, Tylocidaris

13

beckeri, Ditremaster.................... 4, 77, pl. 30

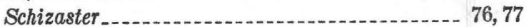

bellula, Salenia

berryi, Cassidulus (Pygorhynchus)

57

biarritzensis, Brissopsis_.................... 4, 85, pl. 38 Phymotaxis.................................. 24

blandis, Cidaris

blanpiedi, Brissopsis......................... 85, pl. 38

bonani, Laganum.

Brachybrissus
Brachybrissus), Schizaster 73 ocalanus, Schizaster................... 4, 78, pl. 29

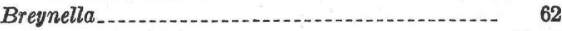

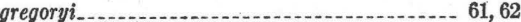

Breynia sulcata............................. 77

Brissidae _... 7, 81-92

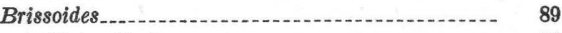

(Brissoides)

(Gymnopatagus) $\ldots$

(Koilospatangus) floridanus .................. 87

(Brissoides), Brissoides........................ 89

Brissoma

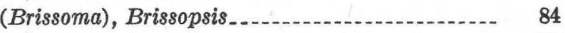

Brissopatagus............ 92

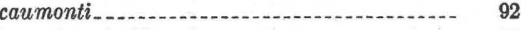

(Brissopatagus), Eupatagus_.......-...-...-.-. 92 alabamensis, Eupatagus............... 4, $92, \mathrm{pl} .43$ georgianus, Eupatagus...................... 92 primus, Eupatagus _..................... 70

Brissopsis atlantica biarritzensis............ 4, 85, pl. 38 blanpiedi_.._....... $85, \mathrm{pl} .38$ crescenticus _. 84

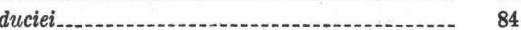
elegans

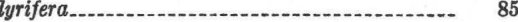

mediterranea poriferus rimulatus_-_- 74 steinhatchee........... 4, $85, \mathrm{pl} .38$ (Brissoma)

Brissospatangus.......... 92

Brissus unicolor _..._... 5, 81, 82, pl. 36

(Meoma) ventricosus _._. 84

(Plagionotus) pectoralis

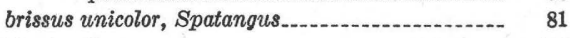

Brochopleurus _ pretiosus _............. 3, 18, pl. 4 stellulatus.-...-..- 19 brodermani, Clypeaster...................... $\quad 37$ bufo, Spatangus

Cardiaster O

cinctus

fimbriatus......

caribbeana, Agassizia-s--

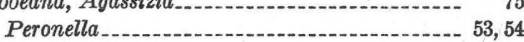

Weisbordella

cariboearum, Cassidulus_........................ 57

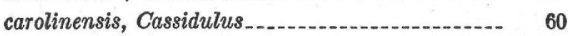

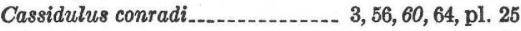
(Paralampas) (Pygorhynchus)

Cidaris _..._......... 11, 12

Coelopleurus............................ 22, 23, pl. 3

Eupatagus........................................ 3, (Gymnopatagus) (Plagiobrissus) 
carolinensis-Continued

I eiocidaris..

Mauritamaster

Unifascia _................... 30, 79, 80, pl. 34

cravenensis, Cassidulus (Pygorhynchus) _..... 65

caroliniana, Leodia .................. 4, 47, pl, 19

Mellita

Scutella

Cassidulidae

Cassidulus

ababamensis_._._.

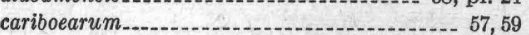

carolinensis_................... 60

conradi

carolinensis_........... 3, 56, 60,64, pl. 25

conradi_............................. 56

lyelli $4,56,60$, pl. 25 cravenensis_................. 65 , pl. 23 ericsoni_...................... $3,4,56,58$, pl. 24 georgiensis..

georgiensis globosus $\quad 3,4,56,61, \mathrm{pl}, 25$ gouldii_.................. 4, 56, $57,58,59$, pl. 24 hayesianus.

lyelli

patelliformis

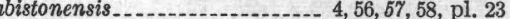

trojanus - 4, 56, 58, pl, 14

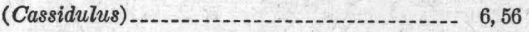

alabamensis.

evergladensis.

gouldii.

sabistonensis

trojanus

(Galerolampas) fontis

(Paralampas)

carolinensis.

conradi

globosus

gregoryi

lyelli_.

(Plagiopygus)

conradi.

georgiensis

globosus

(Pygorhynchus) alabamensis.................. 57

berryi-

carolinensis.

cravenensis.

conradi.

georgiensis.

gouldii.

sabistonensis.

(Rhynchopygus) depressus

evergladensis.

holmesi.

lyelli.

patelliformis

raveneli.

(Cassidulus), Cassidulus.

alabamensis, Cassidulus.

58

gouldii, Cassidulus.

sabistonensis, Cassidulus.

trojanus, Cassidulus

castroi, Antillaster

Asterostoma.-

83,84

Catopygus.

conradi_....................... 61

oviformis -..._. 61,62

patelliformis................................. 64

caumonti, Brissopatagus.

azonesensis, Abertella
Page

chickasawhay, Gagaria _................... 4, 18, pl. 3 Thylechinus (Gagaria)

4,32, pl. 9

chipolanus, Echinocyamus

$\begin{array}{ll}\text { Eocentrotus, Echinus._._._................ } & 25 \\ \text { Echinus (Strongylocentrotus) } & 25\end{array}$

Cidaridae.

Cidarina

Cidaris.

5, 8,9

affinis

alabamensis_.............................. 11, 12

blandis_..._._._._.

carolinensis

cidaris

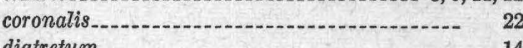

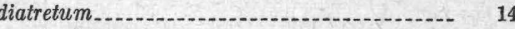

esculenta-...-.-.-16

georgiana ..................................... 11, 12

gibberula

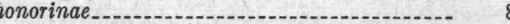

mitchellii_. ............... 11, 12

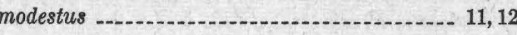

moerens

monilifera

morieri

mortoni.

multipunctata.

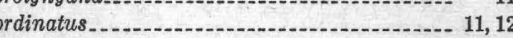

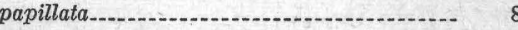

perdubius.___._-

pratti_.__.

propinqua

pustulosa

splendens

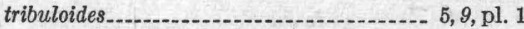

variegata

(Dorocidaris) georgiana papillata smithi

(Phyllacanthus) mortoni

(Rhabdocidaris)

Echinus.

Cidarites armiger

metularia

monilifera

mortoni

scutiger

splendeus

tribuloides -

(Phyllacanthus) _................ 10 dubius.

cinctus, Ananchytes

Cardiaster

Holaster.

Circopeltis (Micropeltis)

clarki, Amphidetus

Lovenia

Maretia

clavigera, Tylocidaris

clevei, Agassizia (Anisaster) Eupatagus.

Euspatangus

Clypeaster

antillarum

34, 35

cotteaui_-_- 4,

douvillei

ellipticus_-_._.

gatuni-_-_- 34,35 , pl. 11

lanceolatus_._.

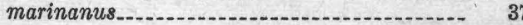

oxybaphon_.................... 4, 34, s5, 36, pl. 11
Clypeaster-Continued

pentaporus.

pinarensis

platygaster

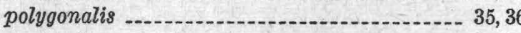

profundus

prostratus_._.

rogersi_..._._._._._..... 4, $33,36,38,44$, pl. 12

rosaceus_..._._._._._._. $5,34, \mathrm{pl} 10$

subdepressus - $5,34,96, \mathrm{pl} .11$

(Echinorodum) _........................... 33

(Stolonoclypus) prostratus................ 36

subdepressus - $\quad 36$

Clypeasteridae_......... 6,33

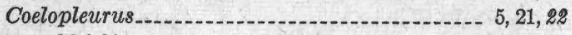

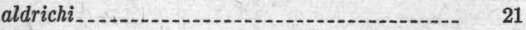

carolinensis.......................... 22, 23, pl. 3

coronalis

equis.

infulatus sloani

colsoni, Oligopygus.

29

conradi, Agassizia

conradi

(Paralampas) -......... 59

(Plagiopygus) _.............. 4, 56, 59, pl. 25

(Pygorhynchus)

Catopygus

Hemiaster

Protoscutella

Rhyncholampas -............ 59,60

Scutella

Sismondia

conradi, Cassidulus

lyelli, Cassidulus _.................. 4, 56,60, pl. 25

Coptosoma speciosum .......................... 23

cordatum, Echinocardium

cordatus, Echinus

coronalis, Cidaris

Coelopleurus

Cosmocyphus

(Cosmocyphus), Phymosom

saemanni, Phymosoma

costulatus, Oligopygus

cotteaui, Clypeaster ................ 4, 33, 37, pl. 12

craniolaris, Echinocyamus................... 30

cranium Hemiaster. -... 68

cravenensis, Cassidulus...................... 65, pl. 23

Cassidulus (Pygorhynchus) carolinènsis...... 65

crescenticus, Brissopsis

crucifer, Echinobrissus

Nucleolites

(Trematopyous) -....... 26

Pygorhynchus........... 26,63

Ravenelia..

Trematopygus

cruciferum, Rhopostoma

cruciferus, Ananchytes............................

Nucleolites.

Nuculites.

Trematopygus

crustuloides, Echinodiscus

Laganum

Peronella

Scutella.

Ctenocidarina.

cubae, Peronella

Weisbordella

cubensis, Eupatagus

Macropneustes

Mauritanaster.

cuneus, Rhynobrisous 


\section{Page}

curvus, Eupatagus (Plagiobrissus) Plagiobrissus declivis.. drewryensis....

Cyphosoma radiatum speciosum.

dalli, Diplothecanthus Echinodiscus Laganum. Neolaganum

Peronella. Weisbordella

declivis, Cyclaster.

77, 78, pl. 33 Cassidulus (Rhynchopygus) Procassidulus.

deshayesii, Macropneustes _. 82, 83

desmoulinsi, Maretia................................. 81

diatreta, Echinopsis _................ 2, 14, pl. 2

diatretum, Cidaris.

Polydiadema

Pseudodiadema

Diplocidarinae.

Diplothecanthus antillarum

dalli.

rosaceus.

34

Discoidea haldemani beckeri

nux- 77

dixie, Dixieus Eupatagus (Plagiobrissus) - -..........-. 87 Phymosoma Plagiobrissus _................................. 40

Dixieus..._. dixie............................ 5 pelorius.

Dorocidaris. abyssicola.

papillata.

porocidaris) georgiana, Cidaris_.............. 11

smithi, Cidaris ...

douvillei, Amblypygus. Clypeaster. dröbachien, Cyclaster-...................- 4, 68, pl. 28 Strongylocentrotus drøbachiensis, Strongylocentrotus.......... 25 dubius, Cidarites (Phyllacanthus) ................ 11 Phyllacanthus.

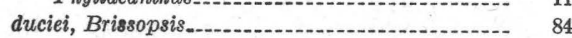
dumblei, Lovenia.

durhami, Neolaganum.

$4,51,52, \mathrm{pl}, 21$

Echanthus. georgiensis

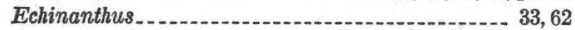
georgiensis. 62 gregoryi....-...- 61

ovatus subdepressa...

Echinarachnilidae.

44 parma Echinidae.......... 5, 16-18

Echino-cidaris.

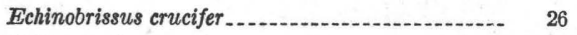

Echinocardium atropos cordatum
depressum
Echinocardium-Continued gothicum

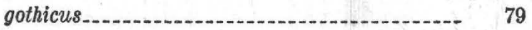
orthonotum ....... $4,5,78$, pl. 33 virginianum_................................. 78

(Echinocardium), Echinospatagus_.........-... 78

Echinocorys ovalis_......... 2, 66, pl. 27

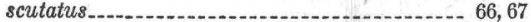
teranus

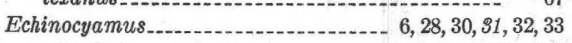
chipolanus_......... 4, 32, pl. 9 craniolaris...-...- 30

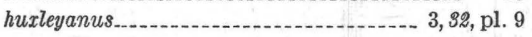
macneili_............. 32, pl. 9 meridionalis _........ 3, 32, pl. 9 parvus pusillus.

texanus.

Echinodiscus archerensis...- 51 crustuloides

dalli.

emarginatus

floridanus

johnsoni

laganum.

quinquies perforatus quinquiesperforatus

sexies perforatus

Echinolampadidae

Echinolampas 3, 55, pl. 22 appendiculata....................... 3, $56, \mathrm{pl} .22$ appendiculatus ovata

ovum-serpentis

(Isolampas) appendiculatus......... 56

(Miolampas).

aldrichi.

Echinometra

atratus_..-...-... 25

lucunter

mammillatus

Echinometridae

Echinoneidae

Echinoneinae

Echinoneus

Echinopsis. diatreta.

elegans.

(Echinorodum), Clypeaster.-

Echinospatagus. -

(Echinocardium)

Echinus.

chlorocentrotus.

cidaris..

cordatus.....

dröbachiensis.

equis....

esculentus.

grandis.

hexaporus.

improcerus

infulatus

lixula

lucunter.

miliaris.

oviformis

philanthropus

punctulatus.

pustulosus.

rosaceus

ruffini

tuberculatus

variegatus.
Echinus-Continued

ventricosus.... 15

(Psammechinus)

(Strongylocentrotus).

chlorocentrotus

egozcuei, Agassizia

elbana, Eurhodia

eldridgei, Laganum ........... 52, 53

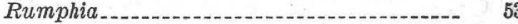

Wythella_....... 4, 50, 53, pl. 21

elegans, Brissopsis................... 84

Echinopsis...-...- 14

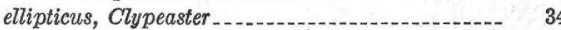

elongata, Lovenia

elongatus, Spatangus............. 77

emarginata, Encope............. 4, 5, 48, 49, pls. 17, 18

emarginatus, Echinodiscus_........... 49

Encope.

emarginata $\quad 4,5,48,49$, pls, 17,18

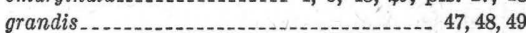

macrophora........... 4, 58,49 , pl. 17

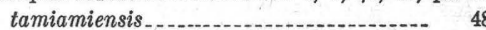

michelini..................... 5, 48, 49, 50, pl. 18 pentapora....... 46 tamiamiensis_...... 4, 48, 49

Eoagassizia _......... 75

eocenicus, Progonechinus..................... 19

equis, Coelopleurus_........ 22

Echinus.

ericsoni, Cassidulus_............. 3, 4, 56, 58, pl. 24

Escheria insignis_..._... 69

esculenta, Cidaris._.

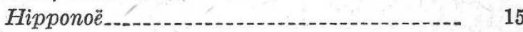

Tripneustes_.......... 15

esculentus, Echinus_........................... 16

Eucidaris_........ 8,9

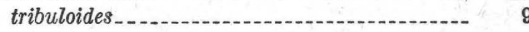

Eupatagus_..._....... 7, 86, 87, 88,92 antillarum__._. $3,87,90,91$

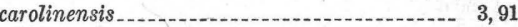

clevei_............. 3, $4,89, \mathrm{pl} .41$

cubensis_.......... 83

floridanus.

georgianus._........ 92, pl. 43

grandiflorus

mooreanus

pectoralis -

86,enciennesii _. 89, 90

(Brissopatagus) alabamensis...... 4, 92, pl. 43 georgianus primus.

(Gymnopatagus) _._._... 89 antillarum carolinensis_._._._............. 3, 91, pl. 42 gardnerae _._._. 4, $90, \mathrm{pl} .42$ mooreanus. 90 ocalanus_......................... 91 pl. 42

(Macropneustes)

(Plagiobrissus) _........ 86 carolinensis_._._. 91 curvus___..... 87 dixie gardnerae grandis_..- 86

holmesii

ocalanus........... 91

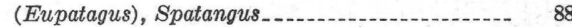

Eurhodia_...... 6, 56,57,63,64,65 elbana_........ 2, 56, 64, pl. 26 holmesi_..._-_._.

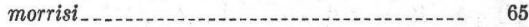
patelliformis raveneli_........... 63 rugosa (Eurhodia)
(Gisopygus) holmesi_a........ 56 


(Eurhodia), Eurhodia
Euspantangus antillarum
Euspatangus
$\quad$ clevei
$\quad$ grandiflorus
evergladensis, Cassidulus (Cassidulus)
$\quad$ Cassidulus (Rhynchopygus)
exoletus, Psammechinus

Fibularia

$6,30,31$

alabamensis

$4,30,31, \mathrm{pl} .9$

huxleyi.

meridionalis

ovulum.

texana...

vaughani

$30,31, \mathrm{pl}, 9$

$4,30,31$, pl. 9

Fibulariidae-............. 6, 30-33

fimbriatus, Ananchytes.......................... 65, 66

Cardiaster.

Holaster.

5-faria, Scutella.

$3,15, \mathrm{pl}$. Psammechinus_............................... 15

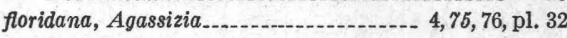

Scutella

floridanum, Laganum ................. 4, 50,51, pl. 20

floridanus, Brissoides (Koilospatangus) ........... 87 Echinodiscus................... 50

Eupstagus Oligopygus_............. 28 Periarchus lyelli................... 3,4,41, 42, pl. 13 Schizaster _ 71,72

fontis, Cassidulus (Galerolampas) .............. 62,63

Formations, echinoid-bearing

Gagaria.

G

americana 18,10

chickasawhay ......... 4, 18, pl. 3

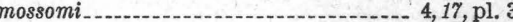

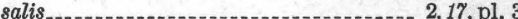

venustula

(Gagaria), Micropsis

chickasawhay, Thylechinus

mossomi, Thylechinus

salis, Thylechinus

Galeraster

$-26$ gardnerae, Eupatagus (Gymnopatagus) ..... 4, $90, \mathrm{pl} .42$ Eupatagus (Plagiobrissus) _................... 90

gatuni, Clypeaster _ _................ 34, 35, pl, 1

Gauthieria speciosa....... 2, 23, pl. 5 gentili, Mauritanaster

georgiana, Cidaris........................ 11, 12 Cidaris (Dorocidaris)

georgianus, Eupatagus.................... 92, pl. 43 Eupatagus (Brissopatagus)

georgiensis, Cassidulus........................ 61 Cassidulus (Plagiopygus) _.......... 4, 60, pl. 25 (Pygorhynchus) _........................... 60

Echanthus___........ 2, 56, 68, 70, pl. 26 Echinanthus.......................

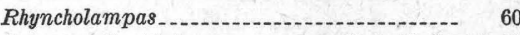
globosus, Cassidulus_........... 3, 4, 56, 61, pl. 25 Cassidulus (Plagiopygus)

gibberula, Agassizia

Cidaris

Tylocidaris

gibberulus, Schizaster

Gisopygus.

(Gisopygus) holmesi, Eurhodia glenni, Brissus

56,65, pl. 23 Spatangus

globosus, Cassidulus georgiensis_...... 3, 4, 56, 61, pl. 25 Cassidulus (Paralampas)

(Plagiopygus) georgiensis
Page

Goniocidarina

gothicum, Echinocardium_._. 79

Echinocardium 79

gouldii, Cassidulus_.............. 4, 56, $57,58,59$, pl. 24 Cassidulus (Cassidulus) ..................... 58

(Pygorhynchus)

Procassidulus (Hardouinia)

Pygorhynchus

Ravenelia

grandiflorus, Eupatagus..

Euspatangus -

grandis, Echinus.

Eupatagus (Plagiobrissus) _....... 47, 48, 49

Meoma

Plagiobrissus_............... 5, 86, 87, 92, pls. 39,40

gratilla, Tripneustes............... 14 gregoryi, Breynella

Cassidulus (Paralampas)

Echinanthus.

grignonensis, Cassidulus (Plagiopygus)

Nucleolites.

Pygorhynchus

Gymnopatagus

valdiviae.

(Gymnopatagus), Brissoides

Eupatagus.

antillarum, Eupatagus

carolinensis, Eup

gardnerae Eupatagus................ 4, 90, pl. 42

mooreanus, Eupatagus.............. 90

ocalanus, Eupatagus_................... 4, 41, pl, 42

Haimea.

aldemani, Discoidea

Oligopygus.

hanoverensis, Linthia

Schizaster (Linthia)

$4,91, \mathrm{pl}, 42$

(ta) 70 gouldii, Procassidulus.

hayesiana, Scutelina

hayesianus, Cassidulus

Hebertia.

Heliocidaris.

Hemiaster

conradi.

cranium.

incrassatus

minimus

moscovensis_................ 2, 68,28

nux 73,76

parastatus $2,67,68, \mathrm{pl} .28$

stella

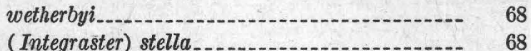

(Leymeriaster) parastatus_................. 67

Hemiasteridae............... 6, 67-69

hemiasteroides, Rhynobrissus_..._....... 88

Hemibrisuss _.

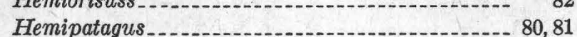

argutus.-

subrostratus

hexapora, Mellita

hexaporus, Echinus.

Hipponoè esculenta

variegata.

Histocidarina.

hoff manni, Spatangus

Holaster.-

fimbriatus.

mortoni...

nodulatus.

nodulosus

parastatus.
Page

Holasteridae..._ 65-67 holmesi, Cassidulus (Rhynchopygus) _..........- 65 Eurhodia (Gisopygus) _............... 3, 56,65, pl. 23 $\begin{array}{ll}\text { Metalia } & \\ \text { Rhyncholampas } & \end{array}$ holmesii, Eupatagus (Plagiobrissus) _............. 87

Plagiobrissus___ 5,

Plagionotus_.......... 87

honorinae, Cidaris_............................... 8

huxleyanus, Echinocyamus_................ 3, 32, pl. 9

huxleyi, Fibularia

hystrix, Lovenia.

I

imperialis, Phyllacanthus

improcera, Arbacia

improcerus, Coelopleurus.....................

Echinus.

Psammechinus

incrassatus,

inflata, Agassizia

infulatus, Coelopleurus....................... 3, 22, pl. 3

Echinus _- 22

insignis, Escheria

Linthia.

(Integraster) stella, Hemiaster

(Isolampas) appendiculatus, Echinolampas....-. 56

$\mathbf{J}$

Jacksonaster

jacksoni, Schizobrissus._.

johnsoni, Echinodiscus......................... 54

Laganum ........ 54

Weisbordella

jonesi, Scutella

K

kewi, Periarchus

Periarchus quinquefarius_.......... 4, 41, 44, pl. 14

44

Kleinia...

luzonica..

koenigi, Phymosoma

(Koilospatangus) floridanus, Brissodies

L

Lagana rogersi

Laganidae _............. 50-51

Laganum _......... 6,50

archerensis_............ 51,52

bonani-........... 50

crustuloides

dalli

eldridgei_............ 52,53

floridanum ..................... 4,50,51, pl. 20

johnsoni_........... 54

laganum 50,51

ocalanum

petalodes

laganum, Echinodiscus............ 50

Laganum ..................................... 50,51

lanceolatus, Clypeaster..................... 34, 35

Leiocidaris_.......... 10,11

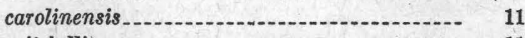

mitchelli_....... 1

Leiosoma tournoueri............................ 24

Leodia

caroliniana

richardsonii_._._.

sexiesperforata...................... 5, 46,47, pl. 19

sextiesperforata

(Leodia), Mellita

sexiesperforata, Mellita

lignoni, Oligopygus

6
8
7
6
8
8
8
9
77


Page

Linthia ..................................... 2, 7,69, 70, 79 alabamensis_..................... 2,69, pl. 29 hanoverensis............................ 3, 70, pl. 29 insignis. maverickensis__ 69,70

prima $2,70, \mathrm{pl} .43$ wilmingtonensis........................ 3, 69, pl. 29

(Linthia), Schizaster

alabamensis, Schizaster

ocalanus, Schizaster.

wilmingtonensis, Schizaster Echinus

Lovenia

alabamensis_............................. 4,77

clarki_................................ 4, 5,77 , pl. 33

elongata

hystrix

Loveniidae.

lucunter, Echinometra............ 5, 25, pl. 6

Echinus

luzonica, Kleinia

lyelli, Cassidulus. 60,61

Cassidulus conradi_................ 4, 56,60, pl. 25

(Paralampas)

(Rhynchopygus) _.................. 60

Nculeolites..

Periarchus.......... 3, 4, 41, 42, 43, 44, 91, pls. 13, 14 lyelli.....-.

Rhyncholampas.

Scutella

Sismondia

lyelli, Periarchus................................. 41

pileus-sinensis, Periarchus__._._. 4, 41, 42, 43, pl. 13

lyrifera, Brissopsis................... 85

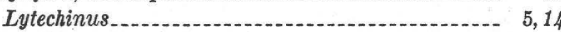

floralanus.

variegatus

M

macneili, Echinocyamus.

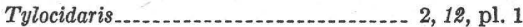

Macrophora macrophora................... 48

raveneli...................................... 48

macrophora, Encope ............... 4, 5, 48, 49, pl. 17

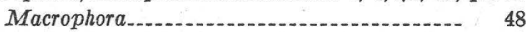

Ravenellia...

Scutella.

tamiamiensis, Encope

Macropneustes -.... 7, 79,82

carolinensis

cubensis ___ 83, 84

deshayesii

mortoni

ventricosus............ $5,84, \mathrm{pl} .37$

(Macropneustes), Eupatagus_................... 82

mammillatus, Echinometra...................... $\quad 25$

mansfieldi, Phymotaxis_.................. 4, 24, pl. 6

Maretia

arguta_._._.

clarki

desmoulinsi.

90
81

subrostrata

twitcheth

34
90

(Maretia), Spatangus.

marginalis, Monostychia

Mortonia (Periarchus)

Periarchus..

Sismondia

marinanus, Clypeaster

Mauritamaster carolinensis

Mauritanaster cubensis

gentili. maverickensis, Linthia.

Page

mediterranea, Brissopsis

69,70

Mellita

ampla.

caroliniana.

hexapora.

pentapora.

quinquefora

ampla.

quinquiesperforato tenuis...................................... 5,46

sexforis...

similis.

testudinata

(Leodia)

sexiesperforata

Meoma

grandis...

ventricosa......

(Meoma), Brissus.

ventricosus, Brissus..

Fibularia

Metalia holmesi

pectoralis................. 86, 87

raveneliana

metularia, Cidarites............................ 8,9

michelini, Encope.................... 5, 48, 49, 50, pl. 18

micra, Porpitella ............................. 3, $38, \mathrm{pl} .7$

Micraster...

Micropeltis

(Micropeltis), Circopeltis...........................

Micropsis venustula....

(Gagaria)

Microsoma speciosum.

miliaris, Echinus

Psammechinus

minimus, Hemiaster

(Miolampas), Echinolampas

aldrichi, Echinolampas Protoscutella Scutella....

mitchelli, Leiocidaris

mitchellii, Cidaris..................................... 11, 12

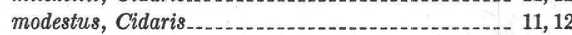

Moera

moerens, Cidaris_....... 11, 12

Moira

atropos

monilifera, Cidaris

Cidarites.

Monostychia

marginalis.

mississippiensis

plana.

mooreanus, Eupatagus

Eupatagus (Gymnopatagus)

morieri, Cidaris

morrisi, Eurhoci.

Pygorhynchus.

Mortonella.

quinquefaria

rogersi.

mortoni, Cidaris.

Cidaris (Phyllacanthus) -

Cidarites 11,12

Holaster -

Macropneustes

Nucleolites _...

Phyllacanthus............................. 3,10,11, pl. 1

Mortonia

quinquefaria

rogersi
Mortonia-Continued

turgida

(Periarchus) _....................................... 41

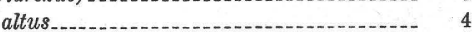

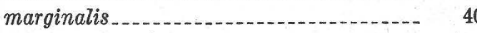

pileus-sinensis........................... 42

planus................................ 40

(Mortonia) rogersi, Scutella

moscovensis, Hemiaster.................... 2, 68, pl. 28

mossomi, Agassizia (Anisaster) _.............. 4,76, pl. 32

Gagaria.......... 4, $17, \mathrm{pl}$

Thylechinus (Gagaria) ....................... 17

multipunctata, Cidaris .......- 8

\section{$\mathrm{N}$}

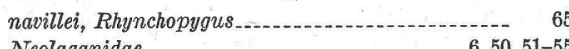

Neolaganidae........................... 6, 50,51-55

Neolaganum

antillarum

archerensis....

dalli__._.

durhami_.......................... 4, 51,52, pl. 21

nodulatus, Holaster.

nodulosus, Holaster............................. 65

Spatangus........ 65

Nucleolites crucifer .......... 26, 64

cruciferus

grignonensis................................ 59

lyelli

mortoni

oviformis

(Trematopygus) crucifer.................. 26

$\begin{array}{ll}\text { Nuculites cruciferus_...... } & 26 \\ \text { nux, Ditremaster }\end{array}$

Hemiaster.................................. 73

0

ocalanum, Laganum (.................. 4, 50,51, pl. 20

ocalanus, Eupatagus (Gymnopatagus) _..... 4, 91, pl. 42

Eupatagus (Plagiobrissus) _.................. 91

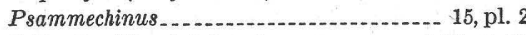

Schizaster (Brachybrissus) _._._._._._... 4, 78, pl. 29 (Linthia).

Oligophyma.

Oligopodia ...

Oligopyginae

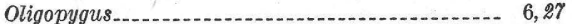

colsoni

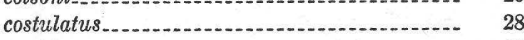

floridanus..................................... 28

haldemani...................... 3, $29,30, \mathrm{pl} .8$

lignoni...

rotundus .................. $39,29, \mathrm{pl} .8$

wetherbyi $\ldots$

orbignyana, Cidaris.............................. 11

ordinatus, Cidaris

Orthanthus..................................... 37

Orthechinus pretiosus............................ 18

orthonotum, Echinocardium _............. 4, 5, 78, pl. 33

orthonotus, Amphidetus..................... 78

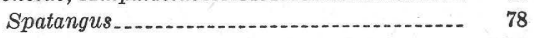

Orthopsidae............... 5,14

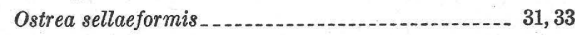

ovalis, Ananchytes

Echinocorys ........................... 2, 66, pl. 27

ovata, Echinolampas_._.............. 55, 56, 62

ovatus, Echinanthus _............................ 55

oviformis, Cassidulus_.............................. 61

Catopygus. . . 61,62

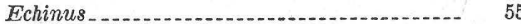

Nucleolites.................................. 61

Phyllobrissus. 61

Santeelampas_....................... 3, 56,61, pl. 26

ovulum, Fibularia

ovum-serpentis, Echinolampas__................... $\quad 28$

oxybaphon, Clypeaster................... 4, 34, 35, pl. 11 


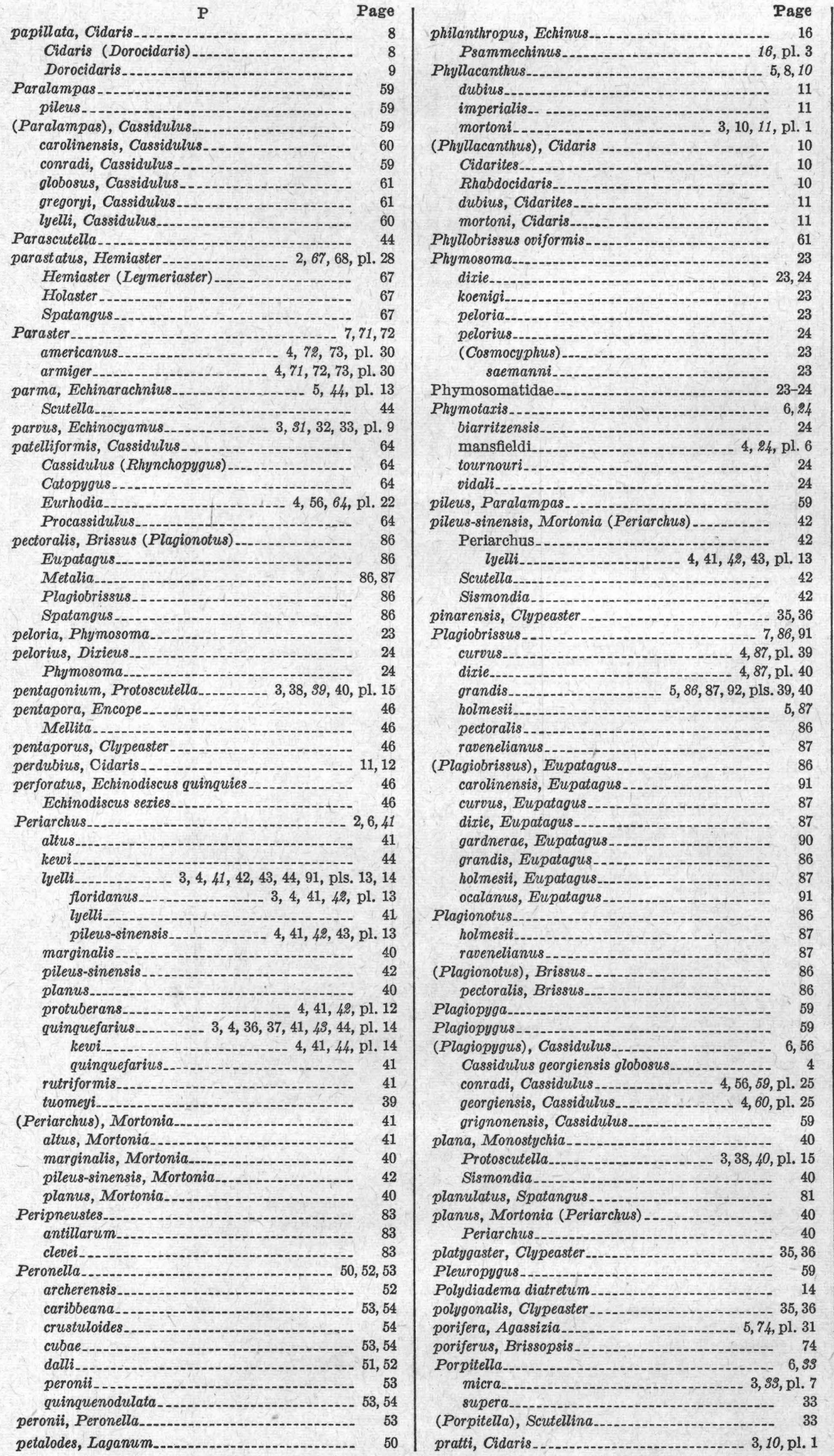

Prenaster alpinus_.... Page

(Anisaster)

pretiosus, Brochopleurus................... 3, 18, pl. 4 Orthechinus_............................. 18

Progonechinus - 18

prima, Linthia ........................ 2, 70, pl. 43

primus, Eupatagus (Brissopatagus) ............. $\quad 70$

Procassidulus depressus ........................ 64 patelliformis -..---.- 64

(Hardouinia) alabamensis_................. 57 gouldii...

profundus, Clypecster

Progonechinus eocenicus pretiosus.

propinqua, Cidaris

Prostethes........................................... 45

prostratus, Clypeaster...................................... 33, 39 Clypeaster (Stolonoclypus)

Protoscutella conradi____._. mississippiensis_............... $3,38,39,40, \mathrm{pl} .15$ pentagonium …......... $3,38,39,40$, pl. 15 plana tuomeyi.................... $38,39,40$, pl. 15

Protoseutellidae _.................... 6, 38-44

protuberans, Periarchus.................. 4, 41, 42, pl. 12

Psammechinus_..._..................... 5, 15, 16 exoletus..._.

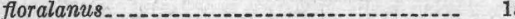

improcerus_._.

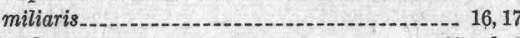

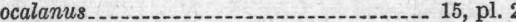

philanthropus_....................... 16, pl. 3

santee

(Psammechinus), Echinus_...................... 16

Pseudodiadema

americanum ................................ 18

pseudodiadema

-

speciosum

pseudodiadema, Pseudodiadema..................- 14

punctulata, Arbacia.............. 5, 19, 20, 21, pl. 4

punctulatus, Echinus..-

purpureus, Spatangus........................... 80

pusillus, Eehinocyamus_........................... 31

Spatangus _............................. 31, 78

pustulosa, Cidaris

pustulosus, Echinus............................. 19

Pygorhynchus _.................................... 59

crucifer

gouldii_.................................... 57

grignonensis............................... 59

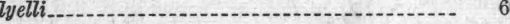

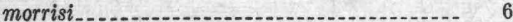

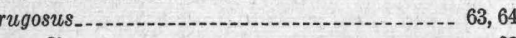

vassali.

(Pygorhynchus), Cassidulus carolinensis cravenensis.-..-. c-

alabamensis, Cassidulus_................. berryi, Cassidulus. conradi, Cassidulus.

georgiensis, Cassidulus

gouldii, Cassidulus...

sabistonensis, Cassidulus.................... 54

pyramidalis, Rhynobrissus........................ 88

quinquefaria, Mortonella

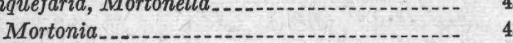

Scutella

quinquefarius, Periarchus_.... 3, 4, 36, 37, 41, 43, 44, pl. 14 Periarchus quinquefarius................. 41 kewi, Periarchus................ 41, 44, pl. 14 quinquefarius, Periarchus_.................... 41 


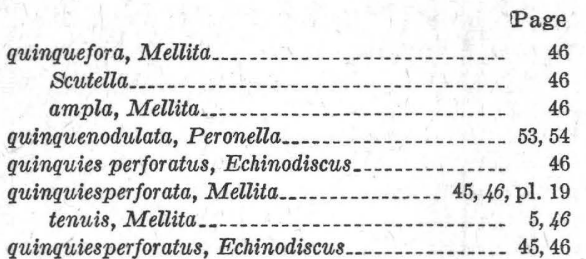

Rabdocidaris

10,11

radiatum, Cyphosoma...-. 32

raveneli, Cassidulus (Rhynchopygus) _............ 63, 64 Eurhodia...

Macrophora

Ravenelia.

crucifer

gouldii.

rugosa

raveneliana, Metalia

ravenelianus, Plagiobrissus

Plagionotus.

Ravenellia macrophora

reticulatus, Echinus.

Rhabdocidarina

Rhabdocidaris - 10,11

(Phyllacanthus)

(Rhabdocidaris), Cidaris_............................ 10

Rhinobrissus_._................................... 88

Rhopostoma_ 2, 6, 26 cruciferum

Rhyncholampas_..._. 56,59

conradi. . 59,60

georgiensis _......... 60

holmesi...

lyelli.

Rhynchopygus navillei rugosus

(Rhynchopygus) depressus, Cassidulus. evergladensis, Cassidulus.

holmesi, Cassidulus.

lyelli, Cassidulus

patelliformis, Cassidulus

raveneli, Cassidulus.

$\mathrm{S}$

Page

sabistonensis, Cassidulus_......... 4, 56, 57, 58, pl. 23 Cassidulus (Cassidulus) (Pygorhynchus) saemanni, Phymosoma (Cosmocyphus) _.......... 23 said, Thylechinus

Salenia

bellula

tumidula

Saleniidae _._. 5,13

salina, Tylocidaris_.......... 2, 12, pl. 1

salis, Gagaria.............................. 2, 17, pl. 3

Thylechinus (Gagaria)

santee, Psammechinus_.................... 3, 17, pl. 3

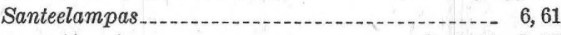

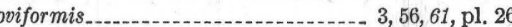

Sarsella

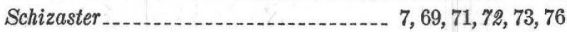

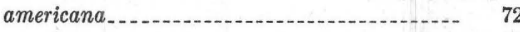
americanus........... 72

armiger

atropos

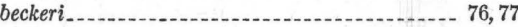

floridanus 71,72

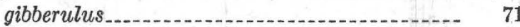

studeri

subcylindricus............................. 77

(Brachybrissus) _............ 73 ocalanus ................ 4, 73, pl. 29

(Linthia) .......... 69

alabamensis.

hanoverensis

ocalanus.

wilmingtonensis.

(Schizaster).

Schizechinus -...-...- 14

jacksoni.

scrobiculata, Agassizia..... 74

scutatus, Echinocorys

Scutella $31,38,44$

aberti

caroliniana.......... 47

conradi....... 40

crustuloides_..._._. 40, 55

5 -faria

floridana

jonesi

lyelli_............. 40, 41, 42

macrophora.

mississippiensis.

parma.

pileus-sinensis

quinquefaria.

quinquefora

rogersi..-

sexiforis.

tuomeyi.

Mortonella

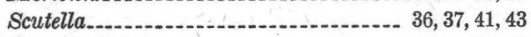

Scutella (Mortonia)

rosaceus, Clypeaster................... 54, pl. 10

Diplothecanthus_._. 34
Echinus_

rostrata, Rumphia

rotundus, Oligopygus.

$3,29, \mathrm{pl} .8$

ruffini, Echinus

rugosa, Eurhodia

16
Ravenelia.. $3,56,57,63,64$, pl. 22

rugosus, Pygorhunchus.......................... 63, 64

Rhynchopygus

64
63

Rumphia

archerensis

eldridgei.

rostrata.

utriformis, Periarchus.
Scutellina

hayesiana.

supera.

(Porpitella).

scutiger, Cidarites

sellaeformis, Ostrea

sexforis, Mellita.

Scutella...

sexies perforatus, Echinodiscus 47 sexiesperforata, Leodia Mellita (Leodia)

sextiesperforata, Leodia.

similis, Mellita.

Sismondia

alta

conradi.
(Mortonia) rogersi
Sismondia-Continued

Page

lyelli.

marginalis

pileus-sinensis

plana.

Coelopleurus._. $4,20,21$, pl. 4

smithi, Cidaris_............. 10, pl. 1

Cidaris (Dorocidaris)

Spatangidae_._.

Spatangus...

ambulacrum

atropos.-.-.- 73

brissus unicolor .

bufo

elongatus_......-...- 77

glenni _... 5,80, pl. 35

hoffmanni...... 80

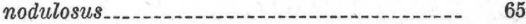

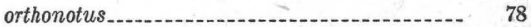

parastatus

pectoralis

planulatus__-_. 81

purpureus

pusillus_.

stella

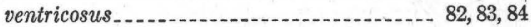

(Eupatagus)

(Maretia)

speciosa, Gauthieria..................... 2, 28, pl. 5.

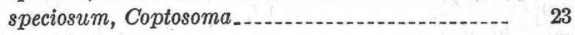

Cyphosoma

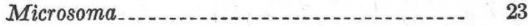

Pseudodiadema

splendens, Cidaris_................ 2, 9, 10, 12, pl. 1

splendeus, Cidarites

steinhatchee, Brissopsis_._._._.
stella, Hemiaster_._._. $85, \mathrm{pl} .38$

Hemiaster (Integraster)

Spatangus..-- 67

stellulatus, Brochopleurus............. 19

Temnechinus.

Stereocidarinae

Stolonoclypus

subdepressus, Clypeaster $\quad 36$

Stomopneustidae................ 24

Streptocidarinae_._.

Strongylocentrotus __ 6, 25

dröbachiensis _._.

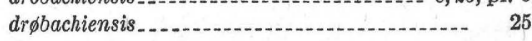

(Strongylocentrotus), Echinus................... 25

chlorocentrotus, Echinus............. 25

studeri, Schizaster

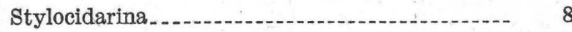

Stylocidaris_._._.

affinis

subcylindricus, Schizaster..._._._.......... 77

subdepressa, Echinanthus...................... 33, 36

subdepressus, Clypeaster............... 5, 34, $\$ 6$, pl. 11

Clypeaster (Stolonoclypus)

subrostrata, Maretia.......................... 81, pl, 34

subrostratus, Hemipatagus................... 81

sulcata, Breynia............... 77

supera, Porpitella............ 33

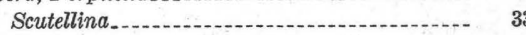

tamiamiensis, Encope._............. 4, 48, 49, pl. 17 Encope macrophora....... 48

Temnechinus stellulatus ...................... 18

Temnopleuridae....... 18-19

tenuis, Mellita quinquiesperforata.............. 5,46

testudinata, Mellita

texana, Fibularia........................ 30,31, pl. 9 
Page

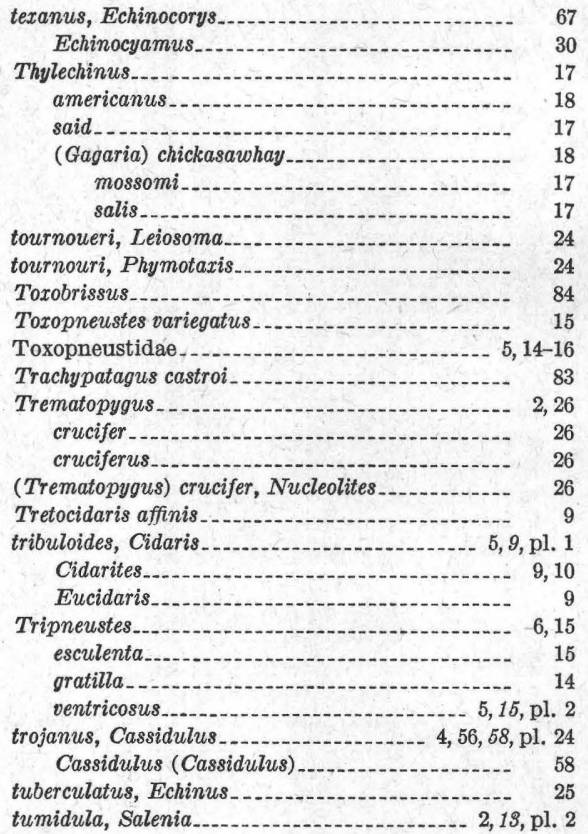

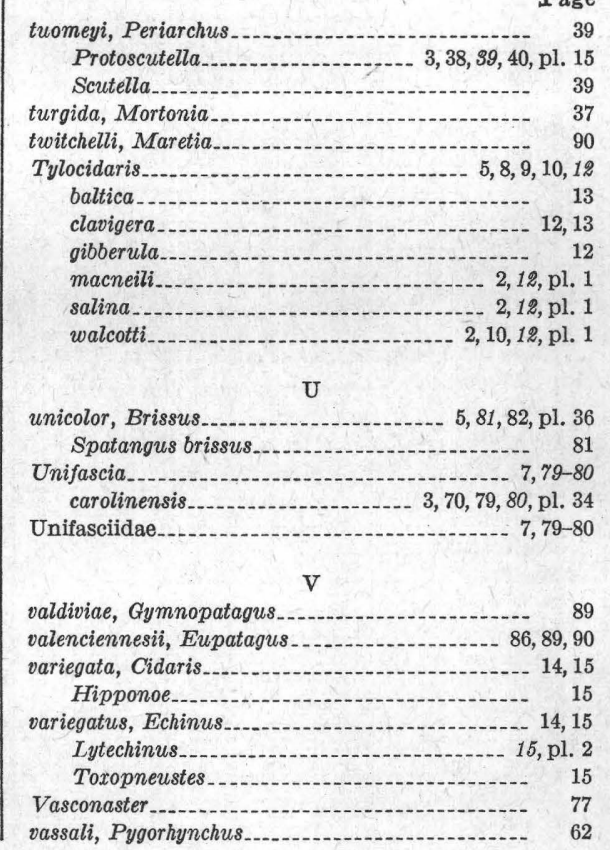

Page

vaughani, Echinocyamus Fibularia. ventricosa, Meoma ventricosus, Brissus (Meoma) Echinus _....... 15 Macropneustes Spatangus_........................... 82, 83, 84 Tripneustes_............ 5, 15, pl. 2 venustula, Gagaria _............................. 18 Micropsis.

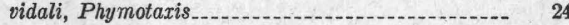
virginianum, Echinocardium _._._._._..... 78 virginianus, Amphidetus_......................... $\quad 78$

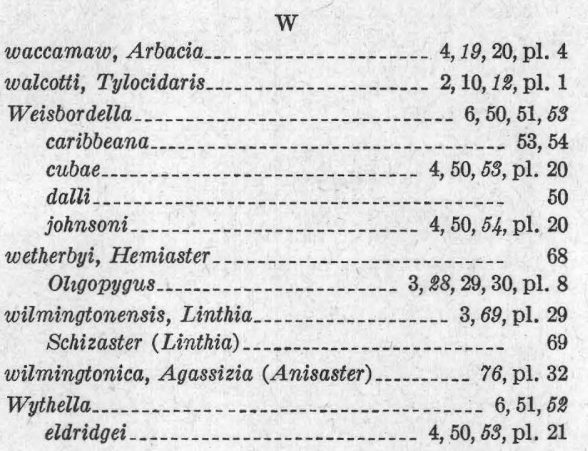




\section{PLATES 1-43}

[Illustrations are natural size unless otherwise indicated] 
Figures 1, 2. Cidaris tribuloides (Lamarck) (p. 9)

\section{PLATE 1}

Top and bottom views $\times 1$ of USNM 562261. Recent. From the beach on the north side of Cuba.

3-5. Tylocidaris macneili Cooke, n. sp. (p. 12)

3 , Holotype, USNM 562262a, $\times 2$.

4, Paratype, USNM 562262b, $\times 2$.

5, Paratype, USNM 562262e, $\times 2$.

From the Clayton formation of Paleocene age at USGS 18053, Henry County, Ala., in the SW 1/4 sec. 36 , T. 9N., R. $28 \mathrm{E}$.

6. Cidaris pratti Clark (p. 10)

Type of Cidaris smithi Clark, USNM 498880, $\times 1$.

Probably from the Ocala limestone of late Eocene age at The Rocks, Clarke County, Ala.

7-9. Tylocidaris walcotti (Clark) (p. 12)

7,8 , Plate $\times 2$ and spine $\times 1$ of USNM 18828. From the Vincentown sand of Paleocene age near Blackwoodstown, N. J.

9, Cotype, Acad. Nat. Sci. Philadelphia $1451 \times 2$. From the Vincentown sand of Paleocene age on Timber Creek, N. J.

10. Cidaris splendens (Morton) (p. 9)

Type, Acad. Nat. Sci. Philadelphia 1454, $\times 1$. From the Vincentown sand of Paleocene age on Timber Creek, N. J.

11. Cidaris sp. aff. C. splendens (Morton) (p. 10)

USNM 498879a, X3. From the Salt Mountain limestone of Paleocene age at USGS 13395, 6 miles south of Jackson, Ala.

12-14. Tylocidaris salina Cooke, n. sp. (p. 12)

Cotypes, USNM $498879 \mathrm{~b}, \times 3$. From the Salt Mountain limestone of Paleocene age at USGS 13395, Salt Mountain, 6 miles south of Jackson, Clarke County, Ala.

15-17. Phyllacanthus mortoni (Conrad) (p. 11)

Side, top, and bottom views $\times 1 \frac{1 / 2}{2}$ of USNM 498881. From the Ocala limestone of late Eocene age at USGS 13611, Bainbridge, Ga.

18, 19. Cidaris pratti Clark (p. 10)

Holotype $\times 2$ and spine $\times 1$, of Cidaris smithi Clark, USNM 498880. Probably from the Ocala limestone of late Eocene age at The Rocks, Clarke County, Ala. 


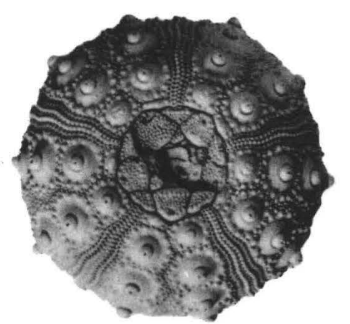

1
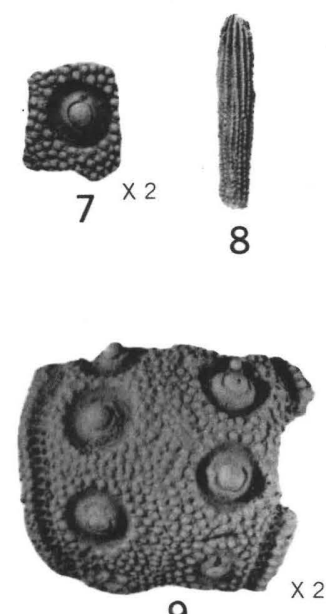

9

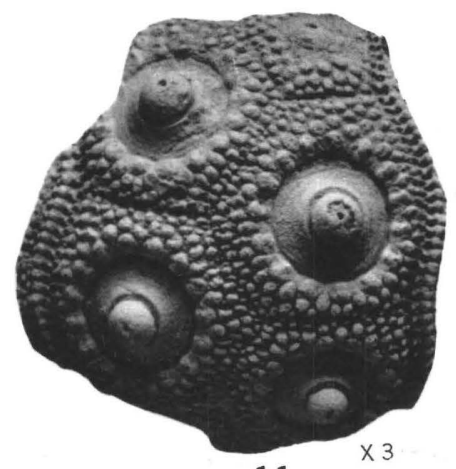

11
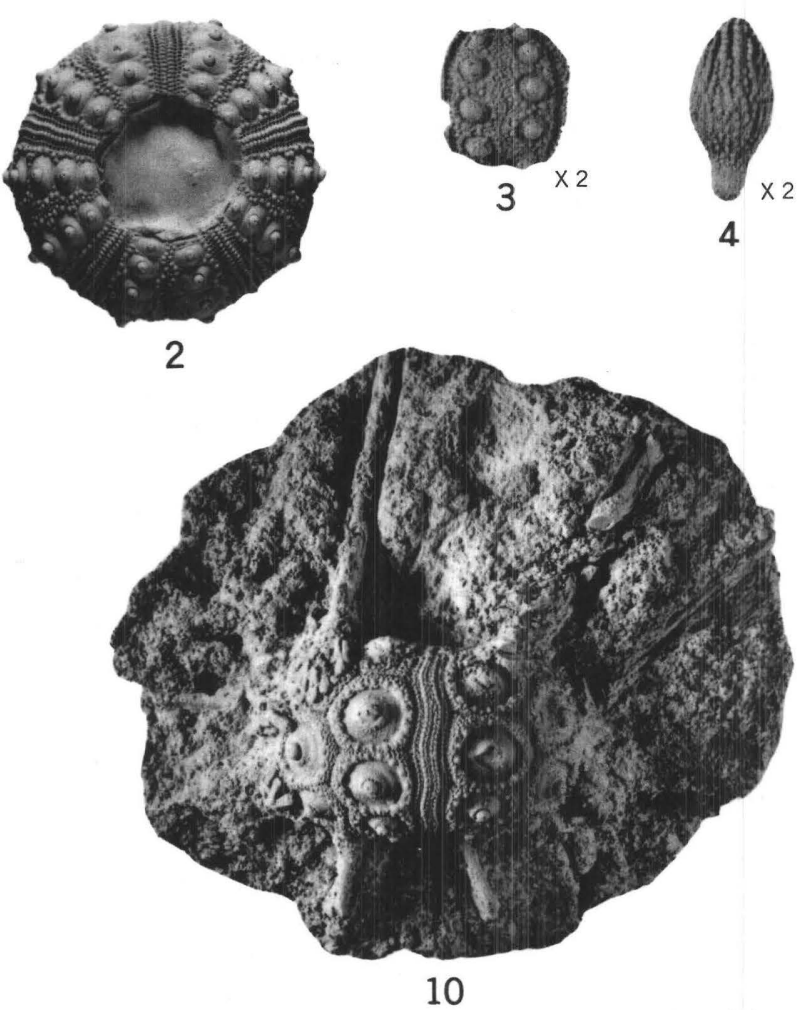
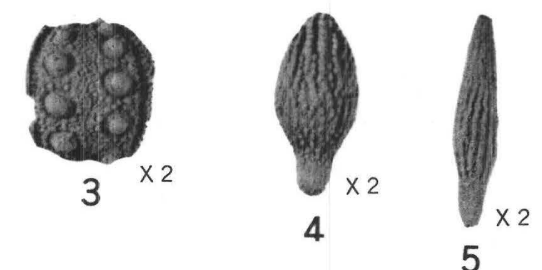

5
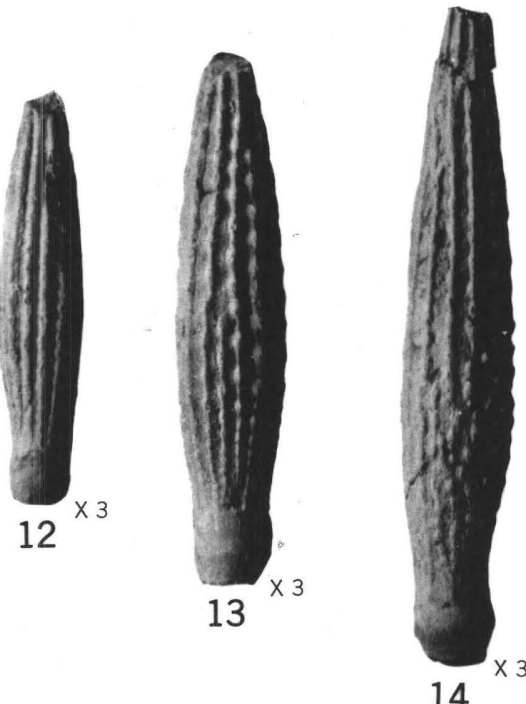
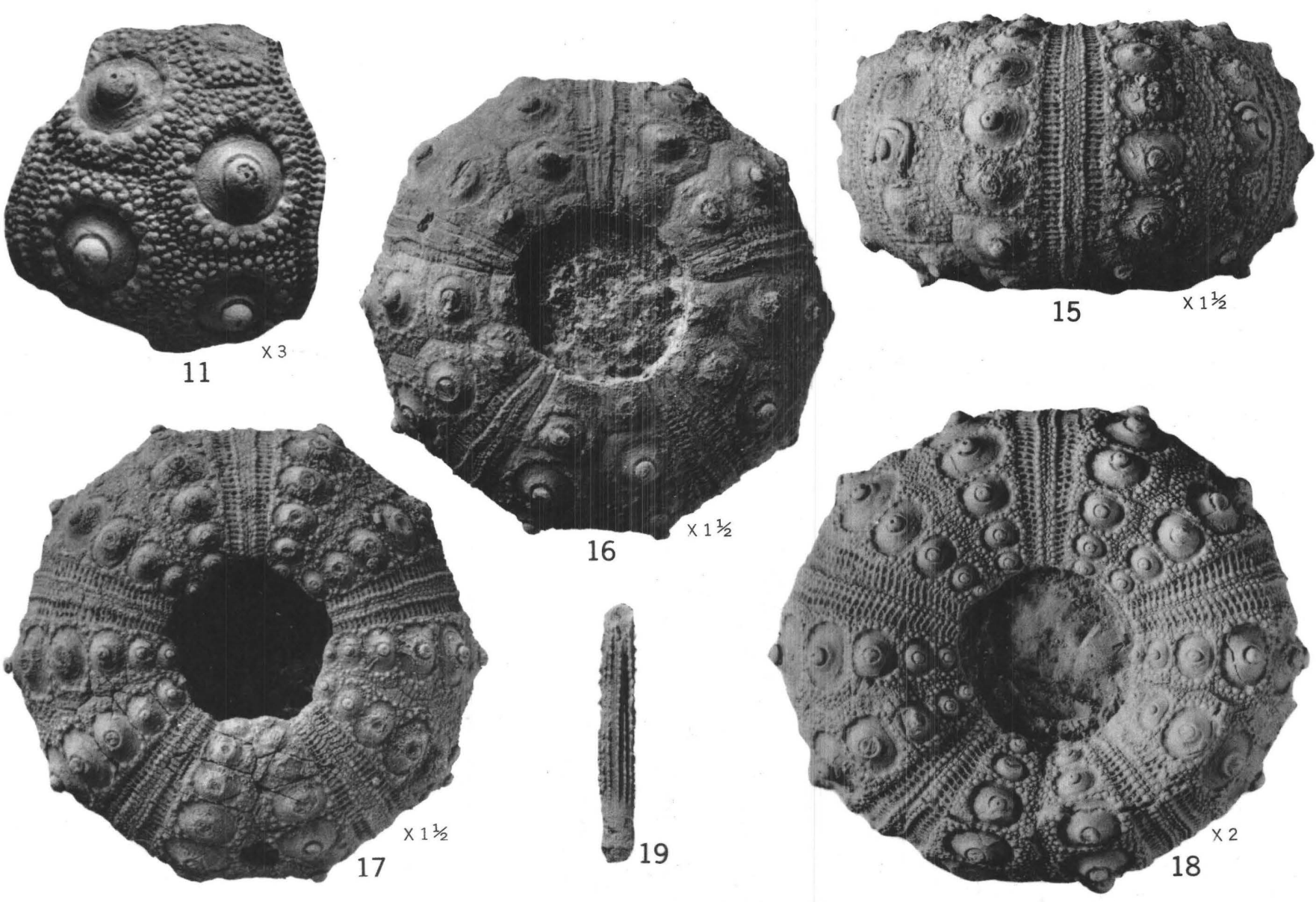

CIDARIS, TYLOCIDARIS, AND PHYLLACANTHUS 

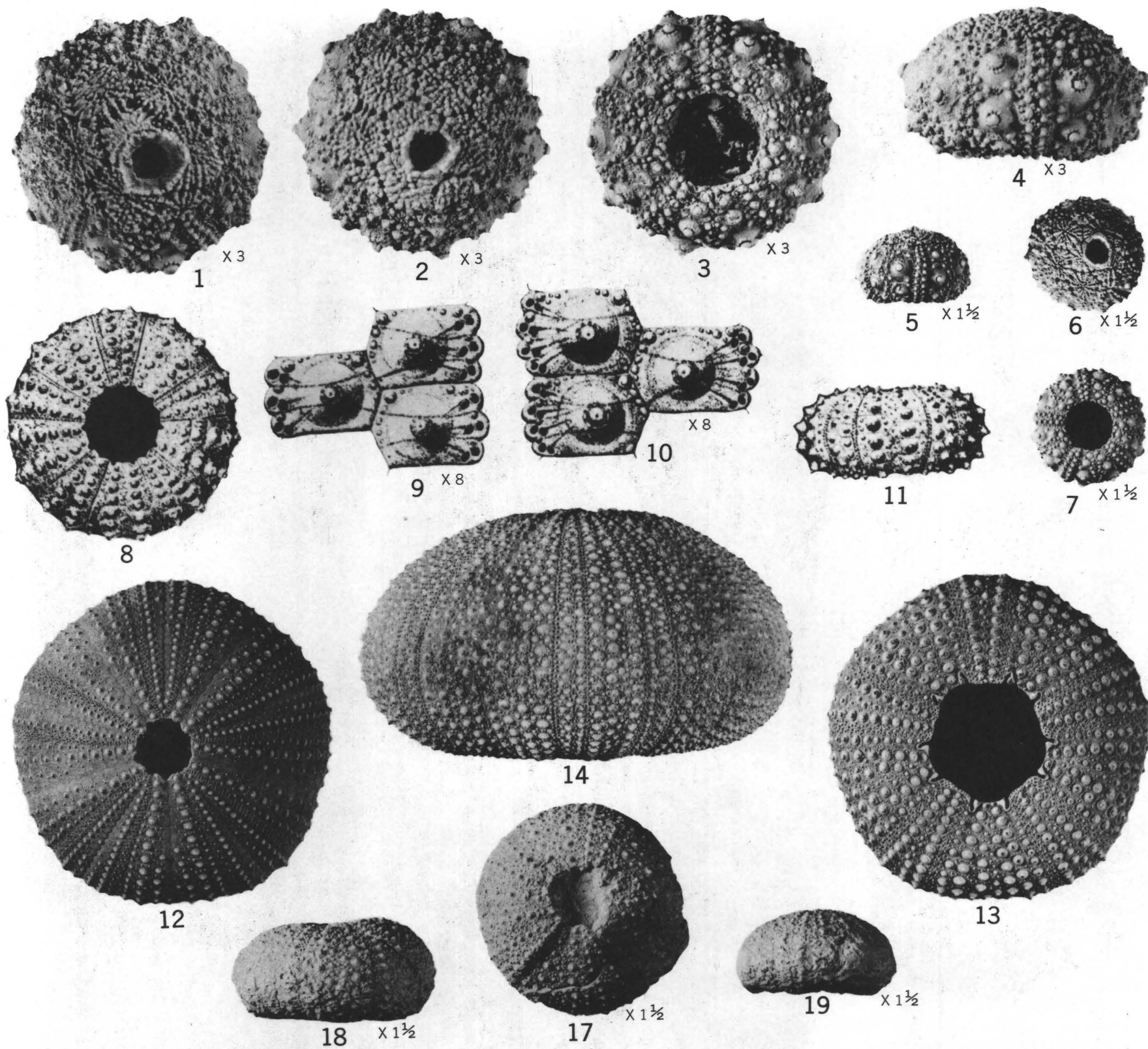
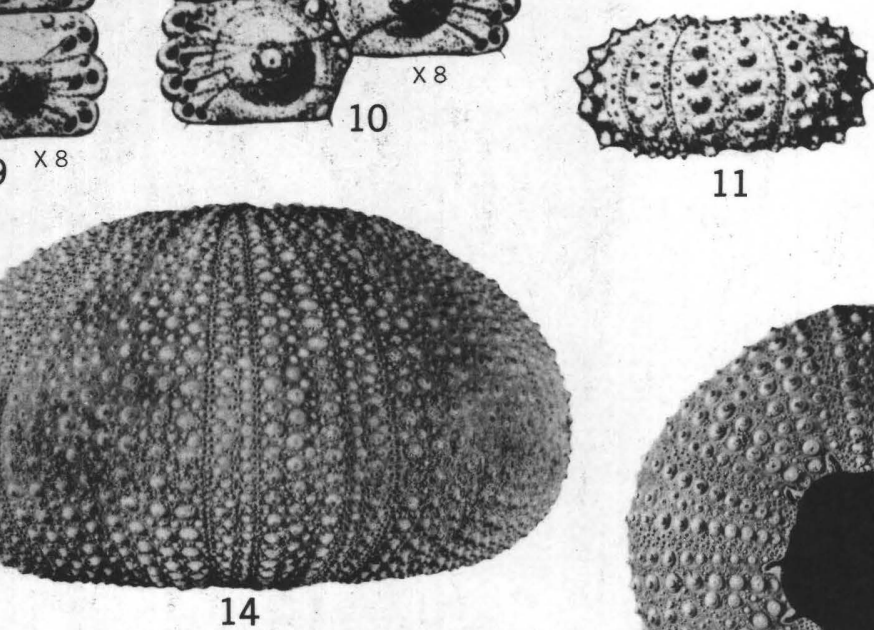

11

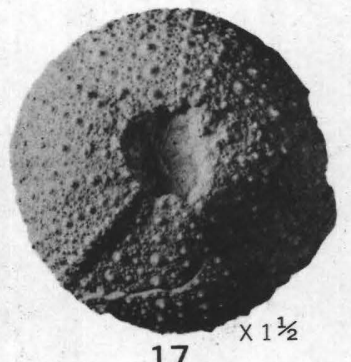

17
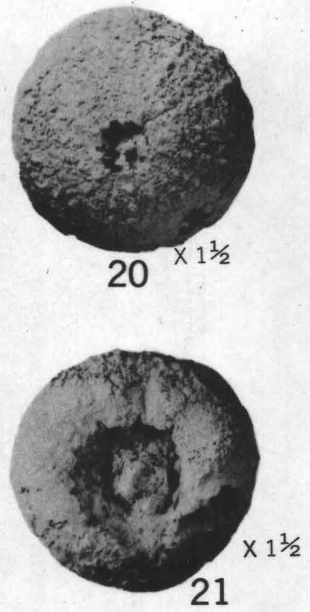
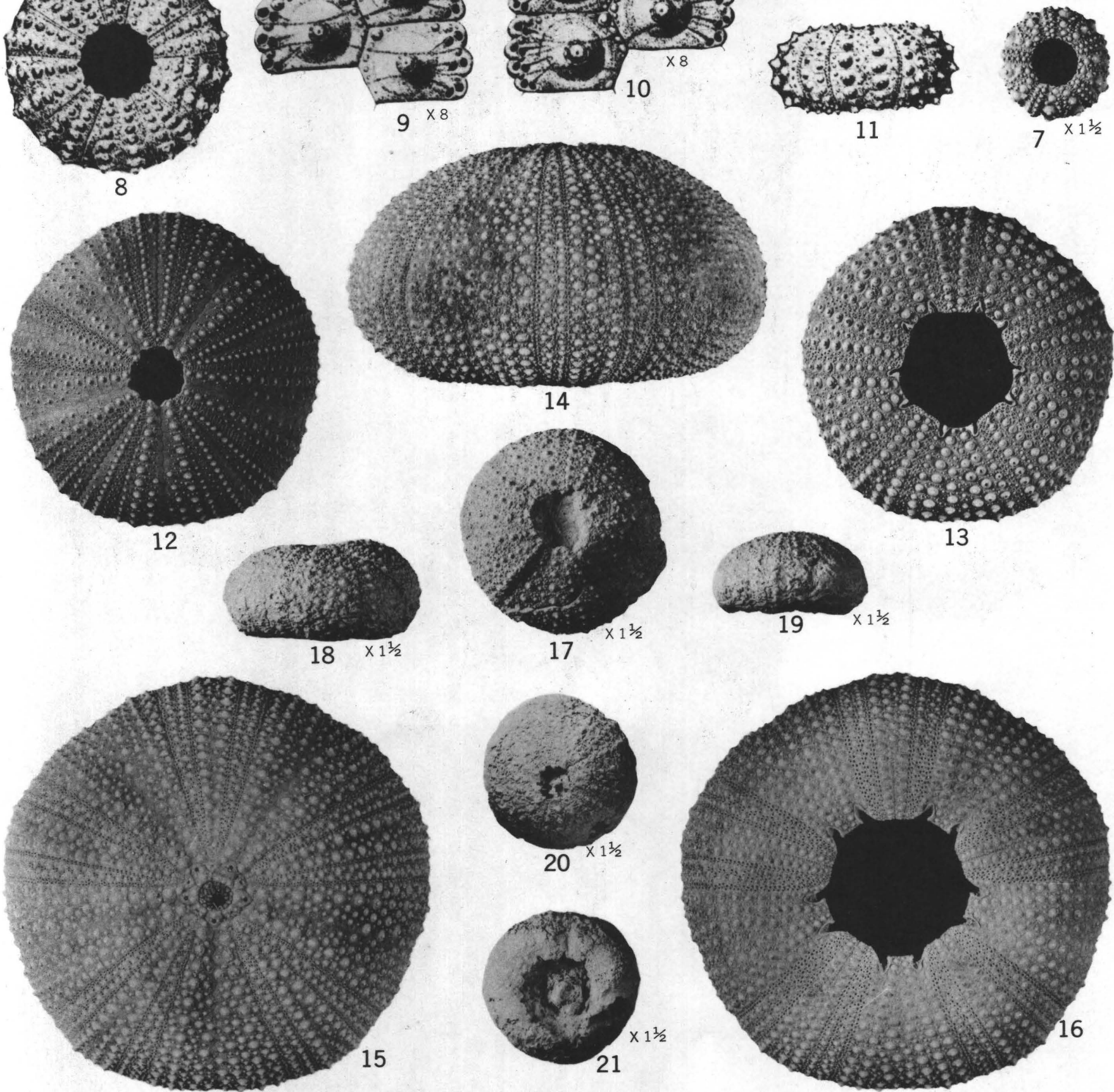

SALENIA, ECHINOPSIS, LYTECHINUS, AND TRIPNEUSTES 
Figures 1-7. Salenia tumidula Clark (p. 13)

\section{PLATE 2}

1, Upper surface $\times 3$ of type, Acad. Nat. Sci. Philadelphia 1448.

2-4, Upper, lower, and side views $\times 3$ of type of Salenia bellula Clark, Acad. Nat. Sci. Philadelphia $1446 . \quad$ Both from the Vincentown sand of Paleocene age on Timber Creek, N. J.

5-7, Side, upper, and lower views $\times 1 \frac{1}{2}$ of USNM 2947a. From the Vincentown sand of Paleocene age on Rancocas Creek near Vincetown, N. J.

8-11. Echinopsis diatreta (Morton) (p. 14)

Type, Acad. Nat. Sci. Philadelphia 1471, after Clark. From the Vincentown sand of Paleocene age on Timber Creek, N. J.

8 , Lower surface $\times 1$.

9,10 , Ambulacral plates $\times 8$.

11 , Lateral view $\times 1$.

12, 13. Lytechinus variegatus (Leske) (p. 15)

Upper and lower views $\times 1$ of USNM 562263. Recent. From the Atlantic coast of Florida.

14-16. Tripneustes ventricosus (Lamarck) (p. 15)

Side, top, and bottom views $\times 1$ of USNM E 3042a. Recent. From Barbados.

17-21. Lytechinus floralanus (Cooke) (p. 15)

17, 18, Upper and side views $\times 1 \frac{1}{2}$ of type, USNM 498891. From the Ocala limestone of late Eocene age in Covington County, Ala.

19-21, Side, top, and bottom views $\times 1 \frac{1}{2}$ of the type of Psammechinus ocalanus Cooke, USNM 498889 . From the Ocala limestone of late Eocene age at Bainbridge, Ga. 


\section{PLATE 3}

Frgures 1, 2. Psammechinus philanthropus (Conrad) (p. 16)

Top and bottom views $\times 1 \frac{1}{2}$ of USNM 562264. From the Yorktown formation of late Miocene age at J. A. Morgart's on James River 5 miles north of Smithfield, Va.

3, 4. Psammechinus santee Cooke (p. 17)

Two guttapercha molds $\times 1 \frac{1}{2}$ of cotypes, USNM 498890 . From the Congaree formation of middle Eocene age at USGS 4255, near Santee River about 41/2 miles northwest of Creston, Calhoun County, S. C.

5, 6. Coelopleurus infulatus (Morton) (p. 22)

Top and bottom views $\times 2$ of USNM 166500, type of Coelopleurus carolinensis Cooke. From the Santee limestone of late middle Eocene age at USGS 18353, Santee-Cooper Diversion Canal near Eadytown, Berkeley County, S. C.

7-9. Gagaria salis (Cooke) (p. 17)

Top, bottom, and side views $\times 1 \frac{1}{2}$ of type, USNM 166497. Probably from the Salt Mountain limestone of Paleocene age at USGS 3643, southern end of Salt Mountain, Clarke County, Ala.

10-14. Gagaria mossomi (Cooke) (p. 17)

10, Top view of paratype, USNM $498884 \mathrm{c} \times 1 \frac{1}{2}$.

11-13, Top, bottom, and side views $\times 1 \frac{112}{2}$ of paratype, USNM $498884 \mathrm{a}$.

14 , Top view $\times 1 \frac{1}{2}$ of paratype, USNM $498884 \mathrm{~b}$.

All from the Suwannee limestone of late Oligocene age at Blackwater Creek, at Seaboard Airline Railway, Hillsborough County, Fla.

15-17. Arbia aldrichi (Clark) (p. 21)

Top, bottom, and side views $\times 1 \frac{1}{2}$ of cotype, USNM 559494. From the Chickasawhay limestone of late Oligocene age at Perdue Hill, Monroe County, Ala.

18. Gagaria chickasawhay (Cooke) (p. 18)

Cotypes, USNM $498885 \times 1 \frac{1}{2}$. From the Chickasawhay limestone of late Oligocene age at USGS 13388 , Chickasawhay River above the highway bridge $2 \frac{1}{2}$ miles south of Waynesboro, Miss. 
GEOLOGICAL SURVEY

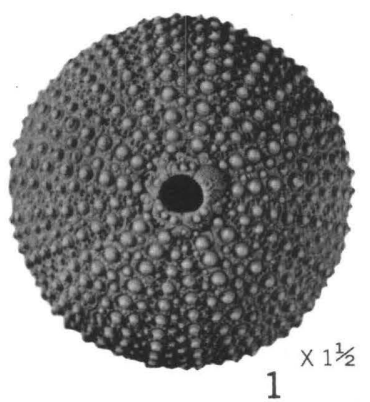

1
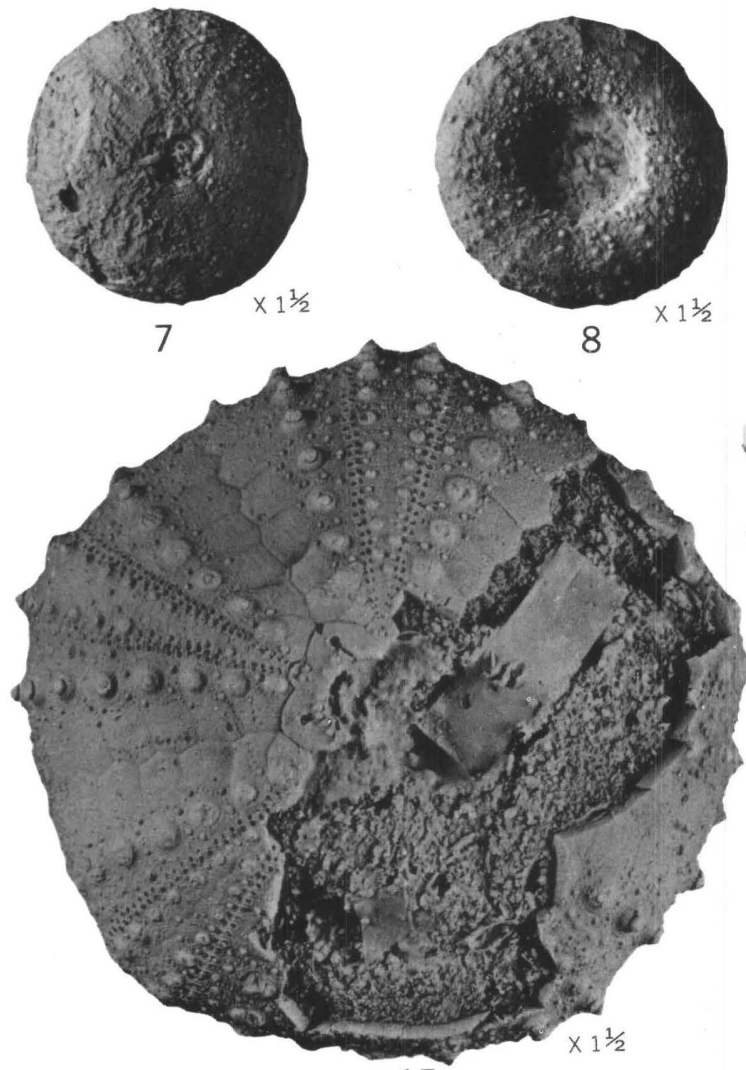

15

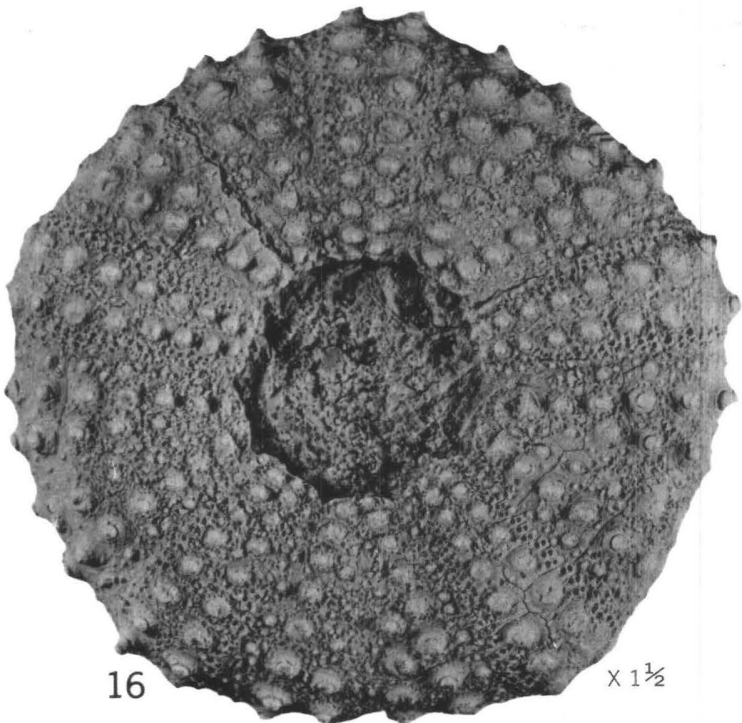

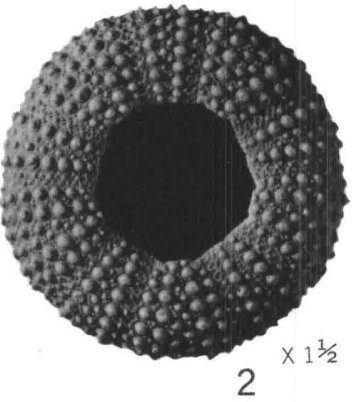
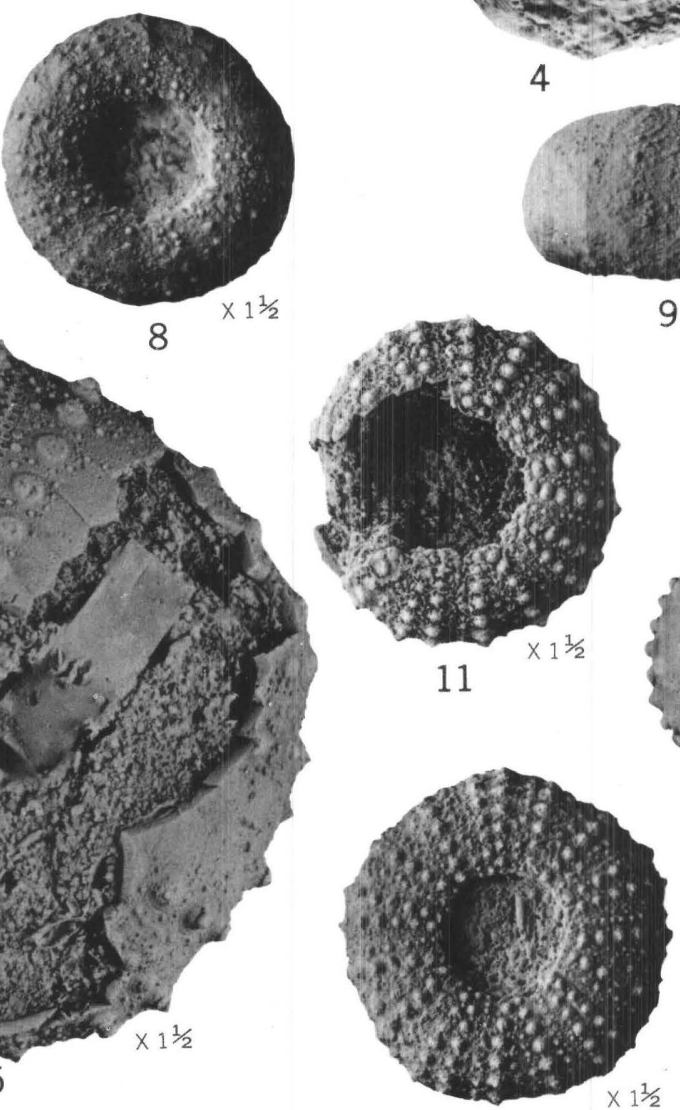

12

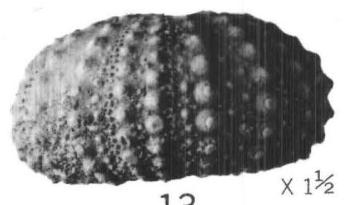

13

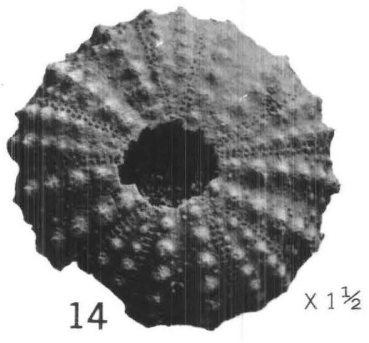

PROFESSIONAL PAPER 321 PLATE 3
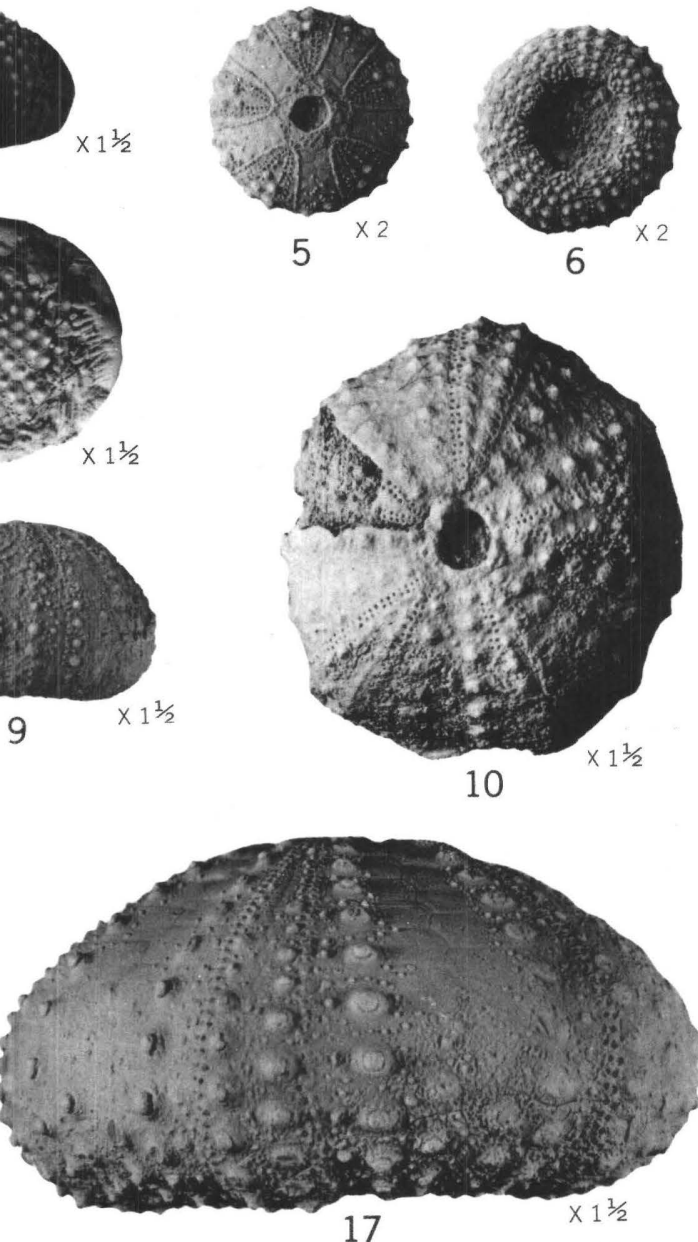

17
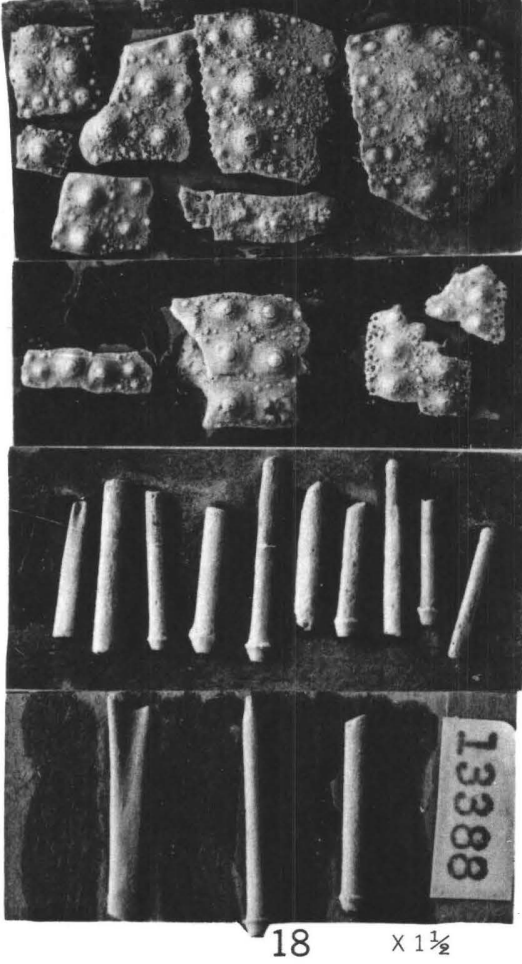

PSAMMECHINUS, COELOPLEURUS, GAGARIA, AND ARBIA 


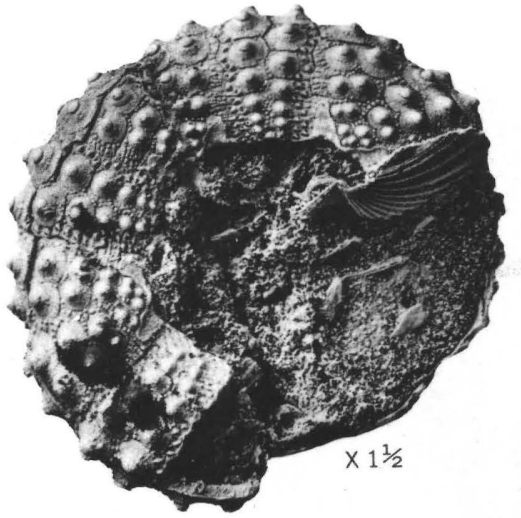

1
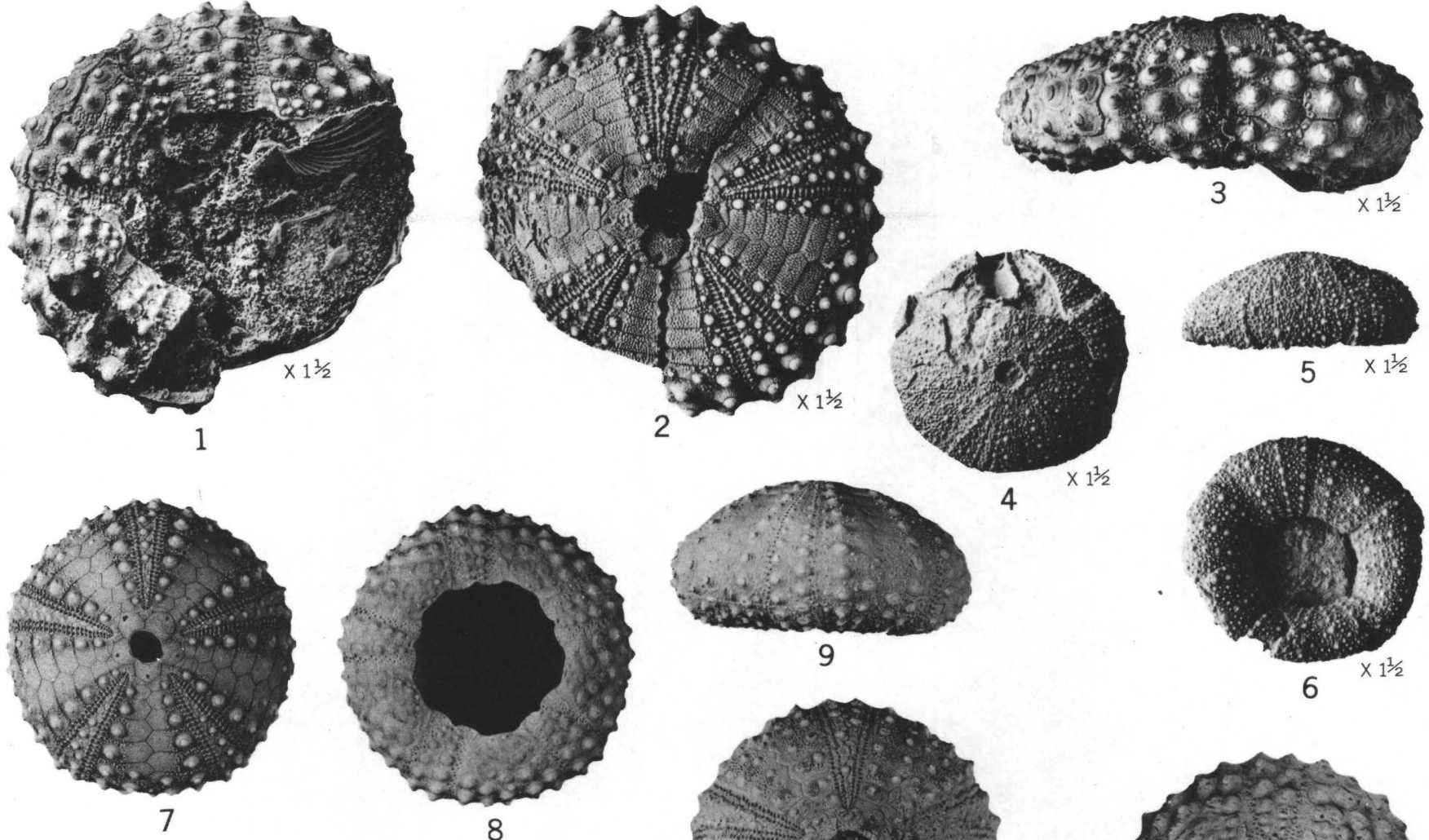

4

9
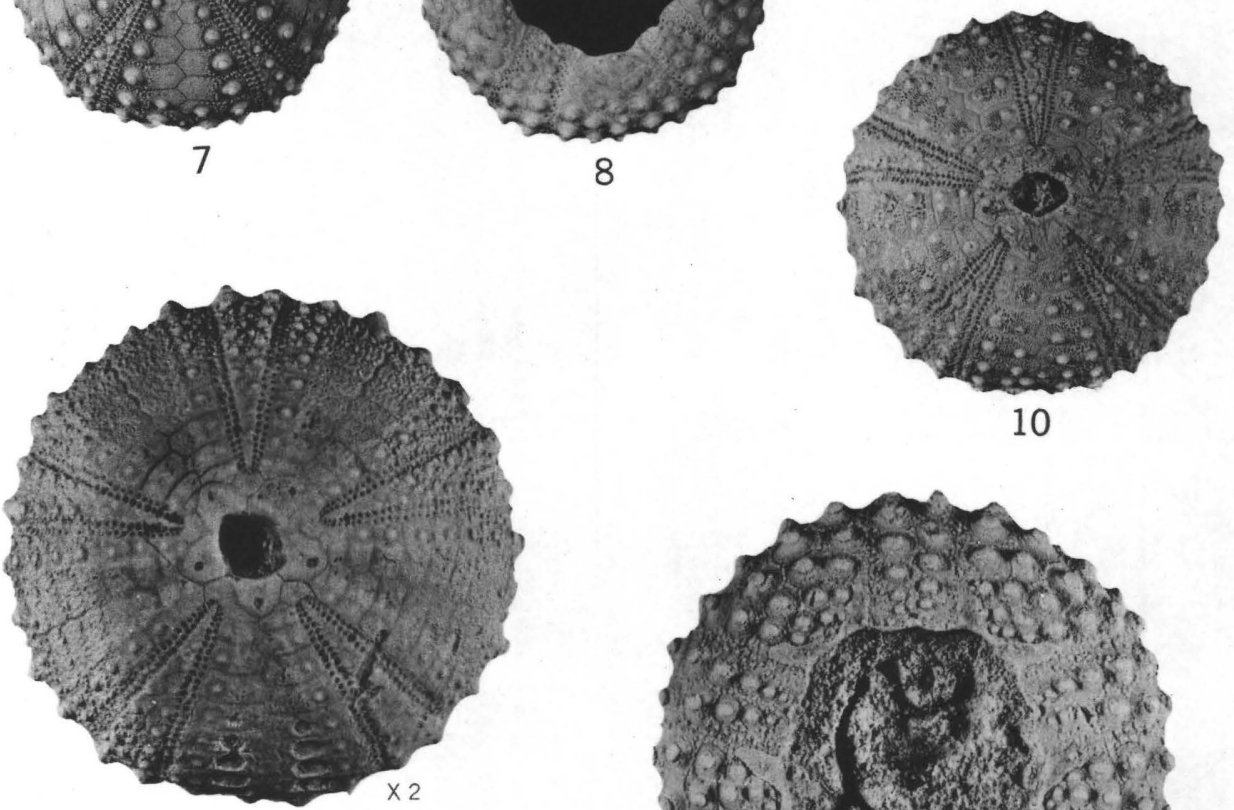

12

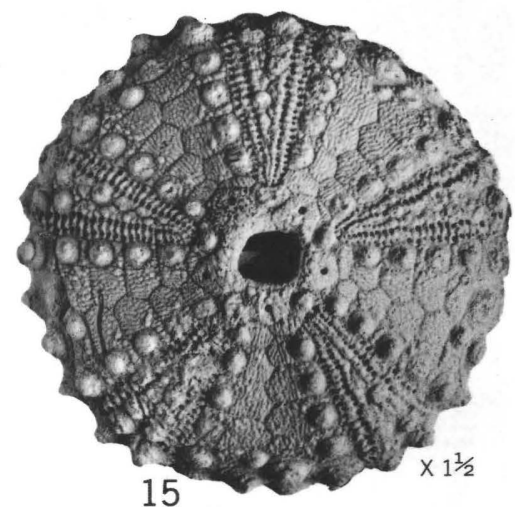

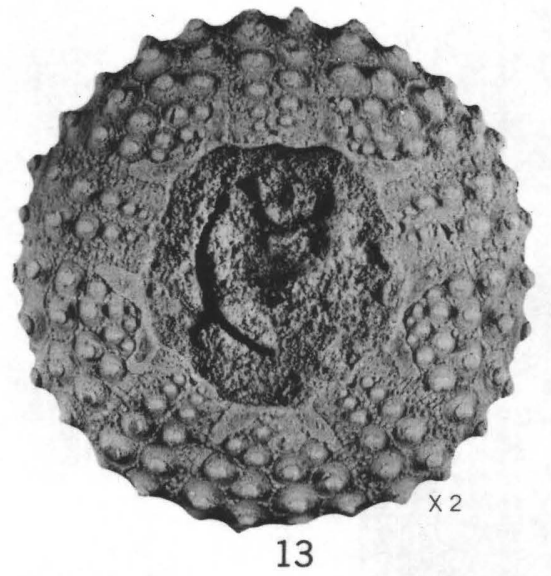
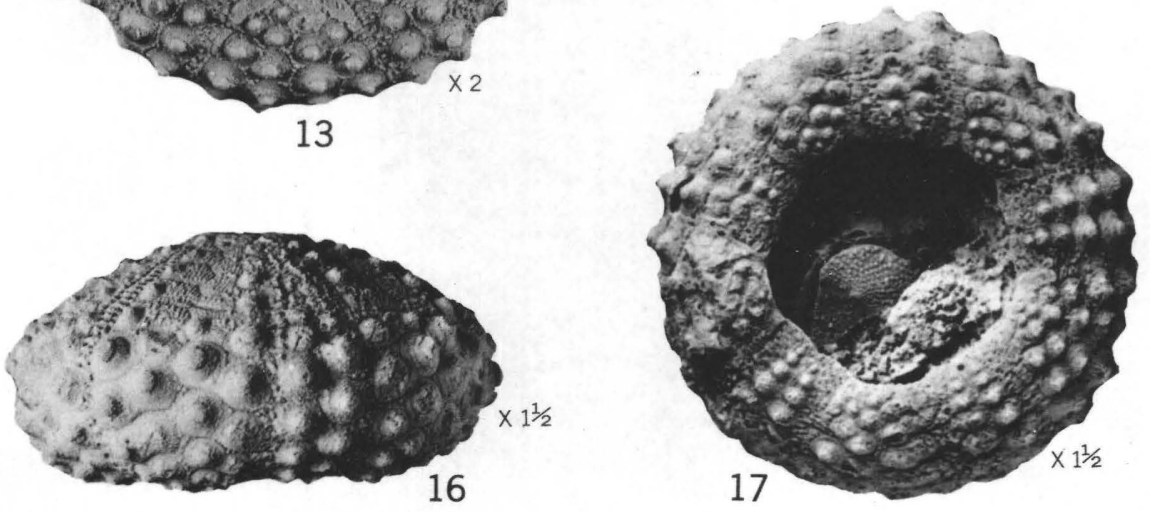

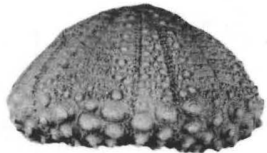

14
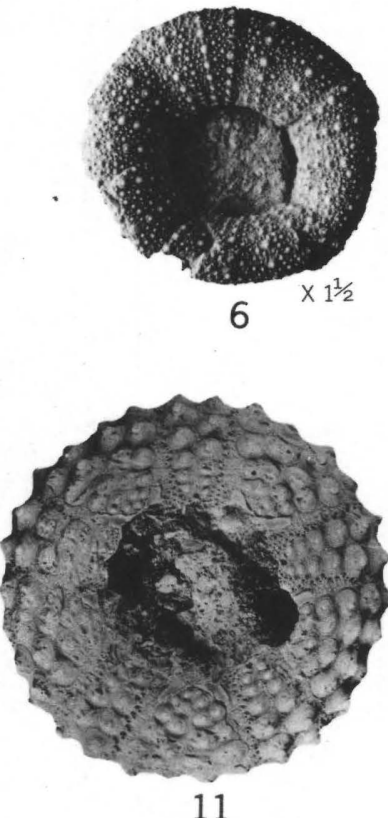
Figures 1-3. Arbacia improcera (Conrad) (p. 20)

\section{PLATE 4}

Bottom, top, and side views $\times 1 \frac{1}{2}$ of USNM 166487 . From the Yorktown formation of late Miocene age on Smith Creek $1 / 2$ mile below the Suffolk, Va., waterworks dam.

4-6. Brochopleurus pretiosus (Clark) (p. 18)

Top, side and bottom views $\times 1 \frac{1}{2}$ of type, USNM 146455. From the Yazoo clay of late Eocene age at USGS 2893, near Dead Level, Choctaw County, Ala.

7-9. Arbacia punctulata (Lamarck) (p. 19)

Top, bottom and side views $\times 1$ of USNM 562291. Recent. From 3 miles north of Crescent Beach, St. Johns County, Fla.

10, 11. Arbacia rivuli Cooke (p. 20)

Top and bottom views $\times 1$ of USNM 562292. From rocks of late Miocene (?) age on the Intracoastal Waterway canal about 5 miles southwest of Little River, Horry County, S. C.

12-14. Arbacia sloani (Clark) (p. 21)

Top $\times 2$, bottom $\times 2$, and side $\times 1$ of type, USNM 166488 . From the Duplin marl of late Miocene age at Bostick's Landing, Great Pee Dee River, Florence County, S. C.

15-17. Arbacia waccamaw Cooke (p. 19)

Top, side and bottom views $\times 1 \frac{1}{2}$ of type, USMN 498888. From rocks of late Miocene (?) age at USGS 13377, Intracoastal Waterway canal about 5 miles southwest of Little River, $\mathbf{8}$. C. 
Frgures 1-7. Gauthieria speciosa (Clark) (p. 23)

\section{PLATE 5}

$1-3$, Top, side, and bottom views $\times 3$ of type, Acad. Nat. Sci. Philadelphia 1468. From the Vincentown sand of Paleocene age on Timber Creek, N. J.

4-7, Fragment $\times 3$, top $\times 1 \frac{1}{2}$, side $\times 1 \frac{1}{2}$, and bottom $\times 1 \frac{1}{2}$ of USNM 29468. From the Vincentown sand of Paleocene age on Rancocas Creek near Vincentown, N. J.

8-10. Dixieus dixie (Cooke) (p. 24)

Top $\times 1 \frac{1}{2}$, bottom $\times 1 \frac{1}{2}$, and detail of top $\times 5$ of type, USNM 372867 . From the Ocala limestone of late Eocene age at USGS 12747, pit in Dixie County, Fla. east of Steinhatchee River and north of US 19, opposite Clara. 

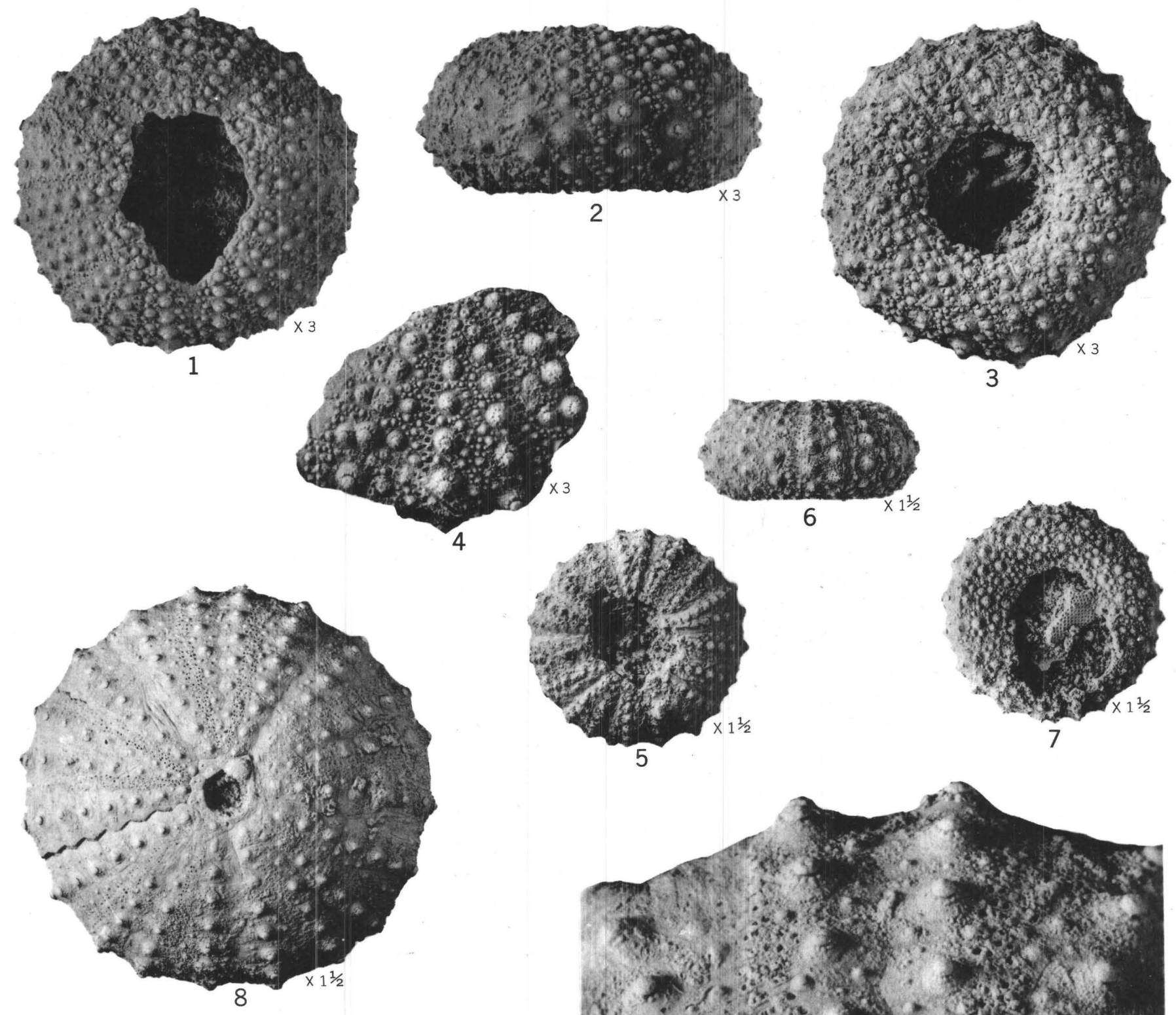

6

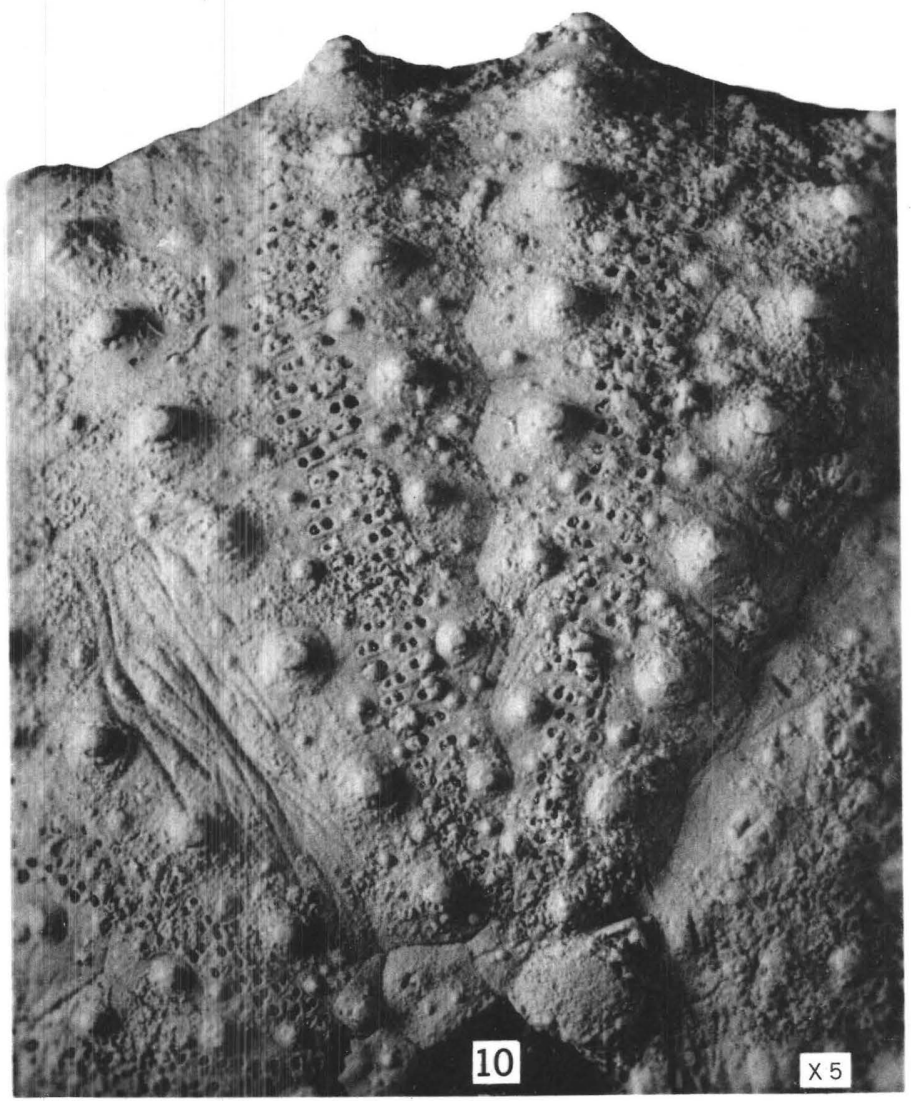

GAUTHIERIA AND DIXIEUS 
GEOLOGICAL SURVEY

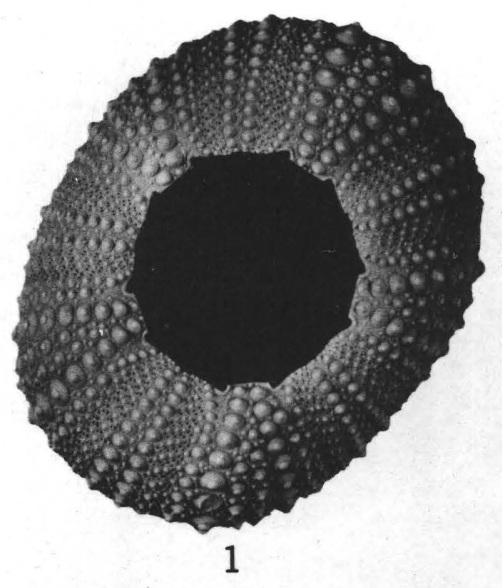

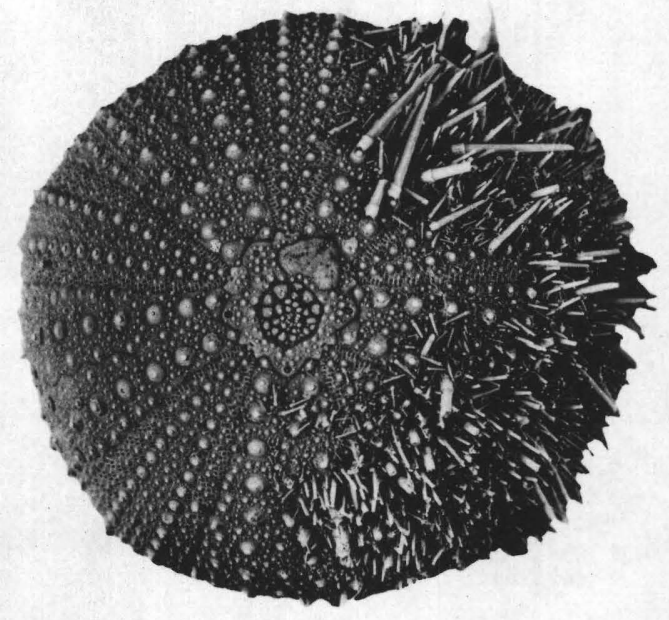

3
PROFESSIONAL PAPER 321 PLATE 6
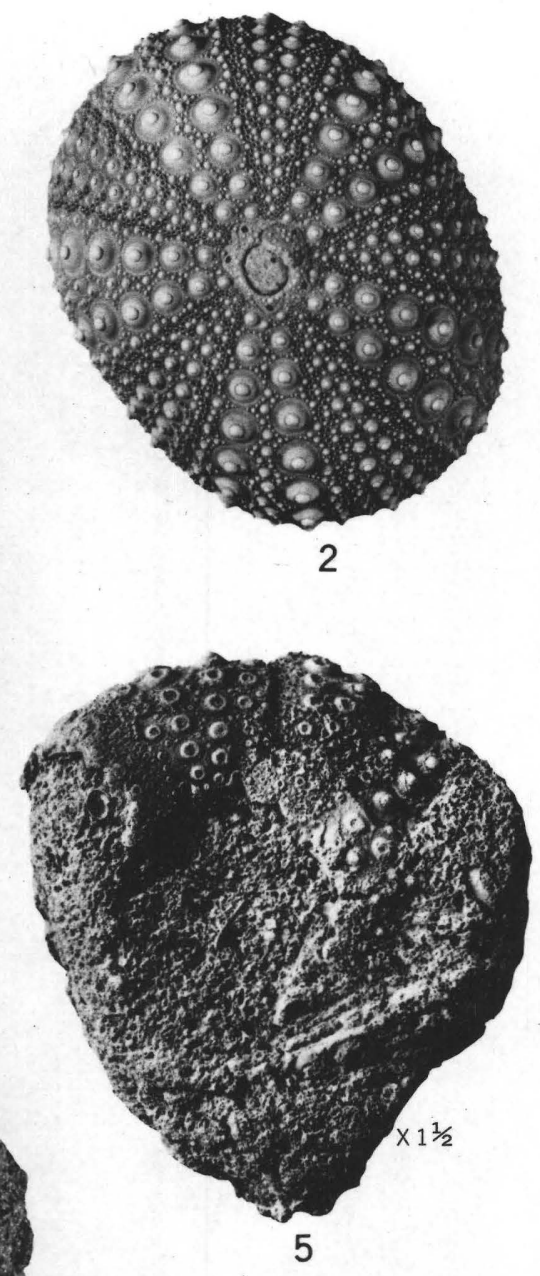

6
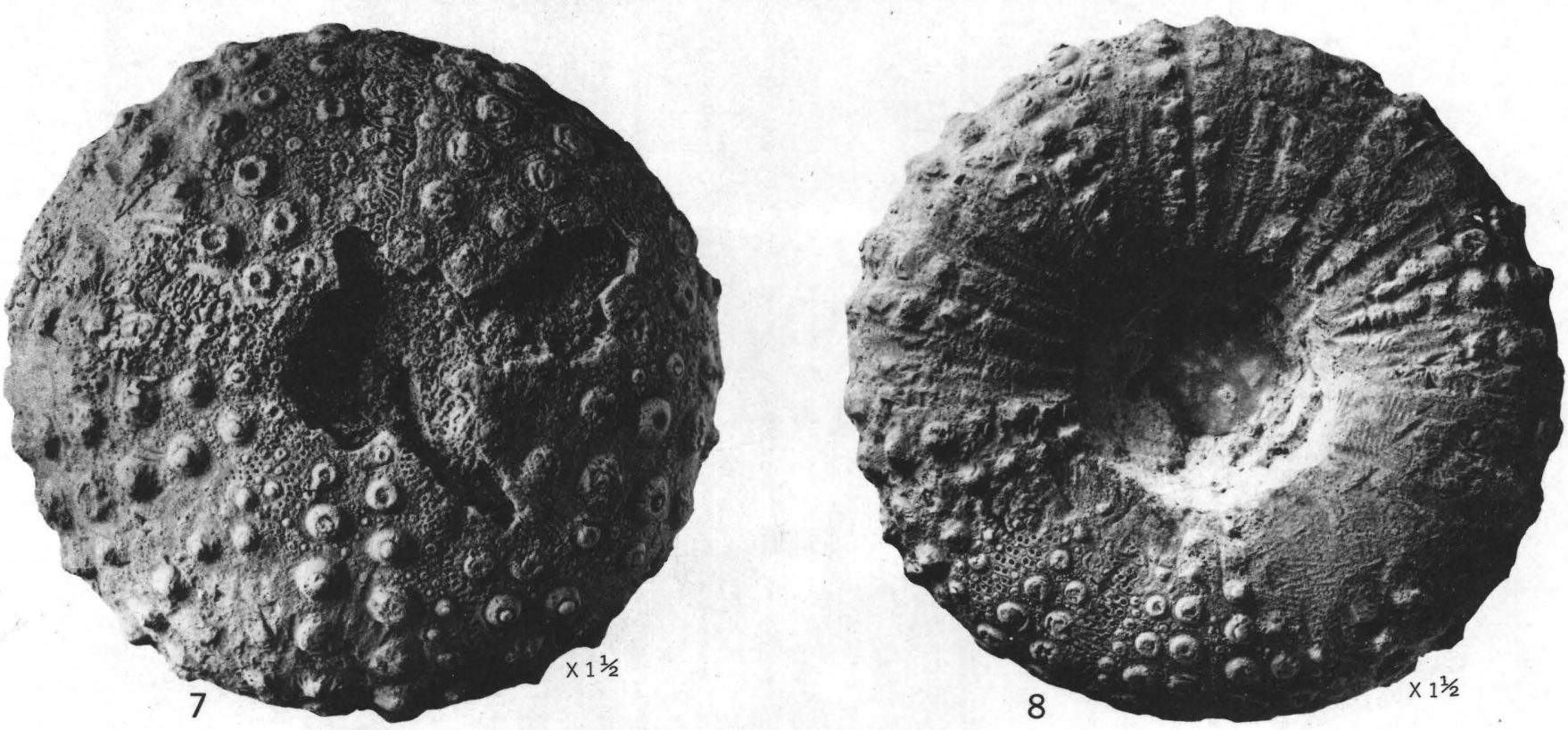

ECHINOMETRA, STRONGYLOCENTROTUS, AND PHYMOTAXIS 
Figures 1, 2. Echinometra lucunter (Linnaeus) (p. 25)

\section{PLATE 6}

Bottom and top views $\times 1$ of USNM 562292. Recent. From Cayo la Vela, Cuba.

3. Strongylocentrotus dröbachiensis (Müller) (p. 25)

Top view $\times 1$ of USNM E 3032a. Recent. From Dumpling Island, North Haven, Maine.

4-8. Phymotaxis mansfieldi Cooke (p. 24)

Top and bottom $\times 1 \frac{1}{2}$ and side, top and bottom $\times 1 \frac{1}{2}$ of cotypes, USNM 372868. From the Suwannee limestone of late Oligocene age at USGS 12755, 3/4 mile southwest of Brooksville, Fla.

$468544-59-10$ 


\section{PLATE 7}

FIGURES 1-4. Rhopostoma cruciferum (Morton) (p. 26)

Top, bottom, posterior, and side views $\times 1$ of type, Acad. Nat. Sci. Philadelphia 1464 . From the Vincentown sand of Paleocene age on Timber Creek, Gloucester County, N. J.

5-7. Porpitella micra H. L. Clark (p. 33)

Top, bottom, and side views $\times 6$ of paratype. From middle Eocene(?) rocks in a well, Oakley Estate No. 2, depth 3800-4000, in sec. 9, T. 3 N., R. 29 E., Houston County, Ala.

8, 9. Amblypygus americanus Desor (p. 27)

Top and bottom views $\times 1$ of USNM 164934, type of Amblypygus merrilli Twitchell. From the Ocala limestone of late Eocene age at USGS 4246, Kendrick, Marion County, Fla. 


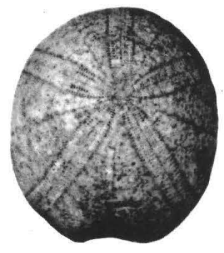

1

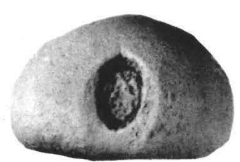

3

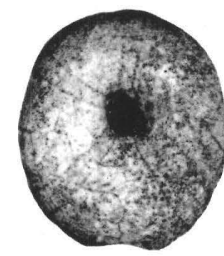

2

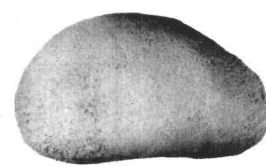

4
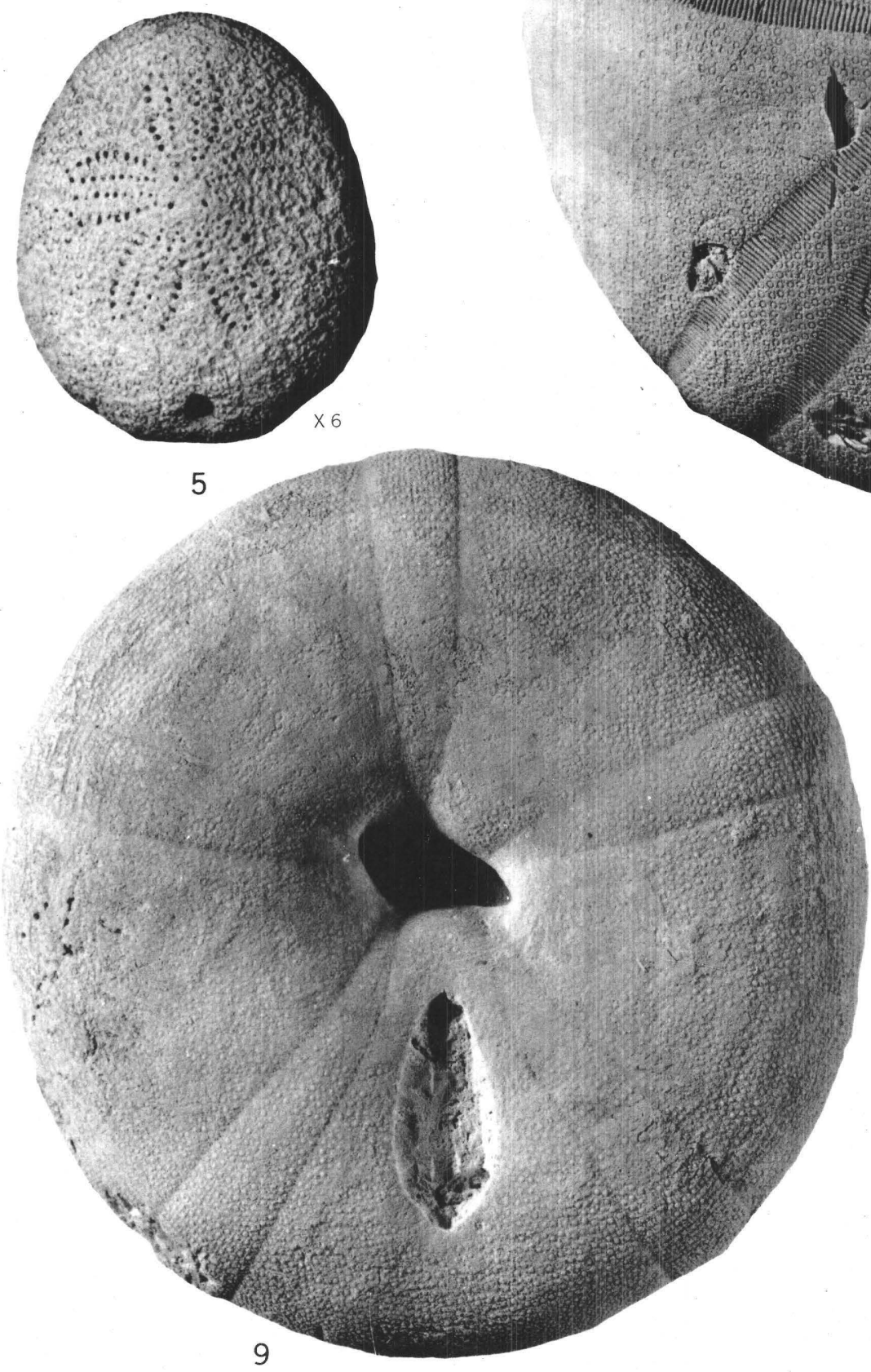

8

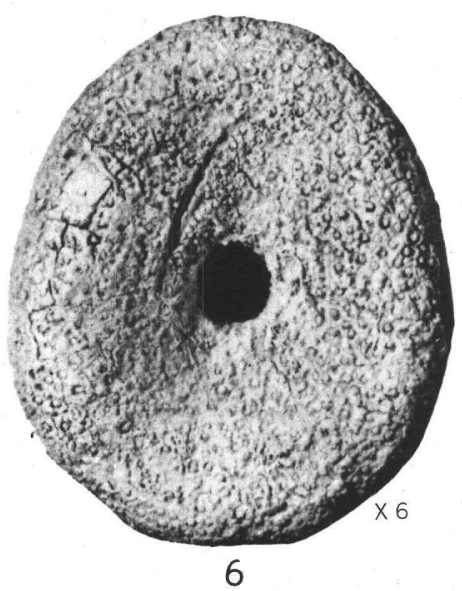

RHOPOSTOMA, PORPITELLA, AND AMBLYPYGUS

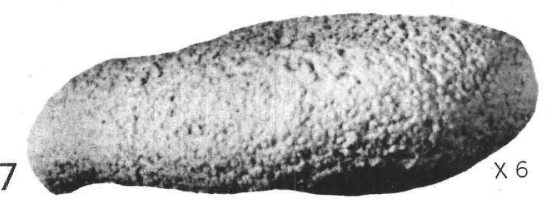


GEOLOGICAL SURVEY

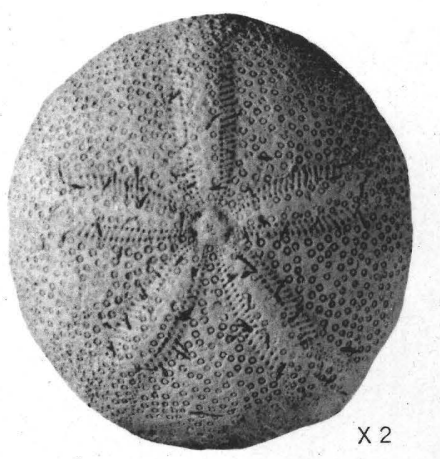

1

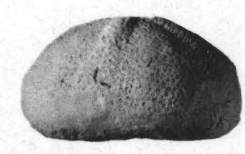

2

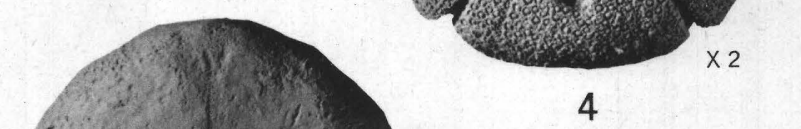

4

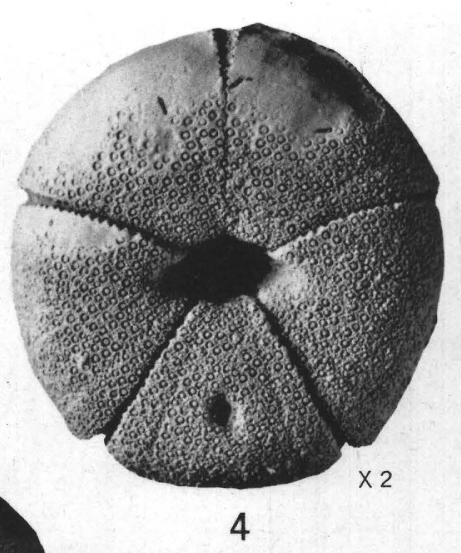

PROFESSIONAL PAPER 321 PLATE 8
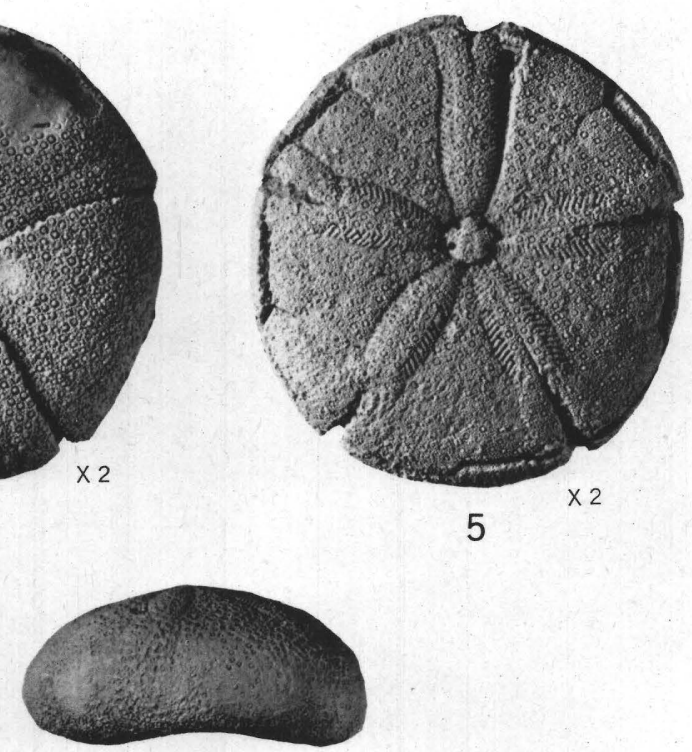

6

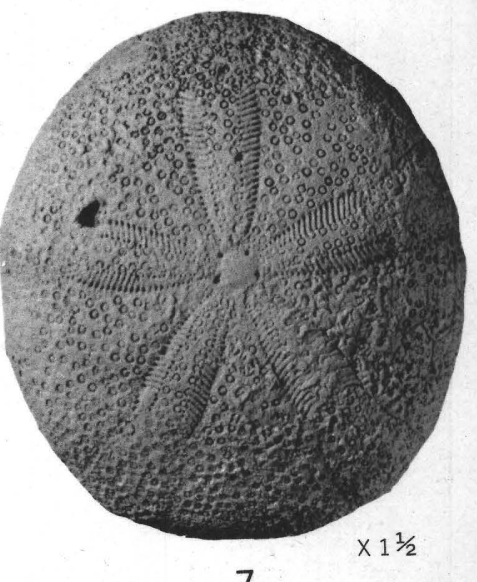

7
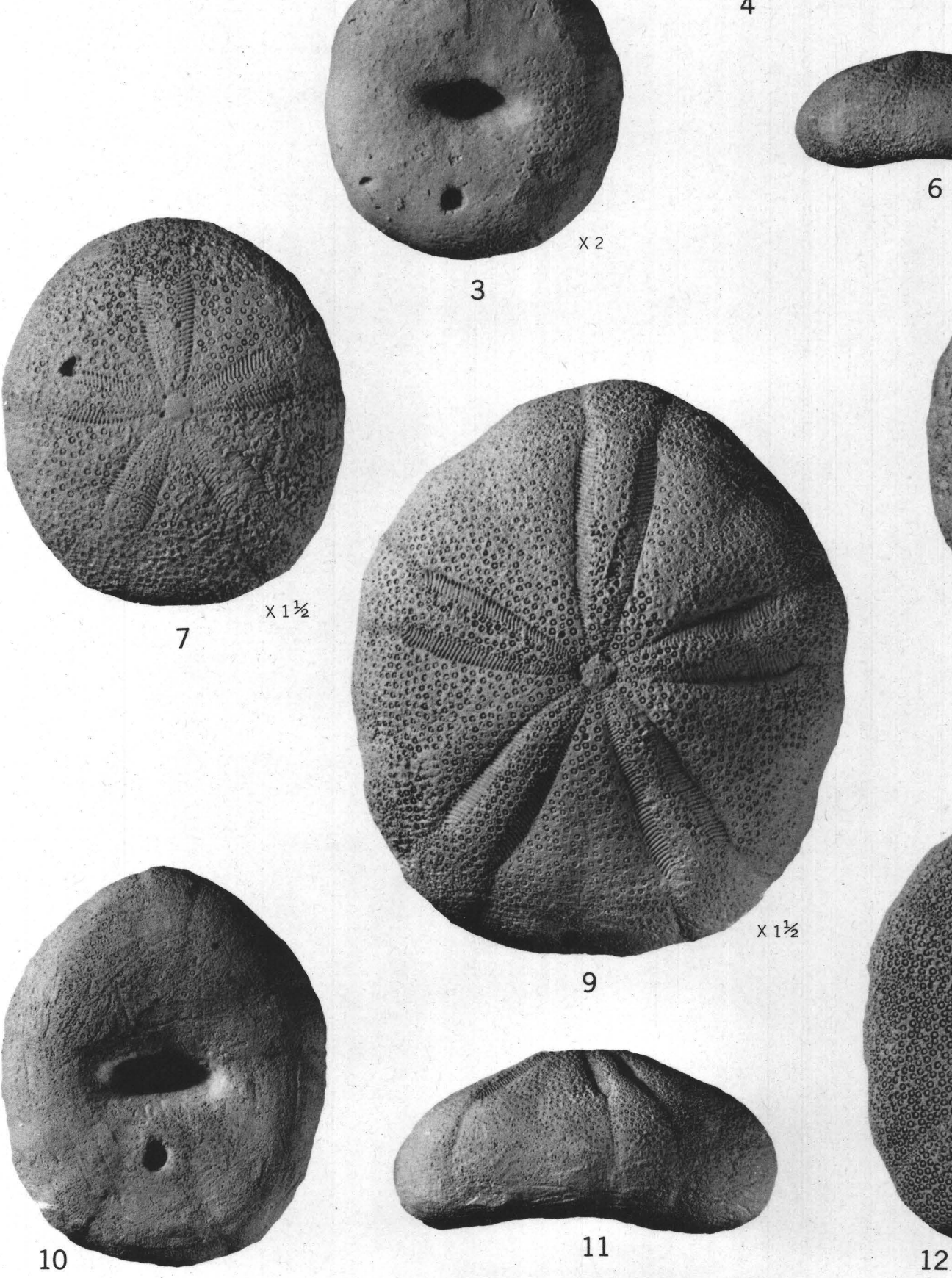

3

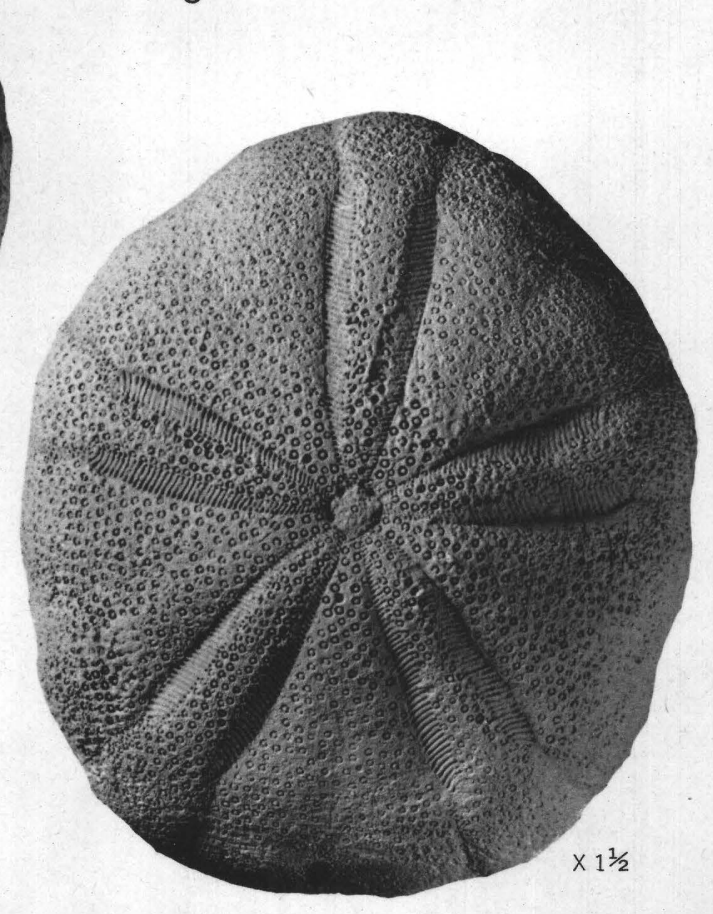

9

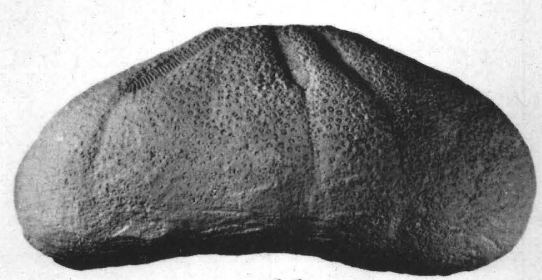

11

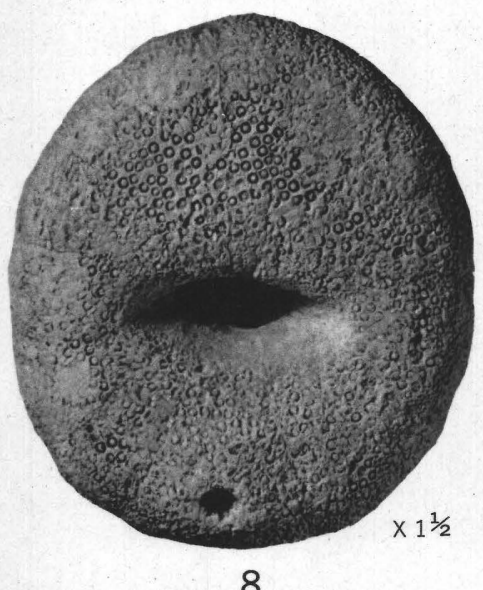

8

OLIGOPYGUS 
Figures 1-5. Oligopygus rotundus Cooke (p. 29)

\section{PLATE 8}

$1-3$, Top $\times 2$, side $\times 1$, and bottom $\times 2$ of type, USNM 498991 . From the rocks of middle or late Eocene age at Koon's Mill on Cripple Creek, Geneva County, Ala.

4, 5, Bottom and top $\times 2$ of USNM 562269. From rocks of middle or late Eocene age on Pea River above old County-line Bridge, Coffee County, Ala.

6-8. Oligopygus haldemani (Conrad) (p. 29)

Side $\times 1$, top $\times 1 \frac{1}{2}$, and bottom $\times 1 \frac{1}{2}$ of USNM 562270. From the Ocala limestone of late Eocene age at USGS 7097, Flint River at old factory above Bainbridge, Ga.

9-12. Oligopygus wetherbyi de Loriol (p. 28)

$9-11$, Top $\times 1 \frac{1}{2}$, bottom $\times 1$, and side $\times 1$ of USNM 562271. From the Ocala limestone of late Eocene age at USGS 14125, Kendrick, Marion County, Fla.

12, Bottom $\times 1 \frac{1}{2}$ of USNM 562272. From the Ocala limestone at USGS 14537a, Taylor County rock pit in Lafayette County 4.8 miles northwest of Mayo, Fla. 
Figures 1-3. Echinocyamus chipolanus Cooke (p. 32)

\section{PLATE 9}

Top, bottom, and side views $\times 6$ of type, USNM 499003. From the Chipola formation of early Miocene age at USGS 2211, lower bed at Alum Bluff, Apalachicola River, Liberty County, Fla.

4, 5. Echinocyamus meridionalis Meyer (p. 32)

Top and bottom views $\times 6$ of USNM 559485. Probably from rocks of later middle Eocene age at Claiborne, Monroe County, Ala.

6-8. Echinocyamus macneili Cooke, n. sp. (p. 32)

Top, bottom, and side views $\times 5$ of type, USNM 562297. From an equivalent of Moodys Branch formation of late Eocene age at USGS 15562, creek flowing into Conecuh River in the NE 1/4 sec. 32, T. 4 N., R. 15 E., Covington County, Ala.

9-11. Echinocyamus parvus (Emmons) (p. 31)

Top, side and bottom views $\times 5$ of USNM 499002. From the Castle Hayne limestone of middle and late Eocene age at USGS 10363 , J. M. Thomas' farm 10 miles north of Jacksonville, Onslow County, N. C.

12-14. Echinocyamus huxleyanus Meyer (p. 32)

Top, side, and bottom views $\times 5$ of USNM 559481. From the Gosport sand of late middle Eocene age at Claiborne, Ala.

15-19. Fibularia texana (Twitchell) (p. 30)

15, 16, Top and bottom views $\times 4$ of USNM 562296. From the Weches greensand member of the Mount Selman formation of middle Eocene age at USGS 15093, San Augustine-Nacogdoches road 6.7 miles east of Attoyac Bayou, San Augustine County, Tex.

17-19, Top, bottom, and side views $\times 5$ of type, USNM 559480. From Lee County, Tex.

20-22. Fibularia alabamensis Cooke, n. sp. (p. 31)

Top, side and bottom views $\times 5$ of type, USNM 372887. From the upper Eocene, probably Moodys Branch formation, at USGS 10014, stream on line between sec. 20 and 29, T. 4 N., R. 15 E., 6 miles west of Andalusia, Covington County, Ala.

23-27. Fibularia vaughani (Twitchell) (p. 30)

23, 24, Top and bottom views $\times 5$ of type, USNM 166486. From the Ocala limestone of late Eocene age at USGS 3380, Flint River at Little Horseshoe Bend, 4 miles below Bainbridge, Ga.

25-27, Top, bottom, and side views $\times 5$ of USNM 562295. From the Inglis limestone of late Eocene age at USGS 18749, Withlacooche River in W 1/2 sec. 3, T. 17 S., R. 16 E., Citrus and Levy Counties, Fla. 
GEOLOGICAL SURVEY

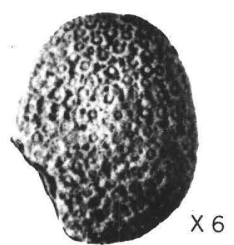

1.
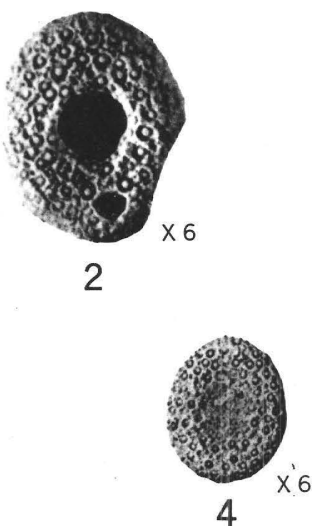

3
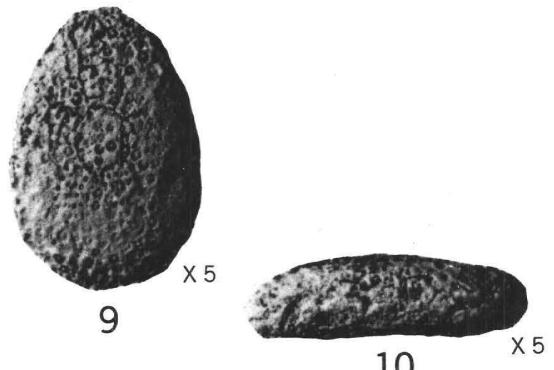

10

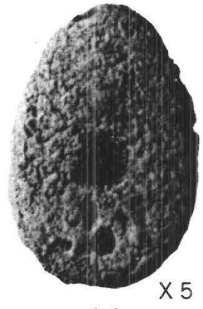

11

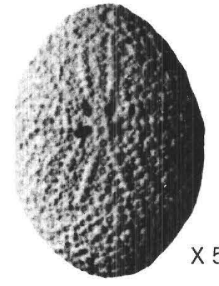

6

PROFESSIONAL PAPER 321 PLATE 9
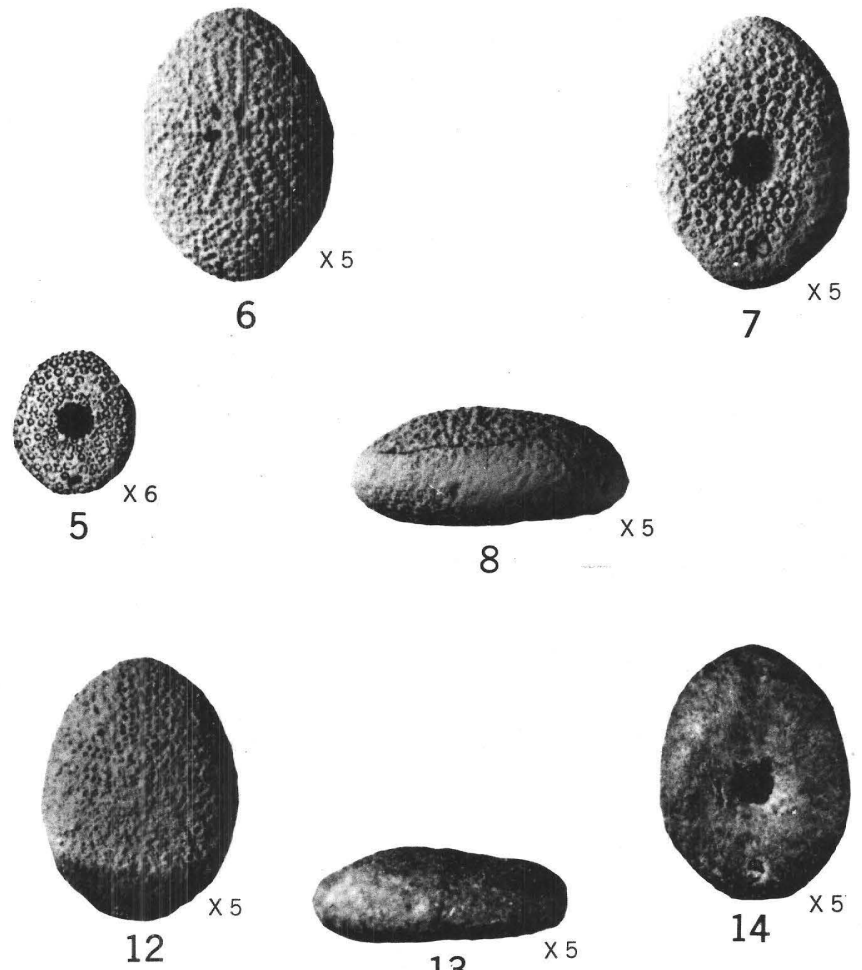

13
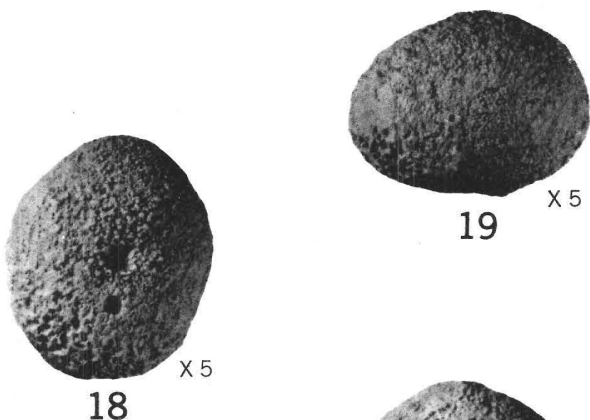

19
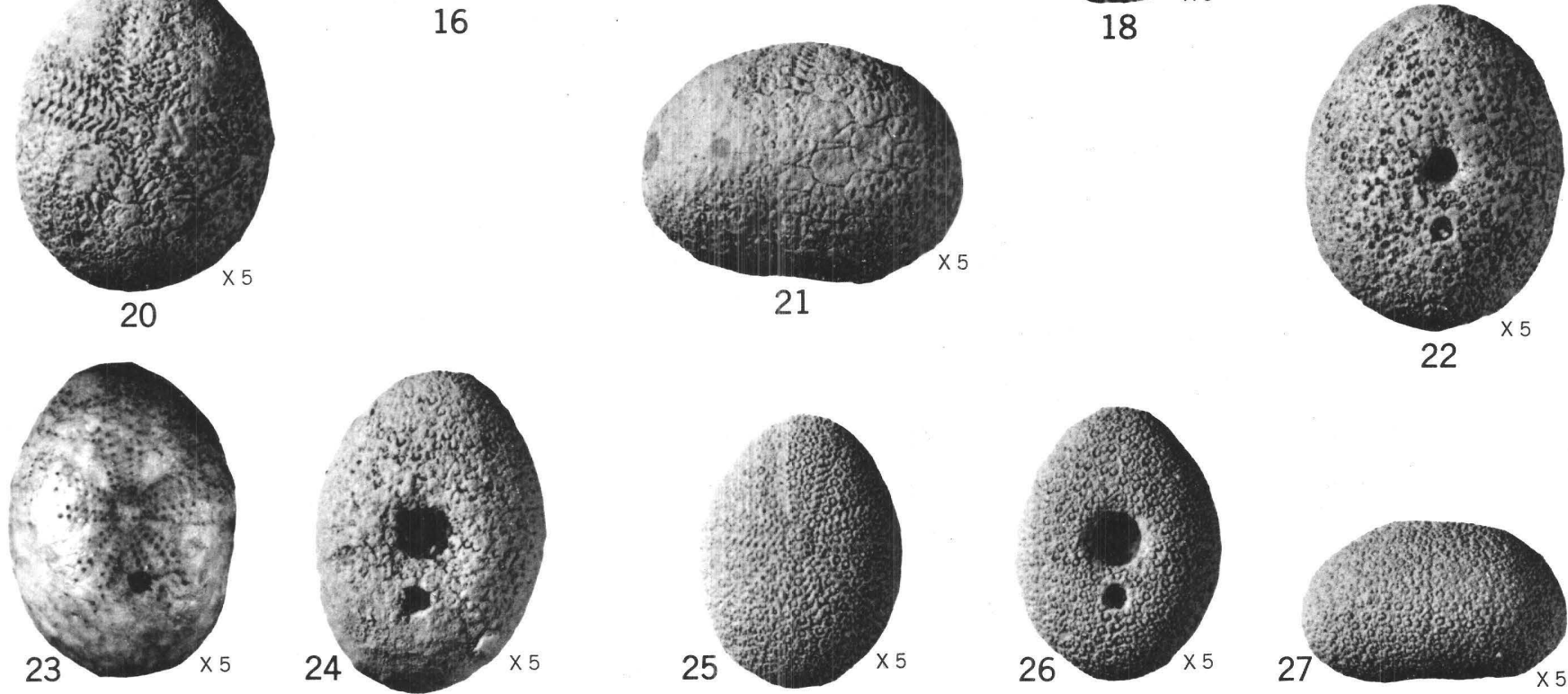

ECHINOCYAMUS AND FIBULARIA 

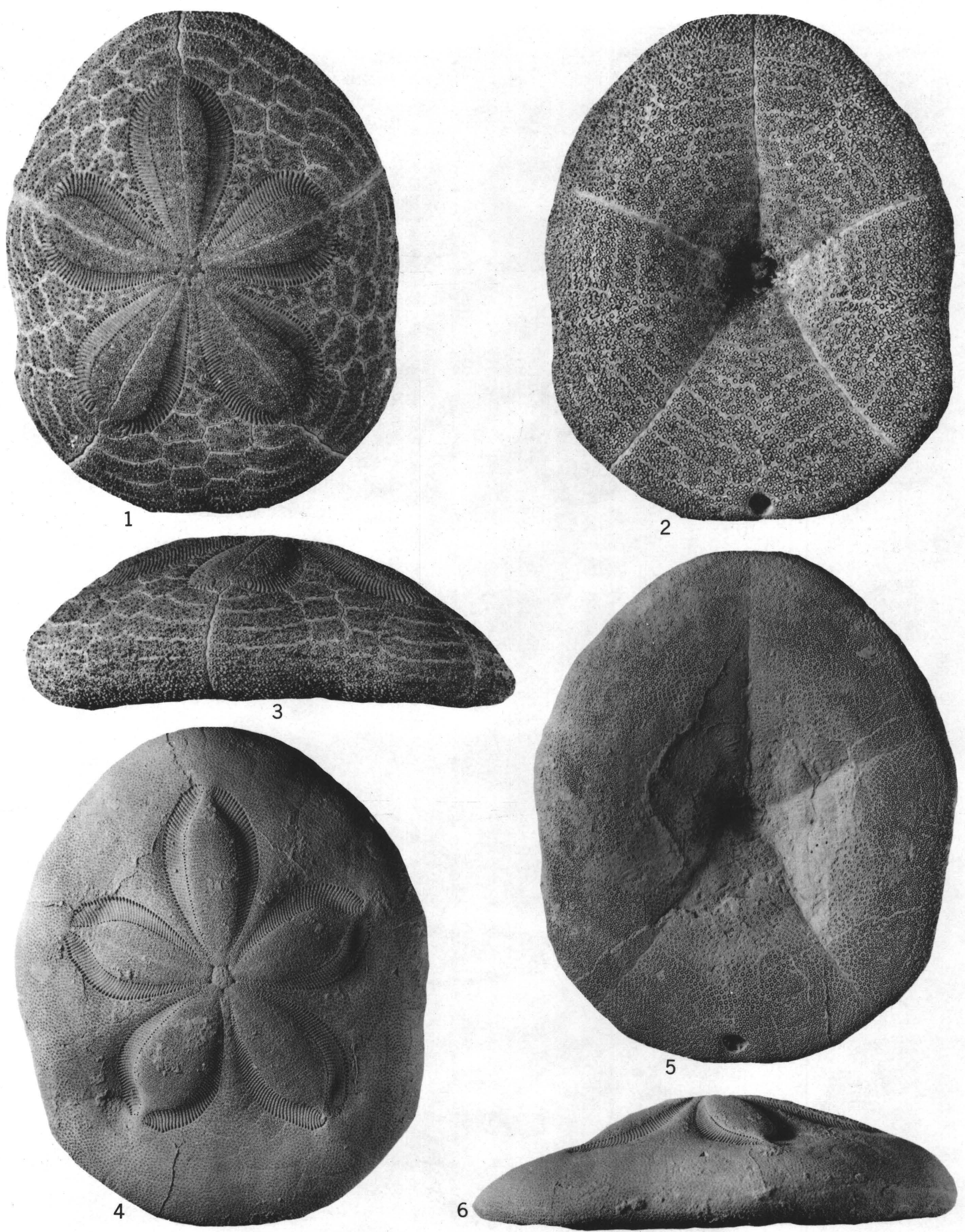

CLYPEASTER 
FiguREs 1-3. Clypeaster rosaceus (Linnaeus) (p. 34)

\section{PLATE 10}

Top, bottom, and side views $\times 1$ of USNM 19632. Recent. From Ragged Keys, Fla.

4-6. Clypeaster concavus Cotteau (p. 34)

Top, bottom, and side views $\times 1$ of USNM 561746. From the Anguilla formation of early Miocene age at Crocus Bay, Anguilla. 
Frgure 1. Clypeaster oxybaphon Jackson (p. 35)

\section{PLATE 11}

Top view $\times 1$ of USNM 499006. From the Suwannee limestone of late Oligocene age at USGS $15068 \mathrm{a}$, NW 34 sec. 36, T. 4 N., R. 13 W., Washington County, Fla. After Cooke, 1942, pl. 8, fig. 7.

2-4. Clypeaster subdepressus (Gray) (p. 36)

2,3 , Side and top views $\times 1$ of USNM $562274 \mathrm{~b}$.

4, Bottom view $\times 1$ of USNM 562274a. From Pleistocene (?) rocks at USGS 18759 , Intracoastal Waterway canal 15 miles northeast of Myrtle Beach, S. C.

5. Clypeaster concavus Cotteau (p. 34)

From the Chipola formation of early Miocene age at USGS 2213, Chipola River 1 mile below Baileys Ferry, Calhoun County, Fla. Figured by Cooke (1942, pl. 1, fig. 15) under the name Clypeaster gatuni Jackson. 


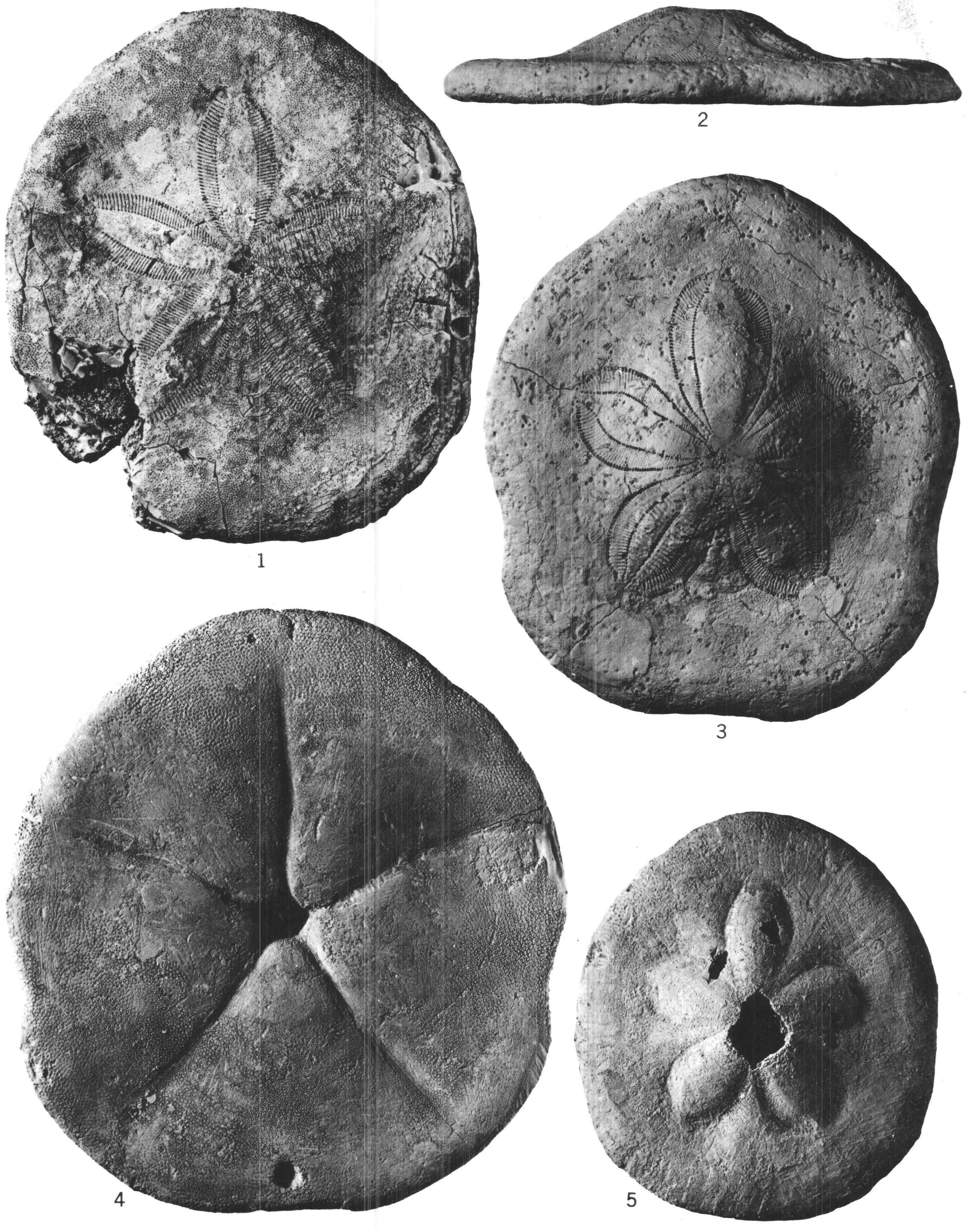

CLYPEASTER 


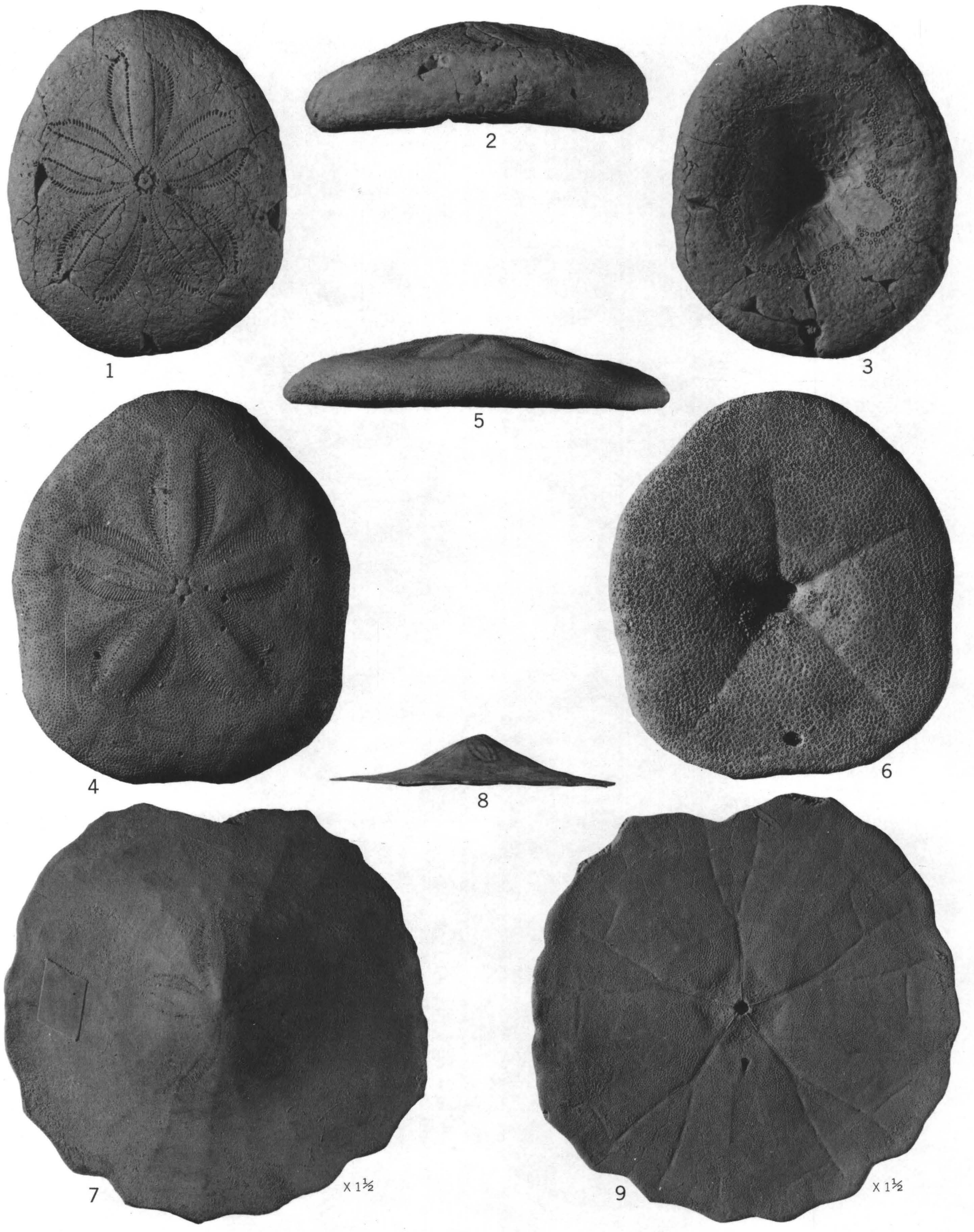

CLYPEASTER AND PERIARCHUS 


\section{PLATE 12}

FiguRes 1-3. Clypeaster cotteaui Egozcue (p. 37).

Top, side, and bottom views $\times 1$ of USNM 499297. From Oligocene rocks on the place of Marco Sanchez at the base of Monte Toro, northwest of Guantánamo, Cuba. Specimen figured by Jackson (1922, pl. 6, figs. 6-8).

4-6. Clypeaster rogersi (Morton) (p. 36)

Top, side, and bottom views $\times 1$ of cotype, Acad. Nat. Sci. Philadelphia 1070. From the Marianna limestone of middle Oligocene age in Monroe County, Ala.

7-9. Periarchus protuberans Twitchell (p. 42)

Top $\times 1 \frac{1}{2}$, side $\times 1$, and bottom $\times 1 \frac{1}{2}$ views of type, USNM 164685 . From the Yazoo clay of late Eocene age at USGS 331, Shubuta Creek 21/2 miles north of Shubuta, Clarke County, Miss. 


\section{PLATE 13}

Figure 1. Periarchus lyelli (Conrad) (p. 41)

Bottom view $\times 1$ of USNM 137165. From rocks of late Eocene age at USGS 295, Alabama River below Marshalltown, Ala.

2. 3. Periarchus lyelli pileus-sinensis (Ravenel) (p. 42)

Side and top views $\times 1$ of USNM 562278. From the Ocala limestone of late Eocene age at USGS 5535, 31/4 miles south of Perry, Ga.

4. Periarchus lyelli floridanus Fischer (p. 42)

Top view $\times 1$ of type, USNM 560418. From the Inglis limestone of late Eocene age at the mouth of Withlacoochee River, Citrus County, Fla.

5, 6. Echinarachnius parma (Lamarck) (p. 44)

Top and bottom views $\times 1$ of USNM E 3303a. Recent. Dredged near Five-fathom Lightship, 14 miles off Wildwood, N. J. 
GEOLOGICAL SURVEY

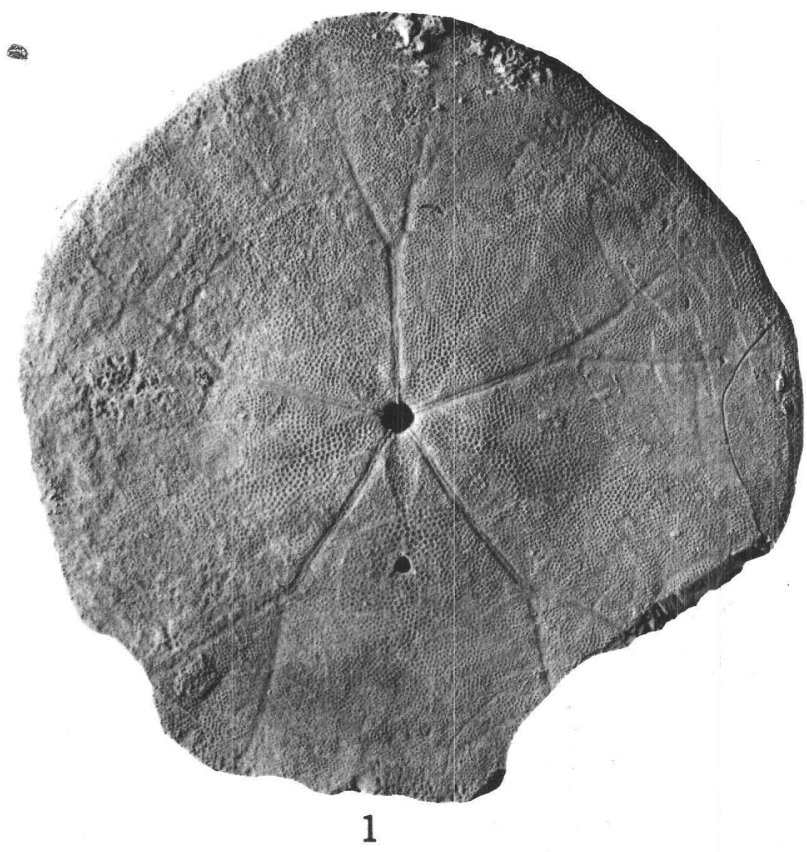

PROFESSIONAL PAPER 321 PLATE 13
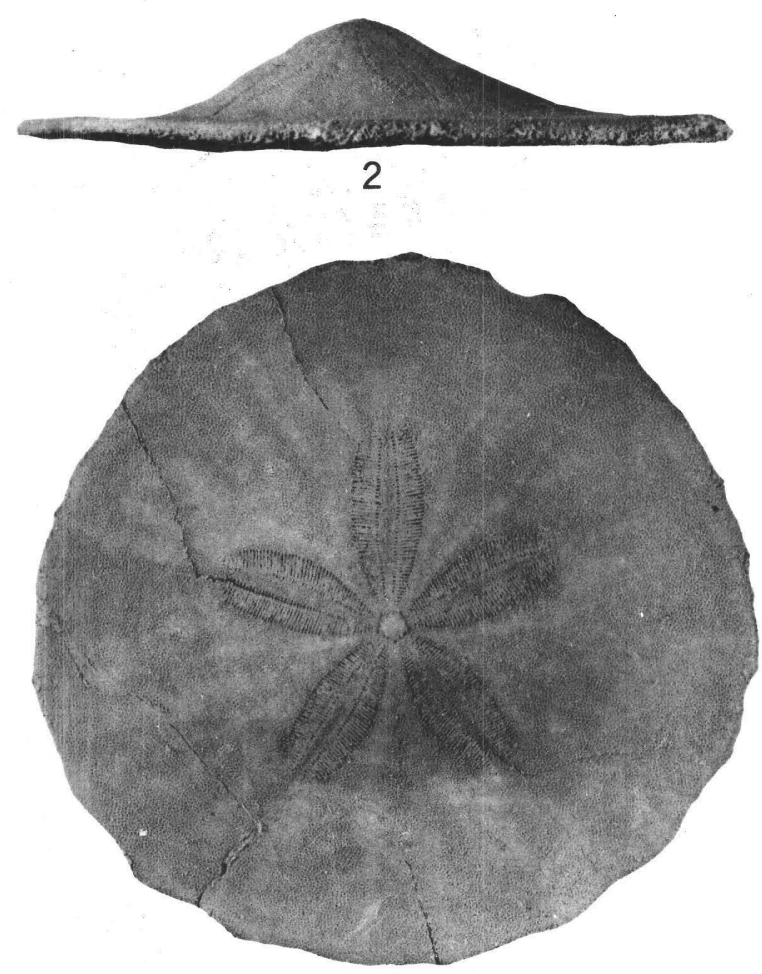

3

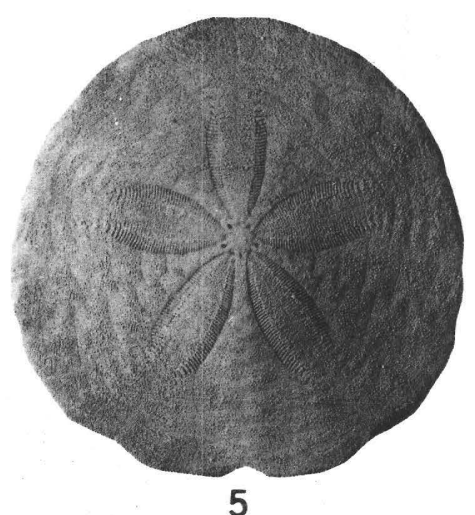

5

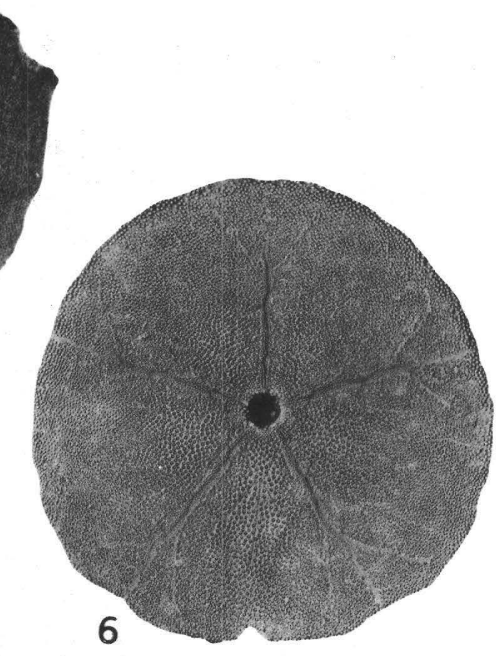

PERIARCHUS AND ECHINARACHNIUS 

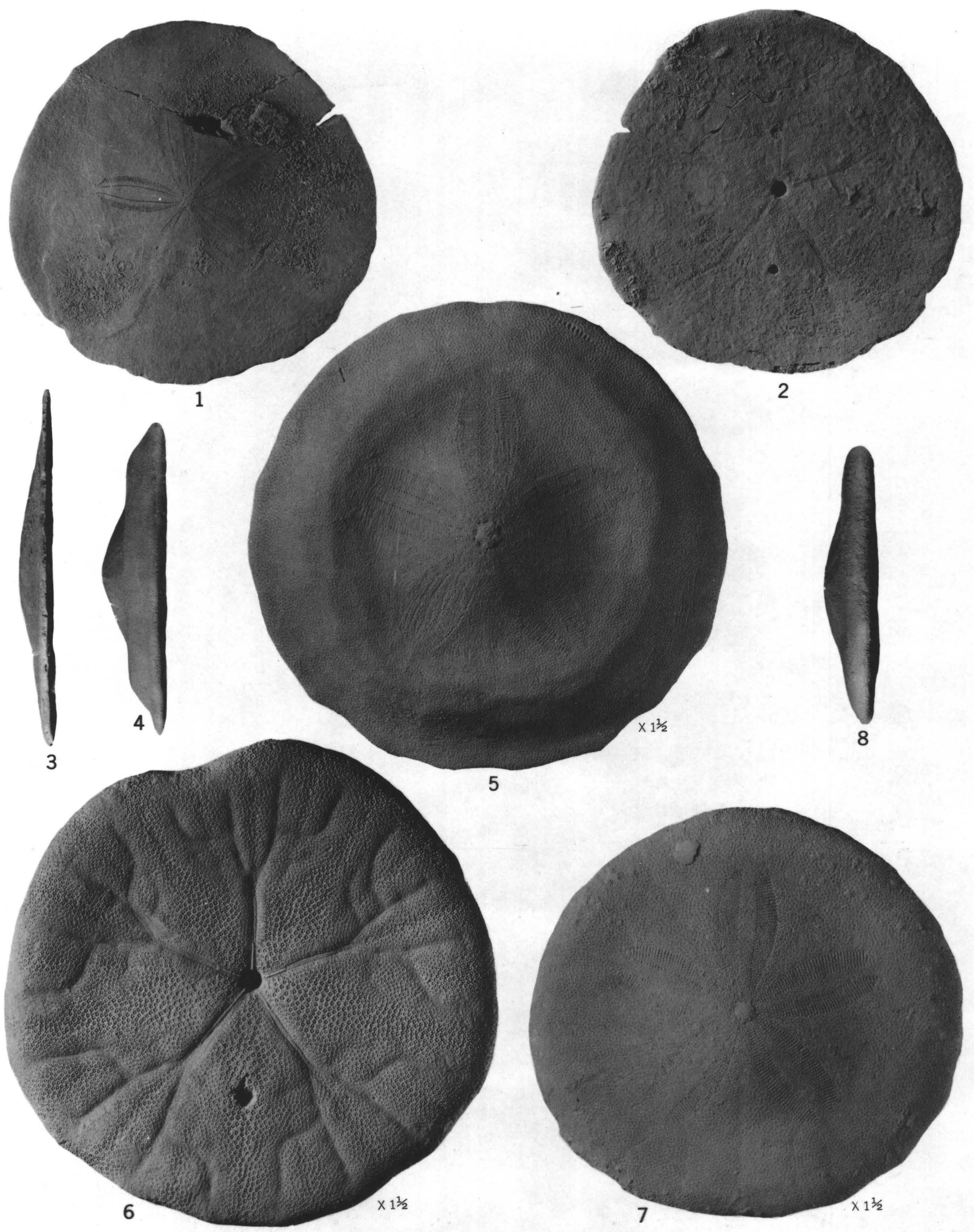

PERIARCHUS 
Fraures 1-3. Periarchus lyelli (Conrad) (p. 41)

PLATE 14

Top, bottom, and side views $\times 1$ of USNM 562277. From the Gosport sand of middle Eocene age at USGS 6087, Gopher Hill, Tombigbee River, Washington County, Ala.

4, 5. Periarchus quinquefarius kewi Cooke (p. 44)

Side $\times 1$ and top $\times 1 \frac{1}{2}$ of type, USNM 499000. From rocks of late Eocene age at USGS 15097, US route 341, 4.2 miles southeast of Clinchfield, Houston County, Ga.

6-8. Periarchus quinquefarius (Say) (p. 43)

6 , Bottom view $\times 1 \frac{1}{2}$ of USNM 562276. From the Sandersville limestone member of the Barnwell formation of late Eocene age at Atlantic Lime Rock quarry 1.5 miles south of Sandersville, Washington County, Ga.

7 , 8, Top $\times 1 \frac{1}{2}$ and side $\times 1$ views of USNM 262279. From the Sandersville limestone member at USGS 15495, a quarry about 1 mile southwest of Sandersville, Ga., under high power line. 
Figures 1-3. Protoscutella plana (Conrad) (p. 40)

\section{PLATE 15}

Top $\times 2$, bottom $\times 2$, and side $\times 1$ of USNM 562275. From the Santee limestone of middle Eocene age at USGS 13391, Eutaw Springs, 2 miles east of Eutawville, Orangeburg County, S. C.

4, 5. Protoscutella conradi (Cotteau) (p. 39)

Bottom and side views $\times 2$ of type, Acad. Nat. Sci. Philadelphia 1081. From the Santee (?) limestone of middle Eocene age near Charleston, S. C.

6-8. Protoscutella pentagonium Cooke (p. 39)

Top $\times 2$, side $\times 1$, and bottom $\times 2$ of type, USNM 498992. From the Lisbon (?) formation of middle Eocene age in a deep well at Falling Water, 4 miles south of Chipley, Washington County, Fla.

9-11. Protoscutella tuomeyi (Twitchell) (p. 39)

Bottom $\times 1$, top $\times 1 \frac{11}{2}$, and side $\times 1$ of type, USNM 137970. From the Warley Hill marl of middle Eocene age at USGS 2017, Cave Hall in Calhoun County, S. C., 14 miles south of Fort Motte.

12, 13. Protoscutella mississippiensis (Twitchell) (p. 38)

Bottom $\times 1 \frac{1}{2}$ of USNM $137674 \mathrm{~b}$ and top $\times 1 \frac{1}{2}$ of USNM $137674 \mathrm{a}$. From the Winona sand of middle Eocene age at USGS 116, Cemetery Branch, Enterprise, Clarke County, Miss. 
GEOLOGICAL SURVEY

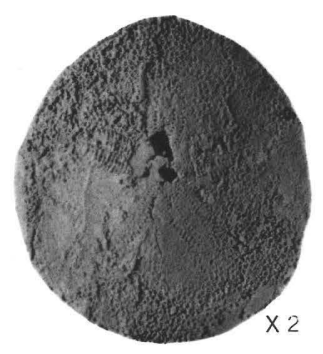

1

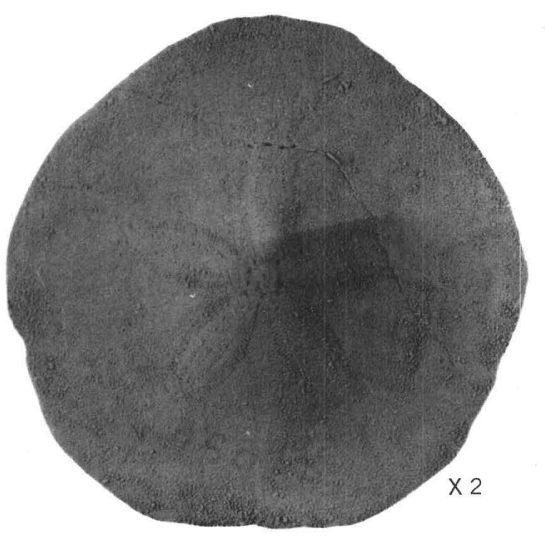

6

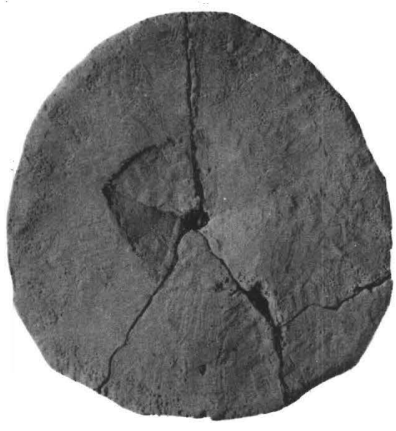

9

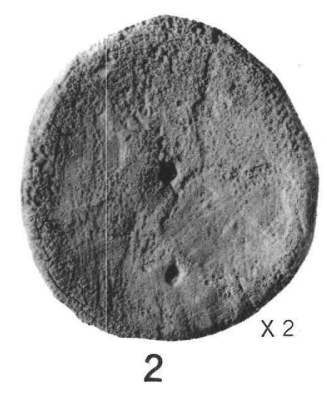

$\frac{}{3}$

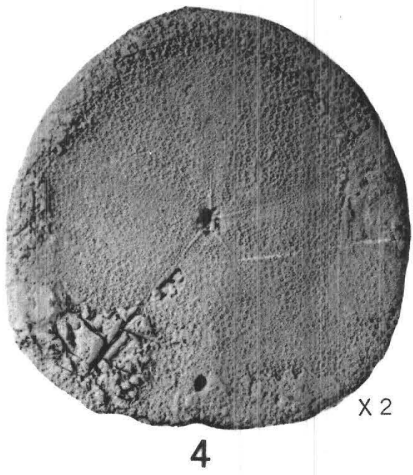

PROFESSIONAL PAPER 321 PLATE 15
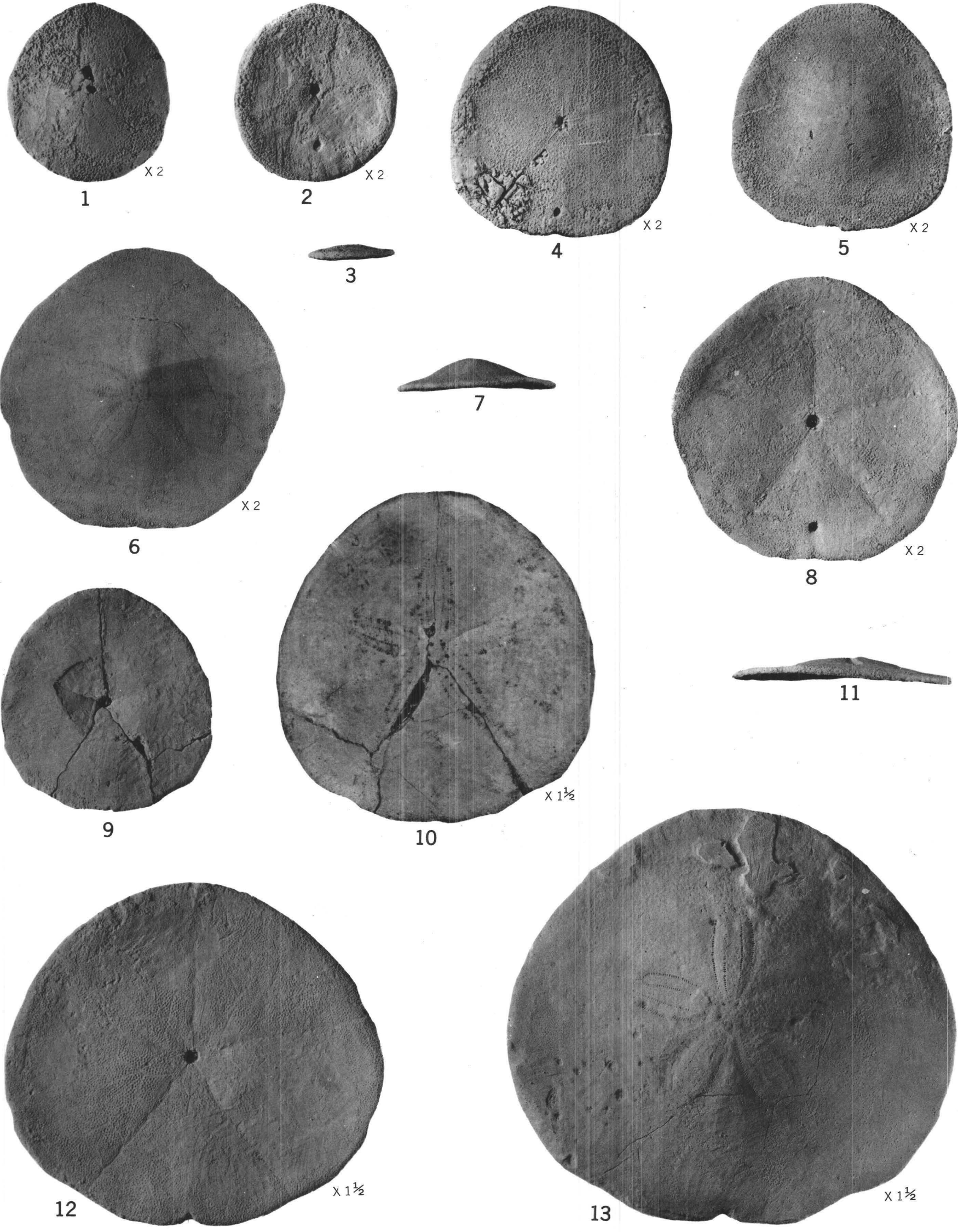

10

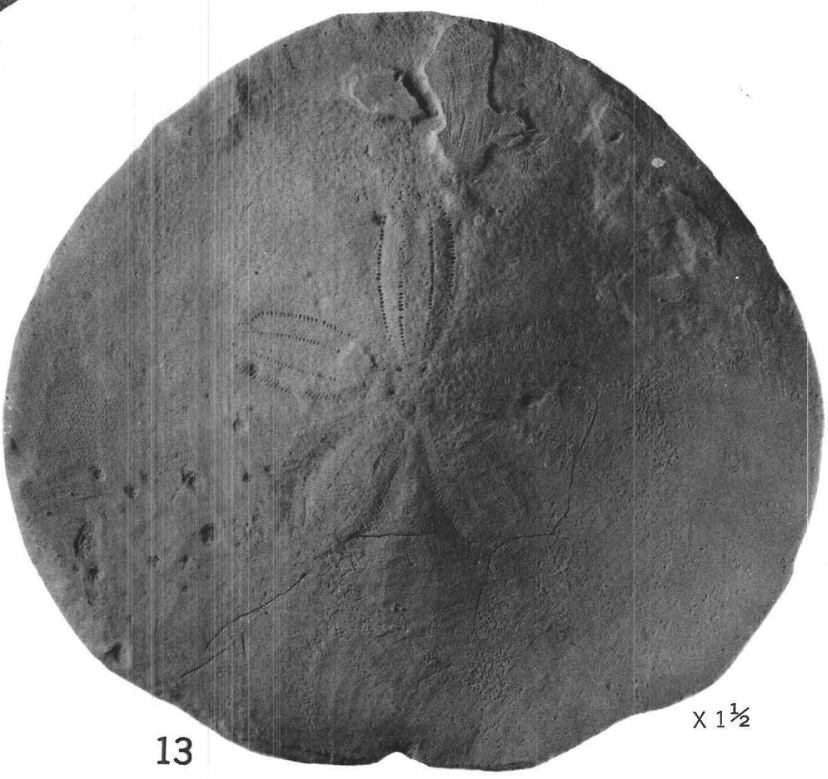

PROTOSCUTELLA 


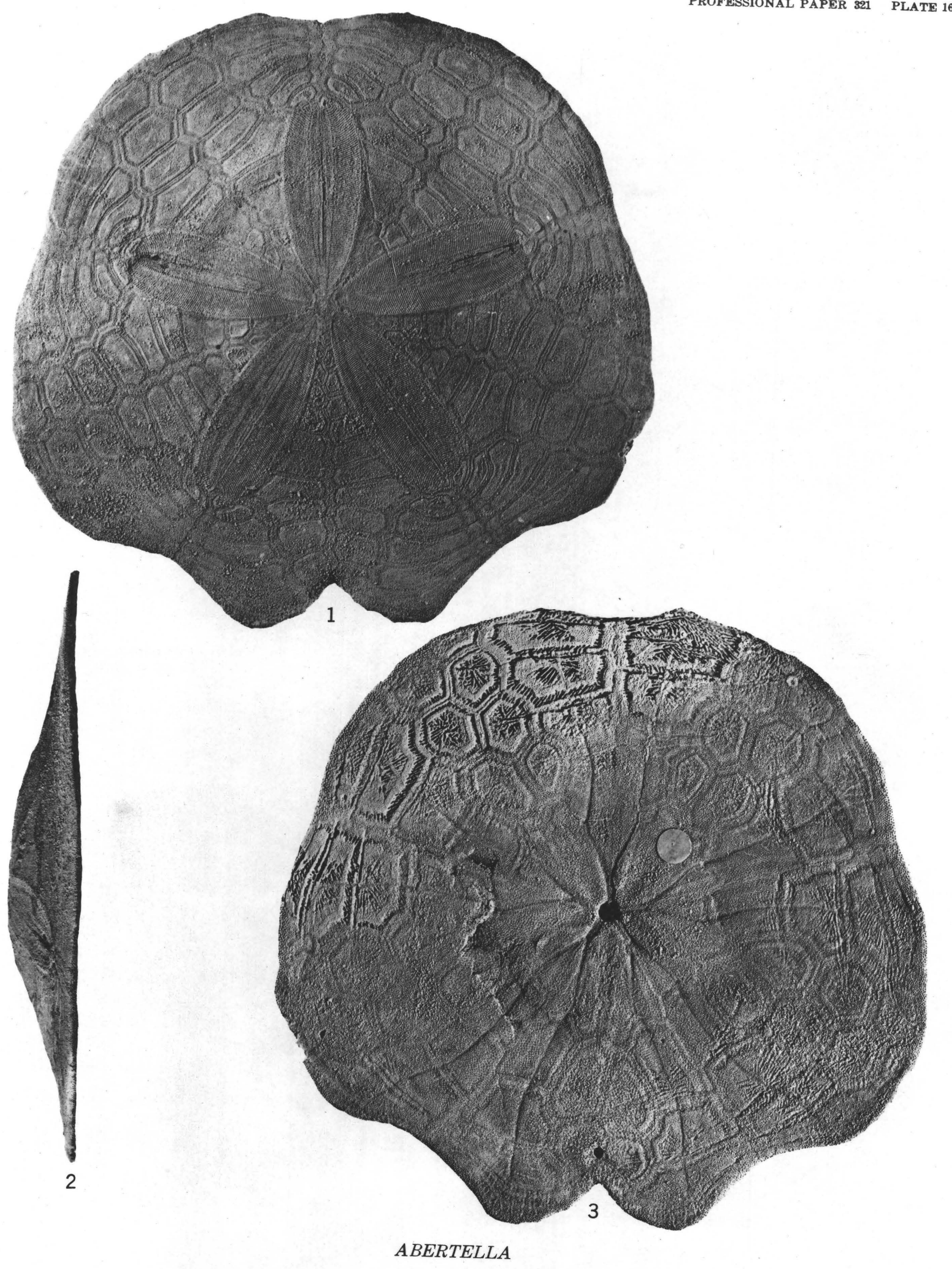


Figures 1-3. Abertella aberti (Conrad) (p. 44)

PLATE 16

Top. side and bottom views $\times 1$ of USNM 562280. From the Choptank formation of Miocene age at USGS 17112 Governors Run, 5 miles southeast of Prince Frederick, Calvert County, Md. 


\section{PLATE 17}

Frgures 1, 2. Encope macrophora (Ravenel) (p. 48)

Top and bottom views $\times 1$ of type, USNM 145410. From rocks of late Miocene (?) age at The Grove, Cooper River 17 miles north of Charleston, S. C.

3,4. Encope tamiamiensis Mansfield (p. 48)

Bottom $\times 1$ of USNM $562284 \mathrm{~b}$.

4 , Top $\times 1$ of USNM 562284 a.

From the Tamiami formation of late Miocene age at USGS 13409, Collier County, Fla., 16 to 22 miles south of Immokalee.

5. Encope emarginata (Leske) (p. 49)

Top view $\times 1$ of USNM 562282. From rocks of Pleistocene age at USGS 18760,1 to 2 miles northeast of the Atlantic Coast Line Railroad bridge near Myrtle Beach, S. C. 
GEOLOGICAL SURVEY
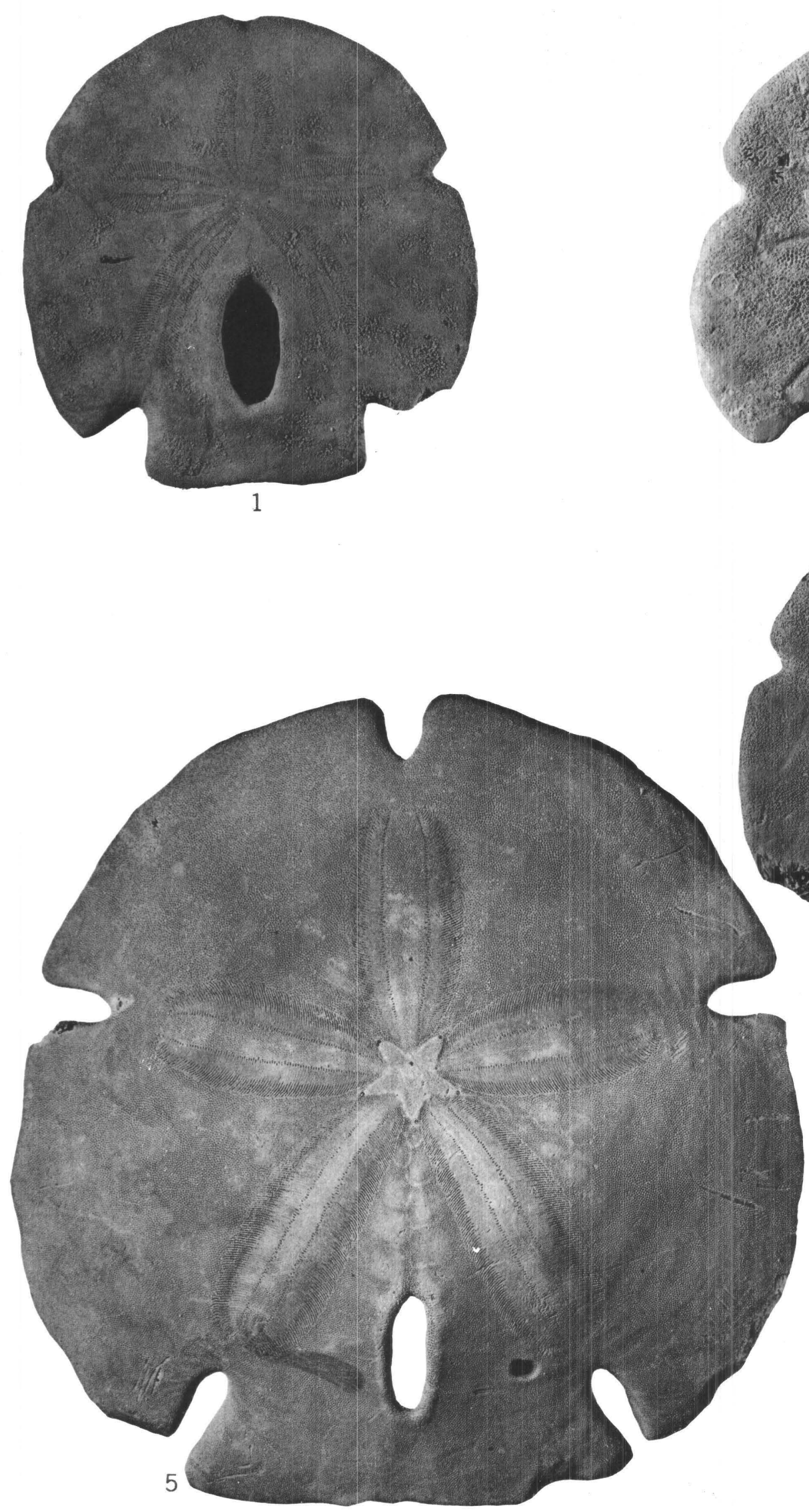

ENCOPE

PROFESSIONAL PAPER 321 PLATE 17

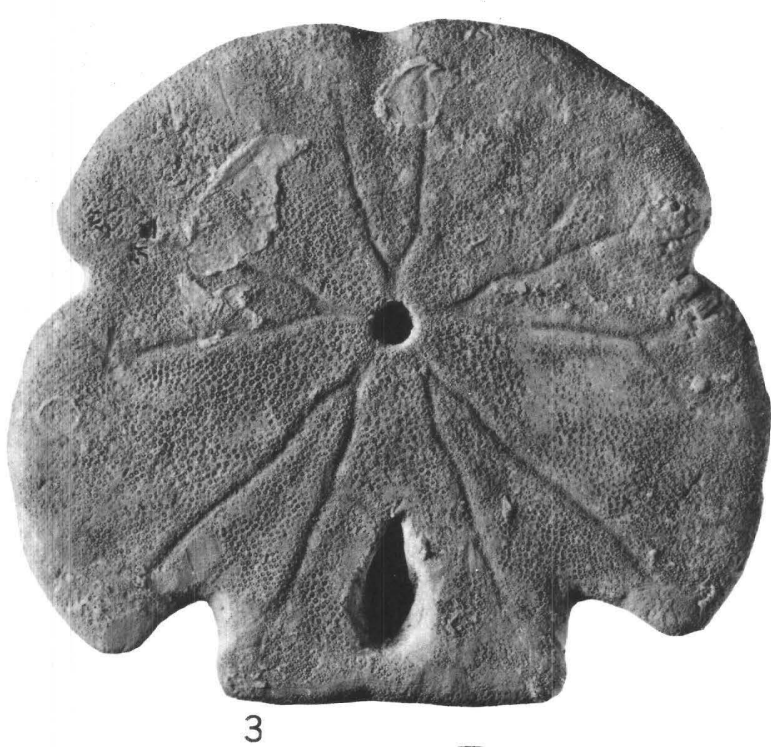



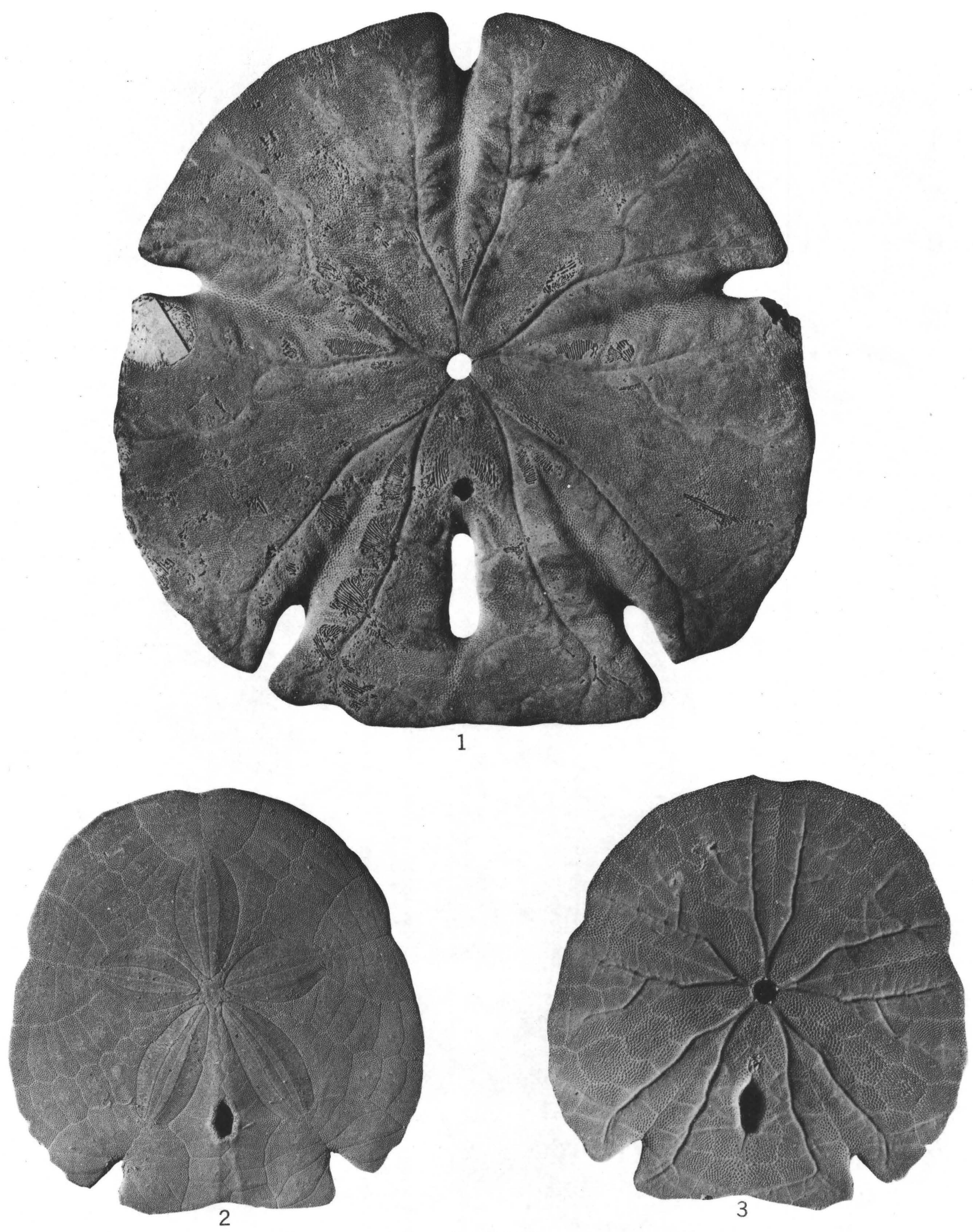

ENCOPE 


\section{PLATE 18}

Figure 1. Encope emarginata (Leske) (p. 49)

Bottom view $\times 1$ of USNM 562282. From rocks of Pleistocene age at USGS 18760, Intracoastal Waterway canal 1 to 2 miles northeast of the Atlantic Coast Line Railroad bridge near Myrtle Beach, S. C.

2, 3. Encope michelini Agassiz (p. 49)

Top and bottom views $\times 1$ of USNM 562283. Recent. From the Gulf of Mexico 2 miles off Longboat Key, Fla.

$468544-59-13$ 


\section{PLATE 19}

Figures 1-3. Leodia caroliniana (Ravenel) (p. 47)

Top, side and bottom views $\times 1$. From rocks of late Miocene (?) age at The Grove, Cooper River, S. C. After Tuomey and Holmes (1857, pl. 1, figs. 4a-c).

4, 5. Leodia sexiesperforata (Leske) (p. 46)

Top and bottom views $\times 1$ of USNM E 1183. Recent. From Morning Star Bay, St. Thomas, Virgin Islands, depth 1 fathom.

6, 7. Mellita quinquiesperforata (Leske) (p. 46)

Top and bottom views $\times 1$ of USNM 562281. Recent. From the beach on Amelia Island, Fla. 

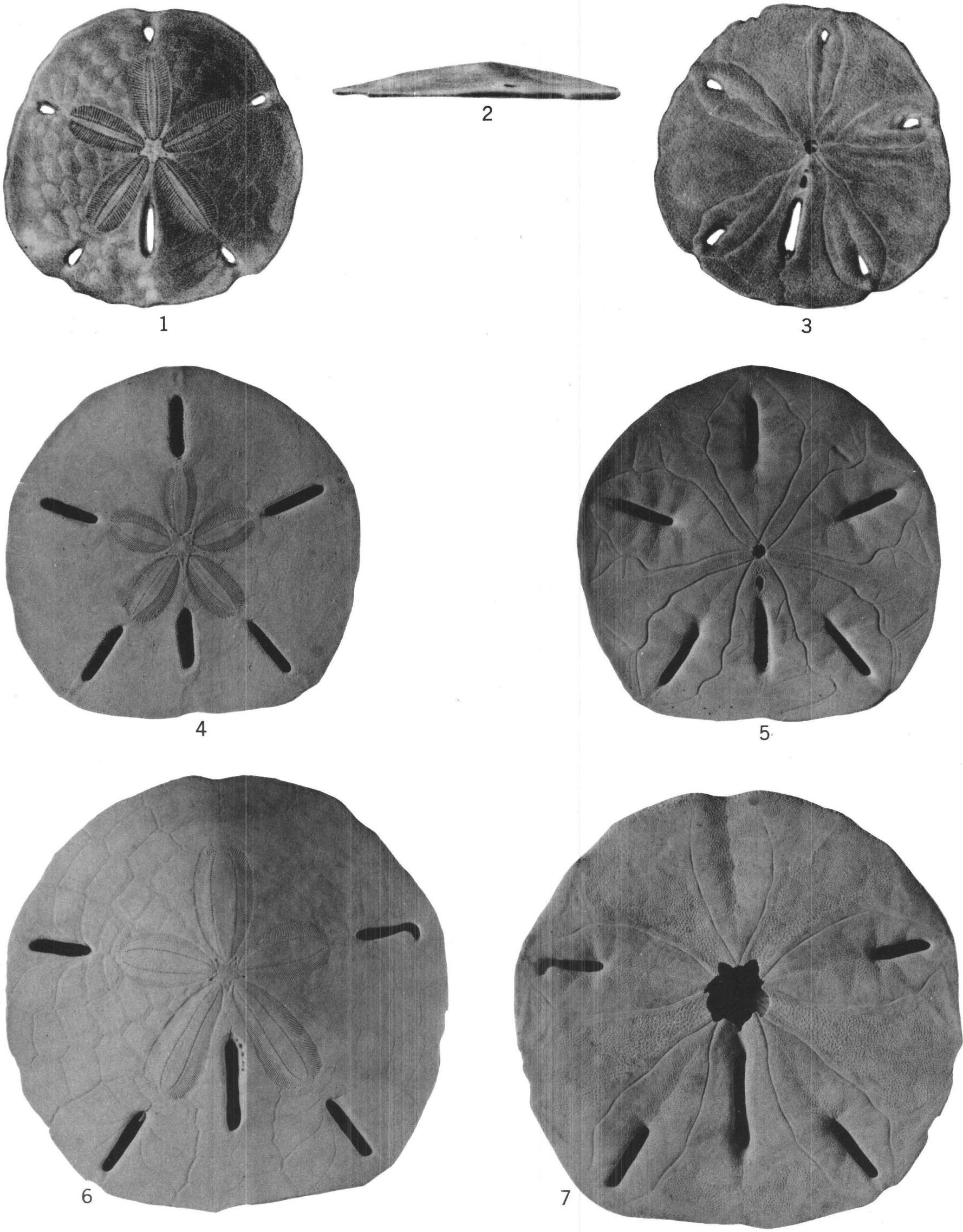

LEODIA AND MELLITA 
GEOLOGICAL SURVEY
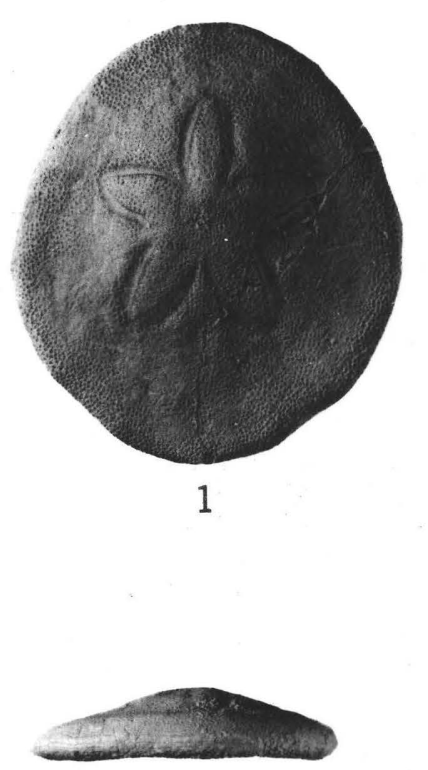

5

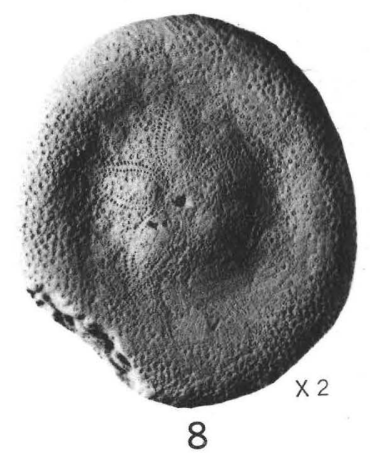

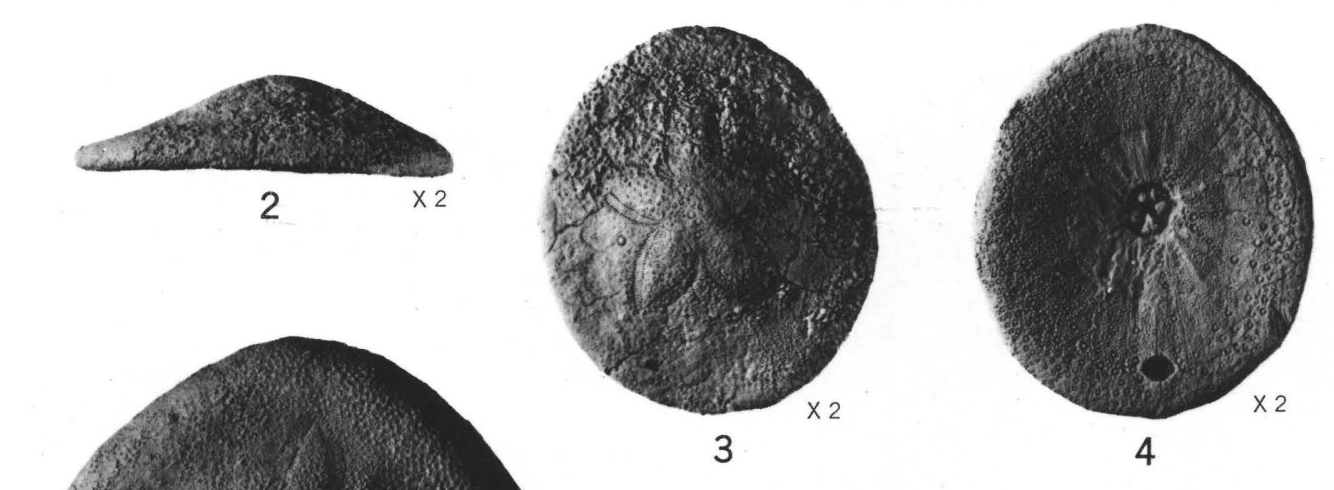

3
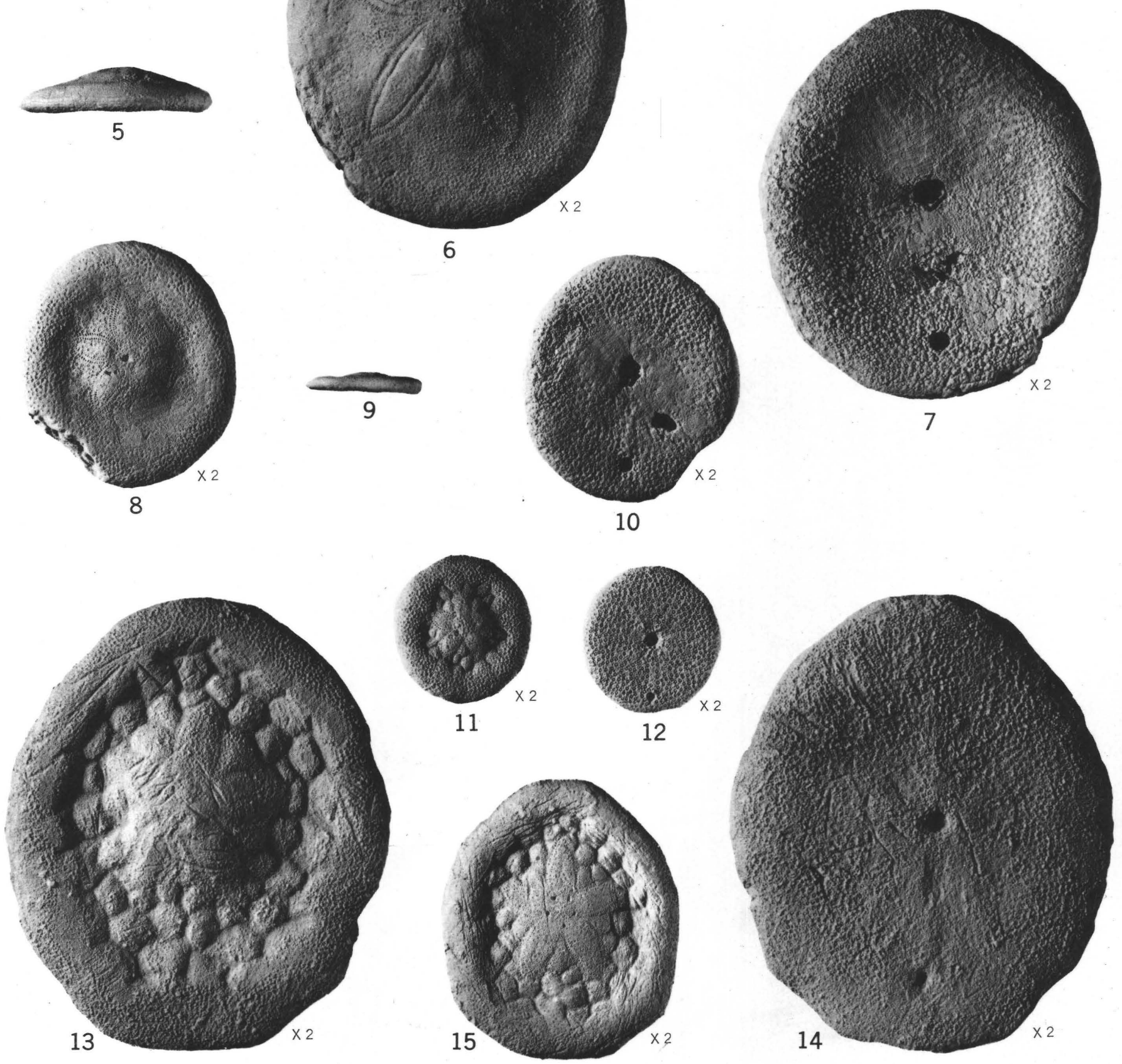

WEISBORDELLA AND LAGANUM 
Figures 1-4. Weisbordella cubae (Weisbord) (p. 53)

\section{PLATE 20}

1, Top view $\times 1$ of USNM 562286. From the Ocala limestone of late Eocene age at USGS 14537, road from Perry to Mayo, Florida, 8.6 miles east of the Taylor County line.

2-4, Side, top, and bottom views $\times 2$ of USNM 499114. From the Ocala limestone of late Eocene age at USGS 7341, Suwannee River at Branford, Fla.

5-7. Weisbordella johnsoni (Twitchell) (p. 54)

Side $\times 1$, top $\times 2$, and bottom $\times 2$ of USNM 372896. From the Ocala limestone of late Eocene age at USGS 10025, Conecuh River 1 mile east of Harts Bridge, Covington County, Ala.

8-10. Laganum floridanum Twitchell (p. 50)

Top $\times 2$, side $\times 1$, and bottom $\times 2$ of type, USNM 137884. From the Ocala limestone of late Eocene age at USGS 365, Johnson's sink, Levy County, Fla.

11-15. Laganum ocalanum Cooke (p. 51)

11,12 , Top and bottom $\times 2$ of USNM 562288. From the Inglis limestone of late Eocene age at USGS 18756, Withlacoochee River in sec. 5, T. 17 S., R. 16 E., Fla.

13,14 , Top and bottom $\times 2$ of paratype, USNM 498993 . From the Ocala limestone of late Eocene age at USGS 6804, Ocala, Fla.

15, Top view $\times 2$ of type, USNM 372873. From the Ocala limestone of late Eocene age at USGS 12751 , pit 2 miles northeast of Sumterville, Fla. 
Figures 1-4. Neolaganum dalli (Twitchell) (p. 51)

\section{PLATE 21}

1, Top view $\times 3$ of type, USNM 164667. Probably from the Avon Park limestone of middle Eocene age in a well near Archer, Florida.

2-4, Top, side and bottom views $\times 3$ of USNM 562285. From the Avon Park limestone of middle Eocene age at a depth of 600 feet in a well of the International Mining and Chemical Company at the Narlyn Plant in sec. 25, T, 30 S, R. 24 E, in Polk County, Fla.

5-7. Neolaganum durhami Cooke, n. sp. (p. 52)

5,6 , Bottom views $\times 2$ of type, USNM 562290a, and paratype, USNM 562290b. From the Inglis limestone of late Eocene age at USGS 18749 , Withlacoochee River in the W. 1/2 sec. 3, T. 17 S., R. 16 E., in Citrus County, Fla.

7, Top view $\times 2$ of USNM 562289. From the Inglis limestone of late Eocene age at USGS 18755 , Withlacoochee River in W. 1/2 sec. 4, T. 17 S., R. 16 E., in Citrus County, Fla.

8-10. Wythella eldridgei (Twitchell) (p. 53)

Top, side and bottom views $\times 1$ of USNM 562287. From the Ocala limestone of late Eocene age at USGS 14541, quarry north of US 19 east of Steinhatchee River in Dixie County, Fla., opposite Clara. 


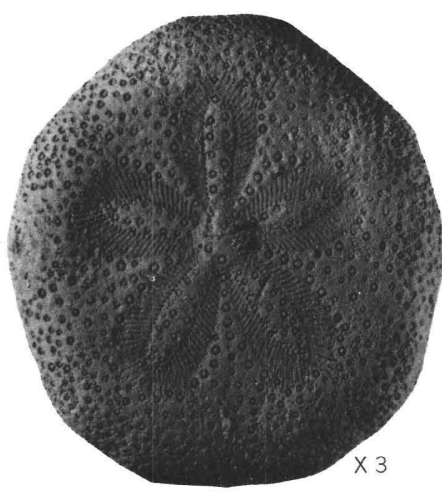

1
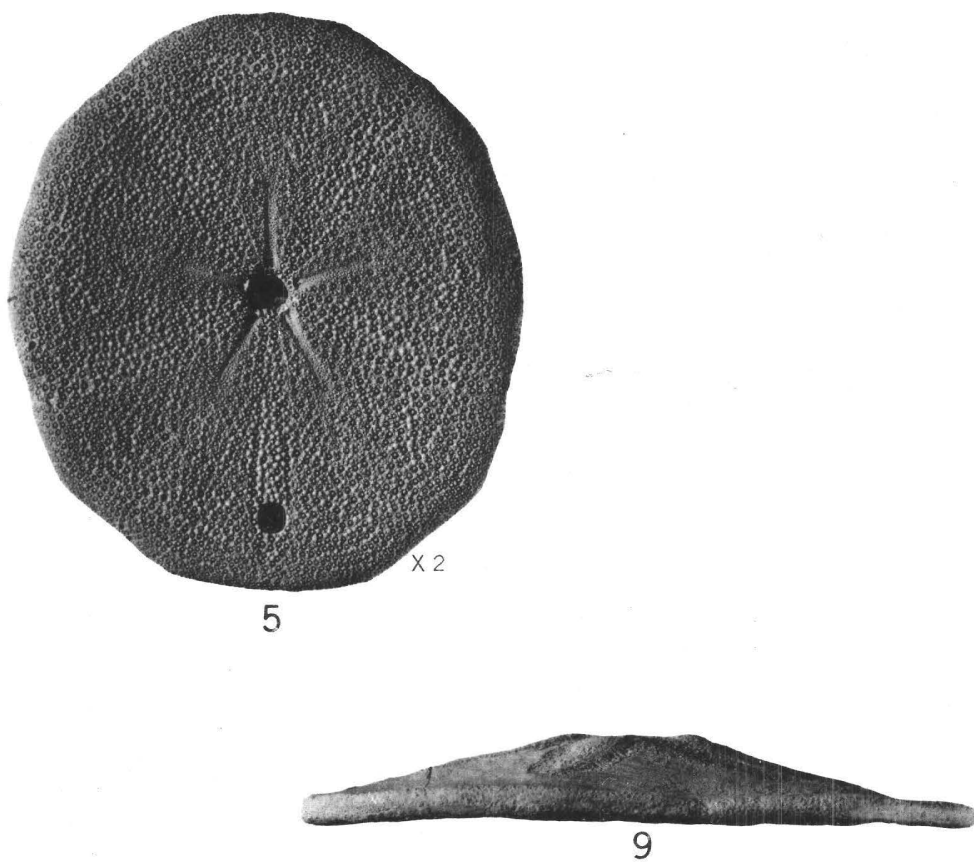
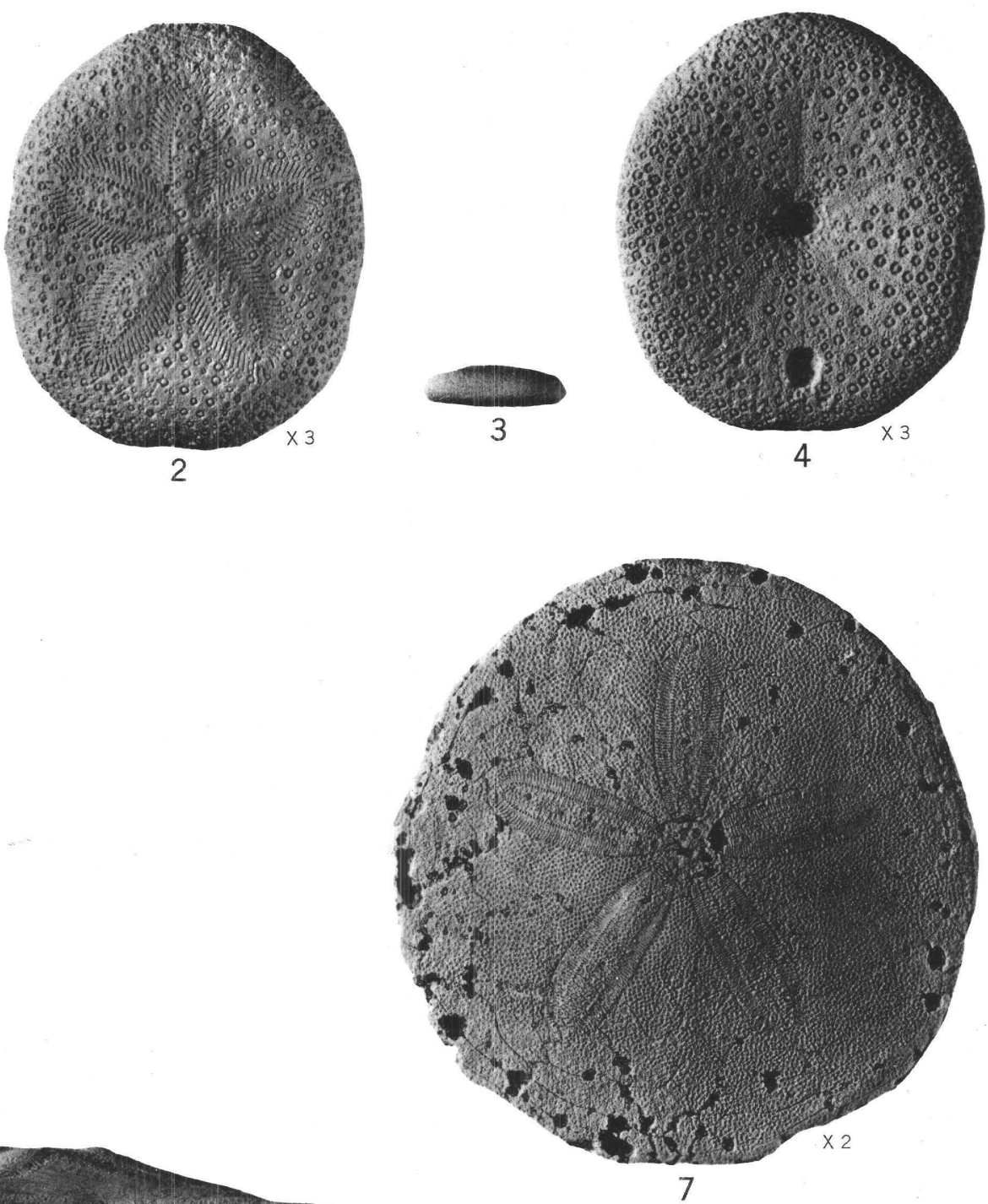
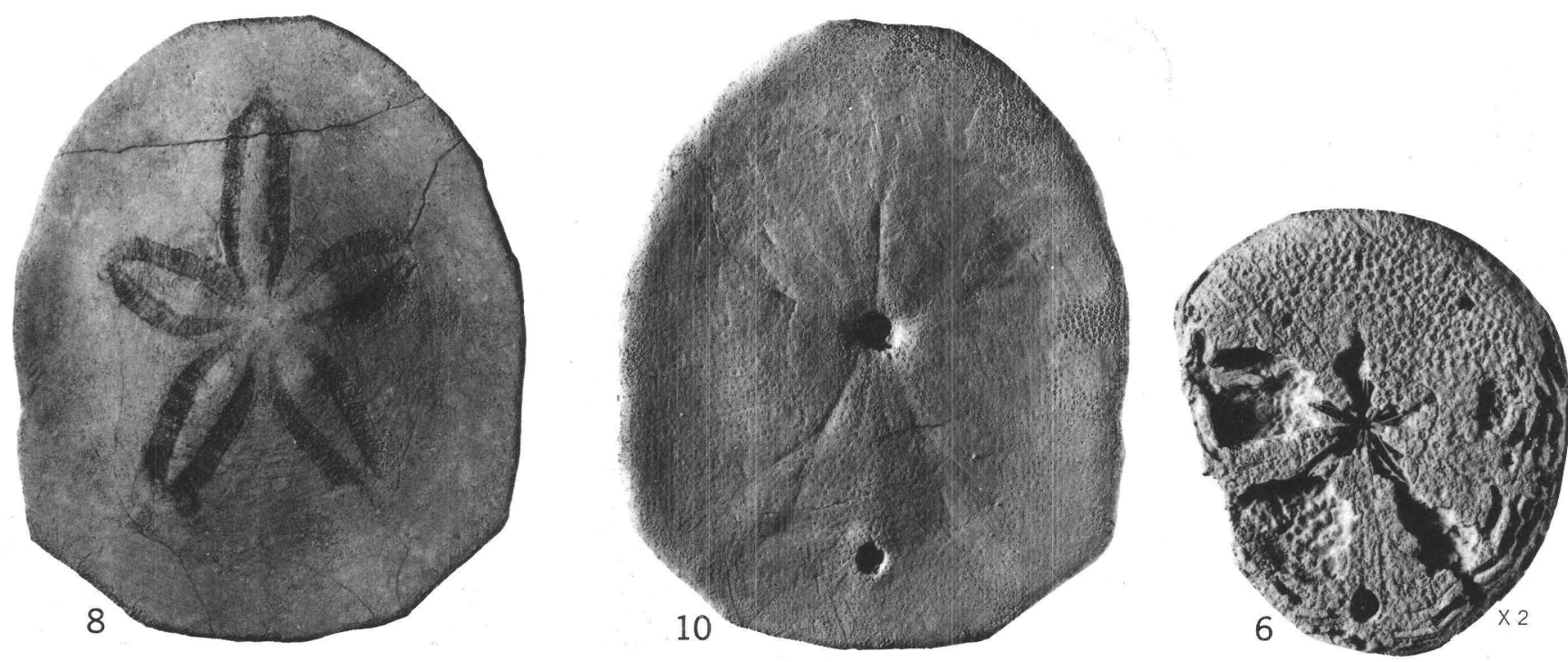

NEOLAGANUM AND WYTHELLA 
GEOLOGICAL SURVEY
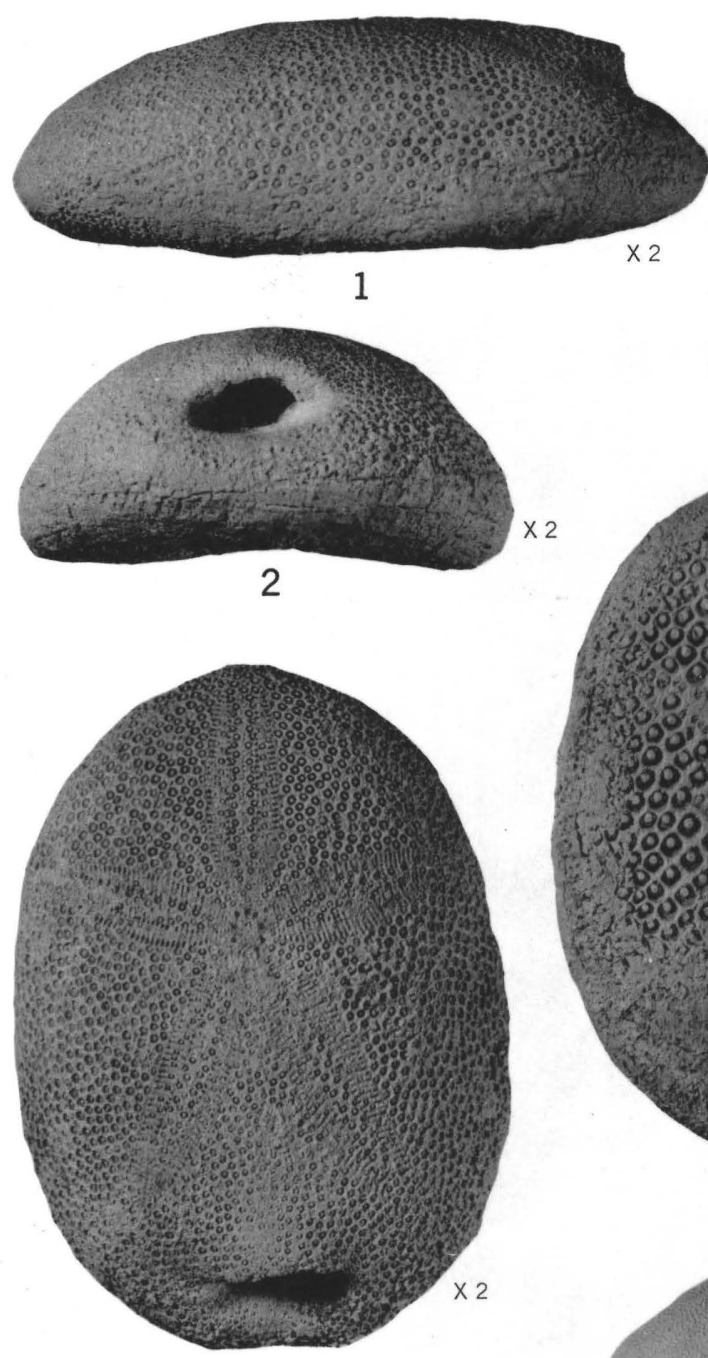

3

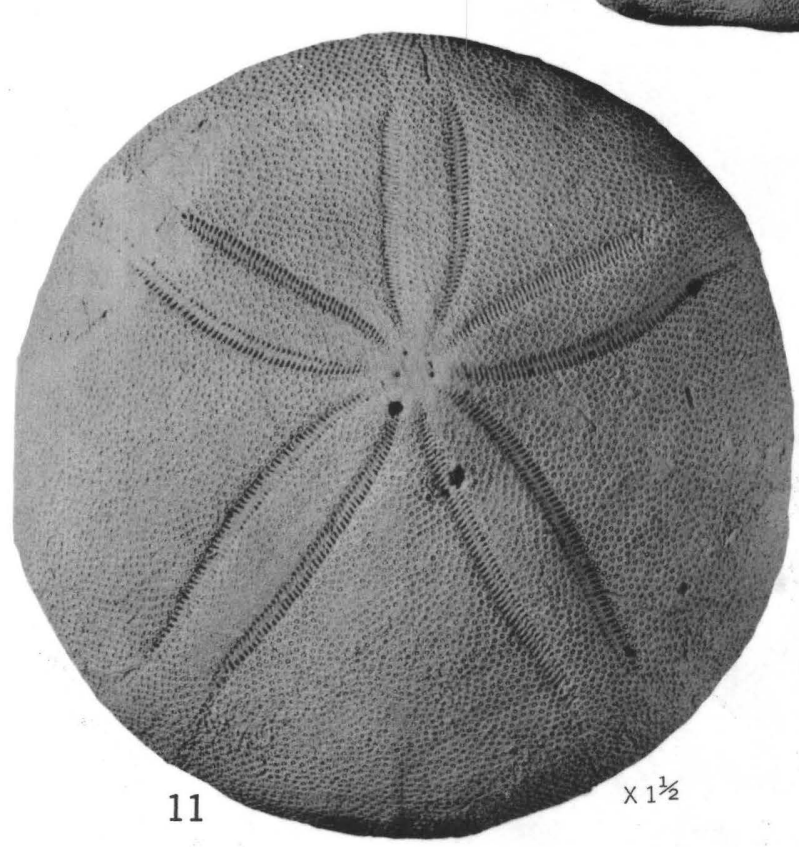

PROFESSIONAL PAPER 321 PLATE 22
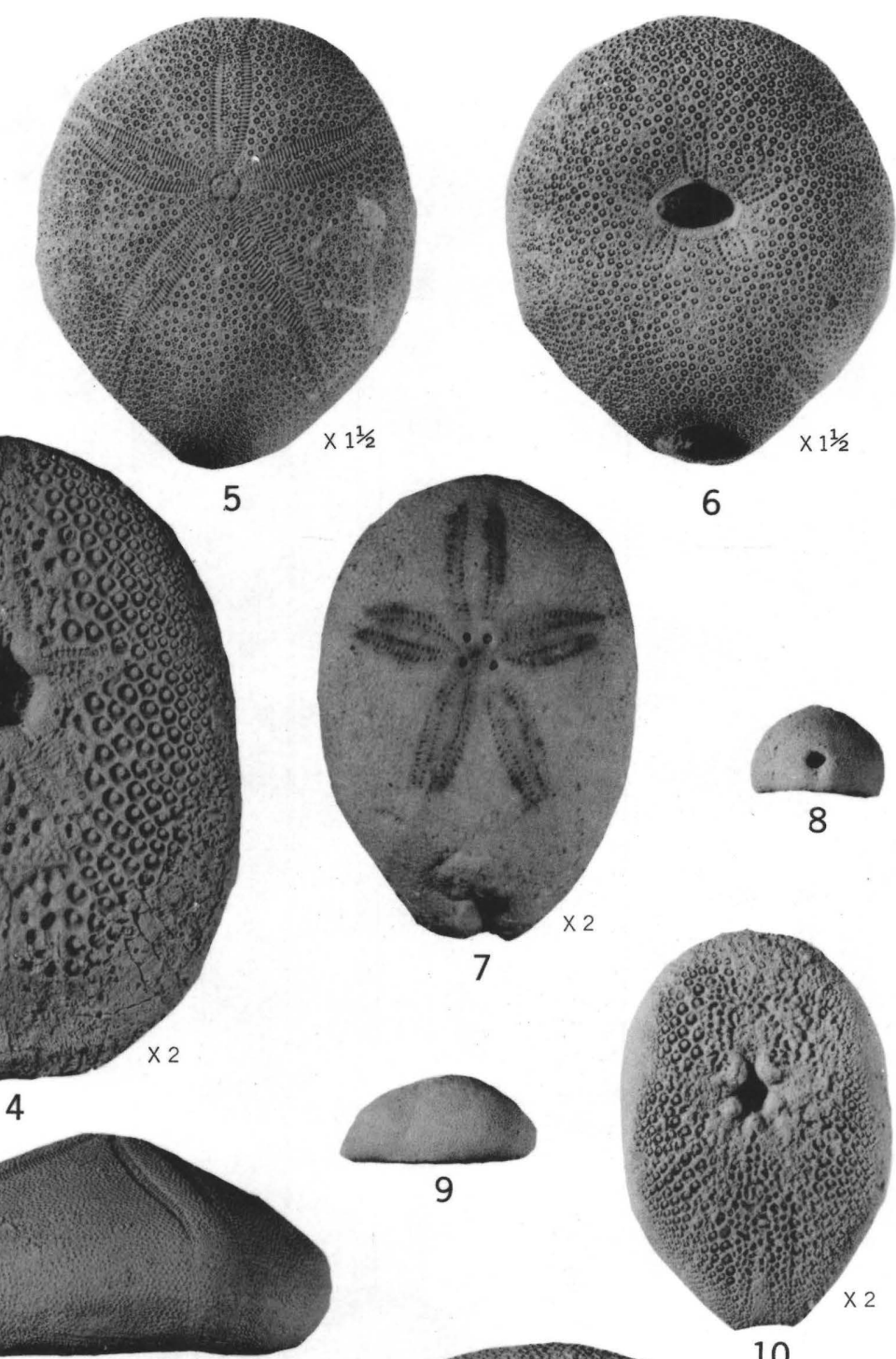

12

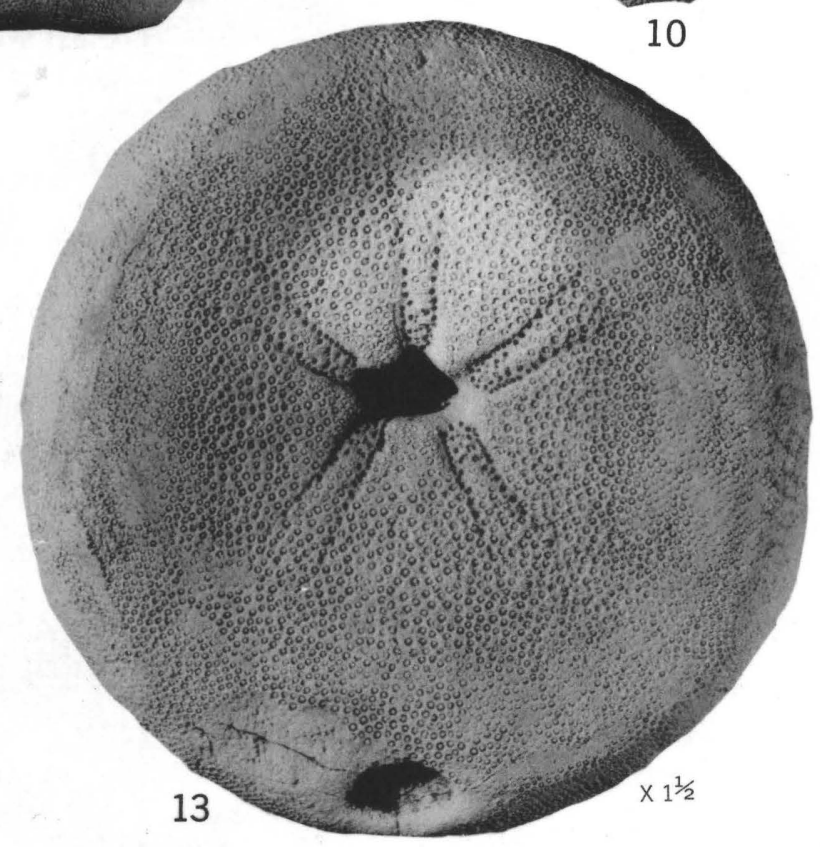

EURHODIA AND ECHINOLAMPAS 
Figures 1-4. Eurhodia rugosa (Ravenel) (p. 63)

\section{PLATE 22}

Side, posterior end, top, and bottom views $\times 2$ of USNM 562300. From the Santee limestone of middle Eocene age at USGS 18353, Santee-Cooper Diversion Canal near Eadytown, Berkeley County. S. C.

5,6. Echinolampas appendiculata Emmons (p. 56)

Top and bottom views $\times 1 \frac{1}{2}$ of USNM 138017. From the Castle Hayne limestone of middle and late Eocene age at USGS 779, Rocky Point, N. C.

7-10. Eurhodia patelliformis (Bouvé) (p. 64)

7 , Top view $\times 2$ of USNM 498988. From the Ocala limestone of late Eocene age at USGS 5054, power plant 2 miles north of Albany, Ga.

8-10, Posterior end $\times 1$, side $\times 1$, and bottom $\times 2$ of USNM 562299 . From the Ocala limestone of late Eocene age at the mouth of Kinchafoonee Creek 3.3 miles north of Albany, Ga.

11-13. Echinolampas aldrichi Twitchell (p. 55)

Top $\times 11 \frac{1}{2}$, side $\times 1$, and bottom $\times 1 \frac{1}{2}$ of type, USNM 559490. From the Chickasawhay limestone of late Oligocene age at Gainestown, Alabama River, Ala. 


\section{PLATE 23}

Figures 1-5. Eurhodia (Gisopygus) holmesi (Twitchell) (p. 65)

$1-4$, Top $\times 2$, bottom $\times 2$, side $\times 1$, and posterior end $\times 2$ of USNM 353256 , type of Cassidulus cravenensis Kellum. 5 , Bottom view $\times 2$ of USNM 562303.

Both from the Santee limestone of middle Eocene age at USGS 10627, farm of T. J. Falkner, 3 miles east of Quinerly and 2 miles north of Neuse River in Pitt County, N. C.

6-14. Cassidulus sabistonensis Kellum (p. 57)

6, 7, Side and bottom views $\times 1$ of type, USNM 353233. Probably from the upper Miocene at USGS 10637, farm of E. W. Sabiston 2 miles north of Jacksonville, Onslow County, N. C.

8-10, Top, posterior end, and side views $\times 1$ of USNM $562301 \mathrm{~b}$.

11-14, Top, posterior end, side, and bottom views $\times 1$ of USNM 562301a. From the upper Miocene(?) at USGS 18759, Intracoastal Waterway canal about 5 miles southwest of Little River, Horry County, S. C. 

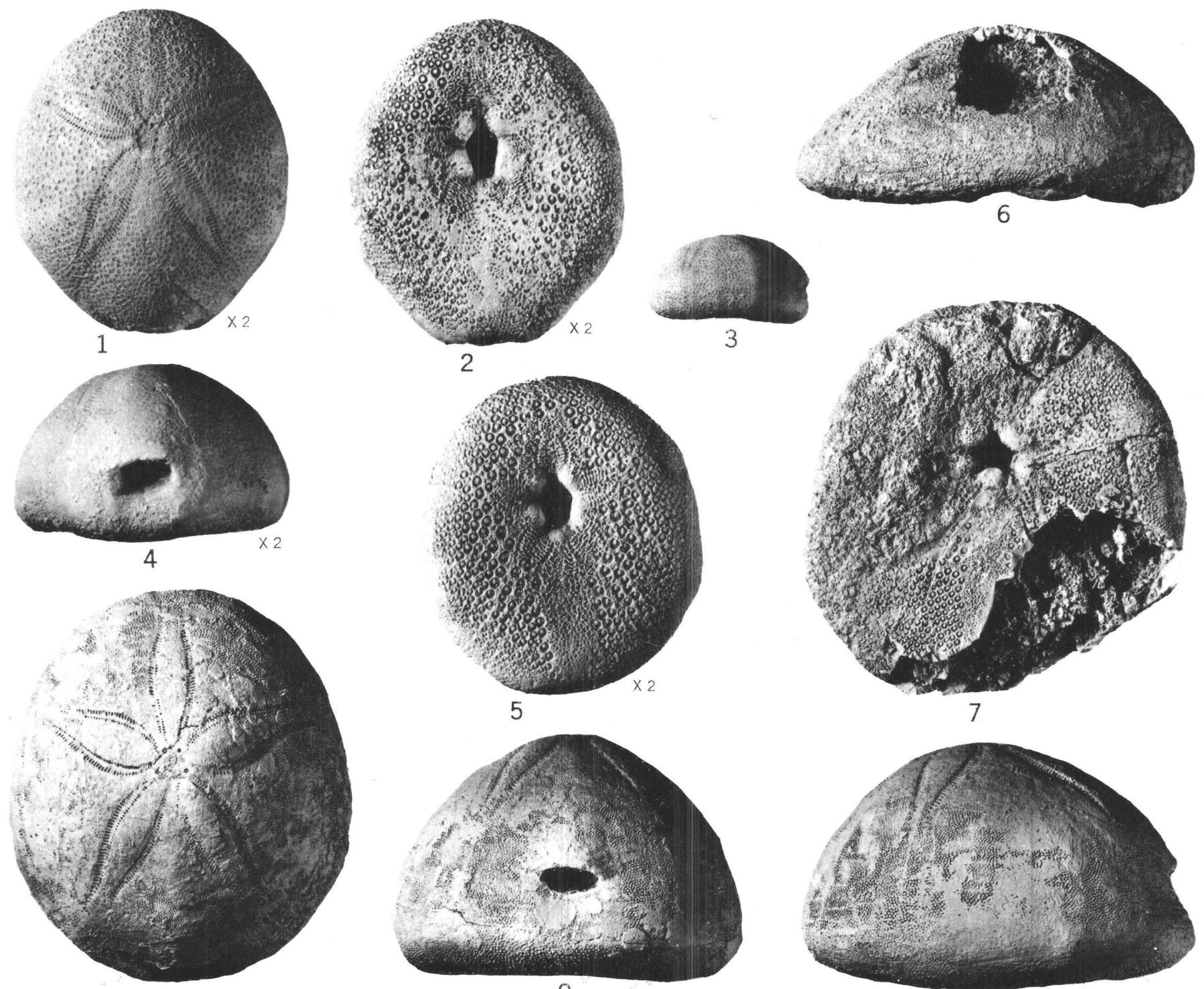

8

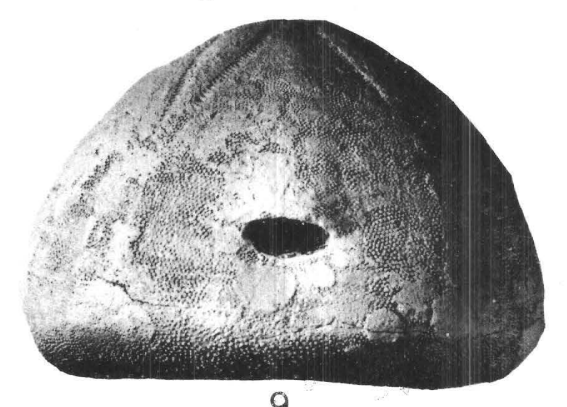

9
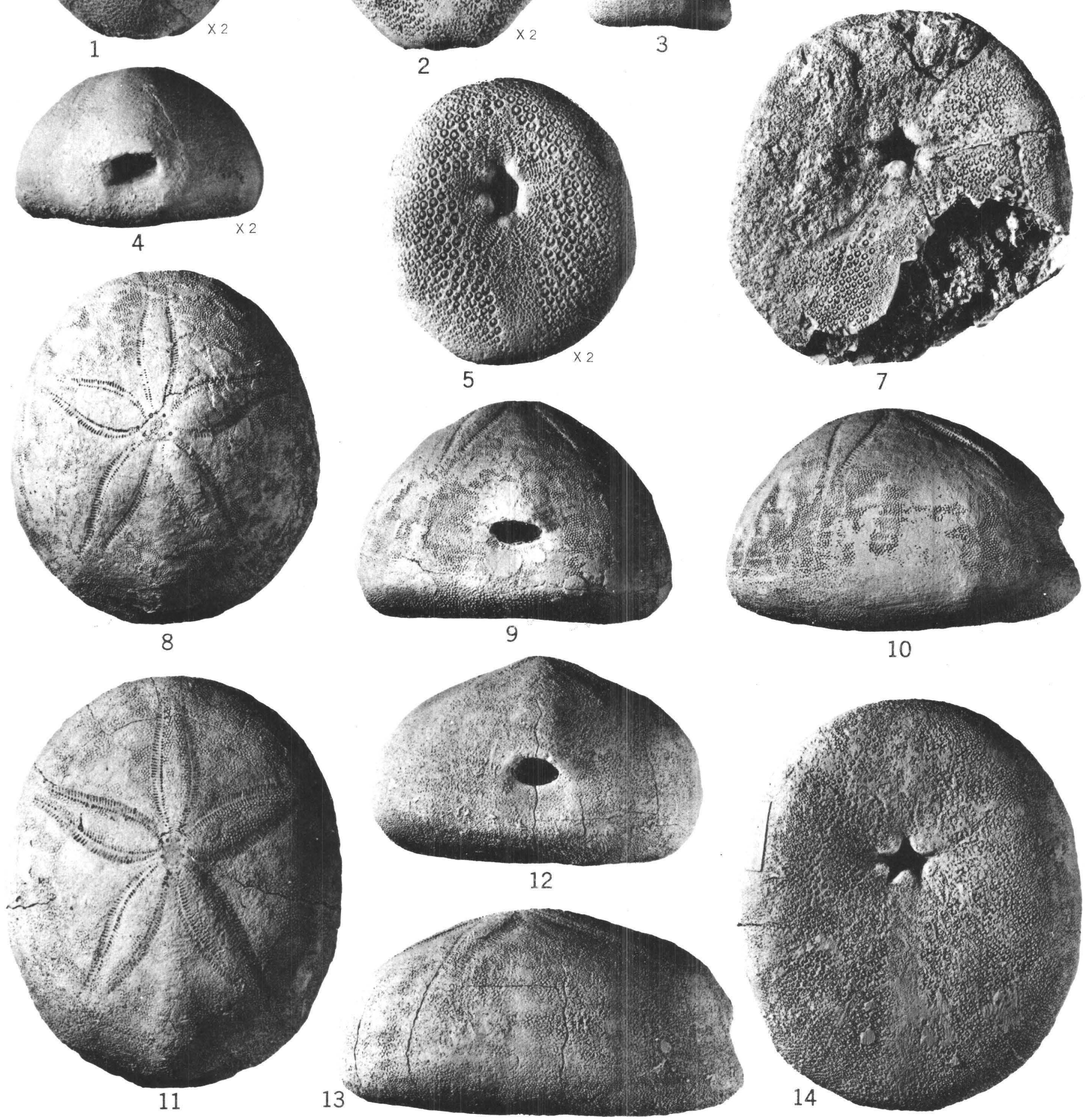

10

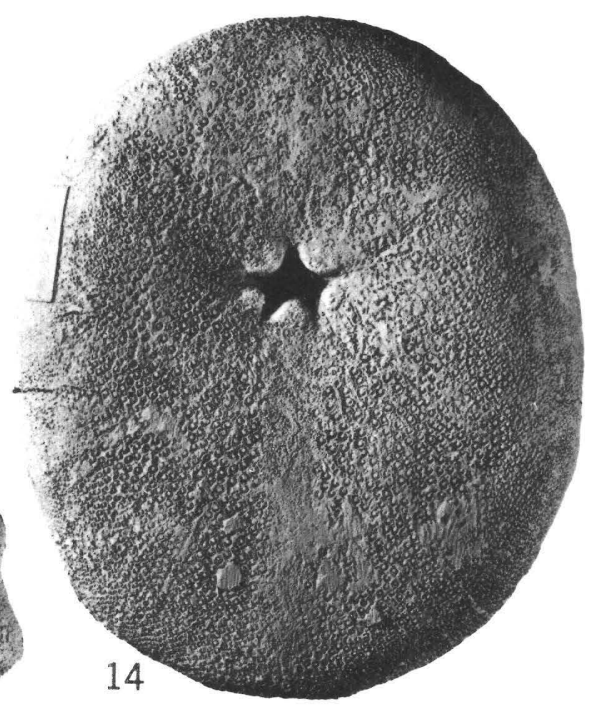

EURHODIA AND CASSIDULUS 


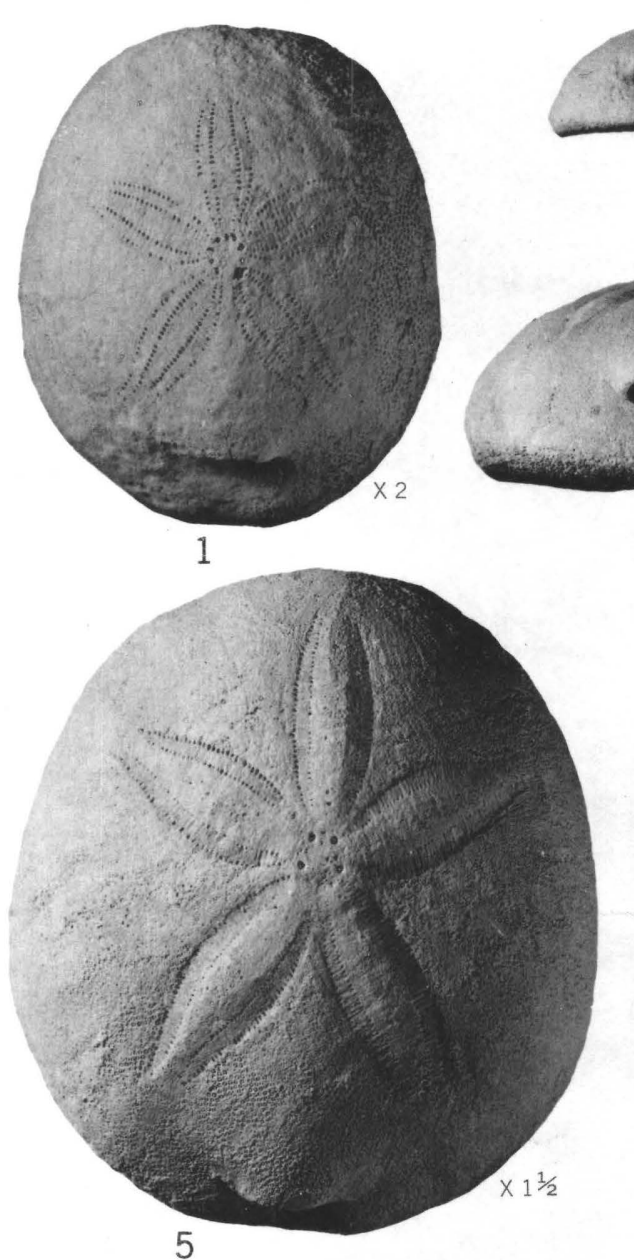

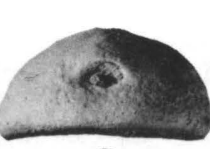

2

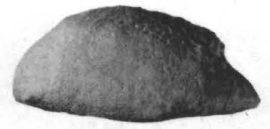

3

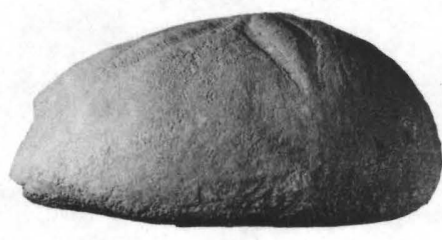

7

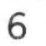

6
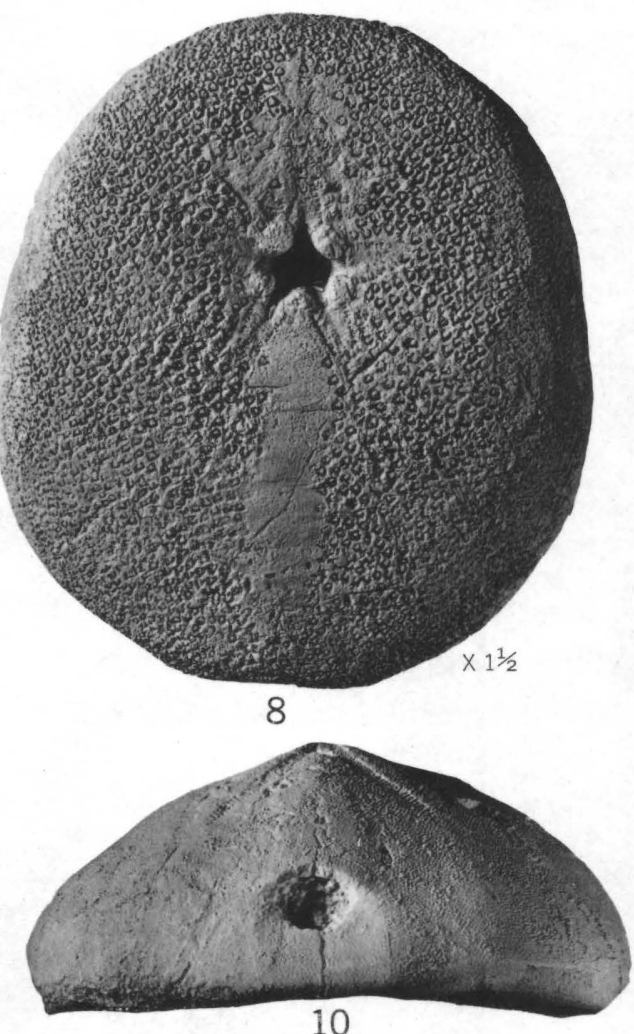

10

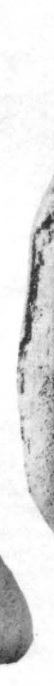

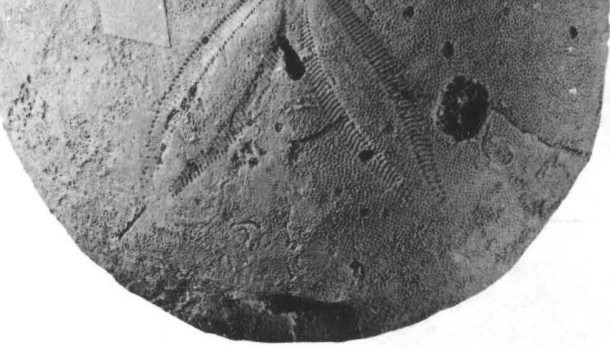

9

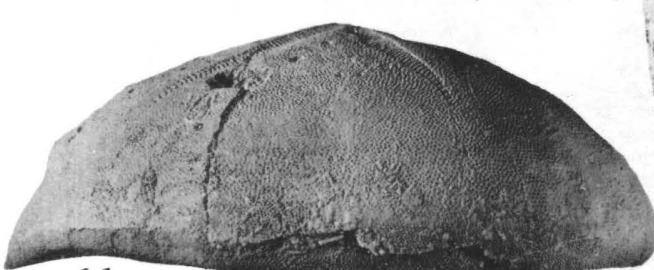

11

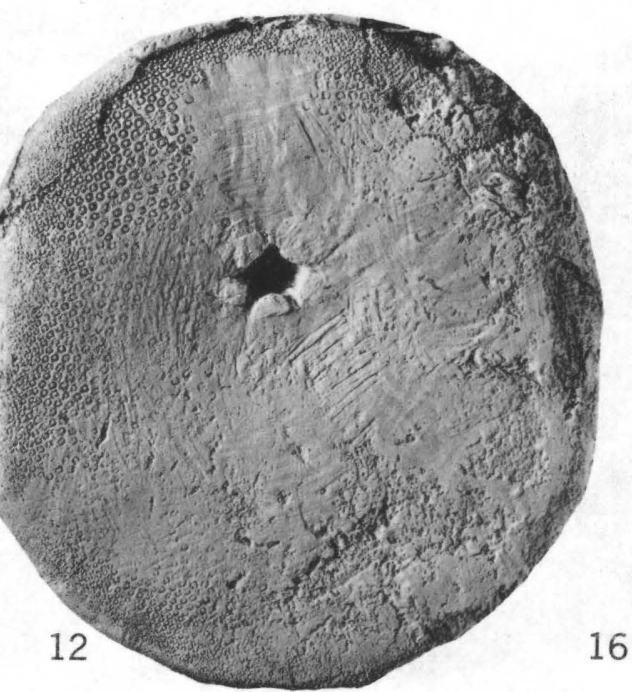

16

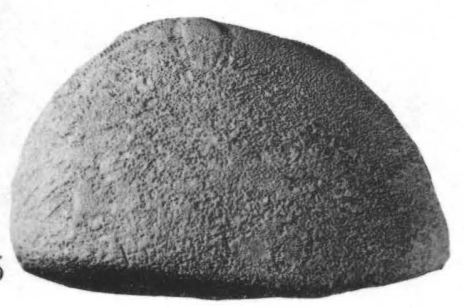

CASSIDULUS 
Figures 1-4. Cassidulus trojanus Cooke (p. 58)

\section{PLATE 24}

Top $\times 2$, posterior end $\times 1$, side $\times 1$, and bottom $\times 2$ of type, USNM 498996 From the Ocala limestone of late Eocene age at USGS 7347, Suwannee River below Troy Springs, Lafayette County, Fla.

5-12. Cassidulus gouldii (Bouvé) (p. 57)

$5-8$, Top $\times 1 \frac{1}{2}$, posterior end $\times 1$, side $\times 1$, and bottom $\times 1 \frac{1}{2}$ of USNM 562302 . From the Suwannee limestone of late Oligocene age at USGS 14924, Aucilla River 6.5 miles south of Nutalls Rise, Taylor County, Fla.

9-12, Top, posterior end, side, and bottom views $\times 1$ of type of Cassidulus alabamensis Twitchell, USNM 559493. From rocks of Oligocene age at Natural Bridge, SE1/4 sec. 26, T. 6 N., R. 20 W., Walton County, Fla.

13-16. Cassidulus ericsoni Fischer (p. 58)

Top, bottom, posterior end, and side views $\times 1$ of paratype, USNM 560420 . From the Inglis limestone of late Eocene age on Withlacoochee River 4 miles below Stokes Ferry, Citrus County, Fla. 
PLATE 25

Figures 1, 2. Cassidulus conradi lyelli (Conrad) (p. 60)

Top and bottom views $\times 1 \frac{1}{2}$ of USNM 562305. From the Ocala limestone of late Eocene age at USGS 13611, Bainbridge, Ga.

3-6. Cassidulus (Plagiopygus) conradi (Conrad) (p. 59)

Posterior end, side and bottom views $\times 1$ and top view $\times 1 \frac{1}{2}$ of USNM 562304. From the Ocala limestone of late Eocene age at USGS 15150, east side Steinhatchee River north of US 19 in Dixie County, Fla., opposite Clara.

7-10. Cassidulus conradi carolinensis Twitchell (p. 60)

Posterior end $\times 1$, side $\times 1$, top $\times 1 \frac{1}{2}$, and bottom $1 \frac{1}{2}$ of type, USNM 559488. From the Castle Hayne limestone of middle and late Eocene age on Smith Creek near Wilmington, N. C.

11-13. Cassidulus georgiensis globosus Fischer (p. 61)

11, 12, Side and top views $\times 1$ of USNM 562308. From the Inglis limestone of late Eocene age in a pit southwest of US 19 in SW34 sec. 34, T. 14 S., R. 16 E., in Levy County, Fla.

13, Side view $\times 1$ of USNM 562307 . From rocks of late Eocene age at USGS 18753 , a borrow pit in sec. 14, T. 15 S., R. 16 E., about 11/2 miles north of Lebanon Station, Fla.

14-17. Cassidulus (Plagiopygus) georgiensis Twitchell (p. 60)

Top, side, posterior end, and bottom views $\times 2$ of USNM 562306. From the Ocala limestone of late Eocene age at USGS 13611, Bainbridge, Ga. 

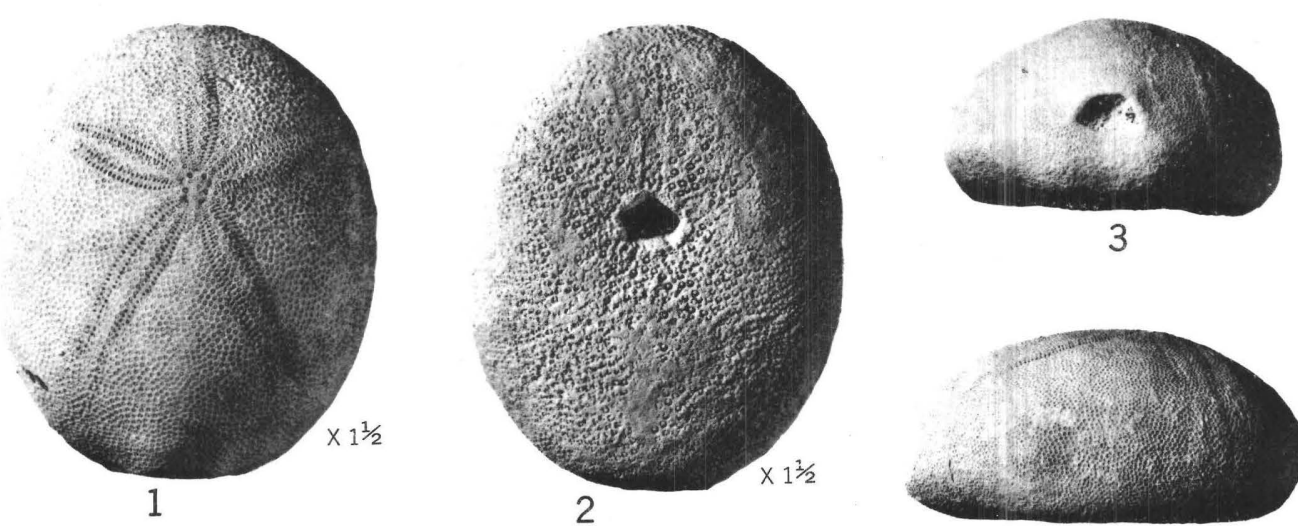

3
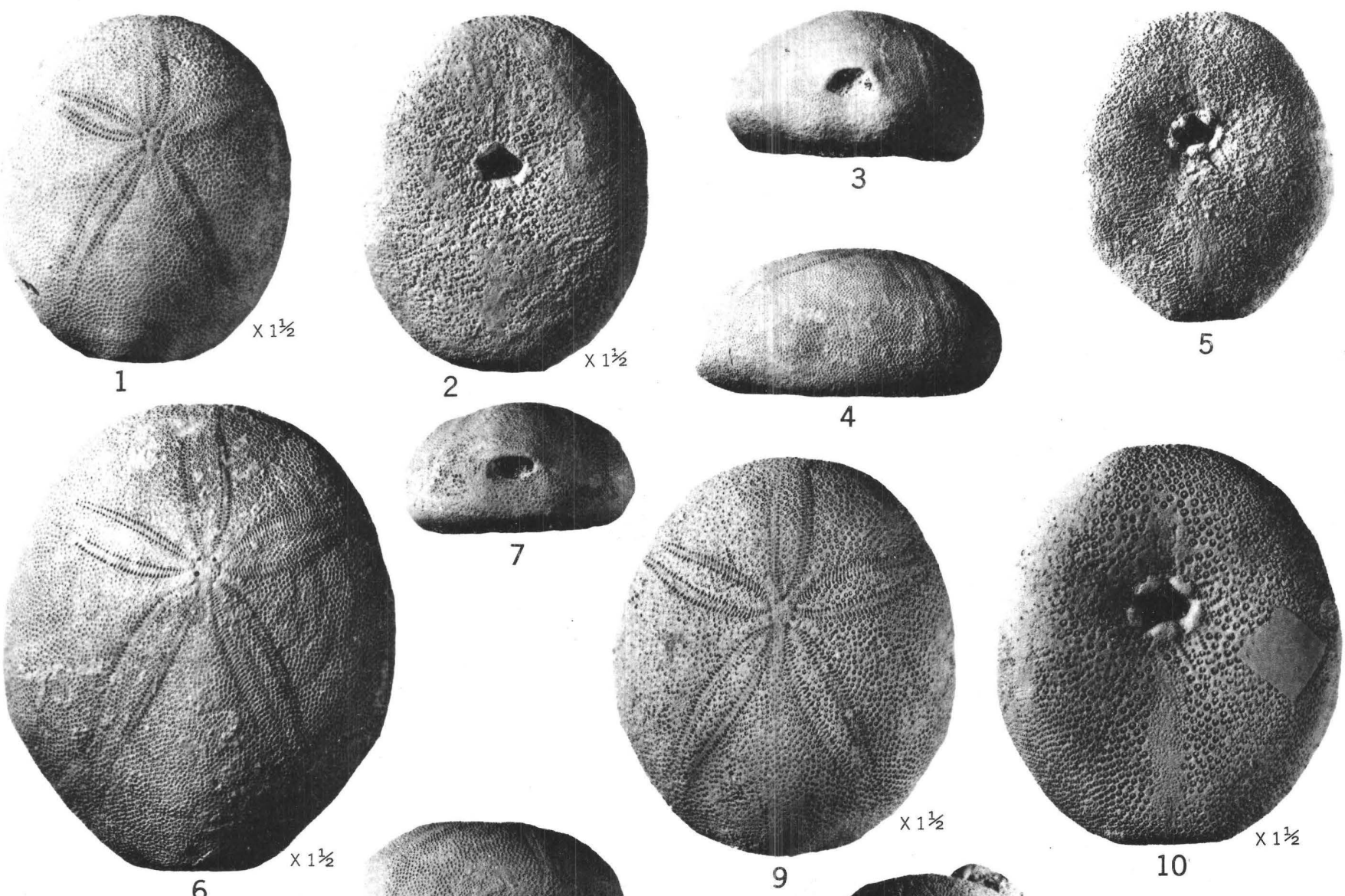

4
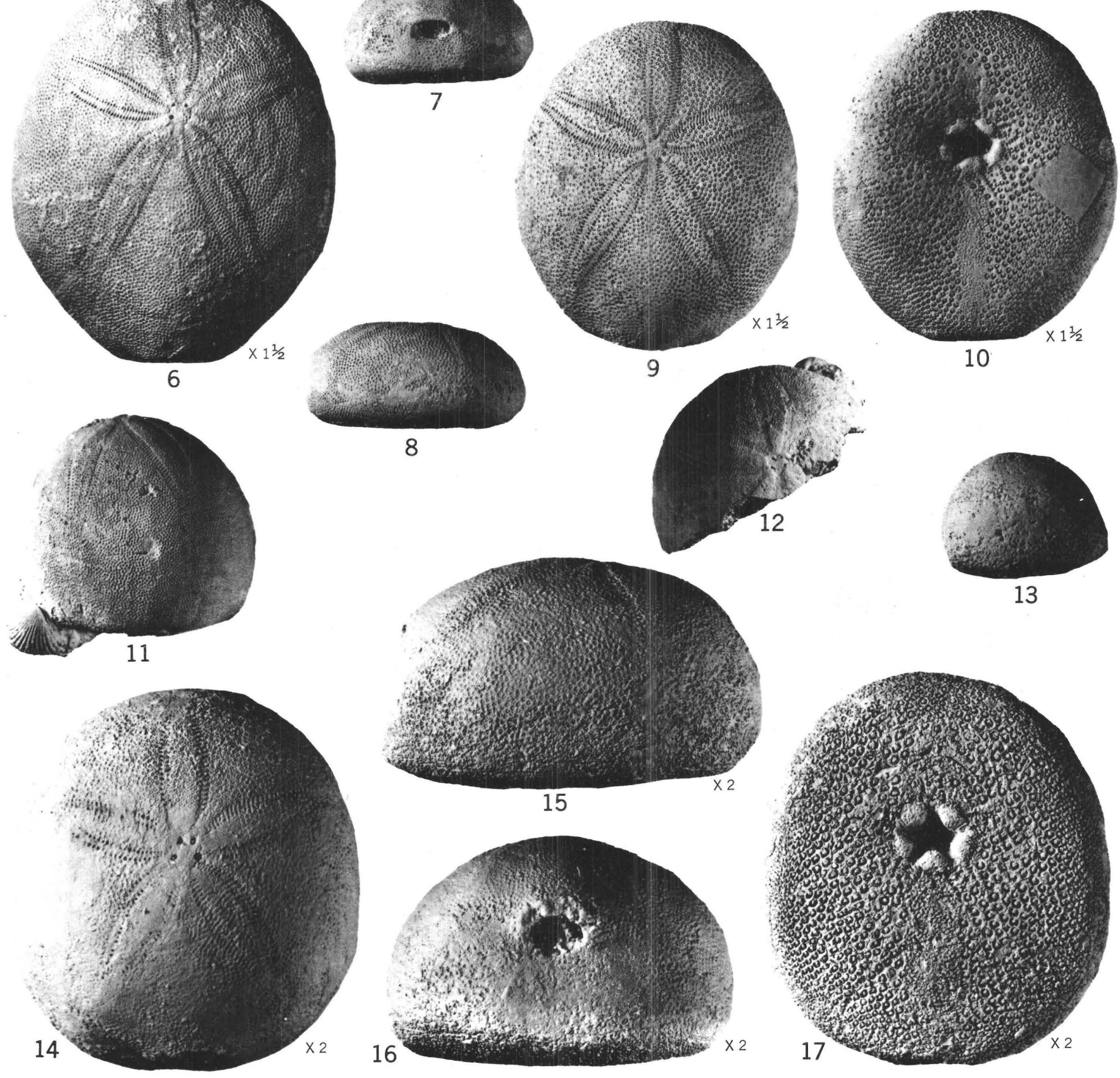

CASSIDULUS 

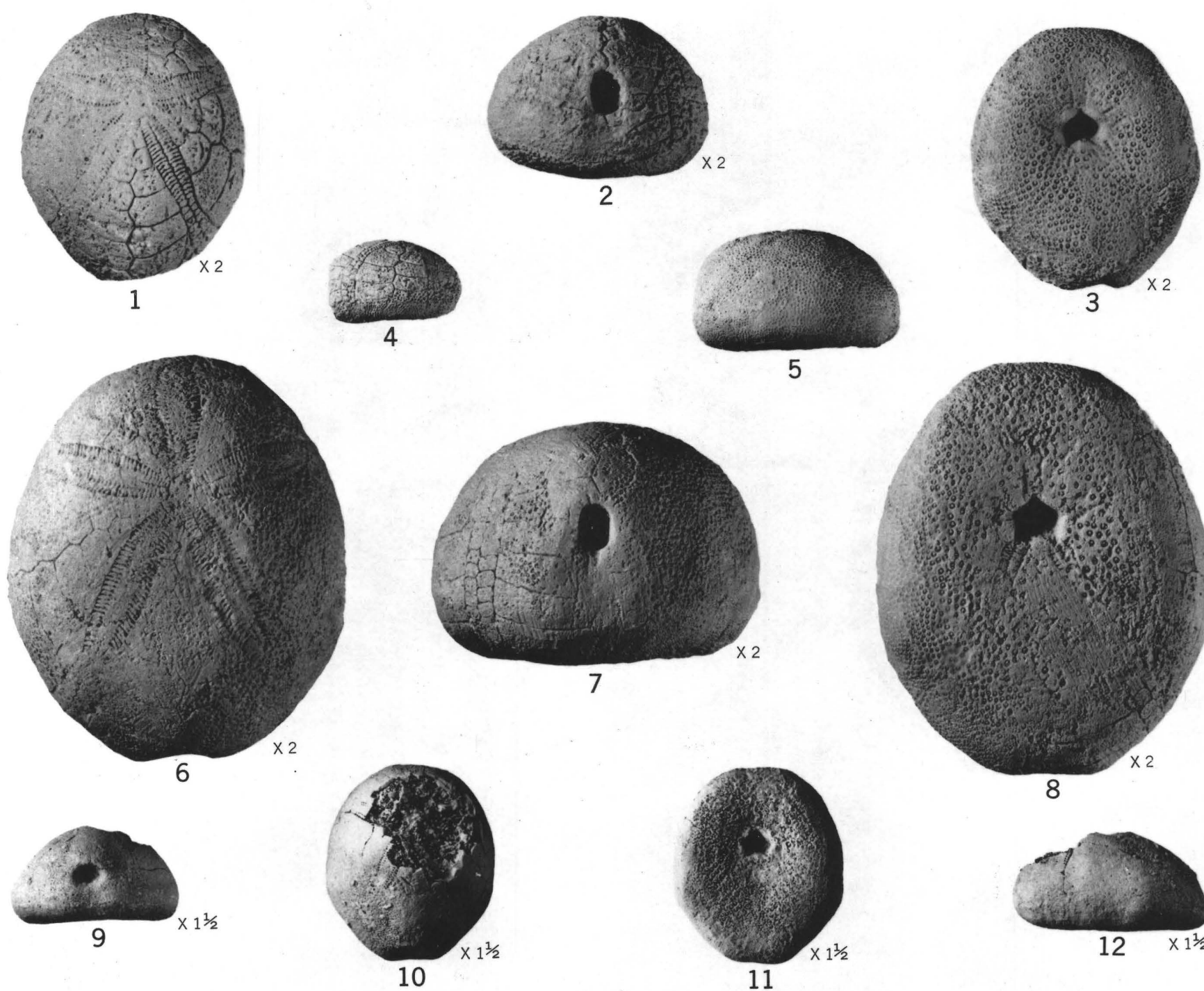

5

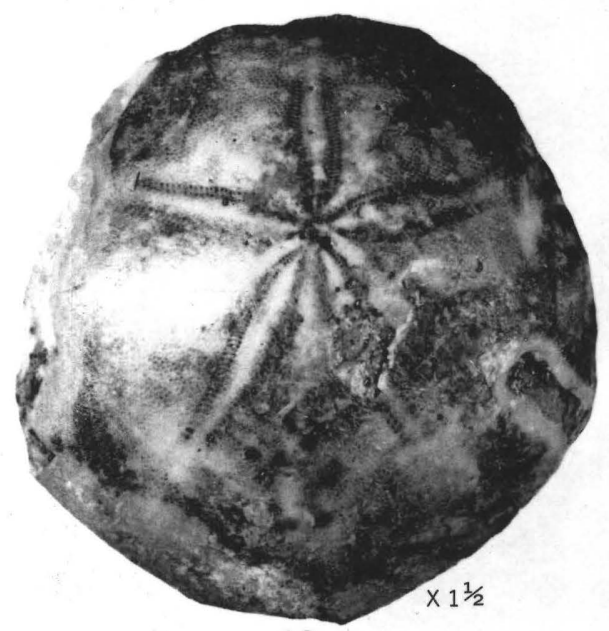

13
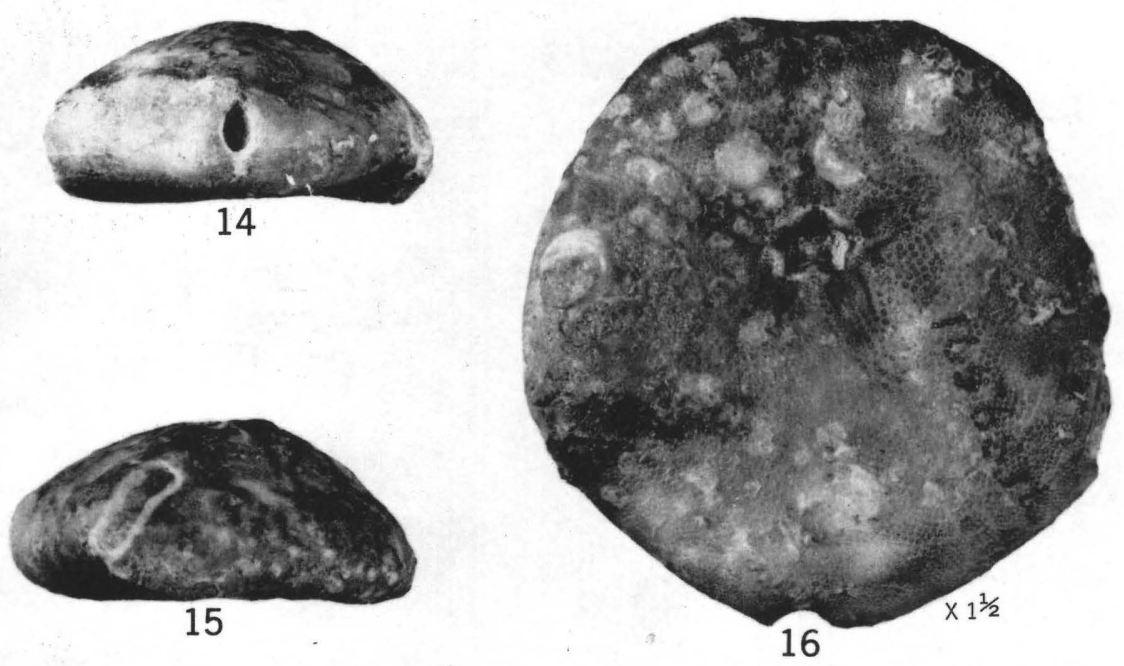

SANTEELAMPAS, ECHANTHUS, AND EURHODIA 


\section{PLATE 26}

FIgURES 1-8. Santeelampas oviformis (Conrad) (p. 61)

$1-4$, Top $\times 2$, posterior end $\times 2$, bottom $\times 2$, and side $\times 1$ of type, Acad. Nat. Sci. Philadelphia 1477 .

5 -8, Side $\times 1$, top $\times 2$, posterior end $\times 2$, and bottom $\times 2$ of USNM 562298 . From the Santee limestone of middle Eocene age at Santee-Cooper dam, in Berkeley County, S. C.

9-12. Eurhodia? elbana Cooke (p. 64)

Posterior end, top, bottom, and side views $\times 1 \frac{1}{2}$ of type, USNM 498981 . From the Bashi formation of early Eocene age at USGS 10012, Pea River at power plant 4 miles below Elba, Ala.

13-16. Echanthus georgiensis (Twitchell) (p. 62)

Top $\times 1 \frac{1}{2}$, posterior end $\times 1$, side $\times 1$, and bottom $\times 1 \frac{1}{2}$ of type, USNM $165683 \mathrm{~b}$. From the Clayton formation of Paleocene age at USGS 4033, Dr. J. A. Parker's farm on the Americus road 5 miles south of Ellaville, Ga. 
GEOLOGICAL SURVEY

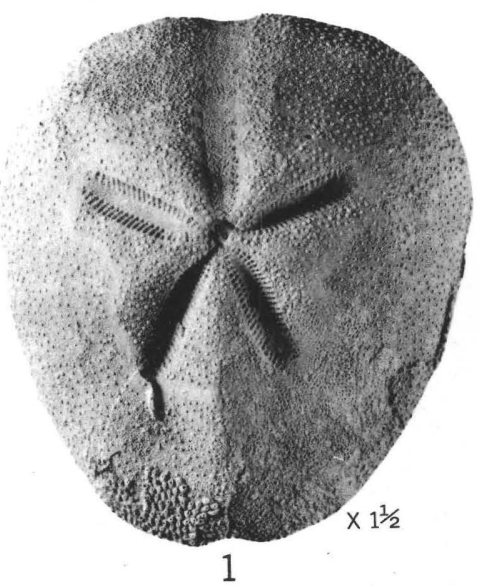

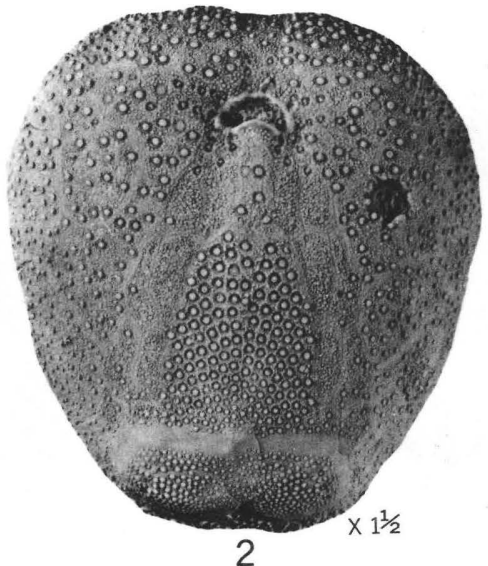

2

PROFESSIONAL PAPER 321 PLATE 28

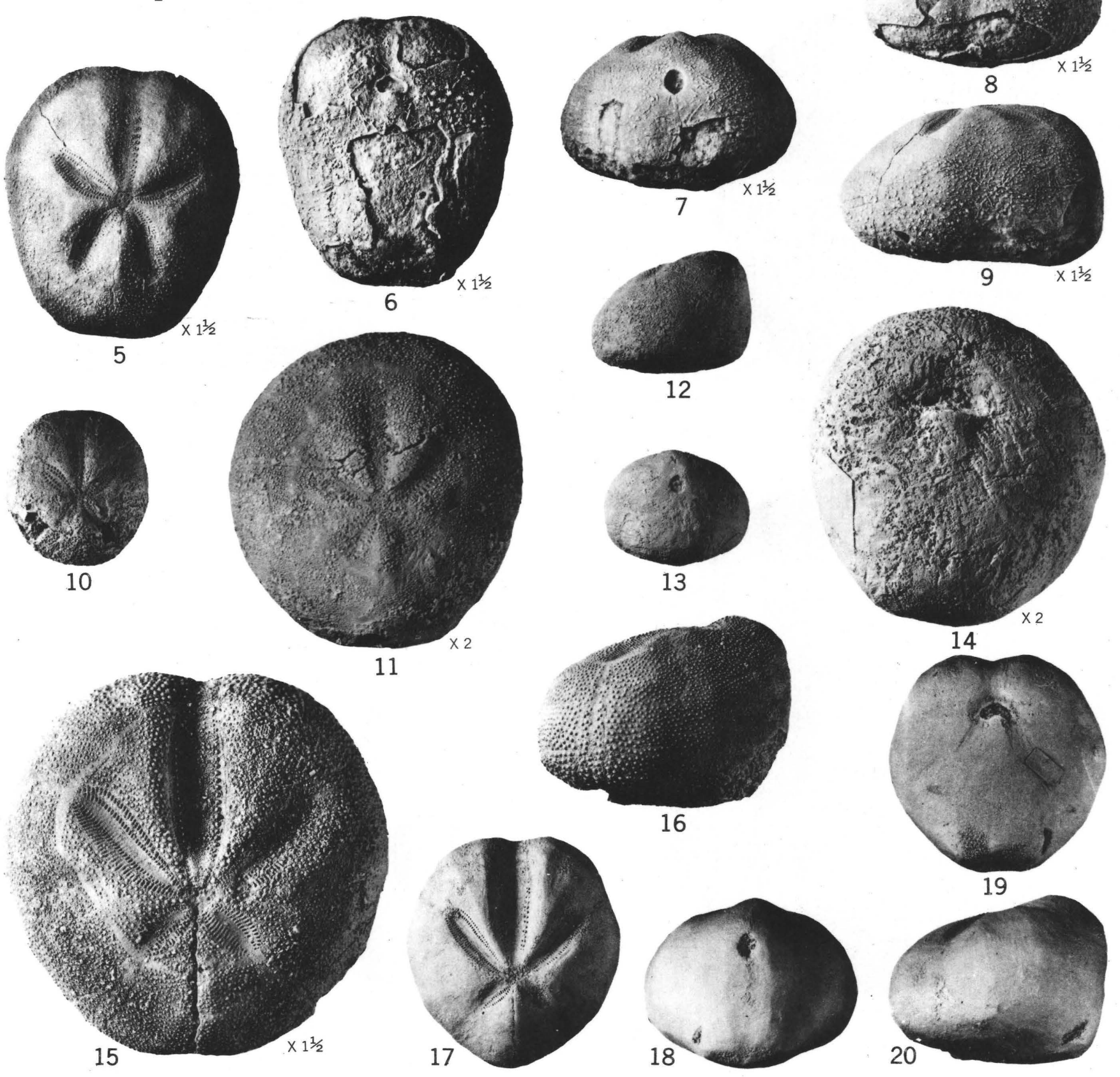

CYCLASTER AND HEMIASTER 
Figures 1-4. Cyclaster drewryensis Cooke (p. 68)

\section{PLATE 28}

$1-3$, Top $\times 1 \frac{1}{2}$, bottom $\times 1 \frac{1}{2}$, and side $\times 1$ of USNM 559882. From the Red Bluff clay of early Oligocene age in the northwestern pit of the cement quarry at St. Stephens, Washington County, Ala.

4, Posterior end $\times 1$ of type, USNM 372880. From the Red Bluff clay of early Oligcene age at USGS 10026, lowest bed at Drewry, Monroe County, Ala., in sec. 15, T. 6 N., R. 8 E.

5-9. Hemiaster moscovensis Cooke, n. sp. (p. 68)

Top, bottom, posterior end, anterior end, and side views $\times 1 \frac{1}{2}$ of type, USNM 562457. From the Porters Creek clay of Paleocene age at USGS 5658, Moscow Bluff, Tombigbee River, Sumter County, Ala.

10-14. Hemiaster stella (Morton) (p. 67)

10, Top view $\times 1$ of type, Acad. Nat. Sci. Philadelphia 1491. From the Vincentown sand of Paleocene age on Timber Creek, N. J.

$11-14$, Top $\times 2$, side $\times 1$, posterior end $\times 1$, and bottom $\times 2$ of USNM 2208. From the Vincentown sand of Paleocene age on Timber Creek near Blackwoods, Camden County, N. J.

15-20. Hemiaster parastatus (Morton) (p. 67)

15, 16, Top $\times 1 \frac{1}{2}$ and side $\times 1$ of USNM 29472. From the Vincentown sand of Paleocene age on Rancocas Creek near Vincentown, N. J.

17-20, Top, posterior end, bottom, and side views $\times 1$ of type, Acad. Nat. Sci. Philadelphia 1487. From the Vincentown sand of Paleocene age on Timber Creek, N. J. 
Frgures 1-4. Linthia wilmingtonensis Clark (p. 69)

\section{PLATE 29}

1, 2, Top and side views $\times 1$ of type, USNM 166482. Wilmington, N. C.

3,4 , Top and bottom views $\times 2$ of USNM 164673 . From USGS 779, Rocky Point, N. C.

Both from the Santee limestone of middle Eocene age (or Castle Hayne limestone).

5-7. Linthia alabamensis Clark (p. 69)

Top $\times 11 / 2$, posterior end $\times 1$, and bottom $\times 1$ of type, USNM 137371 . From the Clayton formation of Paleocene age at USGS 264, Prairie Creek, Wilcox County, Ala.

8-12. Linthia hanoverensis Kellum (p. 70)

8, Top view $\times 1 \frac{1}{2}$ of USNM 562458. From USGS 10613.

9-12, Top, bottom, side, and posterior end views $\times 1 \frac{1}{2}$ of type, USNM 164664. From USGS 782.

Both from the Castle Hayne limestone of middle and late Eocene age (or Santee limestone) at Wilmington, N. C.

13-17. Schizaster (Brachybrissus) ocalanus Cooke (p. 73)

13-16, Top, side, bottom, and posterior end views $\times 1 \frac{132}{2}$ of type, USNM 498990 . From Kendrick, MarionCounty, Fla.

17, Top view $\times 3$ of USNM 562459. From USGS 14141, quarry 6 miles southeast of Crystal River, Citrus County, Fla.

Both from the Ocala limestone of late Eocene age. 

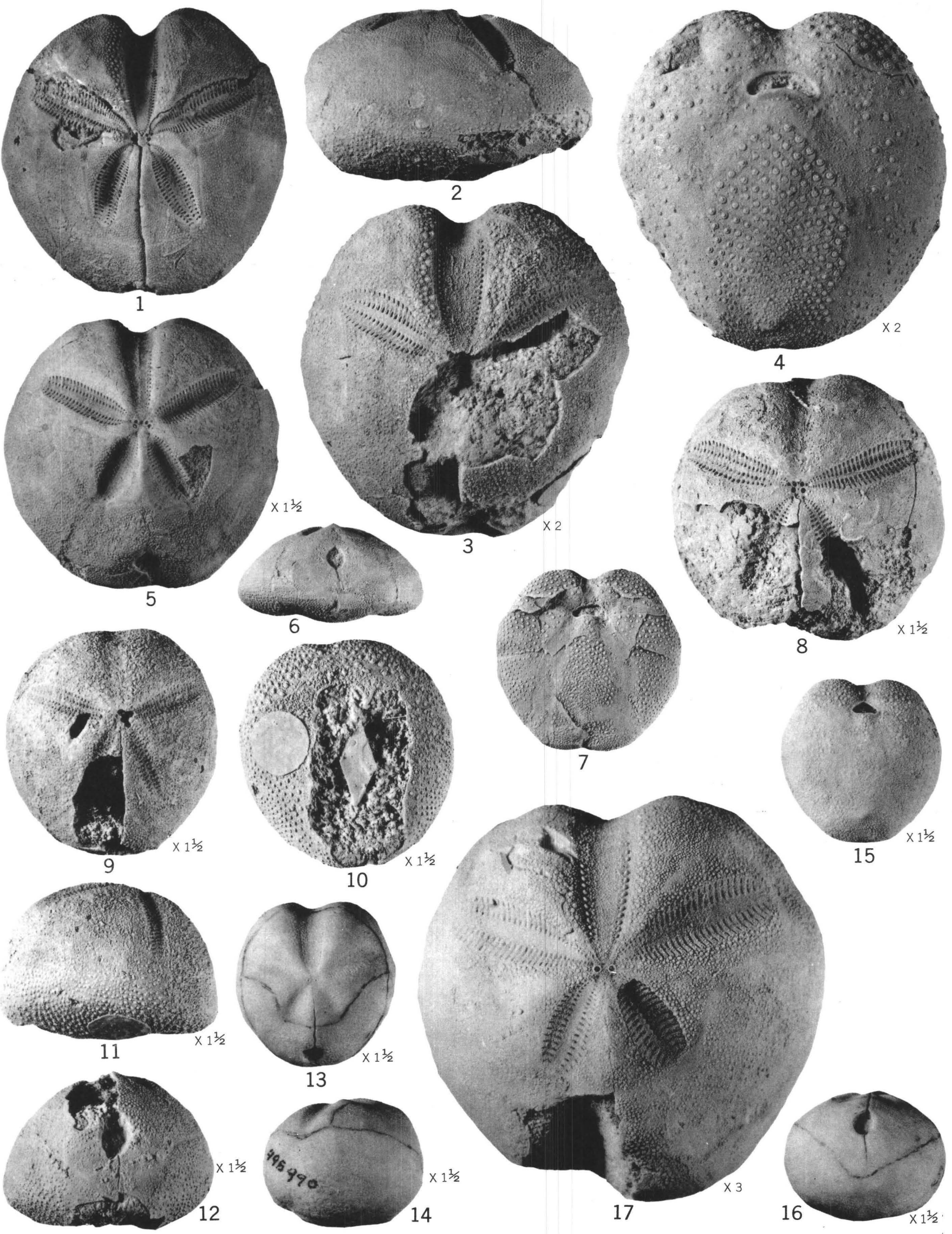
GEOLOGICAL SURVEY
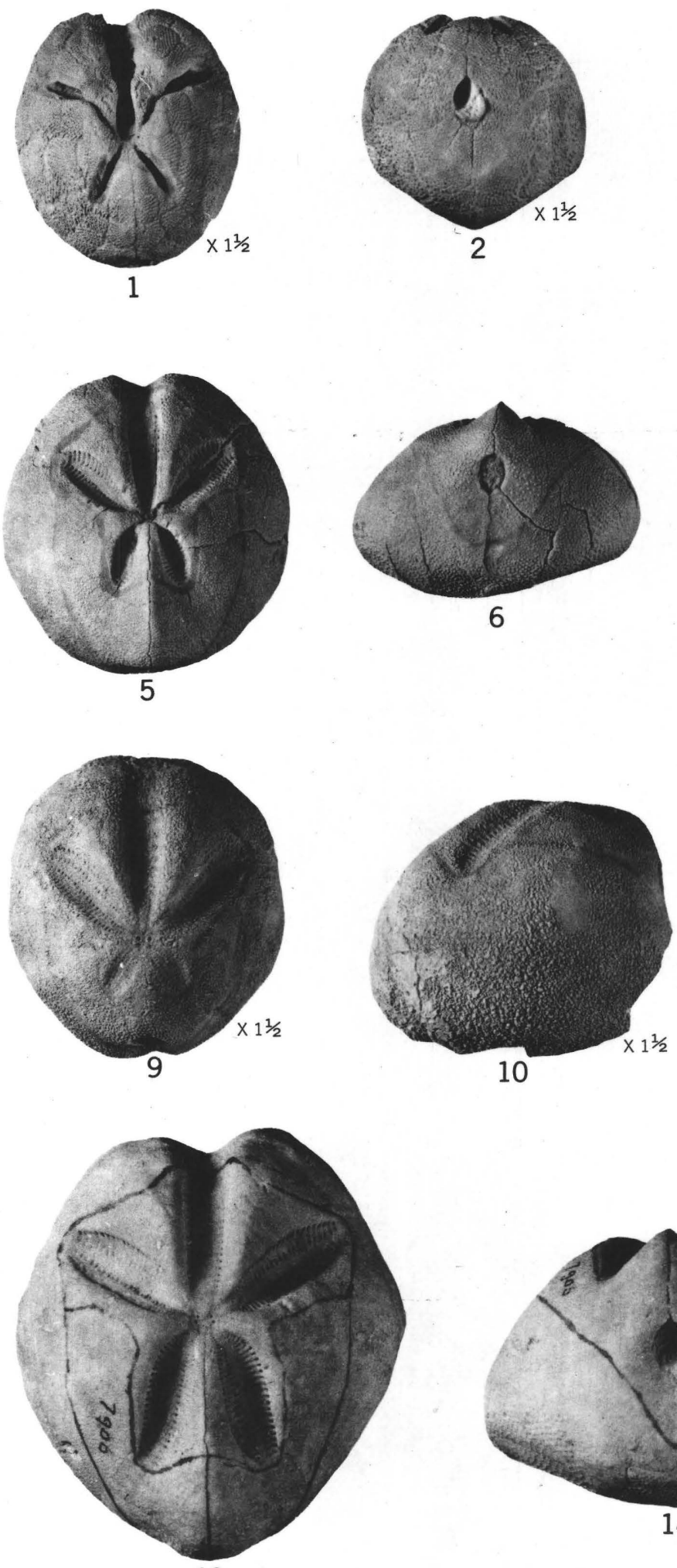

13

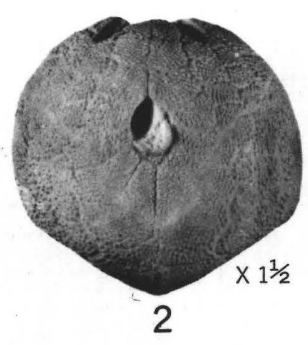

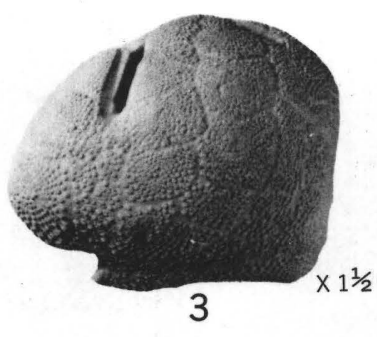

PROFESSIONAL PAPER 321 PLATE 30
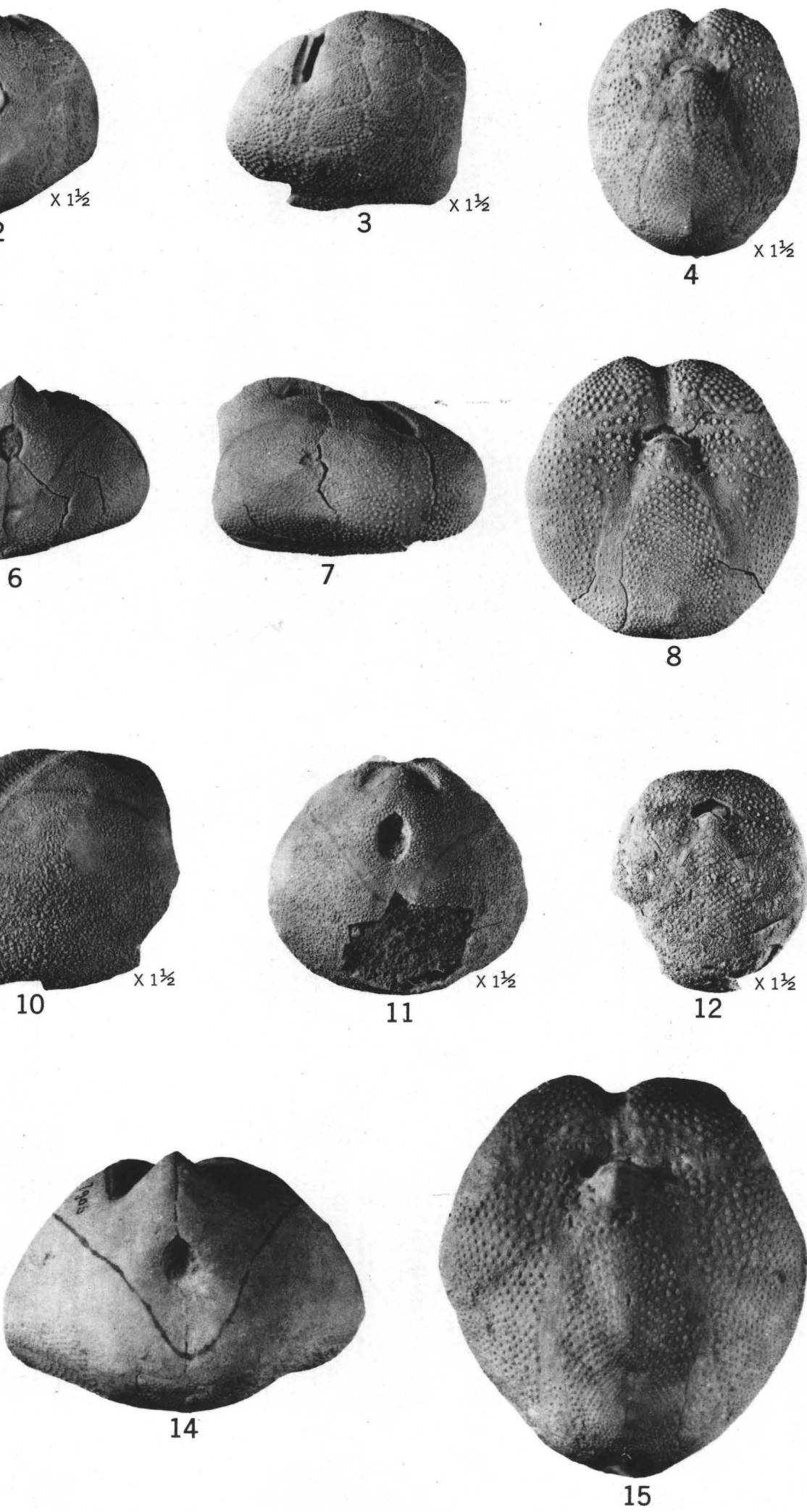

MOIRA, PARASTER, AND DITREMASTER 
FIGUREs 1-4. Moira atropos (Lamarck) (p. 73)

\section{PLATE 30}

Top, posterior end, side, and bottom views $\times 1 \frac{1}{2}$ of USNM 562461. Recent. From Panama City Beach, Fla.

5-8. Paraster americanus (Clark) (p. 72)

Top, posterior end, side, and bottom views $\times 1$ of type, USNM 165695. From the Vicksburg group of Oligocene age at USGS 3951, near Brandon, Rankin County, Miss.

9-12. Ditremaster beckeri (Cooke) (p. 77)

9-11, Top, side, and posterior end views $\times 1 \frac{1}{2}$ of type, USNM 499008. From the Ocala limestone of late Eocene age at Gainesville rock pit southeast of Arredondo, Alachua County, Fla.

12, Bottom view $\times 1$ of paratype, USNM 499009. From the Ocala limestone of late Eocene age at USGS 14553, Suwannee River at bridge near Dowling Park, in Lafayette County, Fla.

13-15. Paraster armiger (Clark) (p. 71)

Top, posterior end, and bottom views $\times 1$ of USNM 562460. From the Ocala limestone of late Eocene age at USGS 7906, bank of Muckafoonee Creek near its confluence with Flint River abcut 11/2 miles above Albany, Ga. 
Figures 1-8. Agassizia porifera (Ravenel) (p. 74)

\section{PLATE 31}

1-4, Top, bottom, side, and posterior end views $\times 1$ of USNM $562462 \mathrm{~b}$.

5-8, Posterior end, side, top, and bottom views $\times 1$ of USNM 562462a. From rocks of late Miocene age at USGS 18759, Intracoastal Waterway canal in Horry County, S. C., 1 to $1 \frac{1}{2}$ miles southwest of the bridge on US 17 near Nixons Crossroads, about 15 miles northeast of Myrtle Beach, 5.6. 


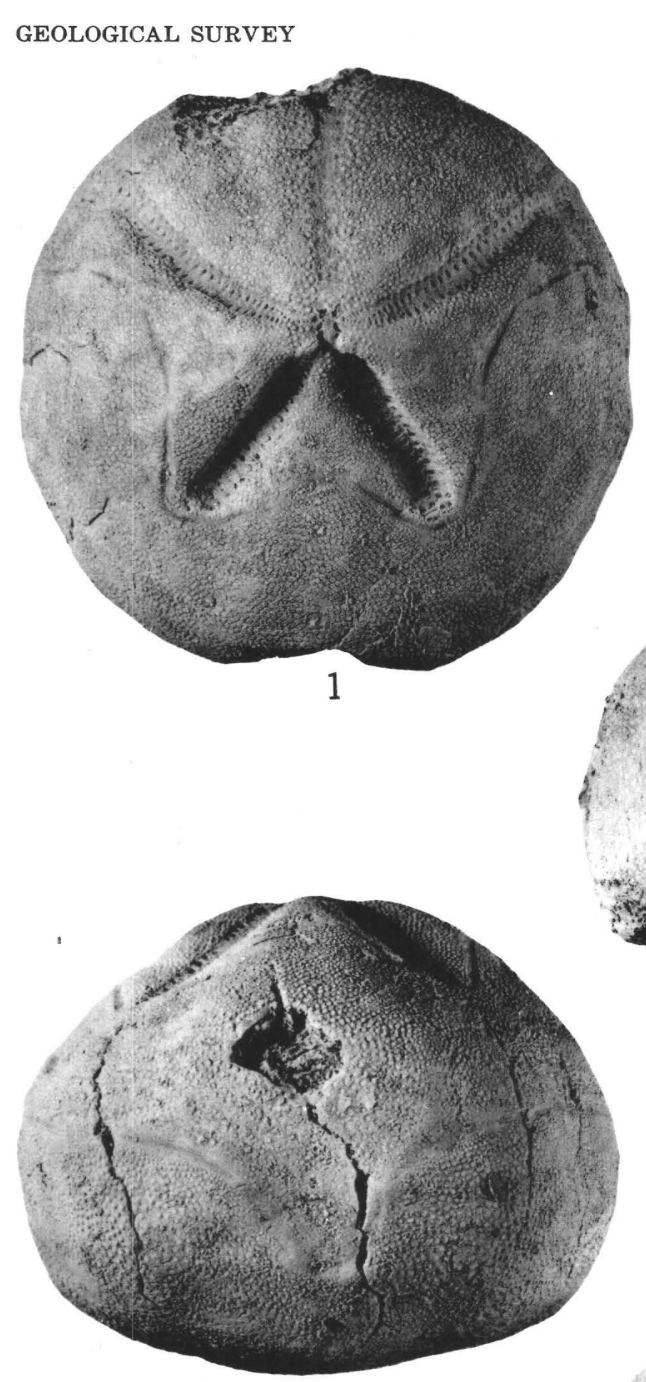

GEOLOGICAL SURVEY 321 PLATE 31
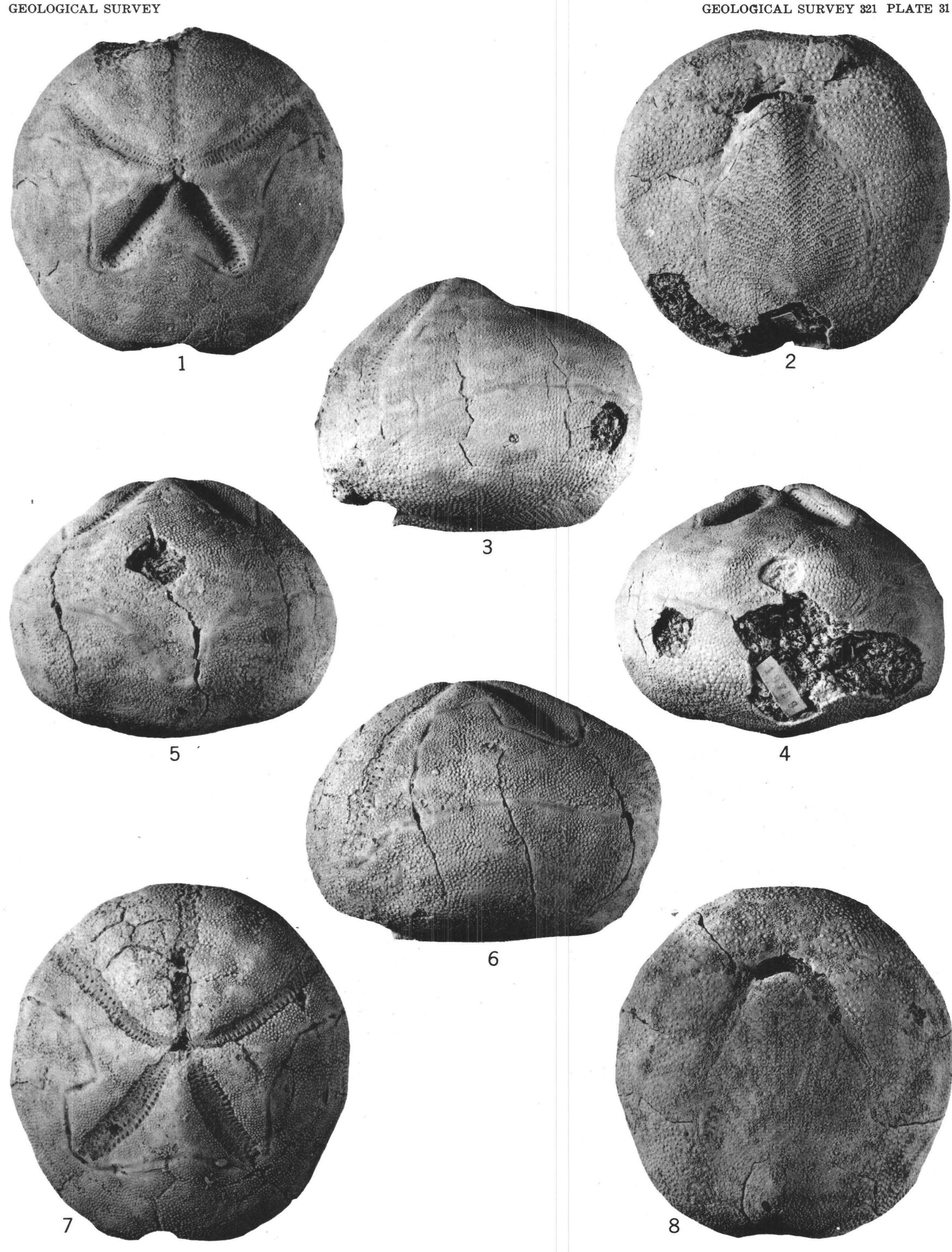
GEOLOGICAL SURVEY

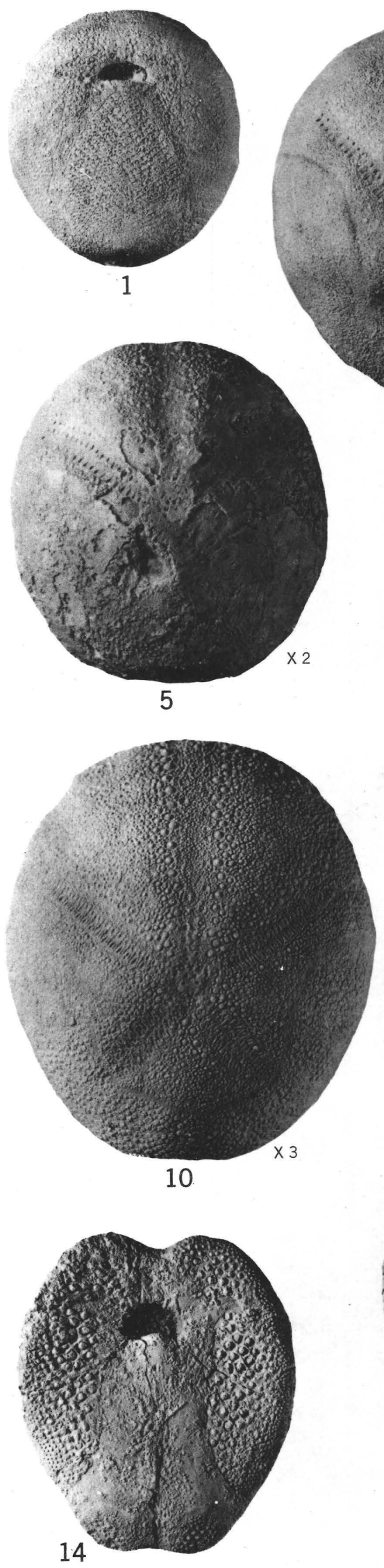

PROFESSIONAL PAPER 321 PLATE 32

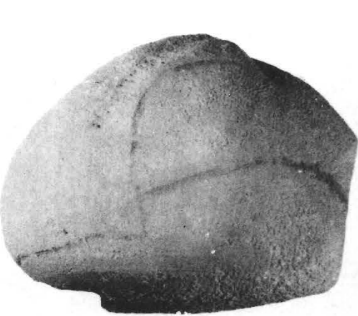

3
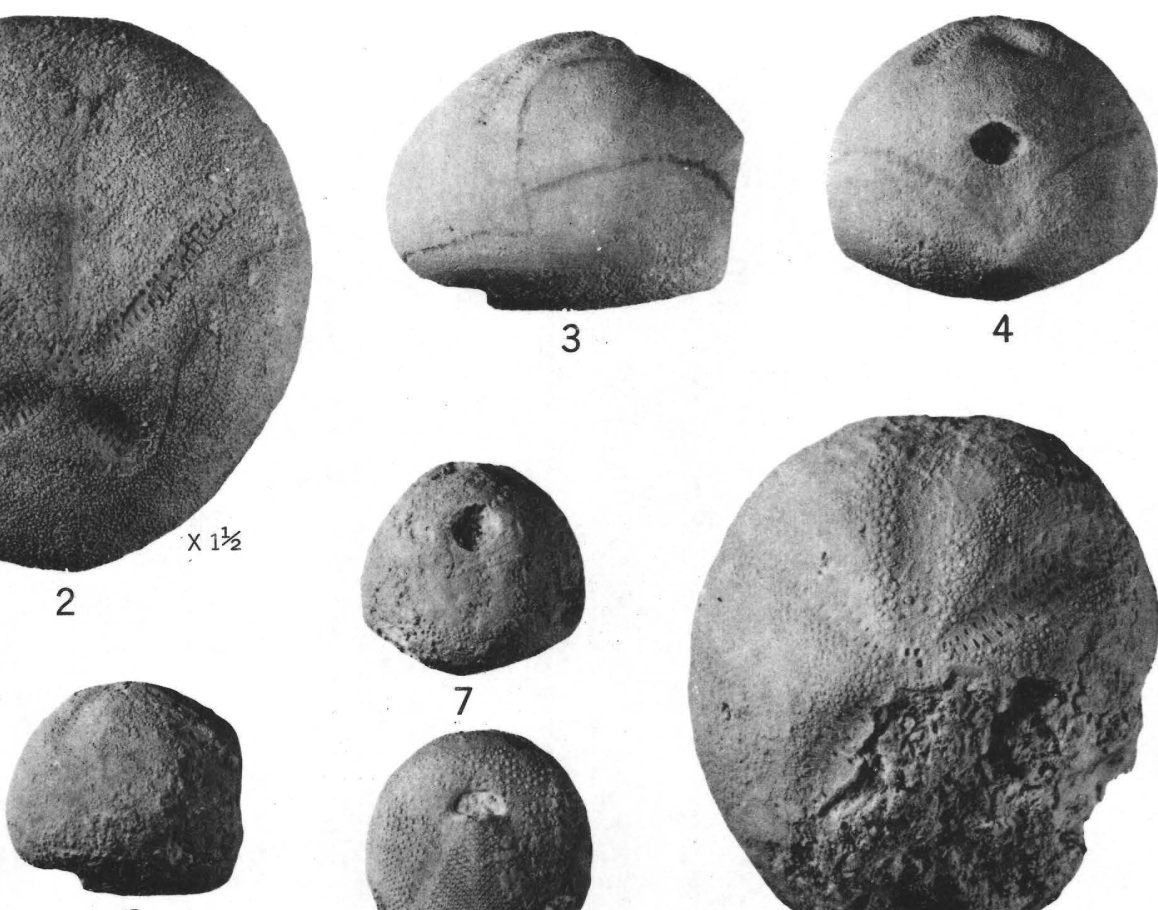

6

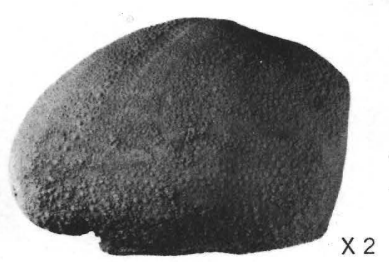

11

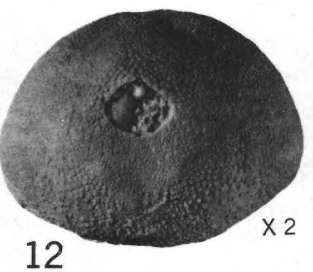

12
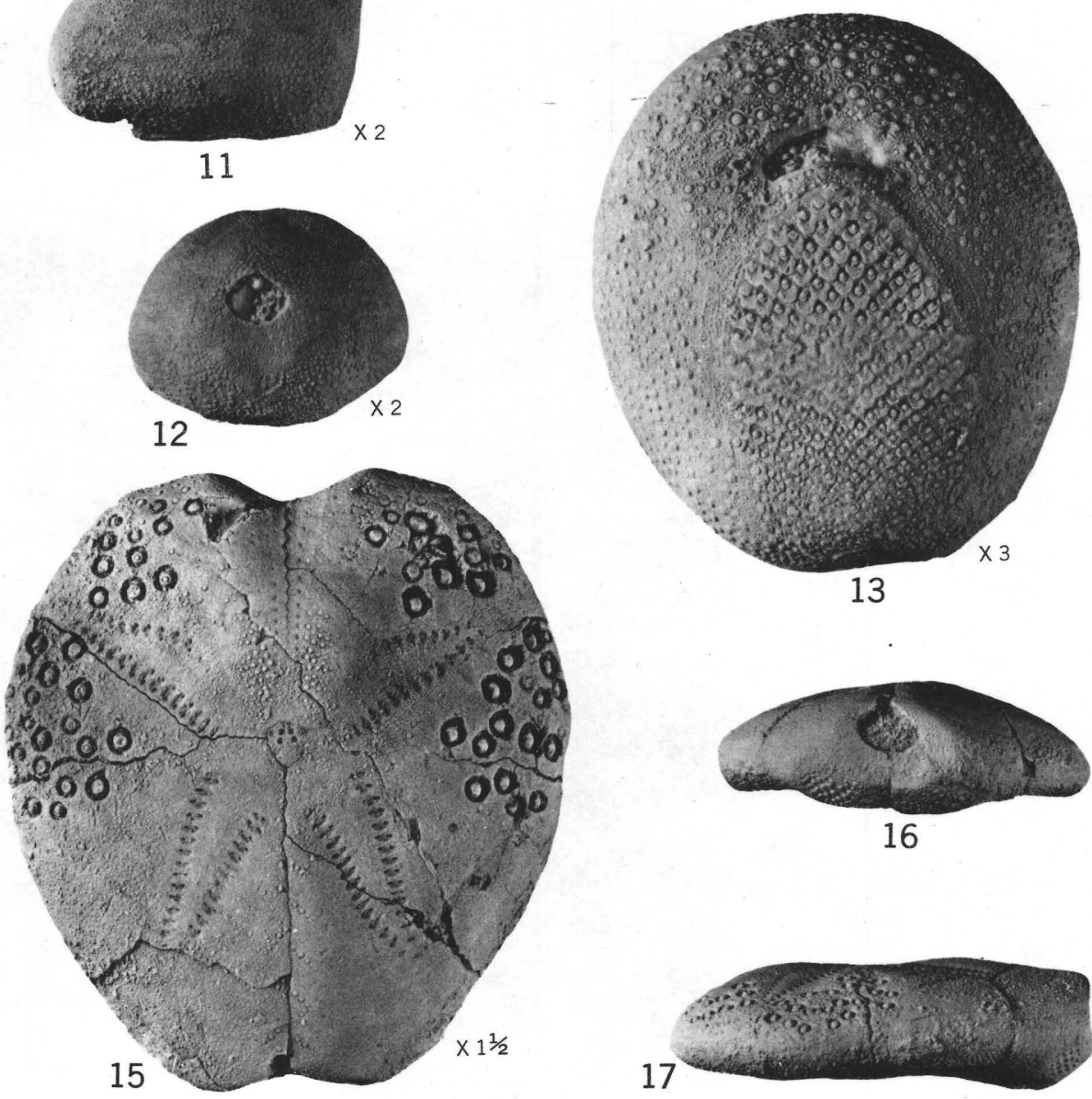

17

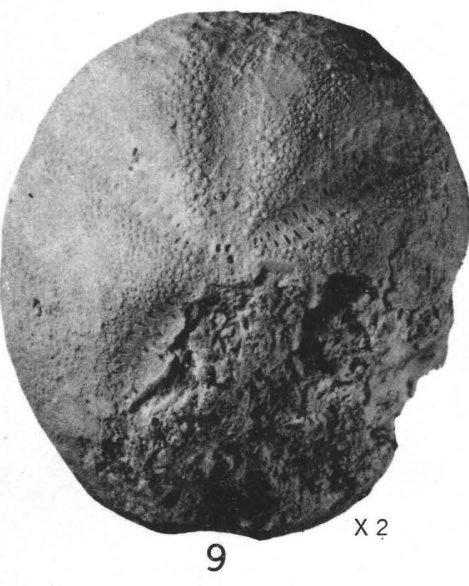

8

AGASSIZIA AND LOVENIA 
Figures 1-4. Agassizia floridana de Loriol (p. 75)

PLATE 32

Bottom $\times 1$, top $\times 1 \frac{1}{2}$, side $\times 1$, and posterior end $\times 1$ of USNM 562463. From the Ocala limestone of late Eocene age at USGS 14541, pit east of Steinhatchee River opposite Clara and north of US 19, in Dixie County, Fla.

5-9. Agassizia (Anisaster) mossomi Cooke (p. 76)

$5-8$, Top $\times 2$, side $\times 1$, posterior end $\times 1$ and bottom $\times 1$ of cotype, USNM 498989 a.

9 , Top $\times 2$ of cotype, USNM 498989 b.

From the Ocala limestone of late Eocene age at USGS 11113, Florida Rock Products quarry $3 / 4$ mile southwest of Brooksville, Fla.

10-13. Agassizia (Anisaster) wilmingtonica Cooke (p. 76)

Top $\times 3$, side $\times 2$, posterior end $\times 2$, and bottom $\times 3$ of type, USNM 499004 . From the Castle Hayne limestone of middle and late Eocene age in the city rock quarry near Wilmington, N. C.

14-17. Lovenia alabamensis Cooke, n. sp. (p. 77)

Bottom $\times 1$, top $\times 11 / 2$, posterior end $\times 1$, and side $\times 1$ of type, USNM 562469. Probably from the Chickasawhay limestone of late Oligocene age in a road cut just south of old mill in NE1/4 sec. 8, T. 6 N., R. 3 E., Clarke County, Ala. 


\section{PLATE 33}

FrgURes 1-5. Echinocardium orthonotum (Conrad) (p. 78)

$1-4$, Top, bottom, posterior end, and side views $\times 1$ of USNM $498960 \mathrm{~b}$.

5, Top view $\times 1$ of USNM 498960a.

From the Choptank formation of Miocene age about 14 mile north of Scientists Cliffs on Chesapeake Bay in Calvert County, Md.

6. Lovenia clarki (Lambert) (p. 77)

Top view $\times 1$ of type, USNM 164654, the type of Echinocardium depressum Clark. Near the base of the Tampa limestone of early Miocene age at USGS 2565, Chattahoochee, Gadsden County, Fla.

7-10. Echinocardium gothicum (Ravenel) (p. 79)

Top, bottom, side, and anterior end views $\times 1$ of USNM 562468. From rocks of late Miocene age at USGS 18759, Intracoastal Waterway canal in Horry County, S. C., 1 to $11 / 2$ miles southwest of the bridge on US 17 near Nixons Crossroads, about 15 miles northeast of Myrtle Beach. 
GEOLOGICAL SURVEY
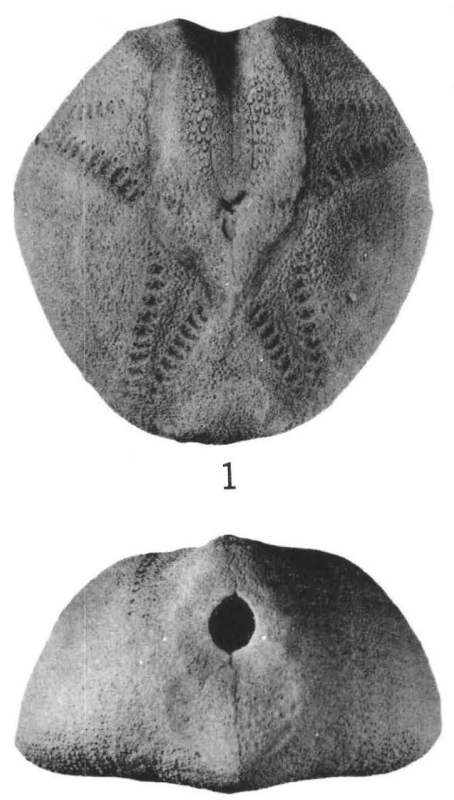

3
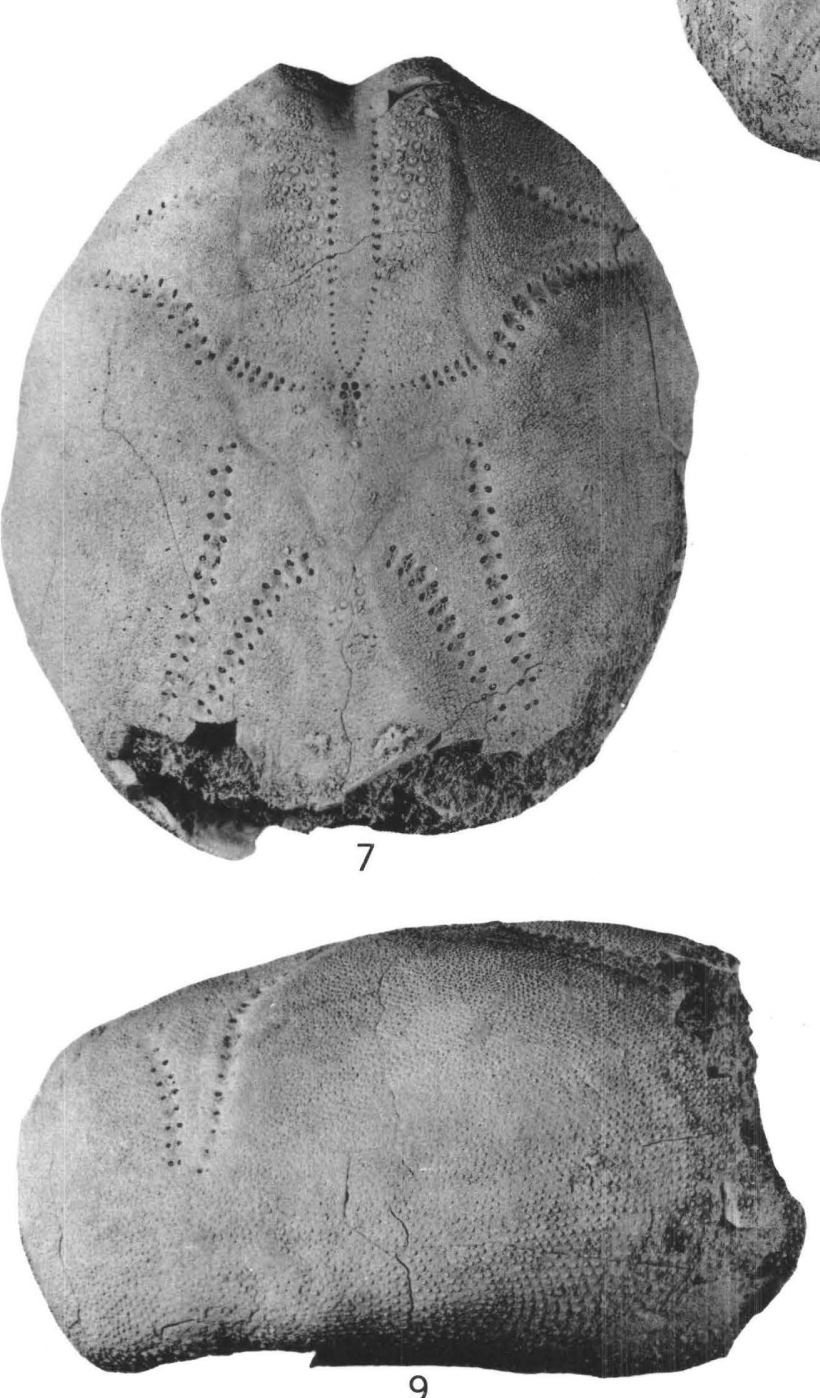

PROFESSIONAL PAPER 321 PLATE 33

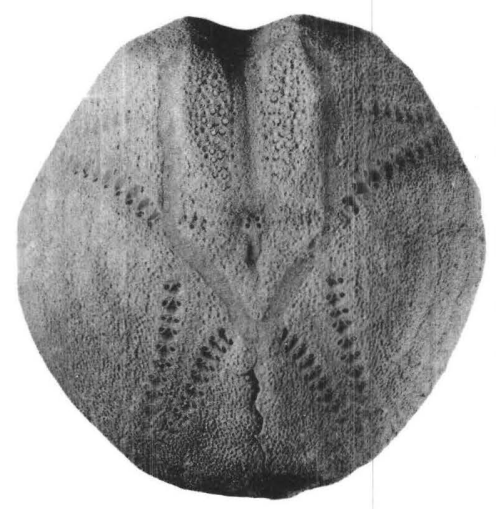

5
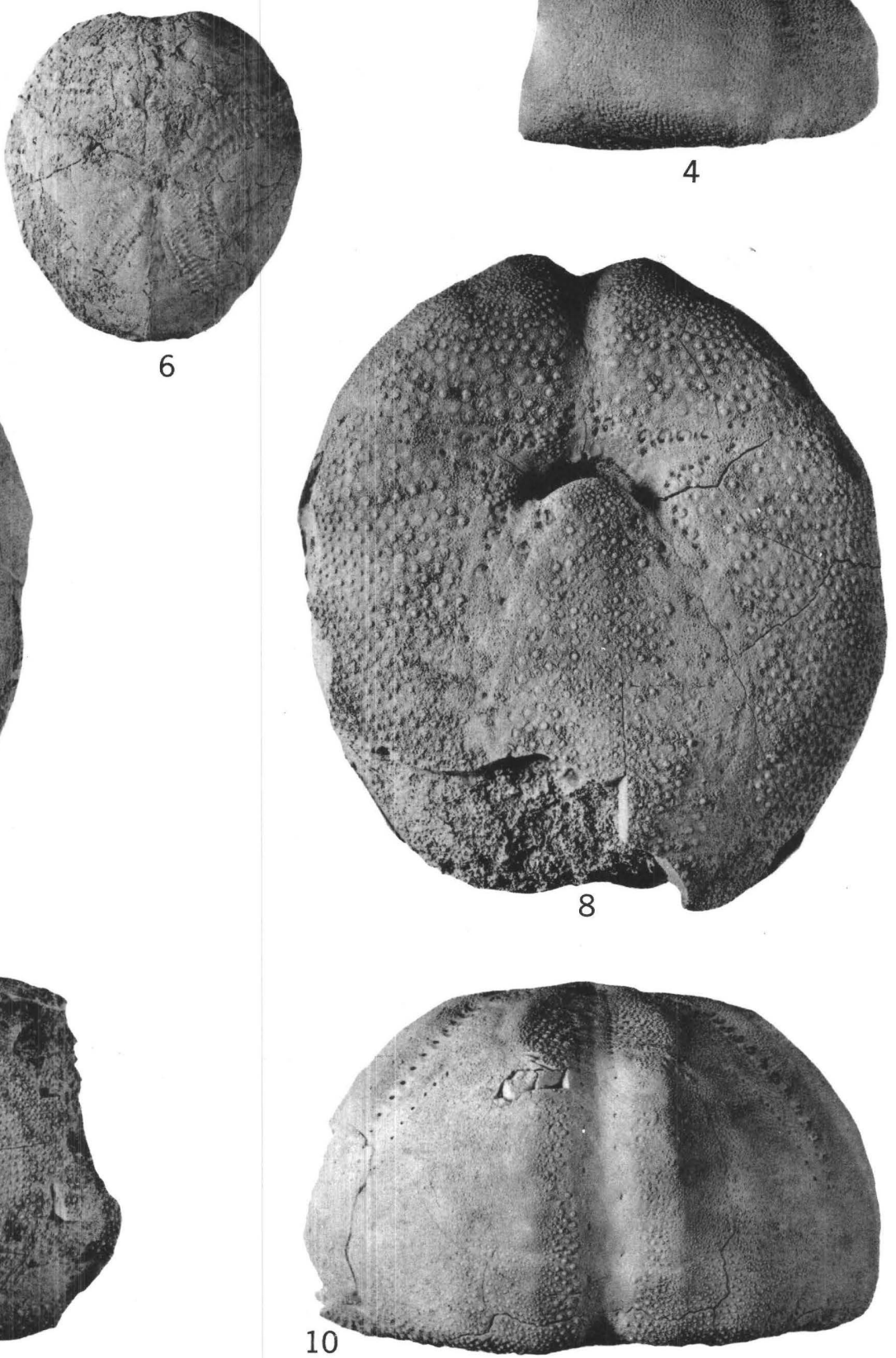

ECHINOCARDIUM AND LOVENIA 
GEOLOGICAL SURVEY
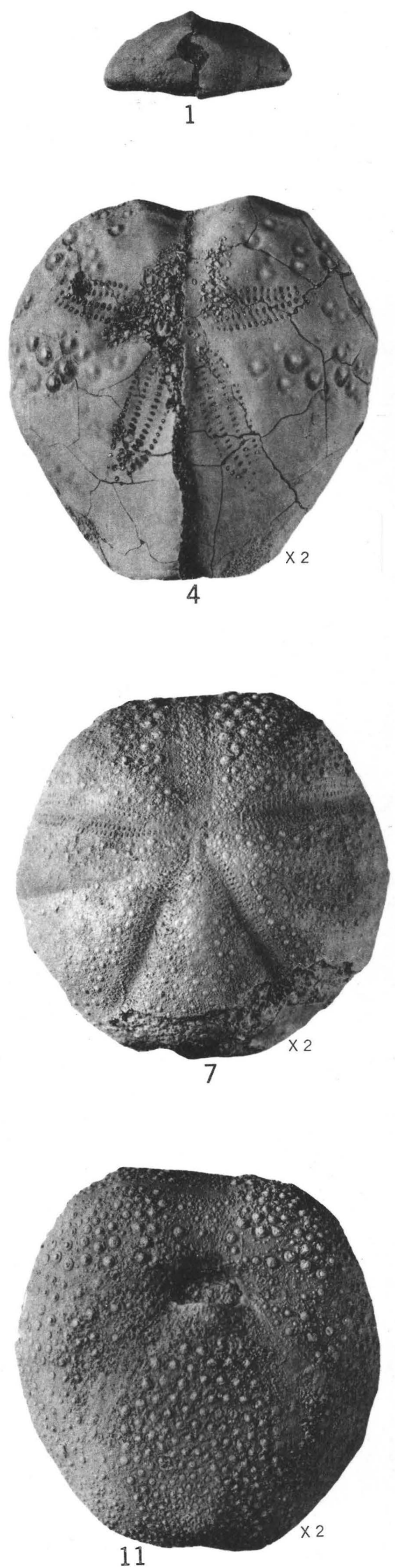
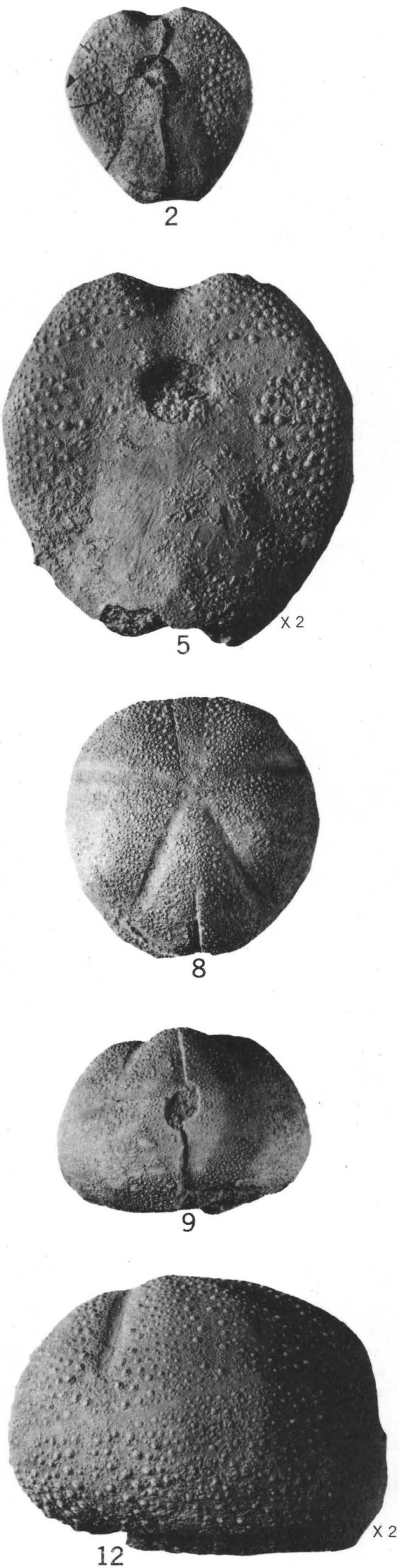

MARETIA AND UNIFASCIA
PROFESSIONAL PAPER 321 PLATE 34

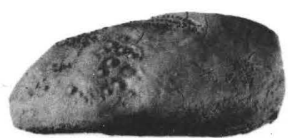

3
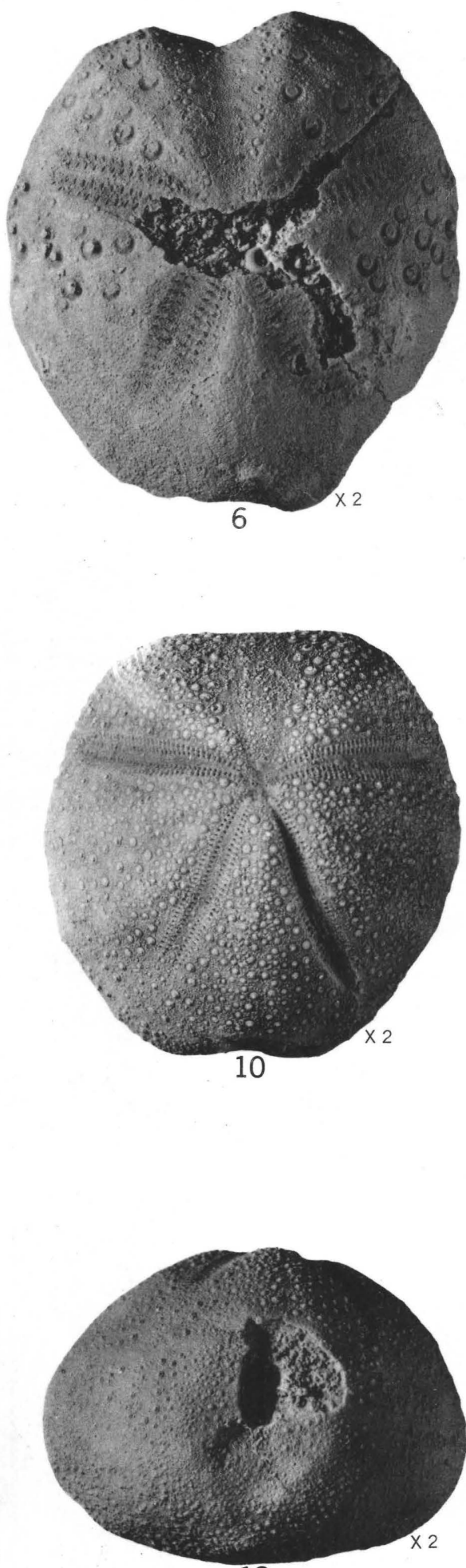

13 
Figures 1-4. Maretia arguta (Clark) (p. 81)

\section{PLATE 34}

Posterior end $\times 1$, bottom $\times 1$, side $\times 1$, and top $\times 2$ of type, USNM 141107 . From the Winona sand of early middle Eocene age at USGS 2629, Chickasawhay River at Enterprise, Clarke County, Miss.

5, 6. Maretia subrostrata (Clark) (p. 81)

5, Bottom view $\times 2$ of USNM 166516. From the county rock quarry near Wilmington, N. C.

6 , Top view $\times 2$ of type, USNM 164652 . From USGS 3602 , Wilimngton, N. C.

Both from the Castle Hayne limestone of middle and late Eocene age or Santee limestone of late middle Eocene age.

7-13. Unifascia carolinensis (Clark) (p. 80)

7, Top view $\times 2$ of type, USNM 164651. From the Castle Hayne limestone at USGS 3602, Wilmington, N. C.

8,9 , Top and posterior end views $\times 1$ of USNM 562448. From the Castle Hayne limestone at USGS 11810, Southern Drainage Canal about 9 miles northwest of Vanceboro, Pitt County, N. C.

10-13, Top, bottom, side and posterior end views $\times 2$ of USNM 562447. From the Castle Hayne limestone at USGS 8165, J. A. Stokes' farm 2 miles north of creek near Maple Cypress, Craven County, N. C. 
Figdres 1-5. Spatangus glenni Cooke, n. sp. (p. 80)

\section{PLATE 35}

$1-4$, Side, bottom, posterior end, and top views $\times 1$ of type, USNM 562449a.

5 , Bottom view $\times 1$ of paratype, $562449 \mathrm{~b}$.

From rocks of late Miocene (?) age at USGS 18759, Intracoastal Waterway canal in Horry County, S. C., 1 to $1 \frac{1}{2}$ miles southwest of the highway bridge on US 17 near Nixons Crossroads, about 15 miles northeast of Myrtle Beach. 


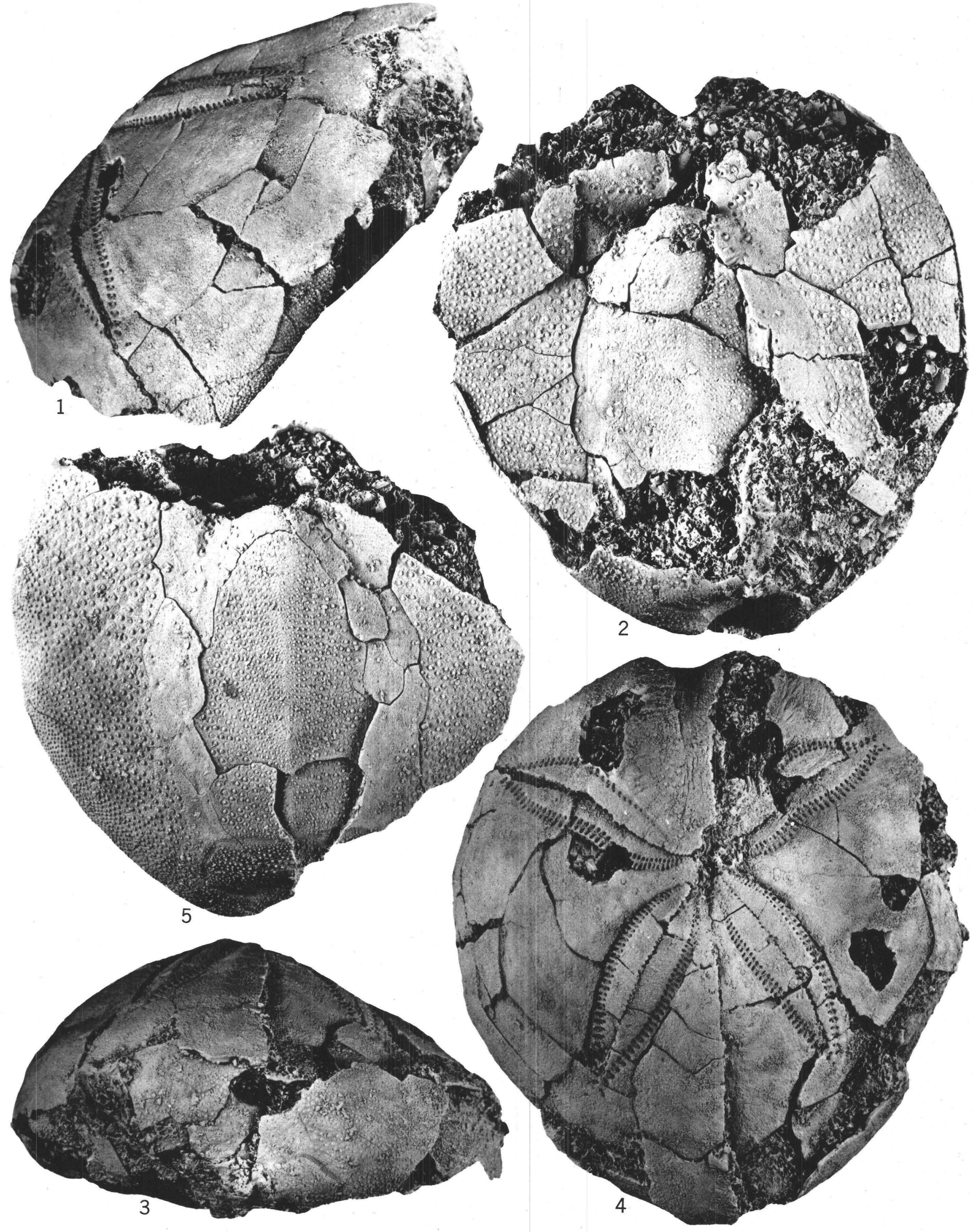

SPATANGUS 

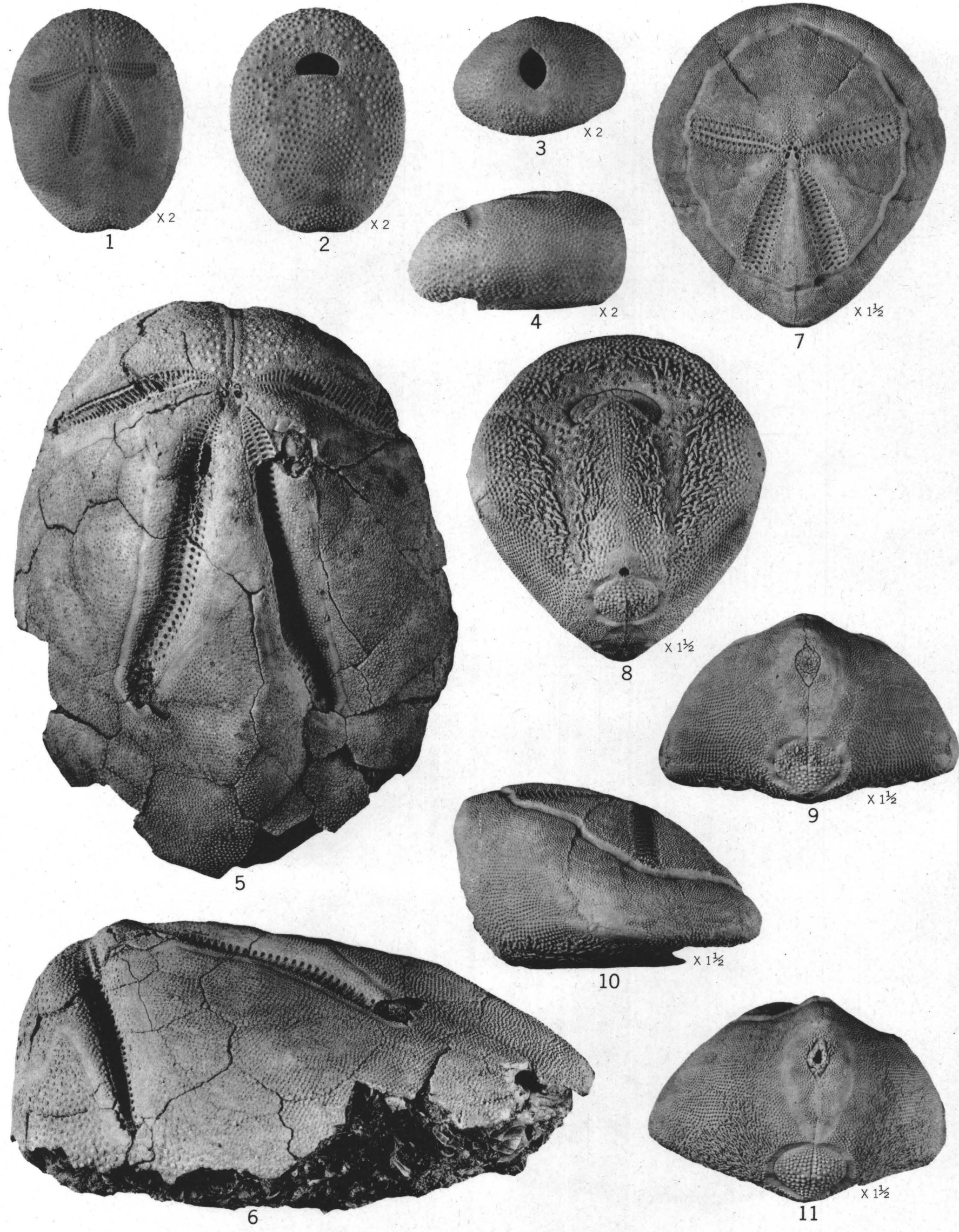

BRISSUS AND RHYNOBRISSUS

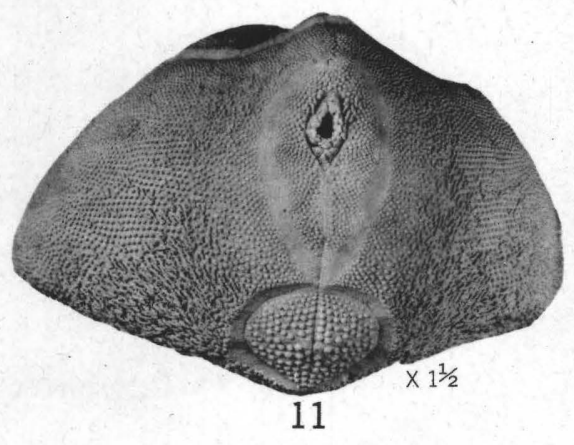


Figures 1-4. Brissus unicolor (Leske) (p. 81)

\section{PLATE 36}

Top, bottom, posterior end, and side views $\times 2$ of USNM 562450. Recent. From Cayo la Vela, Cuba.

5, 6. Brissus glenni Cooke, n. sp. (p. 82)

Top and side views $\times 1$ of type, USNM 562451. From rocks of late Miocene (?) age at USNM 18759, Intracoastal Waterway canal in Horry County, S. C., 1 to $1 \frac{1}{2}$ miles southwest of the crossing of US 17 near Nixons Crossroads, about 15 miles northeast of Myrtle Beach.

7-11. Rhynobrissus cuneus Cooke (p. 88)

7-10. Top, bottom, posterior end, and side views $\times 1 \frac{11}{2}$ of type, USNM E-8032.

11. Posterior end view $\times 1 \frac{1}{2}$ of paratype, USNM E-8033. Recent. From Fort Macon Beach, N. C. 


\section{PLATE 37}

Figures 1-4. Macropneustes ventricosus (Lamarck) (p. 84)

Top, posterior end, side, and bottom views $\times 1$ of USNM E-1034. Recent. From Port-au-Prince, Haiti. 5-9. Macropneustes mortoni (Conrad) (p. 83)

5, 6, Top and bottom views $\times 1$ of USNM 372898. From the Ocala limestone of late Eocene age at USGS 7159, 5 miles southeast of Whatley, Clarke County, Ala.

7-9, Top, posterior end, and side views $\times 1$ of USNM 562452. From the Ocala limestone of late Eocene age at USGS 7121, power plant on Kinchafoonee Creek north of Albany, Ga. 

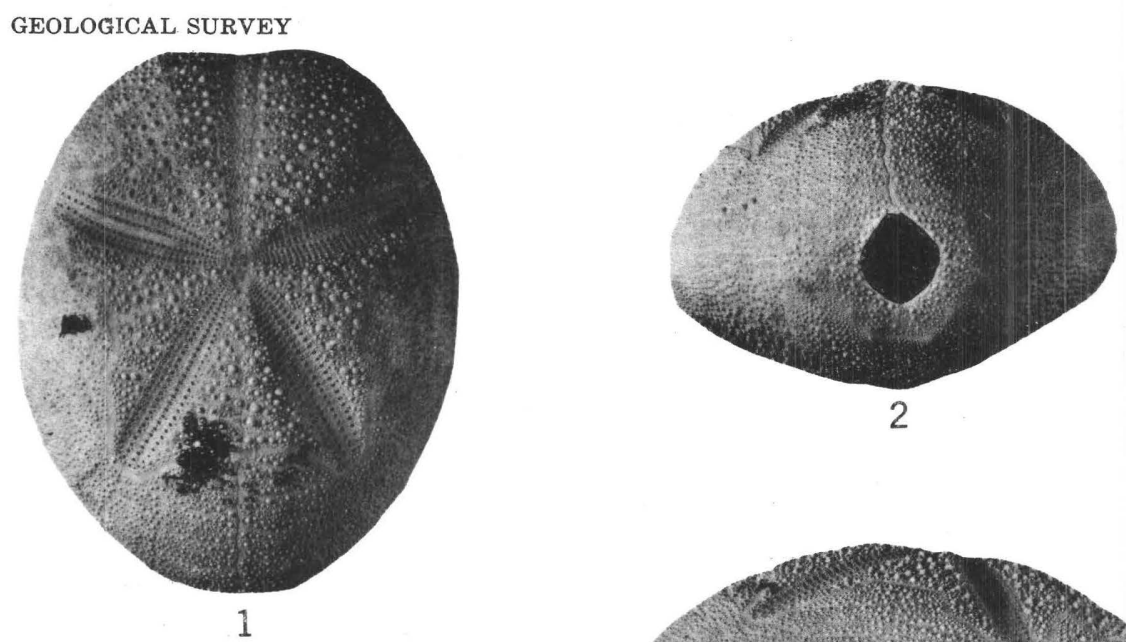

PROFESSIONAL PAPER 321 PLATE 37
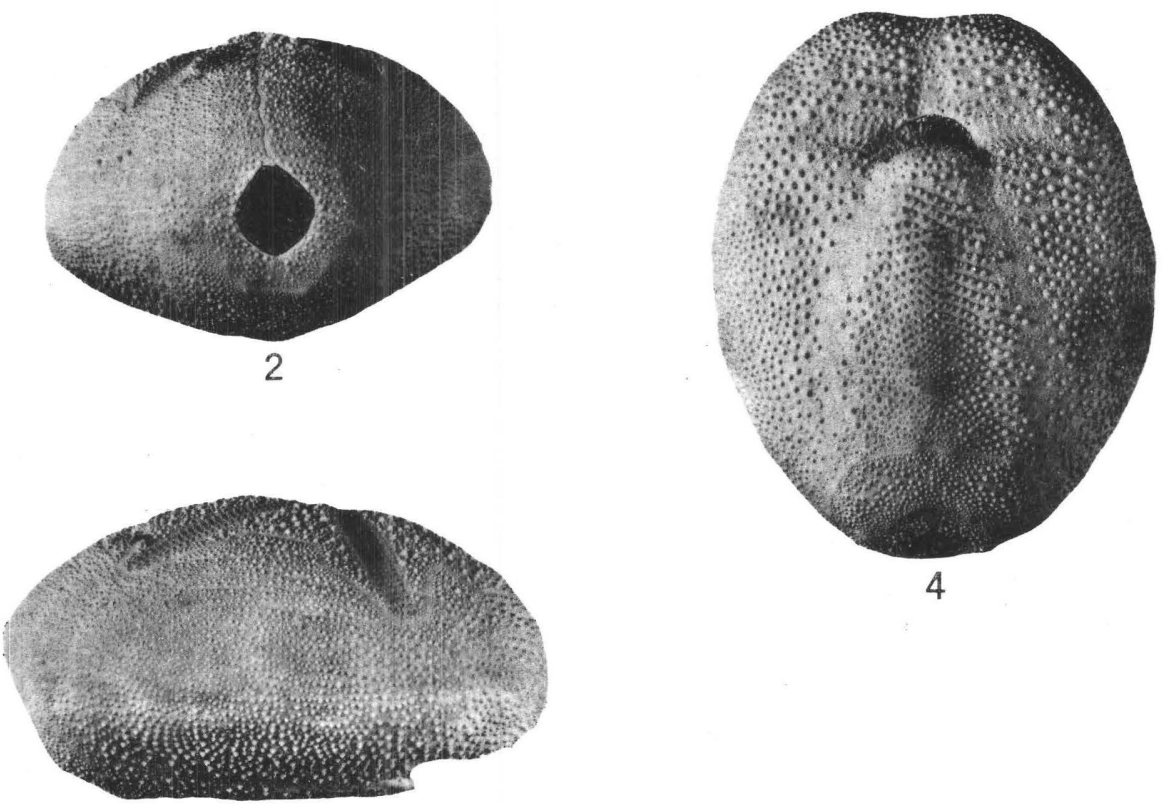

4

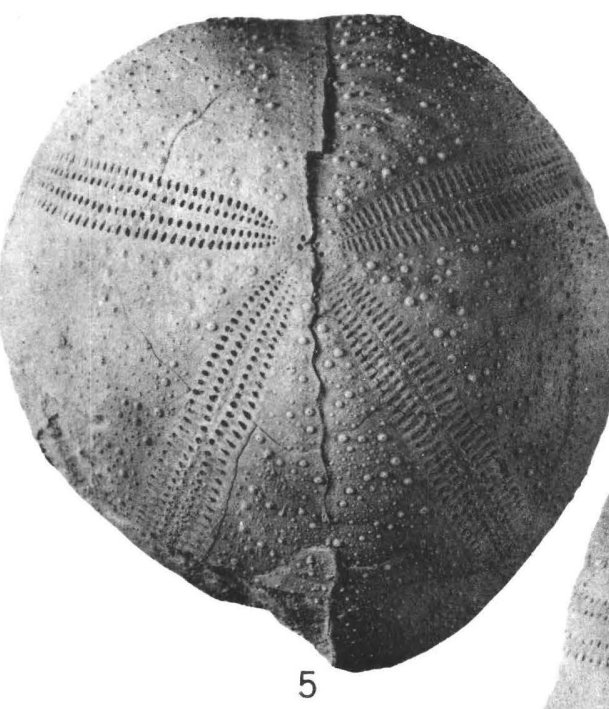

3

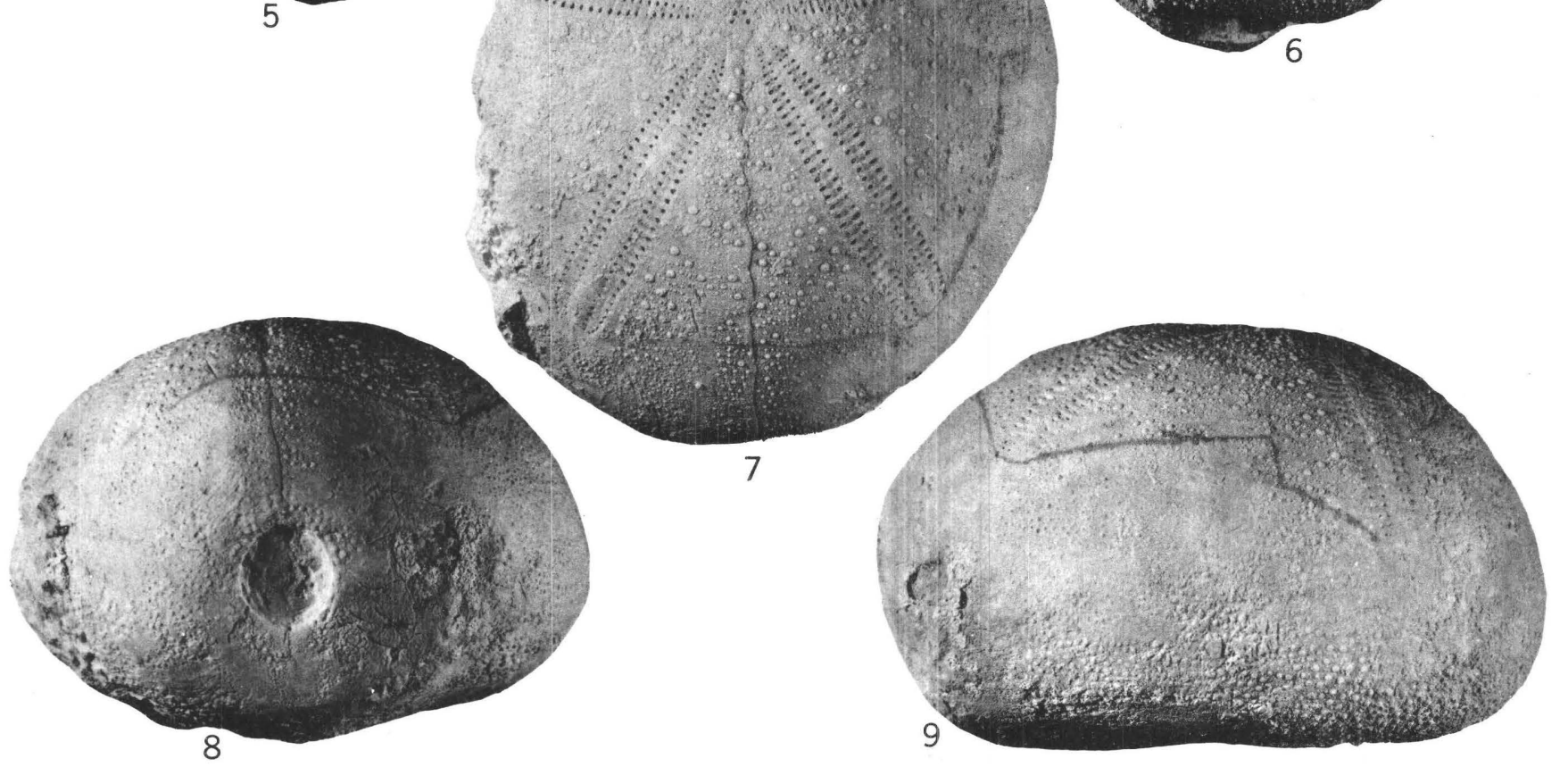


GEOLOGICAL SURVEY
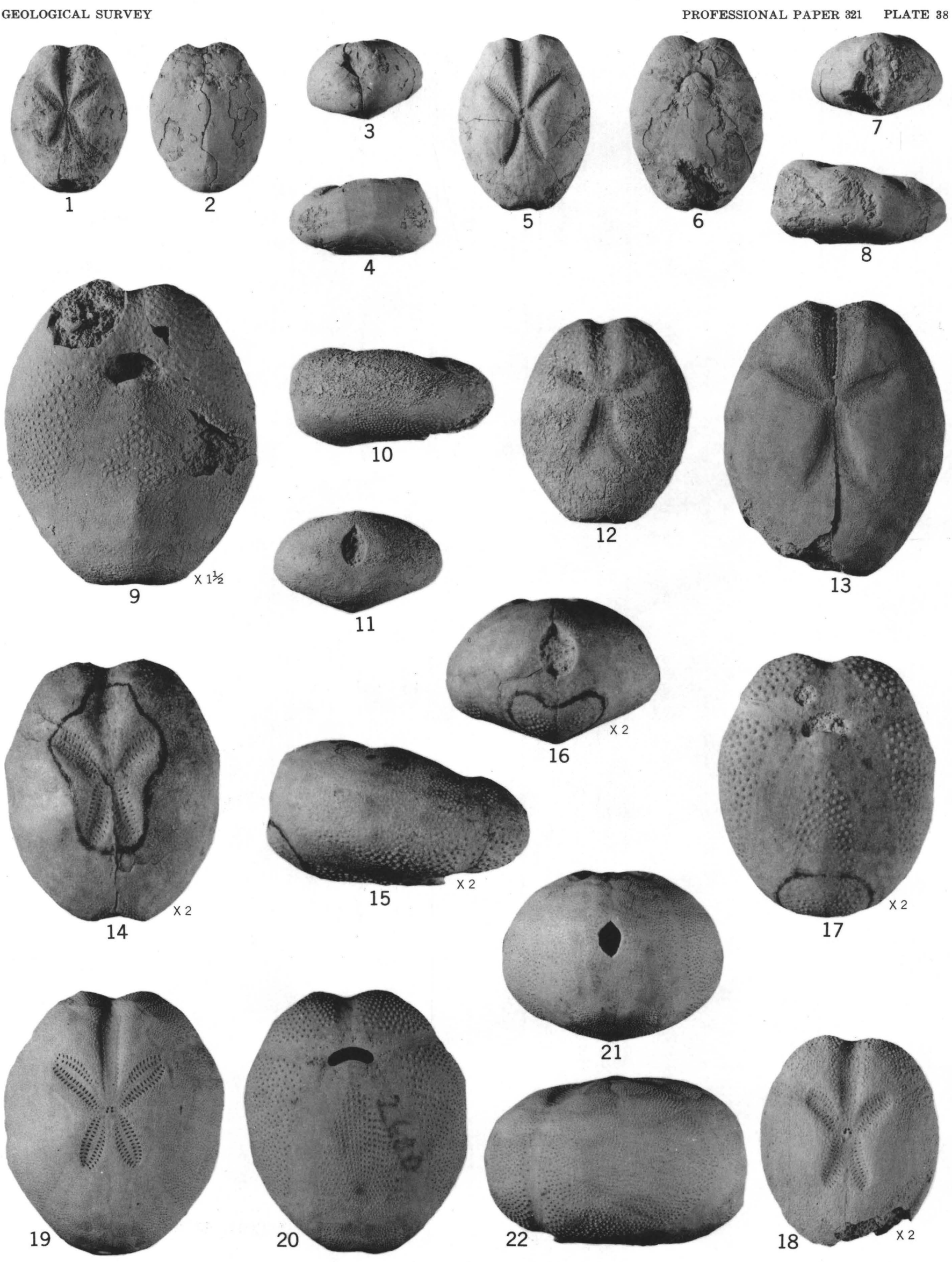

15

\section{BRISSOPSIS}

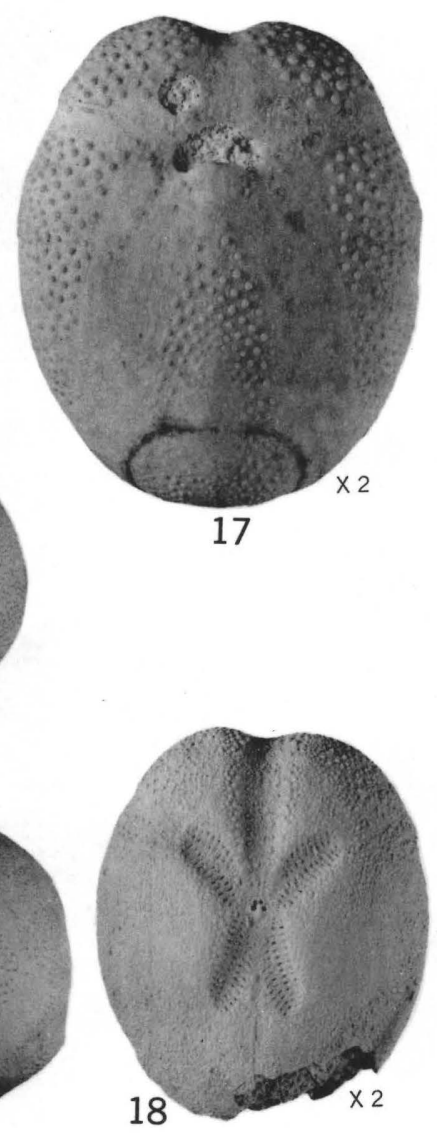




\section{PLATE 38}

Frgures 1-8. Brissopsis blanpiedi Grant and Hertlein (p. 85)

1-4, Top, bottom, posterior end, and side views $\times 1$ of USNM $498998 \mathrm{a}$.

$5-8$, Top, bottom, posterior end, and side views $\times 1$ of USNM 498998 b.

From the Glendon limestone member of Byram formation of middle Oligocene age at USGS 13435, Glaze farm

$1 / 4$ mile west of Lemon and about 9 miles north of Raleigh, Smith County, Miss.

9-13. Brissopsis steinhatchee Cooke (p. 85)

$9-12$, Bottom $\times 1 \frac{1}{2}$, side $\times 1$, posterior end $\times 1$, and top $\times 1$ of paratype, USNM $498987 \mathrm{~b}$.

13, Top view $\times 1$ of type, USNM 498987 a

From the Ocala limestone of late Eocene age at USGS 14541, in Dixie County, Fla., east of Steinhatchee River, north of US 19, opposite Clara.

14-18. Brissopsis biarritzensis Cotteau (p. 85)

14-17, Top side, posterior end, and bottom views $\times 2$ of USNM $562454 a$.

18 , Top view $\times 2$ of USNM $562454 \mathrm{~b}$.

From the Ocala limestone of late Eocene age in the NE $1 / 4$ SE 14 sec. 25, T. 7 N., R. 7 E., Monroe County, Ala.

19-22. Brissopsis atlantica Mortensen (p. 85)

Top, bottom, posterior end, and side views $\times 1$ of USNM 562453. Recent. From U. S. Fish Commission Albatross station 2600, off North Carolina. 
Figures 1, 2. Plagiobrissus grandis (Gmelin) (p. 86)

\section{PLATE 39}

Posterior end and top views $\times \frac{2 / 3}{3}$ of USNM 19295. Recent. From the Bahama Islands.

3-6. Plagiobrissus curvus (Cooke) (p. 87)

3-5, Top, side, and bottom views $\times 1$ of type, USNM 498984. From the Ocala limestone of late Eocene age on Chipola River $1 / 4$ mile above the bridge at Marianna, Fla.

6, Top view $\times 1$ of USNM 562455 . From the Ocala limestone of late Eocene age at USGS 7121, Flint River at mouth of Kinchafoonee Creek above Albany, Ga. 

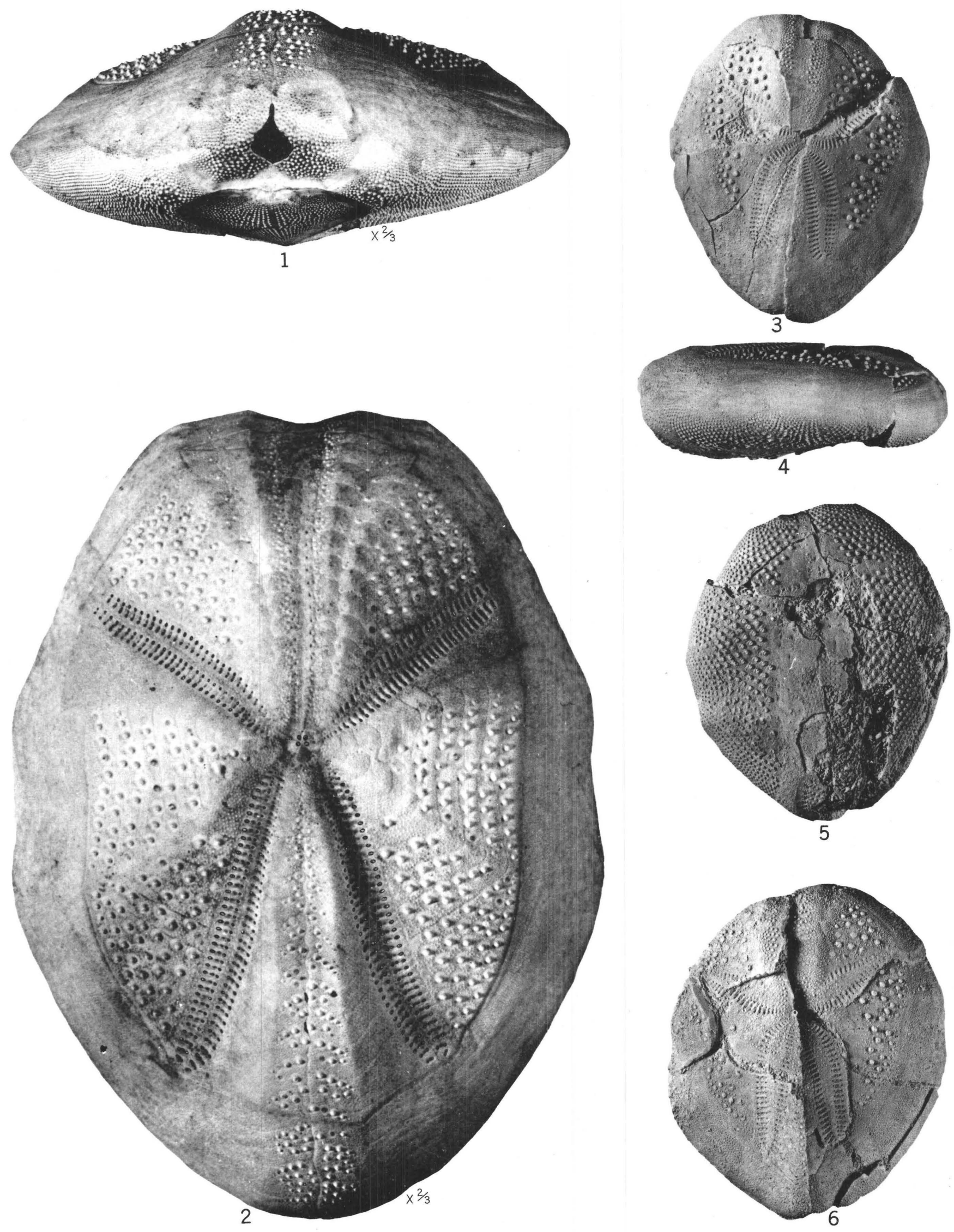

PLAGIOBRISSUS 
GEOLOGICAL SURVEY

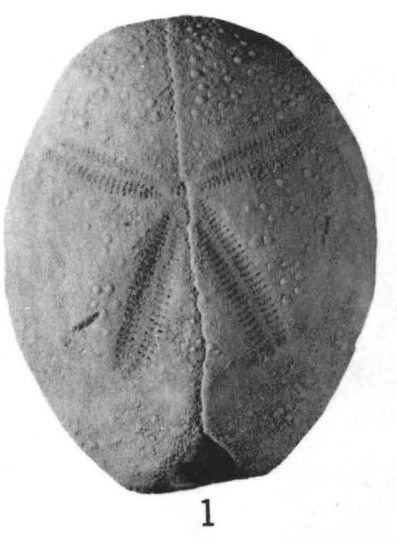

PROFESSIONAL PAPER 321

PLATE 40
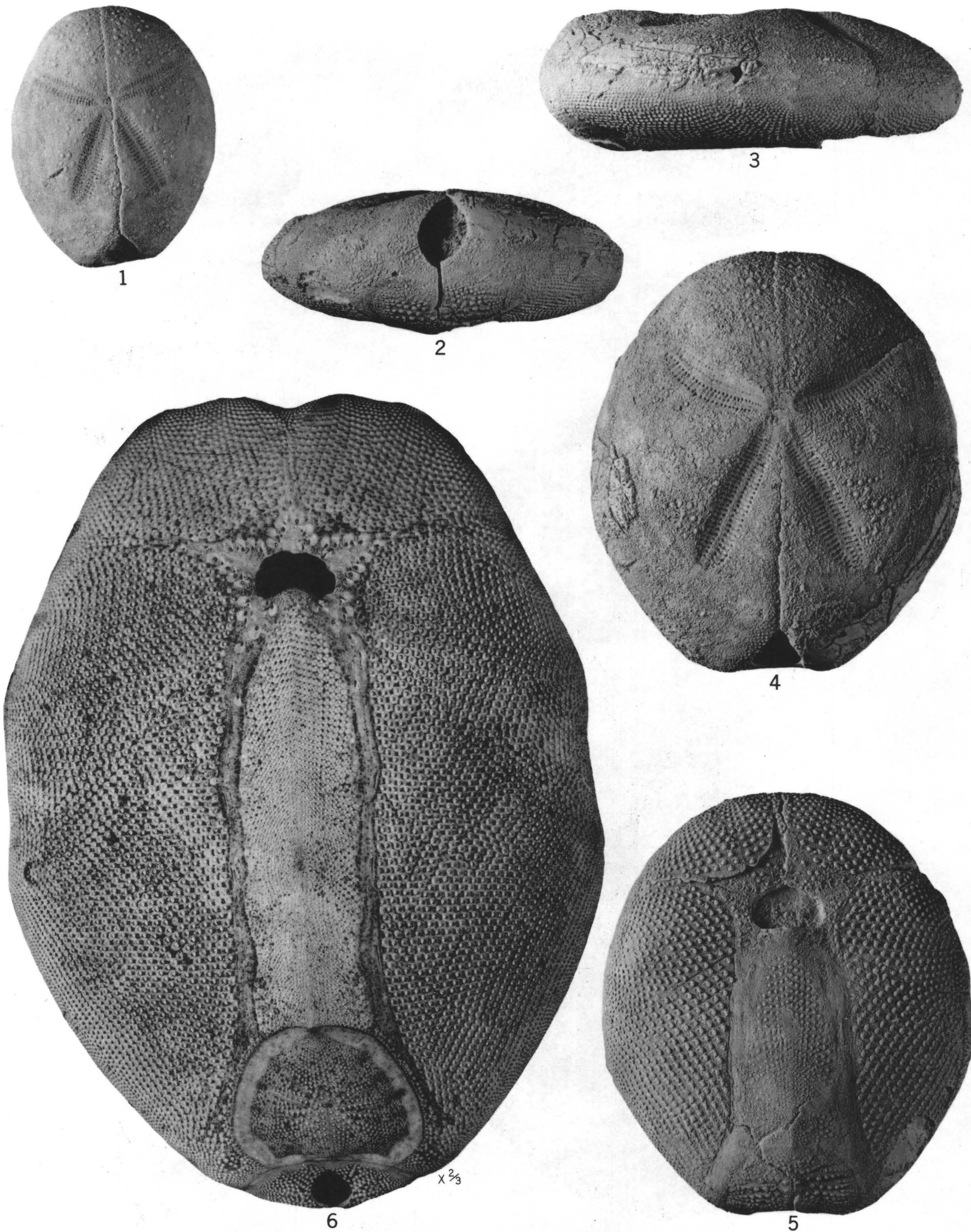

PLAGIOBRISSUS
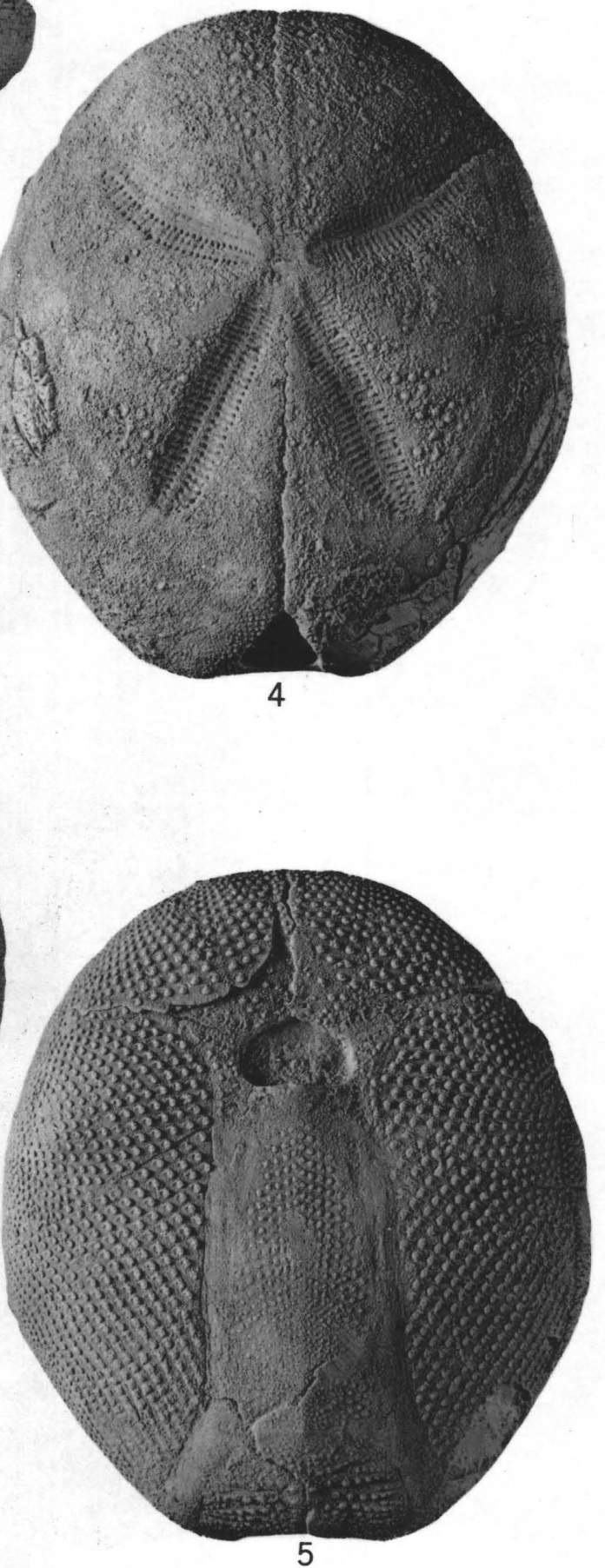


\section{PLATE 40}

Figures 1-5. Plagiobrissus? dixie (Cooke) (p. 87)

1, Top view $\times 1$ of type, USNM 498985 . From the Ocala limestone of late Eocene age 1 mile north of Mayo, Fla.

2-5, Posterior end, side, top, and bottom views $\times 1$ of USNM 562456. From the Ocala limestone of late Eocene age east of Steinhatchee River north of US 19 in Dixie County, Fla., opposite Clara.

6. Plagiobrissus grandis (Gmelin) (p. 86)

Bottom view $\times \frac{2 / 3}{3}$ of USNM 19295. Recent. From the Bahamas. 


\section{PLATE 41}

Figures 1-5. Eupatagus (Gymnopatagus) antillarum (Cotteau) (p. 90)

$1-4$, Top, posterior end, side, and bottom view $\times 1$ of USNM 562465. From USGS 18749, Withlacoochee River in west $1 / 2$ sec. 3 , T. 17 S., R. 16 E., in Levy and Citrus Counties, Fla.

5, Top view $\times 1 \frac{1}{2}$ of USNM 562464. From USGS 18757 , center of sec. 14, T. 17 S., R. 15 E., in Levy and Citrus Counties.

Both from the Inglis limestone of late Eocene age.

6-8. Eupatagus clevei (Cotteau) (p. 89)

Posterior end, top, and bottom views $\times 1$ of USNM 104175. From the Inglis limestone of late Eocene age on Withlacoochee River, Citrus County, Fla., on west line of sec. 3, T. 17 S., R. 16 E. 

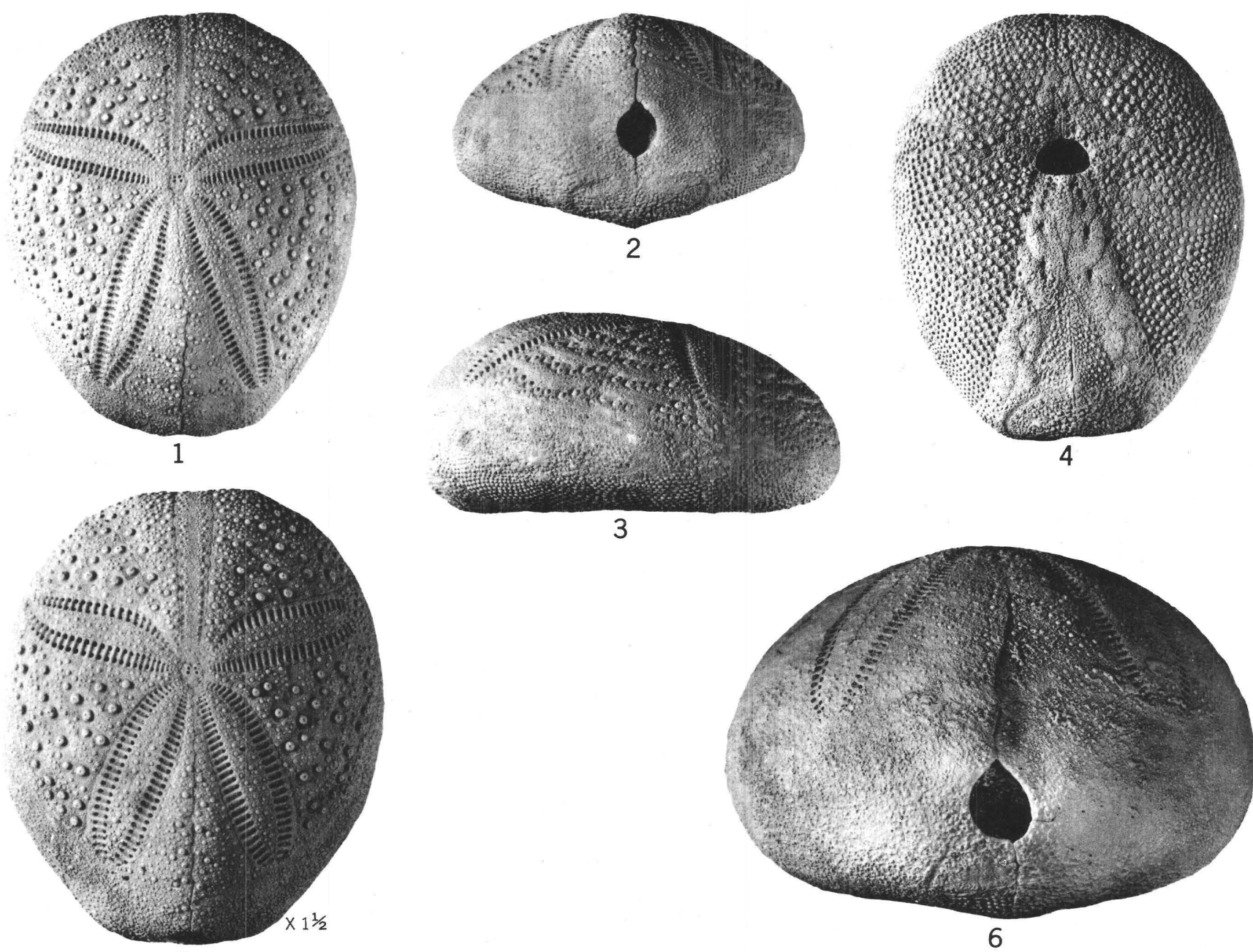

5

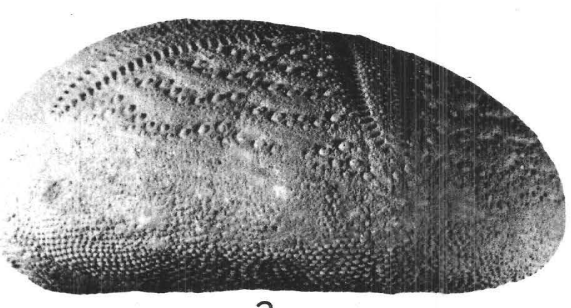

3
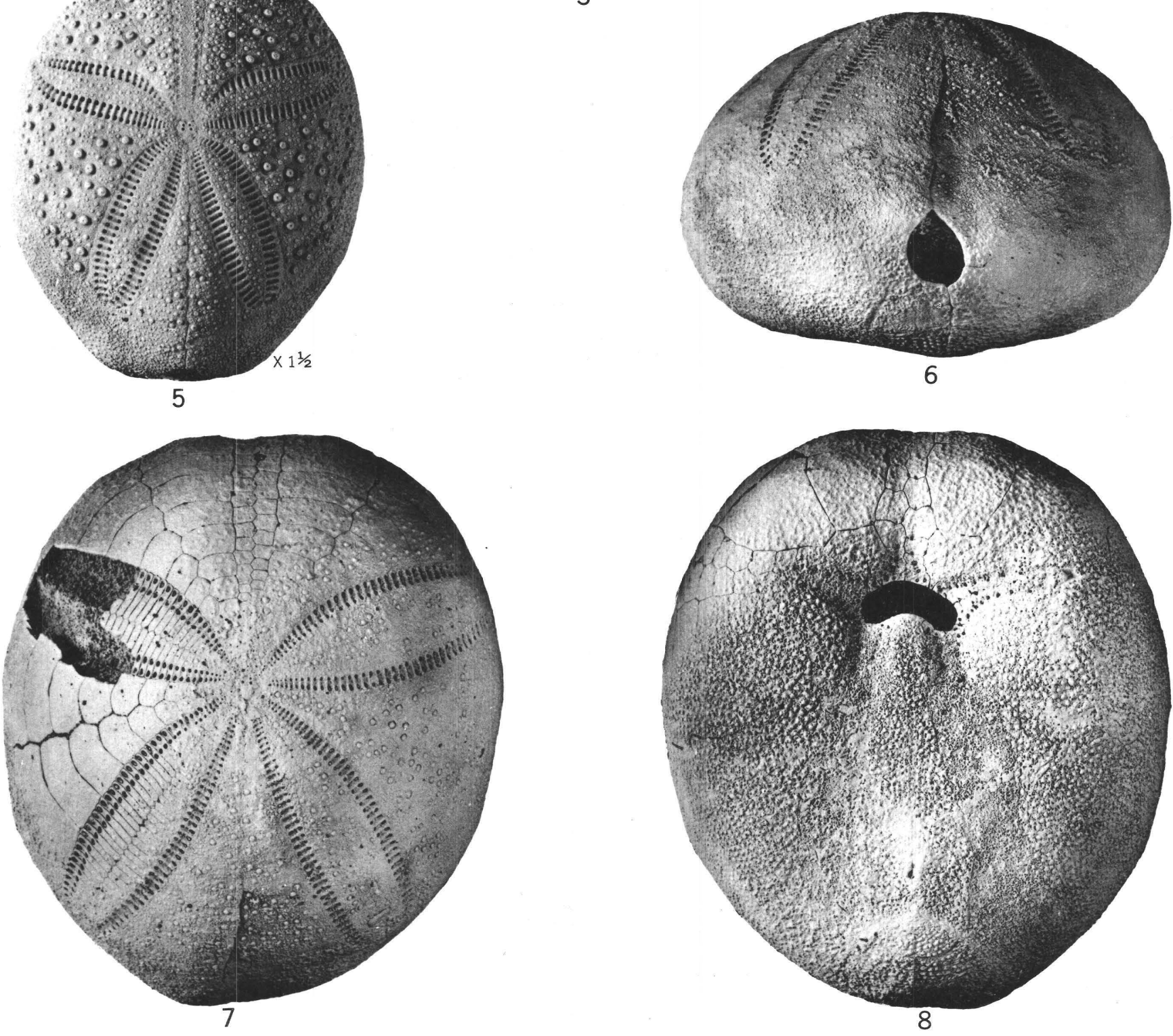

EUPATAGUS 
GEOLOGICAL SURVEY
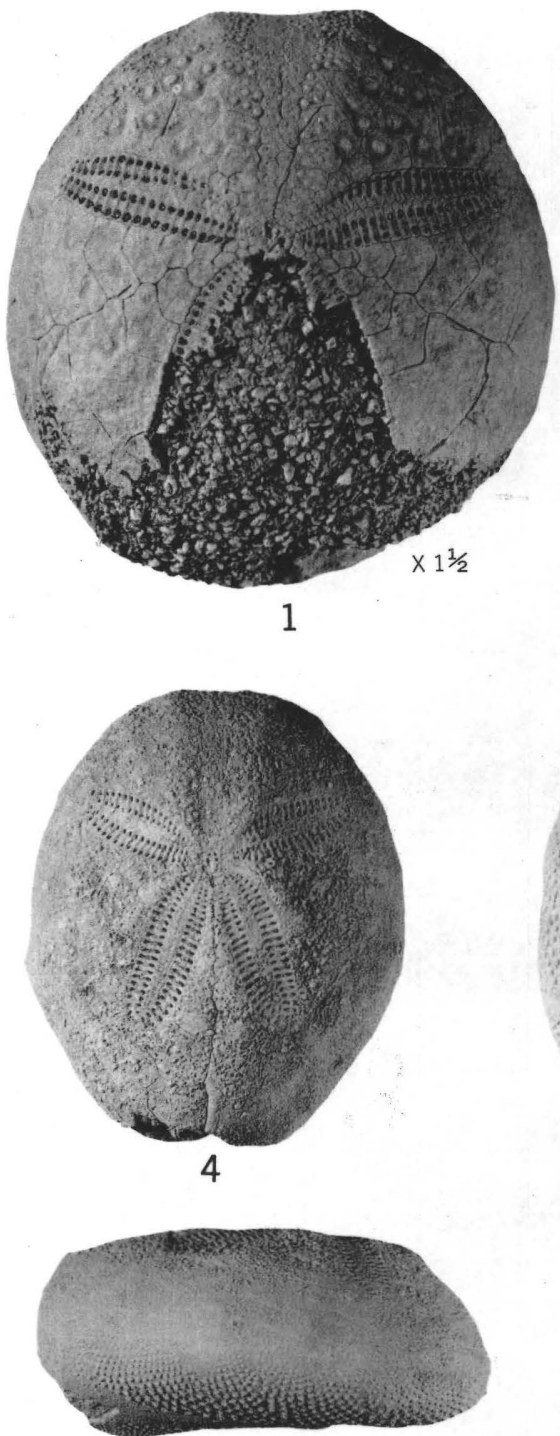

5

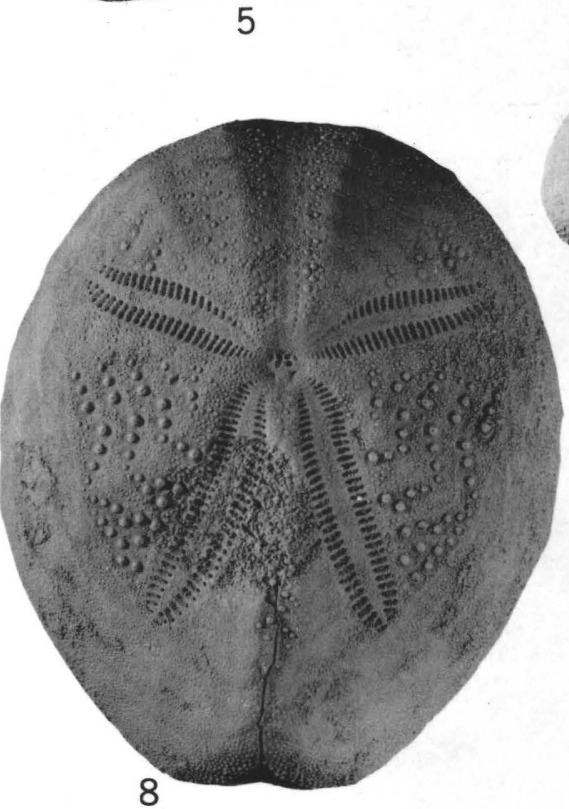

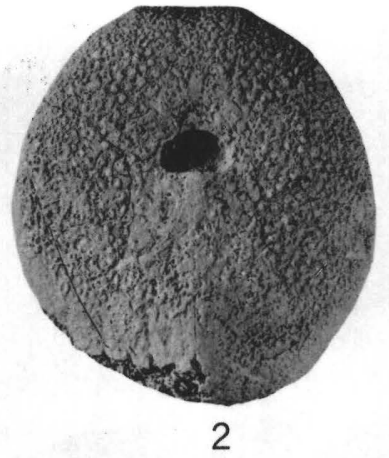

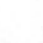

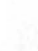

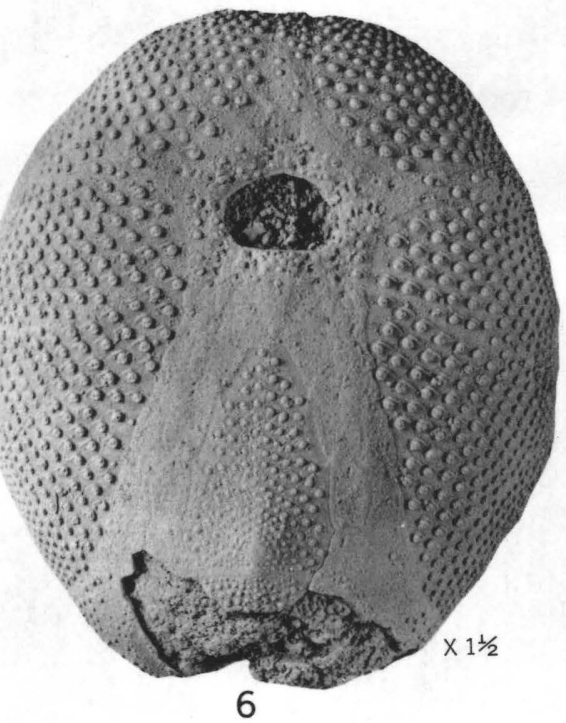

6
PROFESSIONAL PAPER 321 PLATE 42

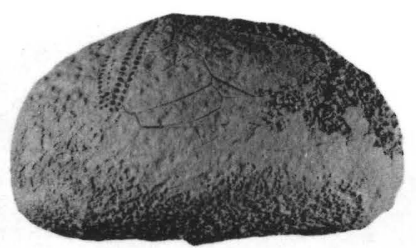

3
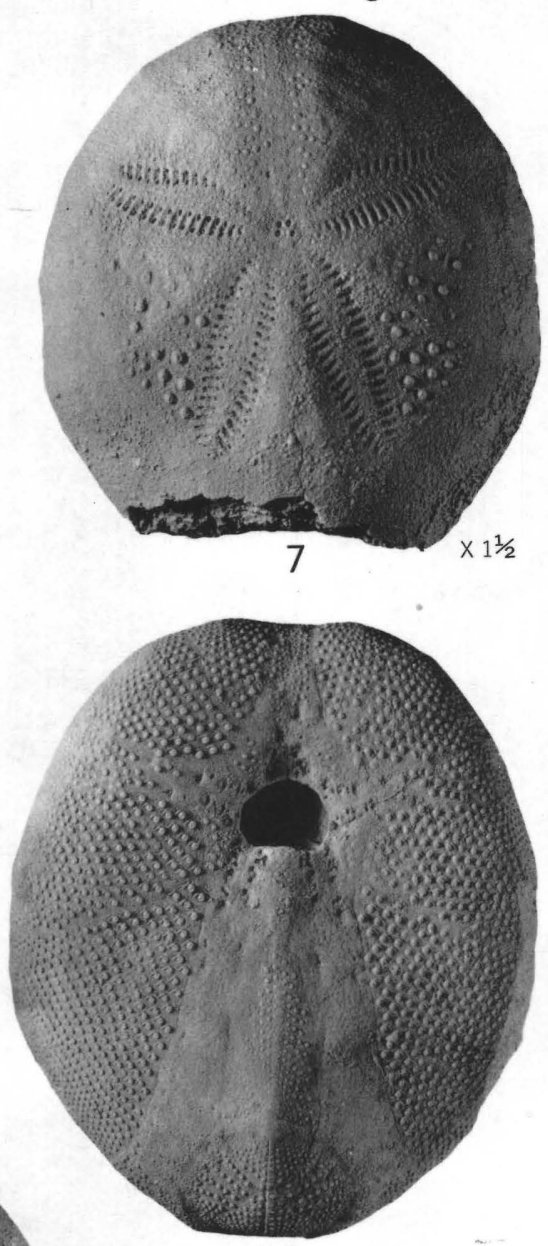

12

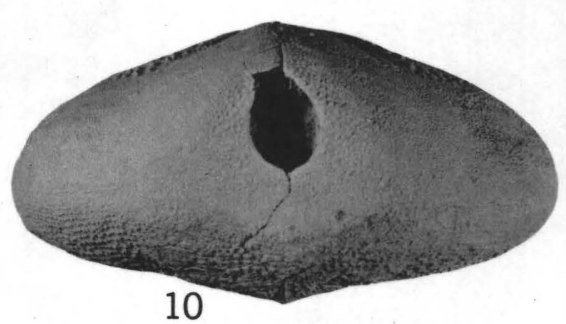

EUPATAGUS

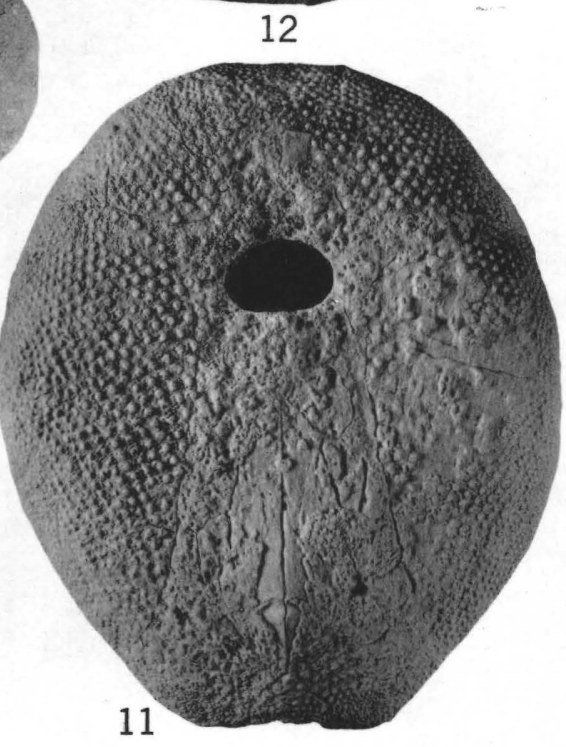




\section{PLATE 42}

FiguRes 1-3. Eupatagus (Gymnopatagus) gardnerae Cooke (p. 90)

Top $\times 1 \frac{1}{2}$, bottom $\times 1$, and side $\times 1$ of type, USNM 498983 . From the Ocala limestone of late Eocene age at USGS 10014, stream 6 miles west of Andalusia, Ala., on line between secs. 20 and 29, T. 4 N., R. 15 E.

4-7. Eupatagus (Gymnopatagus) carolinensis Clark (p. 91)

4-6, Top and side views $\times 1$ and bottom view $\times 1 \frac{1}{2}$ of type, USNM 166484 . From the Castle Hayne limestone of middle and late Eocene age at Wilmington, N. C.

7, Top view $\times 1 \frac{1}{2}$ of paratype, USNM 164674. From the Castle Hayne limestone of middle and late Eocene age at USGS 3602 , Wilmington, N. C.

8-12. Eupatagus (Gymnopatagus) ocalanus Cooke (p. 91)

8-11, Top, side, and posterior end and bottom views $\times 1$ of type, USNM 372884. From the Ocala limestone of late Eocene age in Taylor County rock pit 1 mile north of Mayo, Lafayette County, Fla.

12 , bottom view $\times 1$ of USNM 562466. Locality unknown. 
Frgures 1-4. Linthia? prima Cooke (p. 70)

\section{PLATE 43}

Side, bottom, top, and anterior end views $\times 1 \frac{1}{2}$ of type, USNM 498978 . From the Clayton formation of Paleocene age at USGS 4032, Dr. A. J. Parke's farm on the Americus road 5 miles south of Ellaville, Schley County, Ga.

5-11. Eupagatus (Brissopatagus) alabamensis Cooke (p. 92)

5-8, Top, side, anterior end, and bottom views $\times 1$ of USNM 498982 , type of Eupatagus georgianus Cooke. From the Ocala limestone of late Eocene age at USGS 10507, power plant on Kinchafoonee Creek north of Albany, Ga.

9, Bottom view $\times 1 \frac{1}{2}$ of USNM 562467. From the Ocala limestone of late Eocene age at USGS 15064, Monroe County, Ala., $1 \frac{1}{2}$ miles southwest of Perdue Hill.

10, 11, Top and bottom views $\times 1 \frac{1}{2}$ of type, USNM 498979. From the Yazoo clay of late Eocene age at USGS 12168, base of St. Stephens Bluff on Tombigbee River, Washington County, Ala. 
FEOLOGICAL SURVEY
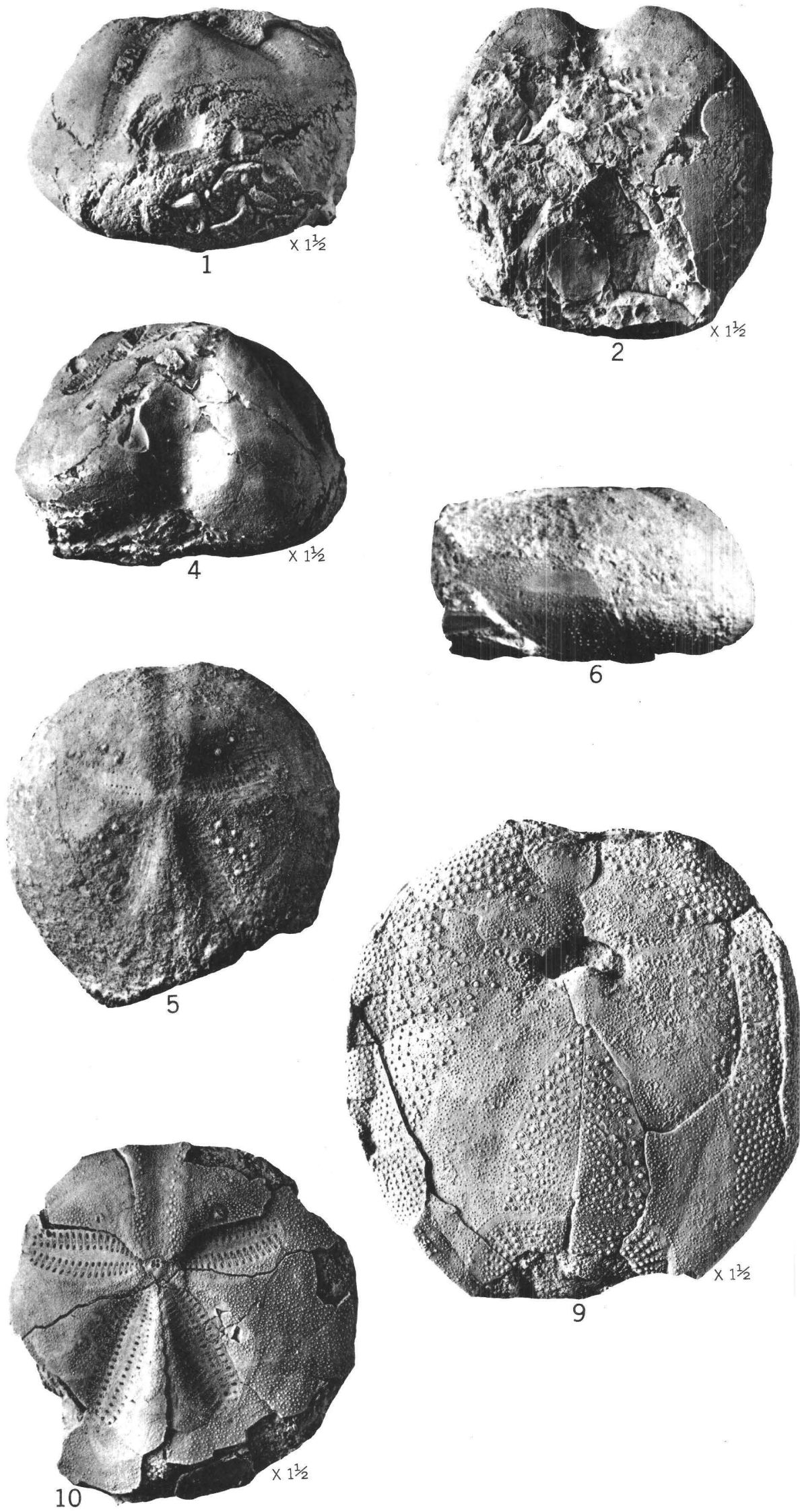
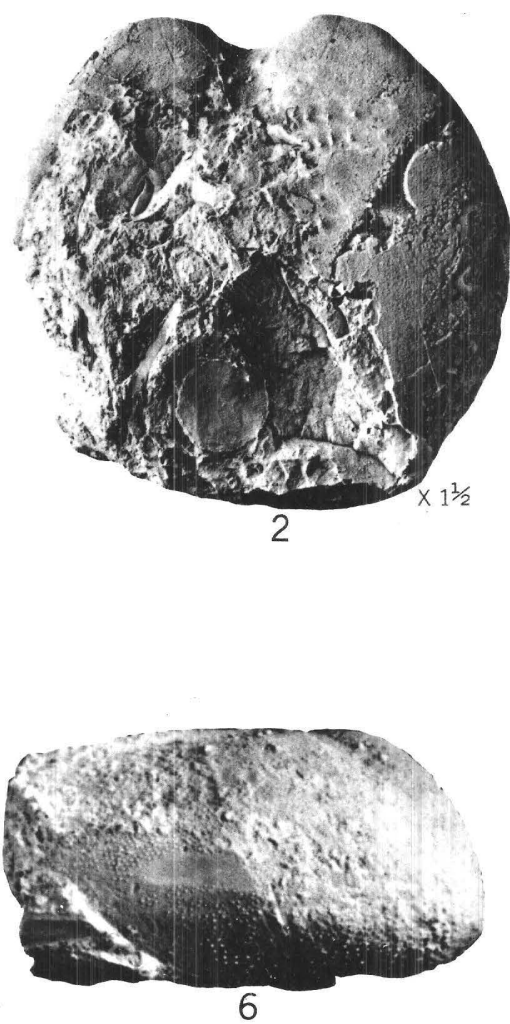

PROFESSIONAL PAPER 321 PLATE 43
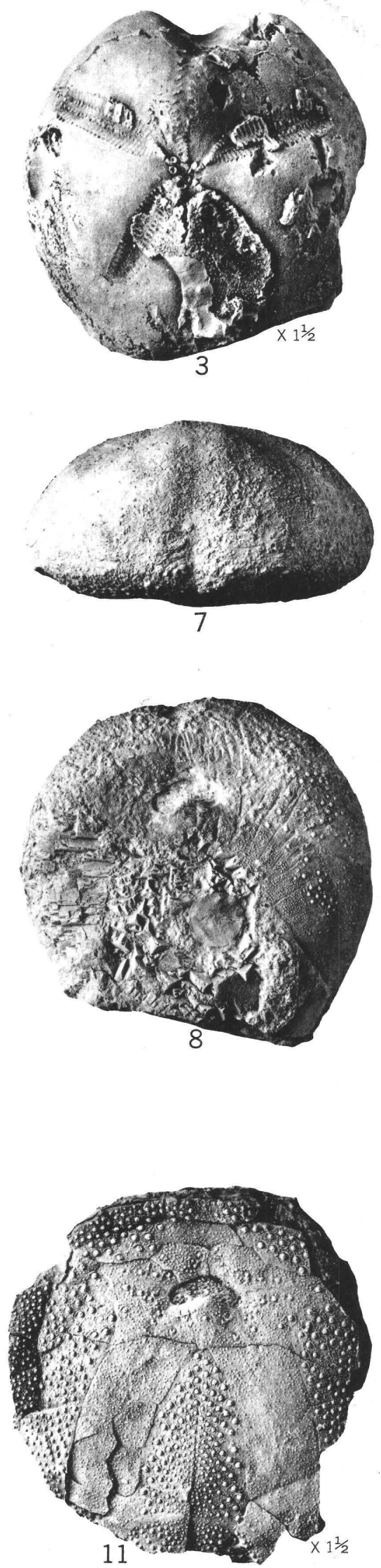